\title{
SENSITIVITY MAPPING AND ANALYSIS of the Bulgarian Black Sea Coastal Zone
}

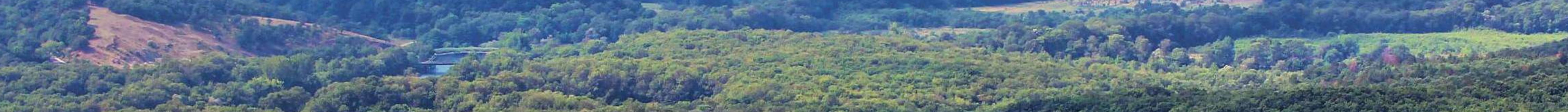

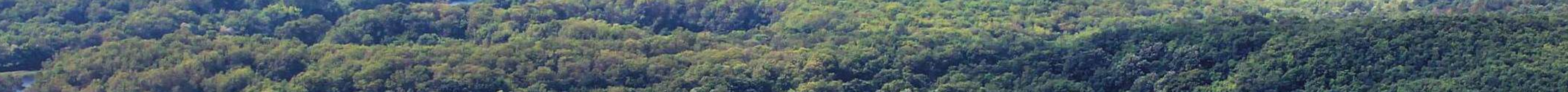

(5)

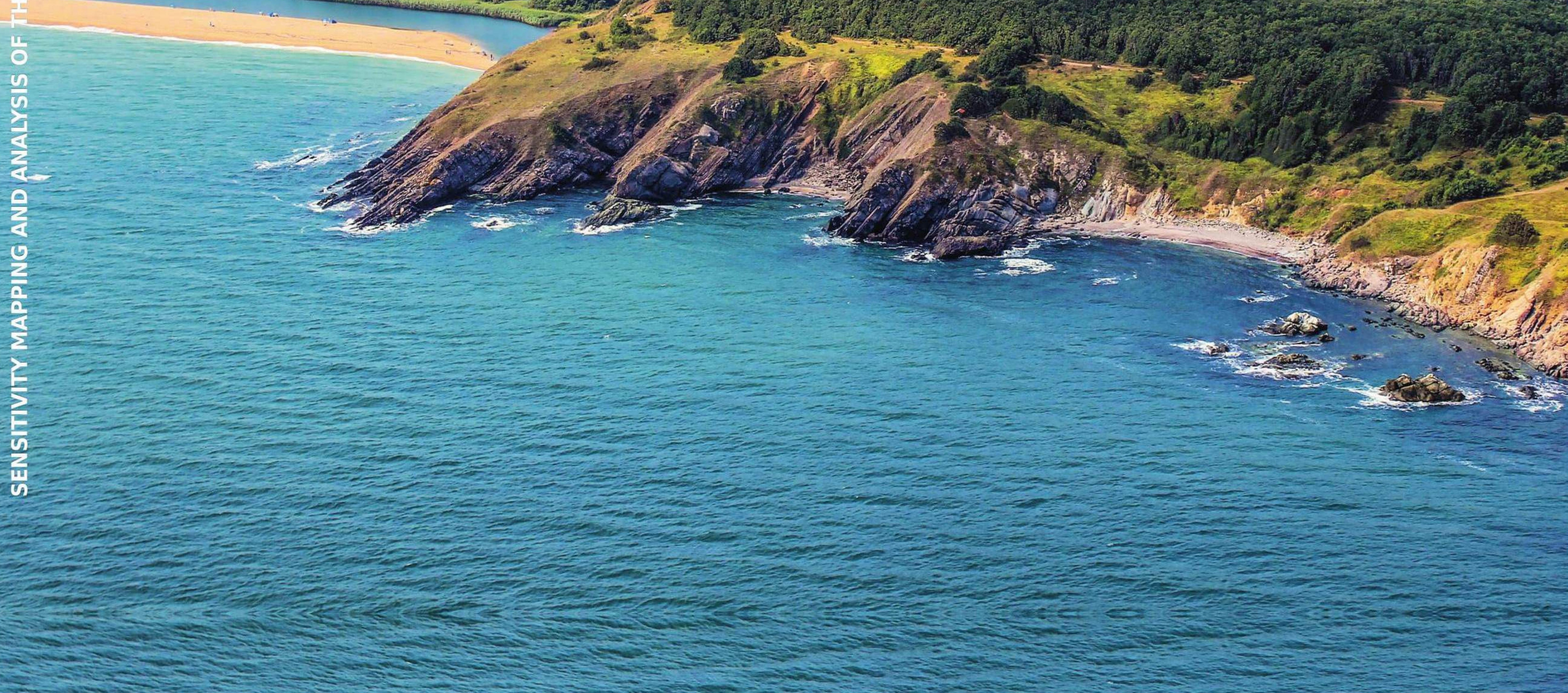


SENSITIVITY MAPPING AND ANALYSIS of the Bulgarian Black Sea Coastal Zone 


\section{SENSITIVITY MAPPING AND ANALYSIS of the Bulgarian Black Sea Coastal Zone}

\section{Editors:}

Dr. lliyan KOTSEV and Dr. Hristo STANCHEV

Contributors:

Dr. lliyan KOTSEV

Dr. Margarita STANCHEVA

Dr. Hristo STANCHEV

Prof. Mariyana FILIPOVA-MARINOVA

Assoc. Prof. Maria YANKOVA

Assoc. Prof. Preslav PEEV

Anton KRASTEV

Prof. Veselin PEYCHEV

Prof. Atanas PALAZOV

Dr. Danail PAVLOV

\section{TOTAL}

Tatiana GUSACHENKO

Stanislav YANKOV

Scientific editing:

Dr. Emanuil KOZHUHAROV

Technical editor:

Ani IVANOVA

Graphic design:

Svetlana FIDANSKA

Ivan ROUSSANOV
Professional underwater photographs

(C) Lyubomir Klissurov

Professional photographs of bird species:

Green Balkans, NGO

Aerial photographs:

Dr. Margarita Stancheva, IO-BAS

Dr. Hristo Stanchev, IO-BAS

Prof. Robert Young, PSDS-WCU, USA

Cover photos:

Dr. Margarita Stancheva, IO-BAS

Prof. Robert Young, PSDS-WCU, USA

Published by:

Total E\&P Bulgaria B.V.

Printed at:

Pulsio Print

DOI: https://doi.org/10.7546/IO.BAS.2018.2

SBN : 978-954-9490-50-3

Bulgarian. First edition. 2017

All rights reserved. 
LIST OF THE TYPING ERRORS

\begin{tabular}{|c|c|c|c|c|c|}
\hline Page № & Column & Row № & Wrong text & Right text & Fault of \\
\hline 17 & right & 19 & metamorfism & metamorphism & technical editor \\
\hline 17 & right & 34 & metamorfism & metamorphism & technical editor \\
\hline 17 & right & 36 & VI. CARBONIFEROUS & VII. CARBONIFEROUS & authors \\
\hline 17 & right & 37 & (Hercynian intrusive rocks granites in southern Bulgaria) & (Hercynian intrusive rocks, granites in southern Bulgaria) & technical editor \\
\hline 19 & left & 14 & 09. Silts - clayish facies & 09. Silts - siliceous biogenic facies & graphic designer \\
\hline 19 & left & 15 & 10. Silts - siliceous biogenic facies & 10. Silts - clayish facies & graphic designer \\
\hline 40 & rightmost & 21 & 5445.5 & $5,445.5$ & technical editor \\
\hline 51 & left & 5 & maximums & maxima & authors \\
\hline 51 & left & 9 & coastal line & coastline & authors \\
\hline 51 & right & 3 & maximum & maximal & authors \\
\hline 56 & left & 3 & common hornmeam (Carpinus betulus) & common hornmeam (Carpinus betulus L.) & authors \\
\hline 56 & right & 12 & Jerusalem thorn (Paliurus spina-christi) & Jerusalem thorn (Paliurus spina-christi Mill.) & authors \\
\hline 67 & right & 14 & asl & a.s.l. & technical editor \\
\hline 68 & left & 19 & fern leaf peony (Paeonia tenuifolia) & fern leaf peony (Paeonia tenuifolia L.) & authors \\
\hline 71 & left & 4 & water depth of $4.5 \mathrm{~m}$ & water depth up to $4-5 \mathrm{~m}$ & authors \\
\hline 80 & left & 3 & asl & a.s.I. & authors \\
\hline 85 & right & 9 & Carcinus aestuarii Nardo, 1847 & Carcinus aestuarii Nardo, 1847 & authors \\
\hline 87 & left & 2 & Pilumnus hirtellus (Linnaeus, 1758) & Pilumnus hirtellus (Linnaeus, 1758) & authors \\
\hline 91 & left & 2 & Engraulis encrasicolus ponticus Alexandrov 192 & Engraulis encrasicolus ponticus Alexandrov, 1927 & authors \\
\hline 91 & right & 15 & depths of up to $20 \mathrm{~m}$ & depths down to $20 \mathrm{~m}$ & authors \\
\hline 95 & left & 10 & The three Cetacean species of the Black Sea: & The three cetacean species of the Black Sea: & technical editor \\
\hline 108 & left & 4 & surf zone & swash zone & authors \\
\hline 109 & left & 5 & Durankulak, Shabla and Pomorie Lakes & Durankulak, Shabla and Pomorie lakes & technical editor \\
\hline 109 & right & 11 & the Bulgarian endemic Linum tauricum & the Bulgarian endemite Linum tauricum & technical editor \\
\hline 110 & right & 17 & $\begin{array}{l}\text { 3. Silene caliacrae is an endemic species for the Bulgarian } \\
\text { Black Sea coast }\end{array}$ & $\begin{array}{l}\text { 3. Silene caliacrae is an endemic species for the Bulgarian } \\
\text { Black Sea coast [12] }\end{array}$ & authors \\
\hline 136 & left & $20-21$ & Paleoprovadiyska River valley & Paleoprovadiyska River & authors \\
\hline 136 & right & 23 & $5^{\text {th }}-6^{\text {th }}$ century $B C$ & $6^{\text {th }}-5^{\text {th }}$ century $B C$ & authors \\
\hline 143 & left & 7 & Pliny the Elder & Plinius the Elder & technical editor \\
\hline 212 & $\begin{array}{l}\text { second } \\
\text { (from left } \\
\text { to right) }\end{array}$ & $17-22$ & $\begin{array}{c}\text { CHAPTER I GEOLOGICAL SETTINGS OF THE BULGARIAN } \\
\text { BLACK SEA COAST AND SHELF } \\
\text { CHAPTER II PHYSIOGRAPHIC AND OCEANOGRAPHIC } \\
\text { CHARACTERISTICS OF THE STUDY AREA }\end{array}$ & $\begin{array}{c}\text { CHAPTER I GEOLOGICAL SETTINGS OF THE BULGARIAN } \\
\text { BLACK SEA COAST AND SHELF } \\
\text { and } \\
\text { CHAPTER II PHYSIOGRAPHIC AND OCEANOGRAPHIC } \\
\text { CHARACTERISTICS OF THE STUDY AREA }\end{array}$ & authors \\
\hline 215 & $\begin{array}{l}\text { third (from } \\
\text { left to } \\
\text { right) }\end{array}$ & $42-45$ & $\begin{array}{c}\text { CHAPTER VI. REGIONALIZATION OF THE BULGARIAN } \\
\text { BLACK SEA COASTAL AREA AND THE CONTIGUOUS } \\
\text { SHALLOW SEABED SECTOR }\end{array}$ & $\begin{array}{c}\text { CHAPTER VI. DESCRIPTION BY REGIONS OF THE BULGARIAN } \\
\text { BLACK SEA COASTAL ZONE }\end{array}$ & authors \\
\hline
\end{tabular}




\section{SENSITIVITY MAPPING AND ANALYSIS of the Bulgarian Black Sea Coastal Zone}

\section{@}




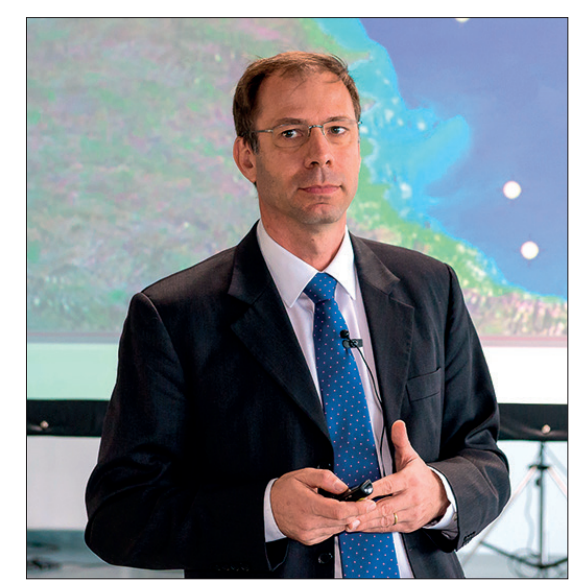

XAVIER FAUGERAS

General Manager, Total E\&P Bulgaria B.V.
Coastal areas are precious spaces where the continent meets the sea, fresh water meets salty water, and all sorts of life forms find suitable conditions to develop. These are also places where people have settled for ages, transited for trading or, more recently, visit to relax for a few days.

The Bulgarian Black Sea coastal area concentrates all of these characteristics with its multiple geology outcrops, diversity of ecosystems, flora and fauna and also human settlements displaying the old and rich history of the region.

TOTAL has set its vision to become the major company of the responsible energy, which means to provide affordable energy while respecting the best environment and safety standards and participating in the economic development of the countries it operates in.

This is why TOTAL has been particularly honored to have inspired this mapping project of the sensitive areas of the Black Sea coast which has gathered, in collaboration with the Institute of Oceanology of Varna, some of the most distinguished Bulgarian specialists in their own fields.

It is a great privilege that those scientists have guided us, through their work, to know the Bulgarian coastal areas much better so we can further appreciate the places that we visit. It is my wish that with this reference book it will be the same for you.
The book summarizes a great portion of the scientific knowledge available today associated with the Bulgarian Black Sea's coastal and marine environment, its cultural and historical heritage included. The identification and mapping of the sensitivity zones is based on current data as regards the geological, physiographic, oceanographic, and nature conservation features of the Bulgarian Black Sea coastal zone.

The methodology proposed by IPIECA is used for the identification and mapping of sensitive coastal sectors. They are classified according to a 10-point scale using an environmental sensitivity index which is of paramount importance in preventing and planning activities that seek to minimize the negative impact in case of hydrocarbon spills.

The book will be of help in determining major sources of negative impact thus contributing to the optimized use of marine resources. In addition, the sensitivity maps could be used for coastal and marine environmental impact assessments.

Making and publishing this book indicates the commitment and responsibility of TOTAL E\&P BULGARIA B.V. as regards the protection of the marine and coastal environment in performing activities that could have a negative impact on it.

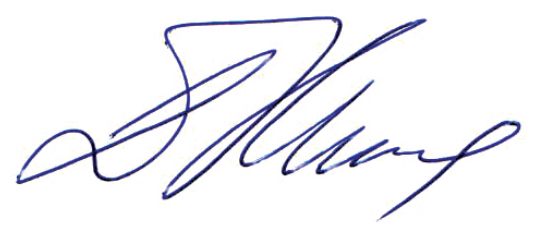

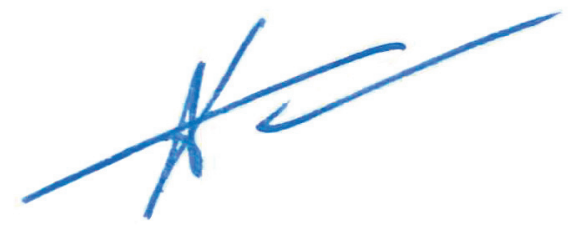

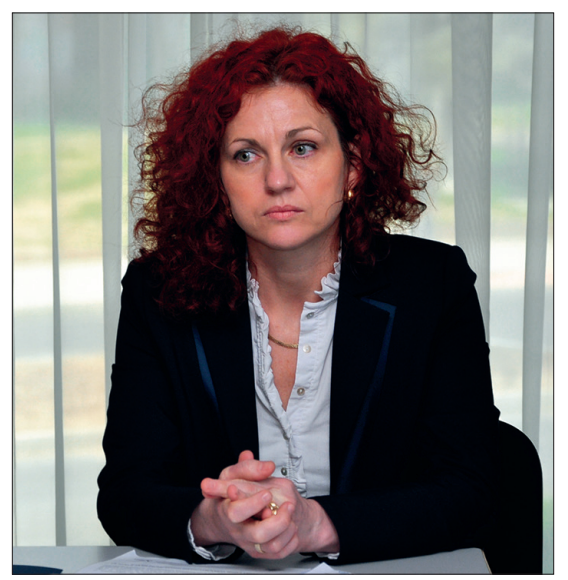

Eng. DESISLAVA KONSULOVA, M.Sc.

Director of Black Sea Basin Directorate, Ministry of Environment and Water 


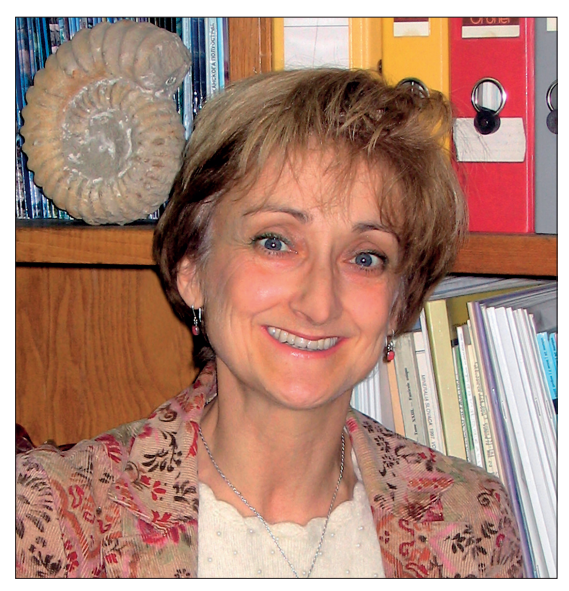

Professor KRISTALINA STOYKOVA, D.Sc.

Geological Institute Strashimir Dimitrov.

Bulgarian Academy of Sciences
The book presents the result of a matchless interdisciplinary research merging a number of fundamental natural sciences (geology. geography, marine geology, oceanography, botany, zoology and ecology) with disciplines studying the Bulgarian cultural and historical heritage (archeology, history) to make a comprehensive assessment of the sensitivity and vulnerability of the Bulgarian Black Sea coastal zone.

The presentation follows the logical course of description of the features of the inanimate and animate nature as well as of the cultural and historical phenomena.

The chapter providing scientific descriptions of nature conservation areas, coastal and marine habitats is a major contribution. The features of the main archaeological sites and monuments of cultural and historical heritage on the Bulgarian Black Sea coast add to the full-scale picture as the latter are integrated in the natural environment.

The penultimate chapter provides an assessment of the Bulgarian Black Sea coastal zone's sensitivity to hydrocarbon spills presented in a set of maps. The maps were made on the basis of an environmental analysis using cutting-edge scientific approaches including GIS applications and remote sensing methods. The superb photographs, a huge asset of the book, illustrate the unique beauty of the Bulgarian nature, its flora and fauna
The book and its professionally set out data and analyses successfully imply in readers confidence about the significance of the results achieved by the creative team. These results refer to parts of the landscape sphere that are transitional between three geospheres varying enormously in terms of properties and dynamics, namely lithosphere, hydrosphere and atmosphere.

In the context of the current global environmental challenges the results of the current comprehensive research offer both grounded levels of detailed analyses of the geo components and correctly drawn synthesis results which are reflected in the landscape-based deciphering of the Bulgarian Black Sea coastal zone's contemporary spatial structure.

The approach to the complexity of the authors' aim is systematic and responsible particularly as regards the essential and functional presentation of nature sites and special protection areas. Entirely positive is the impression created by the authors' intention to study in depth the matter with regard to the major issue of the anthropogenic load exerted upon the coastal and marine landscapes and their complex and multilayered reactions.

The book's content offers extended knowledge on the Bulgarian Black Sea coastal zone to experts and non-experts from the Black Sea region and elsewhere around the world. It can serve as a practical reference for future investment intentions in more than one area of the Bulgarian economy.

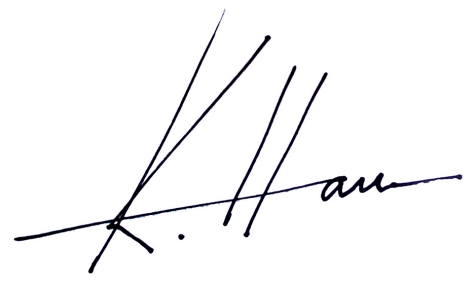

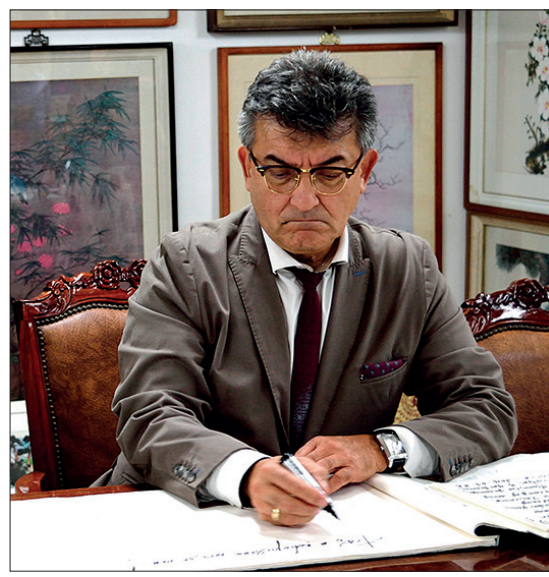

Associate Professor KAMEN NAM, Ph.D.

Department of Landscape Sciences and Environmental Protection Faculty of Geology \& Geography. Sofia University St. Kliment Ohridski 


\section{CONTENTS}

FOREWORD

Iliyan Kotsev, Preslav Peev, Margarita Stancheva, Hristo Stanchev, Atanas Palazov

\section{OBJECTIVES}

lliyan Kotsev, Margarita Stancheva, Hristo Stanchev, Atanas Palazov

\section{GEOLOGICAL SETTINGS OF THE BULGARIAN BLACK SEA} COAST AND SHELF

1. Coastal geology

lliyan Kotsev, Veselin Peychev

2. Seafloor geology

lliyan Kotsev, Veselin Peychev

\section{PHYSIOGRAPHIC AND OCEANOGRAPHIC CHARACTERISTICS OF THE STUDY AREA}

1. Geomorphic pattern and morphological forms of the coastal and submarine relief

Margarita Stancheva, lliyan Kotsev, Veselin Peychev, Hristo Stanchev

1.1. Coastal morphology .

Margarita Stancheva, lliyan Kotsev, Hristo Stanchev, Veselin Peychev

1.2. Seafloor morphology

Iliyan Kotsev, Veselin Peychev

2. Climate of the Bulgarian Black Sea coast

Iliyan Kotsev, Mariyana Filipova-Marinova
3. Hydrographic structure of the Bulgarian Black Sea coast

Iliyan Kotsev

3.1. Black Sea tributaries

lliyan Kotsev

3.2. Coastal firths, lagoons and landslide lakes

Iliyan Kotsev

4. Physical oceanography and marine chemistry of the Black Sea

Anton Krastev

4.1. Physical oceanography

Anton Krastev

4.2. Marine chemistry

Anton Krastev

5. Soil and vegetation cover of the Bulgarian Black Sea coast

Mariyana Filipova-Marinova, lliyan Kotsev, Danail Pavlov

5.1. Soil cover

Iliyan Kotsev, Mariyana Filipova-Marinova

5.2. General characteristics of the coastal vegetation

Mariyana Filipova-Marinova, Danail Pavlov

5.3. Vegetation cover

Mariyana Filipova-Marinova, Danail Pavlov, lliyan Kotsev

6. Macrophytic flora of the Bulgarian sector of the Black Sea 
7. Terrestrial fauna of the Bulgarian Black Sea coast.

Danail Pavlov, Mariyana Filipova-Marinova, lliyan Kotsev

7.1. General characteristics

Danail Pavlov, Mariyana Filipova-Marinova

7.2. Birds with high conservation status according to the International Union for Conservation of Nature (IUCN)

Danail Pavlov, Mariyana Filipova-Marinova, lliyan Kotsev

7.3. Other bird species of interest

Danail Pavlov, Mariyana Filipova-Marinova, lliyan Kotsev

7.4. Important bird areas and NATURA 2000 protected sites

lliyan Kotsev

7.5. Other protected animals

Danail Pavlov, Mariyana Filipova-Marinova

8. Fauna of the Bulgarian Black Sea sector

82

Maria Yankova

\section{Landscape diversity}

lliyan Kotsev, Mariyana Filipova-Marinova

9.1. Coastal landscapes

Iliyan Kotsev, Mariyana Filipova-Marinova

9.2. Submarine landscapes (seascapes)

lliyan Kotsev

\section{COASTAL AND MARINE HABITATS. PROTECTED AREAS} AND NATURA 2000 SITES

1. Coastal habitats

Mariyana Filipova-Marinova, Danail Pavlov, lliyan Kotsev

2. Marine habitats
3. National nature conservation areas and NATURA 2000 protected sites

lliyan Kotsev

IV. ARCHAEOLOGICAL SITES, HISTORICAL AND CULTURAL HERITAGE OF THE BULGARIAN BLACK SEA COAST

Preslav Peev

\section{SENSITIVITY MAPPING AND ASSESSMENT OF THE BULGARIAN} BLACK SEA COASTAL ZONE

Margarita Stancheva, Hristo Stanchev

VI. DESCRIPTION BY REGIONS OF THE BULGARIAN BLACK SEA COASTAL ZONE

Introduction

lliyan Kotsev

1. Northern coastal region.

Iliyan Kotsev, Maria Yankova, Mariyana Filipova-Marinova, Veselin Peychev, Preslav Peev

2. Central coastal region

Iliyan Kotsev, Maria Yankova, Mariyana Filipova-Marinova, Veselin Peychev, Preslav Peev

3. Southern coastal region

Iliyan Kotsev, Maria Yankova, Mariyana Filipova-Marinova, Veselin Peychev, Preslav Peev

\section{ACKNOWLEDGEMENTS.}

Margarita Stancheva, Hristo Stanchev, Iliyan Kotsev, Atanas Palazov

REFERENCES

lliyan Kotsev 
The Black Sea is a typical intercontinental enclosed-type marine basin, located between Europe and Asia, and seen as a constituent part of the Greater Mediterranean Sea. It fills up the so-called Black Sea Depression that is bordered by the East European Plain to the north, the Pontic Mountains of the Asia Minor Peninsula to the south, the Danubian Plain and the folded morphostructures of the Balkanides to the west, and the Caucasus Mountain Chain with the Colchis Lowland to the east [1]

Bulgaria's $432 \mathrm{~km}$-long shoreline [2] is part of the western periphery of the Black Sea basin. It is delimited by Cape Sivriburun to the north (marking the state border with Romania) and the Rezovska River mouth to the south (marking the state border with Turkey) [3]. The Bulgarian coastal zone is a rich mosaic of relic and modern morphologic forms, e.g., denudation surfaces, marine terraces, erosive cliffs and ravines, landslides, sandy beaches with dunes, river mouths, firths and lagoons. There are two larger bays, namely Varna and Burgas, named after the homonymous coastal cities, which are also the two major maritime ports of this European Union member state.

The biological and habitat diversity of the Bulgarian Black Sea littoral zone is outstanding. It includes at least 27 coastal and marine habitat types of fundamental nature conservation importance, plus numerous plant and animal species that are enlisted in the Red Data Book of the Republic of Bulgaria [4]. From the coastal steppes of Dobrudzha, via the native mesophilic and thermophilic woods of the northern coasta

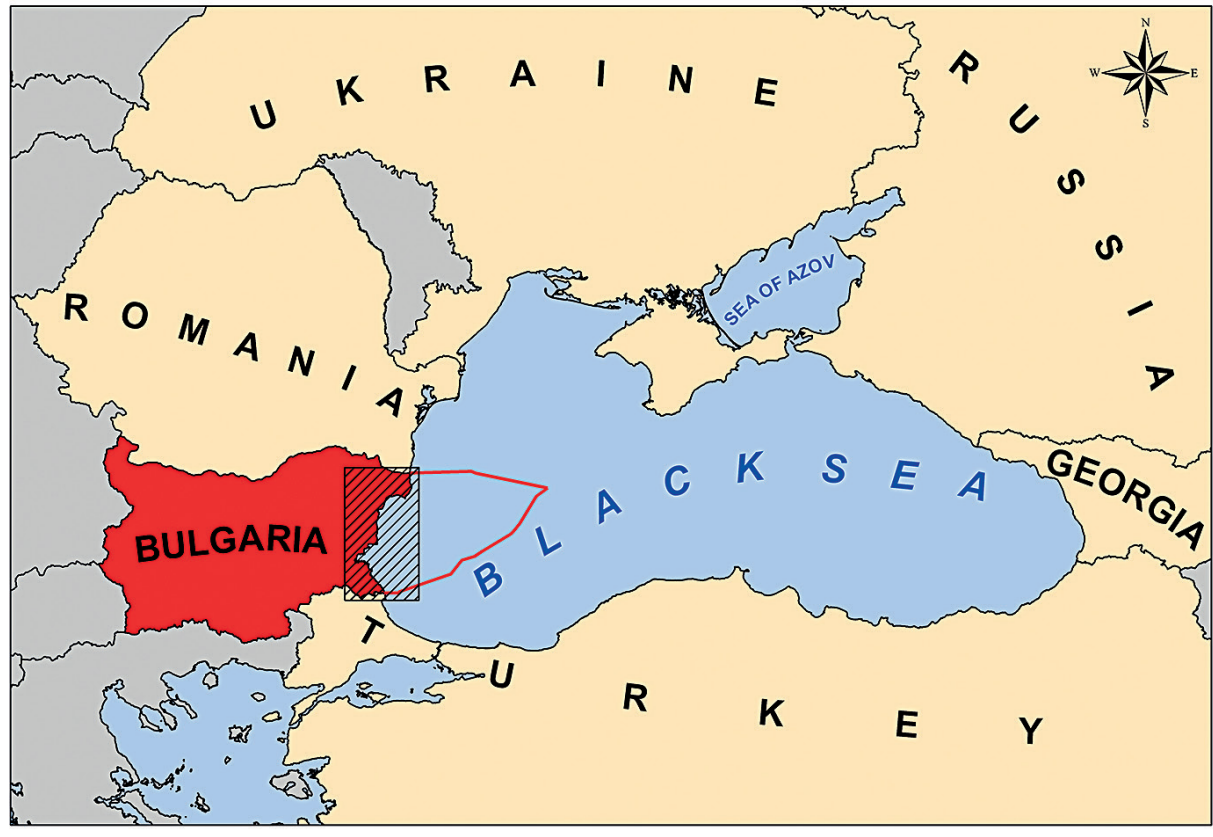

Geographic location of Bulgaria among the remaining Black Sea countries

(the red contours show Bulgaria's Exclusive Economic Zone; the black hatch illustrates the approximate extent of the study area)

plateaus, passing through the endemic hygrophilous longoz forests of the Batova, Kamchia, Ropotamo and Veleka River downstreams, eventually reaching the low-mountainous sub-Mediterranean landscapes of the East Balkan and Strandzha Mountains, the study area is indeed among the most heterogeneous physiographic districts on the Balkan Peninsula. In addition a rich diversity of seabirds is observed along the Bulgarian coast, since it lies on the Via Pontica bird migratory route [5]

The fragile archaeological, historical and cultural heritage of the Bulgarian coast is significant [e.g., 8; 9 10; 11]. It undisputedly belongs to the classical lands often referred to as the cradle of the modern civilization in Europe, alongside the nearby Aegean region. By sharing essential similarities in their development during Antiquity, these two formed a common Ponto-Aegean cultural and historical province that had a significant influence upon the early human societies in
Southeast Europe, Asia Minor, North Africa, the Caucasus, etc.

The vast sand strips with dunes and the mild humid subtropical (Mediterranean-like) climate [e.g., 6; 7] make the Bulgarian coast a preferred inexpensive destination for summer recreation with an active season lasting roughly from early May until early October Tourism is the leading source of revenues for the majority of the coastal settlements, and among the main sources of anthropogenic pressure [e.g., 12; 13; 14] Internationally renowned destinations include Albena Golden Sands, Varna, Obzor, Sunny Beach, Nesebar, Burgas, Sozopol, Primorsko, etc. [e.g., 1; 15; 16]

All of the above specifics of the Bulgarian Black Sea coast make it an immensely important and indeed very sensitive region in terms of its environmental, social and economic properties. 

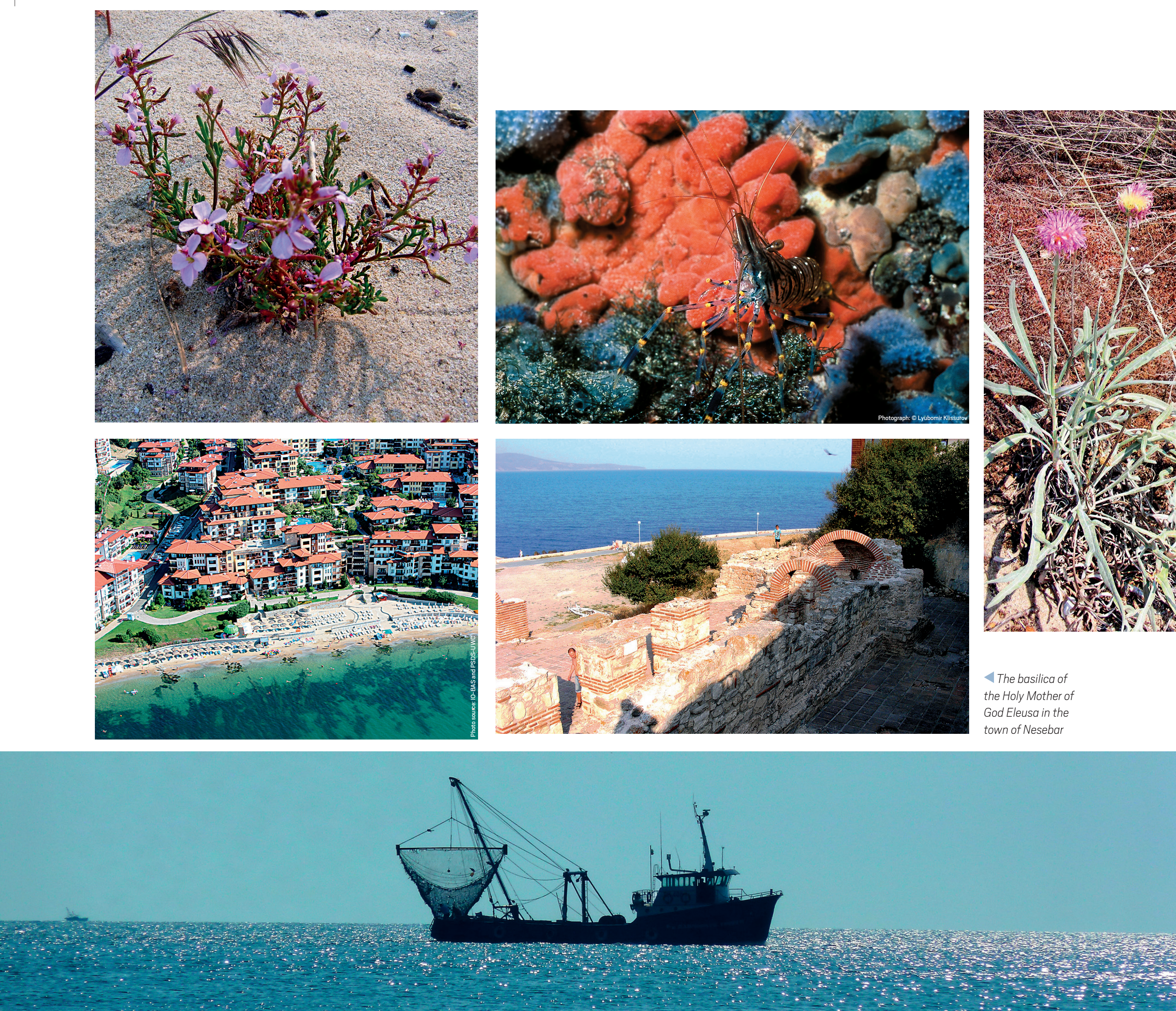

$\triangle$ The basilica of

the Holy Mother of

God Eleusa in the

town of Neseba 
A complex sensitivity assessment of the coastal and marine environment is a multistep process involving a detailed environmental and socio-economic analysis of a given study area. The Bulgarian Black Sea coastal zone encompasses a great variety of coastal and submarine landscape complexes, significant cultural heritage dating from various historical periods, an array of land/marine use practices, and an aggregation of critically important infrastructure. Hence, the aim of this book is to provide an accurate assessment of the importance and the environmental and socio-economic sensitivity of the following elements of the Bulgarian coastal zone:

- terrestrial and marine natural components and resources;

- nature conservation areas, archaeological and historical sites;

- human activities and critical infrastructure

This book will constitute a baseline and, thereby represents an important step in the coastal and marine management policy in Bulgaria with regard to the following:

- Preservation of the coastal and marine environment: the sensitivity assessment allows the identification of highly vulnerable areas which are to receive a priority protection status:

- Preservation of the archaeological, historical and cultural heritage of the Bulgarian Black Sea coast;

- Definition of environmentally friendly activities: the cross-sectional analysis of the physical and biological properties and the human activities (fishing, extraction of marine invertebrates, aquaculture farming, agriculture, residential and recreational areas, tourism, etc.) will lead to the identification of potential conflict zones;

- Elements of a strategic coastal zone sensitivity management plan that integrates the main objectives described above. The superposition of the maps and the accompanying analyses can highlight the sites with potentially high levels of sensitivity and risk. For each sensitive area an overall recommendation would be possible, leading to intervention priorities and specific management approaches [17].
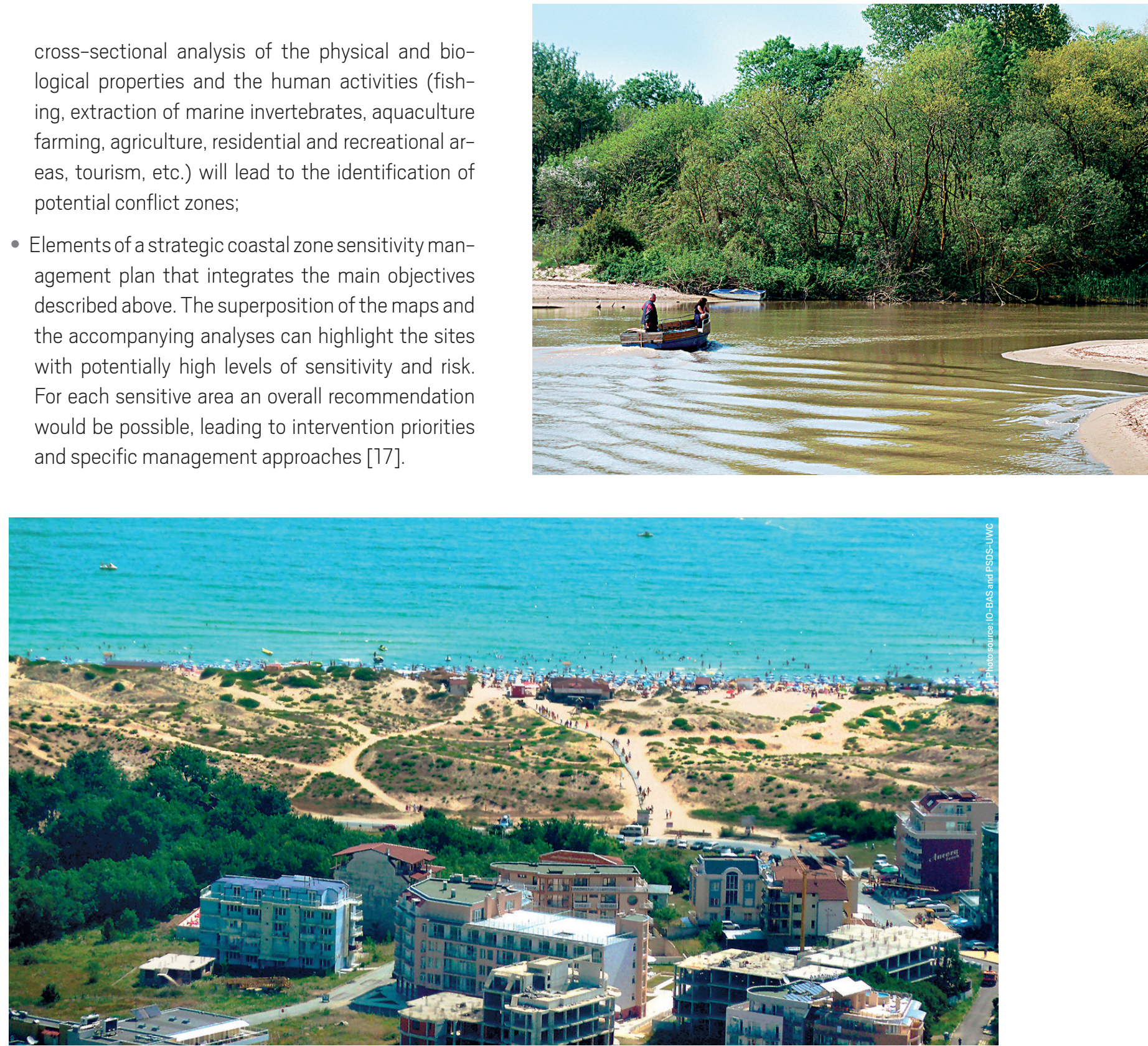


\section{Q}

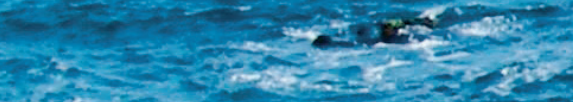

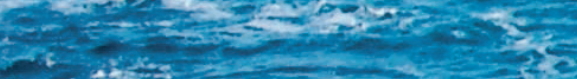

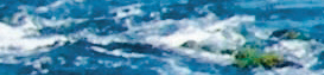

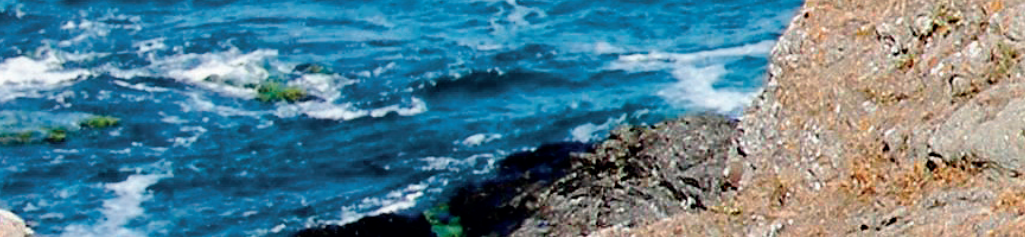

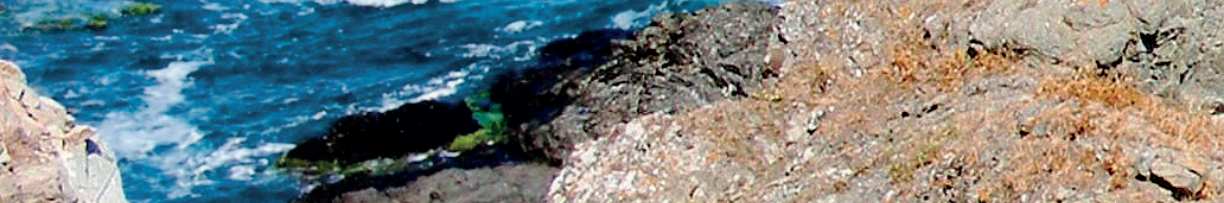

tien

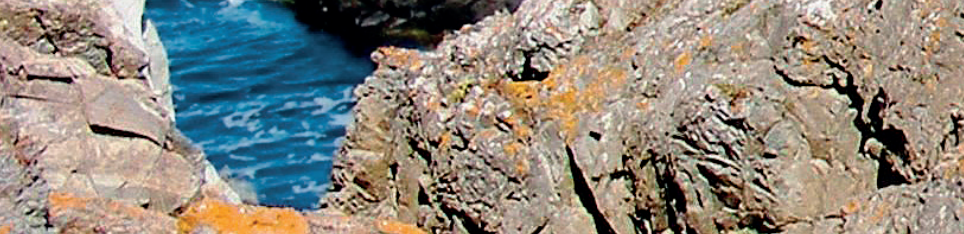

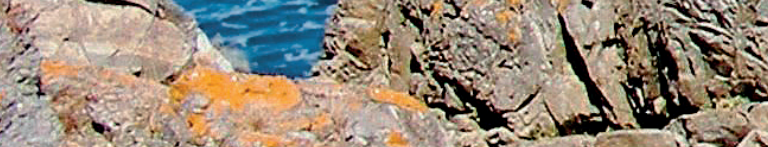

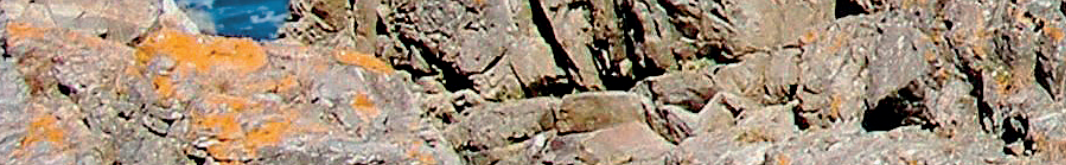

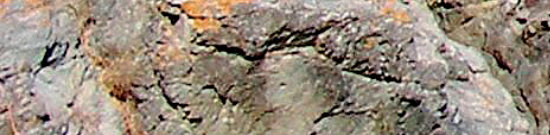

a

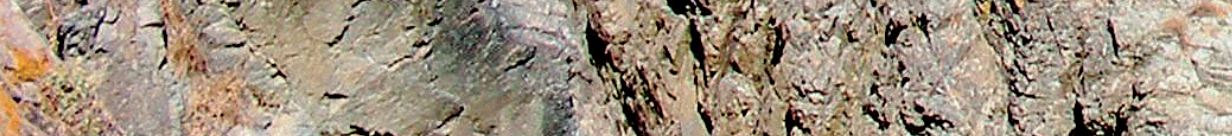

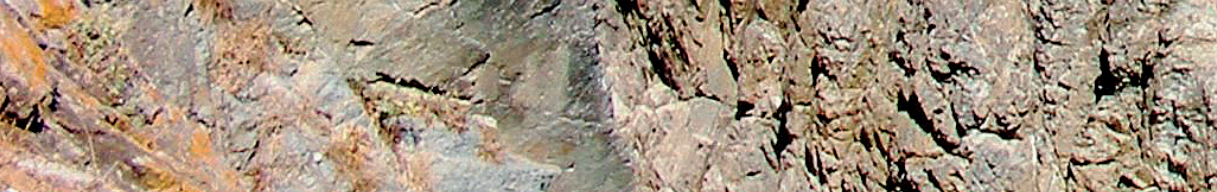

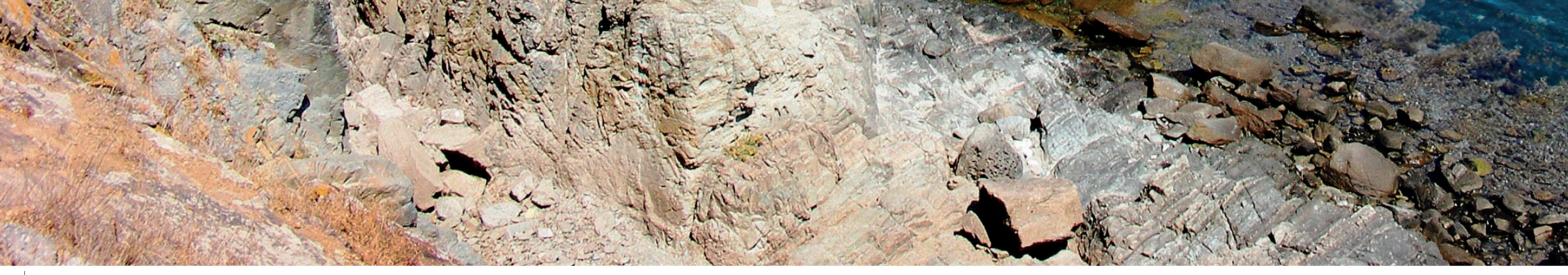




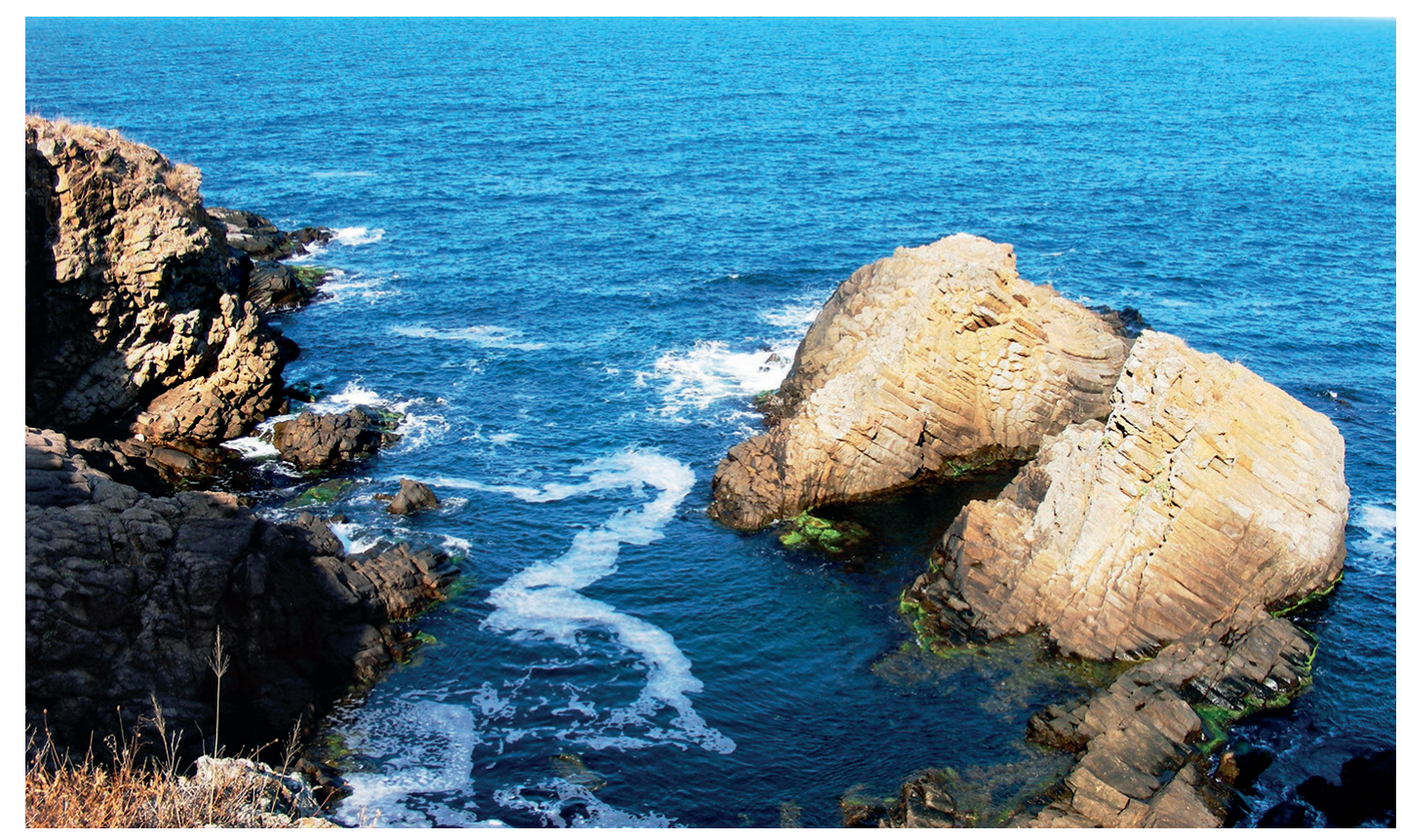

The Bulgarian Black Sea coast includes the easternmost parts of three of the main morphotectonic units which make up this country's territory - the Moesian Epiplatform Plain, the Balkanides (the epigeosynclinal system of the Balkan Mountains), and the Srednogorie block-fault region. In addition, the authors classify the Black Sea Depression as a separate morphostructural unit. Four major geological structures are distinguished within these, namely the Moesian (Danubian) Platform, the Kamchia Depression, the East Balkan zone and the Burgas Synclinorium with the embedded Burgas graben-syncline [1]. To the east, heading towards the sea basin, the above morphostructures gradually transform into the shelf zone and the continental slope of the Black Sea Depression [2]

\section{COASTAL GEOLOGY}

The Moesian (Danubian) Platform occupies the northern part of the Bulgarian Black Sea coast which stretches between the border with Romania to the north and the Kamchia River Valley to the south. Its lithostratigraphic composition is dominated by Miocene sedimentary strata, e.g., sandy limestones, sandstones, marls, clays, etc. A distinctive lithologic feature of the shore between Cape Sivriburun and Cape Shabla (Dobrudzha Plateau) however is the Quaternary loess cover that is up to $19 \mathrm{~m}$ thick
[1]. Except for the above region, the rest of the Dobrudzha coast consists of Sarmatian sedimentary strata, which also build up the lithostratigraphic pattern of the contiguous Franga Plateau at the Varna coastal area alongside layers of Konkian, Karaganian, Chokrakian and Tarkhanian age (Miocene) $[3 ; 4]$. Further south, excluding the Sarmatian, the geological structure of the Avren Plateau is again dominated by the above-mentioned stratigraphic units of the Miocene [5].

In geotectonic sense, the Kamchia Depression represents a transitional zone separating the Moesian Platform from the eastern part of the Balkan young-folded Alpine zone. Its fundament consists of Valanginian-Upper Cretaceous sediments, subsequently covered by thick Neozoic sedimentary strata [3]. The Quaternary deposits are presented by unconsolidated alluvial varieties, e.g., pebbles, sands, silts, clays, etc. The littoral zone of the Kamchia Depression is dominated by contemporary sand accumulations whose genesis is related to the erosion of Chokrakian sandstones [1].

The coastal part of the East Balkan Mountains is predominantly composed of Upper Cretaceous and Paleogene sedimentary strata, e.g., flysch deposits, sandstones, marls, conglomerates, limestones, etc. [4]. Here, the axes of the coastal synclines and anticlines can be clearly traced within the contiguous sector of the submarine coastal slope and even deeper on the shelf [3].

The shores of the Burgas Lowland, Medni rid Ridge and Strandzha Mountain fall within the eastern section of a vast morphostructure known as the Burgas Synclinorium. Its geological structure consists of predominantly Upper Cretaceous extrusive rocks, e.g., andesites, trachiandesites, trachites, volcanoclastic tuffs, etc., while the Burgas graben-syncline is dominated by Upper Eocene coal-rich formations and younger Pliocene, Pleistocene and Holocene sediments [3]. In particular, the coastal part of the Burgas Lowland consists of Paleogene and Neogene strata covered by younger Quaternary alluvial deposits. Further south, the shores of Medni rid and Strandzha are composed of Upper Cretaceous volcanogenic-sedimentary deposits formed by extrusive rocks, e.g., andesites, andesite tuffs, basalts, etc., with interbeds of marine sediments. At certain locations the coastal geology is also diversified by plutonic rocks, e.g., monzonites, monzodiorites, syenites, monzosyenites, etc. [4]. 


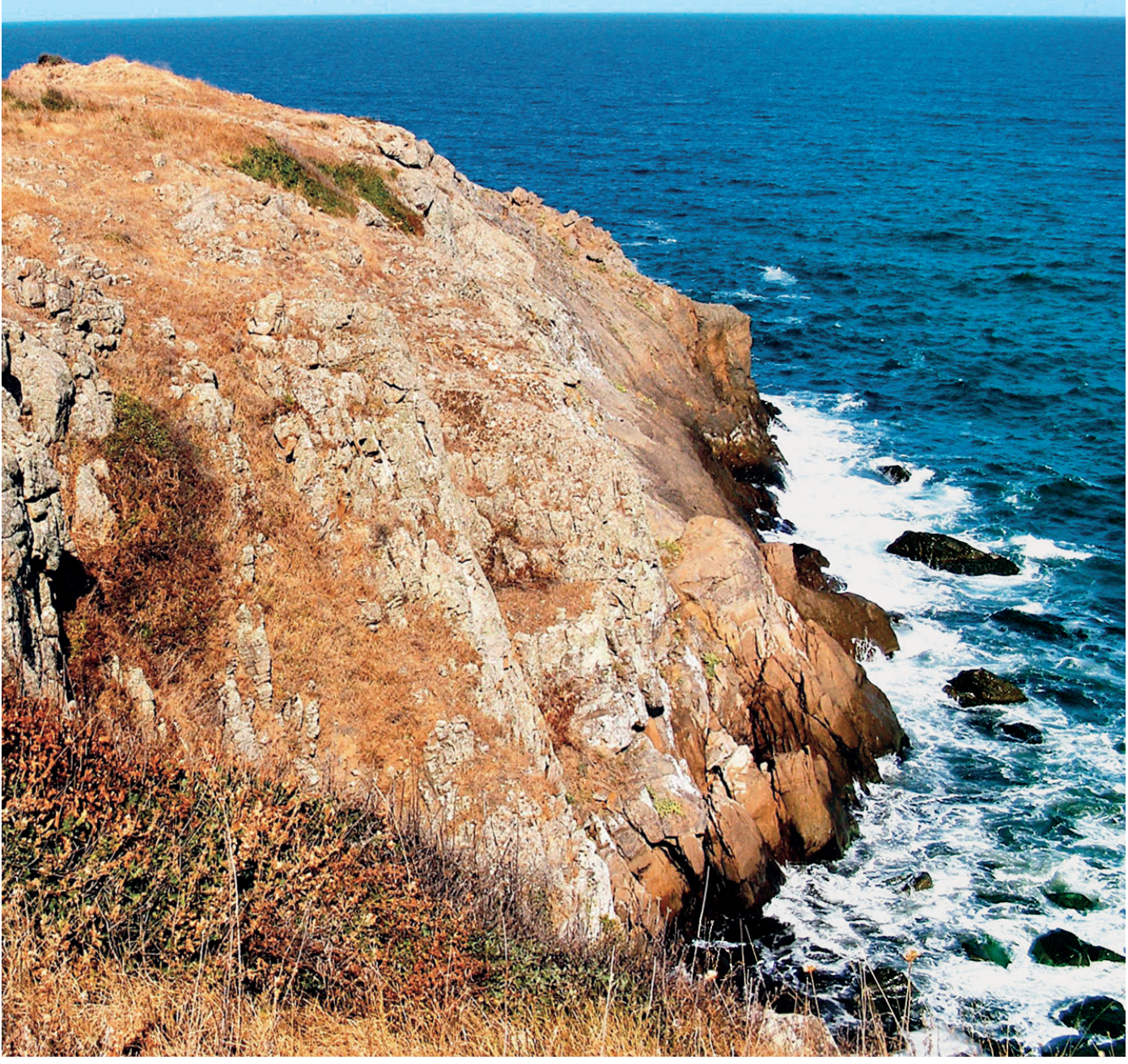

\section{SEAFLOOR GEOLOGY}

The Bulgarian Black Sea shelf represents a relatively shallow area of the sea floor (depths up to $200 \mathrm{~m}$ ), its width varying from 90 to $100 \mathrm{~km}$ to the north near the marine border with Romania to barely 45-50 km in front of the mouth of the Rezovska River that designates the state border with Turkey. In total, the shelf area of Bulgaria is approximately $12,200 \mathrm{~km}^{2}$ [6]. The contemporary sediments of Quaternary age ubiquitously dominate the seabed's lithologic composition. The dominant substrates within the limits of the submarine coastal slope are Holocene sands of various grain size and predominantly terrigenous origin along with a variety of sedimentary and igneous rocks whose geological ages reflect the paleogeographic development of the contiguous rocky coastal sectors.
Since the spatial variations of the deposition rates are controlled by a set of hydrodynamic factors, the Bulgarian Black Sea shelf can be divided into three regions based on differences in the sedimentary environment.

The northern shelf region comprises the seabed between the state border with Romania and Cape Kaliakra, reaching depths of 90-95 m and having a total area of approximately $2,850 \mathrm{~km}^{2}$. Its southern border marks the limit of occurrence of a specific sedimentary formation that consists of shell accumulations of the bean mussel (Modiolula phaseolina) and the Mediterranean (blue) mussel (Mytilus galloprovincialis) mixed with relatively small quantities of silt and sandy silt, typical for the submarine area in front of the Dobrudzha coast [7]. In addition to the above seabed substrates, greenish-grey to light green soft-malleable silts with large variations of the biogenic and terrigenous components are also frequently observed in the western section of the region [6]

The central shelf region covers a section of the accumulative shelf plain that stretches between Cape Kaliakra to the north and Cape Emine to the south occupying an area of approximately $3,470 \mathrm{~km}^{2}$. The seabed substrates are dominated by soft- and medium-malleable silts with varying quantities of shells and shell fragments, their color varying from green to greenish-grey to dark grey and greyish-black [6]

The southern shelf region stretches between Cape Emine to the north and the state border with Turkey to the south on an area of 2,924 km². Resembling the geological settings of the contiguous central shelf region, its northern section is characterized by homogenous seabed substrates dominated by soft- and medium-malleable silts with varying quantities of shells and shell fragments, while the southern section is characterized by the large number of sediment materials of terrigenous origin, eroded from the coastal source provinces at Medni rid Ridge and Strandzha Mountain [6]. 


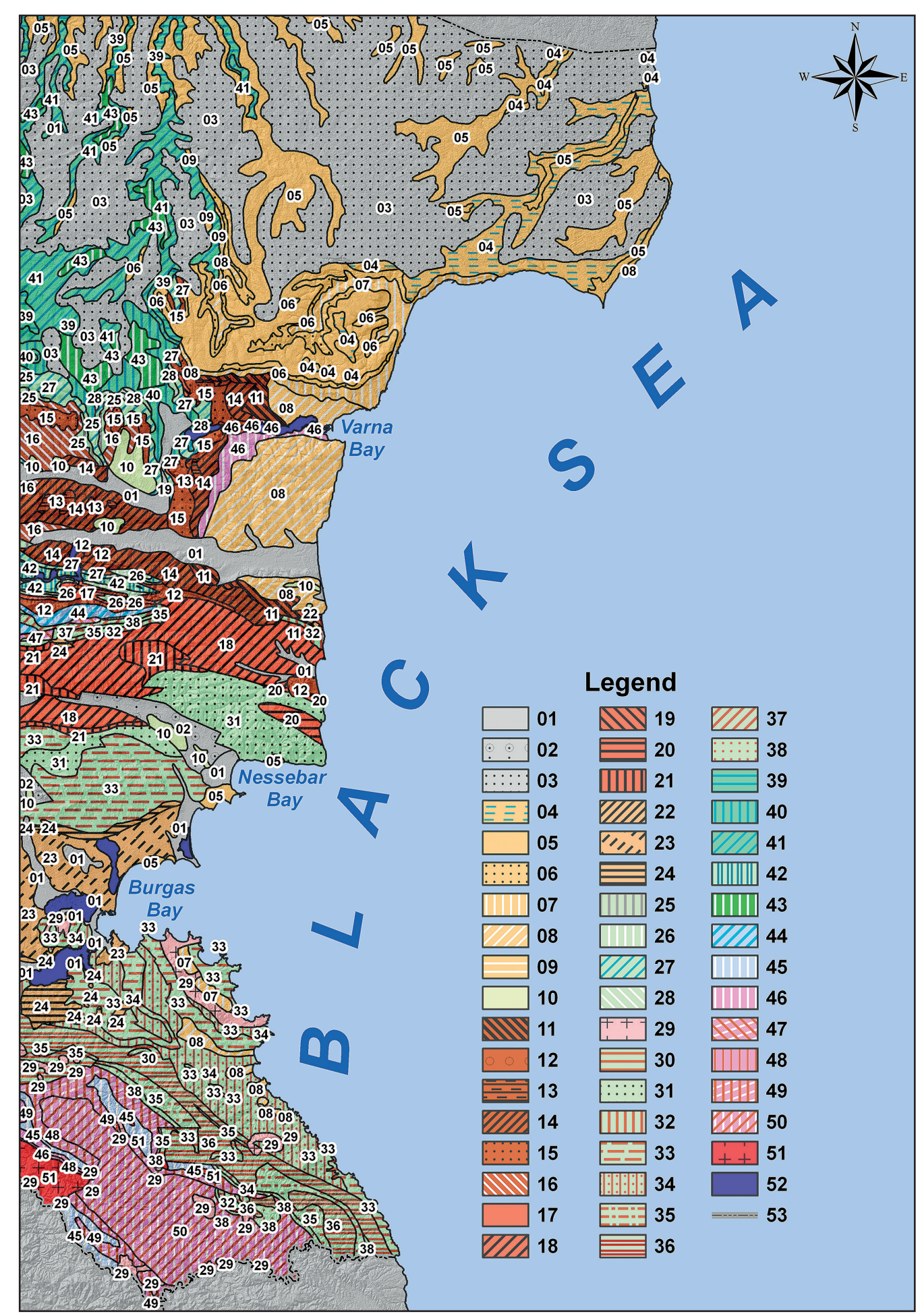

Geological map scheme of the Bulgarian Black Sea coast with the adjacent territory (after Cheshitev et al., 1989 [4] with modifications made by the authors)

\section{QUATERNARY:}

01. Alluvial sediments (pebbles and sands at floodplains and higher fluvial terraces, marine terraces and sand strips, swamp deposits)

02. Alluvial-drift and talus-drift sediments (boulders, pebbles, sands)

03. Aeolian sediments (loess, sandy loess, clayish loess)

\section{NEOGENE:}

A. Predominantly marine sediments in northern Bulgaria

A2. Euxino-Caspian basin. Miocene

04. Middle-Upper Sarmatian (Karvuna Formation - mactra limestones, in the area of Balchik, Kavarna and Topola Formation - banded clays and carbonates)

05. Middle Sarmatian (Odartsi Formation - limestones)

06. Lower-Middle Sarmatian (Franga Formation - sands)

07. Karaganian-Middle Sarmatian (Euxinograde Formation - clays)

08. Tarkhanian-Konkian (Galata Formation - sands with clay interbeds, west of Aksakovo sandstones and limestones)

09. Tarkhanian (Karapelit Formation - organogenic limestones)

B. Continental sediments in the superimposed depressions of southern Bulgaria

10. Neogene terrigenous sediments of Elhovo Formation in the Upper Thracian graben (conglomerates, sands, clays and undivided Neogene in northern Bulgaria)

\section{PALEOGENE:}

\section{A. Marine sedimentary rocks in northern Bulgaria}

11. Upper Eocene-Oligocene (Ruslar Formation - clays, marls, tuffs, manganese ores)

12. Upper Eocene (conglomerate formation - exotic conglomerates)

13. Upper Eocene (detritus sandstone formation - sandstones with detrital origin)

14. Middle-Upper Eocene (Avren Formation - marls, locally with interbeds of detrital sandstones)

15. Lower Eocene (Beloslav, Dikilitash and Aladun formations - clayish sands, sandstones and sands, nummulitic limestones)

16. Lower Eocene (Krivnya Formation - marls locally underlain by sandstones) 
17. Paleocene-Middle Eocene (siltstone and sandstone formation of Paleocene age and sandstone, marl and flysch-like formations of Eocene age)

18. Paleocene-Middle Eocene (flysch alternation of sandstones, siltstones and clays)

19. Thanetian (Komarevo Formation - limestones with flint, glauconitic calcareous sandstones and marls)

20. Undivided Paleocene (sandstone-clay formation - flysch alternation of clays and sandstones)

21. Undivided Paleocene (coarse flysch - alternation of sandstones, sandy limestones with flint, clayish marls, clays and packets of breccia-conglomerates)

B. Continental, partially marine sediments with volcanites in the superimposed depressions of southern Bulgaria

22. Oligocene (continental-molasse coal-rich sediments - conglomerate sandstones, coal-rich bituminous, locally only shale-bituminous formations, varicolored molasse formations, coal-rich formations and shale, locally bituminous formations)

23. Eocene-Oligocene (Mugris Formation - marls)

24. Upper Eocene (continental-molasse, locally also marine, coal-rich sediments - breccia-conglomeratesandstone formations, coal-rich-bitumolite formations, limestone-marl-sandstone flysch-like formations, varicolored molasse, slightly coal-rich formations, at the sub-Balkan grabens sandstone-limestone-marl formations with marine fauna also present)

\section{CRETACEOUS:}

\section{A. North European type}

25. Upper Maastrichtian (Kailaka Formation - limestones)

26. Santonian-Maastrichtian (Asparuhovo Formation - silty limestones, limestones with flint, limestones)

27. Upper Turonian-Maastrichtian (Dobri dol, Dobrina, Venchan and Shumen formations - terrigenous carbonate-rich rocks)

28. Cenomanian-Middle Turonian (Madara and Mogilata formations, at Shumen Plateau - only Madara Formation, southwest of Markovo village - only Mogilata Formation present, as well as sandstone formations at the foothills of the East Balkan Mountains - calcareous sandstones, silty limestones)

\section{B. Mediterranean type}

29. Intrusive magmatic rocks (gabbro, syeno-monzo-diorites, granodiorites, quartz monzonites, monzonites in the Srednogorie region)

30. Maastrichtian (terrigenous-carbonate formation - conglomerates, sandstones, clays, marls, organogenic limestones)

37. Campanian-Maastrichtian (flysch formations in the Srednogorie region, Emine Flysch Formation in the East Balkan Mountains)

32. Santonian-Campanian (carbonate formation - grey and red limestones, limestones with flint, in the East Balkan Mountains - Campanian-Maastrichtian)

33. Coniacian-Santonian (Burgas Group of volcanites - trachybasalts, trachyandesitobasalts, trachytes, potassium-rich trachytes in extrusive, explosive and sub-volcanic facies with sedimentary rocks sandstones, siltstones, marls, clayish limestones)

34. Coniacian-Santonian (Michurin Group of volcanites - basalts, andesitobasalts, in extrusive, explosive and subvolcanic facies, with rare packets of sedimentary rocks - sandstones, siltstones, shales)

35. Turonian-Santonian (Vurshilo Group in the eastern Srednogorie region, marl, sandstone breccia conglomerate and marl limestone formations in the East Balkan Mountains - marls, sandstones and breccia conglomerates, flysch and flysch-like sediments)
36. Turonian-Coniacian (Grudovo Group: sedimentary rocks - fine to block breccias with packets of sandstones, siltstones, shales, marls, clayish limestones, and volcanites basalts, trachybasalts, trachyandesitobasalts in extrusive, explosive and sub-volcanic facies)

37. Cenomanian-Turonian (flysch formation in Luda Kamchia part of the East Balkan Mountains sandstones, siltstones, clays, tuffs, andesites)

38. Cenomanian (sandstone formations in the East Balkan Mountains, Zelenkovska Formation in the eastern Srednogorie region - conglomerates, sandstones, quartzites, shales, coal, marls, reef limestones)

39. Hauterivian-Aptian (Ruse Formation, northeast of Todor Ikonomovo village, also Razgrad Formation limestones, clayish limestones)

40. Hauterivian-Aptian (Gorna Oriahovitsa Formation, east of Pavlikeni together with Pavlikeni Formation marls and clayish marls with sandstone interbeds, orbitoline sandstones)

41. Hauterivian-Aptian (Razgrad Formation - clayish limestones and marls)

42. Valanginian-Hauterivian (Kamchia Formation - thick packets of sandstones and marls)

43. Valanginian-Hauterivian (Kaspichan Formation - intraclastic, organogenic and aphanitic limestones)

\section{JURASSIC:}

44. Middle Jurassic (shales and flysch with olistolites of Lower Jurassic and Triassic rocks - alternation of shales and sandstones)

45. Hettangian-Bathonian (Eastern Thracian Group of sedimentary rocks with low levels of metamorfism - quartzites, quartzitic sandstones, siltstones, re-crystallized limestones, ferruginized biodetrital limestones, slates)

\section{TRIASSIC:}

\section{A. Balkanide typ}

46. Lower-Upper Triassic (Iskar Carbonate Group - limestones, dolomitic limestones, dolomites and occasionally shales, sandstones, siltstones)

\section{B. East Balkan type}

47. Lower-Upper Triassic (marls, limestones, flysch with olistolites of Campilian-Carnian rocks interbeddings of marls, siltstones, sandstones, conglomerates)

\section{Sakar type}

48. Lower Triassic (Tundzha Group - arkose sandstones, siltstones, slates, metaconglomerates, metasandstones)

\section{Strandzha type}

49. Anisian-Norian (Bosna Group - marbles, limestones and re-crystallized limestones)

50. Lower Triassic-Anisian (Grahilovo Group of rocks with low levels of metamorfism - metasandstones, metapelites, marbles and metavolcanites)

VI. CARBONIFEROUS:

51. Late Paleozoic (Hercynian intrusive rocks granites in southern Bulgaria)

\section{ACCOMPANYING MAP SYMBOLS}

52. Inland water basins (lakes, firths, lagoons, reservoirs)

53. Terrestrial state borders with Romania (north) and Turkey (south) 


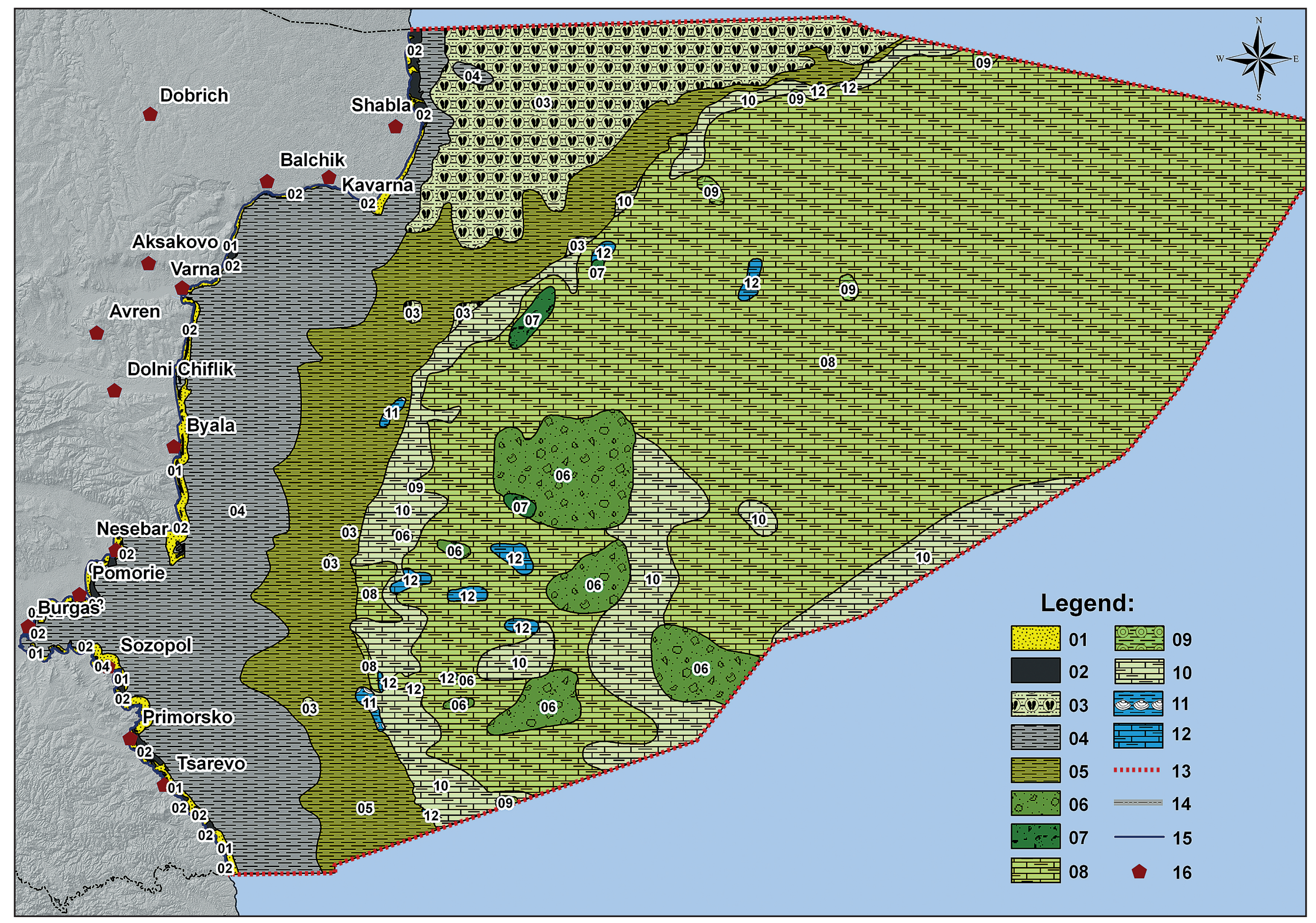

18 GEOLOGICAL SETTINGS OF THE BULGARIAN BLACK SEA COAST AND SHELF 
Map scheme of the surface seafloor substrates within the boundaries of the Bulgarian Exclusive Economic Zone (EEZ) in the Black Sea (after Kozhuharov et al., 2010 [7] Dimitrov et al., 2013 [6]; Prodanov, 2017 [8] with modifications made by the authors):

\section{HOLOCENE:}

\section{Sands}

02. Rocks (of various geological ages)

03. Shell accumulations of Modiolula phaseolina and Mytilus galloprovincialis with a sandy clay matrix

04. Soft-malleable terrigenous silts with whole shells and shell fragments

05. Medium-malleable terrigenous silts with whole shells and shell fragments

06. Intraclastic breccias

07. Silts - biogenic facies (sapropels)

08. Silts - calcareous-biogenic facies

09. Silts - clayish facies

10. Silts - siliceous biogenic facies

\section{PLEISTOCENE}

11. Clayish silts with whole shells and shell fragments

12.Terrigenous calcareous-clayish silts

III. ACCOMPANYING MAP SYMBOLS:

13. Borders of the Bulgarian EEZ in the Black Sea

14. Terrestrial state borders with Romania (north) and Turkey (south)

15. Present-day coastline

16. Regional and municipal centers along the coast

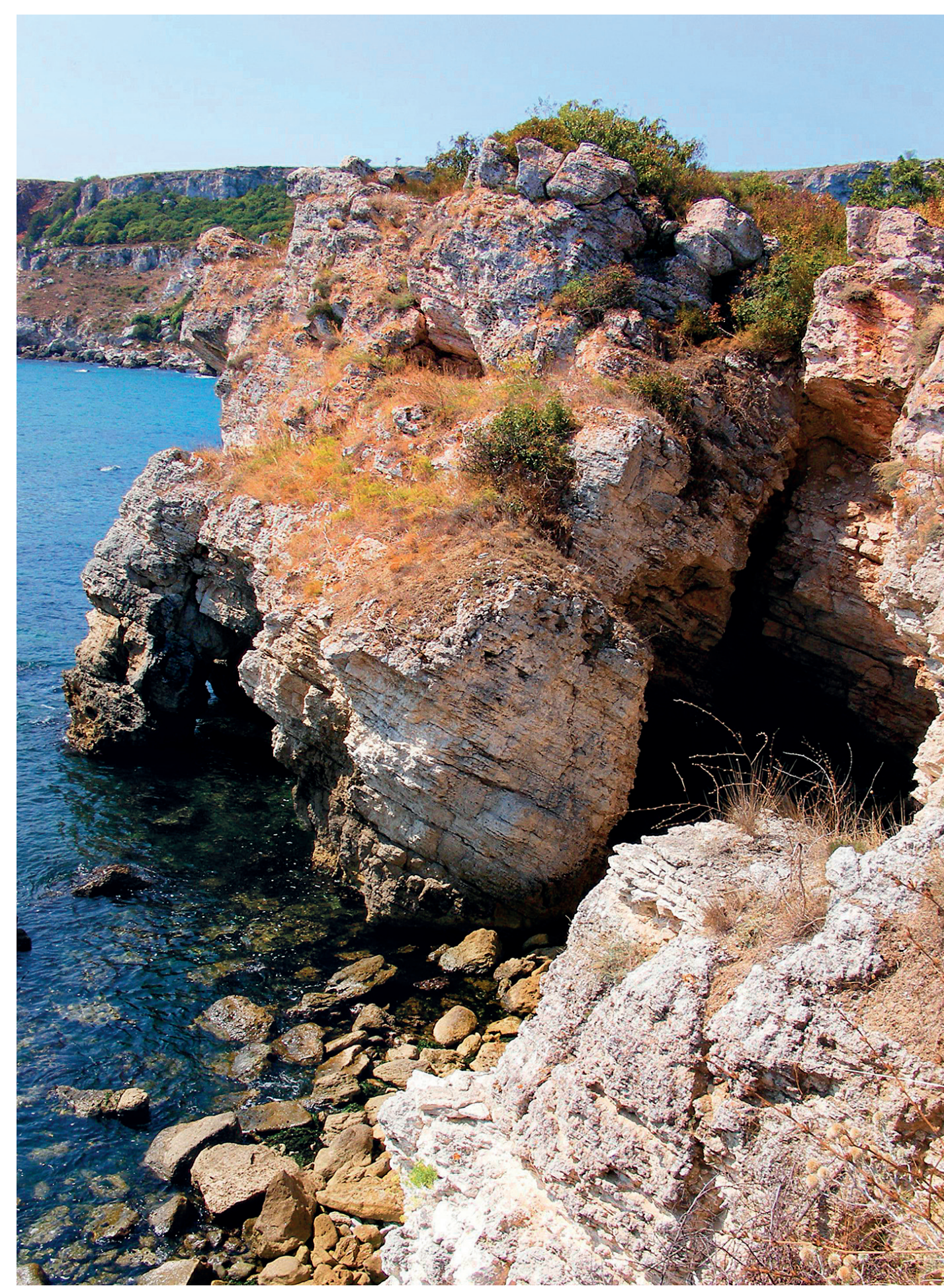

SENSITIVITY MAPPING AND ANALYSIS OF THE BULGARIAN BLACK SEA COASTAL ZONE 


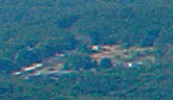

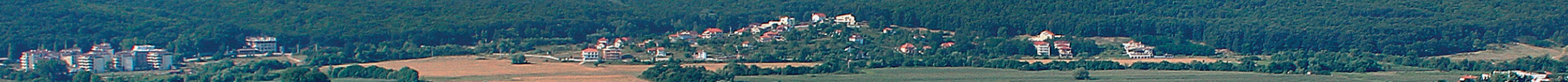

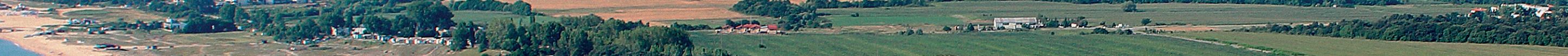

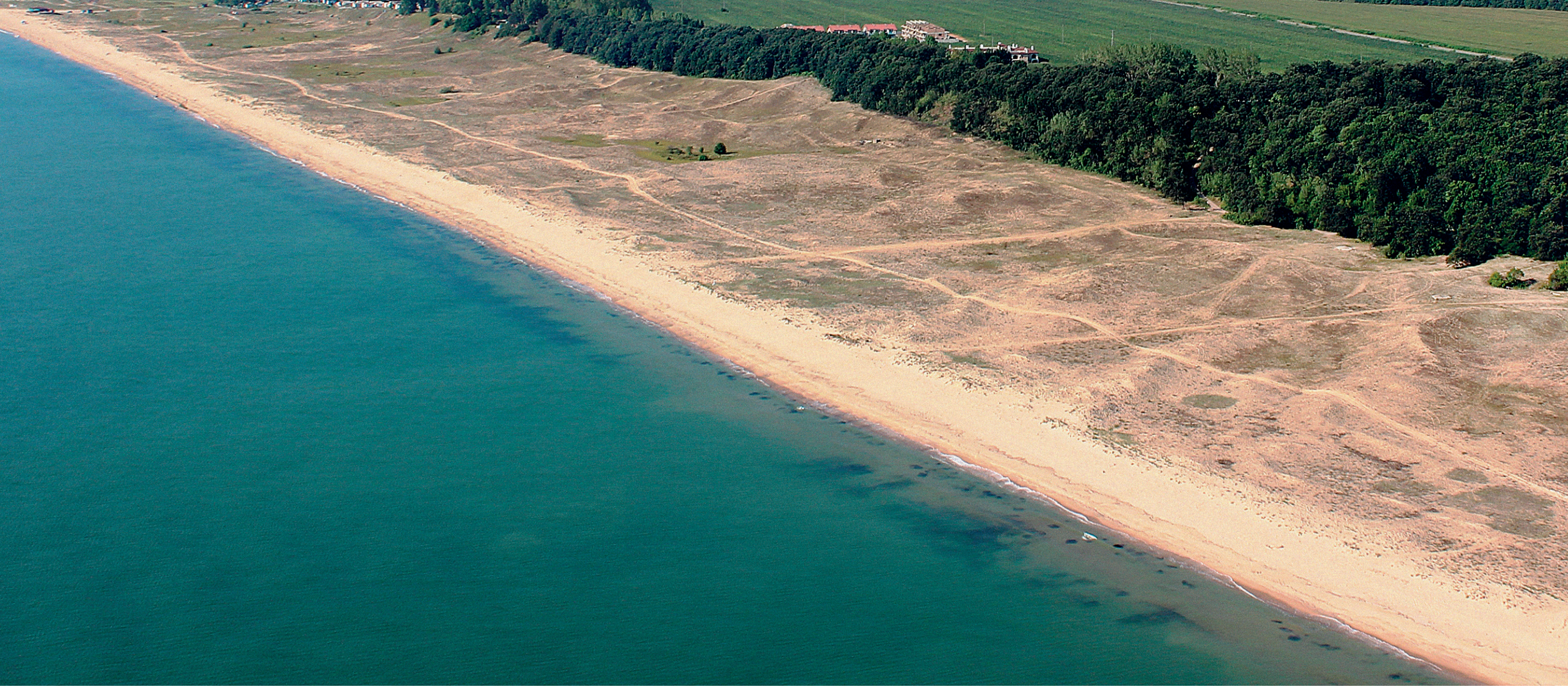


PHYSIOGRAPHIC AND OCEANOGRAPHIC CHARACTERISTICS OF THE STUDY AREA 


\section{GEOMORPHIC PATTERN AND MORPHOLOGICAL FORMS OF THE COASTAL AND SUBMARINE RELIEF}

The modern relief formation of Bulgaria's Black Sea coast and shelf is a result of the complex interaction between tectonics, neotectonic movements and erosion-abrasion processes $[3 ; 9 ; 10 ; 11 ; 12 ; 13$, etc.]. The geomorphic development of the shoreline is closely related to climate change and the associated marine transgressions and regressions during the Neogene and the Quaternary $[3 ; 14 ; 15 ; 16 ; 17 ; 18$, etc.], as well as the present-day exogenous (i.e., morphosculptural), geo- and morphodynamic processes $[19 ; 20 ; 21 ; 22 ; 23 ; 24 ; 25$, etc.]. The complexity of the Bulgarian coast's topography is attributed to the agents of the morphogenesis discussed above and is characterized by a variety of coastal types - e.g., rocky cliffs, sandy beaches and dunes, low-lying parts of bays, firths, lagoons, etc. [3; 9; 24; 25].

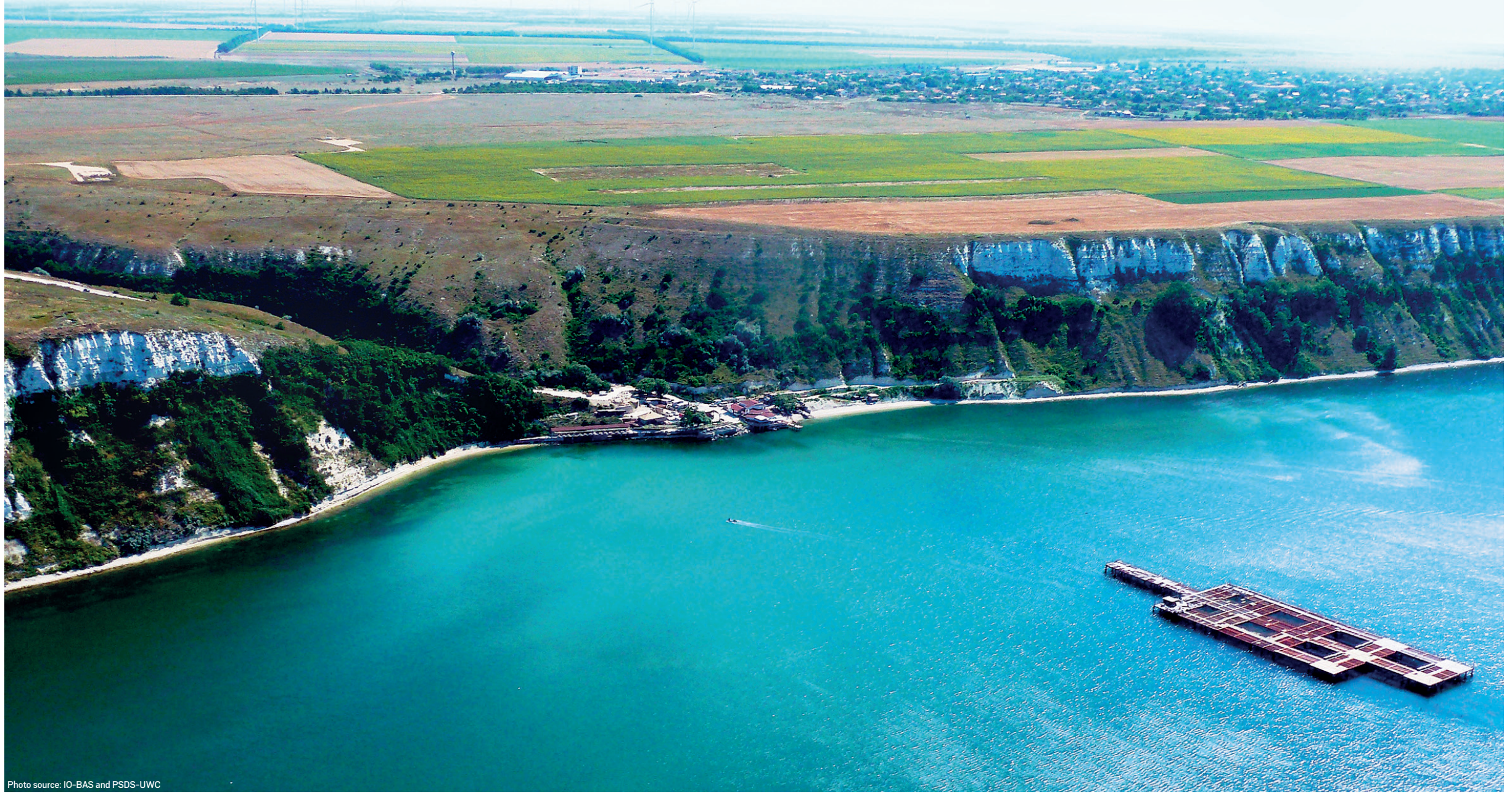

The plain appearance of the agricultural landscapes on Dobrudzha coast (top section of photograph) is due to the Levantian denudation surface. The erosive ravine at Dalboka locality in the area of Balgarevo (left section of photograph) 


\subsection{COASTAL MORPHOLOGY}

Denudation surfaces. Denudation surfaces of Sarmato-Pontian (Middle-Late Miocene), Pontian (Late Miocene) and Levantian (Late Pliocene) age are ubiquitously present across the inland coastal areas. Their hypsometric position varies from $80 \mathrm{~m}$ to $400 \mathrm{~m}$ above sea level depending on the particular area $[3 ; 14 ; 26]$.
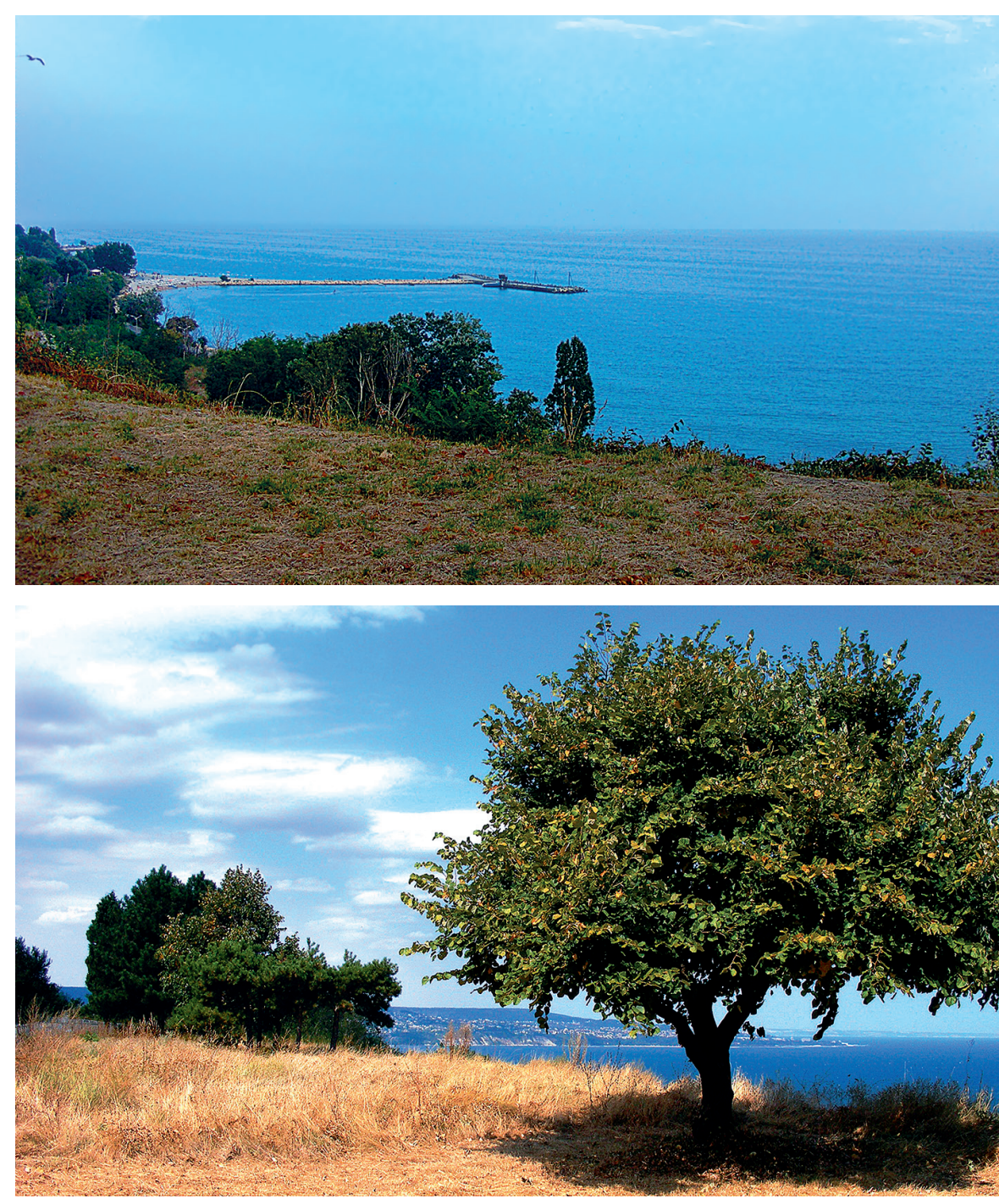

Fragments of marine terraces at Varna Sea Garden, Varna coastal area (above) and Cape Galata near Varna city (below)
Marine terraces. Paleo-erosion or paleo-accumulation types of marine terraces are a rather distinctive and widespread feature along the Bulgarian Black Sea coast. The precise geochronological dating of these landforms remains an open issue and is subject to ongoing paleogeographic, geological and geomorphologic investigations in the Black Sea region $[3 ; 9 ; 15 ; 28$, etc.]

Gullies and ravines. Coastal gullies and ravines, especially ones developed in erosion-prone lithology (e.g., loess, unconsolidated sand, sandstones, etc.) are of major importance as nourishing provinces of the natural sand strips [e.g., 24; 29; 30, etc.] Their genesis and evolution are associated with a number of factors such as the vertical movements of the coastal morphotectonic blocks [31], the specifics of the shore's lithostratigraphic structure [2], the presence/absence and type of vegetation cover, as well as the anthropogenic activity.

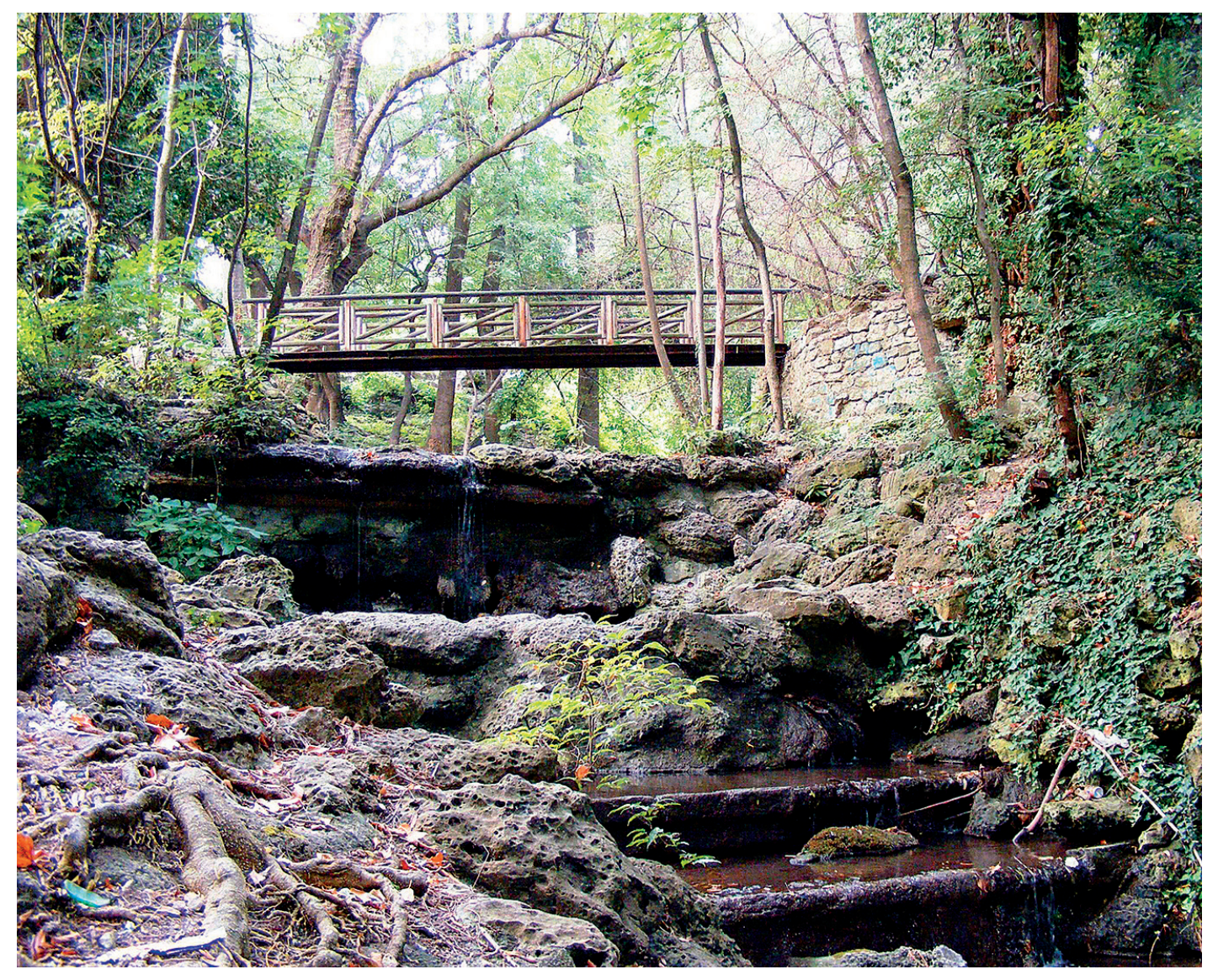

One of the erosive ravines in Varna Sea Garden (Varna coastal area), now a tourist attraction 

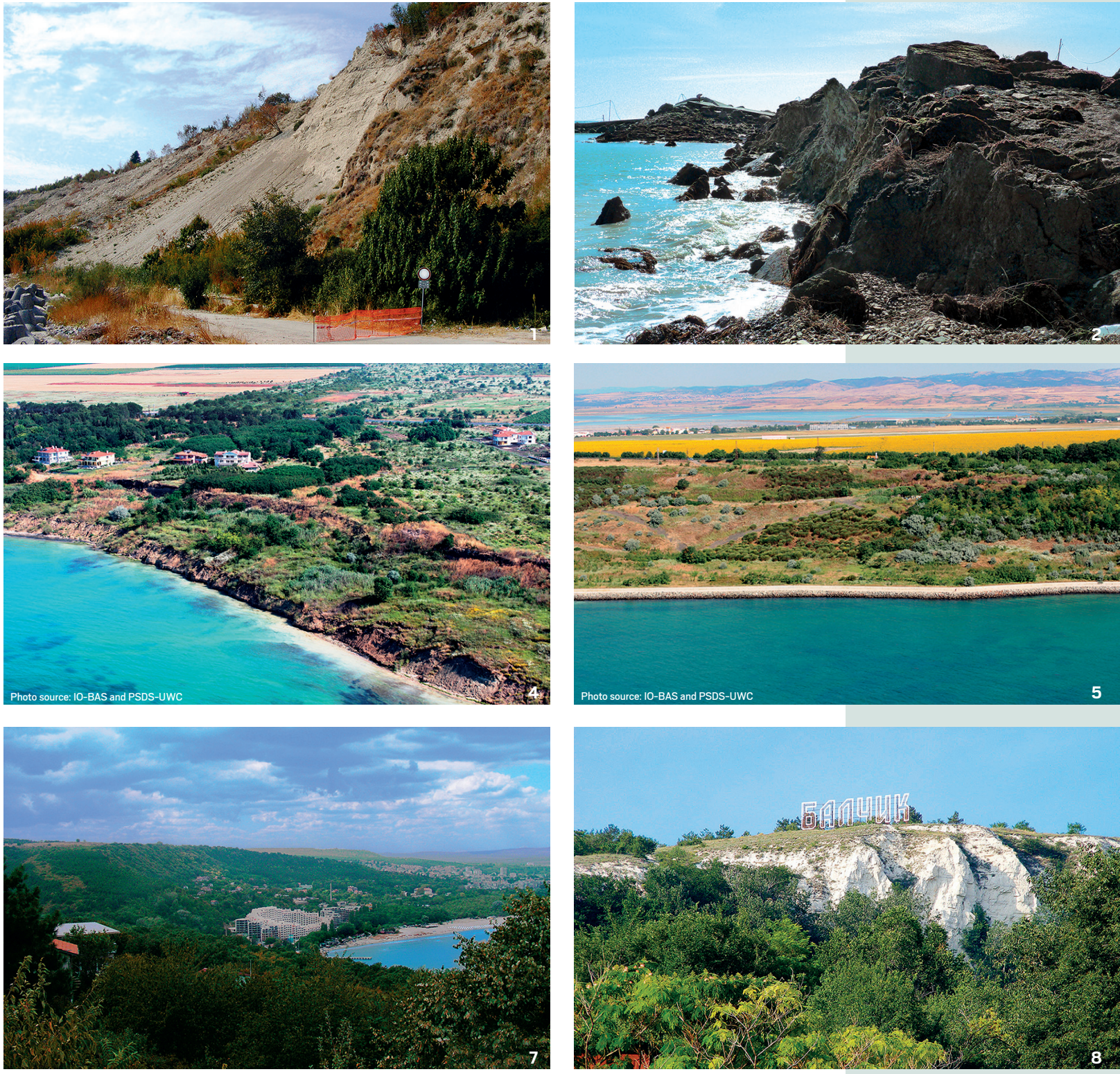
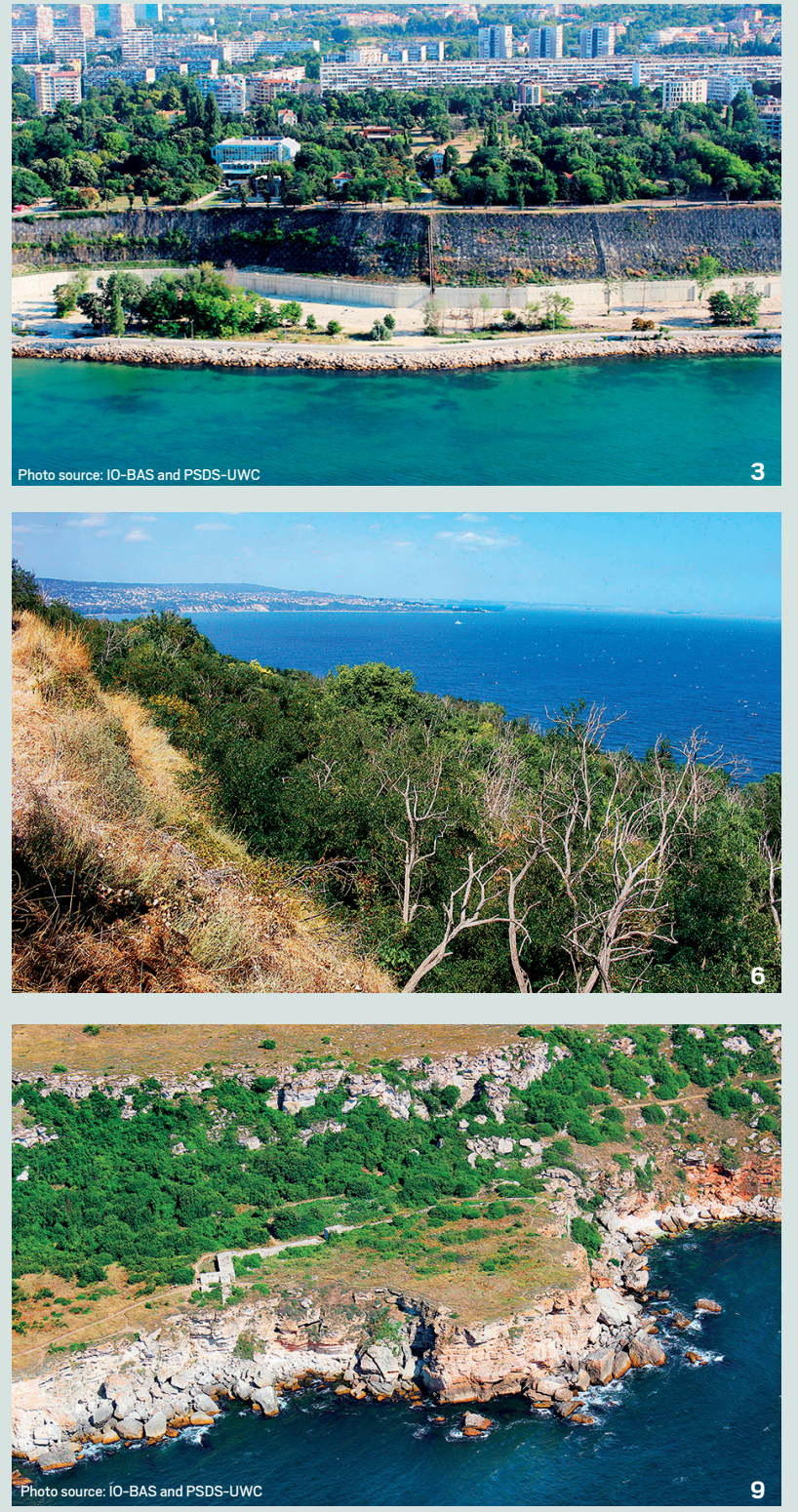

Landslides. Despite being a multivariate geodynamic process, landslide activity on the Bulgarian Black Sea coast is primarily caused by exogenous processes, i.e., wave-induced cliff erosion, surface erosion, ground water discharge, etc. Working along with neotectonic movements and human-induced factors, their occurrence is provoked by the lithostratigraphic settings of the affected shoreline segments, usually consisting of alternating solid and loose (often clayish) sedimentary strata [21].

24 PHYSIOGRAPHIC AND OCEANOGRAPHIC CHARACTERISTICS OF THE STUDY AREA
Examples of active and stabilized landslides on the Bulgarian coast:

1 \& 2. Cape Ekrene (Varna coastal area)

3. Geotextile and concrete reinforcement of a landslide slope in Varna Sea Garden

4 \& 5. Landslide slopes near Cape Lahna in Sarafovo district area of Burgas city and stabilization methods using afforestation and dikes

6 \& 7. Naturally vegetated landslide cliffs near Cape Galata and above Asparuhovo beach in Varna city 8 \& 9. Scarcely vegetated landslide cliffs on the North Bulgarian Black Sea coast near Balchik and at Yaylata Archaeological Reserve 
Landslides on the Bulgarian Black Sea coast total 79 covering $12 \%$ of its length (about $45 \mathrm{~km}$ ) on an area of $37 \mathrm{~km}^{2}$ [38]. They are mainly formed at the sea-facing slopes of the Dobrudzha Plateau (northern part of the Bulgarian coast) and Franga Plateau (Varna city area) in particular. These landslides represent the vastest geomorphic complexes of this kind along the Bulgarian coast. Smaller landslide complexes have also developed in the Avren Plateau coastal area, Kamchia and Emine Mountains, Burgas Bay, Medni rid Ridge and Strandzha Mountain [2; 3].

Cliffs. Cliffed shorelines are the most common type on the Bulgarian Black Sea coast comprising $49.3 \%$, or $213 \mathrm{~km}$ of the entire shoreline [35]. Remarkable examples include cliffs on the northern coast (Cape Kaliakra; Cape Galata), the middle portion of the coast (Cape Beli nos; Cape Emine), and the coast south of Sozopol (Cape Maslen nos; Cape Rezovo)
Variety of cliff types on the Bulgarian coast

1. The cliff at Yaylata Archaeological Reserve (North Bulgarian coast)

2. A spectacular $70 \mathrm{~m}$-high limestone cliff at Cape Kaliakra (North Bulgarian coast)

3. Belite skali, or The White Cliffs, Natural Landmark near Byala (Central Bulgarian coast)

4. The cliff at Cape Emine (Central Bulgarian coast)

5 \& 6. Cliffs formed by igneous rocks (South Bulgarian coast)
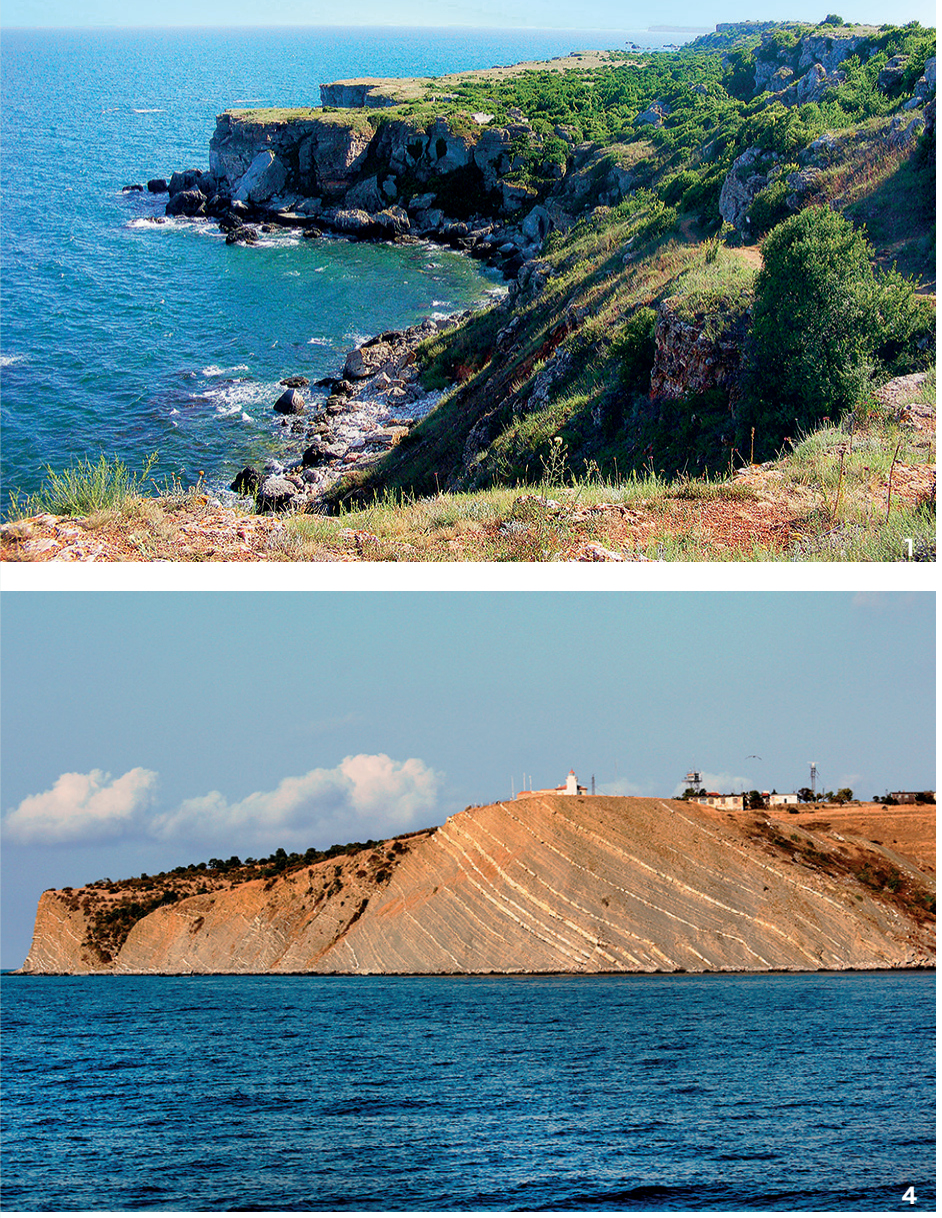
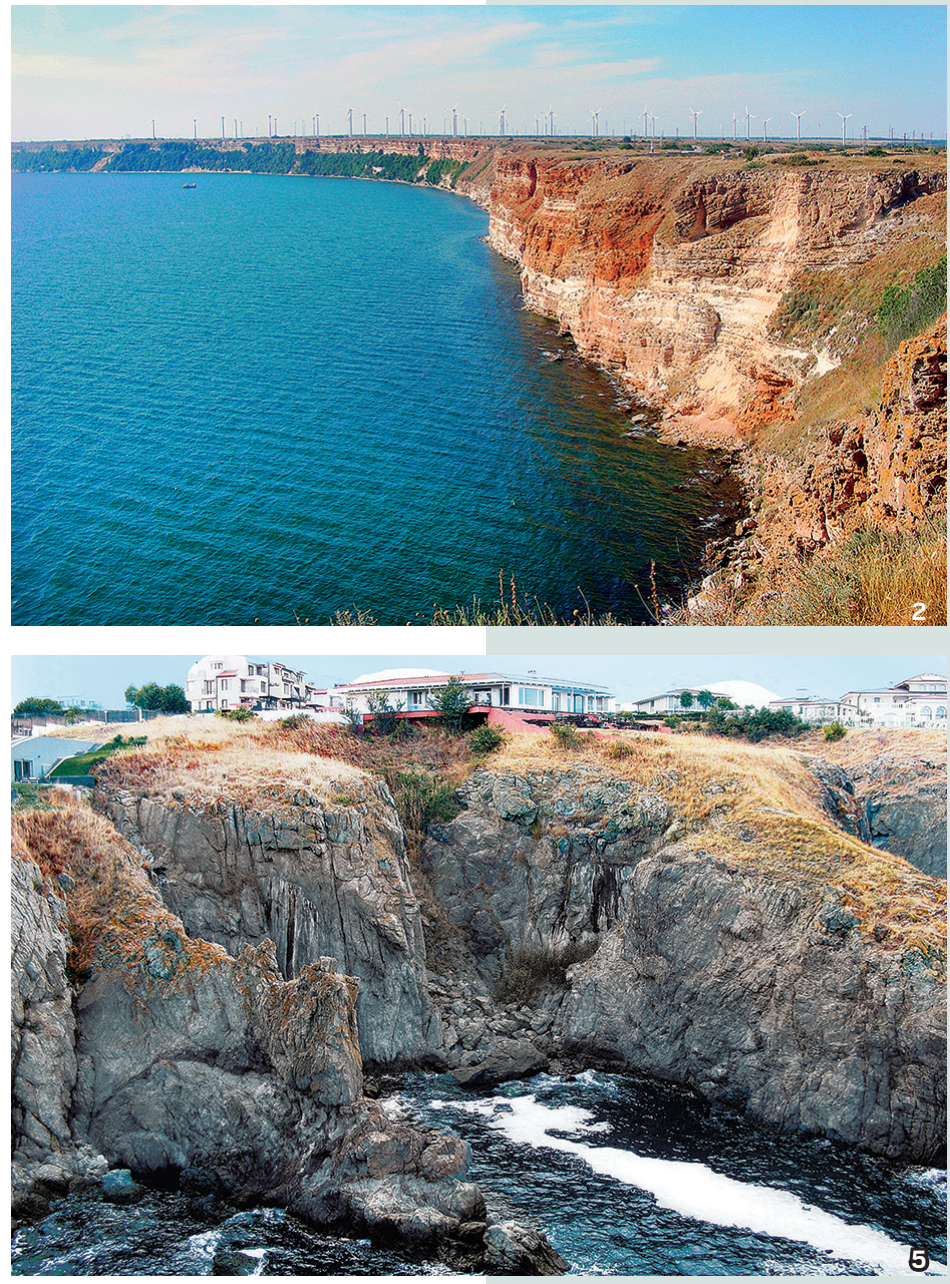
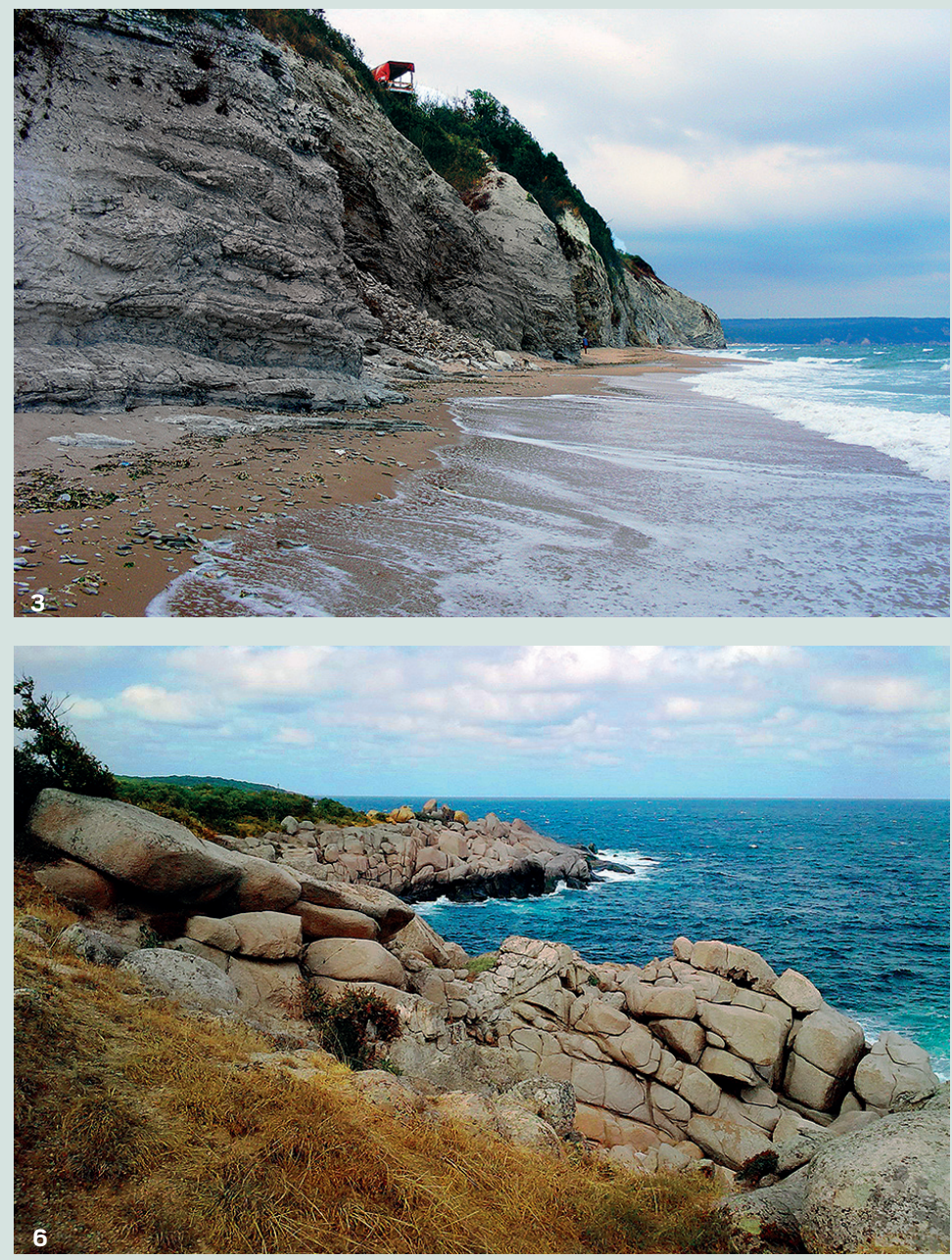

25

SENSITIVITY MAPPING AND ANALYSIS OF THE BULGARIAN BLACK SEA COASTAL ZONE 
Erosive-denudational slopes. This type of landforms is widely spread on the Bulgarian coast at surfaces with inclination exceeding $5^{\circ}$ [27] and where the subaereal morphosculptural processes prevail over those associated with wave activity. This topographic type commonly comprises highly dynamic steep erosive sectors of the above-mentioned denudation surfaces, marine terraces, gullies, ravines, landslides, and erosive cliffs.
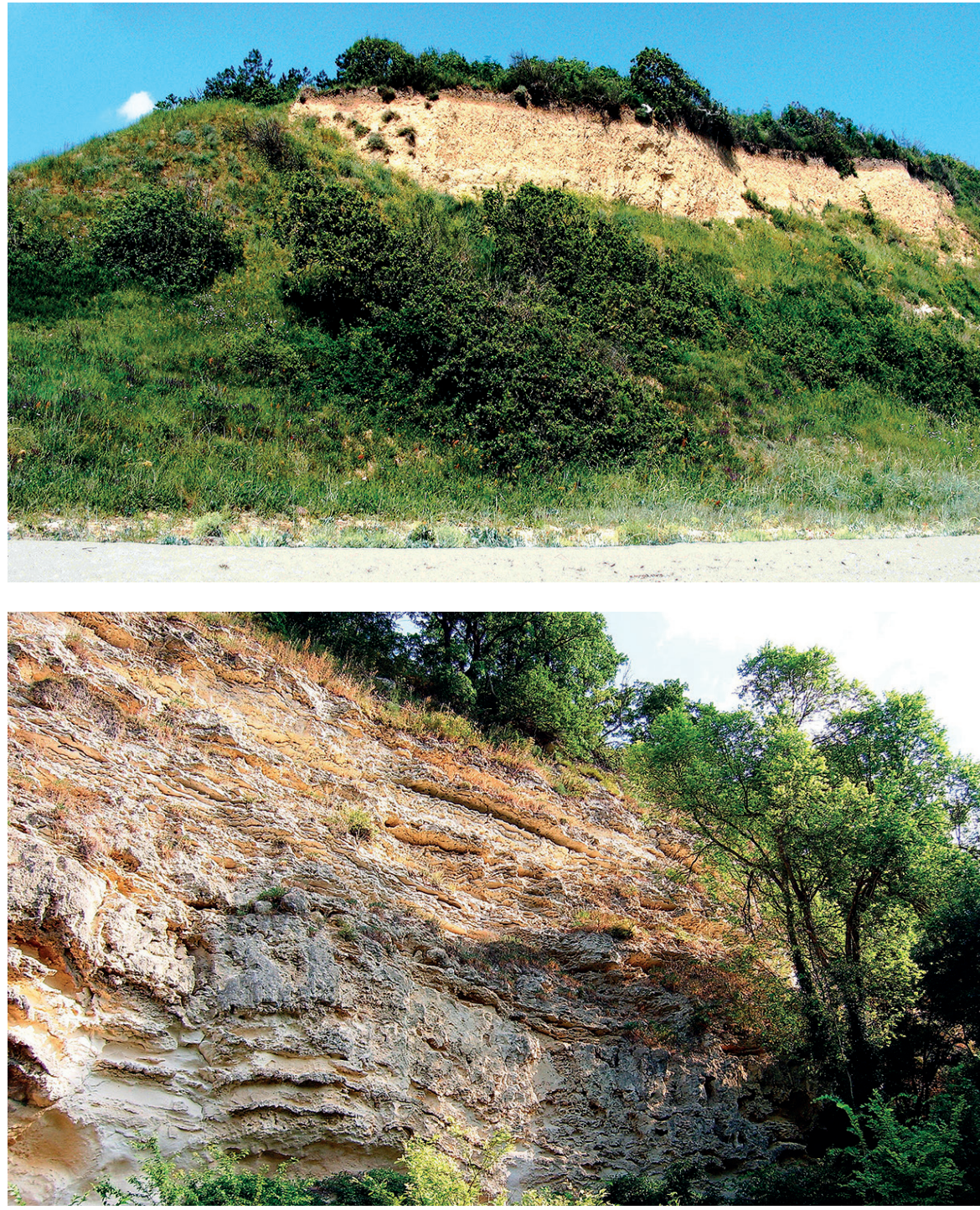

Erosive-denudational slopes formed in a loess clay facies near the firth of Pasha Dere, Avren Plateau coastal zone (above) and in a sandy limestone facies above Golden Sands Resort, Franga Plateau (below)
Karst landforms. Karst relief on the Bulgarian Black Sea coast is mainly associated with the occurrence of Neogene sedimentary strata, e.g., Sarmatian limestones and calcareous sandstones. Among the exposed karst landforms, the most prominent are the ones called kayryatsi, or open karren (clints) fields with sparse vegetation, observed on the Dobrudzha coast, which were normally used as pastures in the past. Other features of the coastal karst relief are the sea arches, sea caves and sea stacks, commonly observed on the North Bulgarian coast [2]

Bulgarian Black Sea islands. Five small islands and several rocky islets in the Black Sea belong to Bulgaria. The five islands - Sveta Anastasia (Burgas Bay), Sveti Kirik (nowadays part of Sozopol harbor), Sveti Ivan and Sveti Petar (Sozopol Bay) and Sveti Toma (a.k.a. Snake Island, located northwest of Cape Maslen nos) are located along the southern portion of the coast. These uninhabited islands are of the continental type, hence their geology and geomorphology resemble the nearby shoreline areas [34].

Firths and lagoons. A total of 28 firths and five lagoons exist in the Bulgarian Black Sea coastal zone. In general, firths are drowned river mouths, while lagoons are shallow former inlets and bays separated from the sea by sand spits. Both types were formed in result of the combination of sea-level rise and vertical land movements (subsidence) during the Holocene. These types of relief are typical for the South Bulgarian coast, the largest complex being the one neighboring Burgas [3; 24; 34, etc.].

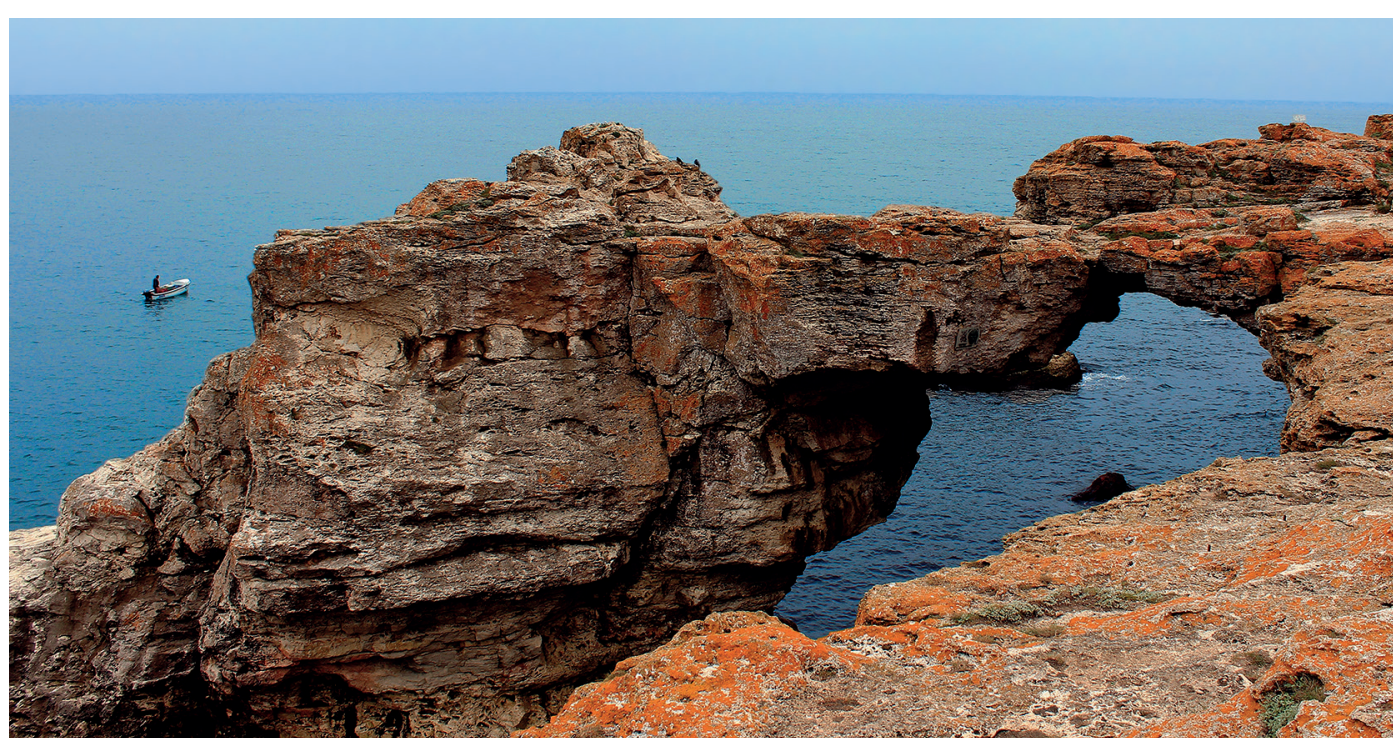


Distinctive karst landforms on the North Bulgarian coast:

1. The sea arch near Tyulenovo

2\& 3. Open karren (clints) fields (kayryatsi) on Dobrudzha coast near Cape Shabla and Yaylata Archaeological Reserve

4. Sea caves on Dobrudzha coast between Tyulenovo and Kamen bryag

5. A karstified boulder in the Avren Plateau coastal zone

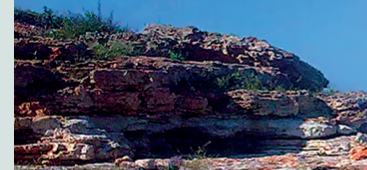
$\frac{1}{3} x_{2}$

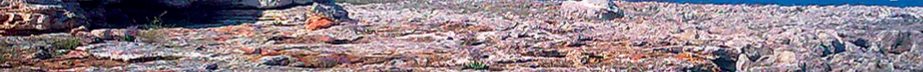

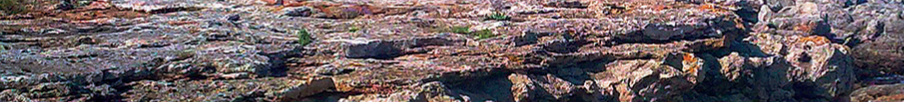

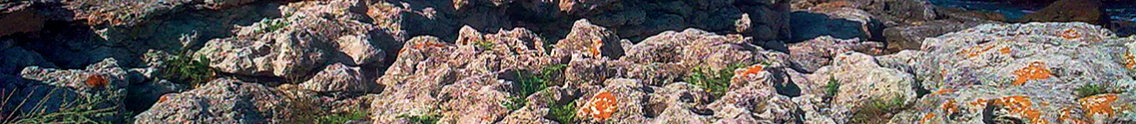
4. t. -

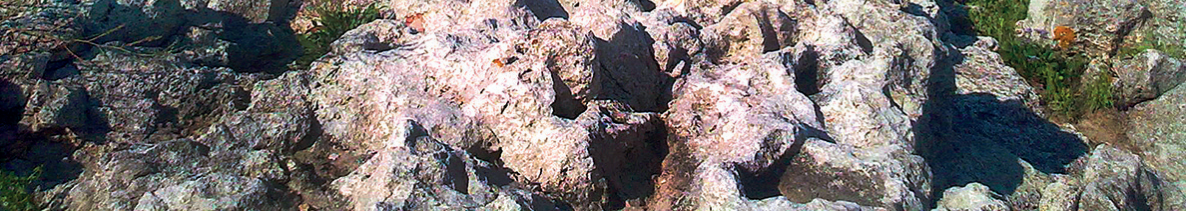

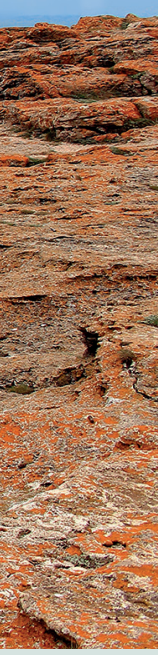

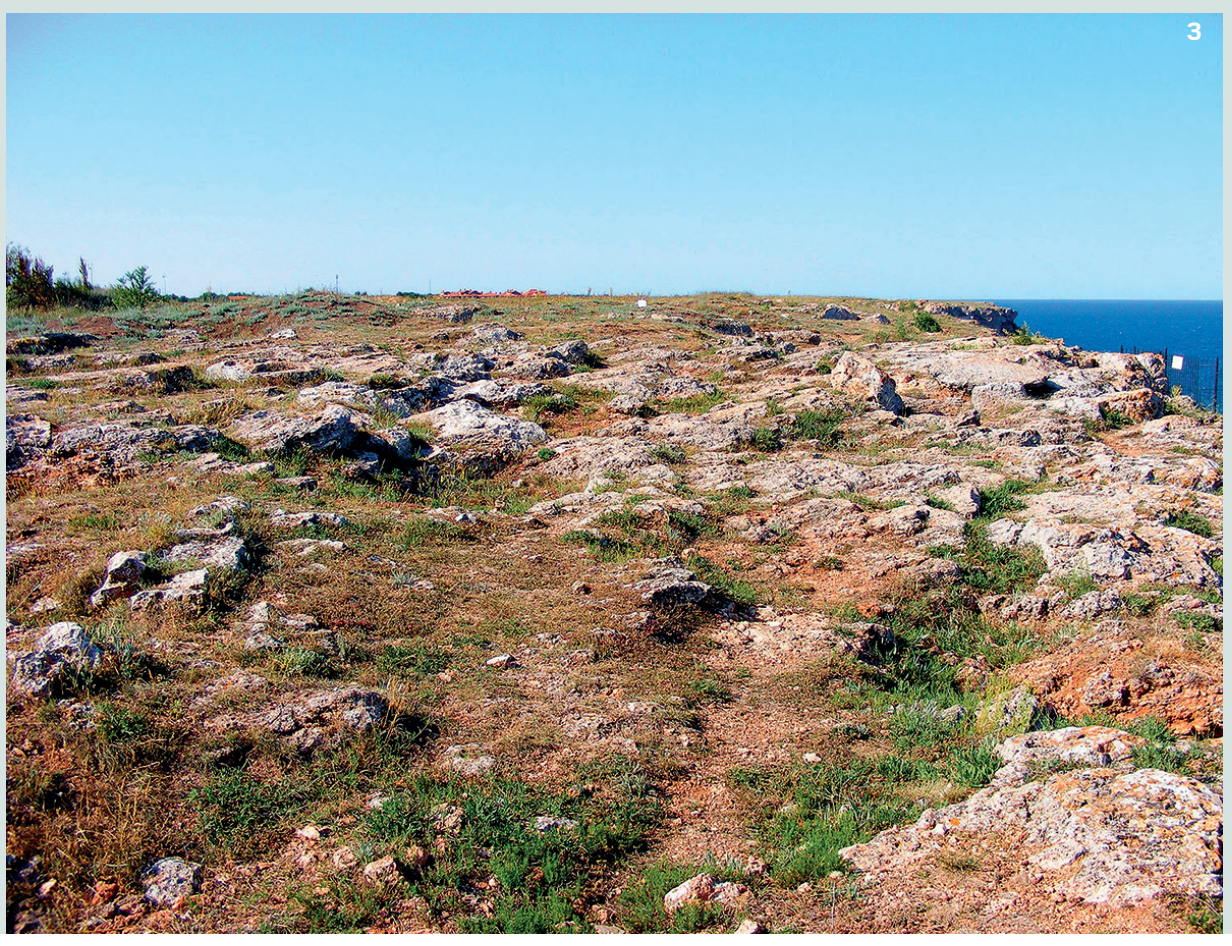

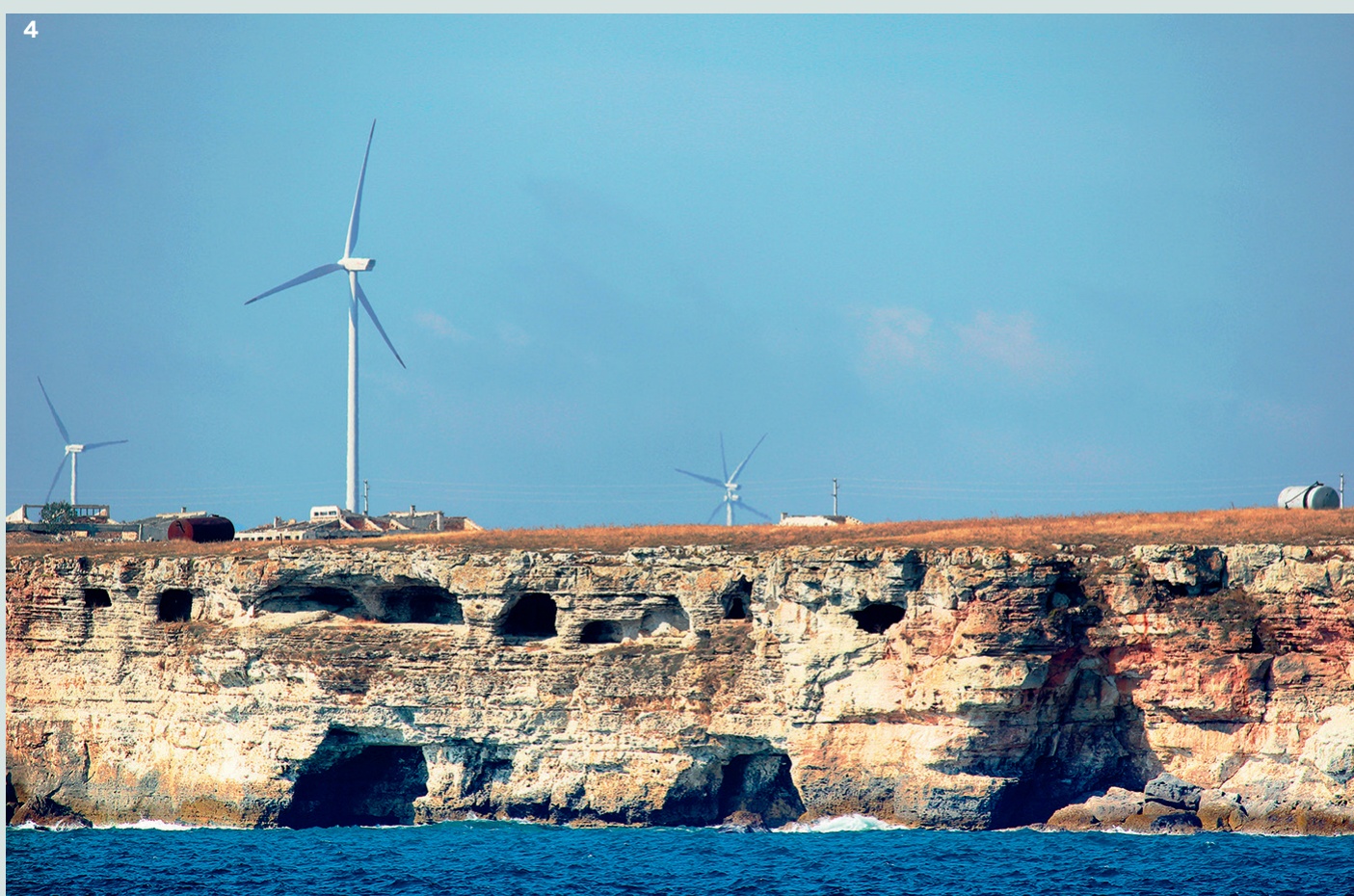

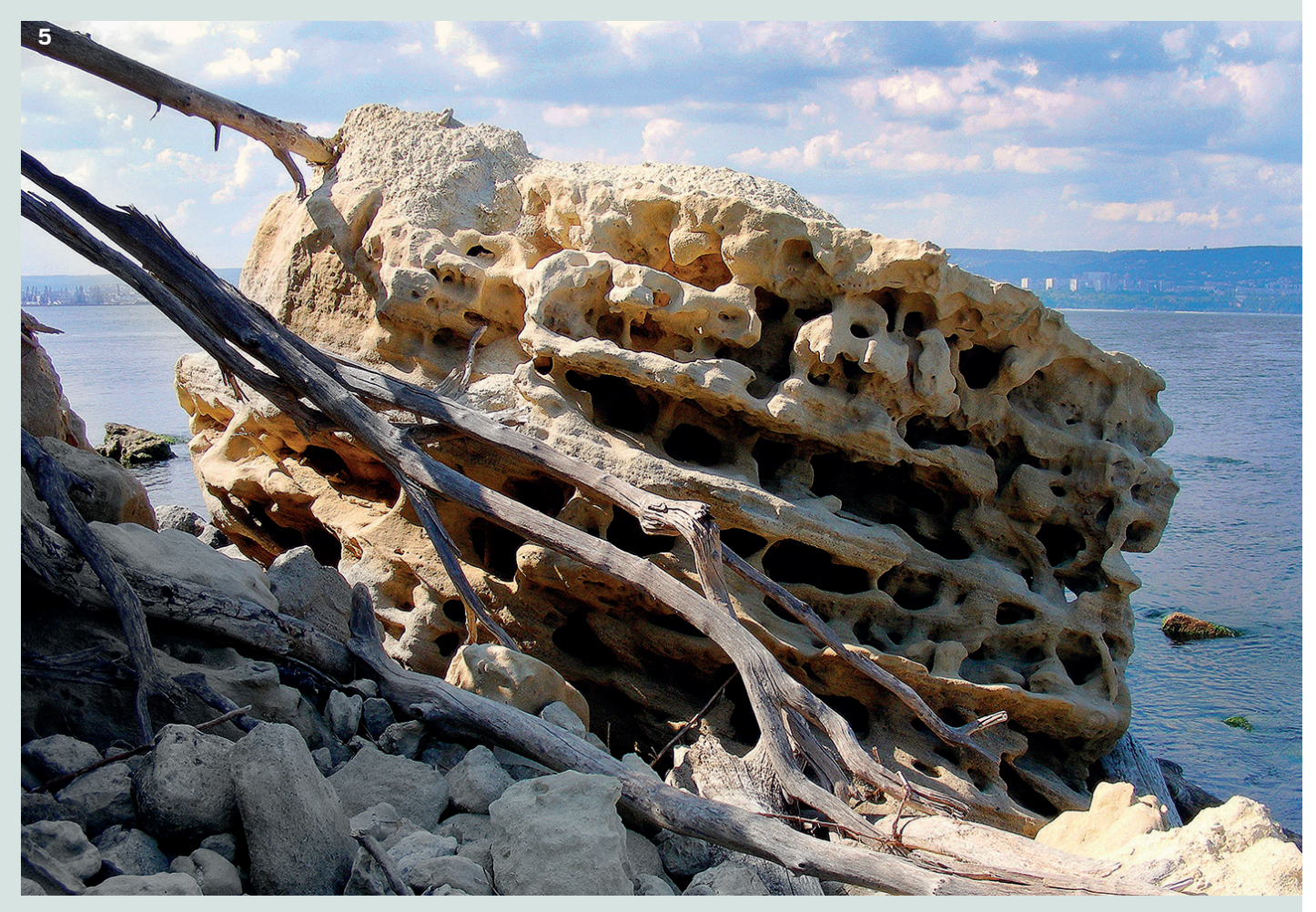

SENSITIVITY MAPPING AND ANALYSIS OF THE BULGARIAN BLACK SEA COASTAL ZONE

27 
Bulgaria's four out of five major

Black Sea islands

1. Sveta Anastasia

2. Sveti Ivan and Sveti Petar

3. Sveti Toma
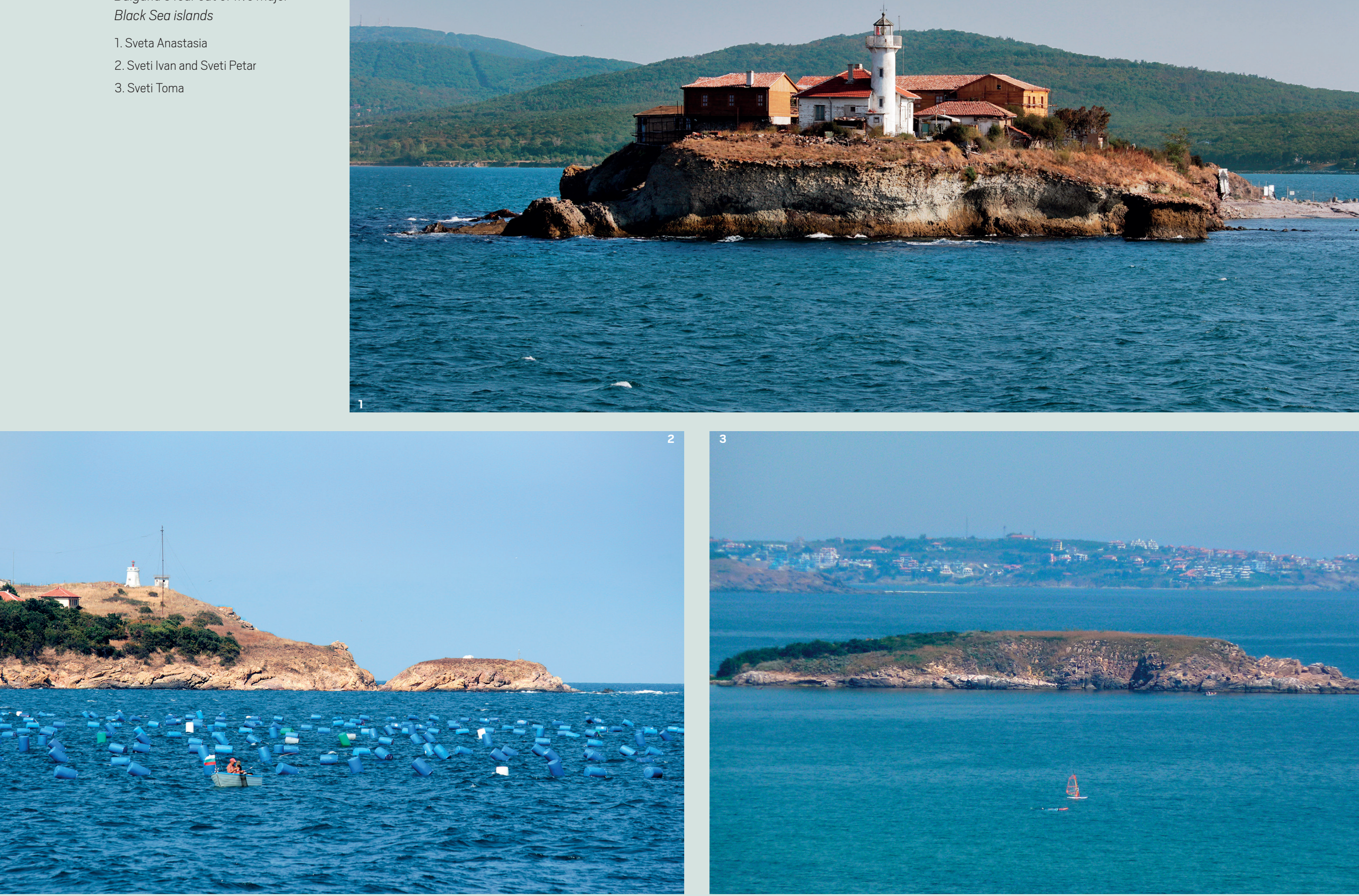
Beaches and dunes. Beaches and dunes are valuable natural recreational resources of the Bulgarian Black Sea coastal zone. Sandy beaches exceed 70 and they stretch on over 121 km [1; 2; 3; 24; 25; 32; 33, etc.]. Generally, dunes are a connected part of the active beach-dune systems, and are characterized by dynamic sand strips and foredunes, with the more stable or fixed dunes located landward [24; 36]. Twenty eight dune sites are identified along the Bulgarian coast [36]. Four large dune sites occur between Cape Kartalburun and Cape Shabla (north of Cape Kaliakra). Five dune sites characterized as wide are located on the middle portion of the coast between Cape Kaliakra and Cape Emine, and 19 dune sites are located on the southern coast between Cape Emine and Cape Rezovo. The largest dune complex is located around the mouth of the Kamchia River behind the largest Bulgarian beach, named Kamchia-Shkorpilovtsi, with a length of 7,180 $\mathrm{m}$ and an area of $2.40 \mathrm{~km}^{2}$ [3; 36; 37]. At least 20 of the 28 dune sites along the coast are subject to some form of legal protection due to their high conservational value as unique habitats, and most of them are major protected sites under the NATURA 2000 ecological network [39].

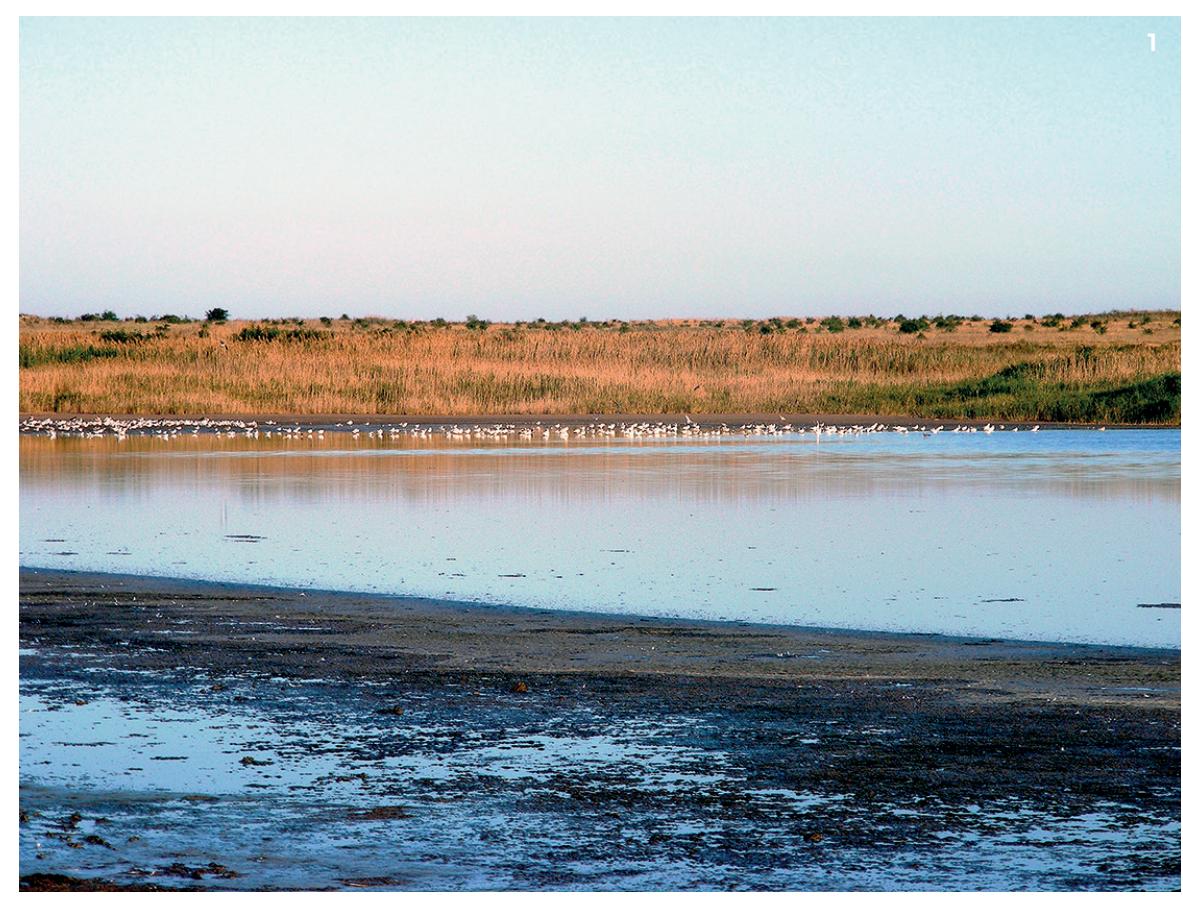

Examples of low-lying firth and lagoon types of relief along the Bulgarian coast:

1. Shablenska tuzla Lagoon in the area of Shabla (North Bulgarian coast)

2. Mandra Lake (converted into a reservoir) in the area of Burgas (South Bulgarian coast)

3. Alepu Lagoon south of Sozopol (South Bulgarian coast)
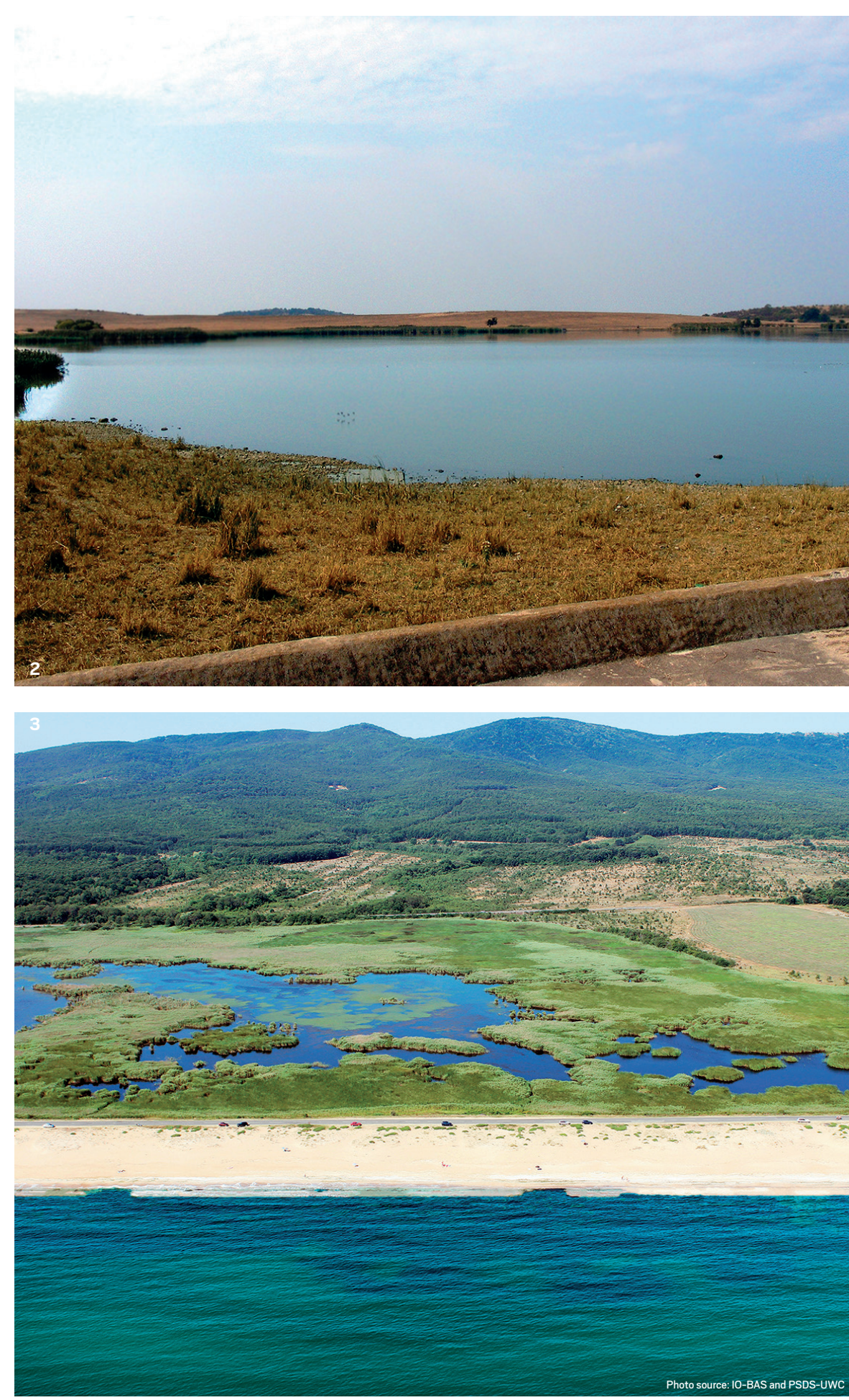

SENSITIVITY MAPPING AND ANALYSIS OF THE BULGARIAN BLACK SEA COASTAL ZONE 
Three of the most distinctive beach-dune systems

formed in the Bulgarian Black Sea coastal zone:

1. Shabla beach (North Bulgarian coast)

2. Kamchia-Shkorpilovtsi beach (Central Bulgarian coast)

3. Arkutino beach (South Bulgarian coast)
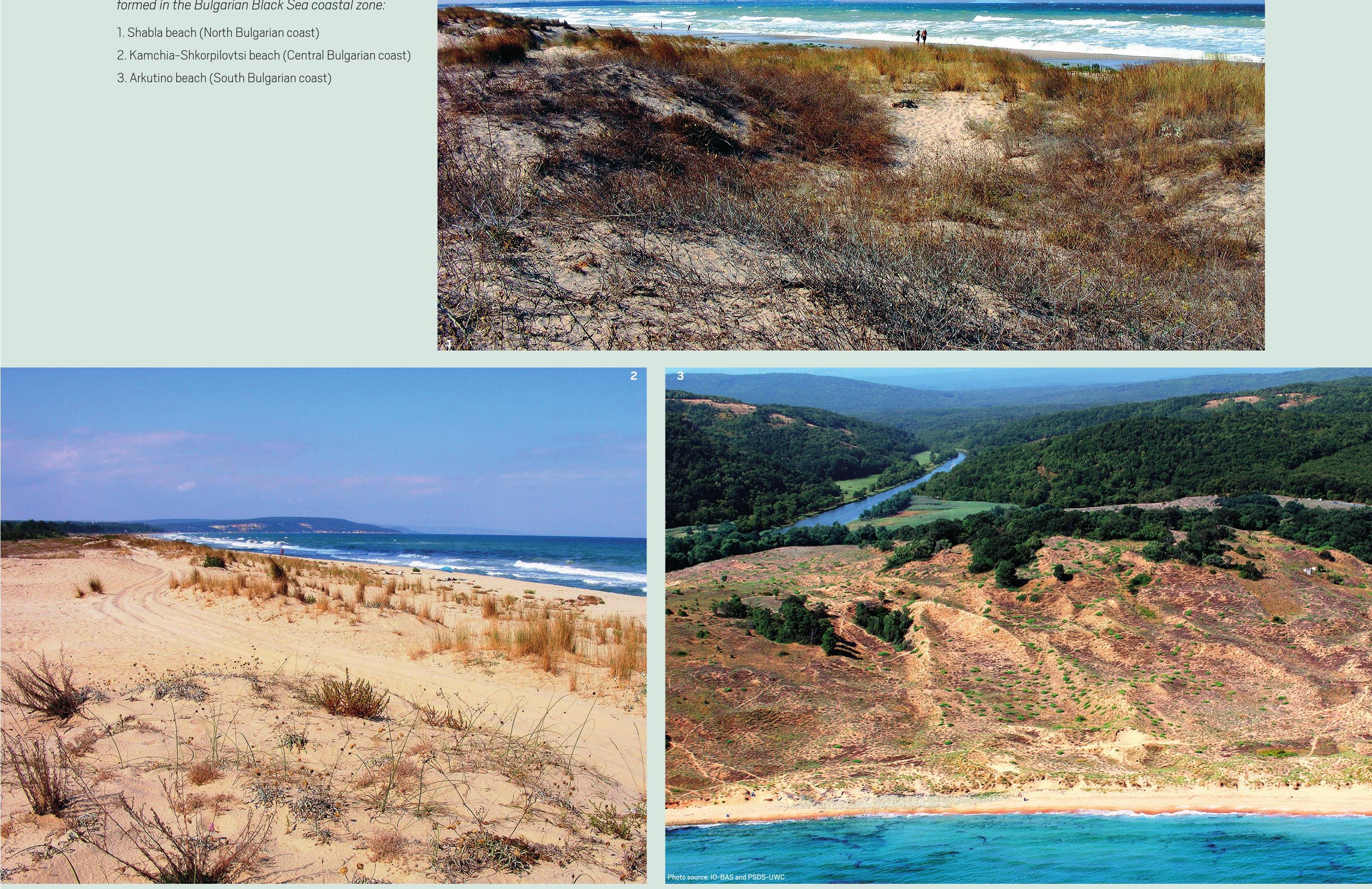
Coastal armoring. Large numbers of protection structures have been built since the 1980s to control erosion and landslide processes along the Bulgarian coast. These mostly include: coastal dikes or rubble-mound embankments, groins and seawalls. Seawalls and dikes on the shoreline, as well as developments of harbor and port infrastructures, have armored the shoreline and currently $16.2 \%$ (or $70 \mathrm{~km}$ ) of the Bulgarian coast is armored. Construction of these structures mostly depends on requirements for protection of the shoreline and the infrastructure of the sections most hazard-prone to flooding and erosion. There are areas with a heavily armored coastline: in the northern part of the Bulgarian coast, between the town of Balchik and Cape Galata where 111 types of maritime structures are identified with a total length of $46 \mathrm{~km}$; and between the towns of Nesebar and Sozopol where 186 structures exist [25; 35; 40].

Examples of the most common coast-protection structures on the Bulgarian coast

1. Seawall with wave-breaking cells (north of Cape Shabla, North Bulgarian coast)

2. A 12-km-long coastal dike (North Bulgarian coast)

3. A solid Y-shaped groin (Varna Bay, North Bulgarian coast)

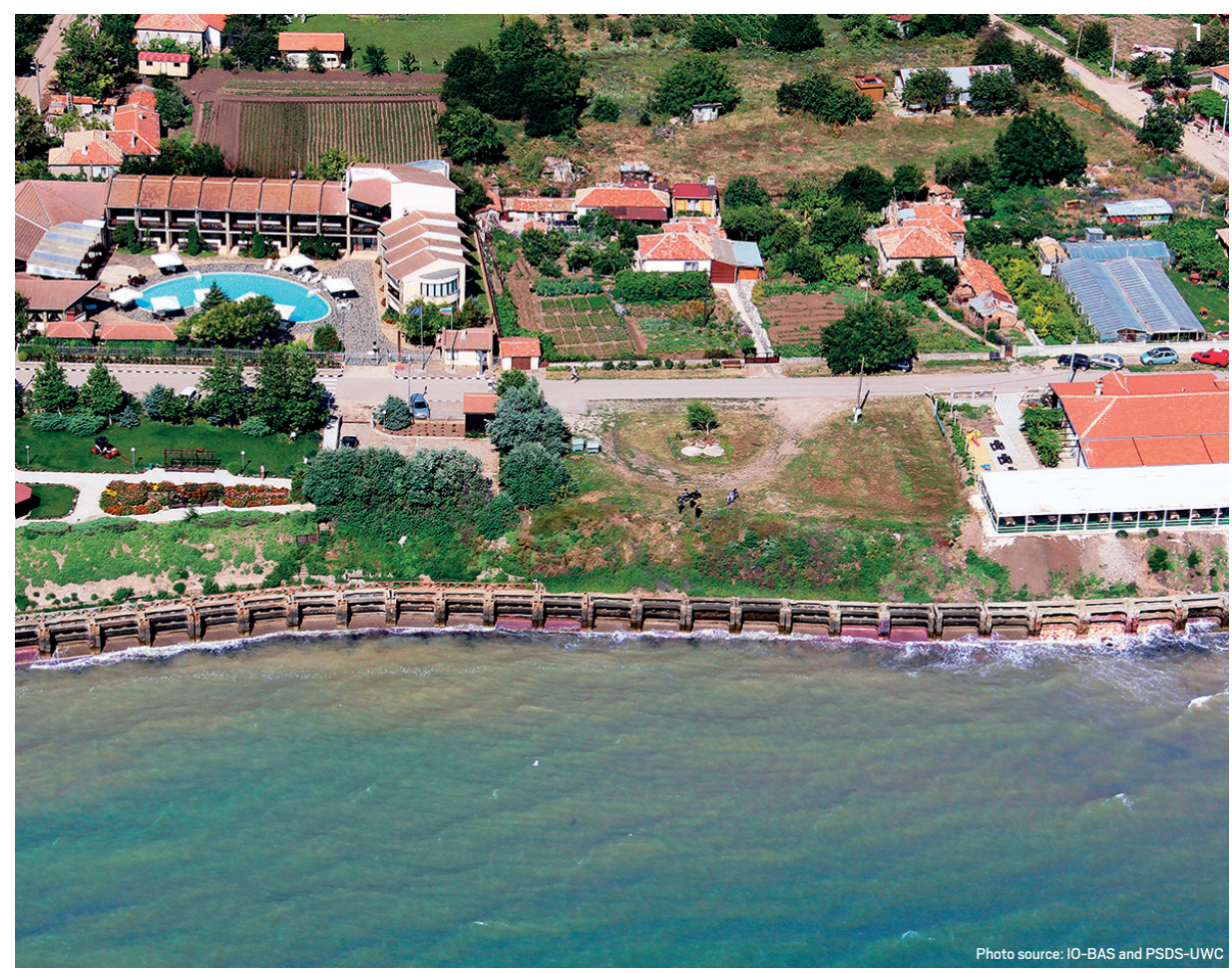

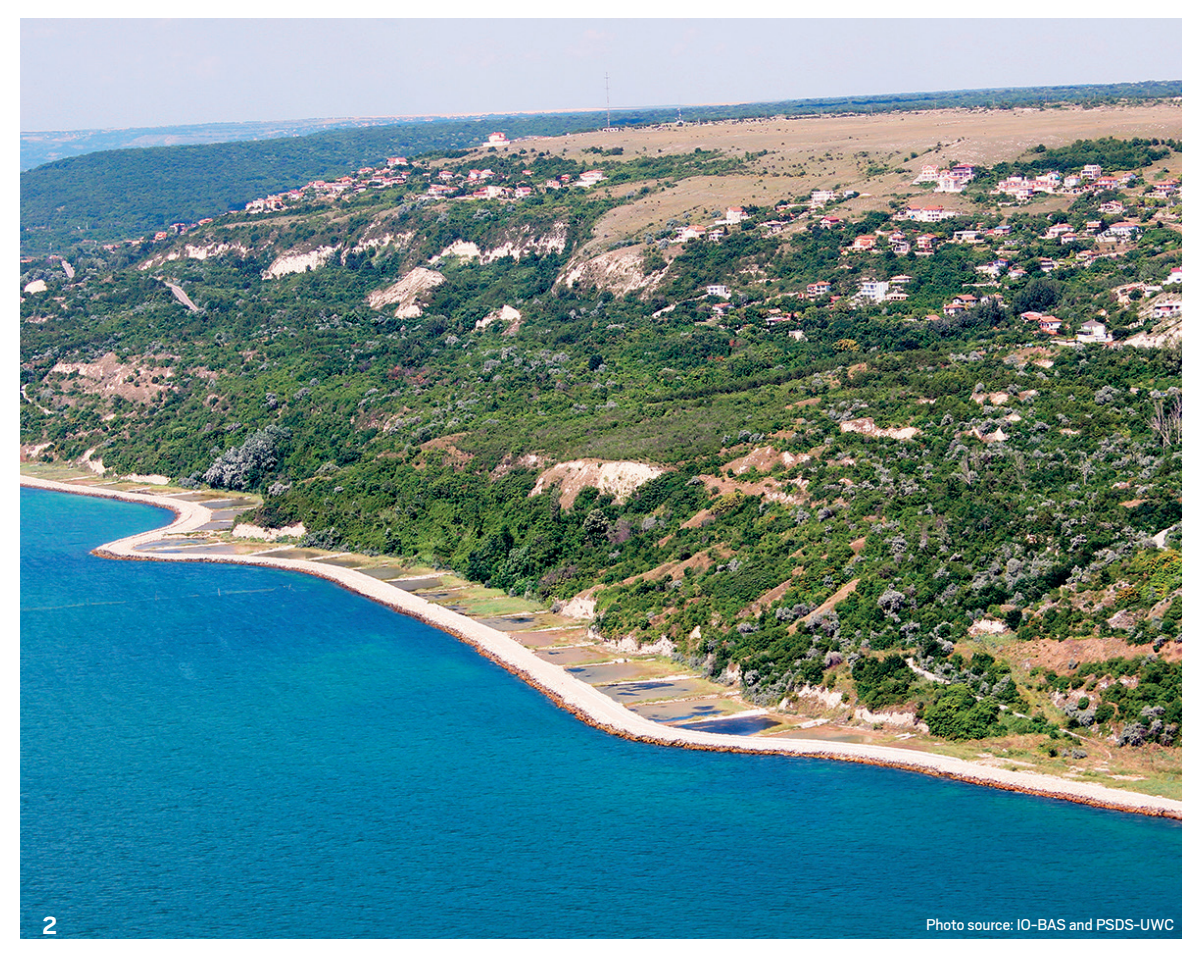

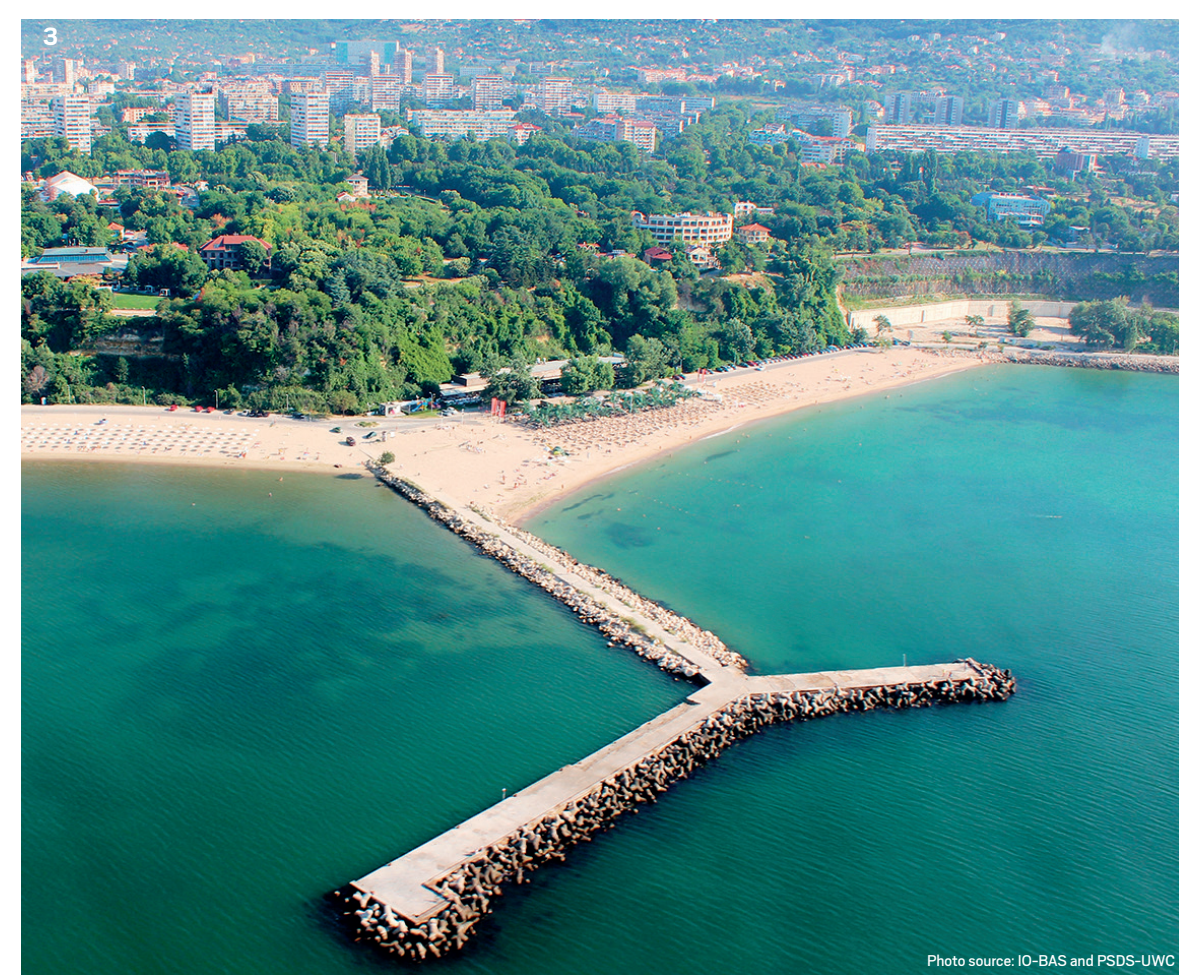




\subsection{SEAFLOOR MORPHOLOGY}

Geomorphic setup and regionalization of the Bulgarian Black Sea shelf. Three main geomorphic zones can be differentiated within the shelf of Bulgaria, namely near-shore, central and peripheral $[6 ; 8 ; 47 ; 42 ; 43$, etc. $]$.

The near-shore zone runs parallel to the coastline and includes the submarine coastal slope together with a complex of relic and contemporary submarine terraces. The lower boundary of the submarine coastal slope is marked by the $25-30 \mathrm{~m}$ bathymetric contours, i.e. the maximum depths at which extreme storm waves cause an impact on the seabed [6; 29; 44; 45, etc.].

The central shelf zone encompasses the greatest portion, occupying the subaqueous areas between the 25-30 m and the 90-95 m bathymetric contours. In geomorphologic sense, the above zone can be divided into four subzones: an inner fore-bar depression, a subzone of accumulative sand bars, a subzone of weakly dissected hilly accumulative plain (differentiated solely north of the parallel of Cape Kaliakra) and a subzone of dissected shelf plain $[6 ; 42 ; 43 ; 44 ; 45$, etc]

The peripheral shelf zone has a width of up to $10 \mathrm{~km}$ and normally includes the seabed area between the 90-95 m and the 130-180 m bathymetric contours, yet reaches depths of up to $200 \mathrm{~m}$ in certain areas. The seafloor topography is characterized by numerous relic features, e.g., sand bars and terraces, most likely formed during the Late Pleistocene regressive stage of the marine basin $[6 ; 42 ; 43 ; 44 ; 45$, etc].

Submarine terraces. Modern terraces of abrasive, abrasive-accumulative and accumulative types are found at various depths within the extent of the submarine coastal slope. Their geomorphic characteristics and lithologic composition are in conformity with the contiguous shoreline sectors. Hence, abrasive terraces (also known as abrasion or wave-cut platforms) are normally found in front of cliff and landslide sectors, while the abrasive-accumulative and accumulative type are predominantly found either in front of accumulative types of coast (e.g, firths, lagoons, larger inlets and bays) or at greater depths [28]. Relic terraces of the above mentioned three varieties are
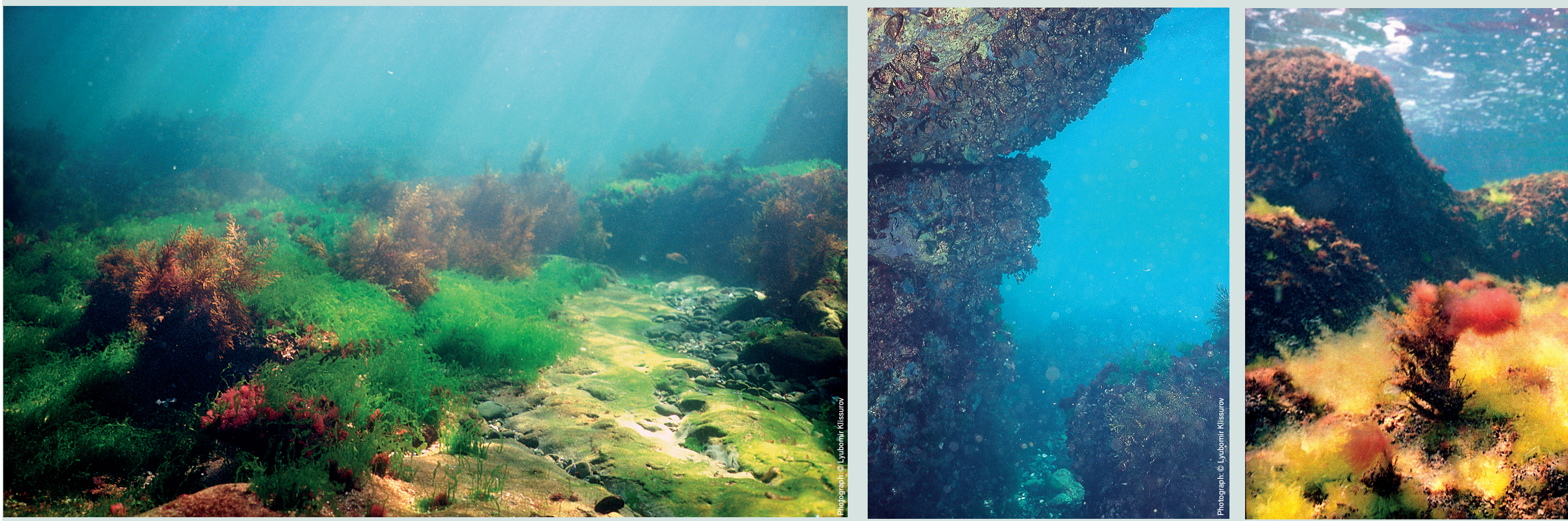

32 PHYSIOGRAPHIC AND OCEANOGRAPHIC CHARACTERISTICS OF THE STUDY AREA 
also observed, the highest concentration of such bedforms being present within the central and peripheral shelf zones $[3 ; 8 ; 13 ; 42 ; 43 ; 44 ; 45$, etc. $]$

Sandbanks. The most representative sandbank in Bulgaria's shallow marine sector is Cockatrice, located some $5 \mathrm{~km}$ south of Cape Emine, at the entrance of Nesebar Bay. The bank represents a system of relic sand bars formed by the Paleohadzhiyska River [1]. A similar, however less representative accumulative bedform, is observed in front of Pomorie Lagoon [42].

Rocky banks. Numerous rocky banks are observed within the submarine coastal slope of Bulgaria. Among these, the most representative are: Aladzha bank formed on the submarine coastal slope in front of Golden Sands and Riviera resorts; the shallow bank running parallel to the shore at Kamchia-Shkorpilovtsi beach; Kreschent, or Crescent (a.k.a. Krastova), Pomoriyska, Stavro and Chimos banks near Pomorie Lahna, Spitfire, Soka, Blonde (Burgas) near Burgas and its Sarafovo district; Kiten Reef in the marine aquatory between Cape Maslen nos and Tsarevo, etc. [1]
Accumulative sand bars. Two vast accumulative bedforms are present within the central shelf zone, namely Kaliakra and Emine bars. The length of Kaliakra Bar exceeds $100 \mathrm{~km}$, while its width reaches up to $15 \mathrm{~km}$. Emine Bar has minor dimensions (72 km of length and up to $6 \mathrm{~km}$ of width). Specific features of their morphology are the asymmetric profiles with steeper western slopes and gently inclined eastern slopes. Other much smaller accumulative bars are also present on the shelf (especially in the central and peripheral zones), with Strandzha Bar being the most distinctive among them [6; 8; 44; 45, etc.].

Accumulative and structural depressions. These bedforms are most common in the central and peripheral shelf zones in subaqueous areas characterized by greater depths, usually contiguous to large accumulative sand bars [6; 8; 44; 45 etc.]

Structural-morphologic steps. These bedforms mark the periphery of the shelf They take the shape of a parallel belt at depths of 95-200 m, thus forming a clearly distinguishable structural-morphologic boundary between the shelf and the continental slope [6; 8; 44; 45, etc.]
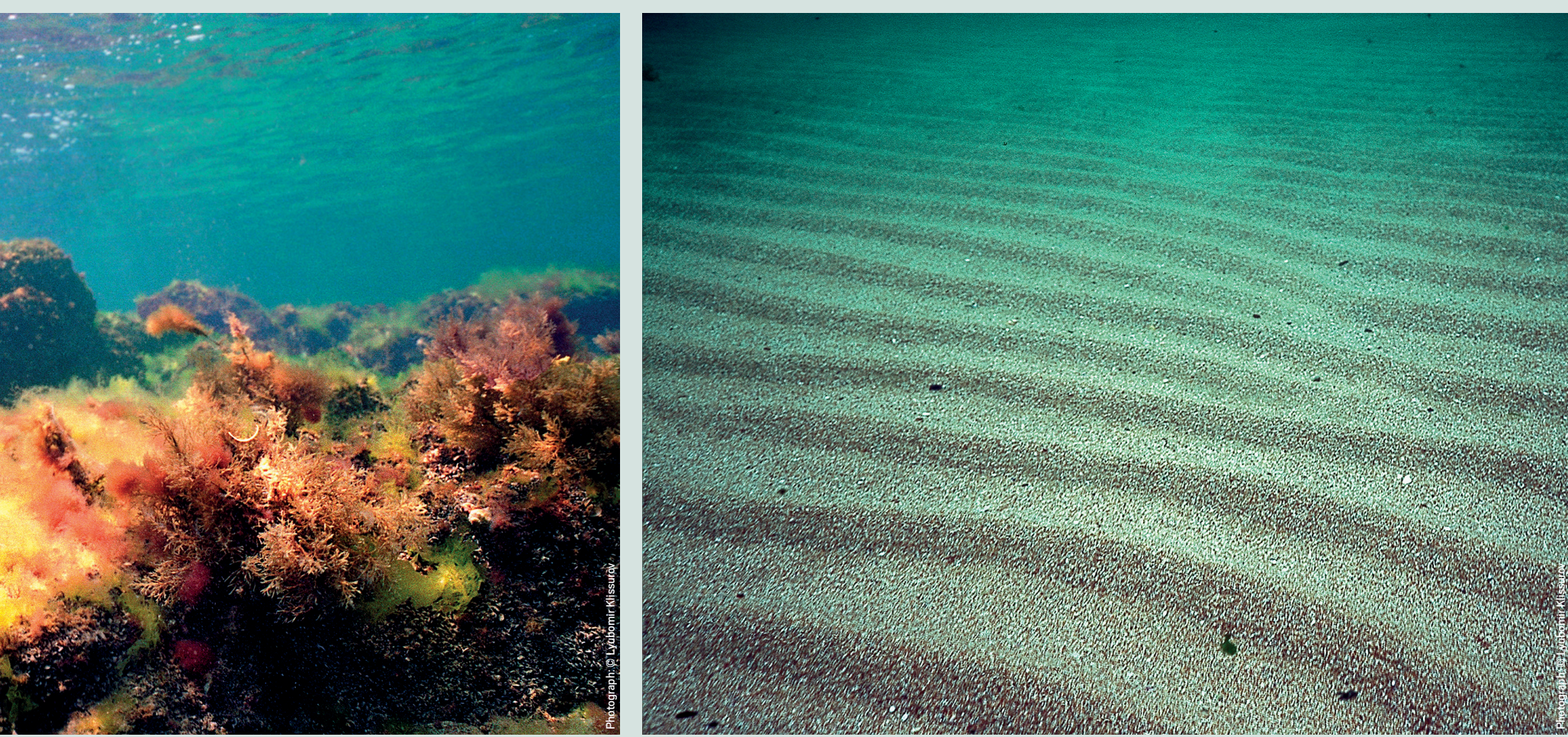

Representative bedforms of the shallow

submarine relief:

1. Abrasion platform

2. Vertical underwater section of a cliff

3. Large boulders in front of an erosiveandslide-collapse coastline sector

4. Shallow seabed sector with sandy substrata and ripples 


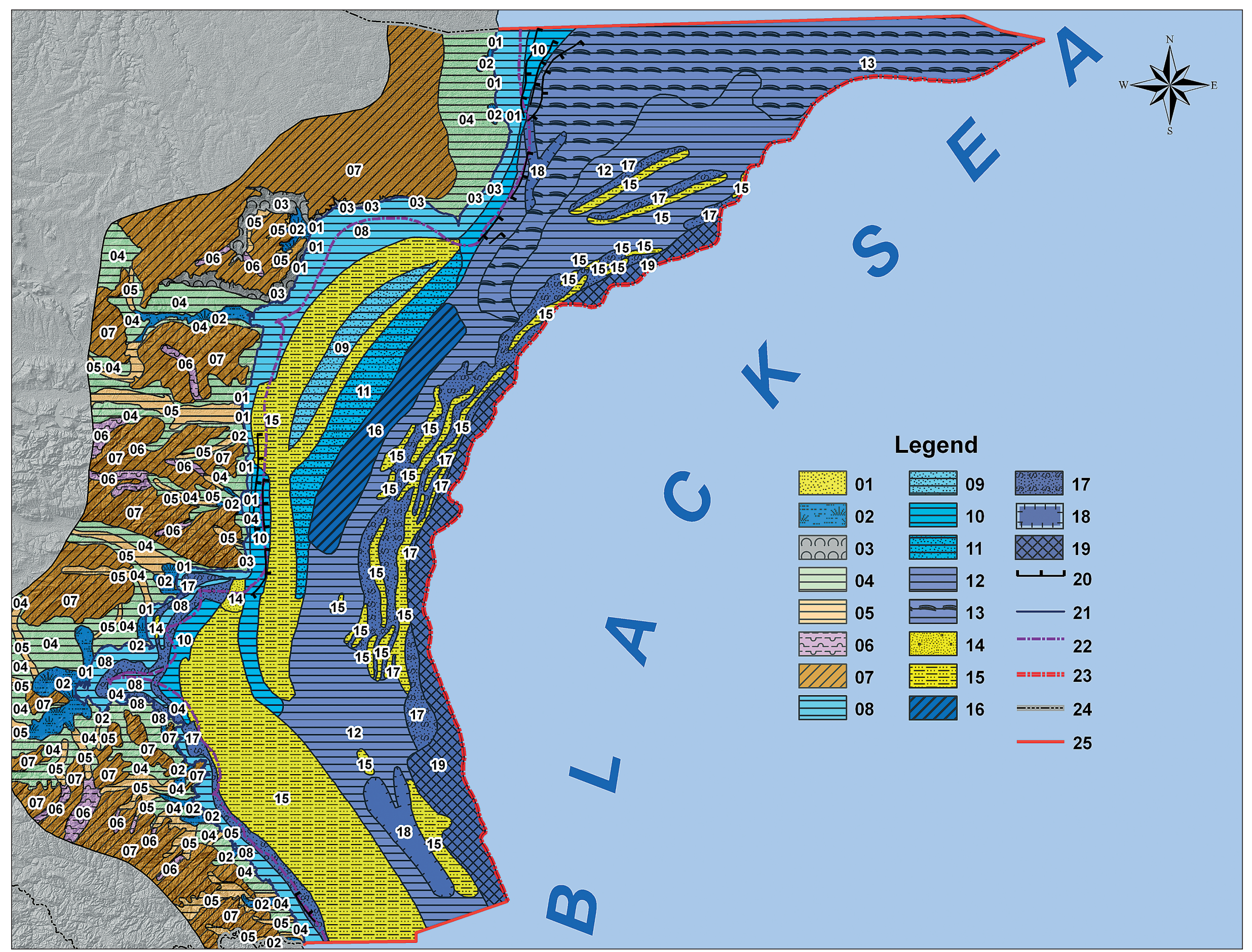

34 PHYSIOGRAPHIC AND OCEANOGRAPHIC CHARACTERISTICS OF THE STUDY AREA 
Generalized map scheme of the coastal and seafloor relief (after Popov, 1975 [46] and Krustev, 1992 [42], with modifications by the authors):

1. COASTAL LANDFORMS

01. Sand strips and dunes

02. Firths and lagoons

03. Landslides

04. Marine terraces

05. Fluvio-marine terraces

06. Fluvial terraces

07. Denudation surfaces and denudational slopes

\section{SUBMARINE BEDFORMS:}

08. Submarine terraces at 4-5, 8-12 and 20-25 m of depth

09. Submarine terraces at 4-5, 8-12 and 20-25 m of depth covered by younger sand bars

10. Submarine terraces at $30-40 \mathrm{~m}$ of depth

11. Submarine terraces at $30-40 \mathrm{~m}$ of depth covered by younger sand bars

12. Submarine terraces at $60-100 \mathrm{~m}$ of depth

13. Submarine terraces at $60-100 \mathrm{~m}$ of depth within the hilly shelf plain

14. Sand banks

15. Accumulative bars

16. Morphologically exhibited zone of Kaliakra Fault

17. Accumulative depressions

18. Structural depressions

19. Structural-morphologic steps

\section{ADDITIONAL MAP SYMBOLS:}

20. Submerged relic cliffs

21. Present-day coastline

22. Lower boundary of the submarine coastal slope

23. Lower boundary of the shelf zone

24. Terrestrial state borders of Bulgaria with Romania (north) and Turkey (south)

25. Marine borders of the Bulgarian Exclusive Economic Zone (EEZ) in the Black Sea with Romania (north) and Turkey (south) (section between the coastline and the periphery of the shelf zone illustrated only)

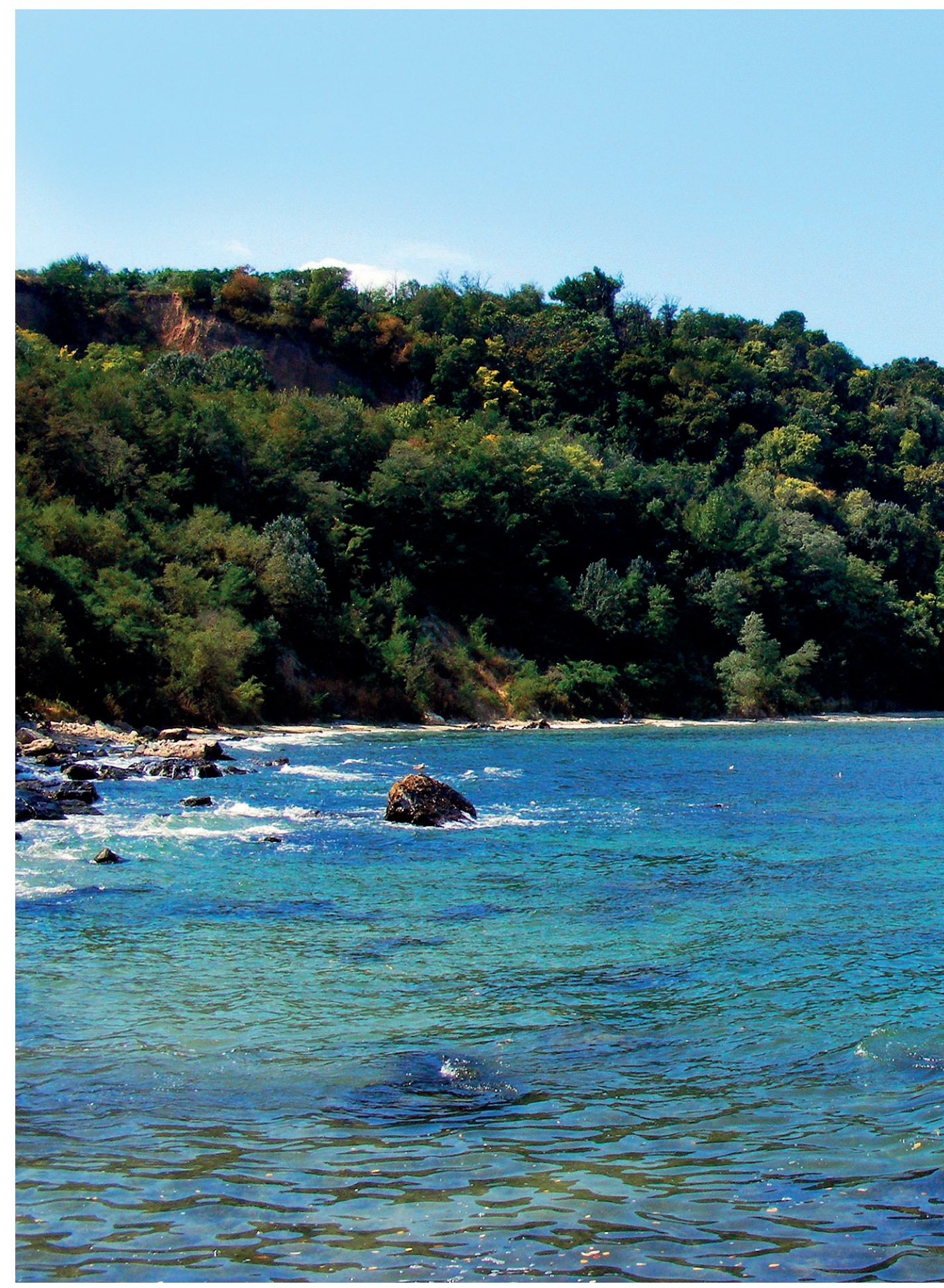

SENSITIVITY MAPPING AND ANALYSIS OF THE BULGARIAN BLACK SEA COASTAL ZONE 


\section{CLIMATE OF THE BULGARIAN BLACK SEA COAST}

The specifics of the climate have a strong influence upon the coast's complex physiographic structure, environmental properties and socio-economic profile. The marine basin's influence on climate largely depends on the coastal topography and is apparent up to 40-60 km inland [2; 47; 48; 49, etc.].

According to Velev [50], the Bulgarian Black Sea coast belongs to the continental-Mediterranean climatic area and is influenced by the proximity of the sea. The climate along the northernmost part of the coast is affected by strong continental influences. Prevailing winds are northeasterly, and the annual precipitation is about 450-500 mm, with a maximum in June and a minimum in February. The mean temperature in January is around $0^{\circ} \mathrm{C}$, dropping to $-2^{\circ} \mathrm{C}$ inland. In the south, especially along the coast of Medni rid Ridge and Strandzha Mountain, the climate is categorized as transitional Mediterranean. The mean annual precipitation is estimated at about 500-600 mm, with precipitations mostly in the fall and winter. The mean temperature is $2-3^{\circ} \mathrm{C}$ in January, and $22^{\circ} \mathrm{C}$ in July. The dry summer period lasts from July to September. Winds blow mostly from the southeast and rarely from the northeast. The mean annual precipitation over the mountainous areas of the coast (500 m a.s.l.) ranges between 600 and 1,000 mm [50].

Climographs for Shabla, Varna, Burgas and Tsarevo stations (according to data published by Penin, 2007 [48])

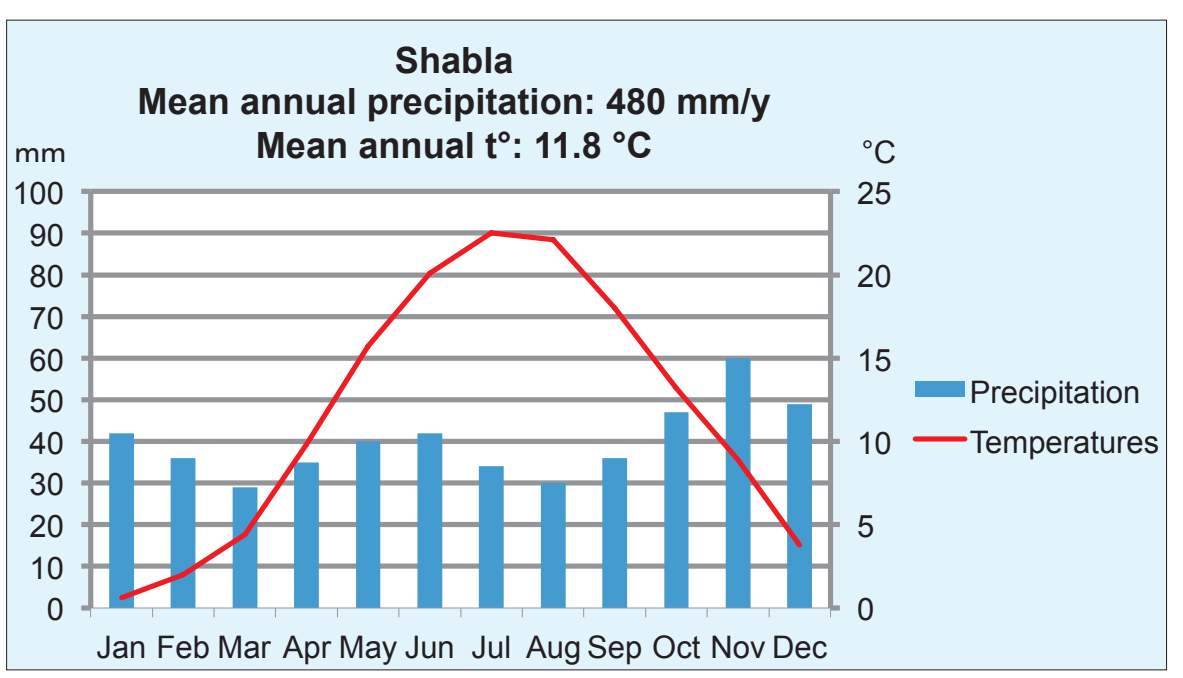

Varna
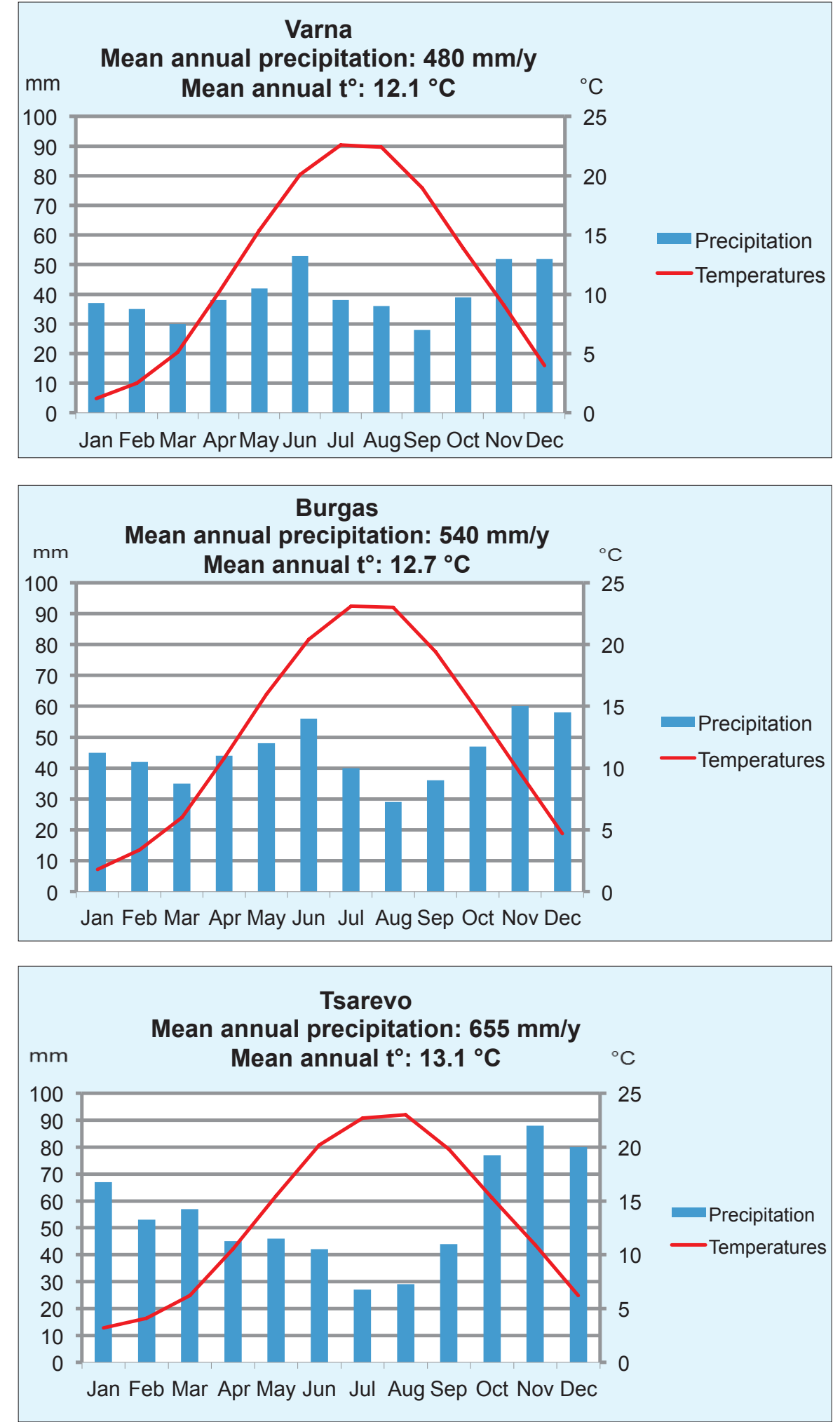

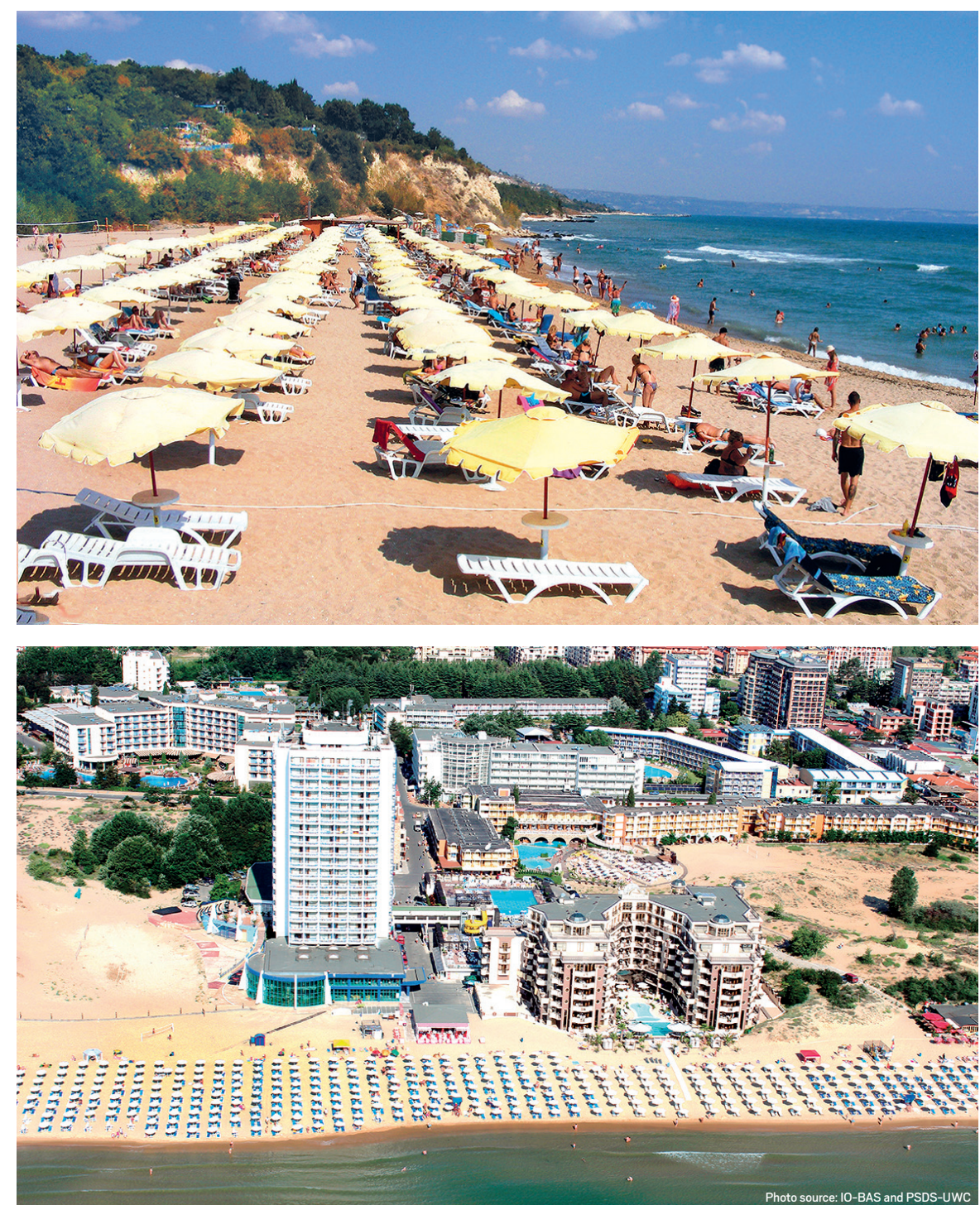

While most of the publications (mainly by Bulgarian researchers) describe the climate along the Bulgarian Black Sea coast to be of continental-Mediterranean type [47; 48; 50; 51; 52; 57, etc.], it seems it is much more correctly categorized by authors who apply the Köppen-Geiger classification scheme [53; 54; 55, etc.]. According to them, the climate of the Bulgarian Black Sea coast is humid subtropical, which better describes the colder winter months, the slightly wetter transitional seasons and the warm, but noticeably cooler summer months in comparison to the continental-Mediterranean climatic area. A characteristic feature of the investigated region is the decreasing temperate-continental influence from north to south, expressed by a rise of the mean annual temperatures and an increase of the annual precipitation quantities with their gradual shift from a late-spring/early-summer maximum into a late-fall/winter maximum. Nevertheless, as described by Velev [50], these climate properties are partially modified by altitude at the near-shore areas of the East Balkan Mountains and Strandzha Mountain.

In general, summers on the Bulgarian Black Sea coast are warm and relatively humid, while winters are cool, yet with positive temperatures in January, varying between $0.6^{\circ} \mathrm{C}$ in the north (Shabla station) and $3.2^{\circ} \mathrm{C}$ in the south near the border with Turkey (Tsarevo station). The annual precipitations are irregularly distributed over the year. They fluctuate between $480 \mathrm{~mm} / \mathrm{y}$ close to the border with Romania and $655 \mathrm{~mm} / \mathrm{y}$ along the South Bulgarian Black Sea coast [48]. A typical feature of the coastal climate are the torrential rains, a major factor for the exogenous morphologic processes, and hence for the natural coastal landscape dynamics as well [56; 57].

The mild Mediterranean-like climate of the Bulgarian Black Sea coast provides excellent conditions for maritime recreation
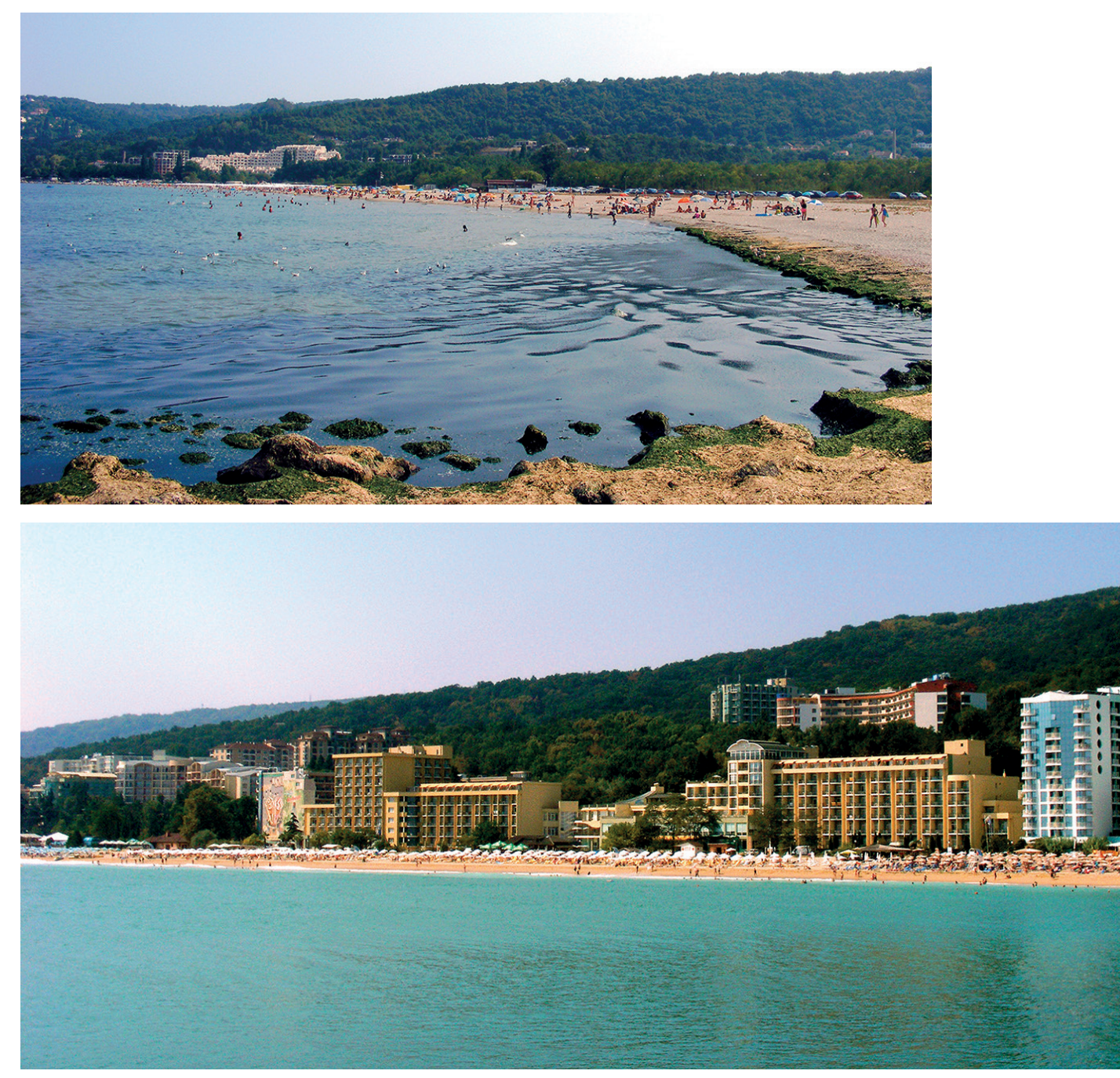


\section{HYDROGRAPHIC STRUCTURE OF THE BULGARIAN BLACK SEA COAST}

Moisture availability is among the principal ecological factors determining the spatial distribution of vegetation along the Bulgarian Black Sea coast. A general peculiarity is the gradual increase of water availability from north to south. This is attributed to specifics of the climate influence, geological structure and topography of the watershed areas that determine surface runoff, groundwater discharge, occurrence of major Black Sea tributaries, presence of coastal lakes, etc. [56].

\subsection{BLACK SEA TRIBUTARIES}

The development of the hydrographic network is largely affected by the coast's structural and geological settings related to the geological evolution of the marine basin and its adjacent areas [2]. A significant number of rivers and ravine-like tributaries run into the Bulgarian sector of the Black Sea or in the coastal lakes and their total catchment area exceeds $16,900 \mathrm{~km}^{2}$ [48; 58; 59; 60, etc.]. The longest rivers with the largest catchment basins and considerable year-round runoff include the Batova, Provadiyska and Devnya (North Black Sea coast), Kamchia (the longest Bulgarian Black Sea tributary with runoff that is approximately $1 / 3$ of all river runoff along the coast) [e.g., 58; 59; 60], Fandakliyska and Dvoynitsa (Central Black Sea coast), Hadzhiyska, Sredetska, Rusokastrenska, Fakiyska, Ropotamo, Veleka and Rezovska (South Black Sea coast), etc. (Table 1). A specific feature of the rivers on the northern coast is their karst source of nourishment [58].

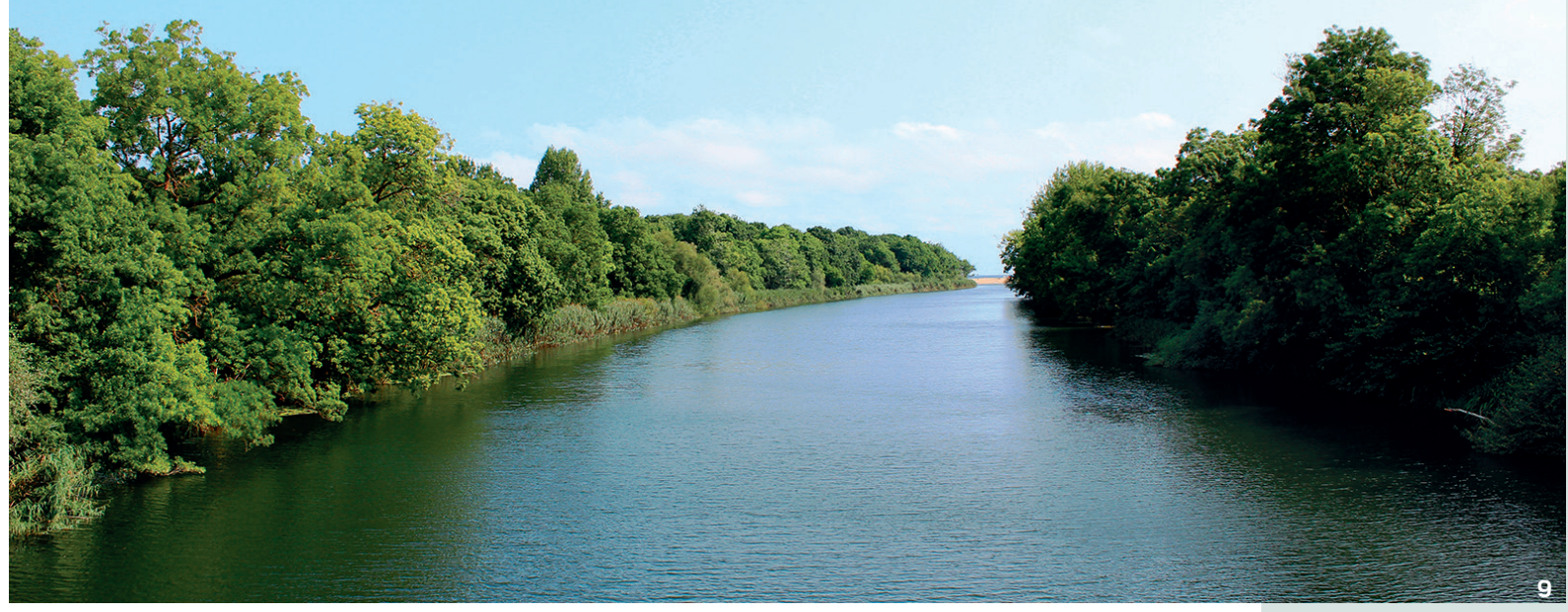

38 PHYSIOGRAPHIC AND OCEANOGRAPHIC CHARACTERISTICS OF THE STUDY AREA
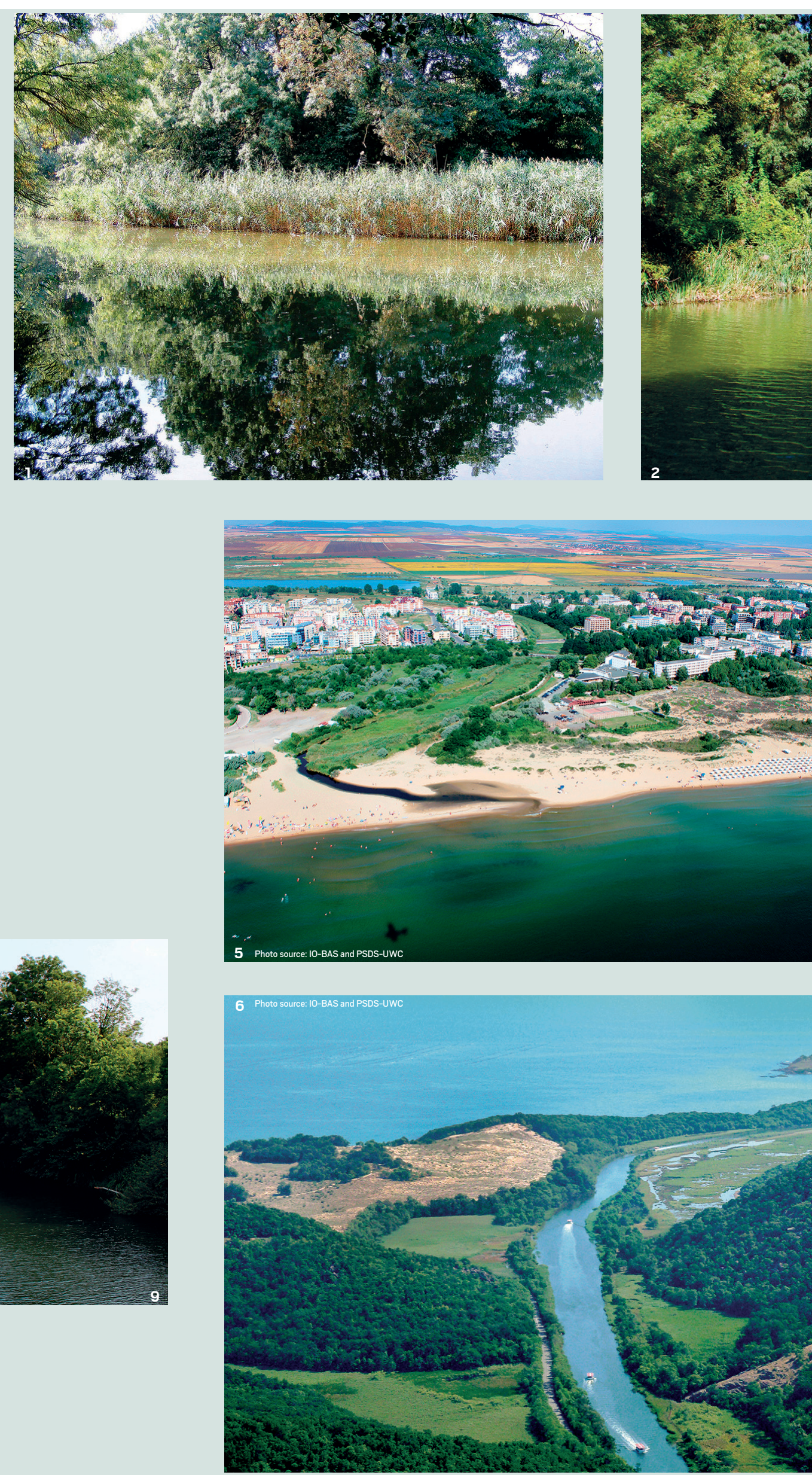
Table 1: Major Bulgarian rivers and ravine-like tributaries flowing into the Black Sea

(after Ivanov et al., 1961 [58]; Popov and Mishev, 1974 [3]; Mishev and Daneva, 1979 [2]; Peychev and Dimitrov, 2012 [1], with additions made by the authors)

\begin{tabular}{|c|c|c|c|c|c|}
\hline River/ravine name & Type & Coastal region & Inflow into & $\begin{array}{l}\text { River/ravine length } \\
(\mathrm{km})\end{array}$ & $\begin{array}{c}\text { Catchment basin } \\
\qquad\left(\mathrm{km}^{2}\right)\end{array}$ \\
\hline Bolata dere & Permanent & North & Black Sea & 5.94 & 4.19 \\
\hline Kavarnenska & Permanent & North & Black Sea & 3.1 & 12.3 \\
\hline Balchishko dere & Permanent & North & Black Sea & 2.65 & 2.32 \\
\hline Dvoretsa (Balchik) & Permanent & North & Black Sea & 3.93 & 5.10 \\
\hline Fish-Fish dere & Intermittent & North & Black Sea & 2.04 & 1.00 \\
\hline Batova & Permanent & North & Black Sea & 38.7 & 338.8 \\
\hline Kranevska & Permanent & North & Black Sea & 13.9 & 84.5 \\
\hline Kaynak dere & Permanent & North & Black Sea & 4.8 & 2.69 \\
\hline Fatriko dere & Permanent & North & Black Sea & 4.34 & 3.82 \\
\hline Shokara (Kemer dere \& Karadzha dere) & Permanent & North & Black Sea & 5.04 & 4.10 \\
\hline Franga dere & Permanent & North & Varna Lake & 5.94 & 2.36 \\
\hline Balam dere & Permanent & North & Varna Lake & 5.57 & 2.14 \\
\hline Devnya & Permanent & North & Beloslav Lake & 27.00 & 201.10 \\
\hline Provadiyska & Permanent & North & Beloslav Lake & 119.00 & $2,131.80$ \\
\hline Galensko dere & Permanent & North & Black Sea & 1.00 & 1.80 \\
\hline Manastirsko dere & Permanent & North & Black Sea & 1.46 & 2.70 \\
\hline Sakama deresi & Intermittent & North & Black Sea & 5.13 & 16.90 \\
\hline Pasha dere & Permanent & North & Black Sea & 10.90 & 47.40 \\
\hline Karasular dere & Intermittent & North & Black Sea & 1.38 & 3.80 \\
\hline Kamchia & Permanent & Central & Black Sea & 244.50 & 5445.5 \\
\hline Fandakliyska (Shkorpilovska) & Permanent & Central & Black Sea & 26.90 & 78.70 \\
\hline Kara dere & Permanent & Central & Black Sea & 6.30 & 17.80 \\
\hline Belensko dere & Permanent & Central & Black Sea & 3.20 & 14.40 \\
\hline Perperi dere & Permanent & Central & Black Sea & 14.90 & 58.20 \\
\hline Dvoynitsa & Permanent & Central & Black Sea & 52.50 & 478.80 \\
\hline Kokarbunar & Permanent & Central & Black Sea & 4.37 & 4.93 \\
\hline Vaya & Permanent & Central & Black Sea & 10.30 & 40.40 \\
\hline Kozluka & Permanent & Central & Black Sea & 11.64 & 23.41 \\
\hline Hadzhiyska & Permanent & South & Black Sea & 49.68 & 427.10 \\
\hline Aheloy & Permanent & South & Black Sea & 35.71 & 157.30 \\
\hline Azmak & Permanent & South & Atanasovsko Lake & 19.67 & 280.20 \\
\hline Aytoska & Permanent & South & Burgas Lake & 44.37 & 692.10 \\
\hline Chukarska & Permanent & South & Burgas Lake & 37.00 & 129.00 \\
\hline Sredetska & Permanent & South & Mandra Lake & 72.14 & $2,482.60$ \\
\hline Rusokastrenska & Permanent & South & Mandra Lake & 65.40 & 525.00 \\
\hline Fakiyska & Permanent & South & Mandra Lake & 87.30 & 641.00 \\
\hline Izvorska & Permanent & South & Mandra Lake & 35.00 & 109.00 \\
\hline Otmanli & Permanent & South & Black Sea & 7.52 & 24.00 \\
\hline Ropotamo & Permanent & South & Black Sea & 43.97 & 265.70 \\
\hline Dyavolska & Permanent & South & Black Sea & 34.66 & 137.00 \\
\hline Karaagach & Permanent & South & Black Sea & 28.09 & 223.00 \\
\hline Veleka & Permanent & South & Black Sea & 147.00 & 995.00 \\
\hline Silistar & Permanent & South & Black Sea & 11.37 & 43.50 \\
\hline Rezovska & Permanent & South & Black Sea & 112.00 & 183.00 \\
\hline
\end{tabular}




\subsection{COASTAL FIRTHS, LAGOONS AND LANDSLIDE LAKES}

Their genesis is generally related to the combined influence of sea level rise and coastal subsidence during the Holocene. The total number of naturally formed coastal lakes within the Bulgarian Black Sea coastal zone is 35, of which 28 are firths, five are lagoons and two are lakes of landslide origin. Their aggregate volume and area are approximately $223 \mathrm{mln} . \mathrm{m}^{3}$ and $291 \mathrm{~km}^{2}$, respectively [2; 3; 58, etc.). The largest firths are Durankulak, Ezerets-Shabla, Varna-Beloslav (the latter has been converted into a navigable estuary) on the North Black Sea coast, the mouths of the Kamchia, Dvoynitsa and Perperi dere in the Central region, Atanasovsko (a salt-water lake despite being a firth) and Burgas-Mandra in the southern region, etc. The largest lagoons are Shablenska tuzla (North Black Sea coast) and Pomorie (South Black Sea coast). The two lakes of landslide origin are Nanevska tuzla and Balchishka tuzla. Both represent salt-water basins with bottoms covered by typical lagoonal sediments [3] (Table 2). Similar to the rivers along the North coast, the water quantities of most firths (e.g., Orlovo blato, Durankulak Lake, Ezerets-Shabla, etc.), and all of the above landslide lakes are nourished by karst sources [58].
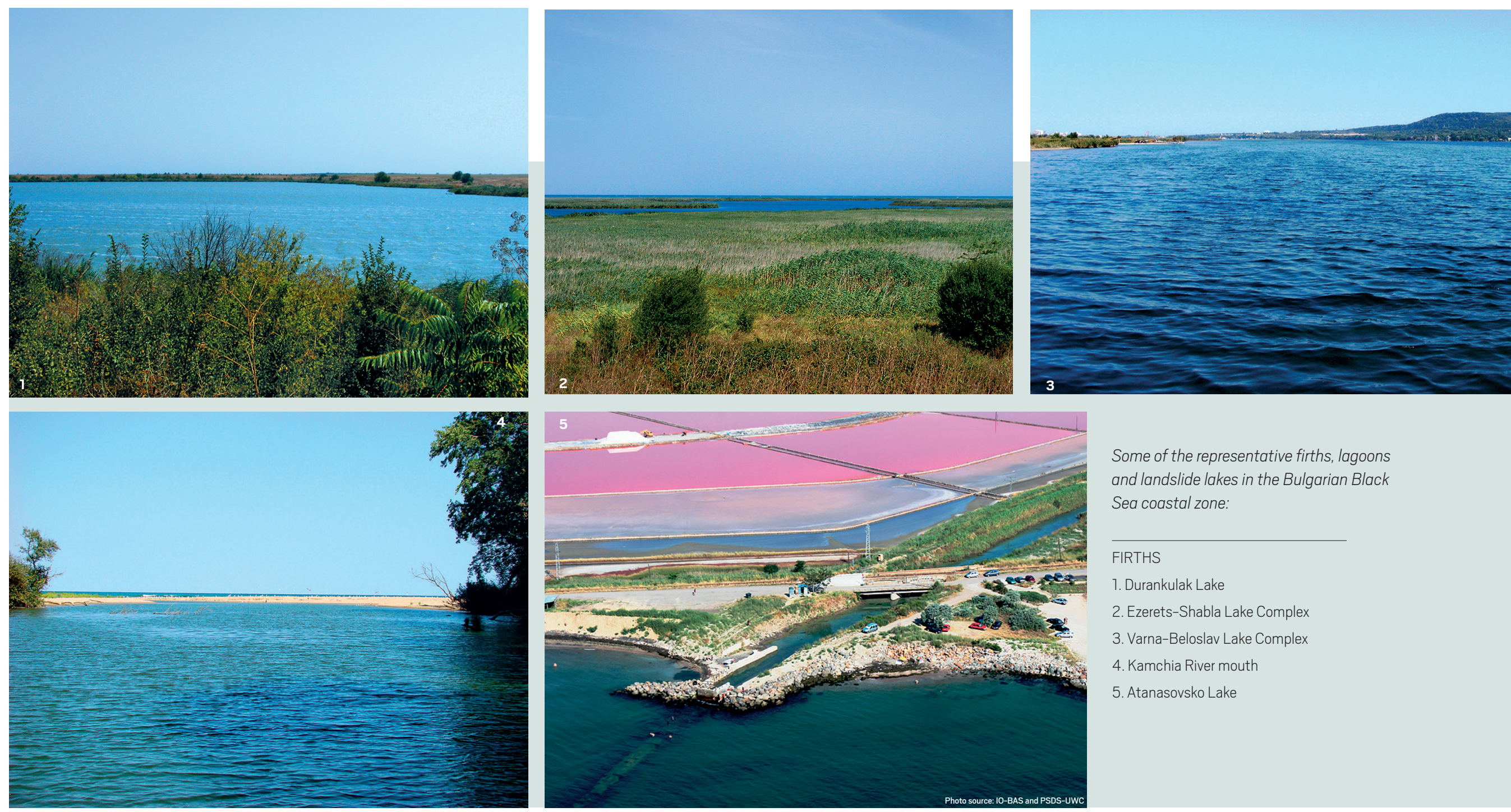

Some of the representative firths, lagoons and landslide lakes in the Bulgarian Black Sea coastal zone:

\section{FIRTHS}

1. Durankulak Lake

2. Ezerets-Shabla Lake Complex

3. Varna-Beloslav Lake Complex

4. Kamchia River mouth

5. Atanasovsko Lake 


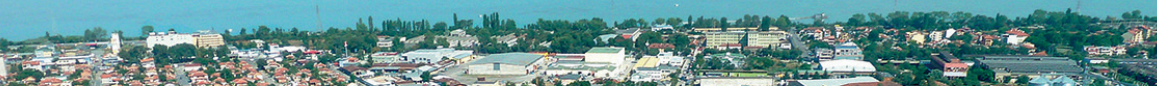

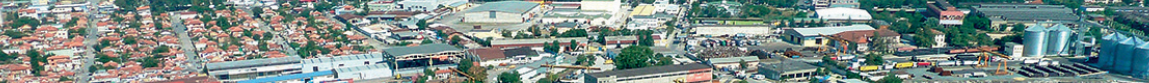

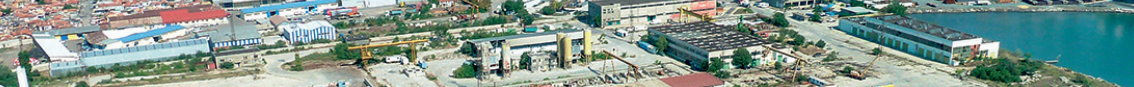

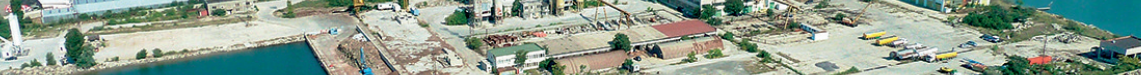

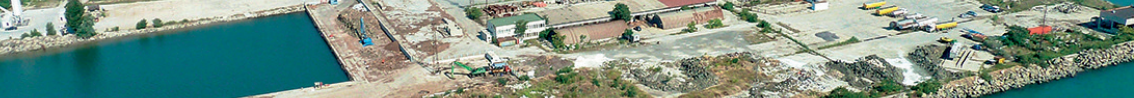

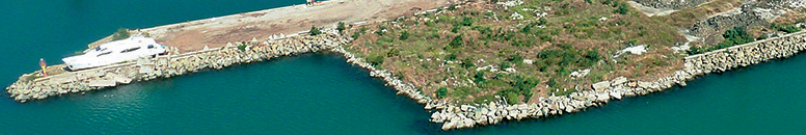
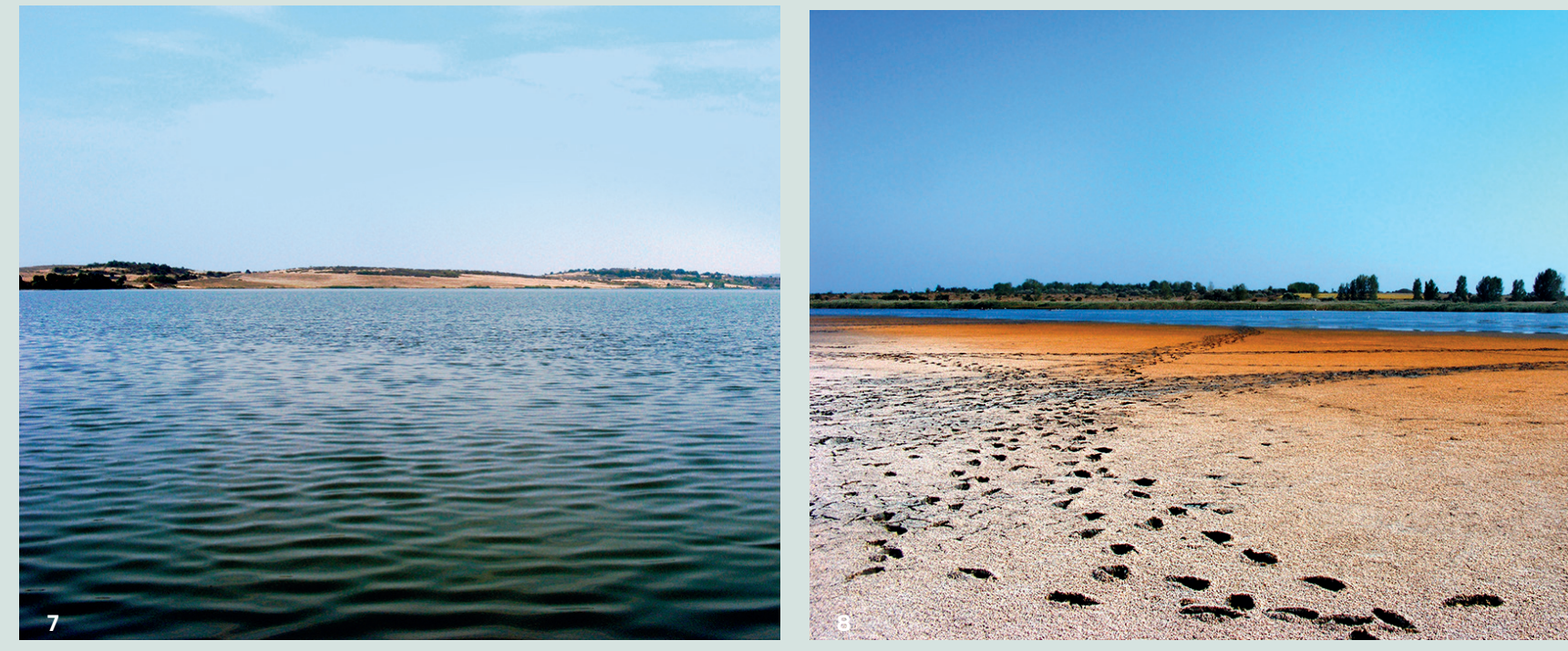

FIRTHS

6. Burgas Lake

7. Mandra Lake (Reservoir)

LAGOONS

8. Shablenska tuzla

9. Pomorie Lake

10. Alepu

1. Arkutino

12. Stomoplo

LANDSLIDE LAKES

13. Nanevska tuzla

14. Balchishka tuzla
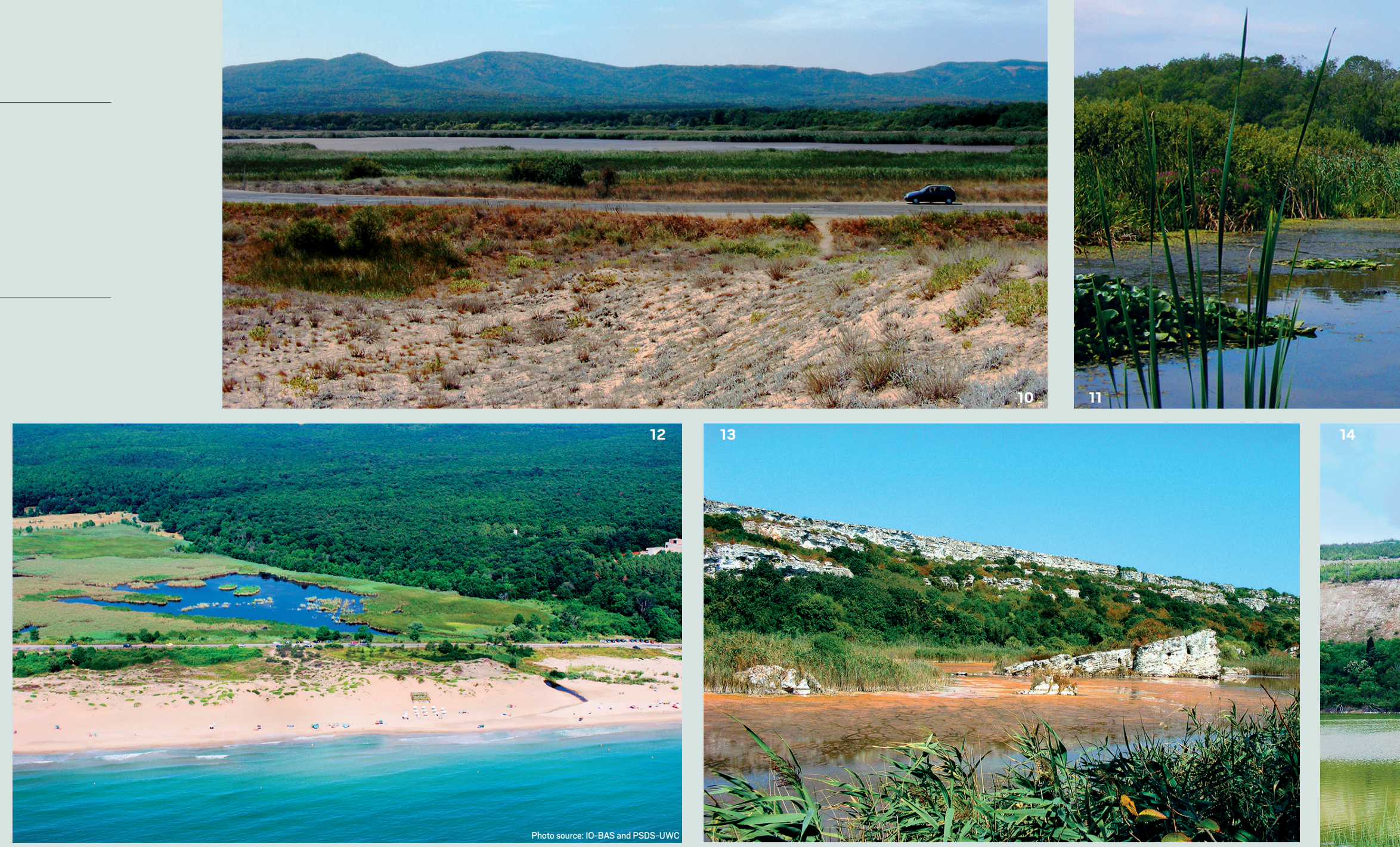

42 PHYSIOGRAPHIC AND OCEANOGRAPHIC CHARACTERISTICS OF THE STUDY AREA 
Table 2: Major lakes and firth-type river mouths in the Bulgarian Black Sea coastal zone (after Ivanov et al., 1961 [58]; Popov and Mishev, 1974 [3]; Mishev and Daneva, 1979 [2] Peychev and Dimitrov, 2012 [1], with additions made by the authors)

\begin{tabular}{|c|c|c|c|}
\hline Name & Type & Coastal region & Area $\left(\mathrm{km}^{2}\right)$ \\
\hline Kartaliysko (Orlovo) blato & Firth & North & $<0.10$ \\
\hline Durankulak & Firth & North & 4.90 \\
\hline Ezerets-Shabla & Firth & North & 4.17 \\
\hline Shablenska tuzla & Lagoon & North & 0.57 \\
\hline Nanevska tuzla & Landslide lake & North & 0.10 \\
\hline Bolata & Firth & North & 0.11 \\
\hline Balchishka tuzla & Landslide lake & North & 0.10 \\
\hline Batova & Firth & North & 13.00 \\
\hline Varna-Beloslav & Firth & North & 47.8 \\
\hline Liman (Pasha dere) & Firth & North & 5.20 \\
\hline Kamchia & Firth & Central & 37.70 \\
\hline Fandakliyska & Firth & Central & 0.40 \\
\hline Kara dere & Firth & Central & $<0.10$ \\
\hline Dvoynitsa-Perperi dere & Firth & Central & 2.99 \\
\hline Vaya & Firth & Central & 0.10 \\
\hline Hadzhiyska & Firth & South & 19.20 \\
\hline Aheloy & Firth & South & 0.14 \\
\hline Pomorie & Lagoon & South & 8.50 \\
\hline Atanasovsko & Firth & South & 25.00 \\
\hline Burgasko-Mandra (with Uzungeren Lake) & Firth & South & 108.60 \\
\hline Marinka & Firth & South & 7.10 \\
\hline Gerena & Firth & South & 3.45 \\
\hline Alepu & Lagoon & South & 0.14 \\
\hline Arkutino & Lagoon & South & $<0.10$ \\
\hline Ropotamo & Firth & South & 2.20 \\
\hline Stomoplo & Lagoon & South & $<0.10$ \\
\hline Dyavolska & Firth & South & 6.54 \\
\hline Karaagach & Firth & South & 4.20 \\
\hline Poturnashka & Firth & South & 0.36 \\
\hline Lisovo dere & Firth & South & 0.49 \\
\hline Papiyska & Firth & South & $<0.10$ \\
\hline Veleka & Firth & South & 0.15 \\
\hline Butamyata & Firth & South & $<0.10$ \\
\hline Silistar & Firth & South & 0.10 \\
\hline Rezovska & Firth & South & 0.17 \\
\hline
\end{tabular}




\section{PHYSICAL OCEANOGRAPHY AND MARINE CHEMISTRY OF THE BLACK SEA}

\subsection{PHYSICAL OCEANOGRAPHY}

The Black Sea is the largest meromictic basin on the Earth. Dense waters flowing from the Bosporus sink, while fresh river input floats at the surface. Deep layers do not mix with surface ones and as a result gas convection is prevented and deep layers remain anoxic. The established water column structure with strongly developed vertical stratification defines the physical parameters' characteristics $[61 ; 62 ; 63 ; 64 ; 65 ; 66]$.

Temperature. The surface temperature in the Bulgarian Black Sea waters is relatively evenly distributed throughout the entire area. In the summer, it reaches $25-30^{\circ} \mathrm{C}$,

and in the winter it decreases to $4-6^{\circ} \mathrm{C}$. During very cold winters it could drop down to $1-2^{\circ} \mathrm{C}[66]$.

The following basic vertical components are established:

- the upper homogeneous layer and seasonal (summer) thermocline connected generally to wind mixing processes and marine surface heat flux seasonal cycle;

- the Cold Intermediate Layer $(\mathrm{CIL})$ with a minimum temperature at depth induced

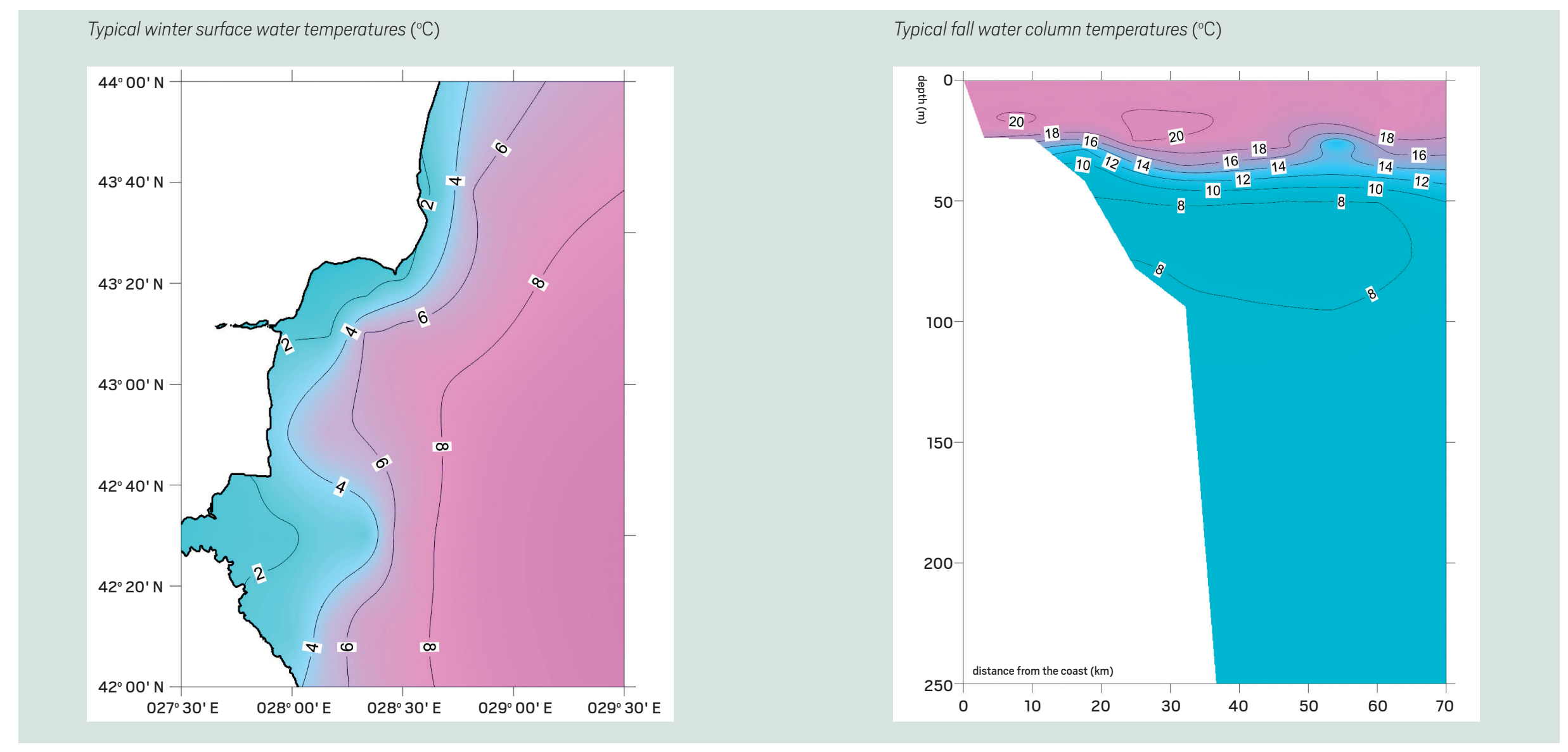


by fall-winter convection and cold water transfer from the northwest. CIL limits are considered to be the isohaline of $8^{\circ} \mathrm{C}$. The quasi-permanent $\mathrm{CIL}$ presence in the open water area at an average depth of 50-100 m is one of the Black Sea's major hydrological specifics;

- the deep layer at $200 \mathrm{~m}$ to the sea floor with relatively homogeneous spatial characteristics with no seasonal changes.

Salinity. The surface water salinity in the Bulgarian Black Sea area varies largely between 11- 13\% in the summer in case of abundant precipitation and between 18$19 \%$ in open waters in the winter. While in the summer its distribution is considerably influenced by the climatic specifics of the respective year, during the transitional seasons and in the winter the salinity is accordingly lower in the coastal waters and bays (about $16 \%$ ) and higher in the open waters [66].
Fresh water river input, mainly from the northwest, and precipitation are distributed by currents and turbulence in the upper water column layer which is 5-10 m thick in the spring and 40-60 $\mathrm{m}$ in late winter. The upper layer salinity increases to 17.518.5\%o. The Bosporus Mediterranean water inflow below 60 m enriches deep layers with more saline water reaching more than $20 \%$. This limit defines the mean longterm boundary of direct impact of the two primary water inputs which are external for the Black Sea. The following basic vertical components are established:

- the upper homogeneous layer;

- the permanent halocline (pycnocline) layer with high salinity and density vertical gradients. It is located between 120 and $200 \mathrm{~m}$ within the contact zone between the upper (Black Sea) and the lower (Mediterranean) water bodies. The density gradients favor the blocking of vertical mixing processes between them and support the existence of sustainable aerobic and anoxic layers:

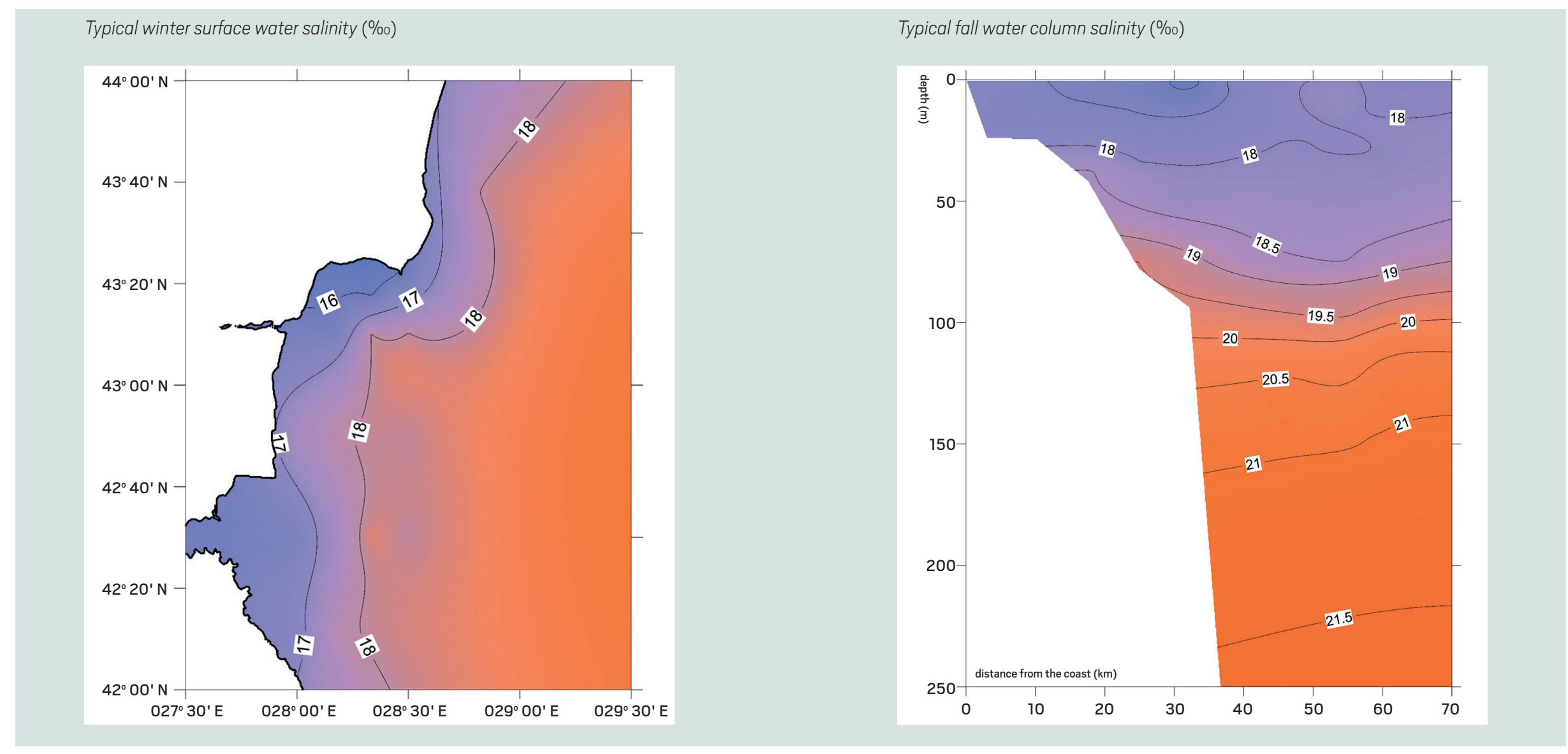


- the deep layer at $200 \mathrm{~m}$ to the sea floor with relatively homogeneous spatial characteristics with no seasonal changes.

Currents. The main factors that are responsible for the surface water circulation of the Black Sea and have an impact upon its character are wind, sea water density distribution, river stream flow, shoreline and bottom features. They define several surface water close gyres throughout the basin.

The principal surface circulation is cyclonic and waters around the perimeter of the Black Sea circulate in a basin-wide gyre known as the Rim Current. The Rim Current has a maximum velocity of about $50-100 \mathrm{~cm} / \mathrm{s}$ and flows at an average $10-30 \mathrm{n} . \mathrm{m}$. distance from the coast. It roughly coincides with the continental slope separating the shelf from the open sea area [67; 68; 69; 70; 71; 72; 73]. The Rim Current forms meanders along its stream, favoring eddies, rims and jet formation.

Three stable cyclonic gyres (western, central and eastern) are located in the open sea area and are enclosed by the Rim Current. Also, there are several Black Sea quasi-stationary anticyclonic eddies (Bosporus, Sebastopol, Batumi). One of them is located west of Cape Kaliakra and a less intensive one occurs in Burgas Bay.

The coastal current caused by the river inflow in the Black Sea's northwestern part is formed only after the Danube waters reception. Along the Romanian and Bulgarian Black Sea coasts the stream flows southward and near Cape Kaliakra it merges with the Rim Current forming a strong (especially in the area close to the continental slope) current generally flowing southward and reaching the maximum velocity for the entire basin [74]. Towards the coast the velocity decreases and counter currents (northward) arise. In immediate proximity to the coast currents are weak, influenced by winds, but generally retain a southerly direction.

The southern current along the Bulgarian coast is most intensive in the winter and spring. In the summer the northern counter-current intensiveness increases and in the fall it is often considerable.

Strong and continuous winds from the coast push out surface waters and form an upwelling of the subsurface layers. The adverse phenomenon, downwelling, combined

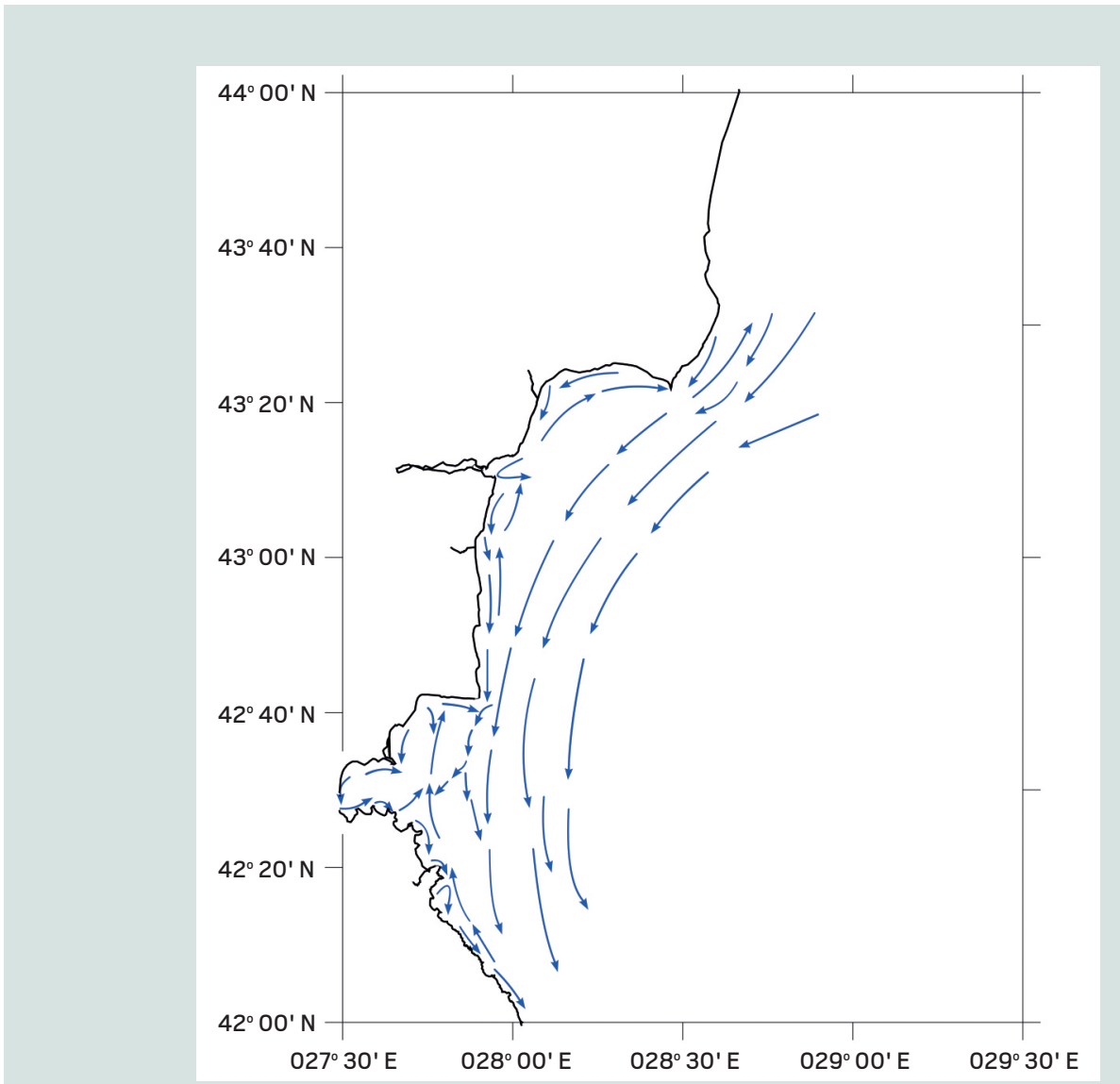

Sea currents on the Bulgarian Black Sea coast in winter (in blue) and summer (in red)

with the strong cooling of the surface waters in the winter favors the vertical circulation and sliding of water masses down the continental slope. The frequency and duration data for the described processes, as well as quantification of oceanographic parameters levels and rates are scarce and insufficient.

A principal characteristic of the current in the shelf area and continental slope is its significant spatial and seasonal variability. In the winter and early summer, the Rim Current stream is stable, while in the summer and early fall it decreases 1.5-2-fold allowing the formation of medium-scale rims, jets and similar filaments. These structures have a direct impact on both horizontal and vertical water transportation. 


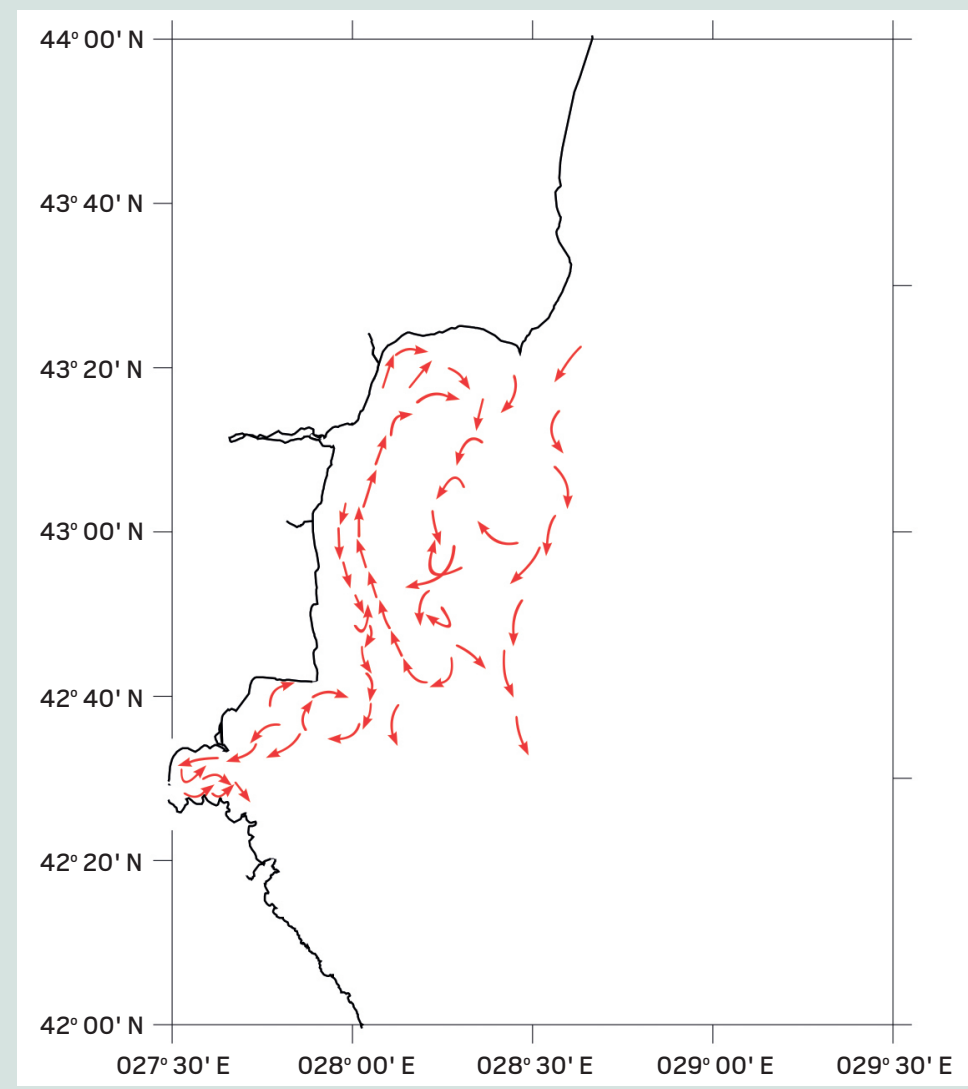

The rims' scale is about $15-100 \mathrm{~km}$ and it occurs in the upper $150-400 \mathrm{~m}$ layer. Their orbital velocity is in the $10-60 \mathrm{~m} / \mathrm{s}$ range, reaching the maximum immediately below the seasonal thermocline. The temperature decrease in the anticyclonical centers is about $7-3.5^{\circ} \mathrm{C}$. Unlike the Rim Current, the meander motion speed rarely reaches $10-$ $15 \mathrm{~cm} / \mathrm{s}$. The structures remain stable for a period varying from 1 week to 5 months. Less stable temporary rims constantly rise and fade, defining the complex and irregular Rim Current structure in the western Black Sea area.

The rim system strongly influences vertical oxygen and nutrient transportation and, in consequence, biological productivity. Depending on the rim intensity the southern regions could be more provided or less provided with nutrients originating from the Danube rim system.
Winds and waves. The western Black Sea, including the Bulgarian Black Sea coast, is subject to stronger winds than the rest of the basin. The wind speed at the open-basin area is higher than the one along the coast. In the winter the wind speed is often over $7 \mathrm{~m} / \mathrm{s}$. Northern quarter winds are predominant and southeastern ones are scarce. In the summer winds from the eastern quarter could occur.

Accordingly, waves are stronger in the fall and winter. Wave height is predominantly in the 1-3 $m$ range, but 5-6 $\mathrm{m}$ swells also occur. The strong eastern and northeastern winds in the fall, winter and spring months cause a considerable storm-wave activity which has a strong negative impact on the coast.

Mild seiches lower than $7 \mathrm{~cm}$ are a common phenomenon in the area, yet $7-2 \mathrm{~m}$ waves have also been recorded. Their duration may be as long as several hours

Tides in the Black Sea are insignificant and are always lower than $15 \mathrm{~cm}$.

A winter coastal storm in Varna Bay (North Bulgarian coast)

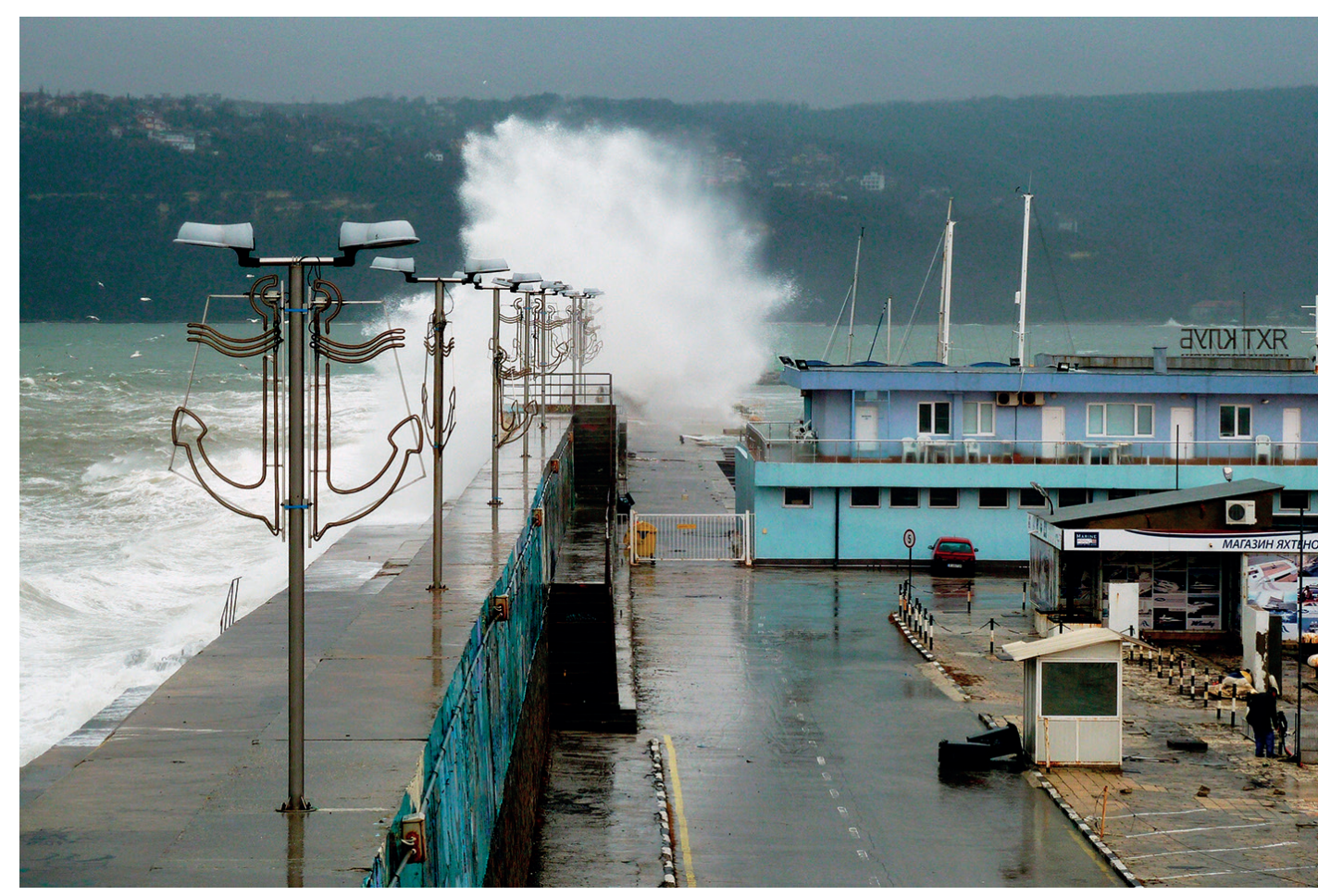




\subsection{MARINE CHEMISTRY}

The Black Sea is an internal semi-closed basin and its chemical regime is defined both by its hydrological specifics and external factors such as climate and river input $[67 ; 75 ; 76]$

Oxygen. Oxygen is provided in the water either by diffusion from the atmosphere, water masses convection or biochemical processes of photosynthesis. It is consumed by living organisms or during organic matter decomposition. Depending on the prevailing processes the equilibrium may be shifted to oversaturation or depletion. As a result of the vertical stratification the surface layer $(0-100 / 150 \mathrm{~m})$ is well aerated, while the deep layer below the halocline is anoxic. Between the aerobic upper layer and the anoxic deep layer lies the redox zone (approximately about 100-120 m) with minimum oxygen content.
Oxygen solubility is better in cold water and in result the oxygen content is higher in the winter. During the winter months the oxygen concentration reaches $360 \mu \mathrm{M}$ in the upper layer cold surface waters, and in the transitional seasons (spring and fall) it decreases to 250-300 $\mu \mathrm{M}$ with higher concentrations in coastal waters. In the summer the oxygen content decreases to $220-230 \mu \mathrm{M}$ excluding the coastal area where the concentration is $250 \mu \mathrm{M}$

Dissolved oxygen vertical distribution is defined both by differences in hydrological characteristics and occurring biochemical processes. Its maximum typically coincides with the chlorophyll maximum in the upper layer. From the thermocline down to the Cold Intermediate Layer $(\mathrm{CIL})$ the oxygen content is relatively constant. Oxygen decrease is initiated in the middle of the CIL and reaches concentrations of 20-30 $\mu \mathrm{M}$ where the hydrogen sulphide appears. In the oxicline the oxygen concentration suddenly decreases practically coinciding with the main pycnocline.
Typical summer surface dissolved oxygen distribution $(\mu \mathrm{M})$

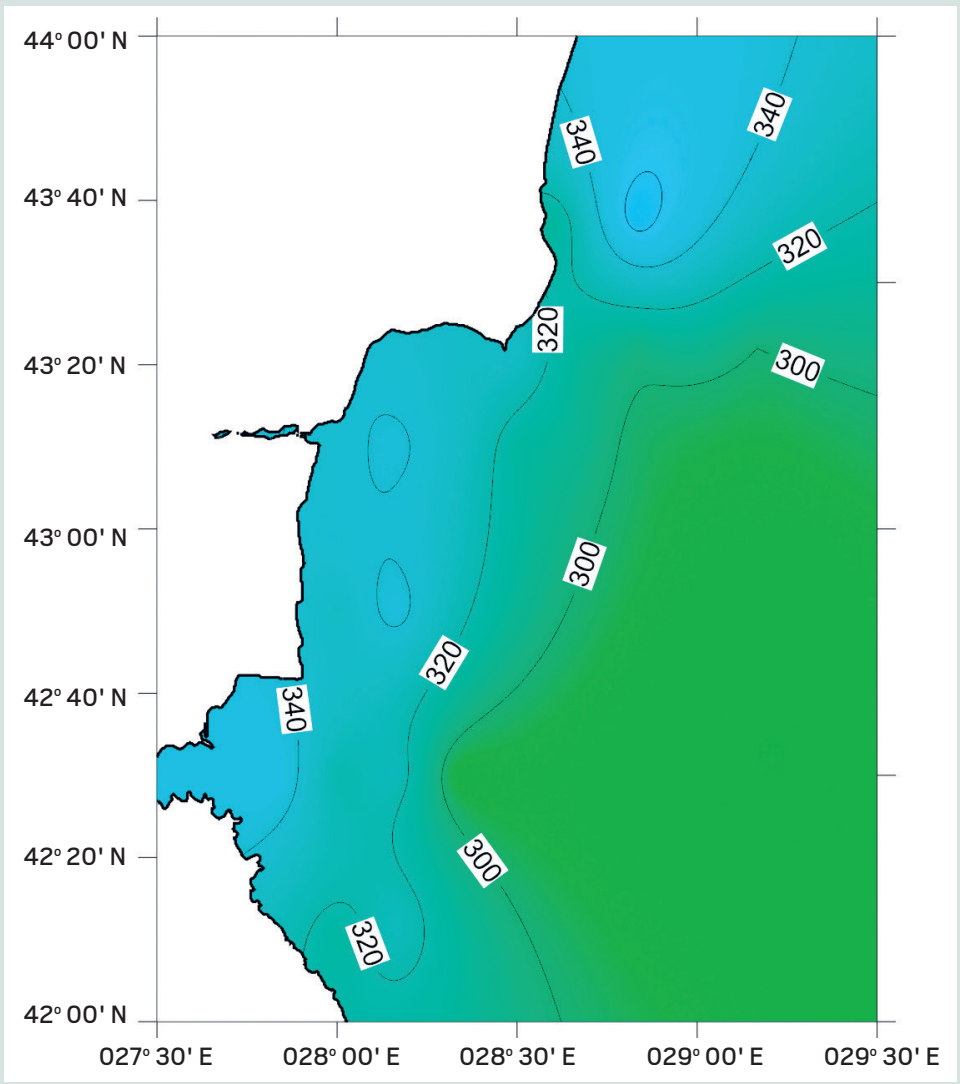

Typical fall water column dissolved oxygen distribution $(\mu \mathrm{M})$

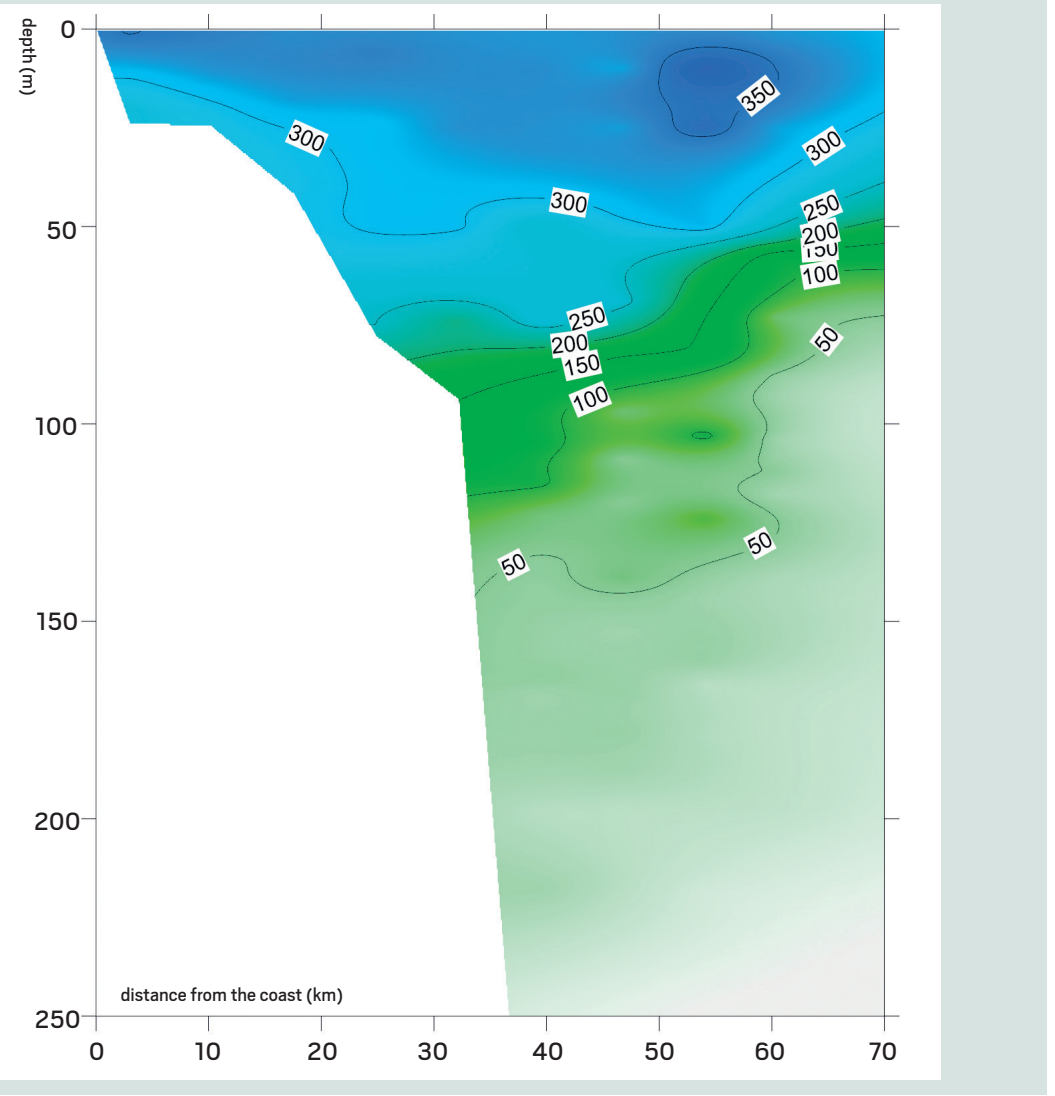

48 PHYSIOGRAPHIC AND OCEANOGRAPHIC CHARACTERISTICS OF THE STUDY AREA 
In the summer lower oxygen concentrations and saturation are detected in the shelf zone bottom layers due to summer water column stratification and oxygen consumption during oxidizing processes. The oxygen saturation in the bottom layer is usually $68-86 \%$. A reduction of oxygen saturation as low as $20 \%$ is possible in coastal waters bottom layers in the summer. Lower values trigger mass mortality in benthic organisms which might occasionally happen.

Nutrients. Nutrients are essential for marine life. Their presence provides primary production capabilities of the water body. The absence of one of them would prevent phytoplankton growth, while establishing a certain nutrient ratio may lead to overgrowth, algal bloom and eutrophication. In the 1990s red tides were common along the Bulgarian coast, but after the 2000s a period of relatively moderate plankton growth began. Nutrients are provided in the area mainly by northern river input, but also by coastal fluxes, precipitation and organics mineralisation. They are consumed by phytoplankton generating primary production.

Typically, the mineral form of one of the nutrient elements is depleted in the euphotic zone (upper water column layer) and is considered as limiting. In deeper waters due to organic matter decomposition nutrients are mineralised again and their concentrations rise significantly. Because of the specific basin water column hydrological structure certain nutrient elements transform to their reduced forms below the CIL.

The coastal and shelf areas are recognized as nutrient enriched regions compared to the open water area, especially the upper homogeneous layer. The CIL is specific and its characteristics depend primarily on the climatic conditions and the possibilities for its restoration.

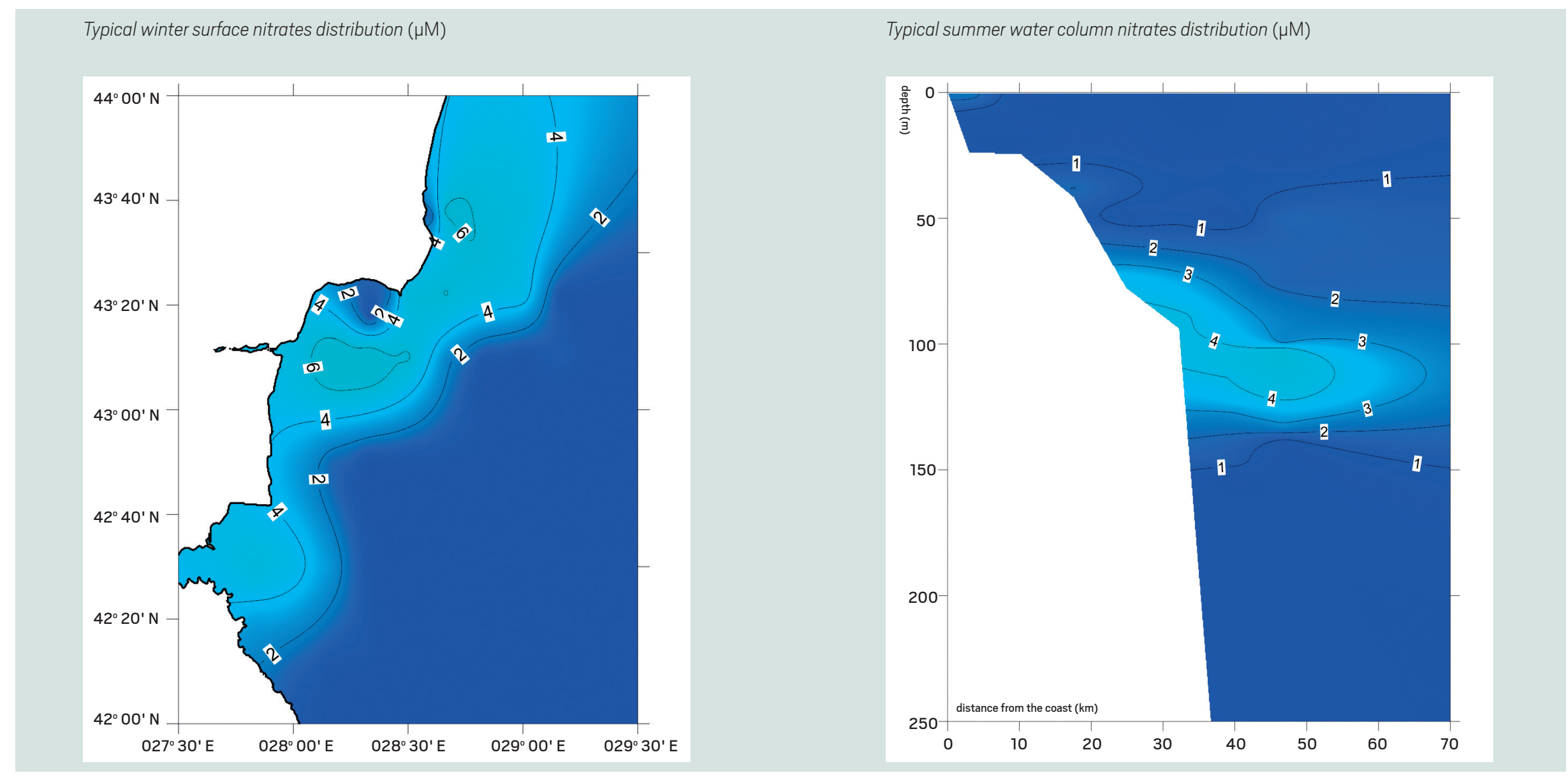




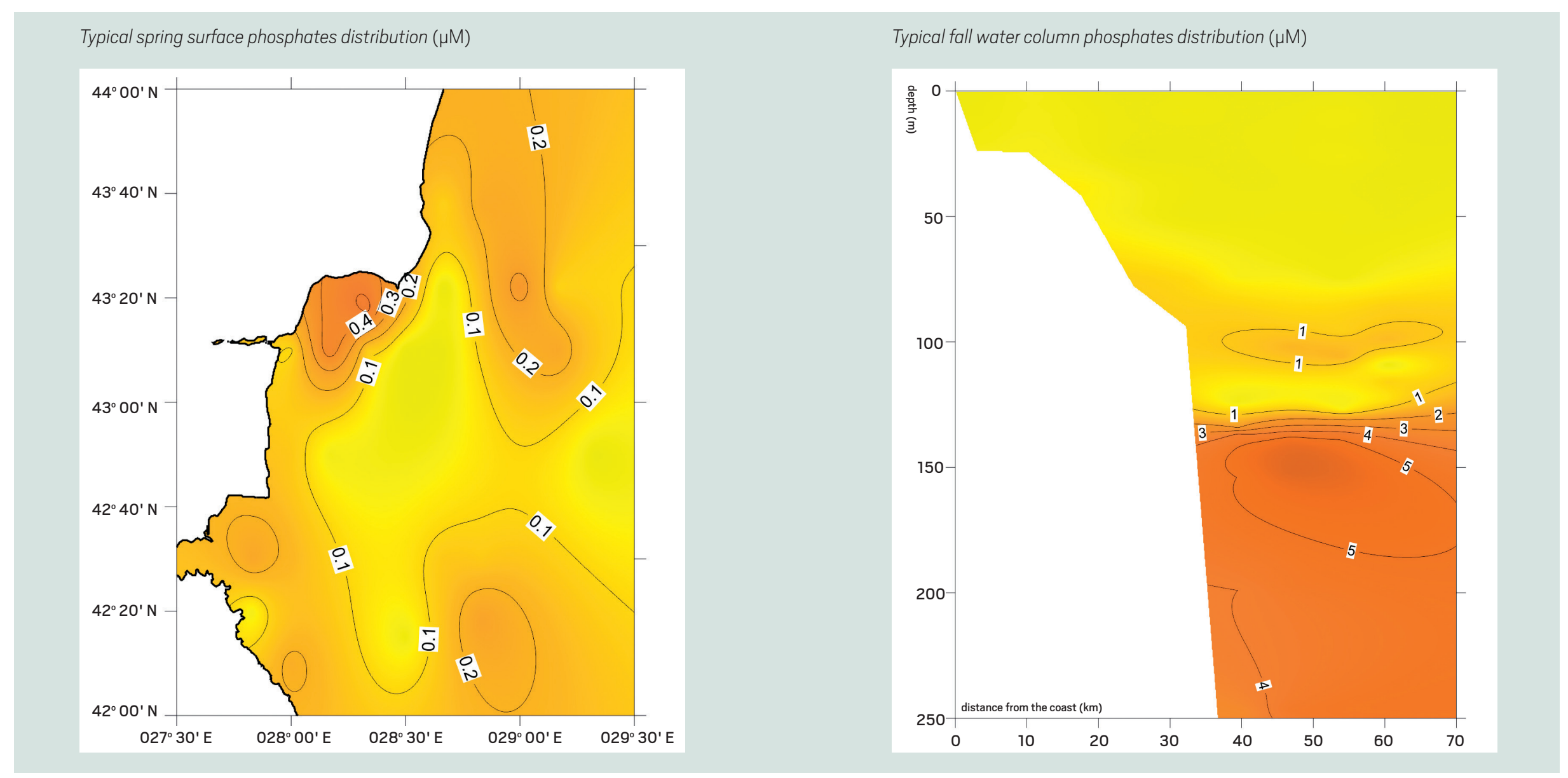

Nitrogen. The principal form of inorganic nitrogen in oxygen conditions are nitrates. In the winter nitrate concentration in coastal waters is an average 5- $6 \mu \mathrm{M}$ gradually decreasing to $0.2 \mu \mathrm{M}$ in the open water area. In the shelf area the nitrate content is lower $(1-2 \mu \mathrm{M})$ in the transitional seasons, and in the summer it decreases further down to $0.2 \mu \mathrm{M}$ and is fairly uniformly distributed throughout the entire area.

While nitrate concentrations are relatively constant $(0.5-0.8 \mu \mathrm{M})$ in the upper layer a maximum of more than $3 \mu \mathrm{M}$ is seen in the $\mathrm{CIL}$. Nitrate accumulation in the $\mathrm{CIL}$ is defined by organic matter mineralisation, as well as nutrient rich waters in the winter. At the lower $\mathrm{CIL}$ boundary and the redox zone upper limit the nitrate content decreases to total depletion due to its reduction to ammonia [62; 64; 65; 66; 75; 76]
The spatial distribution of nitrates is characterized by higher concentrations in the northern shelf area due to the increased transformed water impact of the Danube River inflow [61]. In case of heavy precipitation the nitrate content rises in the coastal congestive zones, mainly bays.

Phosphorous. Phosphate concentrations vary from 0 to $12 \mu \mathrm{M}$ in the water column. In the winter the surface content is in the $0-0.5 \mu \mathrm{M}$ limits and decreases towards the open water area. In the spring and summer the phosphate concentration range is wider, $0-2.7 \mu \mathrm{M}$. The phosphates are often fully depleted especially in the open water area. Values under the detection limits of the analytical methods are common, especially in the open waters. In the summer the range of the phosphate content is 
0-7.5 $\mu \mathrm{M}$ with lower concentrations domination. The vertical distribution of phosphates is characterised by depletion in the surface layer down to $10 \mathrm{~m}$. Its average concentration is $0.1 \mu \mathrm{M}$ in the spring thermocline between $10-25 \mathrm{~m}$. The phosphate content gradually increases in the CIL between 50 and $100 \mathrm{~m}$ in the 0.3-0.5 $\mu \mathrm{M}$ range. There are two maximums in the water column and their depth depends on the season. Below $200 \mathrm{~m}$ the phosphate content gradually increases regardless of the season $[62 ; 64 ; 65 ; 66 ; 75 ; 76]$.

Similarly to the nitrogen mineral forms, phosphorous forms are highly dependable on large Black Sea rivers inflow, current direction, coastal line specifics and precipitation amount. Therefore the typical surface distribution is characterized by higher concentrations of phosphates in the northern Bulgarian Black Sea coast and the congestive zones.

Typical winter surface silicon distribution $(\mu \mathrm{M})$

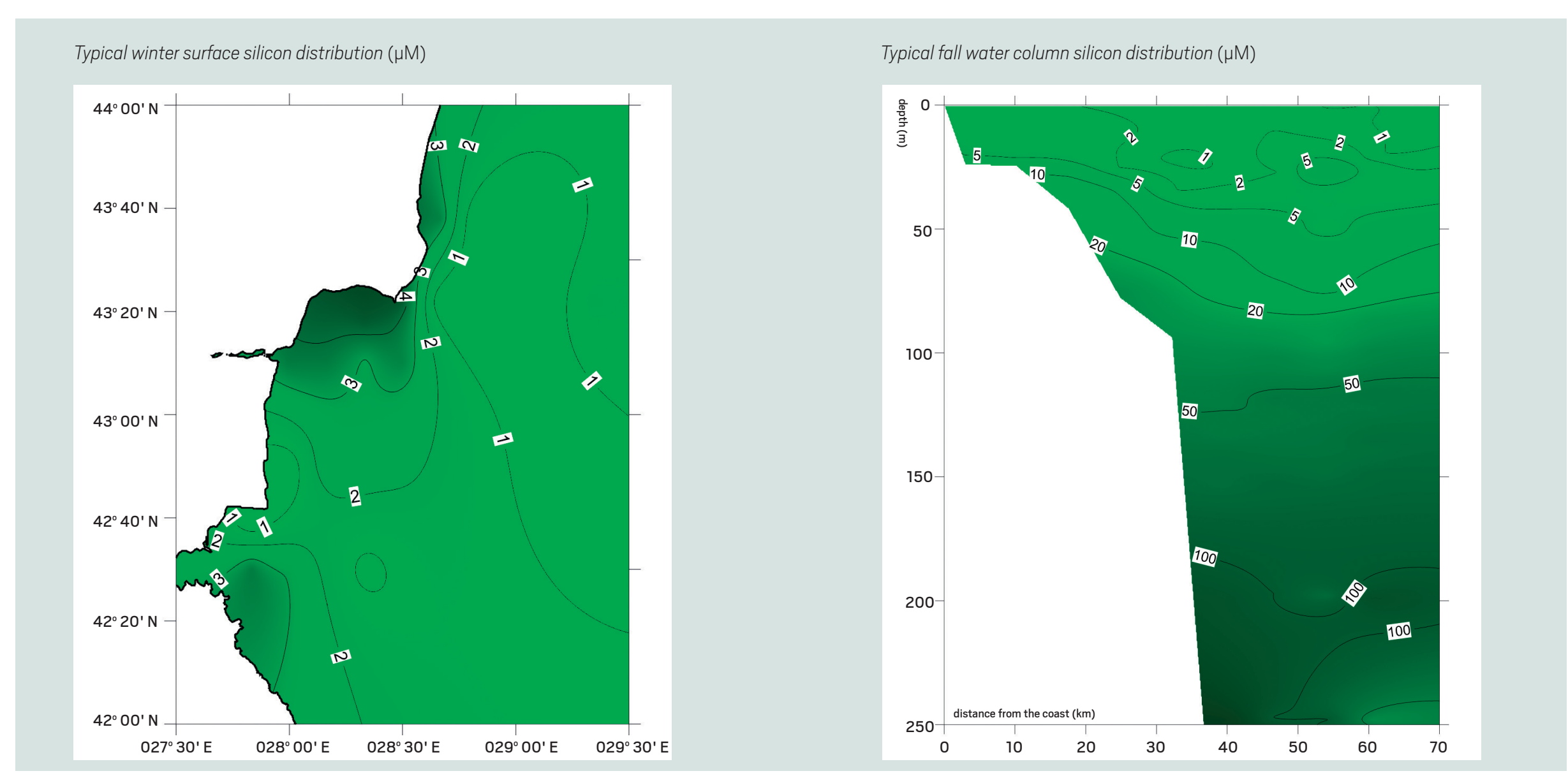

Silicon. The silicon content varies between 0-390 $\mu \mathrm{M}$. In the coastal area silicon concentrations are minimal to totally depleted in the transitional seasons (spring and fall) and maximum in the winter. Silicon depletion is observed in the upper $10 \mathrm{~m}$ layer. The seasonal dynamics in the open water accounts for the lowest concentrations in the winter $(0-100 \mu \mathrm{M})$ and the highest concentrations in the transitional seasons and summer (0-390 $\mu \mathrm{M})$. In the summer silicon is partially to fully depleted in the euphotic layer. The silicon content increases gradually with depth. At $200 \mathrm{~m}$ concentrations are about $100 \mu \mathrm{M}$ increasing to $400 \mu \mathrm{M}$ further down [62; 64; 65; 66; 75; 76].

Surface waters in the Bulgarian Black Sea area are relatively poor of dissolved silicon which rarely exceeds 3-4 $\mu \mathrm{M}$. Higher concentrations are found in coastal waters. Close to the coast the silicate content and its distribution are considerably influenced by both river inflow and the climatic specifics of the respective season. The content could exceed $10 \mu \mathrm{M}$ in case of heavy precipitation. In the open waters surface layer silicon concentrations are always low. 


\section{SOIL AND VEGETATION COVER OF THE BULGARIAN BLACK SEA COAST}

\subsection{SOIL COVER}

Generally, soils are a product of rock weathering caused by climate, surface streams and vegetation taking place in a given topographic environment. Therefore these factors represent the main drivers of pedologic processes.

A total of 14 pedologic types with several subtypes occur on the Bulgarian Black Sea coast $[77 ; 78 ; 79]$. Most of these are of azonal nature and are closely related to the existing lithologic and geomorphic conditions.

Arenosols occur in large beach-dune systems in the coastal zone. The majority of them are located in the section south of Cape Emine, e.g., in the vicinity of Sunny Beach resort, Nesebar, Ravda, Sozopol, Primorsko, etc. [77]. These sandy soils are also present at some of the denudational surfaces of the Avren Plateau where such areas have been converted into vineyards and orchards [56]

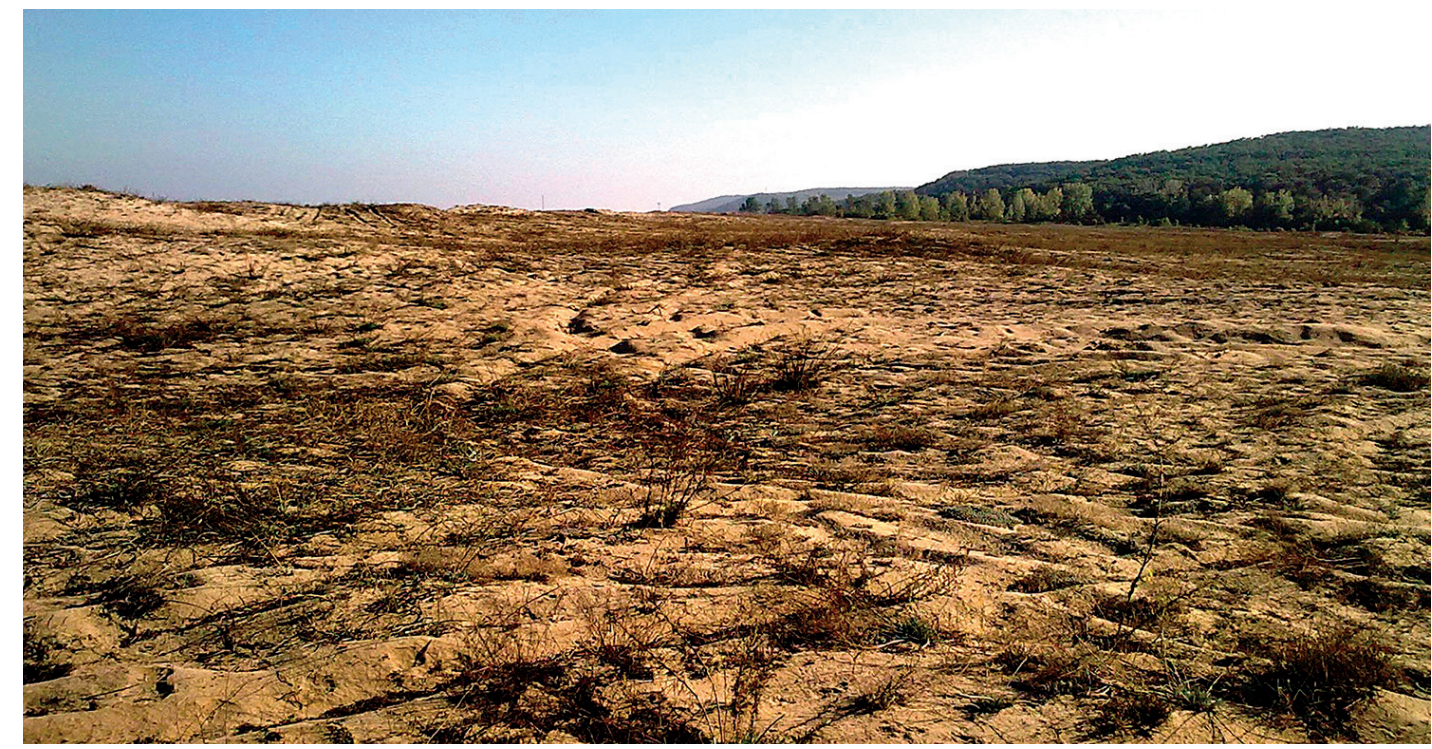

52 PHYSIOGRAPHIC AND OCEANOGRAPHIC CHARACTERISTICS OF THE STUDY AREA
Regosols are a soil type that is poor in organic matter, usually formed at erosive terrains where the lithology is represented by clayish sands and other unconsolidated Neogene material, almost devoid of a vegetation cover [77]. These are typical for the sea-facing slopes of the Franga Plateau, Kamchia and Emine mountains [79]

Leptosols are presented by three major subtypes - lithic (lithosols), rendzic (rendzinas), and umbric. These azonal pedologic subtypes are commonly found at terrains with exposed lithology. Such areas may include cliffs, steep erosive valleys, certain landslide areas, denudation surfaces of sparse vegetation, etc. In most cases, these soils are shallow and provide unfavorable conditions for development of arboreal communities [77]

Colluviosols do not exist as a pedologic taxon in the Food and Agriculture Association (FAO)'s classification [78]. Nevertheless, this soil type is often differentiated and thereby officially adopted in the schemes developed for Bulgaria [77]. As the name implies, such soils occur on accumulated colluvial materials and are commonly found at the base of cliffs, slopes, landslides, ravine beds, etc. Depending on other environmental factors at a given location (moisture availability, exposition, slope steepness, etc.) this pedologic type is able to support a dense vegetation cover.

Colluviosols at Avren Plateau coastal zone (North Bulgarian coast)

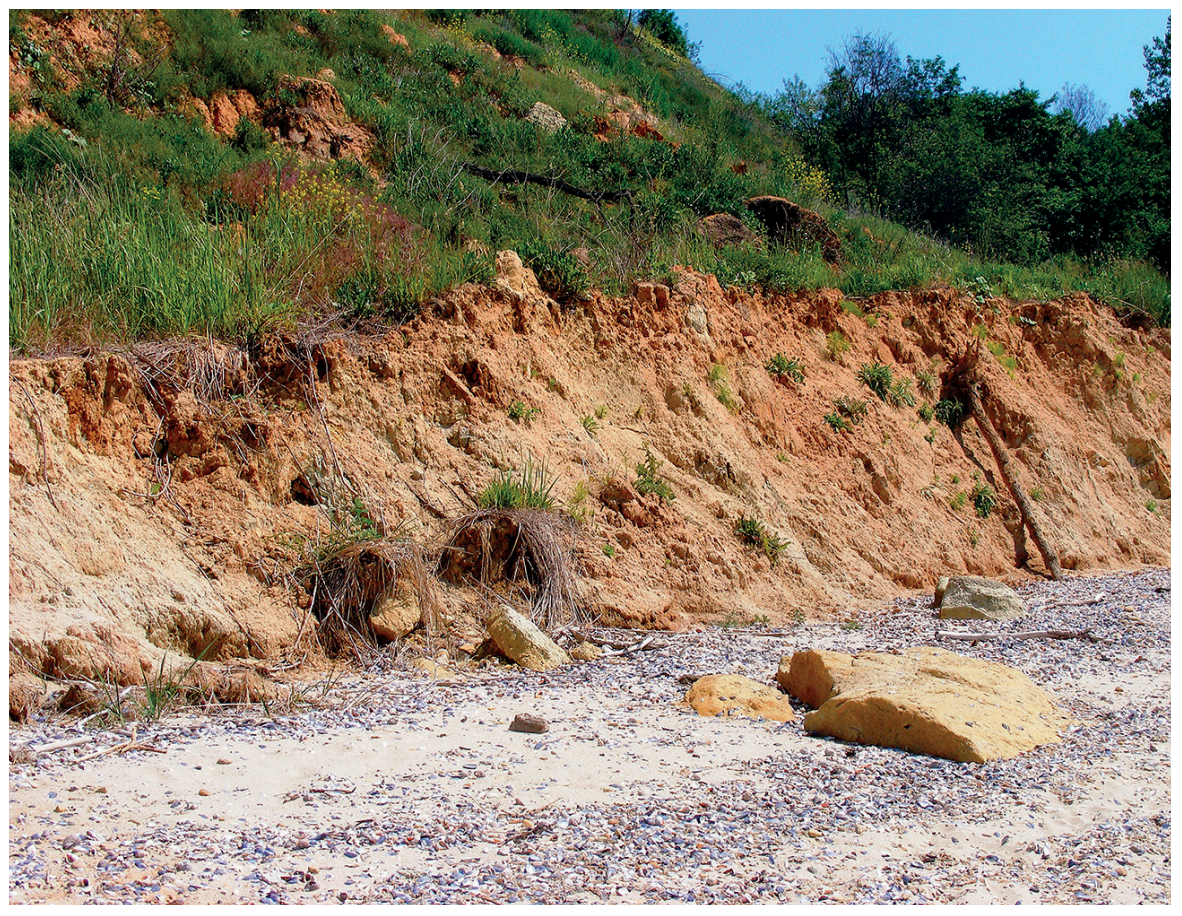


Solonchaks along the Bulgarian shore typically occur at the periphery of saline coastal lakes. This type of soil can be observed at Shablenska tuzla, Nanevska tuzla, and Balchishka tuzla areas (North Black Sea coast), Pomorie Lagoon and Atanasovsko Lake (South Black Sea coast), etc. [79].

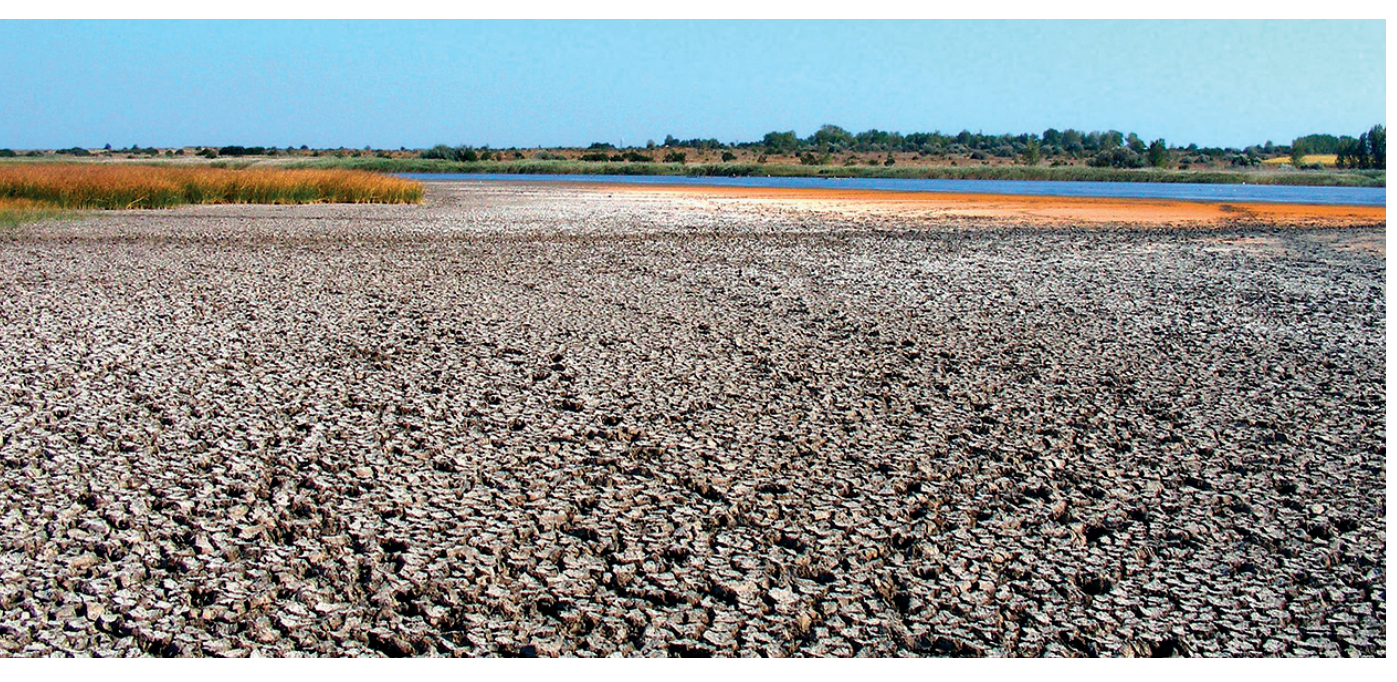

Solonchacks at Shablenska tuzla Lagoon (North Bulgarian coast) with a clearly visible salt crust

Gleysols are found exclusively in waterlogged firth and brackish lagoon areas. This soil type is usually vegetated by various hygrophilous plant associations [77].

Fluvisols along the coast are presented by three subtypes - mollic, calcaric and eutric [77]. These occupy riparian zones and are commonly developed within fluvial terraces along major Black Sea tributaries, e.g., the Provadiyska, Kamchia, Ropotamo, Veleka, Rezovska, etc.

The presence of nitisols in Bulgaria is as yet a subject of ongoing scientific debates. Some authors, e.g., Koleva-Rekalova (1998) [80] describe this pedologic type in the areas with Sarmatian rocks in northeastern Bulgaria.

Alisols are among the most characteristic features of the Strandzha Mountain where they occupy an area of approximately 27,000 ha. These soils are formed under relic Southeuxinian forests and the influence of sub-Mediterranean climate [77].

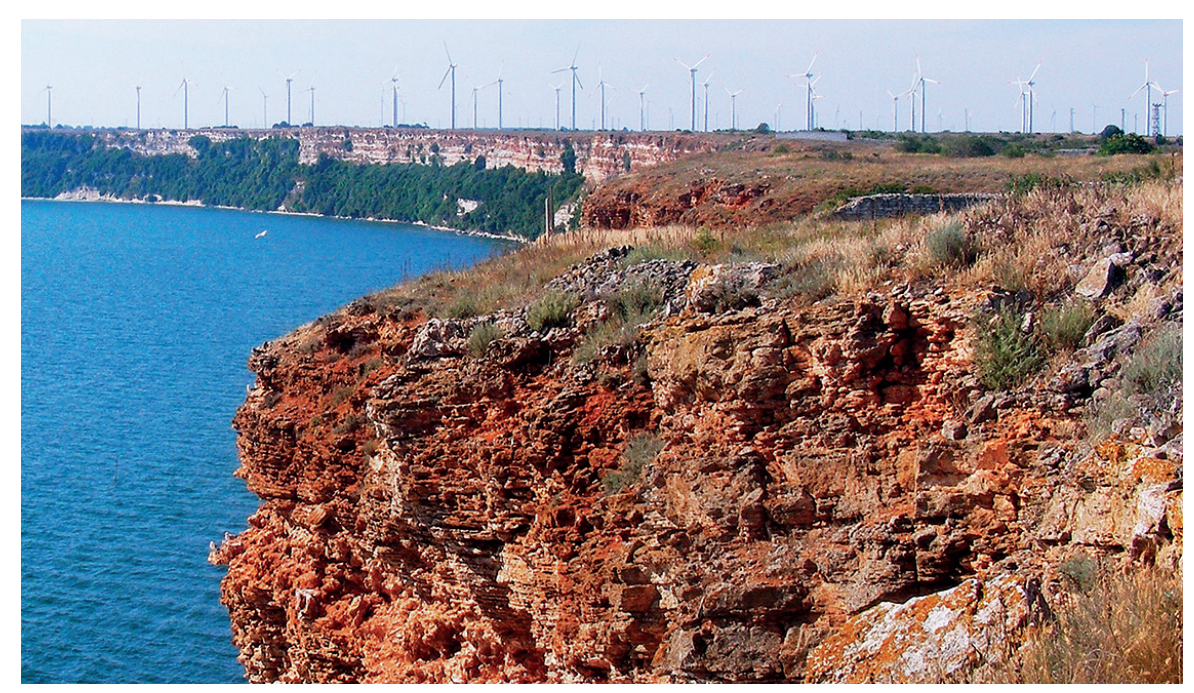

Lithic nitisols or just rendzinas? Some researchers classify the red-colored carbonate-rich shallow soils in the vicinity of Cape Kaliakra as nitisols, also known as terra rossa

Cambisols on the Bulgarian Black Sea coast are presented by the pertinent chromic cambisols subtype. It occurs at the Emine Mountain, in the vicinity of Primorsko, etc., normally under low-productivity deciduous forests, dry grasslands and xeric shrubs [77].

Vertisols normally occupy the floors of the intermontane basins (depressions) of southern Bulgaria [34]. Along the coast these are observed south of the East Balkan Mountains, and the Burgas Lowland in particular [79].

Chernozems and kastanic chernozems in particular (also known as calcic chernozems - [77]) are a distinctive feature of the Dobrudzha and Franga plateaus which are constituent parts of the Lower Danube Plain. Developed exclusively on loess materials, such fertile territories of the North Bulgarian coast are almost entirely converted into agricultural landscapes.

Kastanic chernozems in the vicinity of Shabla (North Bulgarian coast)

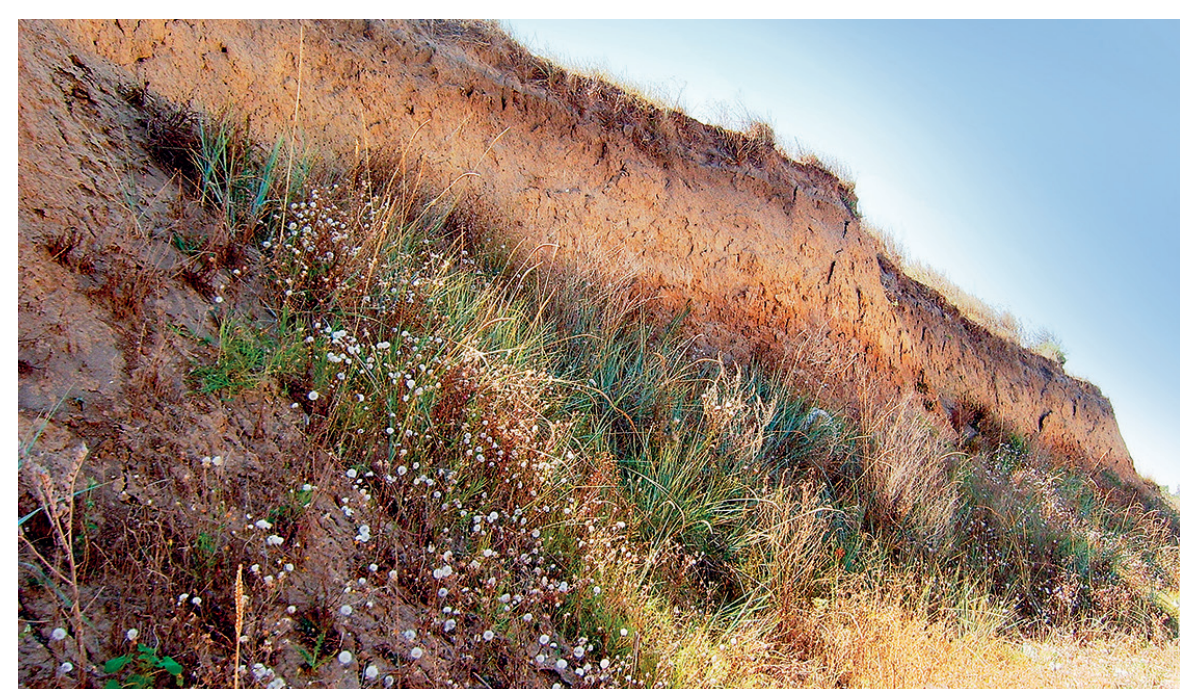


Phaeozems occupy a limited area along the coast. These soils are developed exclusively on loess clays and are almost entirely vegetated with arboreal broad-leaved communities.

Phaeozems at Avren Plateau coastal area (North Bulgarian coast)

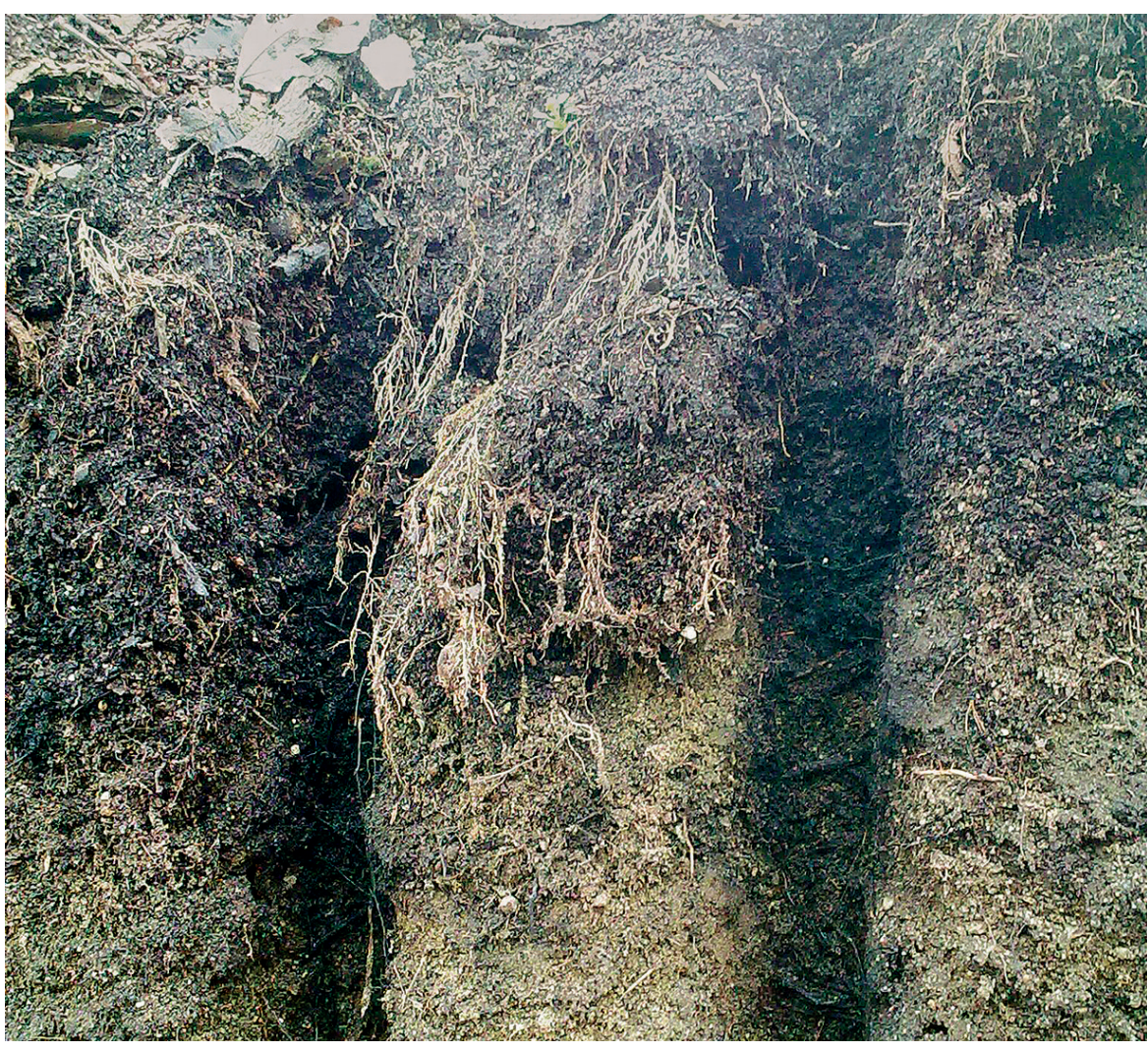

Luvisols in coastal areas are presented by three subtypes - calcic, chromic and albic. The presence of these soils does not depend on topography or lithology, but is largely predetermined by climate, a major factor for their formation along with the deciduous arboreal vegetation [77]. Calcic luvisols are commonly found in the coastal area of the Dobrudzha Plateau. Chromic luvisols are largely present at the sea-facing slopes of the Franga Plateau, the southern portion of the Emine Mountain, Boaza locality north of the mouth of the Kamchia River, the coast of Medni rid Ridge, the Strandzha Mountain, etc. Albic luvisols occupy vast territories of the Avren Plateau, Kamchia Mountain and the northern slopes of the Emine Mountain where they are mostly found under oak- and hornbeam-dominated forests [56].

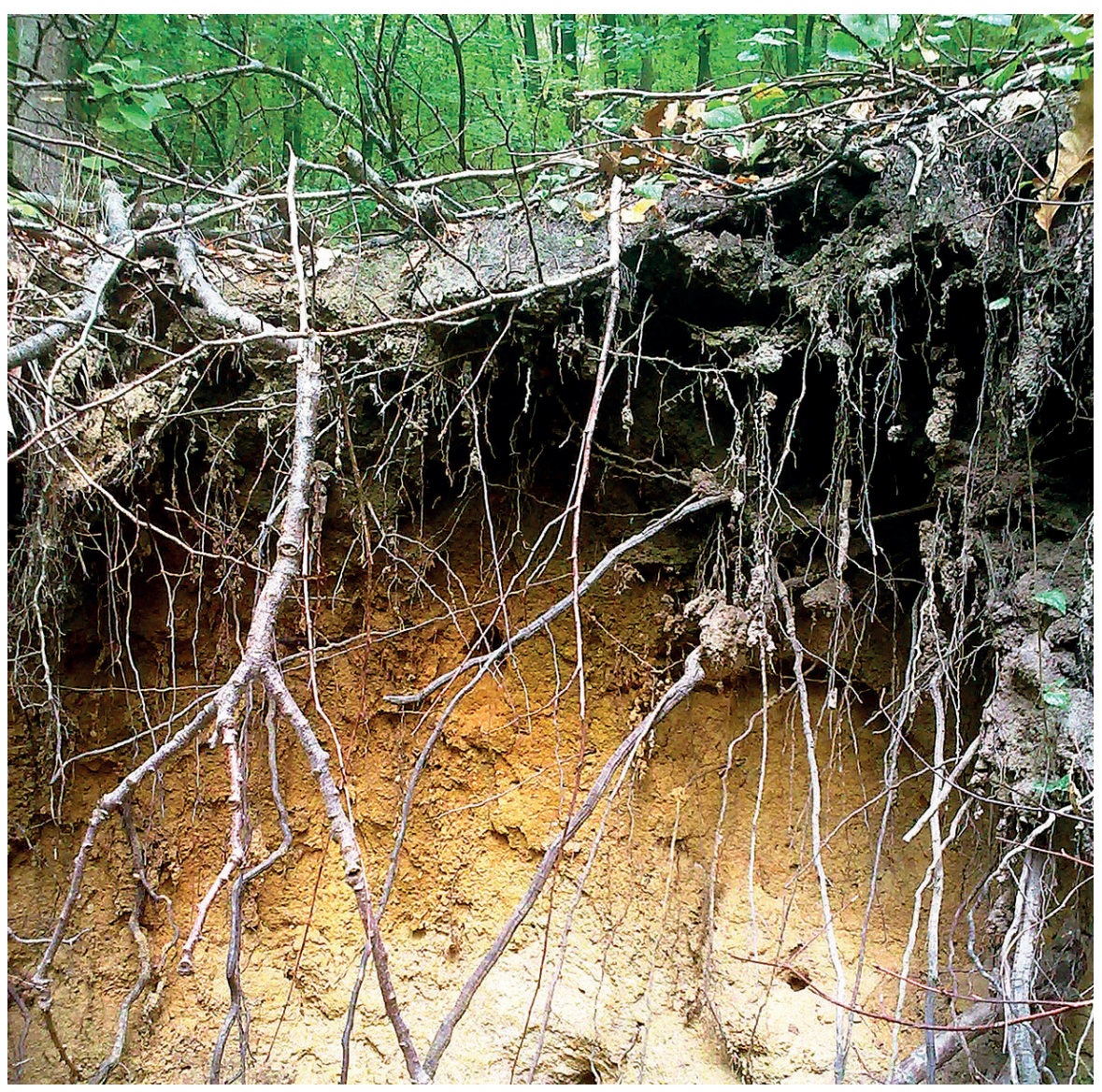

Albic (above) and chromic (below) luvisols in the vicinity of the Kamchia River Valley (Central Bulgarian coast)

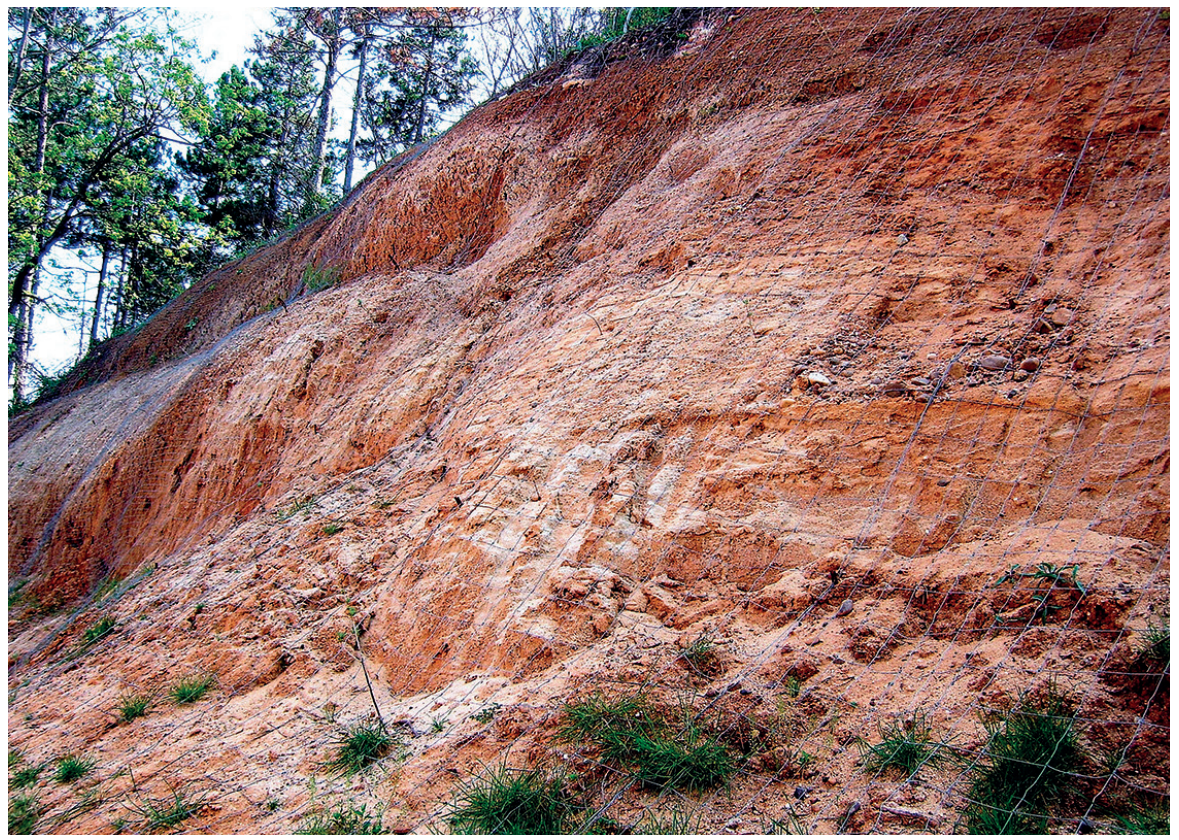


The natural vegetation on the Bulgarian Black Sea coast is characterized by the dominance of temperate forest communities with a prevalence of Turkish oak (Quercus cerris L.) and Italian oak (Q. frainetto Ten.). These forests are spread in lowlands and hilltops, as well as in the Eastern Balkan Mountains Range (East Stara Planina Mountain) and Strandzha Mountain.
Large areas in the Strandzha Mountain are occupied by communities of Oriental durmast oak (Quercus polycarpa Schur.) and common hornbeam (Carpinus betulus L.) with field maple (Acer campestre L.) and silver lime (Tilia tomentosa Moench) Relic Southeuxinian forests of Oriental beech (Fagus orientalis Lipsky) with an undergrowth of the evergreen shrub Pontic rhododendron (Rhododendron ponticum L.) cluster within the more humid ravines of the Strandzha Mountain.

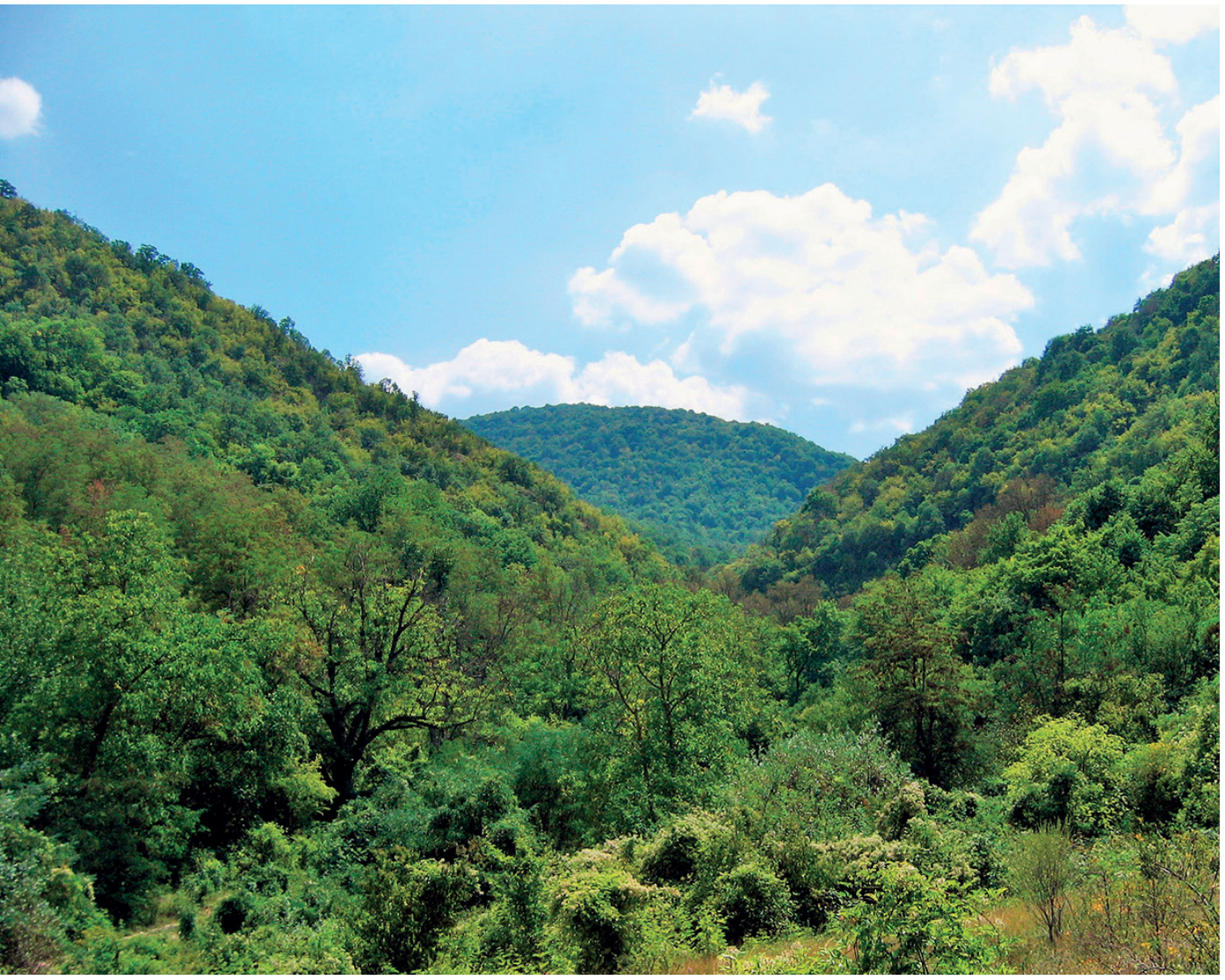

Southeuxinian forests of Oriental beech (Fagus orientalis) with undergrowth of Pontic rhododendron (Rhododendron ponticum), Strandzha Mountain coastal area

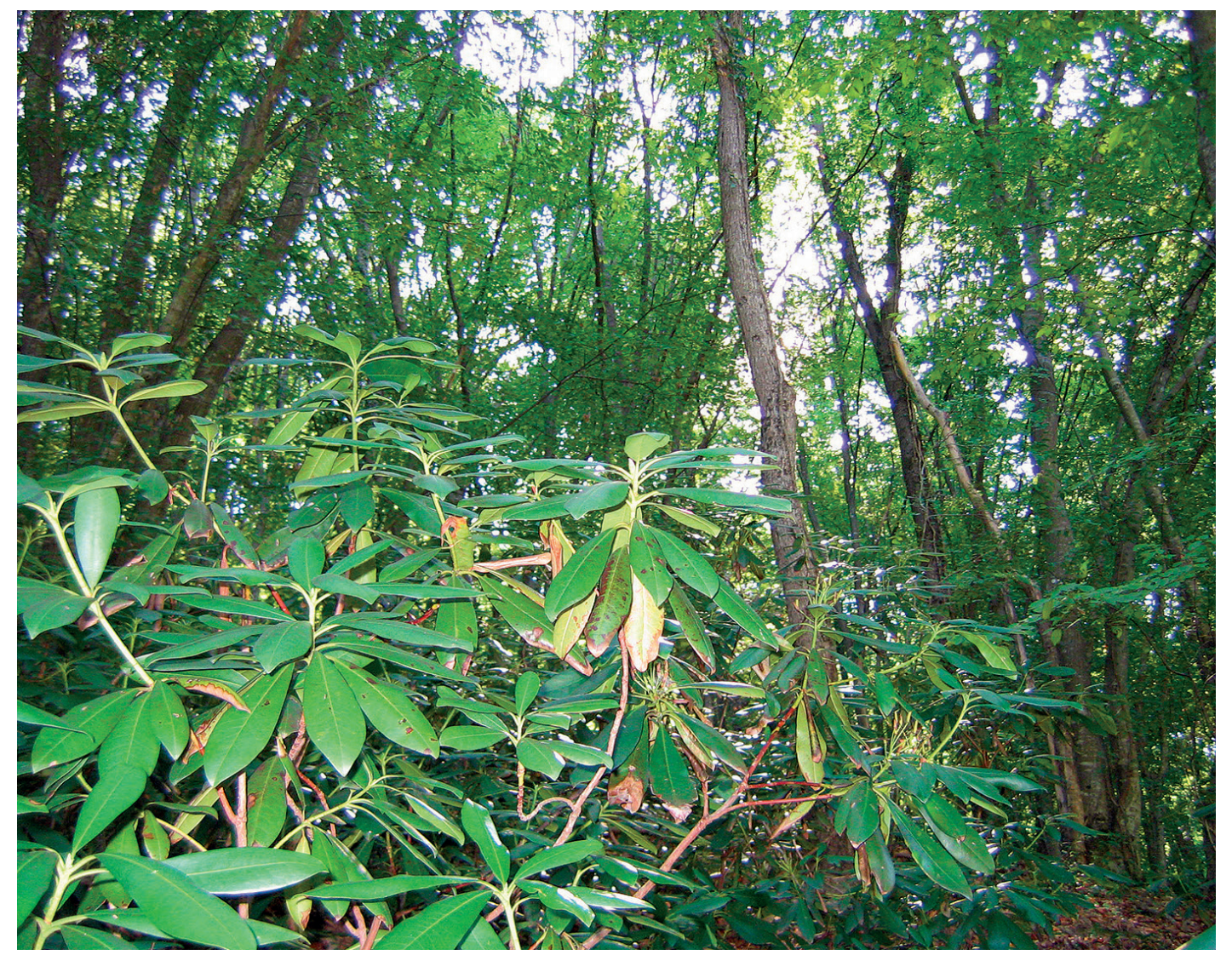


Riparian forests lining rivers and lakes are periodically inundated. Their main components are common ash (Fraxinus oxycarpa Willd.), field elm (Ulmus minor Mill.) common hornbeam (Carpinus betulus), pedunculate oak (Quercus pedunculiflora C Koch) and black alder (Alnus glutinosa (L.) Gaerth). Riparian forests are particularly rich in lianas: Hedera helix L., Periploca graeca L., Smilax excelsa L., Vitis vinifera L., and Clematis vitalba L.
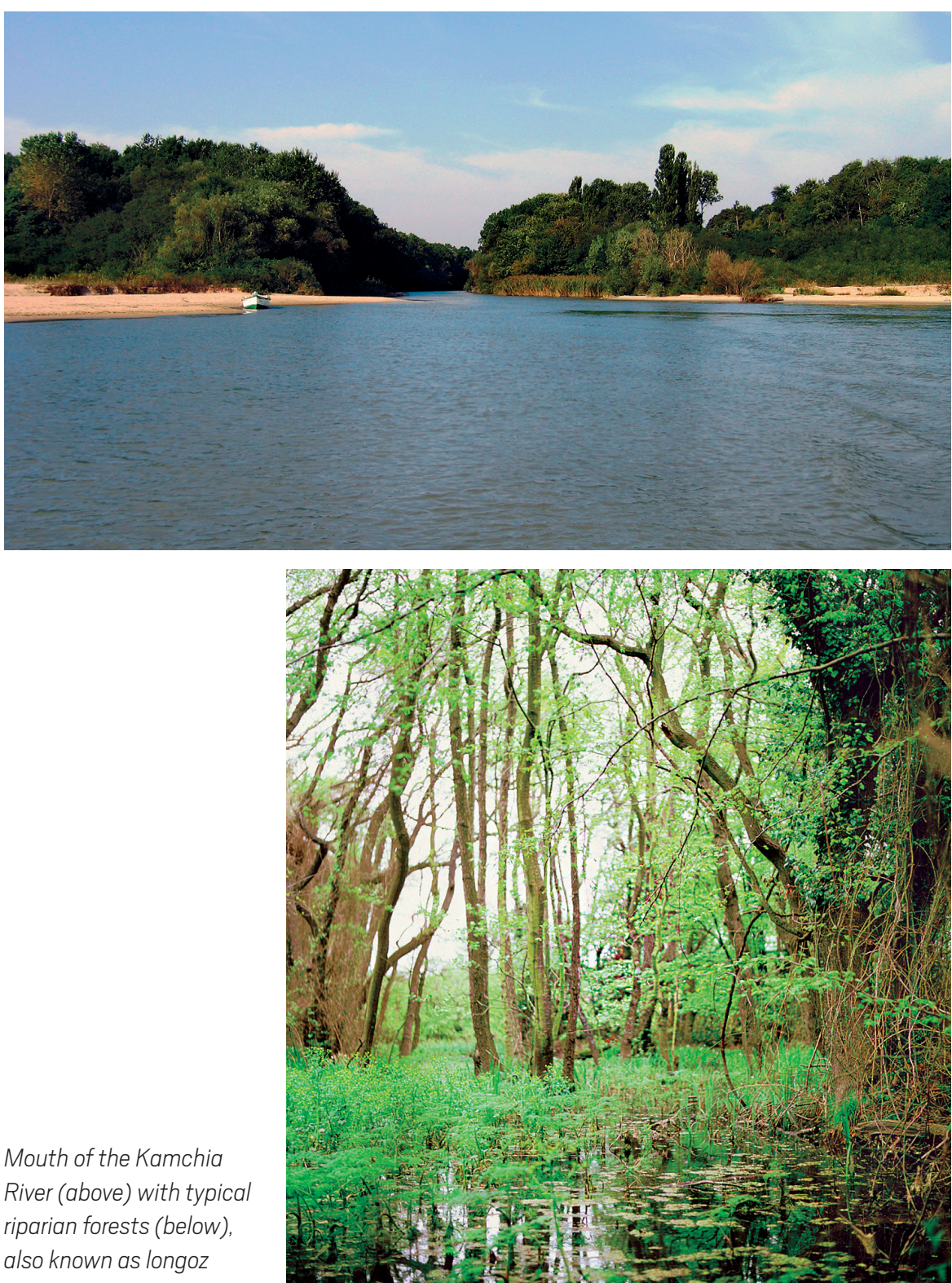

Steppe vegetation dominated by herbaceous species such as Festuca pseudovina Hack. Ex Wiseb., Chrysopogon gryllus (L.) Trin., Dichantium ischaemum (L.) Roberty, Poa bulbosa L., Agropyron brandzae Pantu et Solac., Koeleria brevis Stev., Stipa lessingiana Trin. et Rupr., Artemisia lerchiana Weber, Adonis vernalis L., Paeonia tenuifolia $L$. is only spread in the South Dobrudzha region of the North Bulgarian Black Sea coast (Cape Shabla and Cape Kaliakra areas)

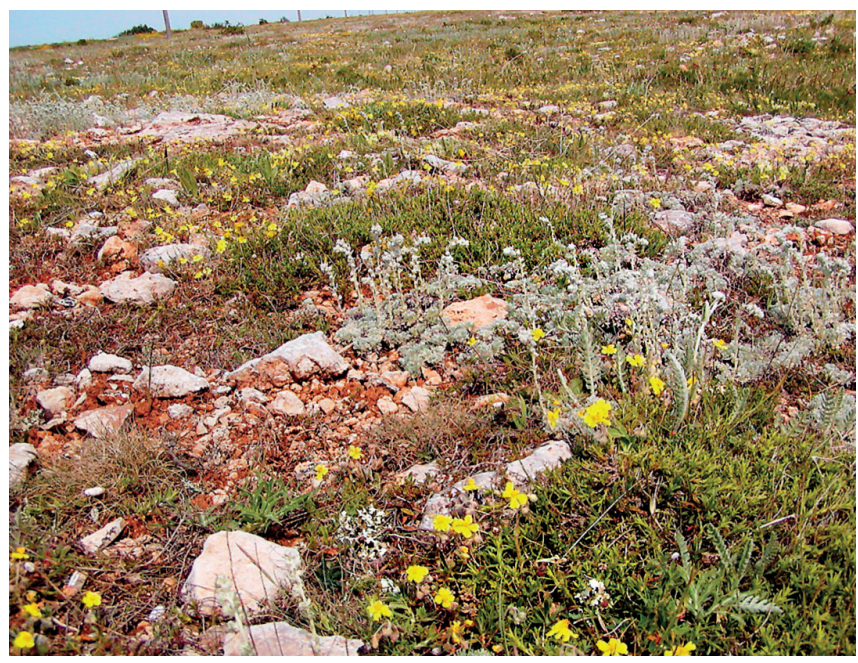

Stepite (The Steppes)

Protected Area near

Cape Kaliakra (North

Bulgarian coast)

Mediterranean vegetation occurs on the South Black Sea coast: there are communities of Jerusalem thorn (Paliurus spina-christi), Oriental hornbeam (Carpinus orientalis Mill.), mock privet (Phillyrea latifolia L.), manna ash (Fraxinus ornus L.), downy oak (Quercus pubescens Willd.) and nettle tree (Celtis australis L.).

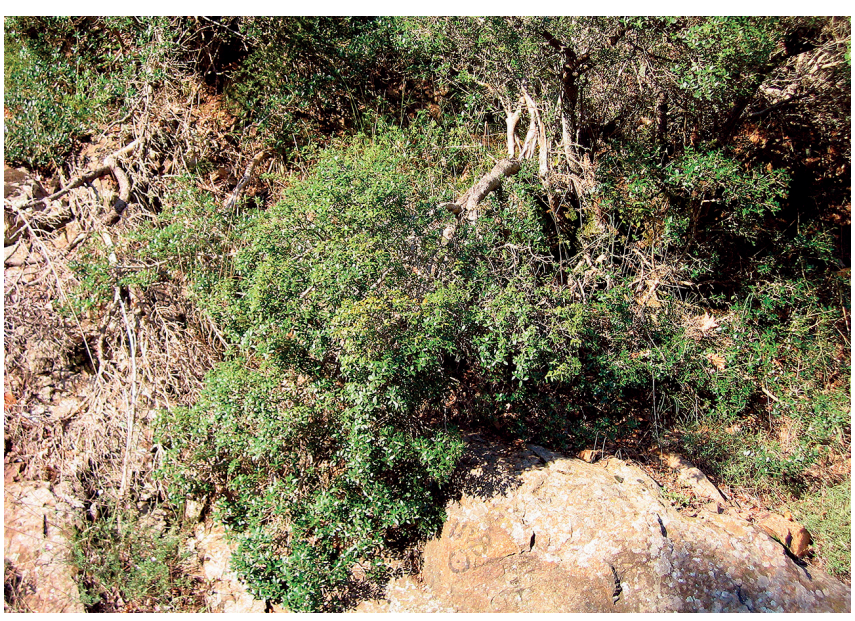

Mediterranean

vegetation (association of Phillyrea latifolia) in Strandzha Mountain 
Aquatic and halophytic formations are distributed along the peripheries of the coastal lakes. These are dominated by reed (Phragmites australis (Cav.) Trin. ex Steud.), Typha latifolia L., T. angustifolia L. and Schoenoplectus lacustris (L.) Palla.

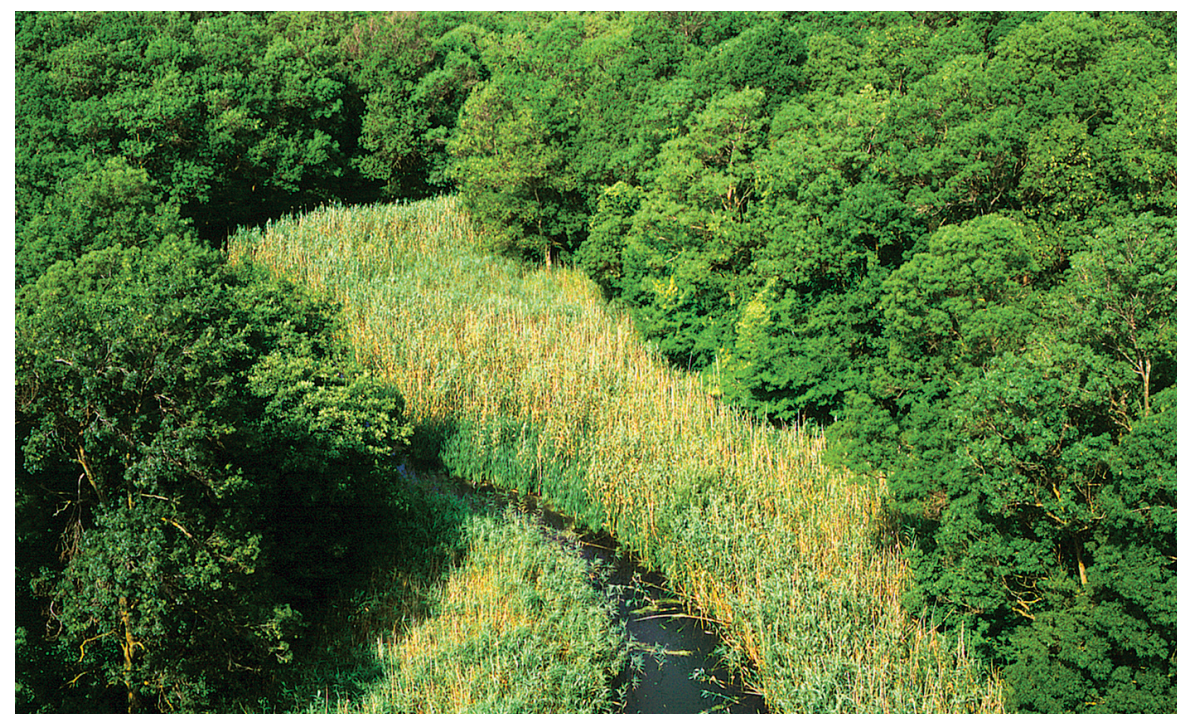

Reed formations in the mouth of the Batova River (above) and Bolata Ravine (below), North Bulgarian Black Sea coast

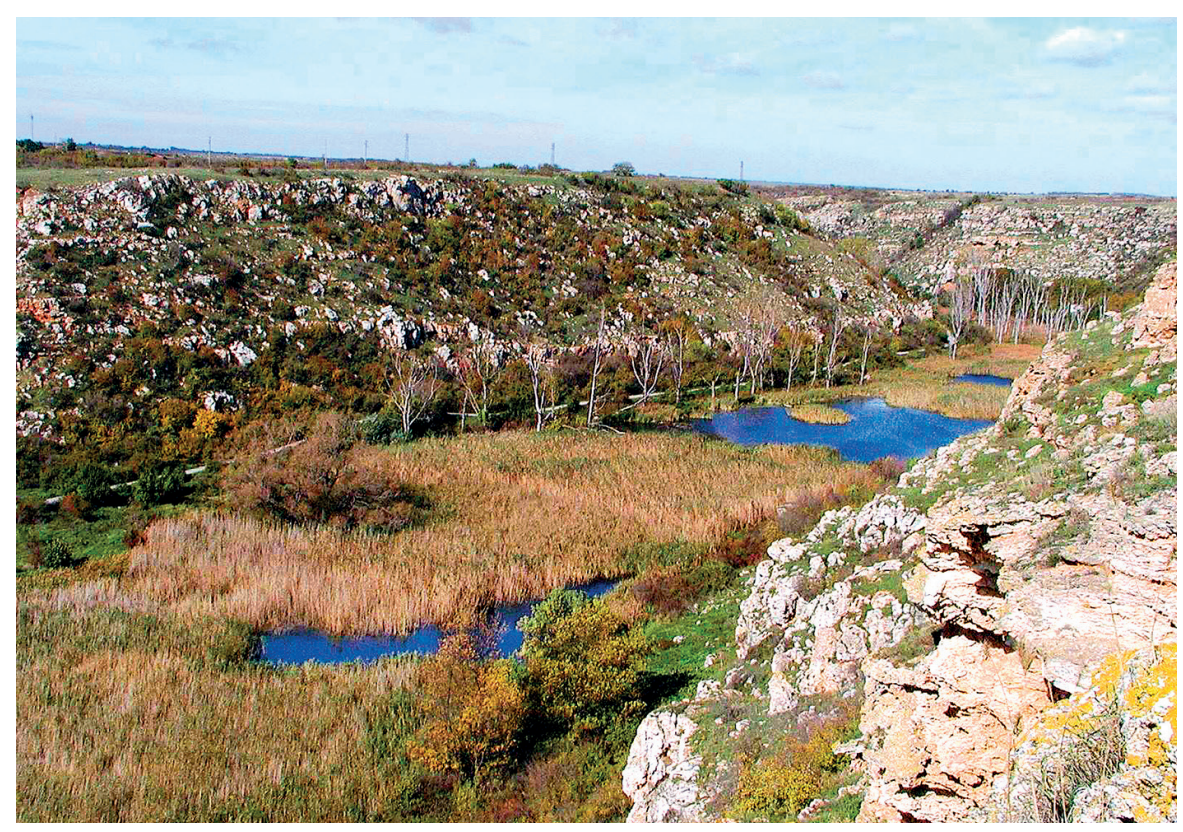

Minor psammophytic herb communities, mostly of Leymus racemosus (Lam.) Tzvel subsp. sabulosus (Bieb.) Tzvel., Ammophilla arenaria (L.) Link, Centaurea arenaria Bieb. ex Willd., Galilea mucronata (L.) Parl and shrub communities of Cionura erecta (L.) Grsb. grow on limited areas of the sandy beaches and dunes.

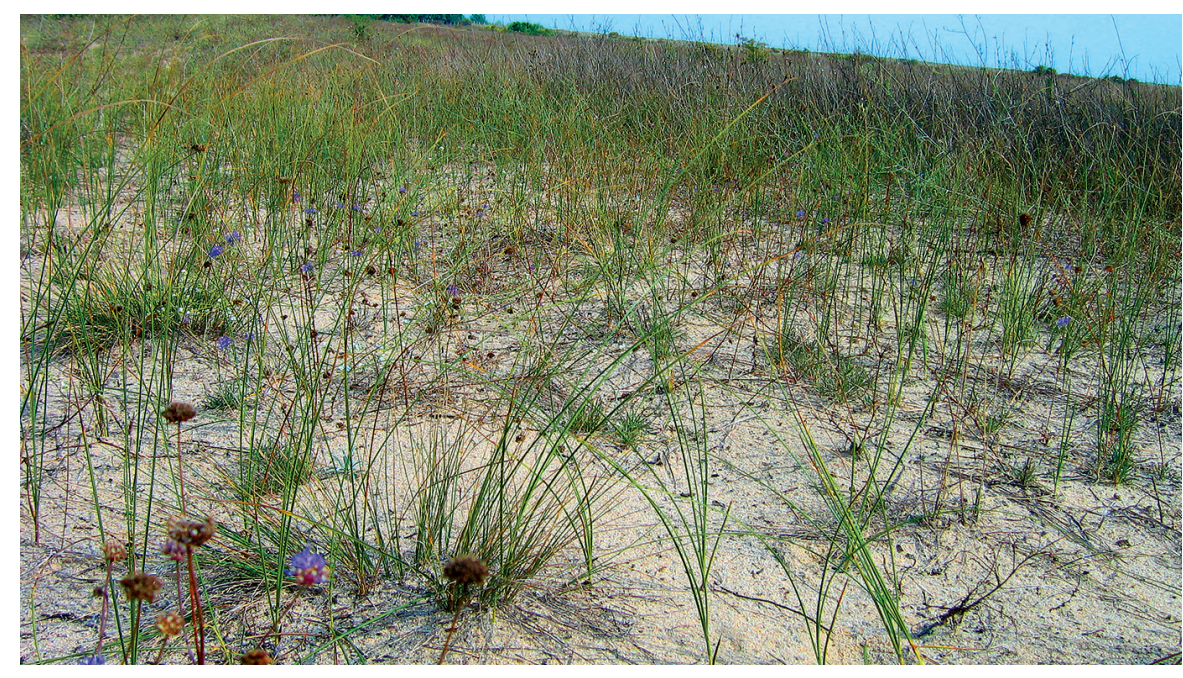

Psammophytic vegetation (association of Carex ligerica at Kamchia Sands locality) Sea daffodil (Pancratium maritimum)

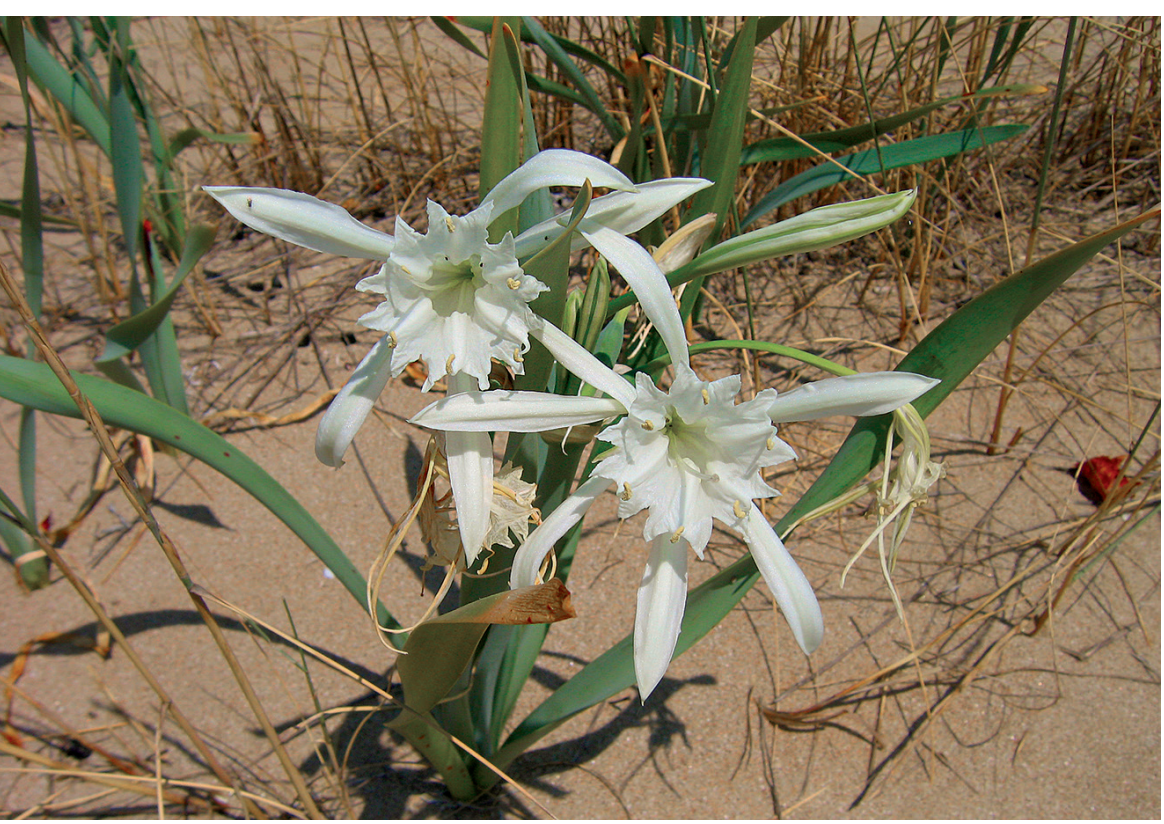




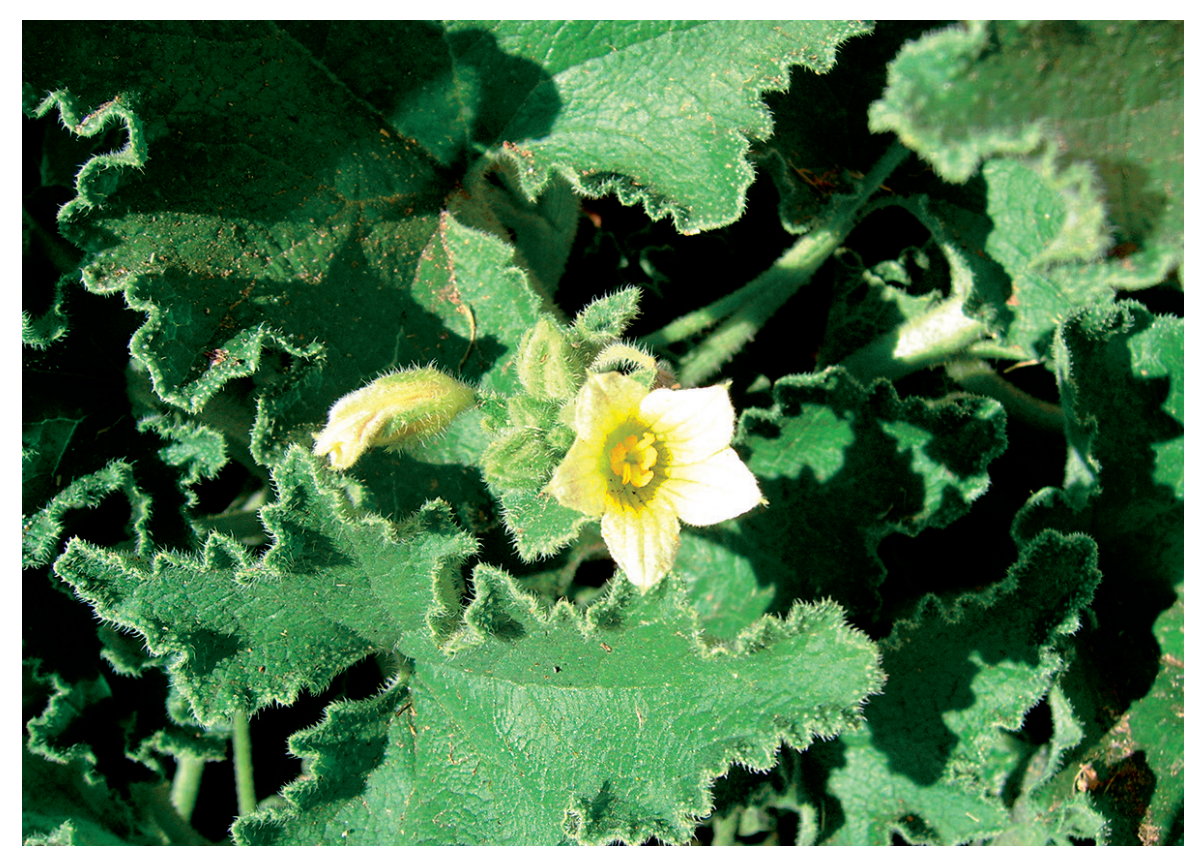

Squirting cucumber (Ecballium elaterium)

The Balkan endemite Jurinea albicaulis subsp. kilaea

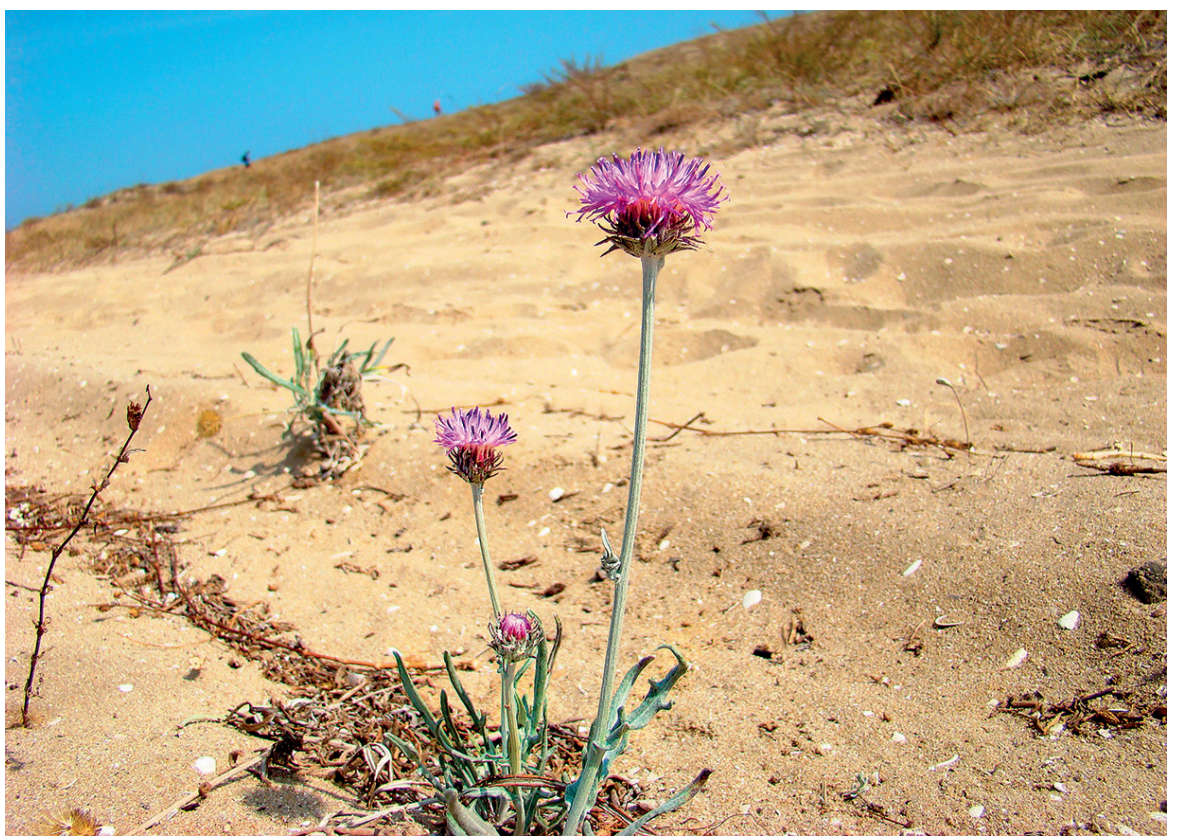

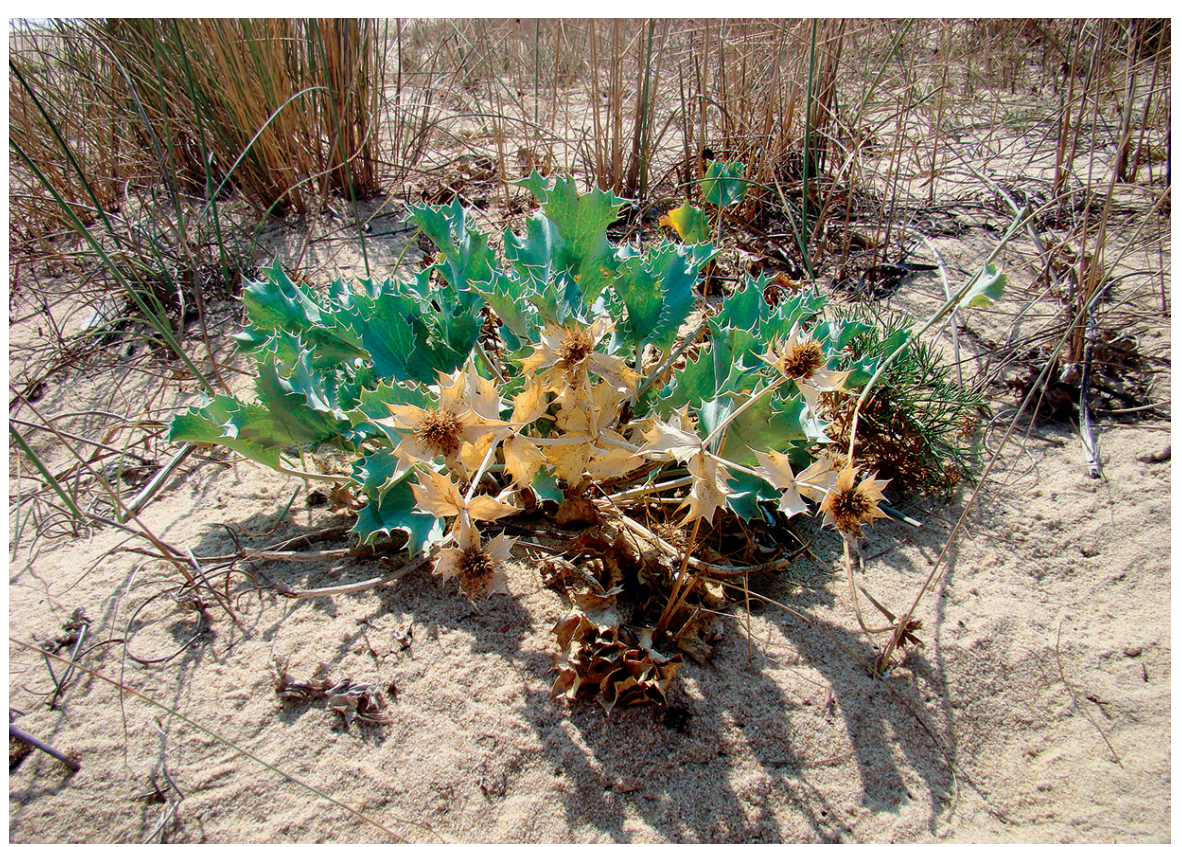

Sea holly (Eryngium maritimum)

European searocket (Cakile maritima)

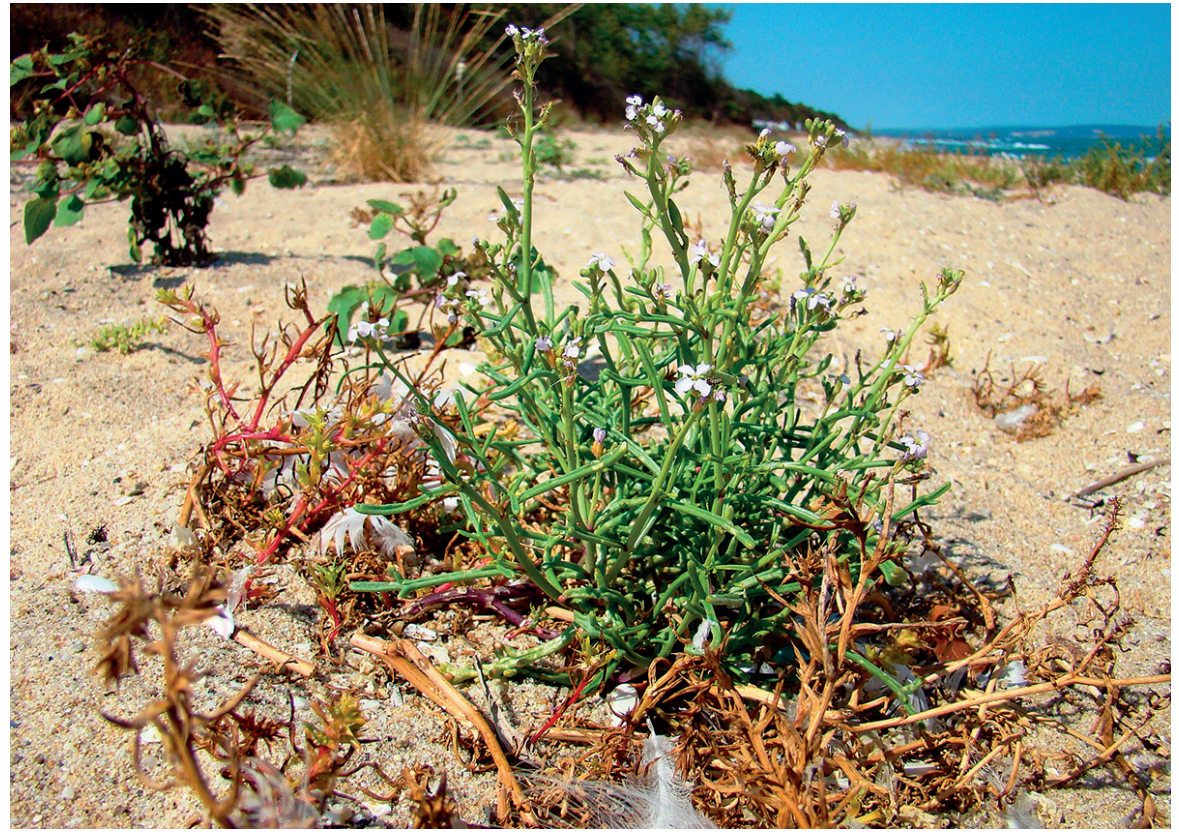




\subsection{VEGETATION COVER}

According to Velchev (2002) [81], four out of all six types of vegetation in Bulgaria occur on the Bulgarian Black Sea coast: temperate forest, steppe, Mediterranean and aquatic

\section{LEGEND}

1. Mixed forests of Moesian beech (Fagus sylvatica L. subsp. moesiaca (K. Maly) Hyelmg.), Oriental hornbeam (Carpinus orientalis Mill.) and common hornbeam (C. betulus L.)

2. Common hornbeam forests (Carpineta betuli), partly mixed with Oriental hornbeam (C. orientalis Mill.)

3. Mixed forests of common hornbeam (Carpinus betulus L.) and field maple (Acer campestre L.)

4. Mixed forests of common hornbeam (Carpinus betulus $L$.) and Turkish oak (Quercus cerris L.), partly with Balkan durmast oak (Q. dalechampii Ten.) and field maple (Acer campestre L.)

5. Balkan durmast oak forests (Querceta dalechampii)

6. Mixed forests of Balkan durmast oak (Querceta dalechampii Ten.) and Oriental hornbeam (Carpinus orientalis Mill.), partly of secondary origin

7. Silver lime forests (Tilieta tomentosae), partly of secondary origin

8. Oriental beech forests (Fageta orientalis)

9. Mixed forests of Oriental beech (Fagus orientalis Lipsky), common hornbeam (Carpinus betulus L.) and silver lime (Tilia tomentosa Moench.)

10. Mixed forests of Oriental beech (Fagus orientalis Lipsky) and Oriental hornbeam (Carpinus orientalis Mill.)

11. Oriental durmast oak forests (Querceta polycarpae)

12. Mixed forests of Oriental durmast oak (Quercus polycarpa Schur), Italian oak ( $Q$. frainetto Ten.) and Turkish oak ( $Q$. cerris L.)

13. Mixed forests of Oriental durmast oak (Quercus polycarpa Schur) and Italian oak (Q. frainetto Ten.)

14. Mixed forests of Oriental durmast oak (Quercus polycarpa Schur) and Oriental hornbeam (Carpinus orientalis Mill.), partly of secondary origin

15. Turkish oak forests (Querceta cerris)

16. Mixed forests of Turkish oak (Quercus cerris L.) and Italian oak (Q. frainetto Ten.)

17. Mixed forests of Turkish oak (Quercus cerris L.), Italian oak (Q. frainetto Ten.) and Mediterranean elements

18. Mixed forests of Turkish oak (Quercus cerris L.), Italian oak (Q. frainetto Ten.) and Oriental hornbeam (Carpinus orientalis Mill.). partly of secondary origin
19. Mixed forests of Turkish oak (Quercus cerris $L$ ), downy oak ( $Q$. pubescens Willd.) and Virgilian oak (Q. virgiliana Ten.)

20. Mixed forests of Turkish oak (Quercus cerris $L$.) and downy oak ( $Q$. pubescens Willd.) with secondary-origin undergrowth of smoke tree (Cotinus coggygria Scop.)

21. Mixed forests of Turkish oak (Quercus cerris L.) and Oriental hornbeam (Carpinus orientalis Mill.), partly also with manna ash (Fraxinus ornus L.)

22. Italian oak forests (Querceta frainetti)

23. Italian oak forests (Querceta frainetti) with Mediterranean elements

24. Mixed forests of Italian oak (Quercus frainetto Ten.), downy oak ( $Q$. pubescens Willd.) and Virgilian oak (Q. virgiliana Ten.)

25. Mixed forests of Italian oak (Quercus frainetto Ten.) and manna ash (Fraxinus ornus L.)

26. Mixed forests of Italian oak (Quercus frainetto Ten.) and Oriental hornbeam (Carpinus orientalis Mill.)

27. Downy oak forests (Queceta pubescentis) with Virgilian oak (Q virgiliana Ten.)

28. Mixed forests of downy oak (Quercus pubescens Willd.) Virgilian oak (Q. virgiliana Ten.) and field maple (Acer campestre L.)

29. Mixed forests of downy oak (Quercus pubescens Willd.) Virgilian oak (Q. virgiliana Ten.) and Oriental hornbeam (Carpinus orientalis Mill.)

30. Mixed forests of downy oak (Quercus pubescens Willd.), Virgilian oak (Q. virgiliana Ten.) and Oriental hornbeam (Carpinus orientalis Mill.) with Mediterranean elements

31. Mixed forests of manna ash (Fraxinus ornus $L$.) partly mixed with Oriental hornbeam (Carpinus orientalis Mill.)

32. Mixed forests of Oriental hornbeam (Carpinus orientalis Mill.) and manna ash (Fraxinus ornus L.), partly of secondary origin

33. Forests of Oriental hornbeam (Carpineta orientalis)

34. Forests of Oriental hornbeam (Carpineta orientalis) with Mediterranean elements

35. Steppe communities with a prevalence of Chrysopogon gryllus (L.) Trin. and Dichantium ischaemum (L.) Roberty

36. Formation of Jerusalem thorn (Paliurus spina-christi Mill.)
37. Steppe communities of False Sheep's fescue (Festuca pseudovina Hack. Ex Wiseb)

38. Formation of mock privet (Phyllirea latifolia L.) and Jerusalem thorn (Paliurus spina-christi Mill.) mixed with bush jasmine (Jasminum fruticans $\mathrm{L}$.)

39. Formation of mock privet (Phyllirea latifolia L.)

40. Xeromesophytic steppe vegetation with a prevalence of bulbous bluegrass (Poa bulbosa L.)

41. Plantations of black locust tree (Robinia pseudoacacia L.)

42. Forests of pedunculate oak (Querceta pedunculiflorae), partly mixed with field maple (Acer campestre L.)

43. Mixed forests of pedunculate oak (Quercus pedunculiflora $C$. Koch) and Turkish oak (Q. cerris L.) or Virgilian oak (Q. virgiliana Ten.)

44. Forests of common ash (Fraxinus oxycarpa Willd.) and field elm (UImus minor Mill.)

45. Black alder forests (Alneta glutinosae), willow forests (mostly Saliceto albae, Saliceta fragilis) and poplar forests (Populeta nigrae, Populeta albae), partly combined with poplar plantations and hygrophilous herb communities

46. Aquatic vegetation

47. Halophytic vegetation

48. Psammophytic vegetation

\section{Meadows}

\section{$\mathrm{Br}$ - bare rocks}

$\mathrm{Bu}$ - built-up areas

Ds - dump sites

Up - urban parks

Qm - quarries and mines

Aa - agricultural areas

$\mathrm{Pa}$ - plantations of Pinus spp. (also marked with A on the map
indexes)

$\mathbf{W b}$ - water bodies 


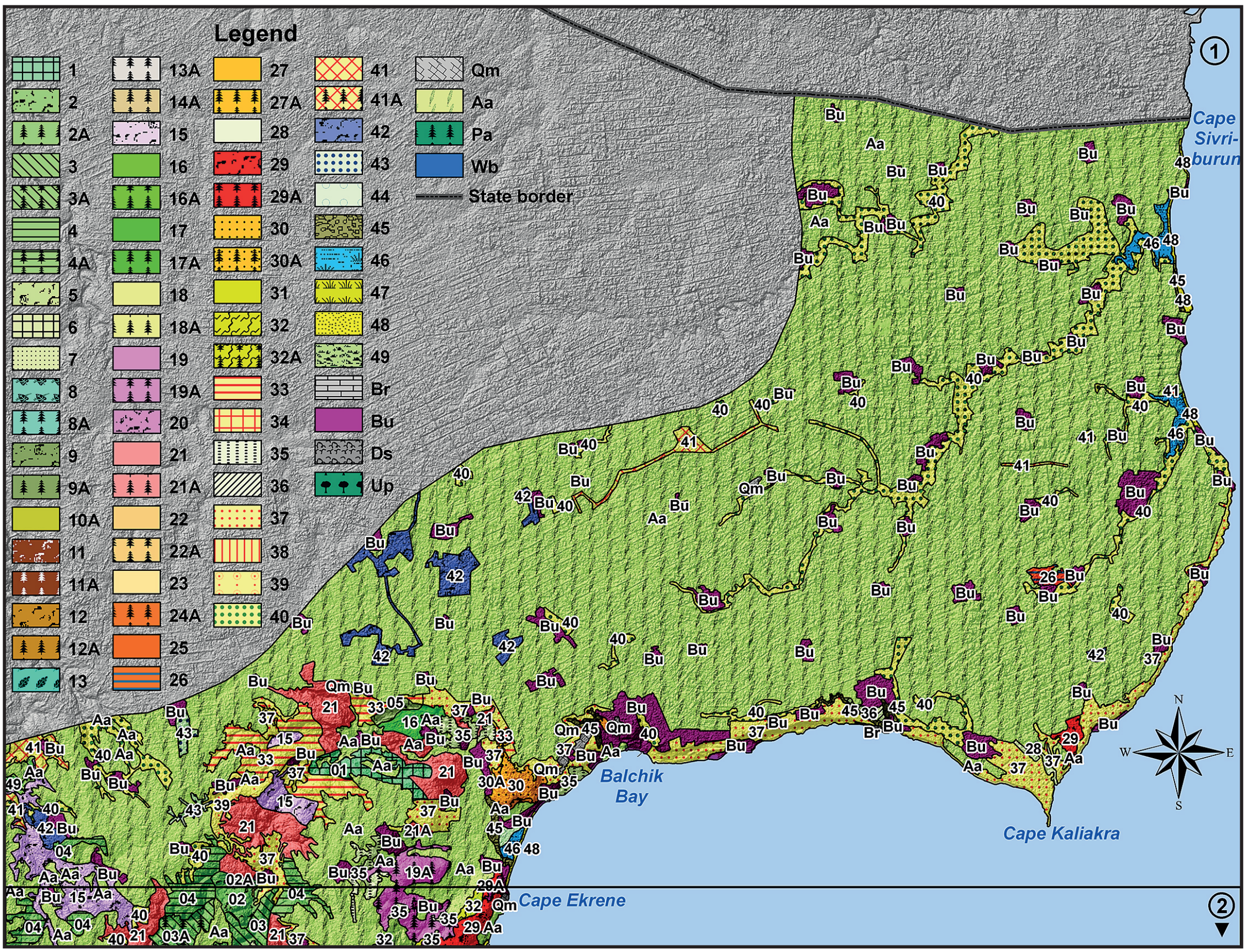

60 PHYSIOGRAPHIC AND OCEANOGRAPHIC CHARACTERISTICS OF THE STUDY AREA 


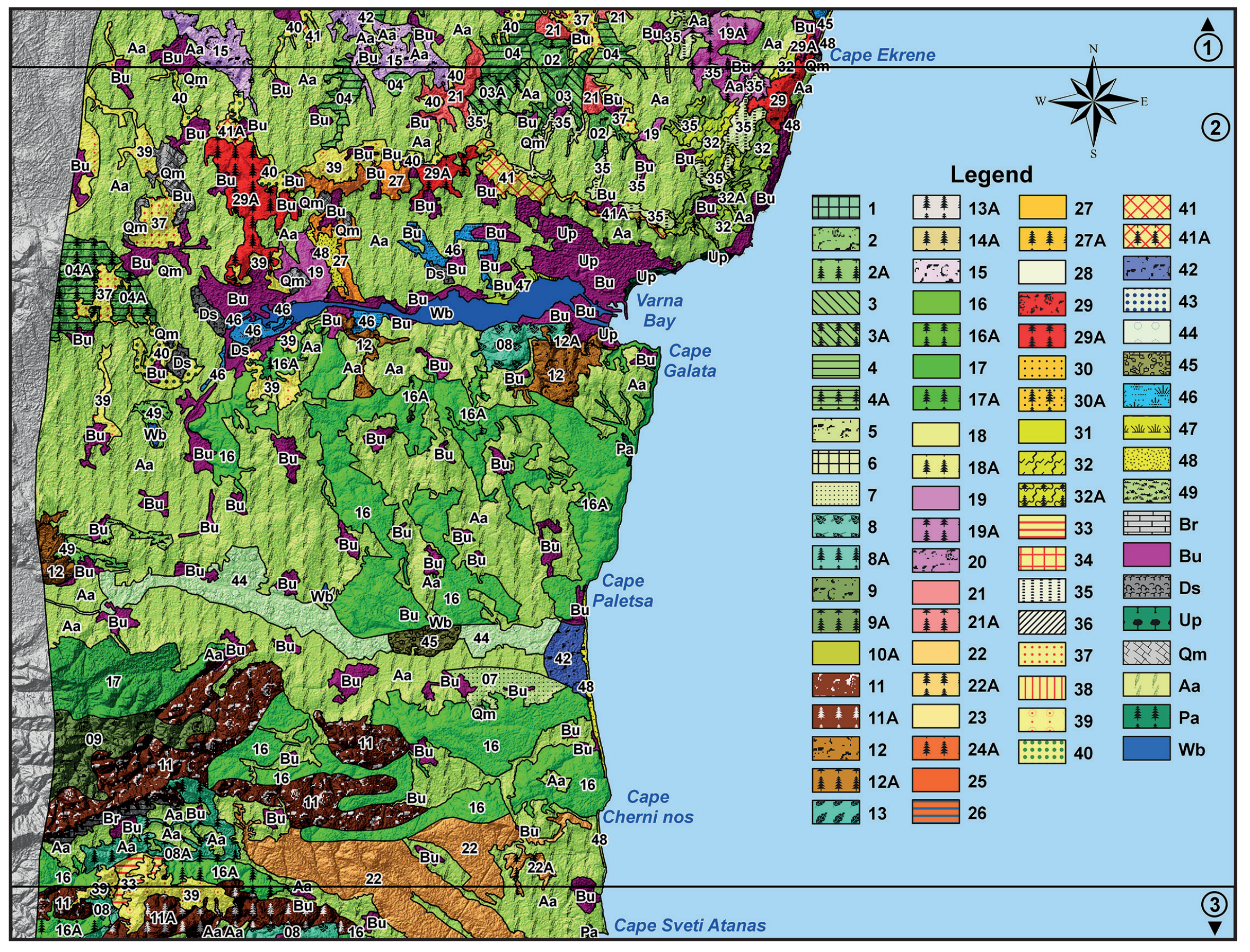




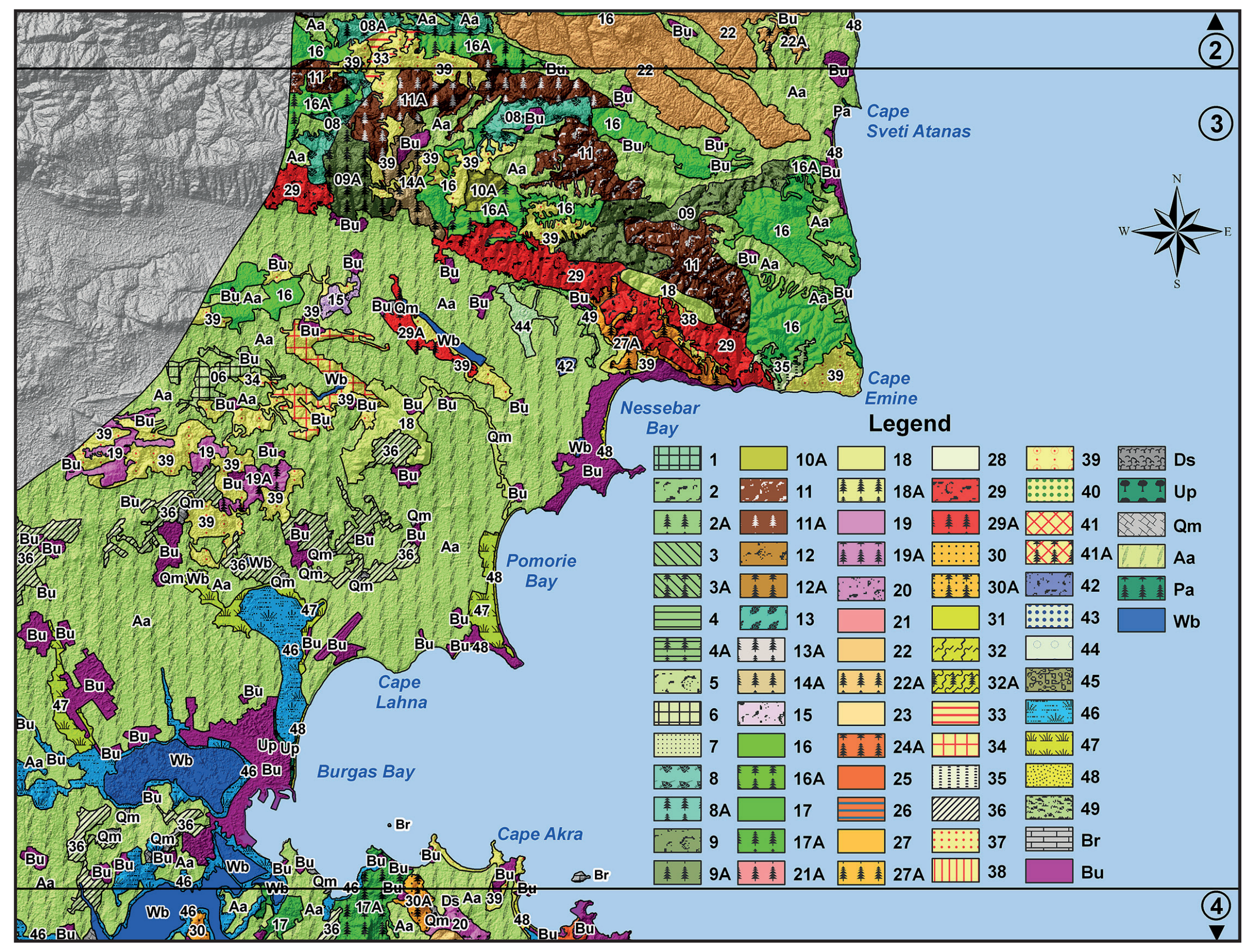

62 PHYSIOGRAPHIC AND OCEANOGRAPHIC CHARACTERISTICS OF THE STUDY AREA 


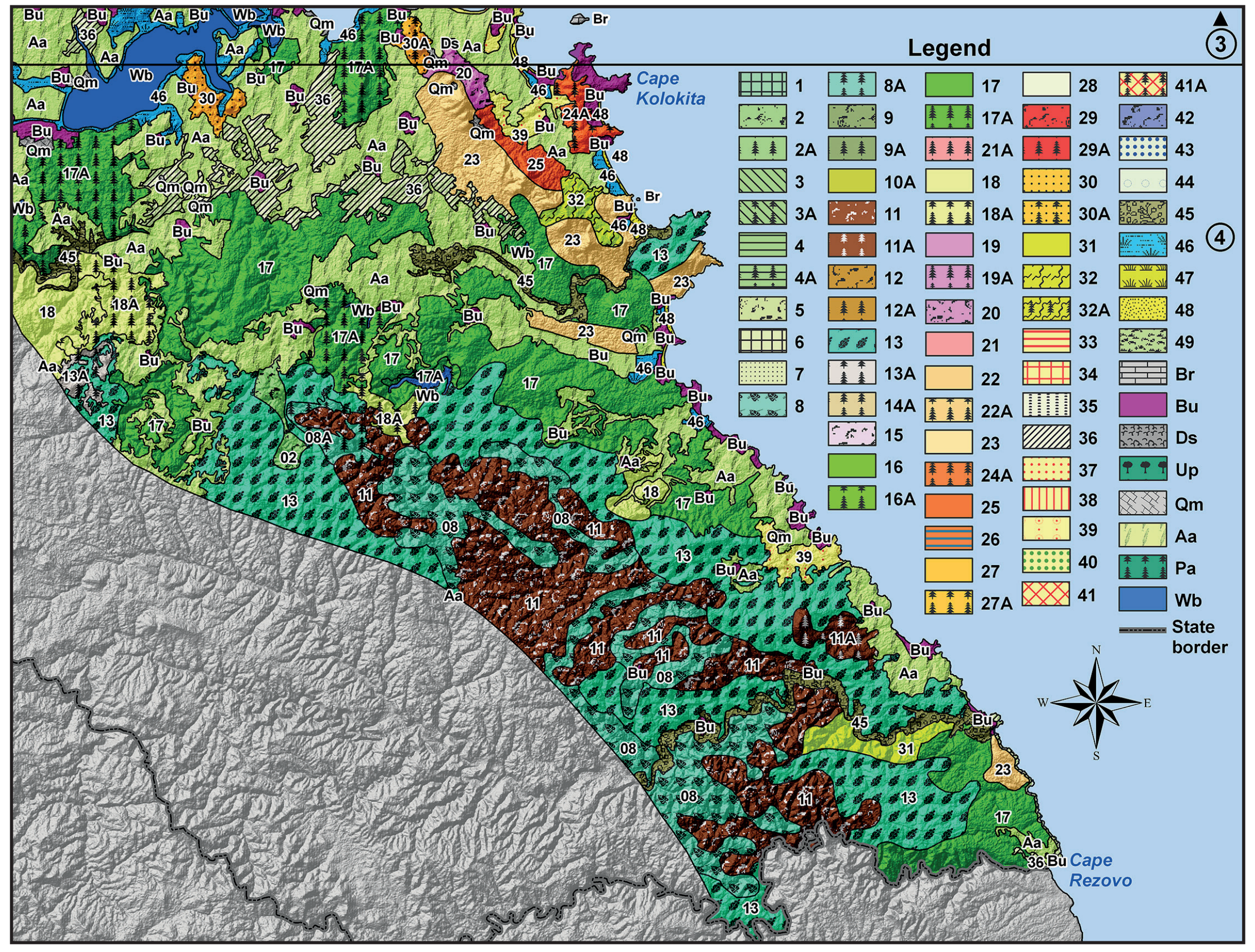




\section{TEMPERATE FOREST VEGETATION}

The most typical representatives of the temperate forest vegetation are the forest communities dominated by broad-leaved deciduous species widely spread in the European deciduous forest biome: oaks (Quercus cerris L., Q. frainetto Ten., Q. pubescens Willd., Q. polycarpa Schur., Q. robur L.), ashes (Fraxinus oxycarpa Willd., F. ornus L.) hornbeams (Carpinus betulus L., C. orientalis Mill.), beeches (Fagus orientalis Lipsky, F. sylvatica L. subsp. moesiaca (K. Maly) Hyelmg.), etc. [82].

\section{Formation of the Turkish oak (QUERCETA CERRIS)}

Map indexes of typical associations: 15, 16, 17, 18, 19, 20, 27.

The formation of the Turkish oak (Quercus cerris) is wide-spread on slopes, plain terrains and hills. It is a representative of the typical xerophytic vegetation. The formation refers to the natural (autochthonous) vegetation, but some of its communities are of secondary origin. The associations with a mixed composition are the most widespread ones within this formation. Most common are the associations where Italian oak (Quercus frainetto) is subdominant.

Italian oak (Quercus frainetto)

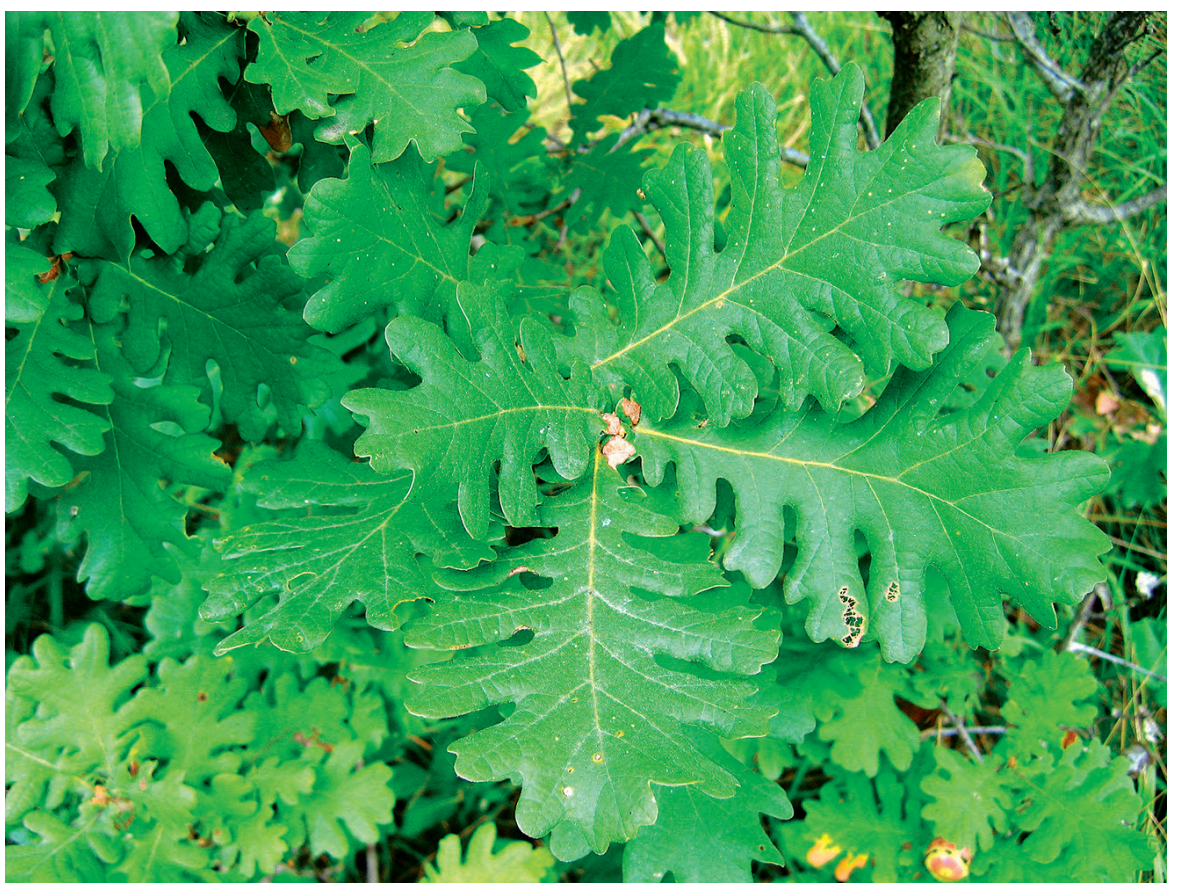

Formation of the Italian oak (QUERCETA FRAINETTI)

Map indexes of typical associations: 22, 23, 24, 25, 26

The formation of the Italian oak (Quercus frainetto) is the main element of the temperate forest vegetation in plains, hilly areas and the xerothermic oak zone. It is a representative of the typical xerophytic vegetation and refers to the natural (autochthonous) vegetation. Most common are the monodominant associations. The Turkish oak (Quercus cerris) is the most widespread subdominant in the mixed communities of this formation. The Oriental durmast oak (Quercus polycarpa) is the main subdominant in the forest associations of the Strandzha Mountain.

\section{Formation of the downy oak (QUERCETA PUBESCENTIS)}

Map indexes of typical associations: 27, 28, 29, 30

The formation of the downy oak (Quercus pubescens) is typical for convex slopes and hills. Its communities are more xerophytic and thermophilic compared to the formations of Italian and Turkish oaks. It belongs to the natural (autochthonous) vegetation. The sclerophyllous forest communities of this species in the northern Strandzha Mountain are also related to Mediterranean vegetation. The most common are monodominant associations. The Oriental hornbeam (Carpinus orientalis) is the most widespread subdominant in mixed associations.

\section{Formation of the Oriental hornbeam (CARPINETA ORIENTALIS)}

Map indexes of typical associations: 37, 32, 33, 34

The formation of the Oriental hornbeam (Carpinus orientalis) is distributed mainly on southern slopes and plateau plains. It is more xerophytic compared to the preceding three formations, and is often referred to Mediterranean vegetation. The formation belongs to the secondary vegetation. Its communities were formed in areas of various natural forest communities that had been destroyed by human activities.

\section{Formation of the common ash (FRAXINETA OXYCARPAE)}

Map index: 44

The formation of the common ash (Fraxinus oxycarpa) is locally distributed as a main element of the riparian forests (also known as longoz) on fluvial terraces at the downstreams of rivers flowing into the Black Sea: the Batova, Kamchia, Ropotamo, Veleka and Rezovska, and also in the Golden Sands Nature Park. The formation is of an autochthonous and relic nature. It is subdominated mainly by field elm (UImus mi- 
nor Mill.), and also by pedunculate oak (Quercus pedunculiflora C. Koch), black alder (Alnus glutinosa (L.) Gaertn.) and field maple (Acer campestre L.). The most typical feature of these forests is the massive growth of lianas such as high catbrier (Smilax excelsa L.), Greek silkvine (Periploca graeca L.), old man's beard (Clematis vitalba L.) and ivy (Hedera helix L.). There is a characteristic spring synusium of Bithynian squill (Scilla bithynica Boiss.) and summer snowflake (Leucojum aestivum L.)

\section{Formation of the pedunculate oak (QUERCETA PEDUNCULIFLORAE)}

Map indexes of typical associations: 42, 43.

The formation of the pedunculate oak (Quercus pedunculiflora) inhabits plane terrains and depressions. It belongs to the mesophytic ecological type. The formation is part of the natural (autochthonous) vegetation. Monodominant communities are rarely spread. The main subdominants in the mixed communities of the Kamchia Reserve are field elm (Ulmus minor) and common ash (Fraxinus oxycarpa).
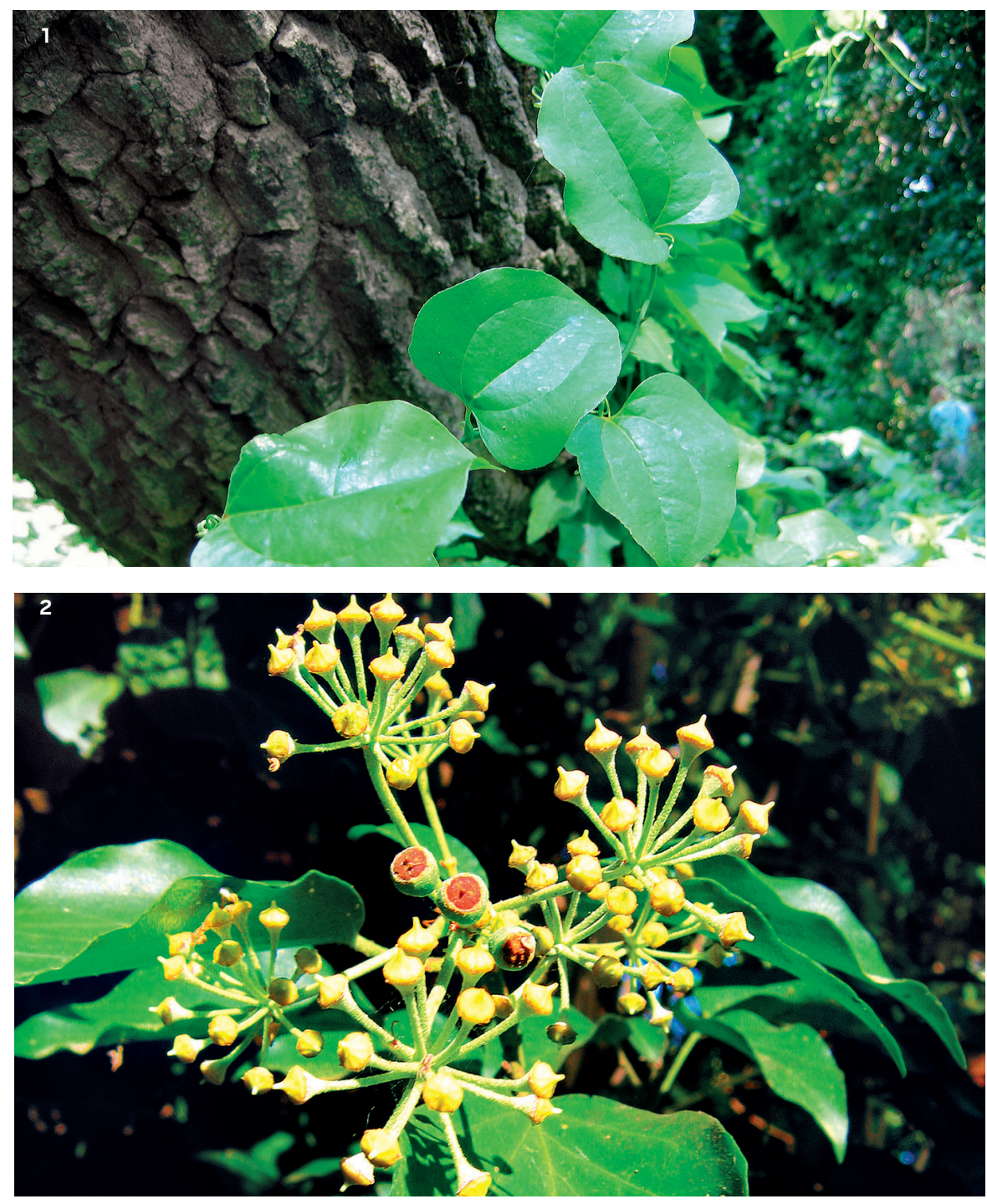

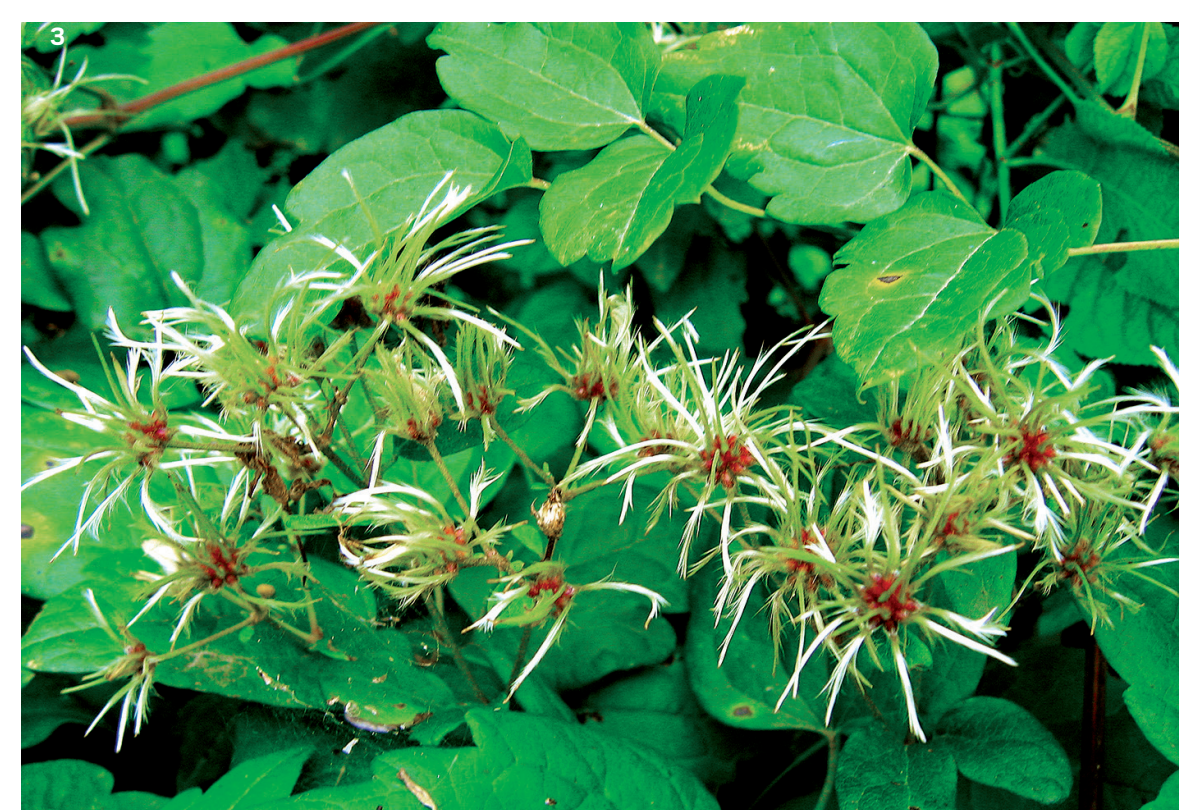

Lianas in the riparian forests of the Ropotamo River: (1) high catbrier (Smilax excelsa), (2) ivy (Hedera helix) and (3) old man's beard (Clematis vitalba)

Summer snowflake (Leucojum aestivum)

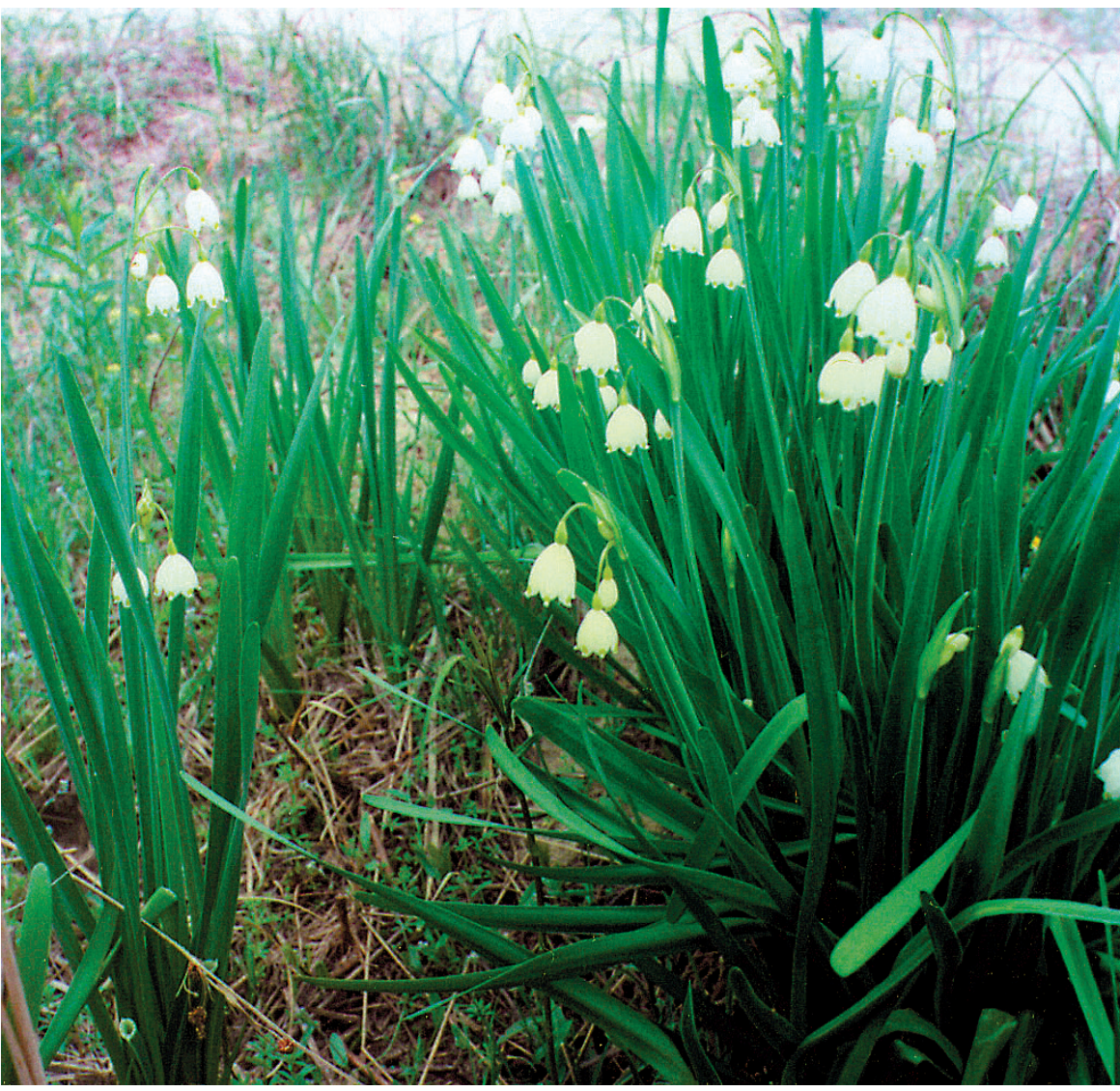




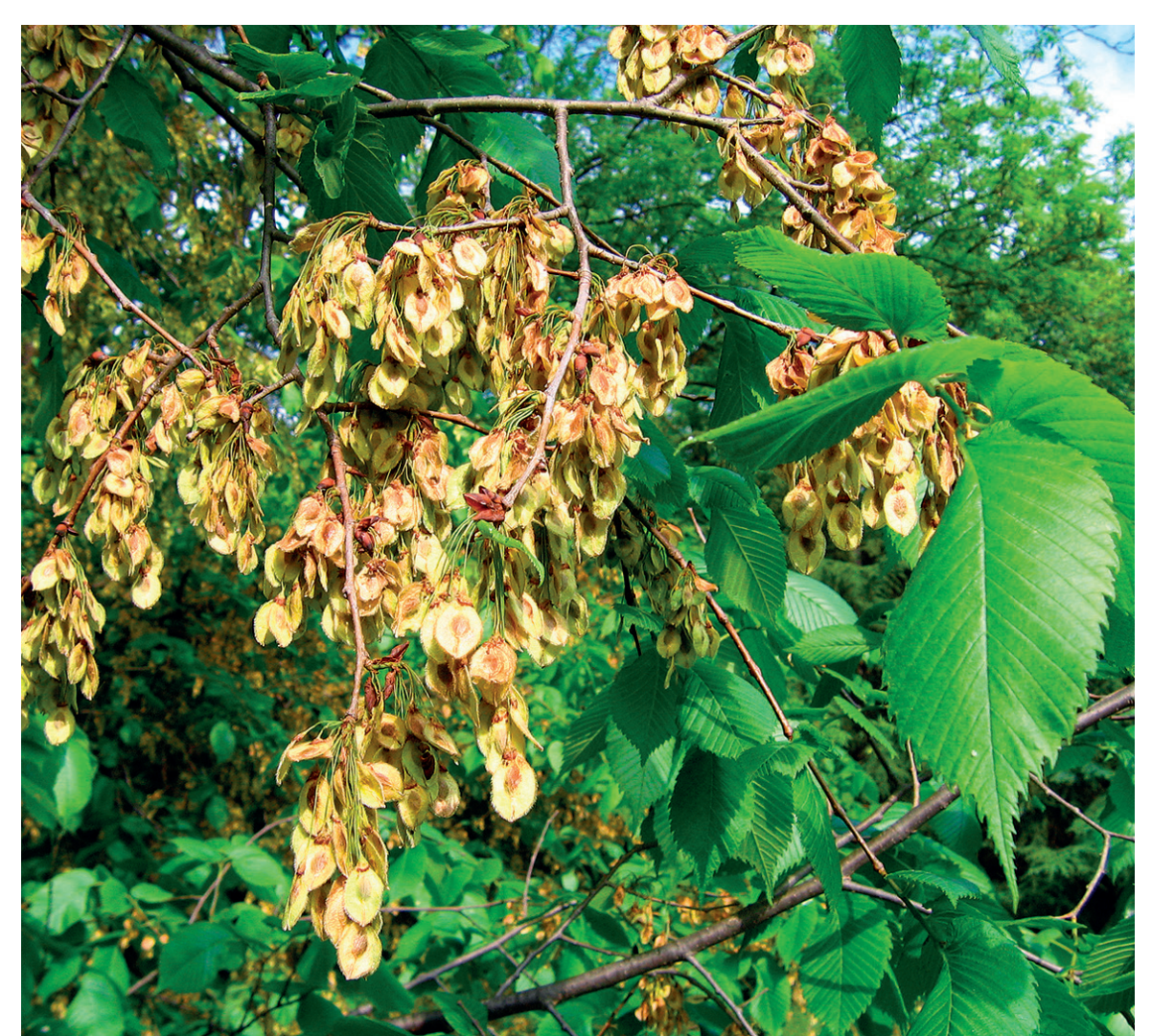

Field elm (Ulmus minor)

Formation of the Oriental durmast oak (QUERCETA POLYCARPAE)

Map indexes of typical associations: 17, 12, 13, 14.

The formation of the Oriental durmast oak (Quercus polycarpa) is spread on slant slopes and depressions with a lower mean annual temperature and higher humidity compared to the adjacent convex areas which are dominated by communities of Italian oak (Q. frainetto) and Turkish oak (Q. cerris). It has an inverse character in the Strandzha Mountain. The formation belongs to the natural (autochthonous) vegetation. The most widespread of all associations are the monodominant communities. The Italian oak (Quercus frainetto) is the main subdominant in the mixed associations. There are some typical southeuxinian species in the undergrowth such as Pontic rhododendron (Rhododendron ponticum L.), Caucasian whortleberry (Vaccinium arctostaphylos L.) and Pontic daphne (Daphne pontica L.). There is a characteristic spring synusium of pink primrose (Primula acaulis (L.) L. subsp. rubra (Sm.) Greut.).

66 PHYSIOGRAPHIC AND OCEANOGRAPHIC CHARACTERISTICS OF THE STUDY AREA
Formation of the Oriental beech (FAGETA ORIENTALIS)

Map indexes of typical associations: 8, 9, 10.

The formation of the Oriental beech (Fagus orientalis) is mainly distributed in the Strandzha Mountain and on limited areas in the East Stara Planina Mountain. It has an expressed inverse nature and is typical of shady and moist areas of ravines, depres-

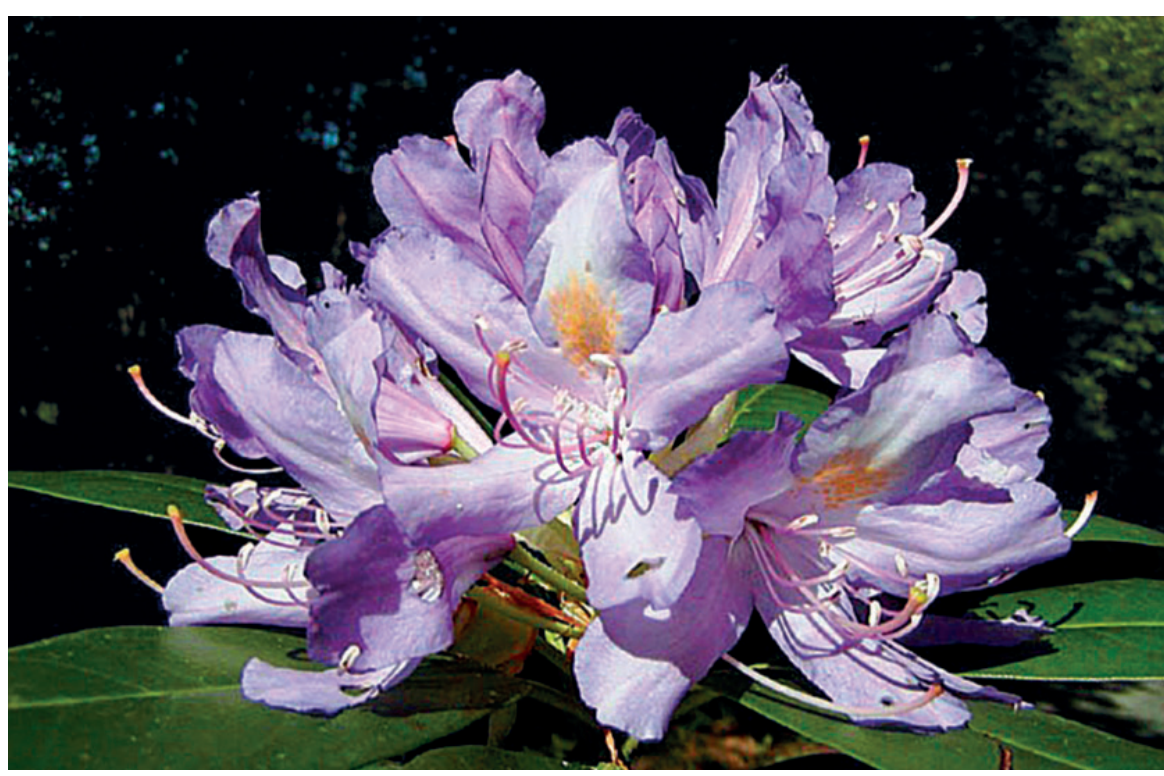

Pontic rhododendron (Rhododendron ponticum)

Pink primrose (Primula acaulis subsp. rubra)

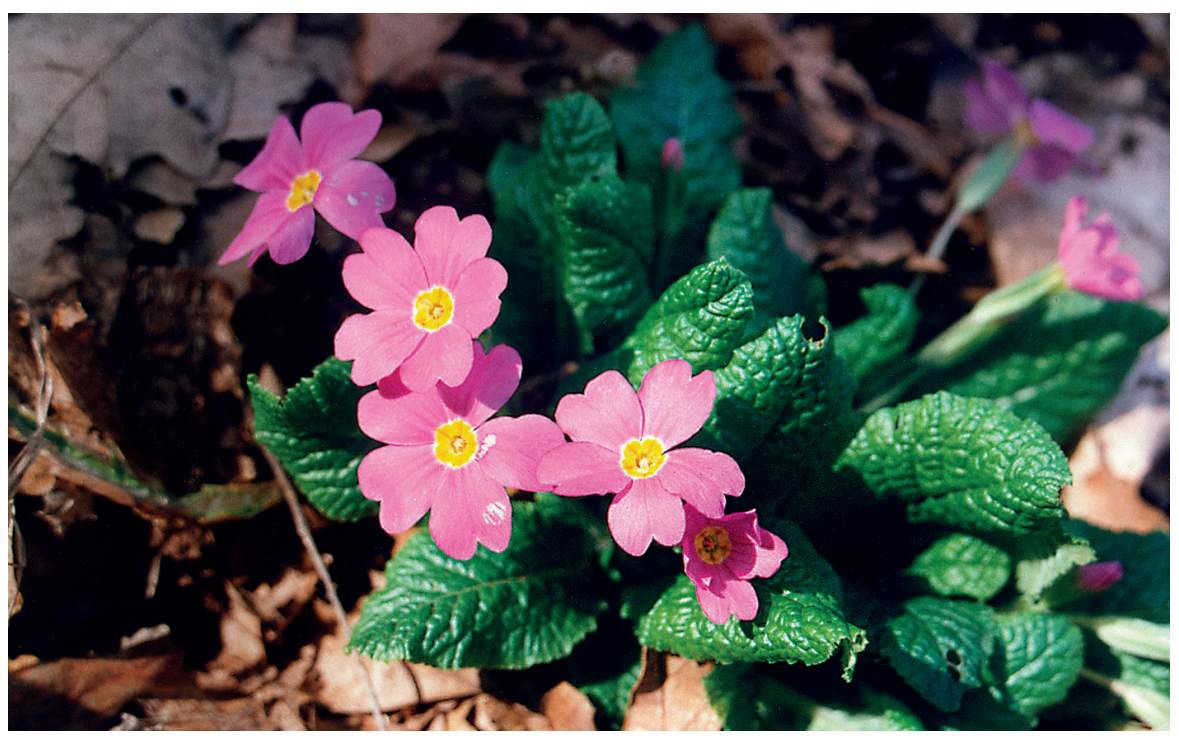


sions and slopes. The formation is of an autochthonous and relic nature. Monodominant communities are more widespread. The communities also feature yew (Taxus baccata L.) and Turkish hazel (Corylus colurna L.). The associations of evergreen undergrowth of Pontic rhododendron (Rhododendron ponticum) and cherry laurel (Laurocerasus officinalis Roem.) are unique in terms of origin.

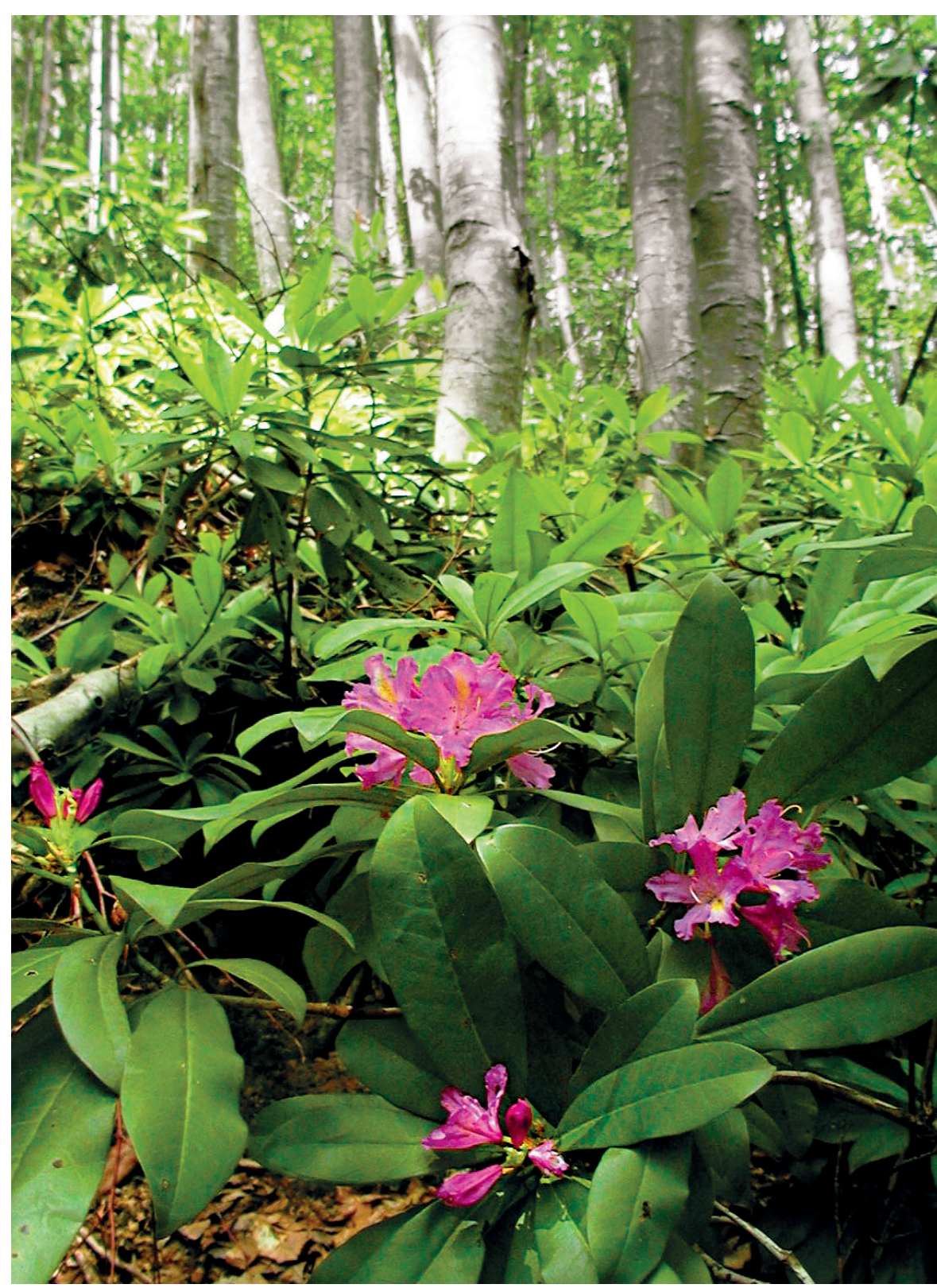

Formation of the common hornbeam (CARPINETA BETULI)

Map indexes of typical associations: 2, 3, 4 .

The formation of the common hornbeam (Carpinus betulus) is spread in limited areas in the Strandzha Mountain and the East Stara Planina Mountain, as well as on plateau hills of the North Bulgarian Black Sea coast. It belongs to the mesophytic ecological type. The formation belongs to the natural (autochthonous) vegetation. The most common are the monodominant communities. These associations are occasionally mixed with Turkish oak (Quercus cerris), Moesian beech (Fagus sylvatica subsp. moesiaca) and others.

\section{Formation of the Moesian beech (FAGETA MOESIACAE)}

\section{Map index: 7.}

The formation of the Moesian subspecies of common beech (Fagus sylvatica subsp. moesiaca) is locally spread in limited areas in the East Stara Planina Mountain. It forms monodominant and mixed communities at 100-200 m asl and belongs to the mesophytic ecological type. The formation belongs to the natural (autochthonous) vegetation.

\section{Minor forest communities}

Map indexes of typical associations: 5, 6, 7, 47, 45, A.

There are mesophytic communities in limited mountain areas such as the associations of the Balkan durmast oak forests (QUERCETA DALECHAMPII) (5 and 6) and silver lime forests (TILIETA TOMENTOSAE) (7). Black alder forests (ALNETA GLUTINOSAE), willow forests (SALICETA ALBAE, SALICETA FRAGILIS) and poplar forests (POPULETA NIGRAE, POPULETA ALBAE) (45) are spread locally in limited areas near water bodies. Plantations of black locust tree (Robinia pseudoacacia L.) (41) and all pine plantations (Pinus spp.) (A) are considered secondarily naturalized.

Southeuxinian forests of Oriental beech (Fagus orientalis) with undergrowth of Pontic rhododendron (Rhododendron ponticum) 


\section{STEPPE VEGETATION}

The spread of natural steppe vegetation in the southern Dobrudzha area is a characteristic of the recent vegetation of the North Bulgarian Black Sea coast. It is represented by the communities of xerothermic species such as Festuca pseudovina Hack. Ex Wiseb., Chrysopogon gryllus (L.) Trin., Dichantium ischaemum (L.) Roberty and Poa bulbosa L. These communities are subdominated by Stipa pennata L., S. capillata L., S. lessingiana Trin. et. Rupr., Koeleria brevis Stev., Agropyron brandzae Pantu et Solac., Adonis volgensis DC., Paeonia tenuifolia L., pygmy iris (Iris pumila L.), Artemisia pedemontana Balb. and A. lerchiana Weber, that could be found in limestone terrains.

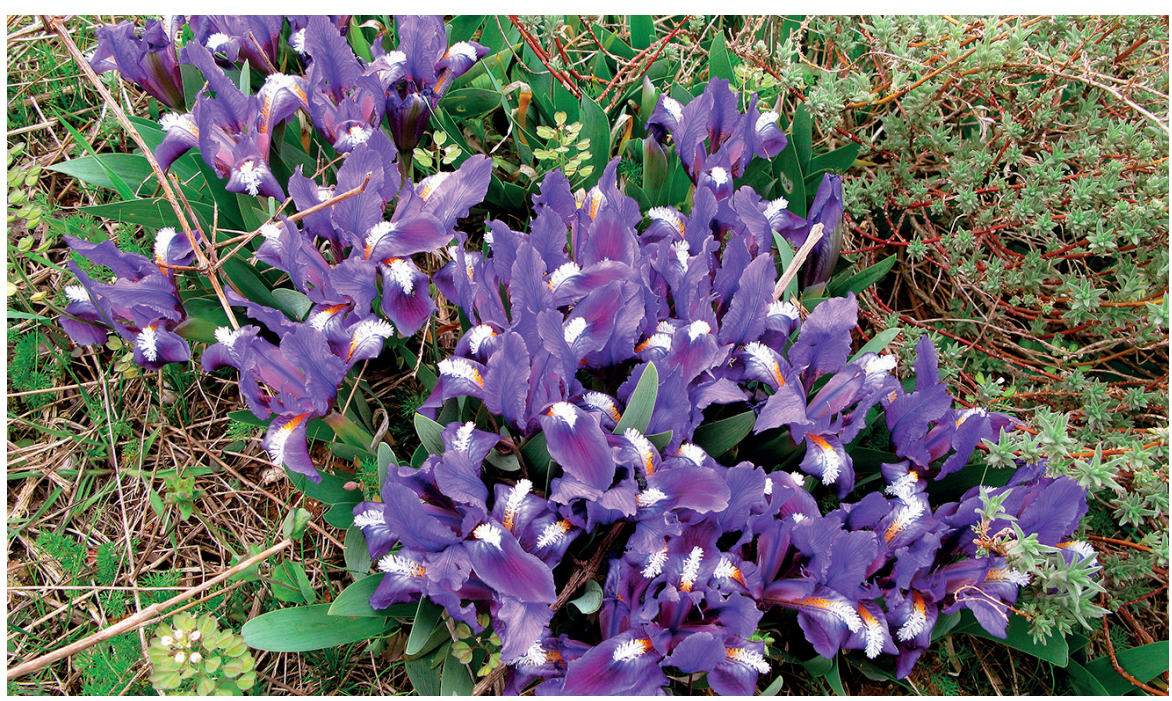

Pygmy iris (Iris pumila)

Formation of the false sheep's fescue (FESTUCETA PSEUDOVINAE)

Map index: 37.

The formation of the false sheep's fescue (Festuca pseudovina) is locally spread on slant slopes, plateau hills and depressions mostly near the towns of Balchik and Kavarna. It belongs to the xerophytic ecological type. Mixed associations are more widespread. The main subdominants are spring pheasant's eye (Adonis vernalis L.), bow sage (Salvia nutans L.), Centaurea napulifera subsp. thirkei (Sch.Bip.) Dostál and fern leaf peony (Paeonia tenuifolia).

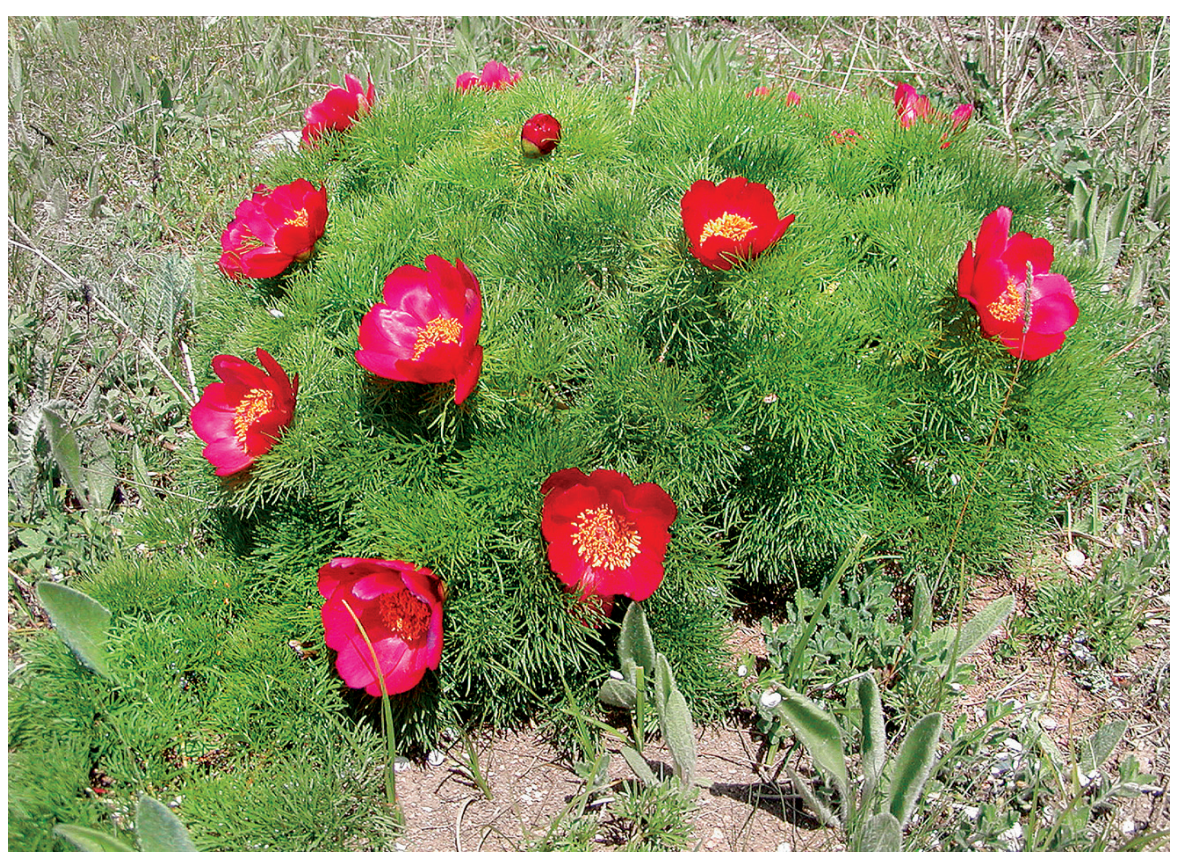

Fern leaf peony (Paeonia tenuifolia)

Centaurea napulifera subsp. thirkei

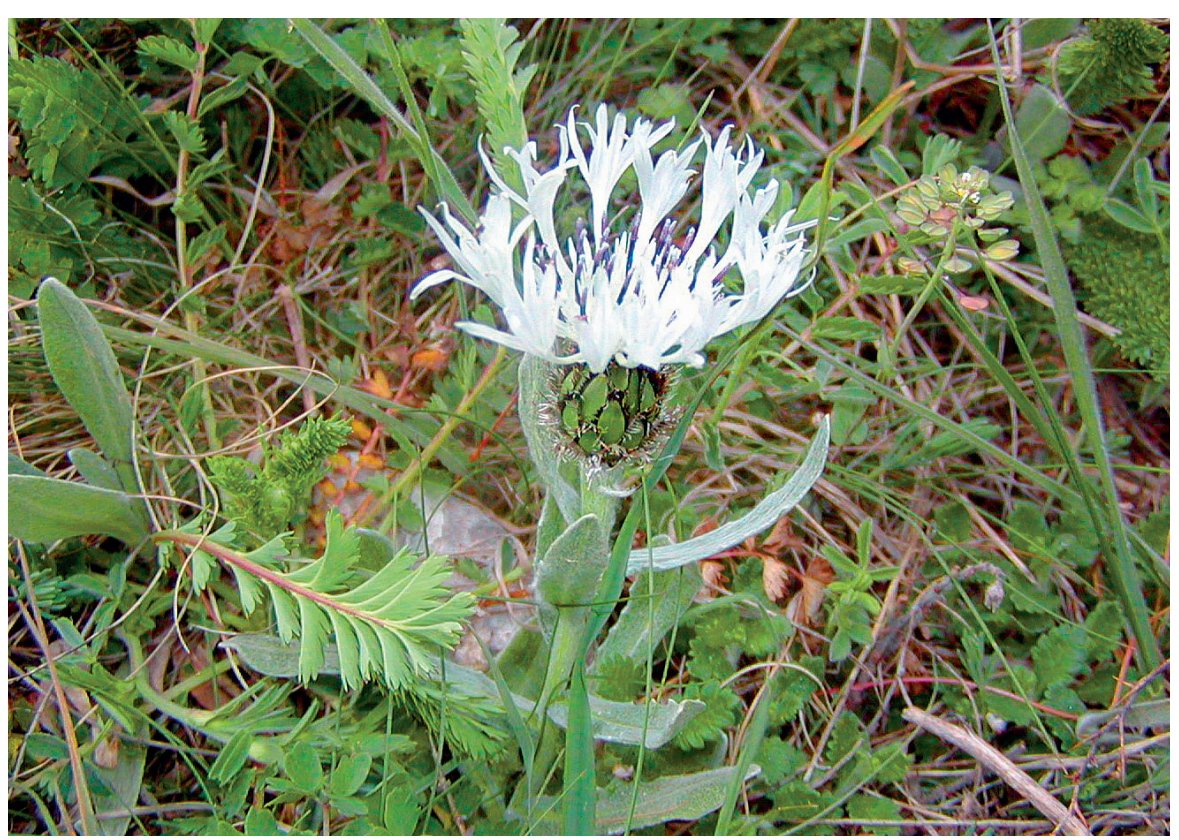




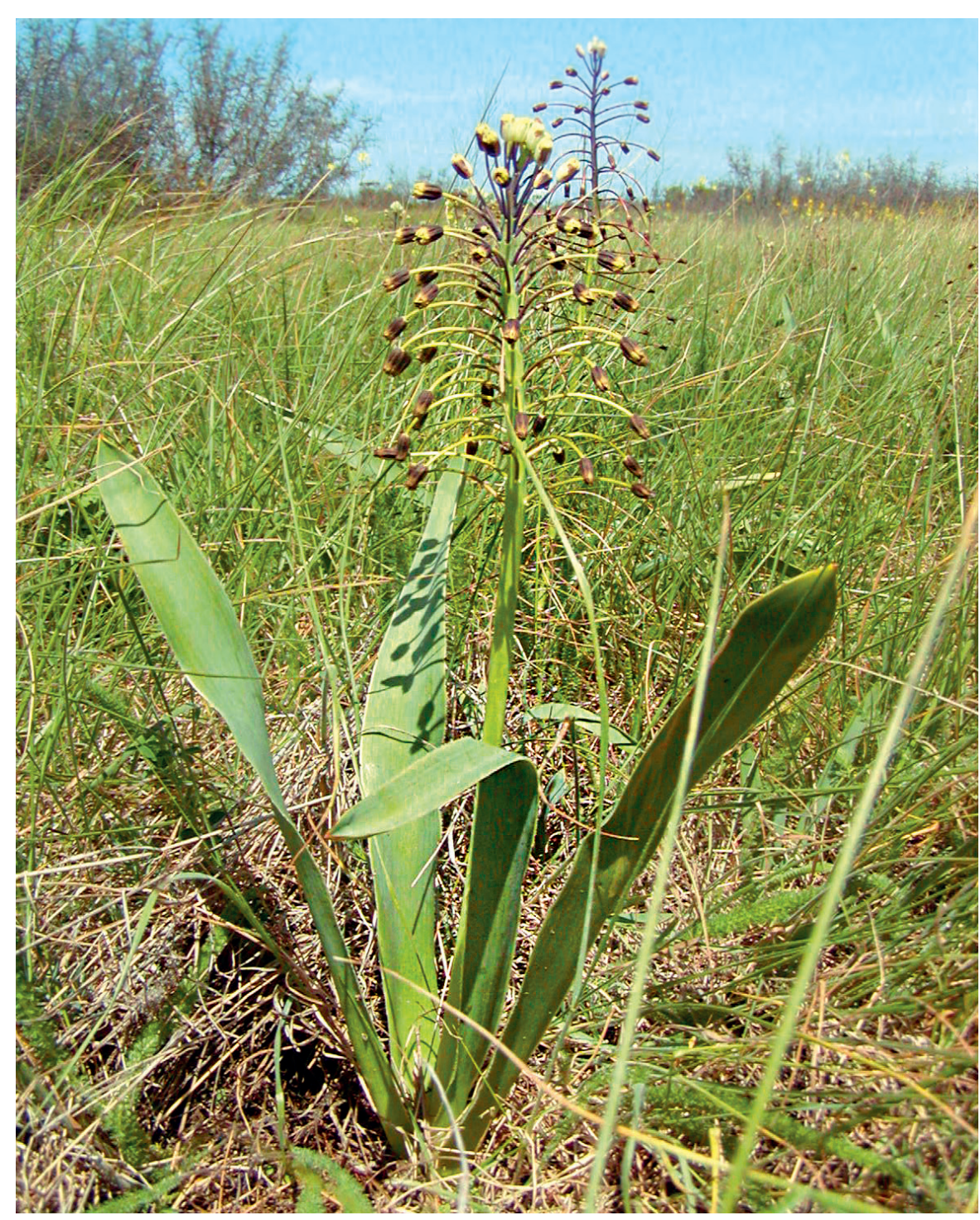

The exceptionally rare Bellevalia ciliata (Kaliakra Reserve, North Bulgarian Black Sea coast)

Formation of the scented grass (CHRYSOPOGONETA GRYLLI)

Map index: 35

The formation of the scented grass (Chrysopogon gryllus) is spread in plains and slopes with a southern exposure. It belongs to the xerophytic ecological type. Dichantium ischaemum and Linum bienne Mill. are the subdominants in mixed associations.

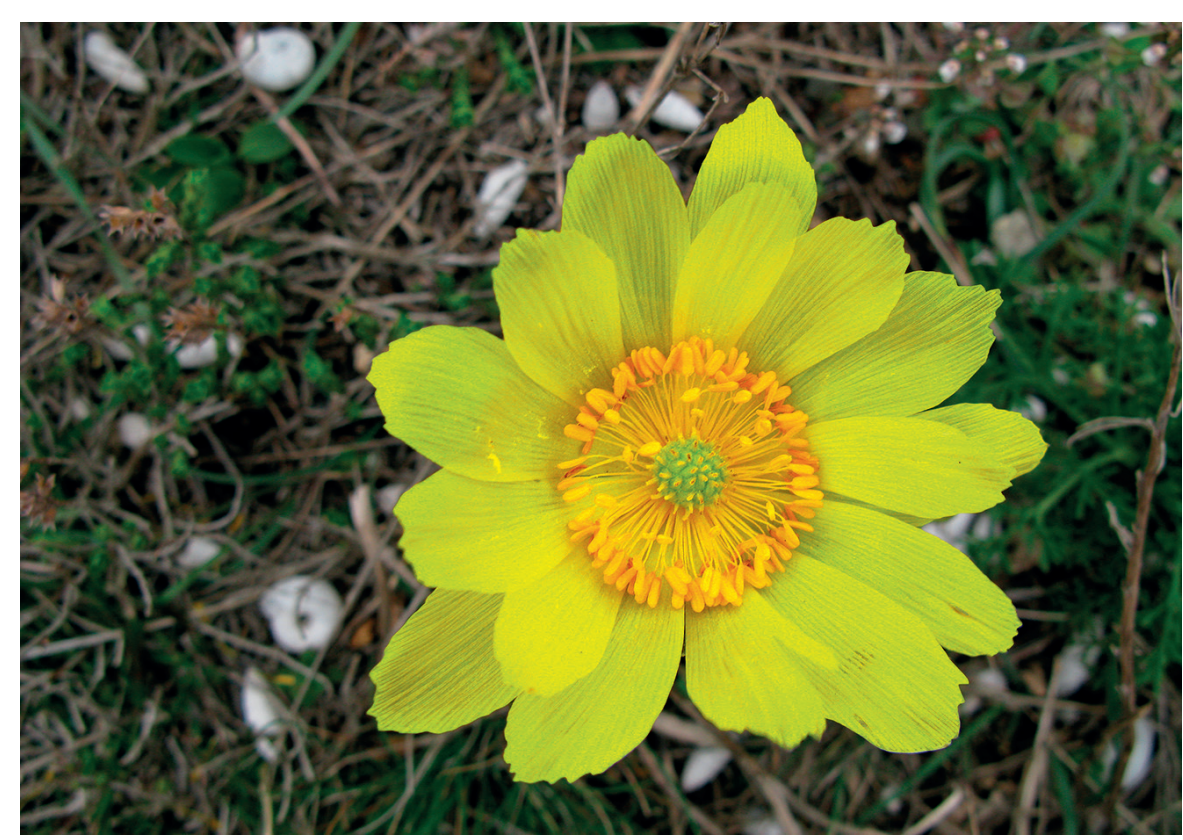

Spring pheasant's eye (Adonis vernalis)

Pale flax (Linum bienne)

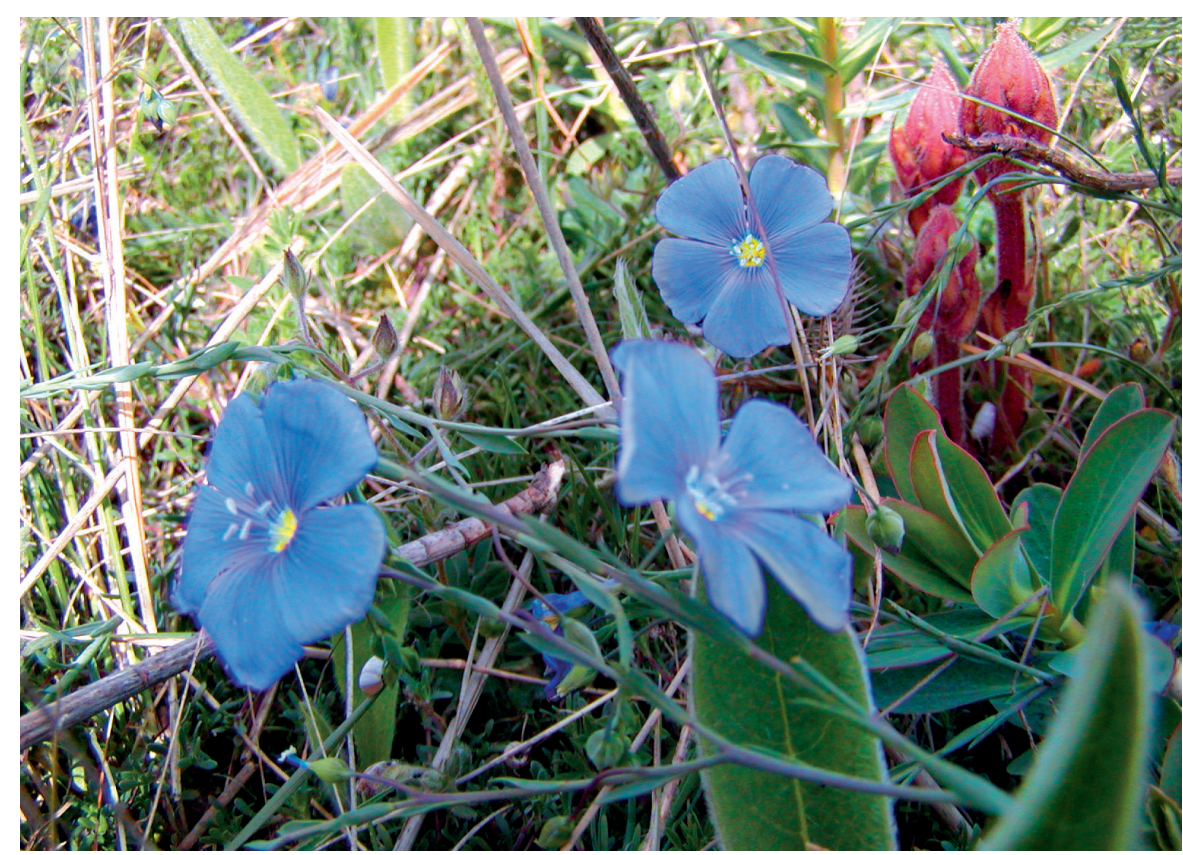


Formation of the bulbous bluegrass (POAETA BULBOSAE)

Map index: 40.

The formation of the bulbous bluegrass (Poa bulbosa) is commonly spread in limited areas of plains and hilly terrains and is of a xeromesophytic nature as it develops during the wet spring. During the dry summer, it takes the form of a ground bulbous formation.

\section{MEDITERRANEAN VEGETATION}

The Mediterranean vegetation is represented by associations of the evergreen shrub species mock privet (Phyllirea latifolia L.). It also includes the xerophytic communities of Jerusalem thorn (Paliurus spina-christi Mill.) mixed with giant heather (Erica arborea L.), bush jasmine (Jasminum fruticans L.) and others.

\section{Formation of the mock privet (PHYLLIREETA LATIFOLIAE)}

Map index: 38, 39

The formation of the mock privet (Phyllirea latifolia) and Jerusalem thorn (Paliurus spina-christi) is mixed with bush jasmine (Jasminum fruticans). It is spread on the South Bulgarian Black Sea coast, especially the southern slopes of the Strandzha Mountain, where the monodominant associations are typical. It belongs to the xerophytic ecological type.

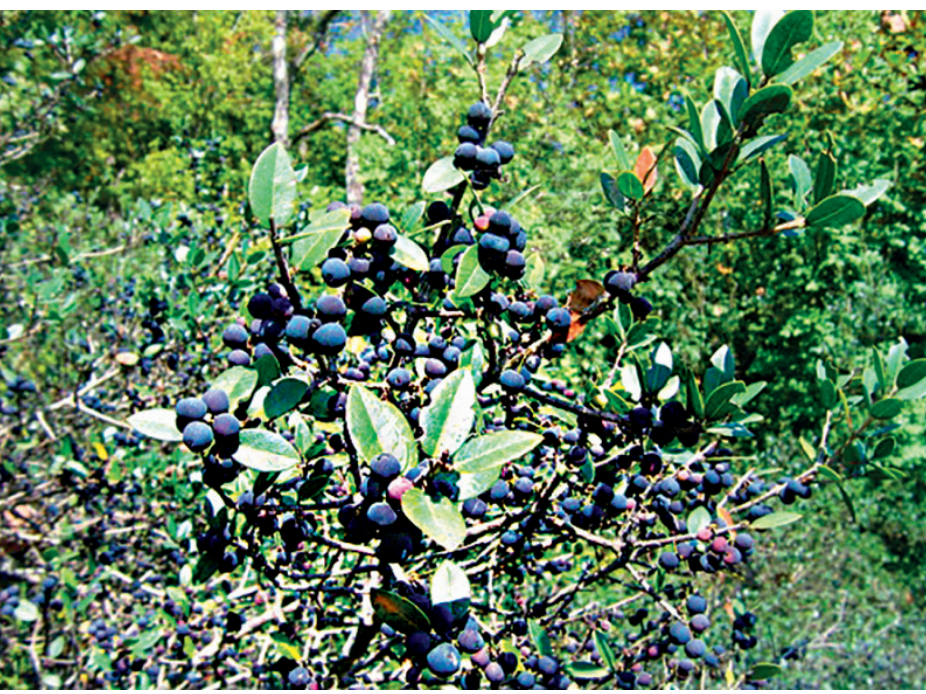

Formation of the Jerusalem thorn (PALIURETA SPINA-CHRISTI)

Map index: 36

The formation of the Jerusalem thorn (Paliurus spina-christi) is the most xerophytic one. It is spread on dry hills and slopes and wavy plains. Monodominant communities are widespread

\section{AQUATIC VEGETATION}

Map index: 46

Aquatic vegetation along the Bulgarian Black Sea coast is represented by communities dominated by vascular plants that grow in aquatic environment. Some of them are completely submerged in the water and are either attached to the bottom as the common eelgrass (Zostera marina L.), or free floating such as the rigid hornwort (Ceratophyllum demersum L.). Others float on the water surface and are attached to the bottom, e.g., white water lily (Nymphaea alba L.), water chestnut (Trapa natans L.), yellow water lily (Nuphar lutea (L.) Sm.), water fringe (Nymphoides peltata (SG Gmel.) O. Kuntze), floating pondweed (Potamogeton natans L.), etc. Other species are free floating such as water fern (Azolla filiculoides Lam.), common duckweed (Spirodela polyrhiza (L.) Schleid.), small duckweed (Lemna minor L.), etc. Some species have stems that protrude above the water such as reed (Phragmites australis (Cav.) Trin. Ex Steud., narrow-leaved cattail (Typha angustifolia L.), broad-leaved cattail (T. latifolia L.), etc.

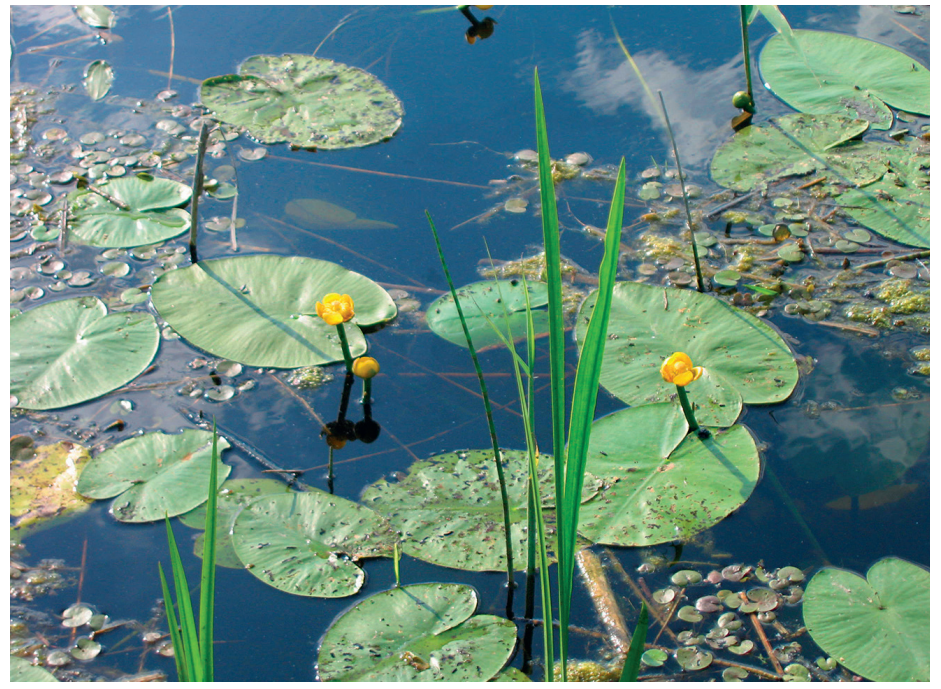

Yellow water lily (Nuphar lutea) 


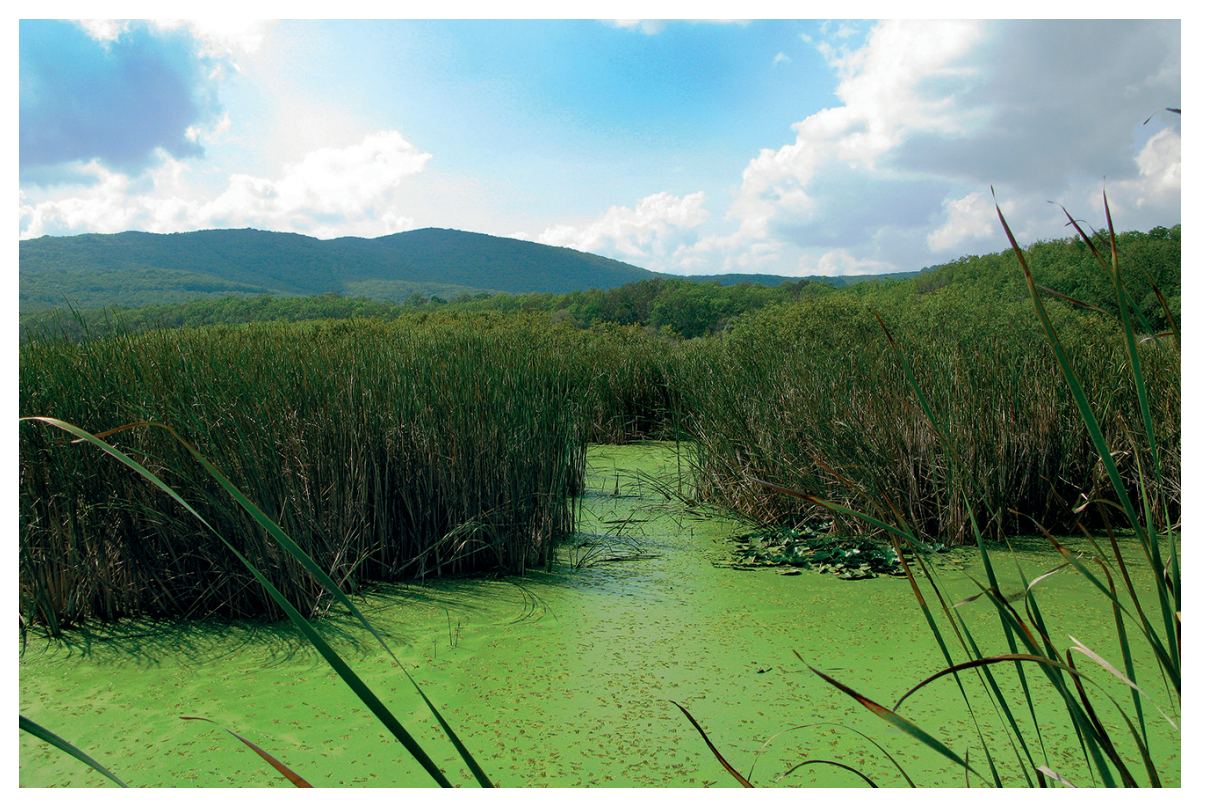

Aquatic vegetation in Arkutino Lake

The formation of the common eelgrass (ZOSTERETA MARINAE) is spread in the brackish to saline waters of Atanasovsko and Varna lakes, and also in the Black Sea at a water depth of $4.5 \mathrm{~m}$, on sandy or sandy silt bottoms. It belongs to the halophytic vegetation. There is only one monodominant association described.

The formation of the white water lily (NYMPHAETA ALBAE) is spread at the mouth of the Kamchia River, the downstream of the Ropotamo River, and Shabla-Ezerets and Arkutino lakes at a water depth of 2-2.5 m. The waters are stagnant or low-flow while the bottoms are sandy or silty sand. There are cases of temporary dewatering of areas occupied by these communities. The species forms only monodominant associations.

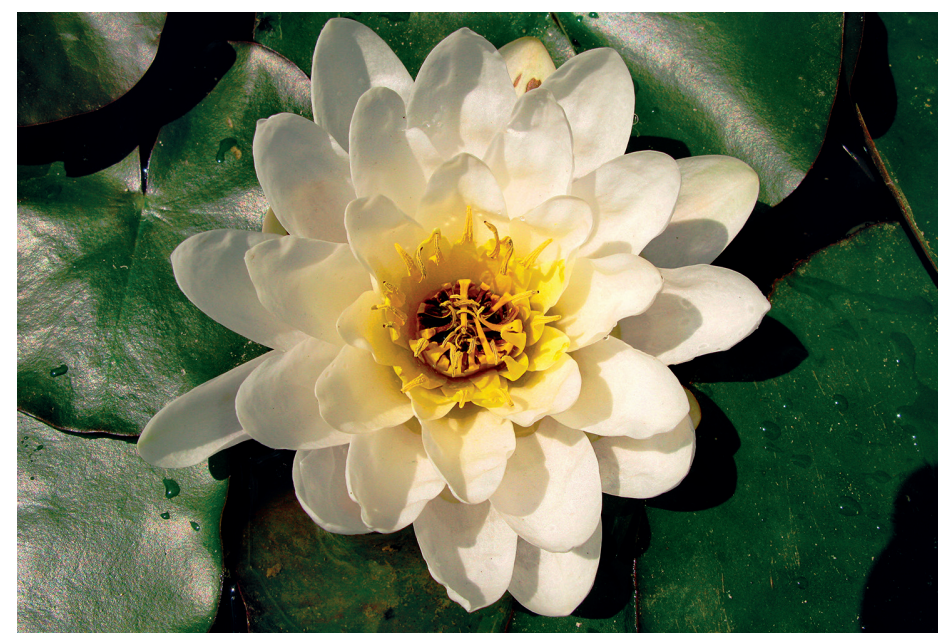

White water lily (Nymphaea alba) in the Ropotamo River

The formation of the reed (PHRAGMITETA AUSTRALIS) is spread at the Bulgarian Black Sea coastal lakes of Shabla-Ezerets, Durankulak, Varna, Beloslav, Mandra, Burgas and Alepu, as well as in firths of the Dyavolska and the Karaagach rivers and the old firths of the Kamchia River. The water depth is commonly 0.5-1.5 m, but it can reach up to 3-4 m. Floating communities are formed in the deeper basins. The most common association is monodominant, or it can be mixed with narrow-leaved cattail (Typha angustifolia)

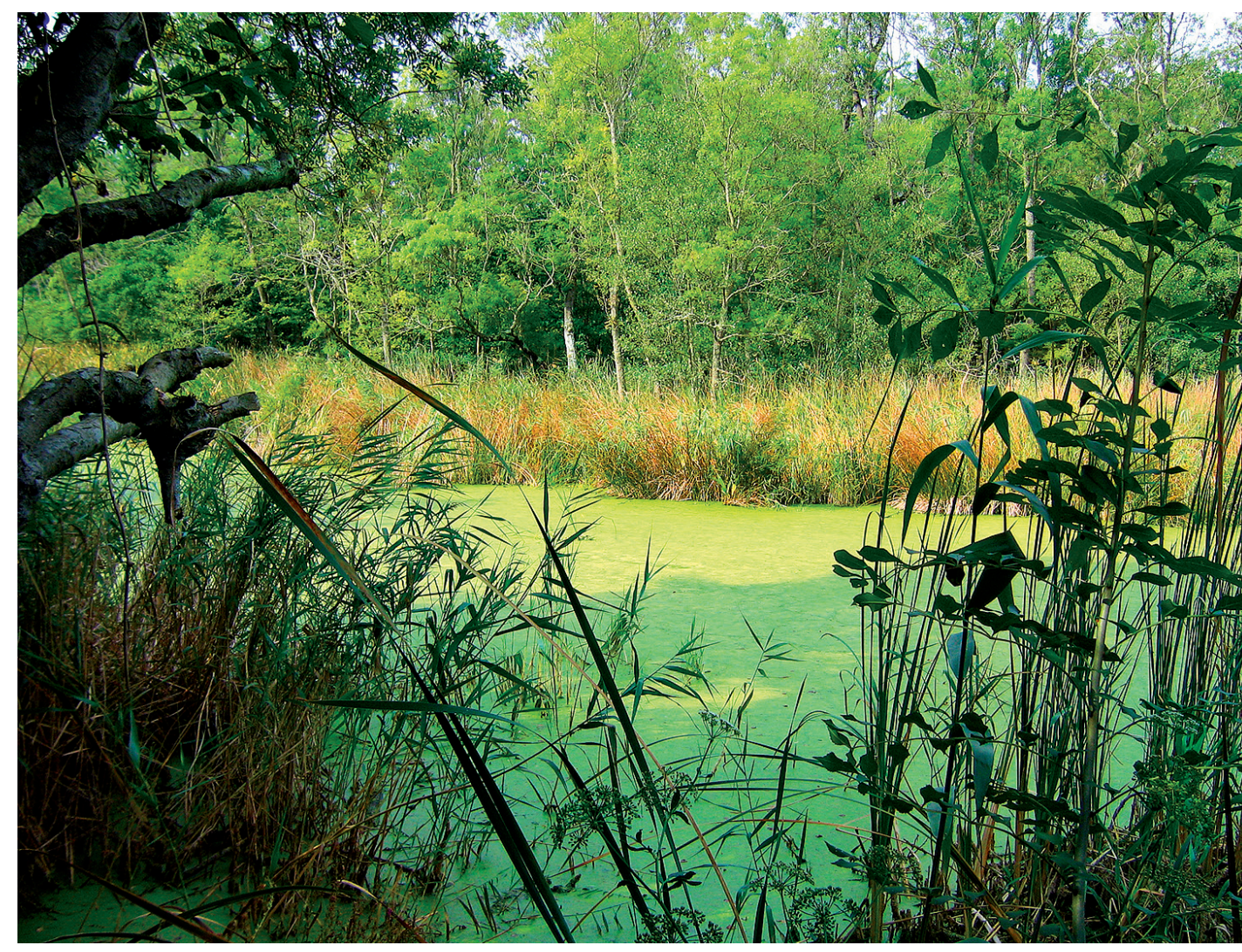

Reed formation in the riparian flooded forests of the old firths of the Kamchia River

The formation of the narrow-leaved cattail (TYPHETA ANGUSTIFOLIAE) is also widespread in the Bulgarian Black Sea coastal lakes, but it is more limited than the reed formation. It could be found predominantly in freshwater basins with muddy bottoms, and the depth of the water layer is between 0.4-1.2 m. The monodominant association is more common, covering substantial areas at Durankulak Lake. 


\section{MACROPHYTIC FLORA OF THE BULGARIAN SECTOR OF THE BLACK SEA}

The Black Sea flora includes 292 macrophytic algae and a few angiosperms [84] Due to their habitat engineering properties and high nature conservation importance, some of these species (or their communities) are enlisted in the Black Sea Red Data Book and the Red Data Book of Bulgaria [85; 86]. As a rule, the macrophytic algae in the Black Sea grow on hard substrata (mostly shallow bedforms such as boulders and block accumulations, underwater sections of cliffs, abrasional platforms, structural steps, etc., but also submerged structures with anthropogenic origin) while sea grasses populate shallow soft-bottom areas of the accumulative type (depths of 0.5-10 m) where substrates may vary from shelly sand to silty sand and sandy silt [87].
Green algae (Chlorophyta). These are presented by 84 species and are typical for the rocky sectors at depths normally ranging from 0 to $10 \mathrm{~m}$, but with highest concentrations of biomass at depths of 0-1 m [84]. Typical species include Chaetomorpha aerea, Bryopsis plumosa, representatives of Ulva spp. (e.g., Ulva rigida, U. linza, U. intestinalis etc.), Cladophora spp. (e.g., Cladophora sericea, Cl. vadorum, Cl. albida etc.), Urospora spp., Rhizoclonium spp., etc. [88]. Most of these green algae are known to form communities together with a range of red algae having similar ecological requirements, and their presence is a sign of poor ecological status of the coastal marine waters [87]. Representatives of phylum Charophyta (e.g., Chara papulosa, Ch. tomentosa etc.) are also commonly found in coastal firths, river mouths and lagoons [84].

Green algae overgrowing collapsed boulders in the Avren Plateau coastal zone south of Varna (North Bulgarian coast)
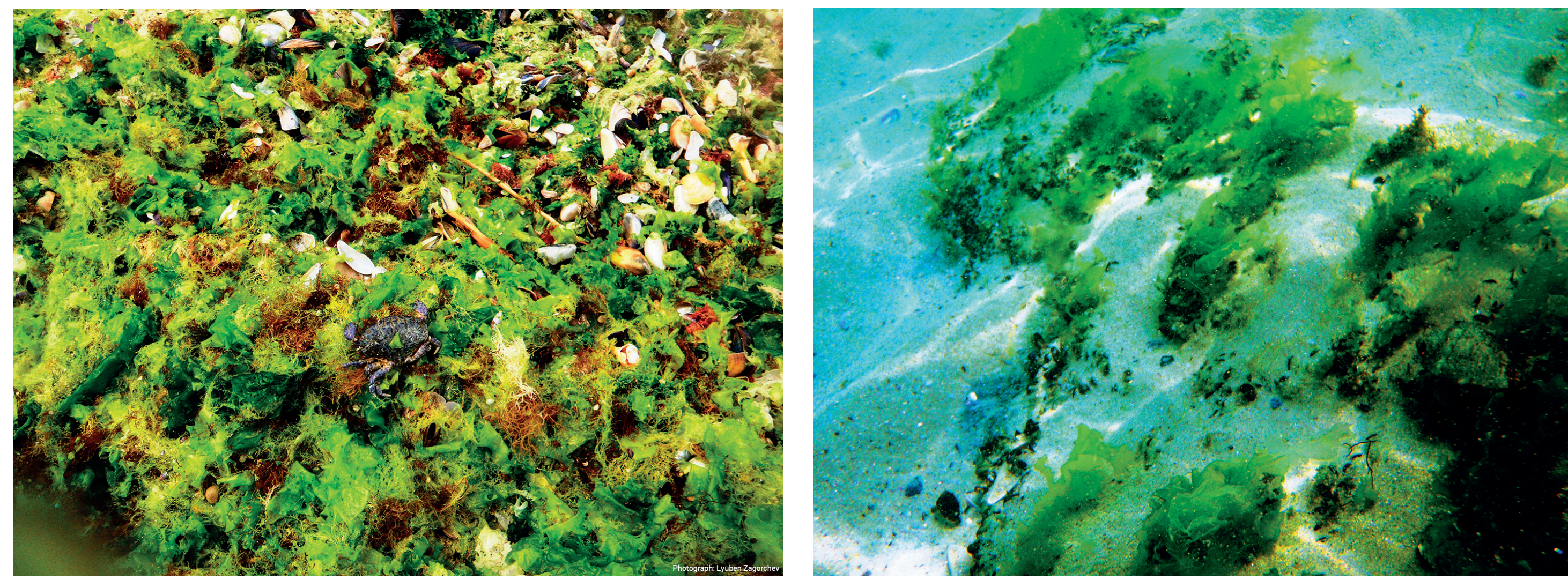
Brown algae (Phaeophyta). Species belonging to this phylum are usually found at depths of 0-20 m. A total of 74 species of the kind occur in the Black Sea [84] Among the most characteristic ones are Cystoseira crinita and C. barbata, which prefer areas with clean transparent waters, sufficient light availability, and low concentrations of biogenic elements. As a result of the above ecological requirements, the occurrence of these two species is commonly used as an indicator of good ecological status of the coastal marine waters $[87 ; 88]$. Cystoseira barbata also represents a potentially important commercial species containing alginic acid, used in the food industry as a natural gelatinization agent [84]. Cystoseira crinita and C. barbata form communities of high nature conservation value enlisted as an endangered habitat in the Red Data Book of Bulgaria, and in the Black Sea Red Data Book as species requiring basin-scale protection [86; 89].

\section{Cystoseira spp. beds near the Old Town of Nesebar (South Bulgarian coast)}

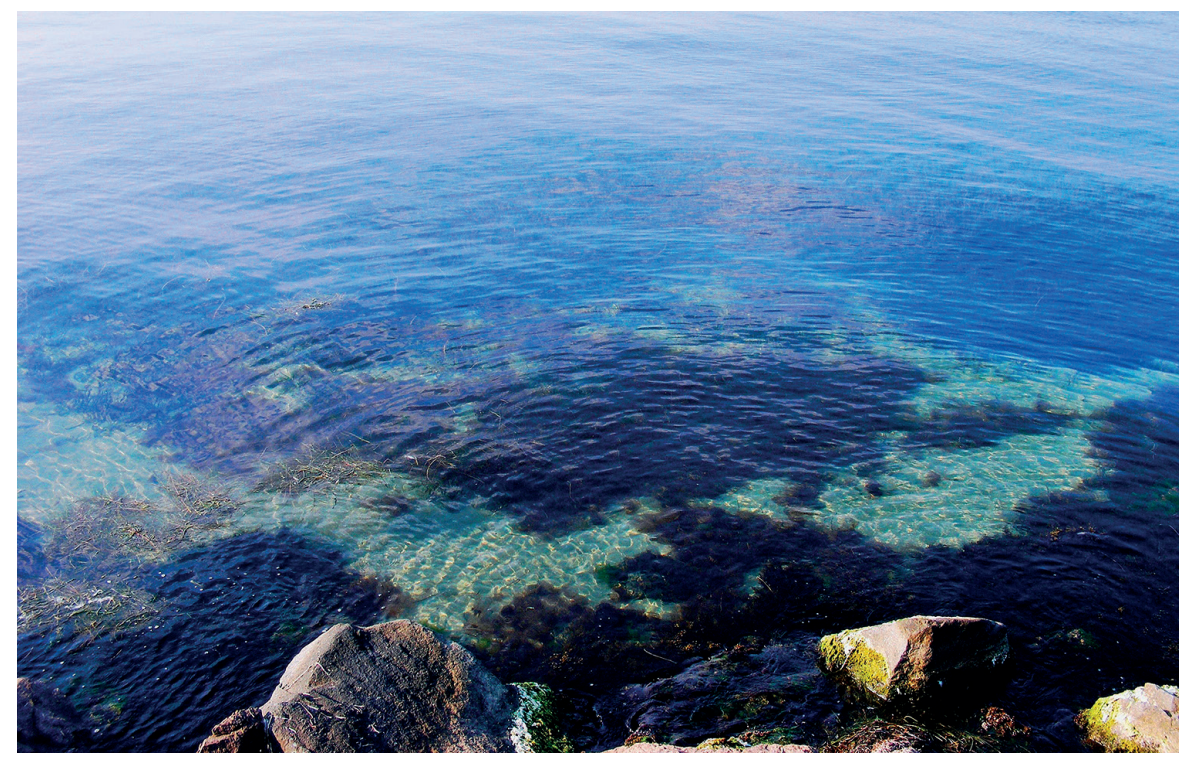

Red algae (Rhodophyta). This phylum is represented by 134 species whose lower vertical boundary of distribution is marked by the $40-60 \mathrm{~m}$ bathymetric contours. Commonly observed are representatives belonging to genera Laurencia, Palisada, Nemalion, etc., inhabiting areas with clean marine waters; Corallina, Polysiphonia (species of this genus are registered even at depths of 45-50 m) [84], Gracilaria. Gracilariopsis, etc., which are highly adaptable, but rarely found at sectors with deteriorated state of the marine environment; Ceramium rubrum, $C$. diaphanum var elegans, Pyropia leucosticta etc., whose presence and mass development usually indicates poor ecological status [88]. An interesting species of the above phylum is the sciophilic Phyllophora crispa which is enlisted in the Black Sea Red Data Book as vulnerable at the regional level [86]

Communities of green and red algae overgrowing collapsed boulders in the Avren Plateau coastal zone south of Varna (North Bulgarian coast)

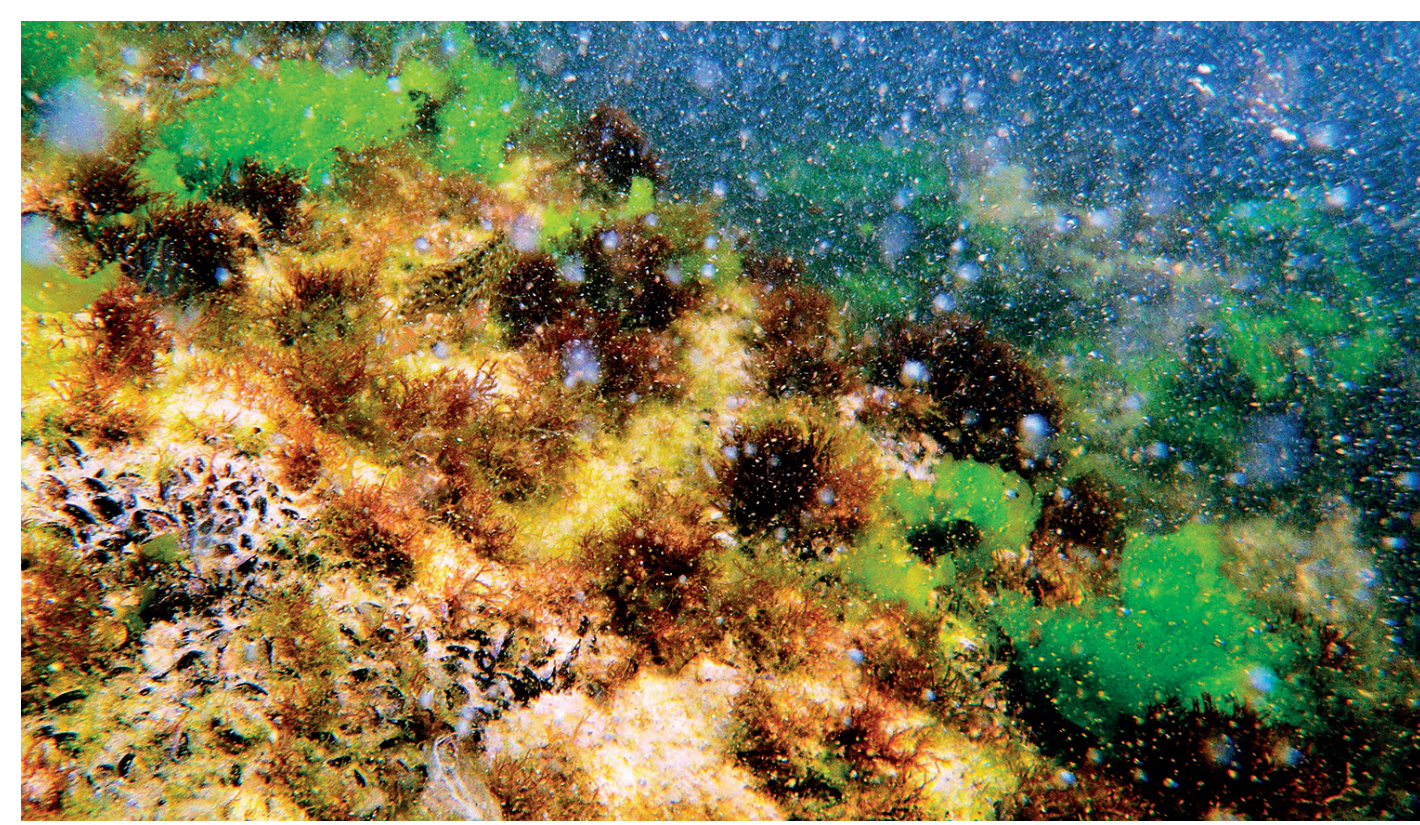

Angiosperms (Magnoliophyta). The most common aquatic plants in the shallow sector of the Bulgarian Black Sea and its contiguous coastal river mouths, freshwater and brackish lakes, are the narrow-leaved eelgrass (Zostera marina), dwarf eelgrass (Z. noltei), Fennel pondweed (Stuckenia pectinata), widgeon grass (Ruppia spiralis, R. maritima), Zannichellia major, and Z. palustris var. pedunculata [84]. These form typical subaqueous "meadows" at depths of 0.5-10 $\mathrm{m}$ at wave-protected sites with unconsolidated substrata, e.g., bottoms of river mouths, firths, brackish lagoons, shallow inlets and bays, etc. Among these, the narrow-leaved eelgrass (Zostera mari$n a$ ) and the dwarf eelgrass (Z. noltei), both included in the Black Sea Red Data Book, form communities of high nature conservation importance which are enlisted in the Bulgarian Red Data Book as an endangered habitat [90]. The presence of such subaqueous sea grass "meadows" is also commonly used as an indicator of good ecological status of the coastal marine waters [87; 88] 


\section{TERRESTRIAL FAUNA OF THE BULGARIAN BLACK SEA COAST}

\subsection{GENERAL CHARACTERISTICS}

In terms of zoogeography, the Bulgarian coast's fauna belongs to the Mediterranean zoogeographic subregion. It includes many thermophilic Ponto-Mediterranean species along with less numerous faunal elements of Iranian-Turanian, Pontic, Montane Mediterranean, etc., origin [91; 92]. It is very rich as over 2,260 species and subspecies of animals inhabiting the open sea, the shores of lakes and the littoral zone have been found.

Bulgaria is among the European countries with the highest bird diversity. 420 species, or $70 \%$ of all bird species in Europe are found here. Europe's second most important migratory route, Via Pontica, passes over the Bulgarian Black Sea coast and millions of birds fly on their way to Africa and back every year. The Poda Protected Area near Burgas is the place with the highest number of birds per square kilometer in Europe (269 species).

\subsection{BIRDS WITH HIGH CONSERVATION STATUS ACCORDING TO THE INTER- NATIONAL UNION FOR CONSERVATION OF NATURE (IUCN)}

The red-breasted goose (Branta ruficollis Pallas, 1769) is a Palearctic species of the Russian tundra. $90 \%$ of its population migrates to Shabla, Ezerets and Durankulak lakes (occasionally to the Burgas Lake Complex as well). More than 67,000 individuals have been observed annually over the past 10 years. The species is enlisted in the Bulgarian Red Data Book as vulnerable [91]

The greater spotted eagle (Aquila clanga Pallas, 1811) is a Palearctic species that nests in northeastern Europe, Russia and China, with a total number of some 810 1,100 pairs. It migrates regularly along the Black Sea coast (Cape Kaliakra, town of Balchik, the Batova River, Kamchia River, Atanasovsko Lake, Ropotamo River) and could be found around Shabla, Ezerets and Durankulak lakes, and the Ropotamo River in the winter. The species is enlisted in the Bulgarian Red Data Book as critically endangered [91]

The Dalmatian pelican (Pelecanus crispus Bruch, 1832) is a Sarmatian species that occurs along the Bulgarian Black Sea coast during migration and in the vicinity of Burgas in the winter (Mandra and Burgas lakes). The only place for its breeding in Bulgaria is the Srebarna Biosphere Reserve. The species is enlisted in the Bulgarian Red Data Book as critically endangered [91].

The lesser white-fronted goose (Anser erythropus L., 1758) is a monotypical Palearctic species that breeds in the taiga and the arctic and subarctic regions between Scandinavia and the Far East. It could be found along other goose species during the winter, mostly on fields of winter wheat or maize grains left after harvest. The species is enlisted in the Bulgarian Red Data Book as critically endangered [91].

The white-headed duck (Oxyura leucocephala Scopoli, 1769) is a Palearctic species with a fragmented breeding area spreading from southwestern Europe and northeastern Africa to Central Asia and China. It could be found in Bulgaria in the winter, especially in the Burgas Lake area with a maximum population of 2,260 individuals. The species is enlisted in the Bulgarian Red Data Book as endangered [91].

The slender-billed curlew (Numenius tenuirostris Vieillot, 1817) is a species with a Siberian type of distribution and on the threshold of full extinction. In the past it inhabited the zone of the forest steppes from Ural to the Ob River valley. It could be found during migrations and in the winter at Atanasovsko Lake, Poda locality and Chengene skele Bay near Burgas. There have been no confirmed observations in Bulgaria since 1999. It is possible for singular birds or small groups consisting of 2-3 individuals to be passing through this country every year. The species is enlisted in the Bulgarian Red Data Book as critically endangered [91].

The great bustard (Otis tarda L., 1758) is a species with a trans-Palearctic range (from Portugal to northeastern China) that breeds in the steppe areas. Presently, it is probably extinct as a breeding species in Bulgaria. It is enlisted in the Bulgarian Red Data Book as critically endangered [91]. 
The Yelkouan shearwater (Puffinus yelkouan Acerbi, 1827) is a Mediterranean colonial species that breeds in the Mediterranean basin where over $95 \%$ of the world population is located. Part of the population scatters in the Black Sea region between June and October and spends the winter at Atanasovsko Lake and the area near the town of Ahtopol. The species is enlisted in the Bulgarian Red Data Book as endangered [91].

\subsection{OTHER BIRD SPECIES OF INTEREST}

The common shelduck (Tadorna tadorna L., 1758) is a Sarmatian species that breeds in Europe and Asia. Its largest concentrations are registered in the winter in Atanasovsko and Pomorie lakes. The species is enlisted in the Bulgarian Red Data Book as vulnerable [91]

Common shelducks (Tadorna tadorna)
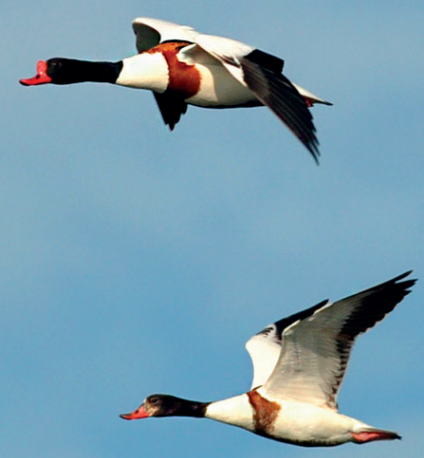

The great white egret (Egretta alba L., 1758) is a cosmopolite species. It could be found along the Black Sea coast during migration and in the winter, yet isolated pairs episodically also breed in the Burgas Lake Complex. The species is enlisted in the Bulgarian Red Data Book as critically endangered [91].

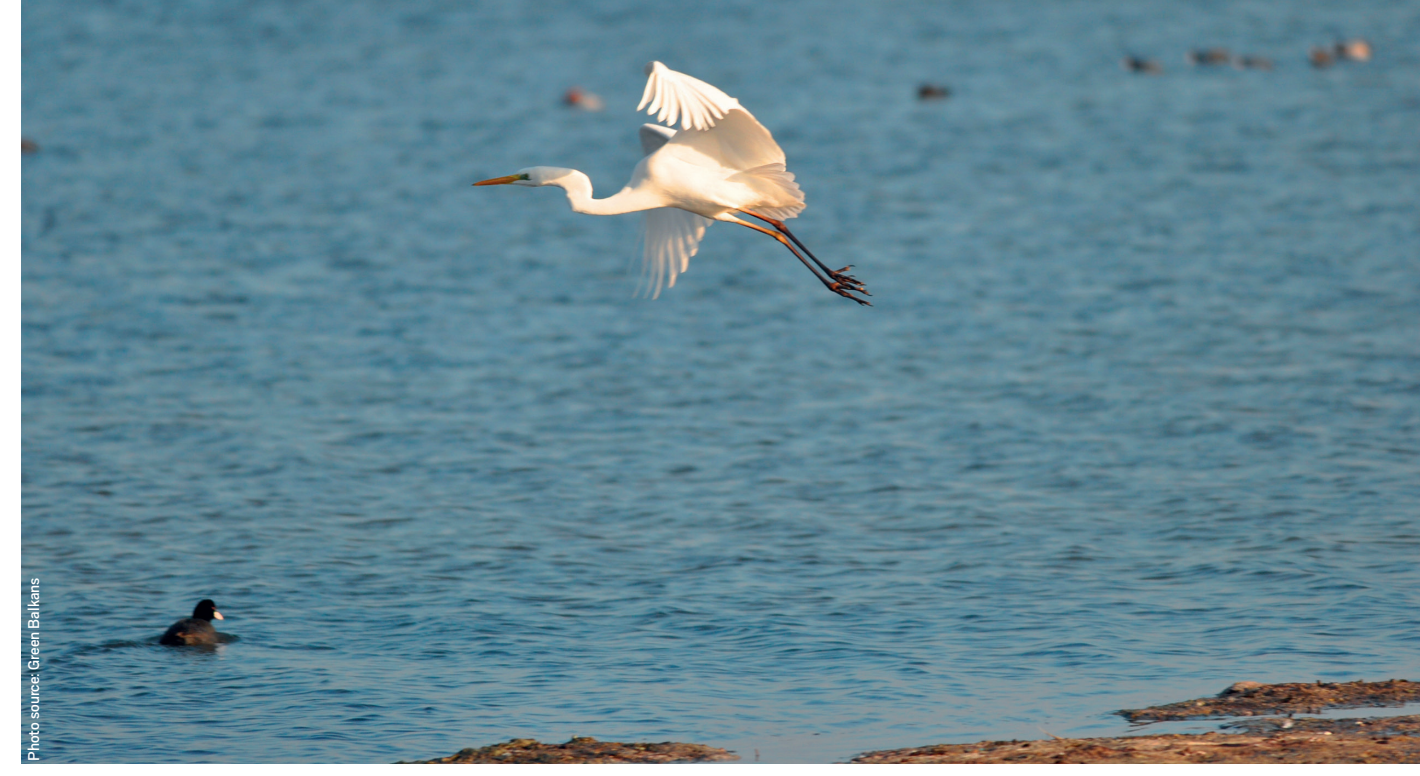

Great white egret (Egretta alba)

The little egret (Egretta garzetta L., 1766) is a cosmopolite species. 147 breeding habitats with different degrees of certainty have been identified in Bulgaria so far. Some of these are the Burgas Wetlands. The species is enlisted in the Bulgarian Red Data Book as vulnerable [91]

Little egret (Egretta garzetta) 
The lesser kestrel (Falco naumanni Fleischer, 1818) is a Turkestan-Mediterranean species. Since 2000 it has been migrating over the entire territory of Bulgaria, mostly along the Black Sea coast. The species is enlisted in the Bulgarian Red Data Book as critically endangered [91]

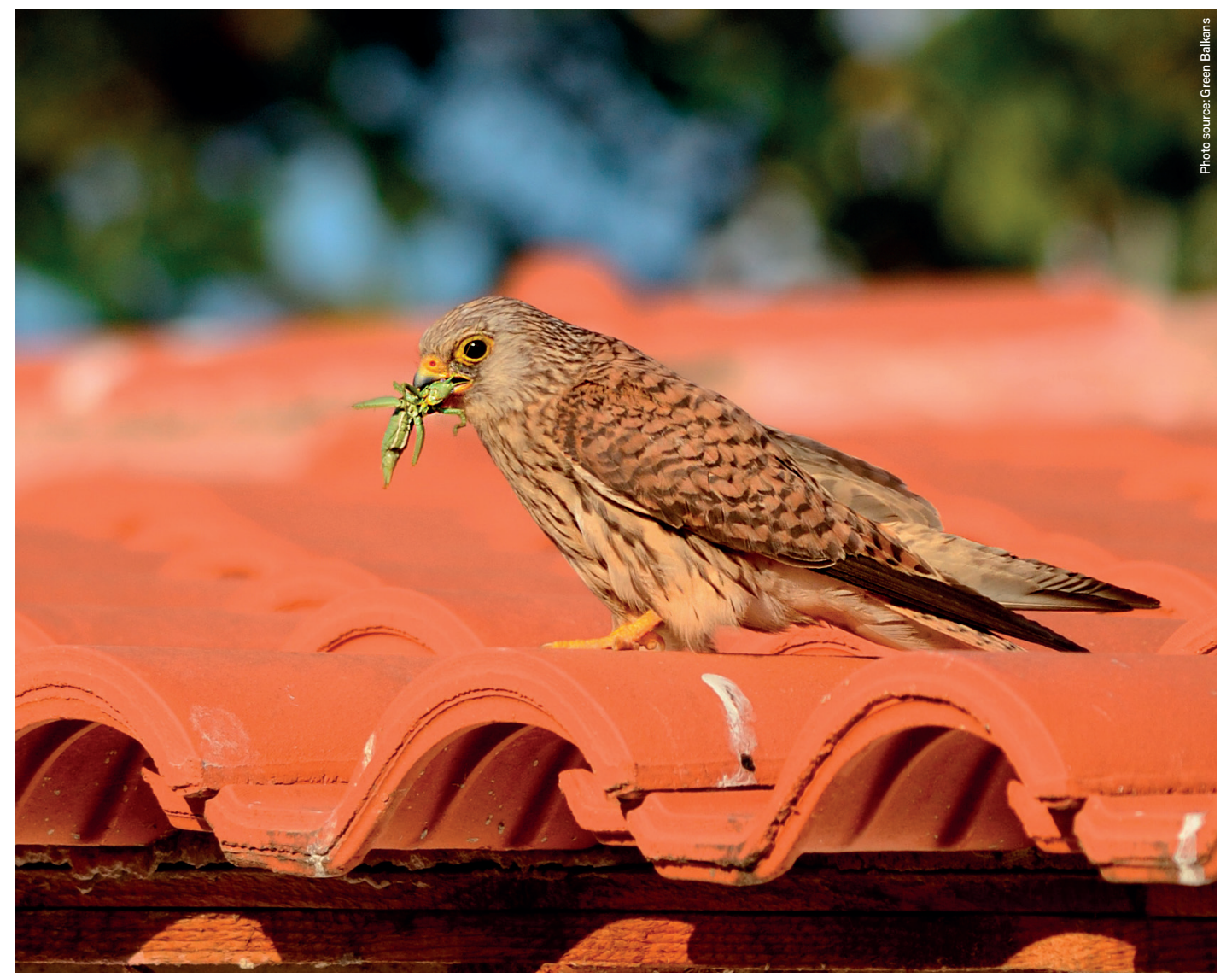

Lesser kestrel (Falco naumanni)

The Black-winged stilt (Himantopus himantopus L., 1758) is a cosmopolite species with scattered distribution. At present, it breeds along the coastal lakes of Durankulak (4 pairs) and Shablenska tuzla Lagoon (8-15 pairs), in the Yatata locality near the town of Beloslav (10 pairs), in Atanasovsko (40-55 pairs), Pomorie (10-15 pairs) and Mandra (1-3 pairs) lakes, and Poda locality (10-15 pairs). Its population has decreased by $50 \%$ over the past 10 years. The species is enlisted in the Bulgarian Red Data Book as endangered [91].

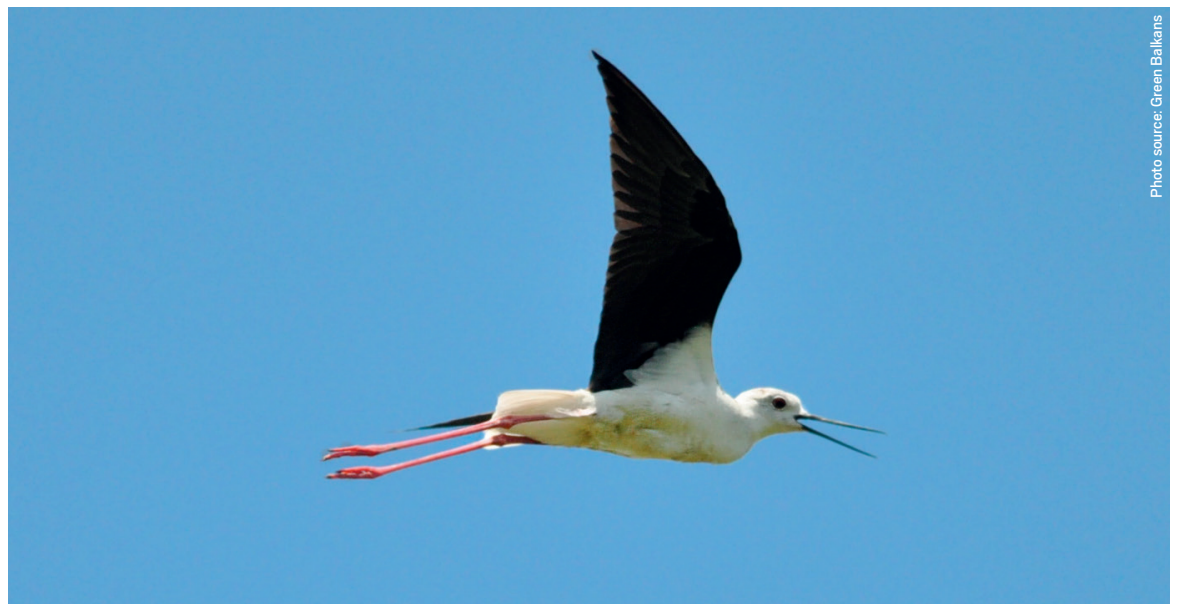

Black-winged stilt (Himantopus himantopus)

The Mediterranean gull (Larus melanocephalus Temminck, 1820) is a Western Palearctic species. The basic breeding population is concentrated along the Black Sea coast of Ukraine. Larger concentrations have been observed near Cape Kaliakra and the Burgas Lake Complex during the fall migration. The species is enlisted in the Bulgarian Red Data Book as vulnerable [91].

Mediterranean gulls (Larus melanocephalus)

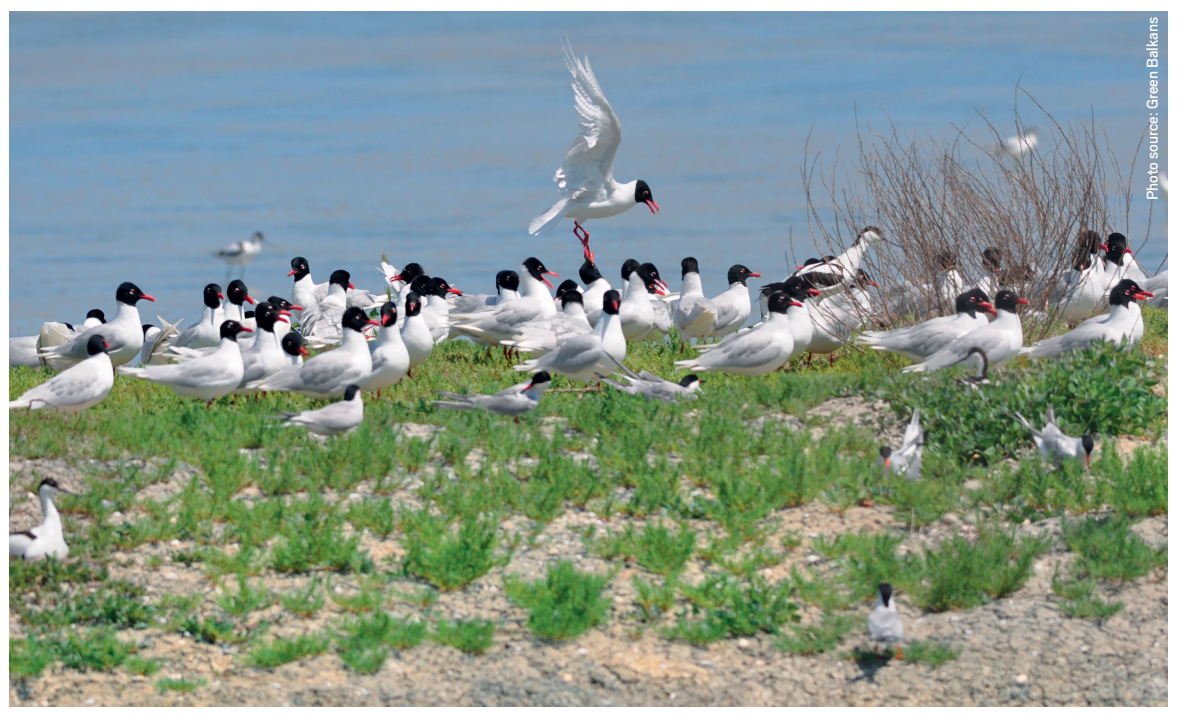


The avocet (Recurvirostra avosetta $L ., 1758$ ) is a cosmopolite species with a scattered distribution in Europe: from Sweden to Spain and to the Black Sea to the east. It is most numerous in Atanasovsko Lake during migration, where it could occur in the winter. The species is enlisted in the Bulgarian Red Data Book as endangered [91]

\section{Avocet (Recurvirostra avosetta)}

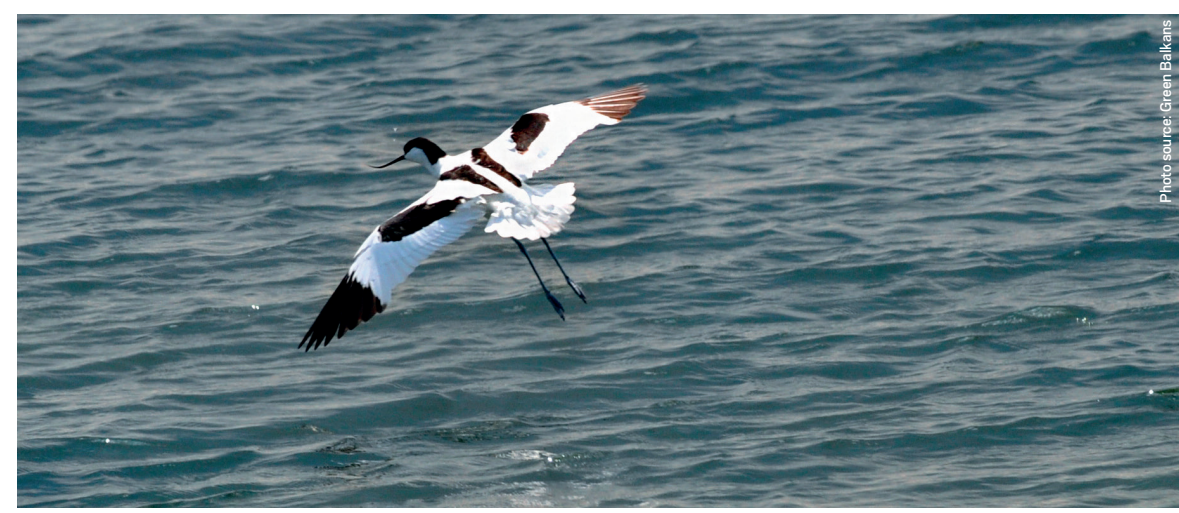

The collared pratincole (Glareola pratincola L., 1766) is an Indo-African species. It is spread in a scattered manner in Europe. At present, there are regular breeding sites along the Black Sea coast - up to the Shabla-Ezerets Lake Complex to the north (8 pairs), Pomorie (8 pairs), Atanasovsko (25-30 pairs), and Mandra (5-15 pairs) lakes to the south. The species is enlisted in the Bulgarian Red Data Book as endangered [91].

Collared pratincole (Glareola pratincola)

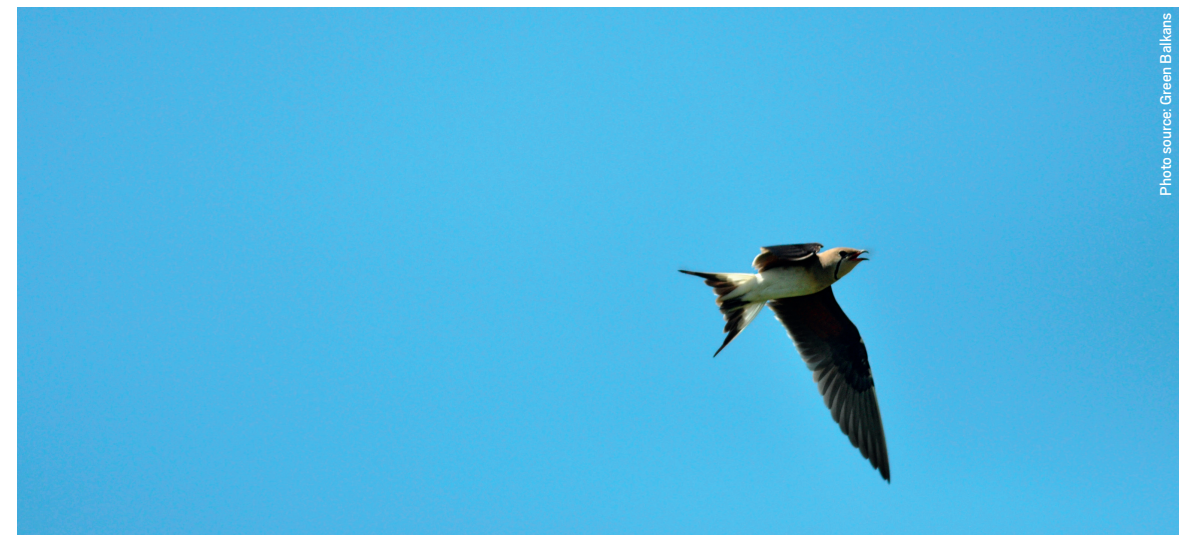

The common tern (Sterna hirundo L., 1758) is a Holarctic species with a breeding area encompassing Europe (without Portugal), Asia, Siberia, North America, and the Caribbean Sea. At present, it breeds in 13 habitats, the major ones being Atanasovsko Lake, Pomorie Lake, Poda Protected Area, Sveti Toma Island, and the mouth of the Ropotamo River. The species is enlisted in the Bulgarian Red Data Book as endangered [91]

\section{Common terns (Sterna hirundo)}

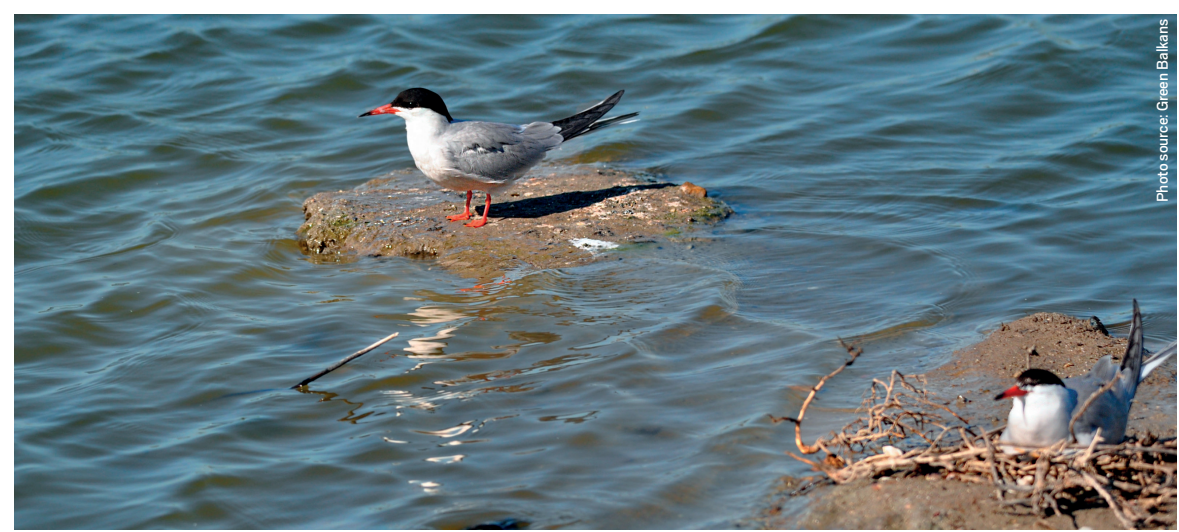

The mute swan (Cygnus olor Gmelin, 1789) is a Palearctic species, a partial migrant In the winter, it is mainly found along the Black Sea coast, where between 193 4,039 birds occur (1,377 individuals on the average). The species is enlisted in the Bulgarian Red Data Book as vulnerable [91].

Mute swans (Cygnus olor)

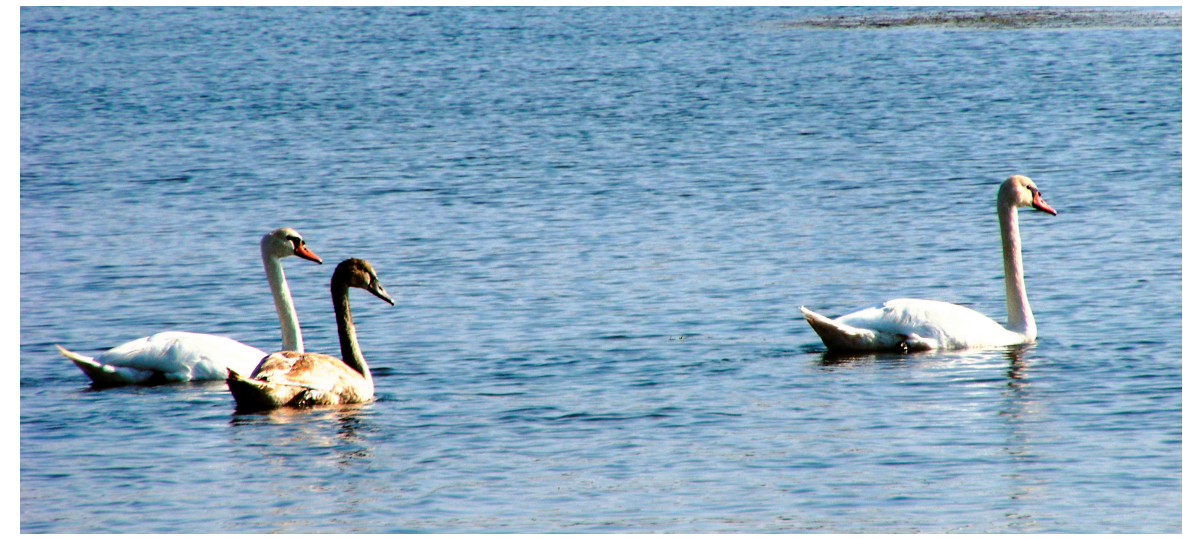


The Great cormorant (Phalacrocorax carbo L.., 1758) is a cosmopolite non-threatened species that is widely spread along the Bulgarian Black Sea coast. It is found in all coastal lakes and sea cliffs.

Great cormorants (Phalacrocorax carbo)

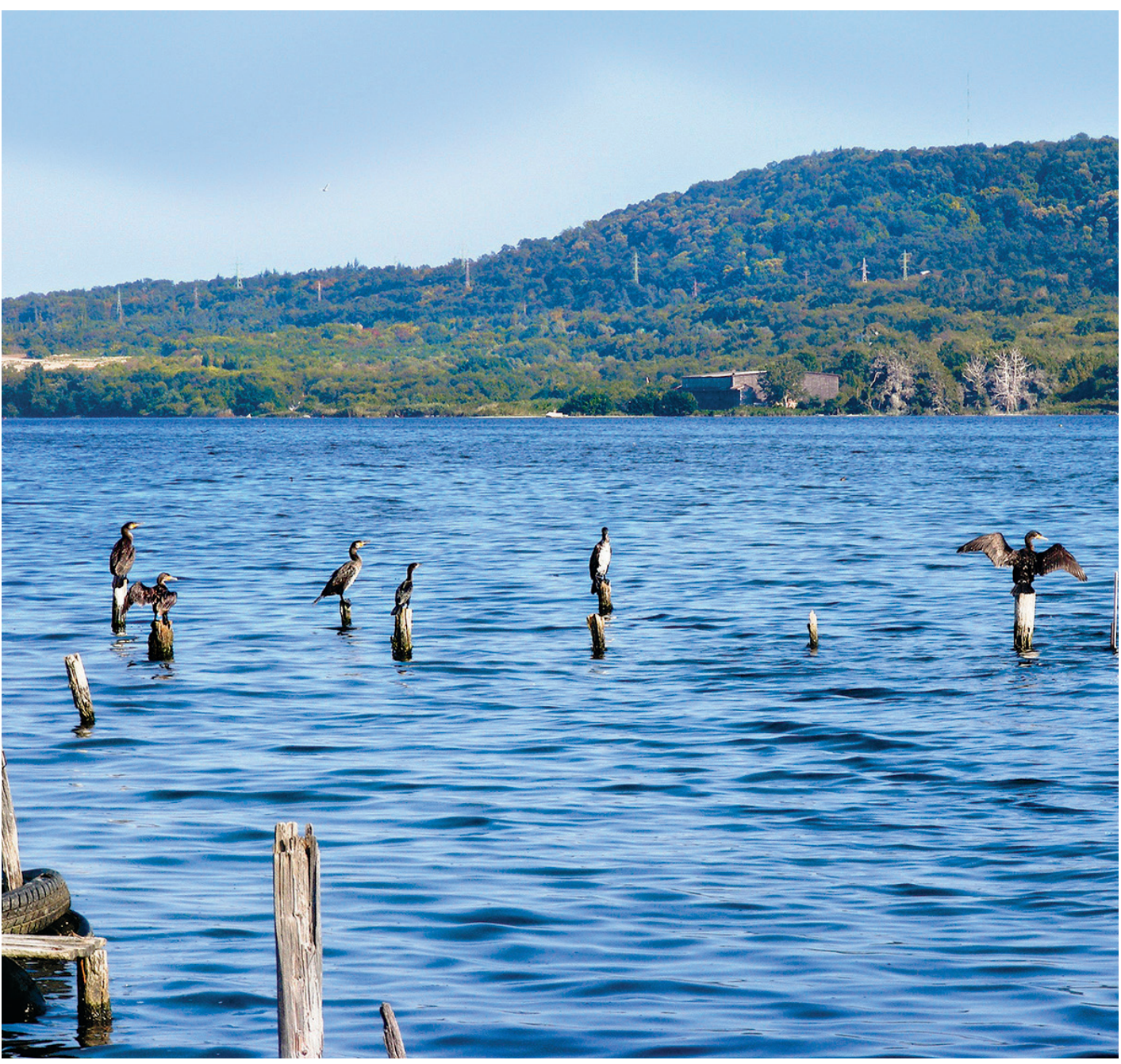

78 PHYSIOGRAPHIC AND OCEANOGRAPHIC CHARACTERISTICS OF THE STUDY ARE

\subsection{IMPORTANT BIRD AREAS AND NATURA 2000 PROTECTED SITES}

NATURA 2000 represents a European ecological network of internationally recognized protected sites aiming to guarantee the long-term preservation and survival of conservationally important species and their habitats. Along with sites established in compliance with Directive 92/43/EEC (Habitats Directive) for the protection of habitats of wild life flora and fauna, NATURA 2000 also comprises the so-called special protection areas (SPAs) designated in compliance with Directive 2009/147/EC (Birds Directive). Among others, important areas designated as NATURA 2000 sites for the preservation of birds in Bulgaria include Durankulak Lake, Shabla-Ezerets Lake Complex, the Batova River Valley, Varna-Beloslav Lake Complex, Kamchia River Valley, Pomorie Lagoon, Burgas Lake Complex, Poda locality, Chengene skele Bay, Medni rid Ridge, Ropotamo River Valley, etc. [39]

Generalized map scheme of the NATURA 2000 protected sites on the Bulgarian coast designated in compliance with Directive 2009/747/EC (Birds Directive)

(according to data from the National Information system for protected sites of the Bulgarian NATURA 2000 Network) [39] 


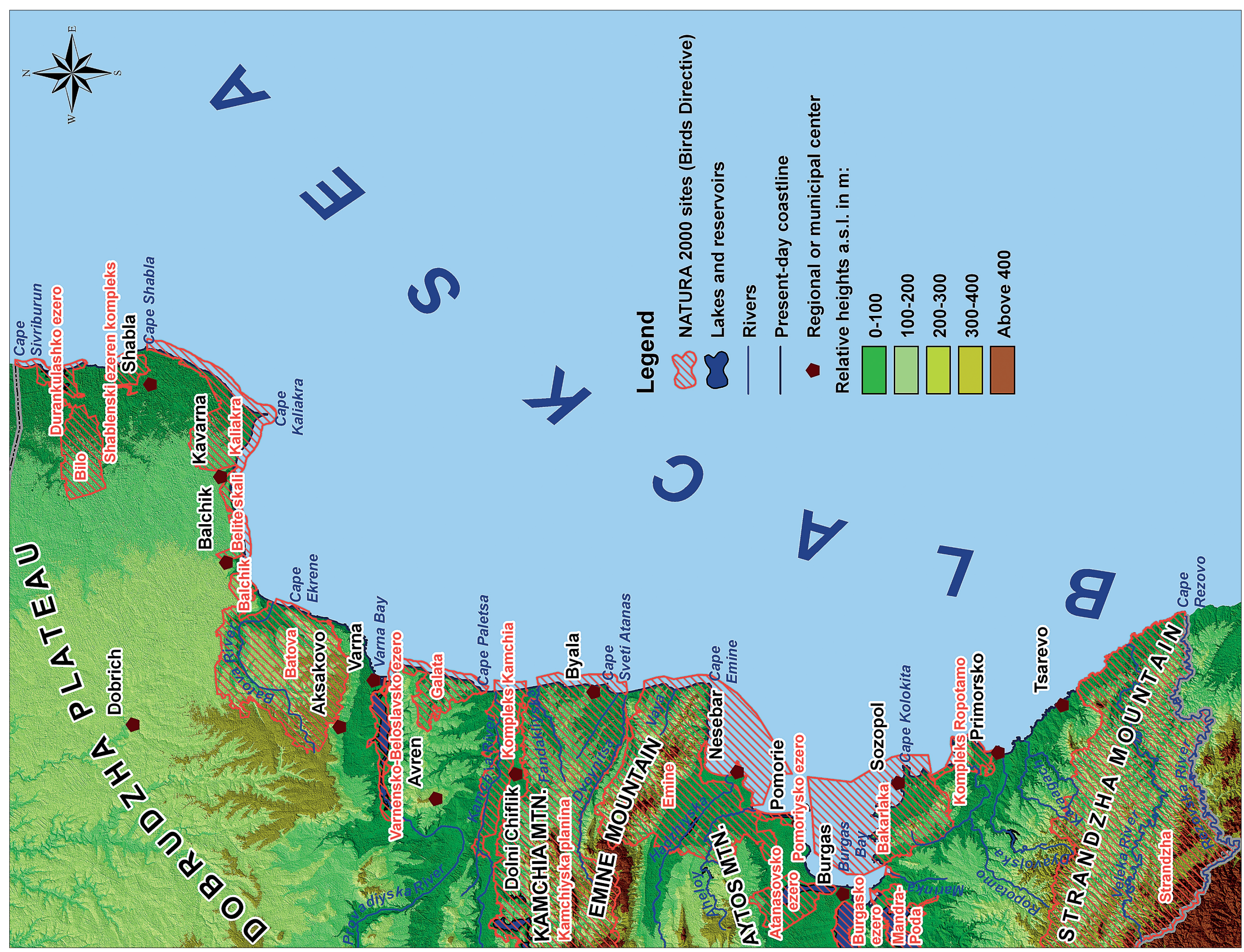




\subsection{OTHER PROTECTED ANIMALS}

The Balkan spadefoot (Pelobates syriacus balcanicus Karaman, 1928) occurs in the Southeast Balkans. A very rare species, it is spread between 0-350 $\mathrm{m}$ asl along the South Bulgarian Black Sea coast. It is self-buried in sands up to $30 \mathrm{~cm}$ deep. The species is subject to protection in compliance with the national Biological Diversity Act [111].

The Balkan gecko (Mediodactylus kotschyi danilewskii Strauch, 1877) is the single species representative of Gekkonidae in Bulgaria. It is spread along the entire Bulgarian Black Sea coast on sea rocks and in uninhabited houses, especially in the Sozopo area. The species is not threatened.

The European worm snake (Typhlops vermicularis Merrem, 1820) is a small serpent that can reach $40 \mathrm{~cm}$ in length. It is blind, and since it lives mostly underground it is colored pink and resembles a worm. It is spread along the South Bulgarian Black Sea coast near Sozopol and Cape Maslen nos. The species is subject to protection in compliance with the national Biological Diversity Act [111].

European worm snake (Typhlops vermicularis)

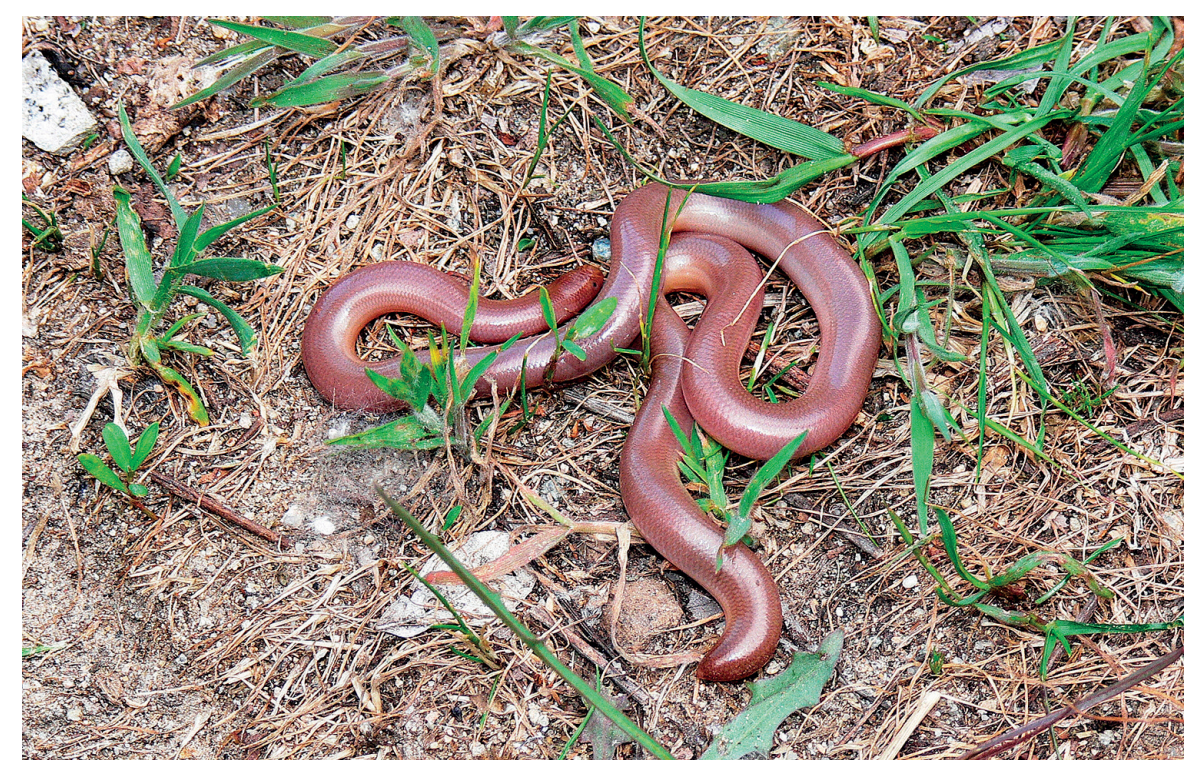

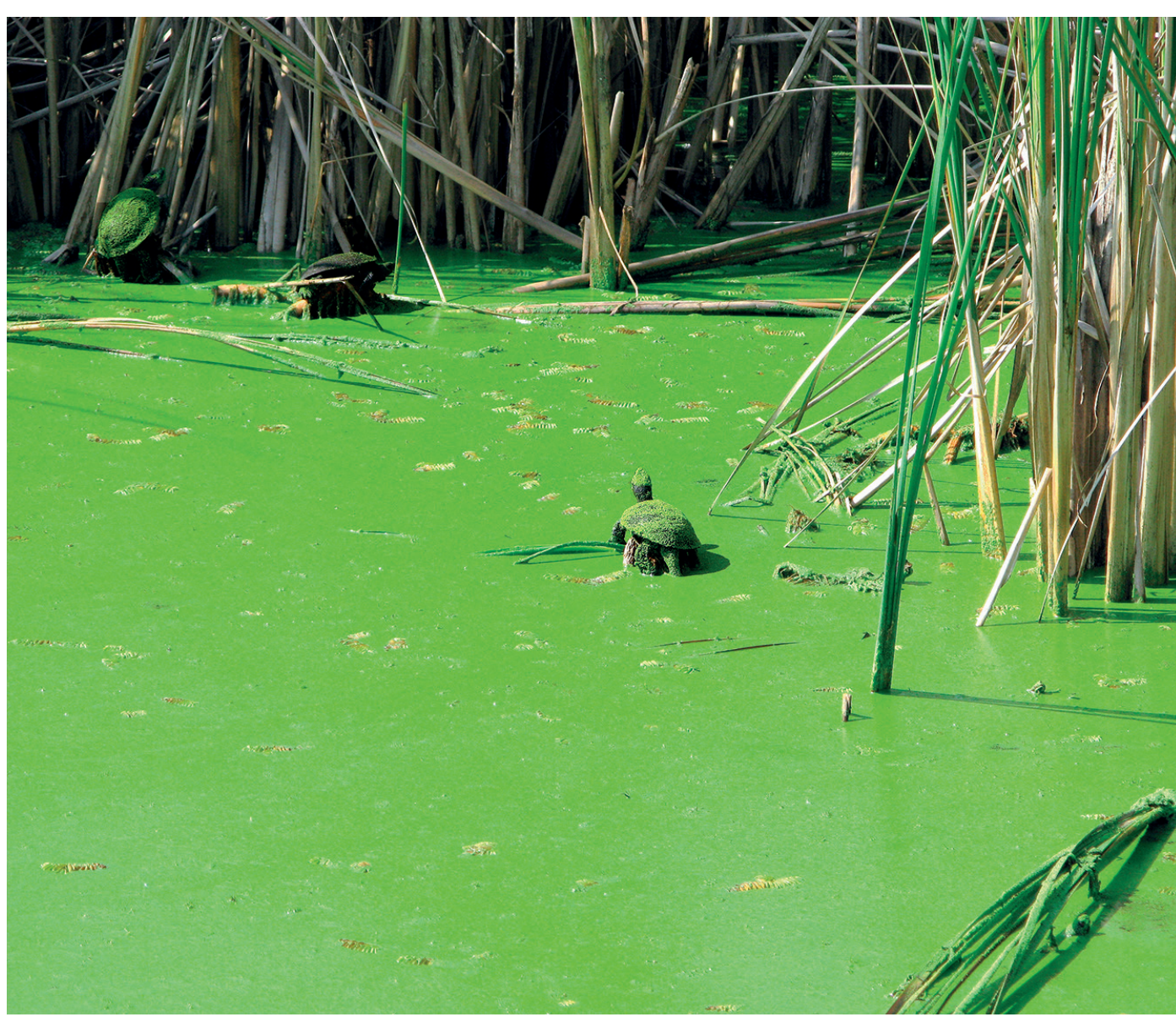

European pond turtle (Emys orbicularis)

The reddish whip snake (Platyceps collaris Muller, 1878) is found in dry, rocky and bushy habitats of the South Bulgarian Black Sea coast between the towns of Sozopol and Ahtopol. It is enlisted in the Bulgarian Red Data Book as critically endangered [91].

The European pond turtle (Emys orbicularis L., 1758) is widely spread in all coastal lakes and the downstreams of rivers flowing into the Black Sea. It prefers habitats rich in aquatic vegetation. The species is subject to protection in compliance with the national Biological Diversity Act [111]. 
The Eastern Hermann's tortoise (Testudo hermanni boettgeri Mojsisovics, 1889) is similar to the spur-thighed tortoise (Testudo graeca ibera Pallas, 1814), both occurring in many places. It differs from the latter in shape and location of the small corneous shields on the back, especially the middle longitudinal row of 5 small shields. The tail of $T$. hermanni is considerably longer and ends in a horn ray. At present, the species rarely occurs in Bulgaria, except in its northeastern part, where only $T$. graeca is spread. Both species are enlisted in the Bulgarian Red Data Book as endangered There is a rescue and visitor center, Gea chelonia, for these species in the village of Banya, Nesebar Municipality.

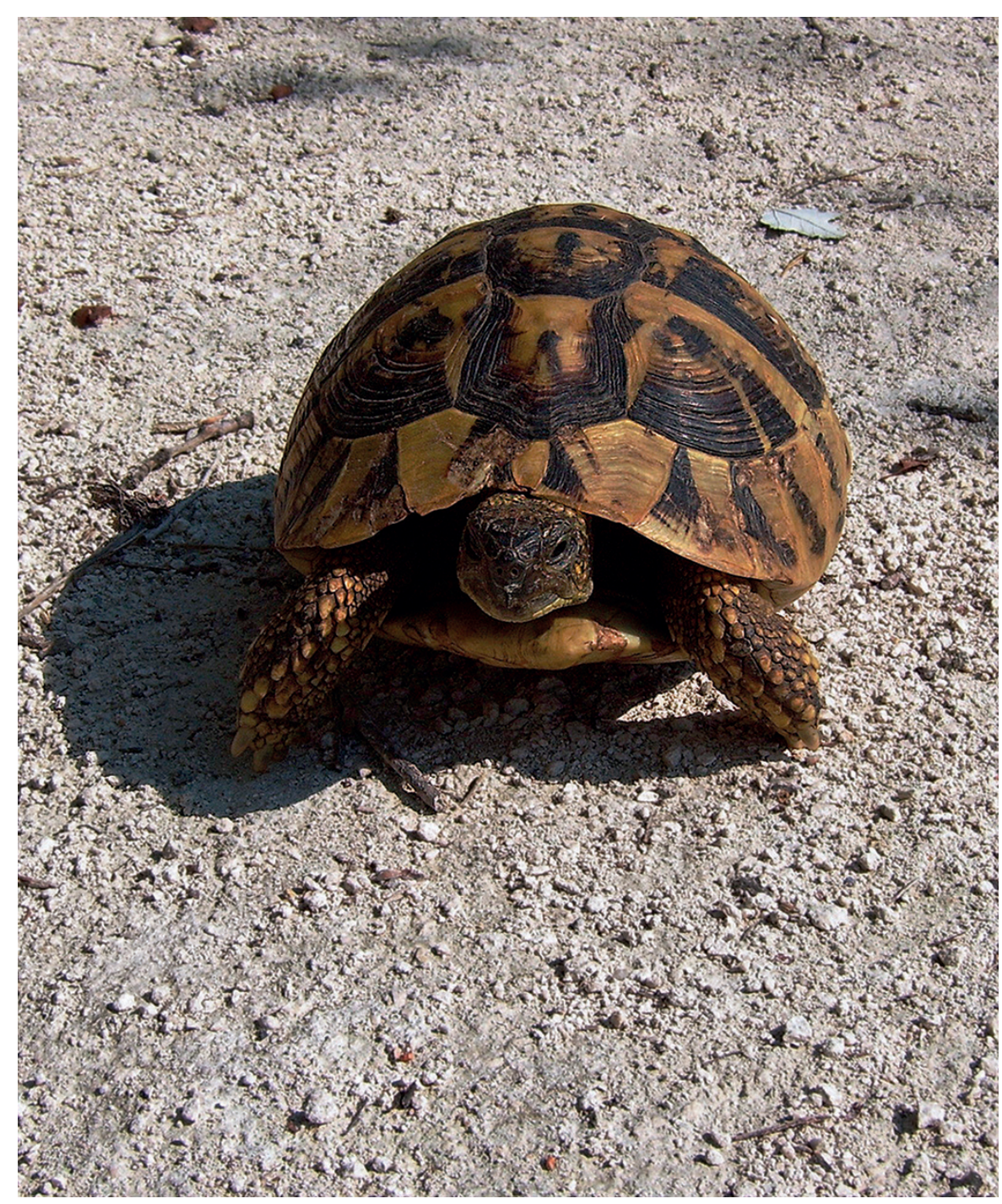

The lesser noctule (Nyctalus leisleri Kuhl, 1817) is a rare bat species found mainly in tree hollows, as well as bird houses around the town of Chernomorets, south of Burgas. It is enlisted in the Bulgarian Red Data Book as vulnerable

The steppe polecat (Mustela eversmanii Lesson, 1827) is a rarely observed mammalian species in the steppe habitats of the Dobrudzha Plateau, North Bulgarian Black Sea coast. It is a predator that used to attack the European souslik (Spermophilus citellus L., 1766). The species is enlisted in the Bulgarian Red Data Book as vulnerable.

The Eurasian otter (Lutra lutra L., 1758) is a rare species that is spread in the natural river currents and closed water basins as well as the Black Sea. It has a higher population density in southeastern Bulgaria. The species is enlisted in the Bulgarian Red Data Book as vulnerable.

The Eurasian lynx (Lynx lynx L., 1758) was assumed to be extinct. There is just one reported observation along the Bulgarian Black Sea coast, near the Ropotamo River. The endangered autochthonous Balkan population inhabits southwestern Serbia, Montenegro, Macedonia, Albania, Bosnia and Herzegovina and possibly the Strandzha Mountain (Bulgaria and Turkey). The species is enlisted in the Bulgarian Red Data Book as critically endangered

The Mediterranean monk seal (Monachus monachus Hermann, 1779) is an extinct species. In the past there were groups of 50-100 animals each (for example, at Cape Kaliakra and north of it). In the past decades, single individuals inhabited empty small bays and rock shores. Caves that had been inhabited in the past are known in the regions of Kaliakra, Maslen nos, the Ropotamo Reserve and between the villages of Sinemorets and Rezovo. It is possible for a small number of seals to be still living on the Turkish shore of the Sea of Marmara. The species is enlisted in the Bulgarian Red Data Book as extinct.

Spur-thighed tortoise (Testudo graeca ibera) 


\section{FAUNA OF THE BULGARIAN BLACK SEA SECTOR}

\section{SEA SPONGES (SPONGIA)}

Sea sponges are commonly found in the Black Sea on rocky substrata and mollusk shells. Typical fouling species, they are very flexible and occur in a wide range of marine habitats. They come in various forms and can be hard to identify. Some forms have a granular surface, which has given them their common name and sometimes their surface is smooth, even glassy. The species Halichondria panicea (Pallas, 1766) is enlisted in the Black Sea Red Data Book [86].

\section{SEA WORMS}

Ophelia bicornis Savigny in Lamarck, 1818

Family Opheliidae

A typical contourobiont inhabiting almost exclusively the sandy bottom mediolittoral (pseudolitoral). Its preferred habitat is the clean coarse sand free of any mud content. Its larvae are potentially capable of long-distance dispersal, adopting a benthic lifestyle after several weeks of planktonic life. Ophelia bicornis is a species enlisted in the Black Sea Red Data Book [86].

\section{BIVALVES AND GASTROPODS (MOLLUSCA)}

\section{Mytilus galloprovincialis Lamark, 1819}

\section{Common English name: Mediterranean (blue) mussel}

Family Mytilidae

The Mediterranean mussel is presented by two forms in the Black Sea. The first form is coastal, overgrowing hard substrata in the mediolittoral and the shallow sublittoral zones [87]. A specific feature of Mytilus galloprovincialis is that it does not populate

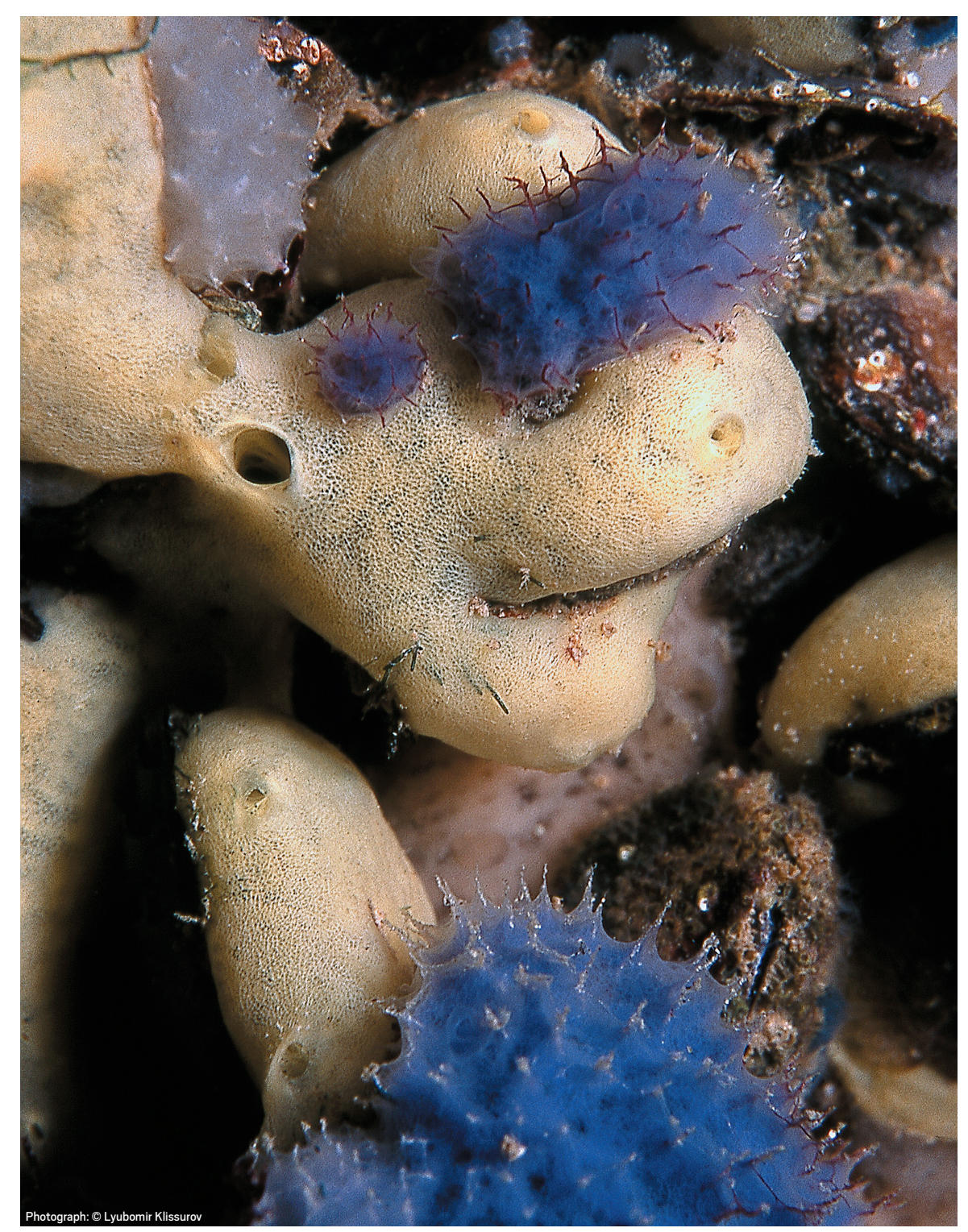

Sea sponges from the Black Sea

certain lithologic types, e.g., solid clays, marls, etc. The other form populates deeper soft-bottom sectors, whose assemblages represent a rather important benthic habitat of nature conservation interest [93]. Both forms of Mytilus galloprovincialis play an important ecological role in the Bulgarian Black Sea as edificators and for their bio-filtrating properties. 
Mytilaster lineatus (Gmelin, 1791)

Family Mytilidae

Similar to the Mediterranean mussel, this species overgrows hard substrata in the mediolittoral and the infralittoral zones, forming communities together with it [87].

\section{Donax trunculus (Linnaeus, 1758)}

\section{Common English name: Wedge-shell}

Family Donacidae

Donax trunculus is a clam species of the family Donacidae that lives in the coarse and medium sand along the coast, forming large colonies. It usually inhabits shallow seabed areas at a water depth down to $7 \mathrm{~m}$ [35]. The shells of Donax trunculus can vary greatly in color.

\section{Donacilla cornea (Poli, 1791)}

Common English name: Corneous wedgeclam

Family Mesodesmatidae

The corneous wedge clam Donacilla cornea is a fast burrowing bivalve, which lives in the midlittoral of exposed sandy beaches with medium to coarse sand and heavy wave action. It is enlisted in the Black Sea Red Data Book as endangered [86] Donacilla cornea is the dominant macrobenthic species of the midlittoral coarse sand biocoenosis throughout the Mediterranean Sea and the Black Sea, and is considered an indicator species of mediolittoral sandy habitats [94].

\section{Mytilus}

galloprovincialis and Mytilaster lineautus on wave-exposed mediolittoral rocks

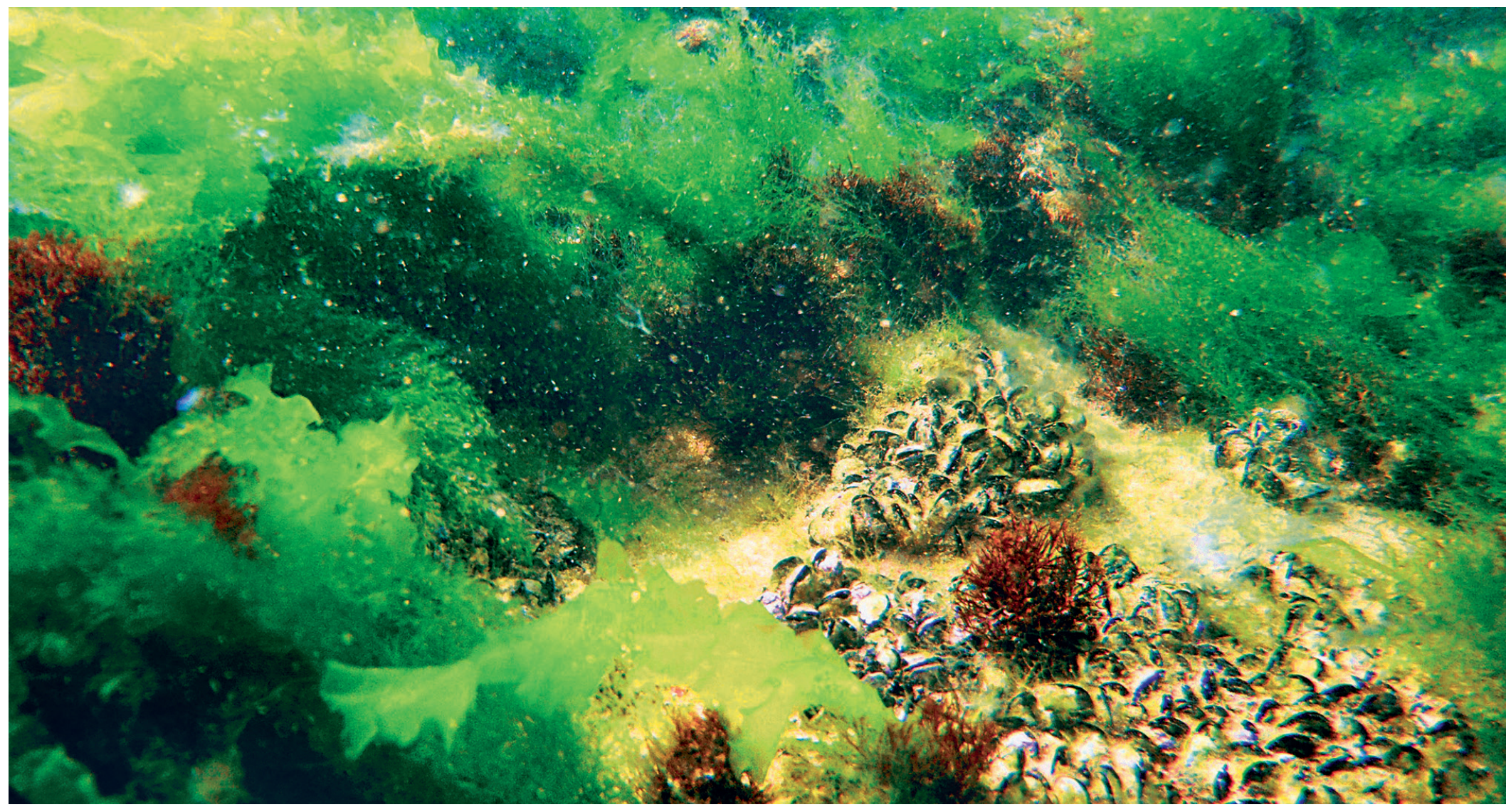


Chamelea gallina (Linnaeus, 1758)

Family Veneridae

Chamelea gallina inhabits clean and muddy sands at a depth of 3-30 m. It is a filter feeder, taking in a variety of microalgae, bacteria and small particles of detritus [87; 95].

\section{Petricola lithophaga (Retzius, 1788)}

\section{Common English name: Boring petricola}

Family Veneridae

The genus Petricola includes 24 species of bivalve mollusks, distributed mainly in the subtropical and tropical littoral zones. In the Black Sea, this genus is represented only by $P$. lithophaga (Retzius, 1788). It bores into hard, carbonate-rich rocks, e.g., limestones and calcareous sandstones [87]

\section{Pholas dactylus Linnaeus, 1758}

\section{Common English name: Common piddock}

Family Pholadidae

Unlike the boring petricola, the common piddock has a preference for soft rock varieties, e.g., marls, flysch, solid clays, etc. [87]

\section{Rapana venosa (Valenciennes, 1846)}

\section{Common English name: Veined rapa whelk}

Family Muricidae

Rapana venosa is an invasive species in the Black Sea, which exerts an unprecedented predatory pressure upon the natural stocks of mussels and clams. It occurs on soft- and hard-bottom substrates down to a depth of $40 \mathrm{~m}$. In particular, individuals congregate on hard surfaces such as bedrock outcrops and man-made structures in order to reproduce in the late spring and summer months [96]. The species is commercially exploited.

\section{Tritia reticulata (Linnaeus, 1758)}

\section{Common English name: Netted dog whelk}

Family Nassariidae

The netted dog whelk is a small European sea snail, a marine gastropod mollusk of the family Nassariidae. It is an important shell-providing species for the two hermit crabs found in the Black Sea [86]

Mass congregations of Rapana venosa

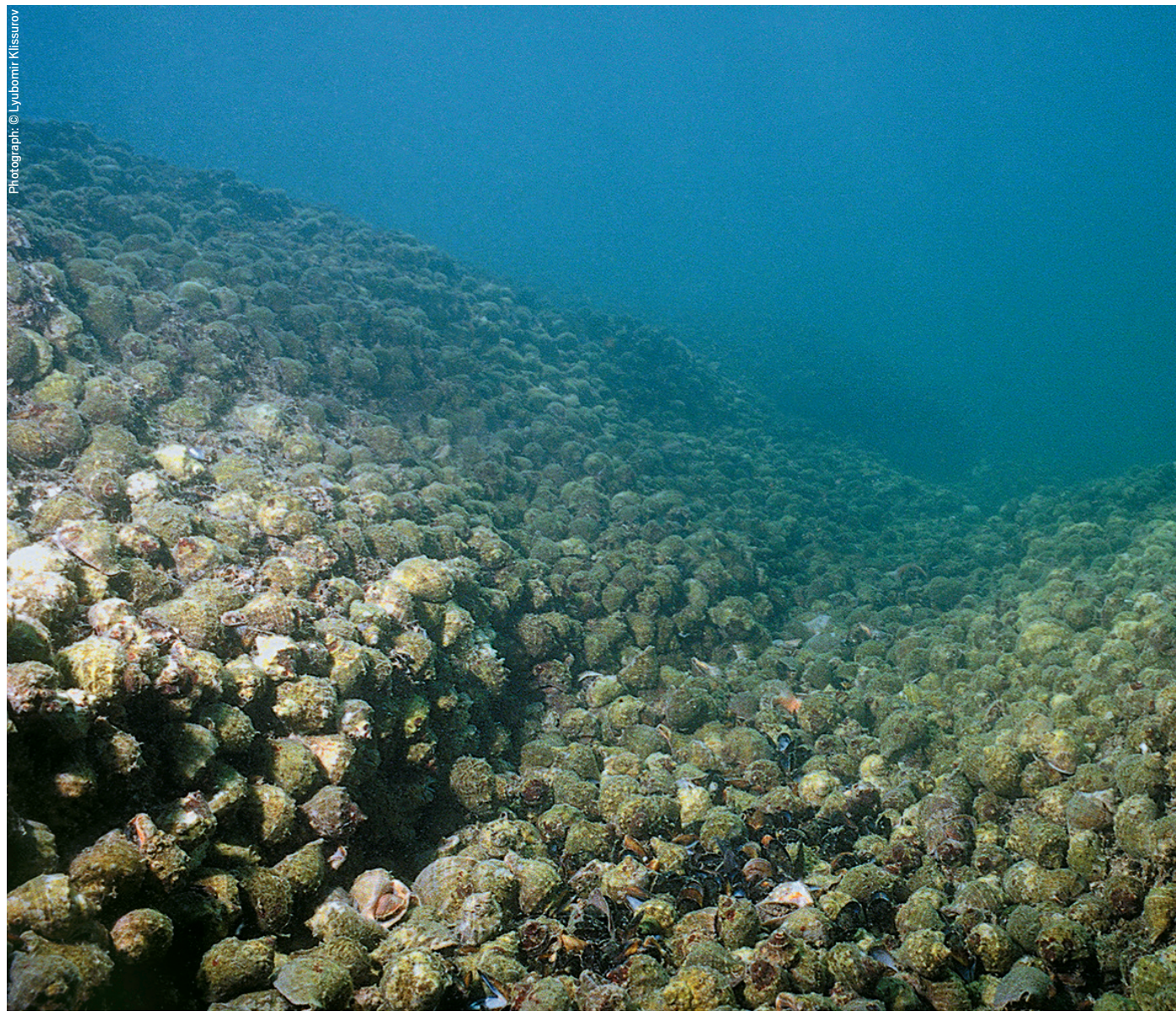


Cerithium vulgatum (Bruguière, 1792)

Family Cerithiidae

Cerithium vulgatum is a sea snail species belonging to the family Cerithiidae. It lives in all types of substrata including sandy mud and is often associated with the sea grass Zostera noltei where it feeds on its rhizomes. The snail's diet consists of diatoms and epibenthic microalgae. Similarly to Tritia reticulata, it too is a shell-providing species for the two hermit crabs found in the Black Sea [86].

\section{CRUSTACEANS (CRUSTACEA)}

\section{Liocarcinus navigator (Herbst, 1794)}

Common English name: Arch-fronted swimming crab

Family Portunidae

This crab is found on mixed sandy substrata, from the shallow sublittoral zone to the offshore seabed areas [99].

\section{Arch-fronted swimming crab (Liocarcinus navigator)}

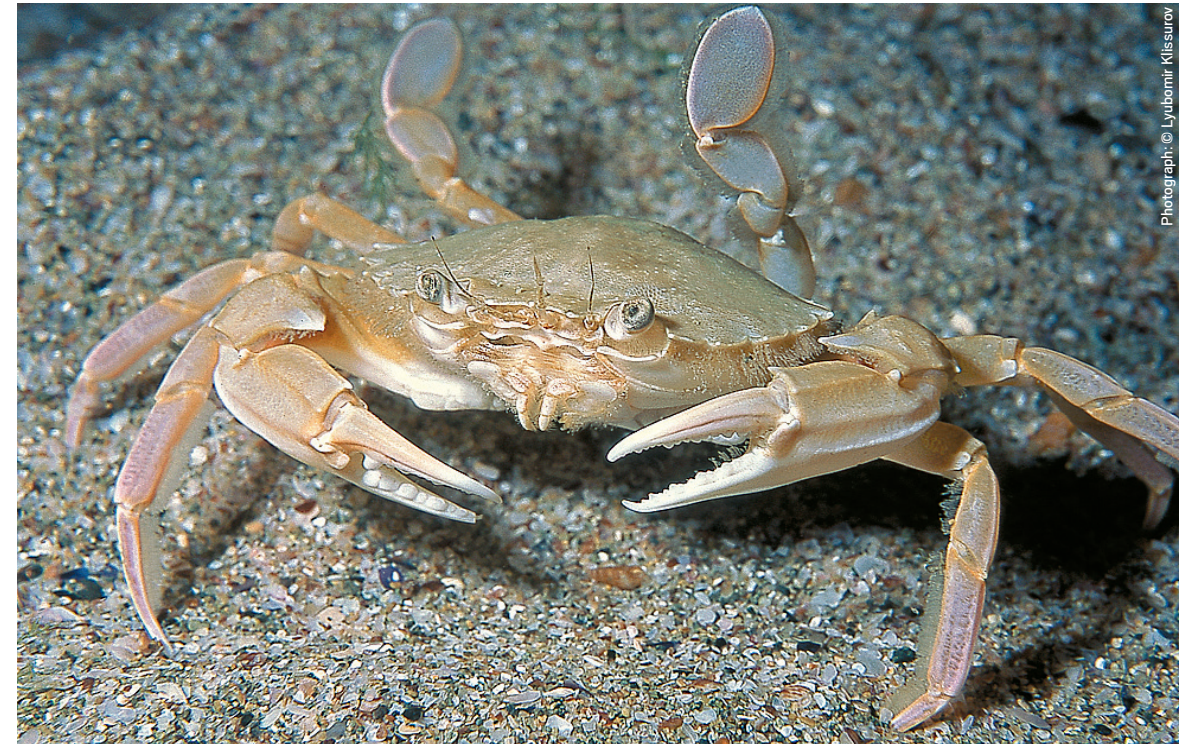

Necallianassa truncata (Giard \& Bonnier, 1890)

\section{Common English name: Calianassa burrowing shrimp}

Family Callianassidae

Necallianassa truncata is a widely spread shrimp species. It is found sometimes in very high densities from the surge zone down to at least the edge of the submarine coastal slope, and occurs in all types of environments from brackish to euryhaline to stenohaline [100]

Calianassa shrimp (Necallianassa truncata)

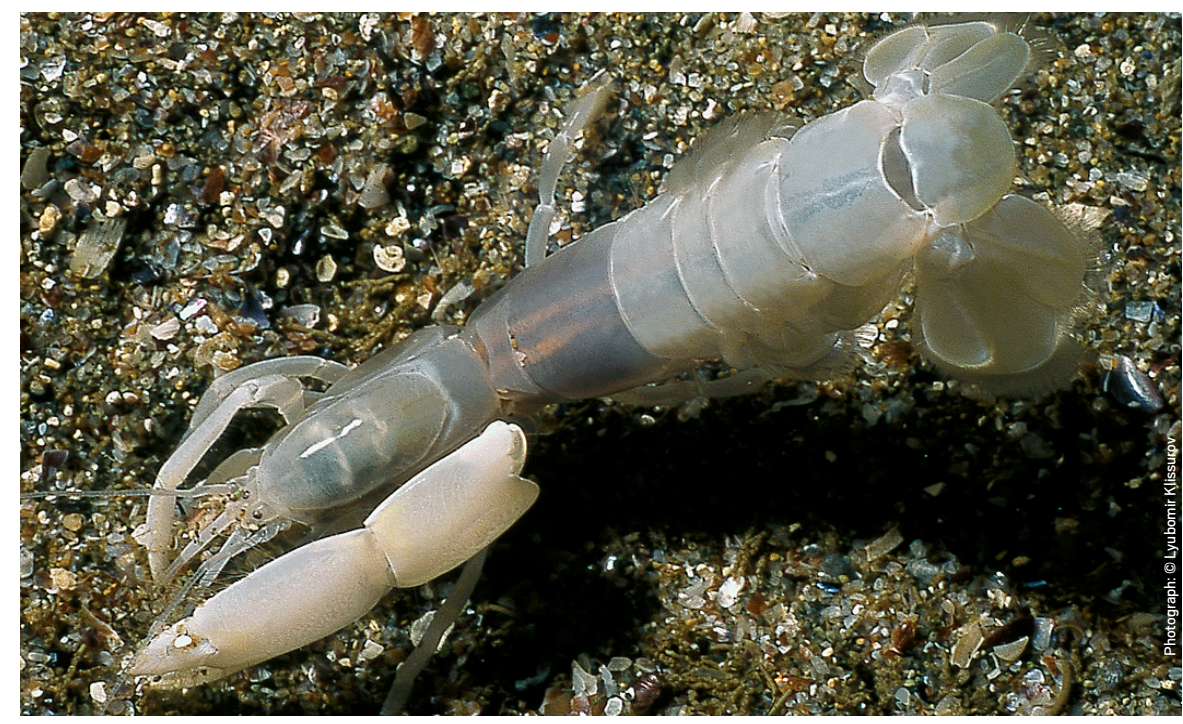

Carcinus aestuarii Nardo, 1847 (Carcinus mediterraneus Czerniavsky, 1884)

Common English name: Mediterranean (green) crab

Family Portunidae

It prefers shallow sublittoral areas, river mouths, firths and lagoons, where it is commonly observed in the subaqueous seagrass meadows. In the spring and summer it loses its exoskeleton and its body remains soft for a certain period of time until the new exoskeleton becomes hard. It is a euryterm and euryhaline species. The Mediterranean (green) crab is a carnivor that preys on small fish and shrimps. The species is enlisted in the Black Sea Red Data Book [86]. 


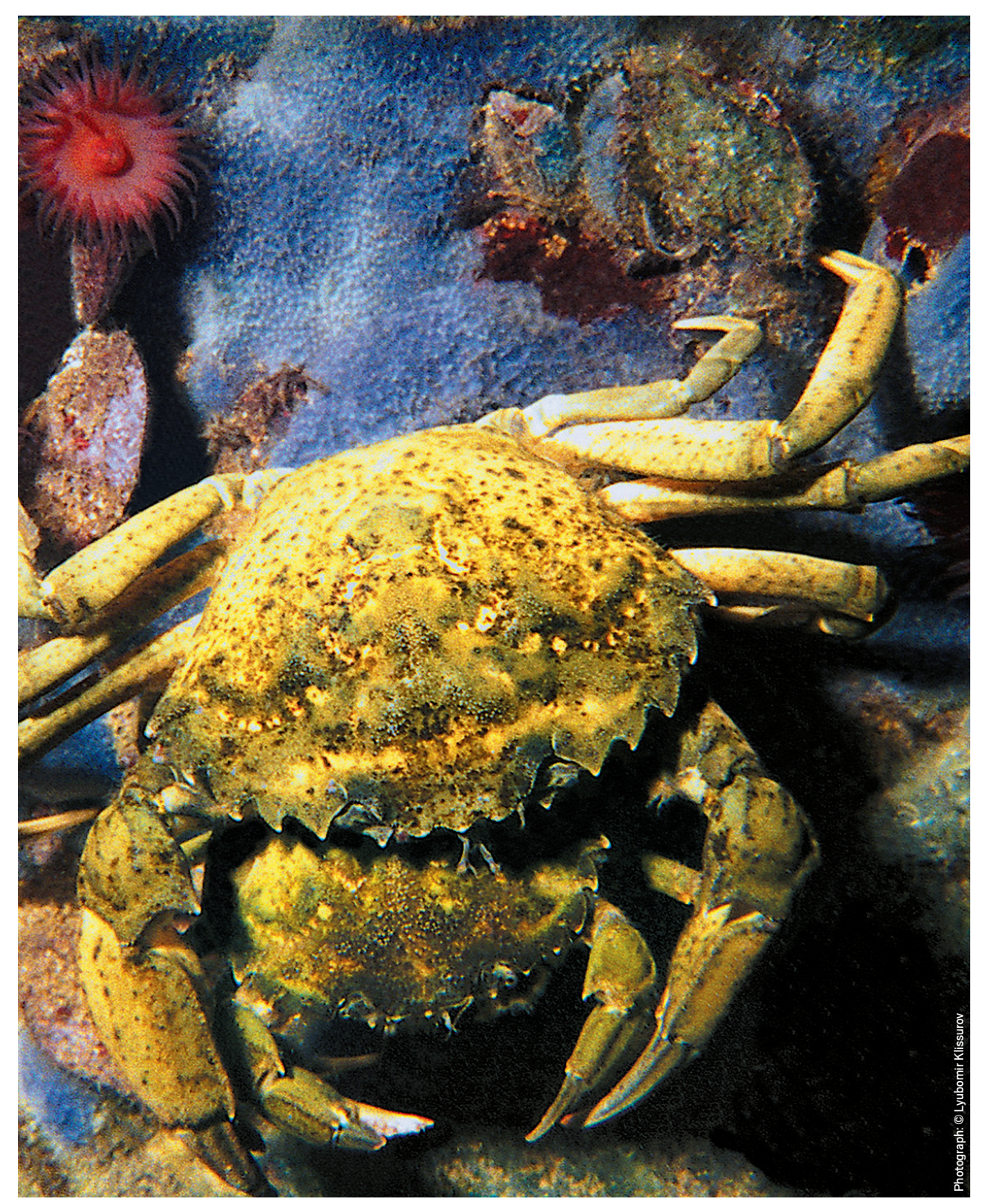

Mediterranean (green) crab (Carcinus aestuarii)

\section{Upogebia pusilla (Petagna, 1792)}

Common English name(s): Mediterranean/flat-browed mud shrimp

Family Upogebiidae

Upogebia pusilla inhabits most often the sandy-clayish and muddy bottoms, digging its holes there [86]. Occasionally after a heavy storm it is found cast on the shore. A specific feature of the Upogebia pusilla behavior is that it leaves the holes during the night in search of food. It is monosexual, with summer reproduction. Many benthic fish species feed on it including flounder, gobbies, etc. The species is enlisted in the Black Sea Red Data Book [86].

86 PHYSIOGRAPHIC AND OCEANOGRAPHIC CHARACTERISTICS OF THE STUDY AREA
Clibanarius erythropus (Latreille, 1818)

Common English name: Hermit crab

Family Diogenidae

Clibanarius erythropus is a hermit crab species that inhabits rock pools and sublittoral areas. It uses a variety of different gastropod shells. Like other hermit crabs, $C$. erythropus feeds on organic debris, decayed and fresh macroalgae with the associated fauna and epiphytic algal flora, small invertebrates, and microscopic pieces of dead and alive animal tissues [101].

\section{Diogenes pugilator (Roux, 1829)}

\section{Common English name: Small hermit crab}

Family Diogenidae

Hermit crabs are typical marine organisms, although some species have physiological and behavioral adaptations that enable them to live in various habitats (shallow biotopes including low salinity aquatic areas). Most of them are small decapod crustaceans that occupy empty gastropod shells for protection from predators and depend on them throughout their lifespan [102]. The species is enlisted in the Black Sea Red Data Book [86]

Hermit crab (Clibanarius erythropus)

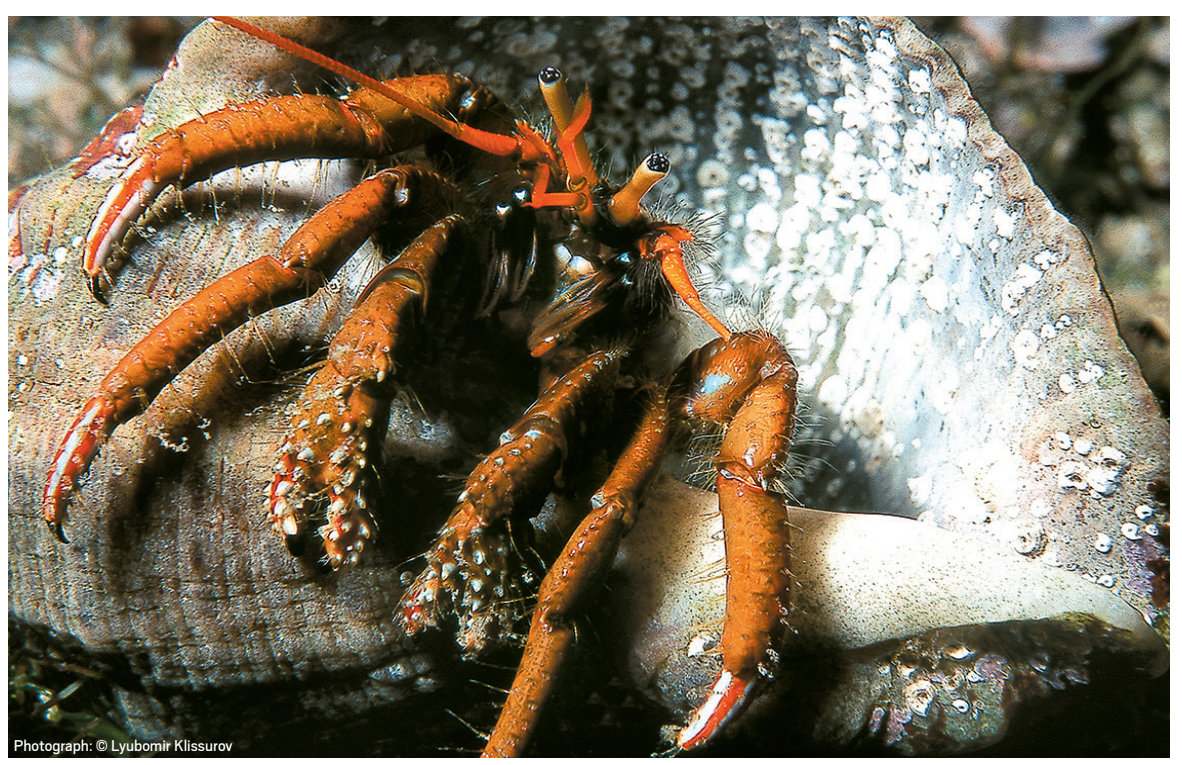




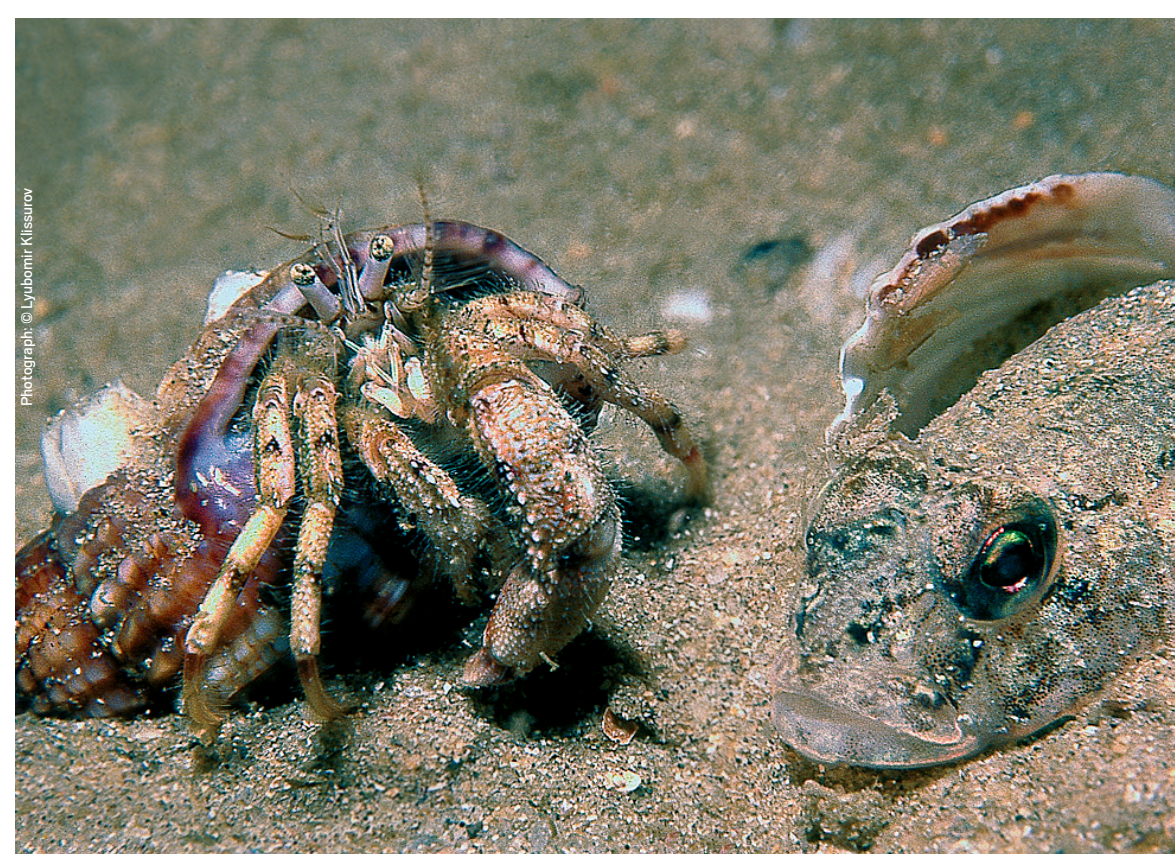

Small hermit crab (Diogenes pugilator)

Pilumnus hirtellus (Linnaeus, 1758)

Common English name: Hairy (Bristly) crab

Family Pilumnidae

Pilumnus hirtellus lives at depths of down to $80 \mathrm{~m}$, preferring ones that are shallower than $10 \mathrm{~m}$. It can be found on various substrates, including muddy, sandy and rocky bottoms, under stones and even among seaweeds. In the Black Sea, the species is common in rocky areas with abundant algae and mussels. Its diet consists mainly of carrion [103]. The species is enlisted in the Black Sea Red Data Book [86].

Hairy (Bristly) crab (Pilumnus hirtellus)

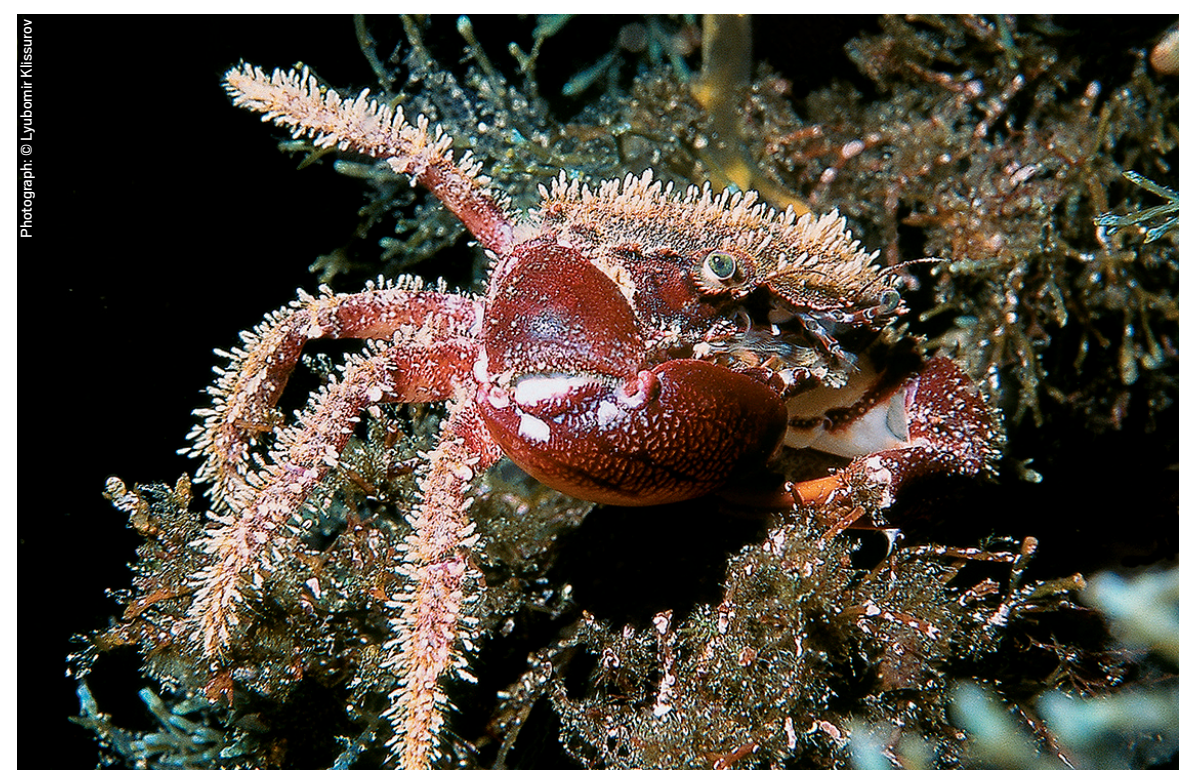

Eriphia verrucosa (Forskall, 1755)

Common English name: Warty (yellow) crab

Family Eriphiidae

Eriphia verrucosa lives among stones and seaweeds in shallow waters along rocky coastlines at water depths down to $15 \mathrm{~m}$. In the spring it migrates to much shallower seabed areas ( $0-1 \mathrm{~m}$ of depth). It feeds on mollusks and polychaetes. The species is extremely threatened by eutrophication and pollution in the Black Sea. It is enlisted in the Black Sea Red Data Book [86].

Warty (yellow) crab

(Eriphia verrucosa)

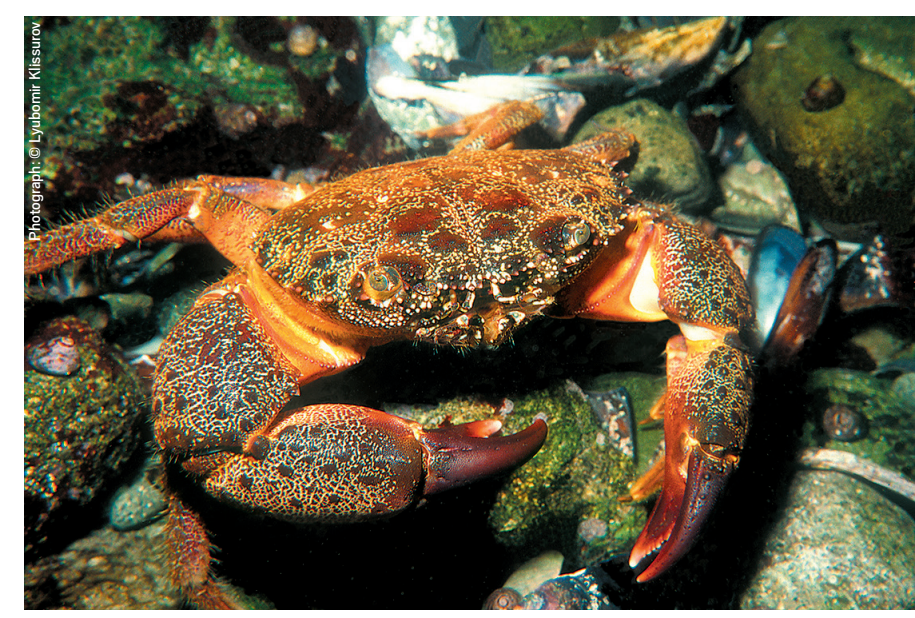

\section{FISH SPECIES (PISCES)}

\section{Trachurus mediterraneus ponticus Aleev, 1956}

Common English name: Black Sea horse mackerel

Family Carangidae

The Mediterranean horse mackerel (Trachurus mediterraneus) is a benthopelagic marine fish species in the family Carangidae [104; 105]. In the summer it feeds on different development stages of small fish (anchovy, sprat) and crustaceans such as Mysidacea [106]. Young horse mackerel feed on zooplankton [106; 107; 108]. The species is commercially exploited. 


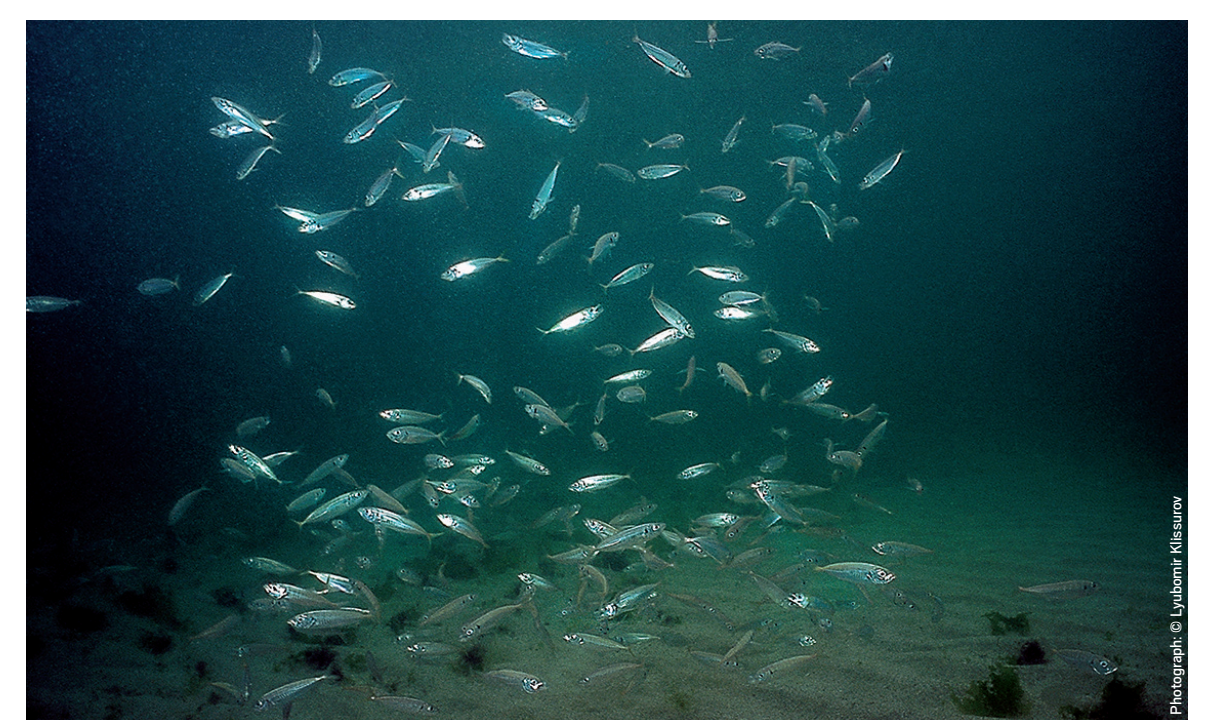

Black Sea horse mackerel (Trachurus mediterraneus ponticus)

Pomatomus saltatrix (Linnaeus, 1766)

Common English name: Bluefish

Family Pomatomidae

The bluefish (Pomatomus saltatrix) occurs in large bays and estuaries as well as across the entire continental shelf. Adult bluefish are strong and aggressive, and live in loose groups. They are cannibalistic and can prey their own young [109]. The species is commercially exploited.

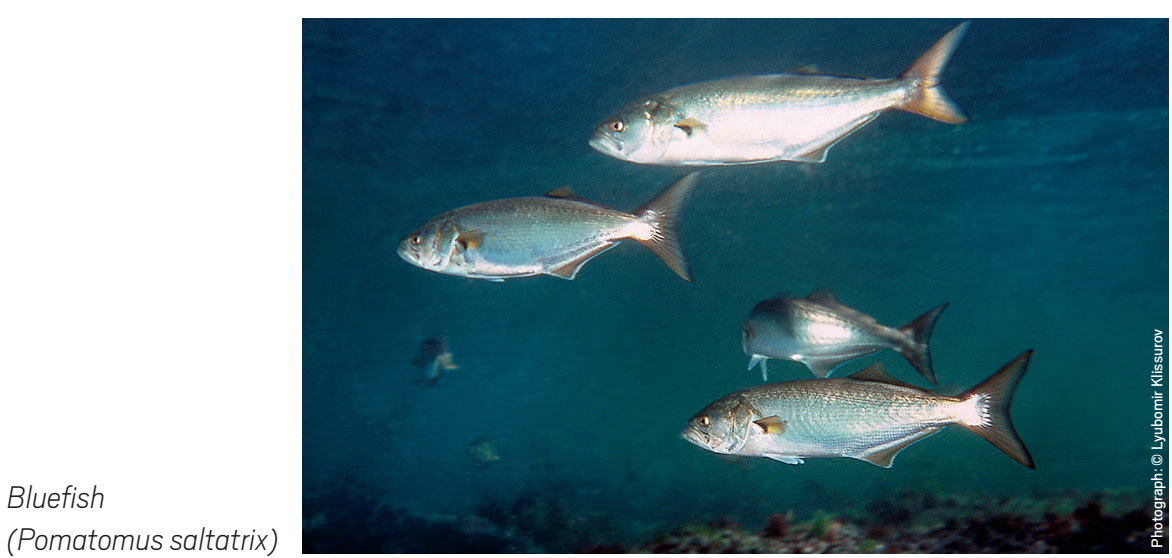

Dicentrarchus labrax (Linnaeus, 1758)

Common English name: European seabass

Family Moronidae

The European seabass inhabits coastal waters at a depth of 100 m (normally in the winter), as well as brackish waters in firth areas and coastal lagoons (in the summer). Young fish are gregarious, especially during the seasonal migrations, and form schools. Adults are less gregarious. The seabass is a voracious predator, feeding on crustaceans, mollusks and fish [109]. The species is commercially exploited.

European seabass (Dicentrarchus labrax)

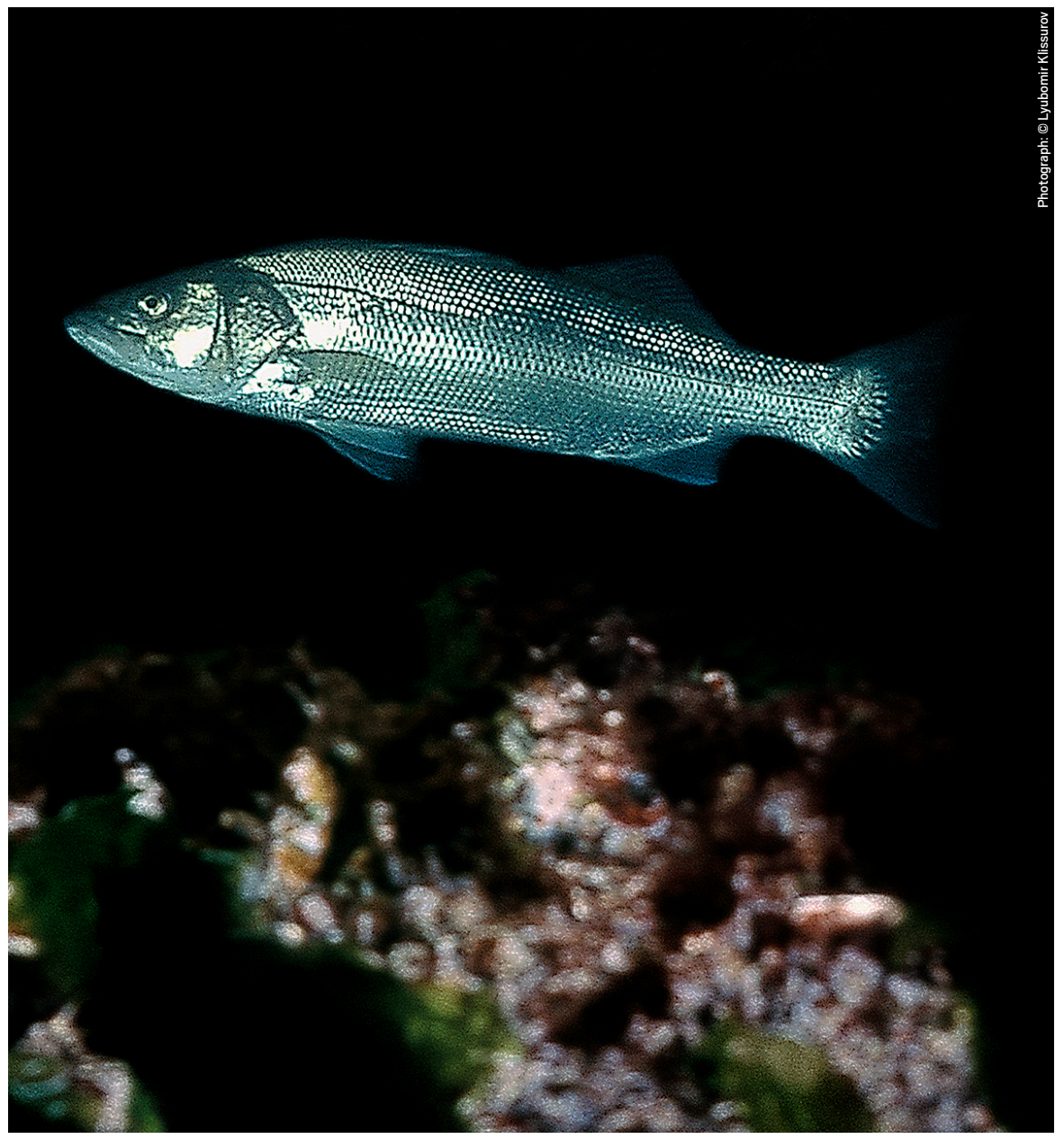


Mugil cephalus Linnaeus, 1758

Common English name: Flathead mullet

Family Mugilidae

The flathead mullet is a coastal species that often enters estuaries and rivers. It usually schools over sandy or silty bottoms, feeding on zooplankton, benthic organisms and detritus. Adults feed on algae in fresh water. Spawning apparently takes place in the open sea. The species is euryhaline, meaning that the fish can adapt to different levels of salinity [109].

Flathead mullets (Mugil cephalus)

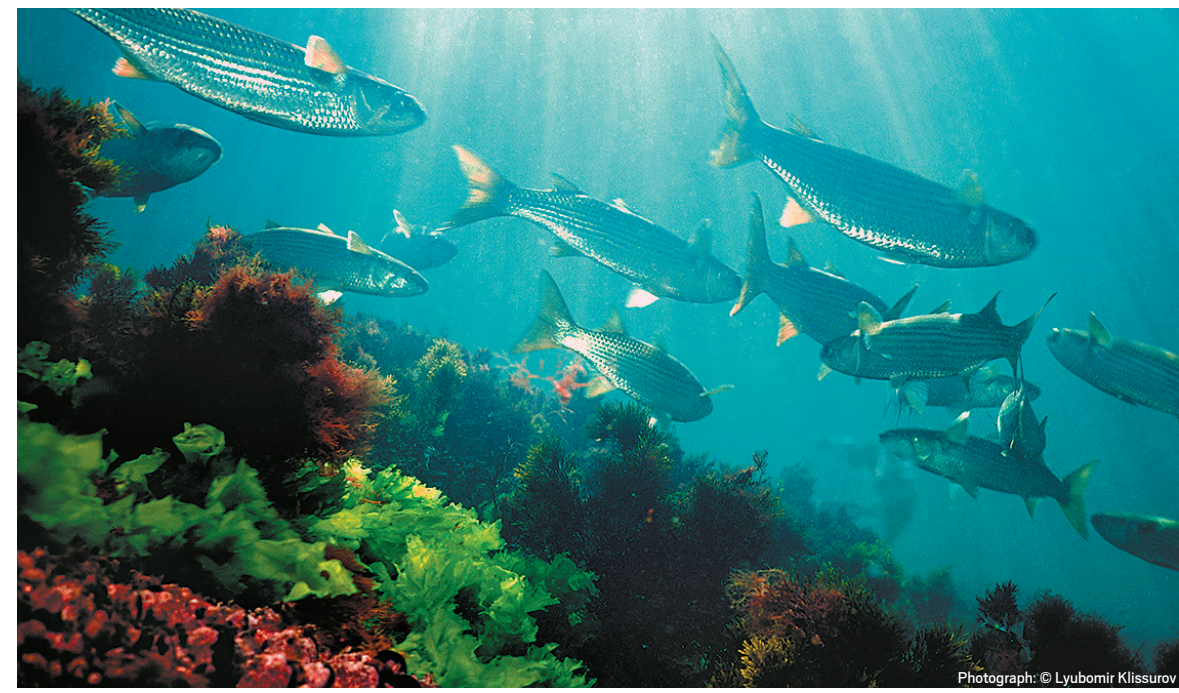

\section{Trachinus draco Linnaeus, 1758}

\section{Common English name: Greater weever}

Family Trachinidae

The greater weever commonly inhabits muddy, sandy or gravelly bottoms. It usually rests on the seabed, often with its eyes closed, exposing the tip of the first dorsal fin [109]. The species feeds at night, pelagically, preying on crustaceans, shrimps and crabs, as well as on smaller fish [107]. It is enlisted in the Black Sea Red Data Book [86].

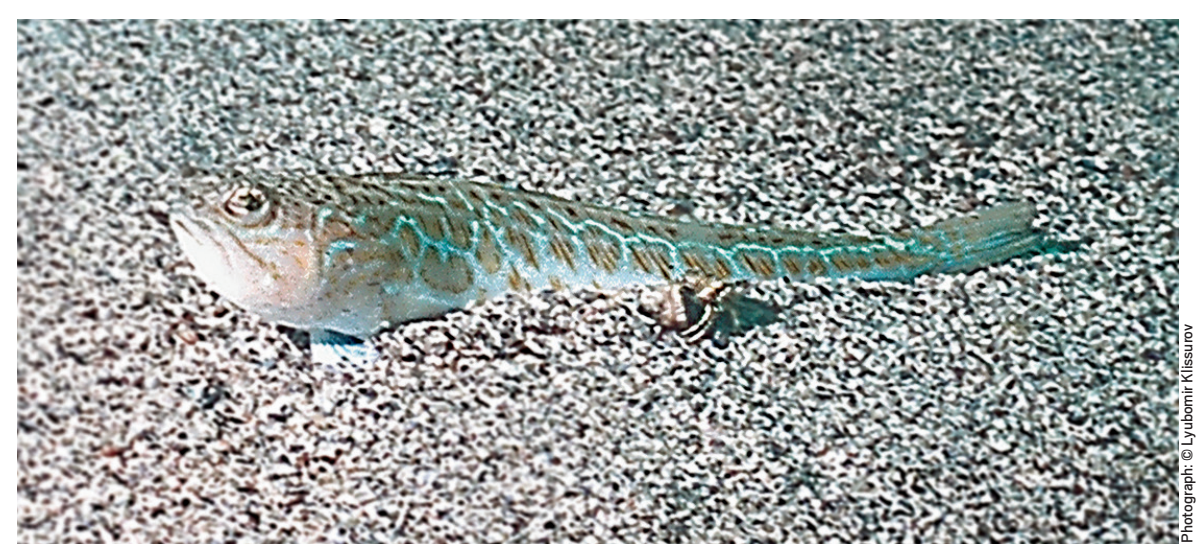

Greater weever (Trachinus draco)

\section{Syngnathus tenuirostris Rathke, 1837}

Common English name: Narrow-snouted pipefish

Family Syngnathidae

The species inhabits the infralittoral zone of the sea, hiding among macroalgae and sea grasses. Males carry the eggs in a brood pouch under their tails [110]. This species is herbivore. It is enlisted in the Black Sea Red Data Book [86]

Narrow-snouted pipefish (Syngnathus tenuirostris)

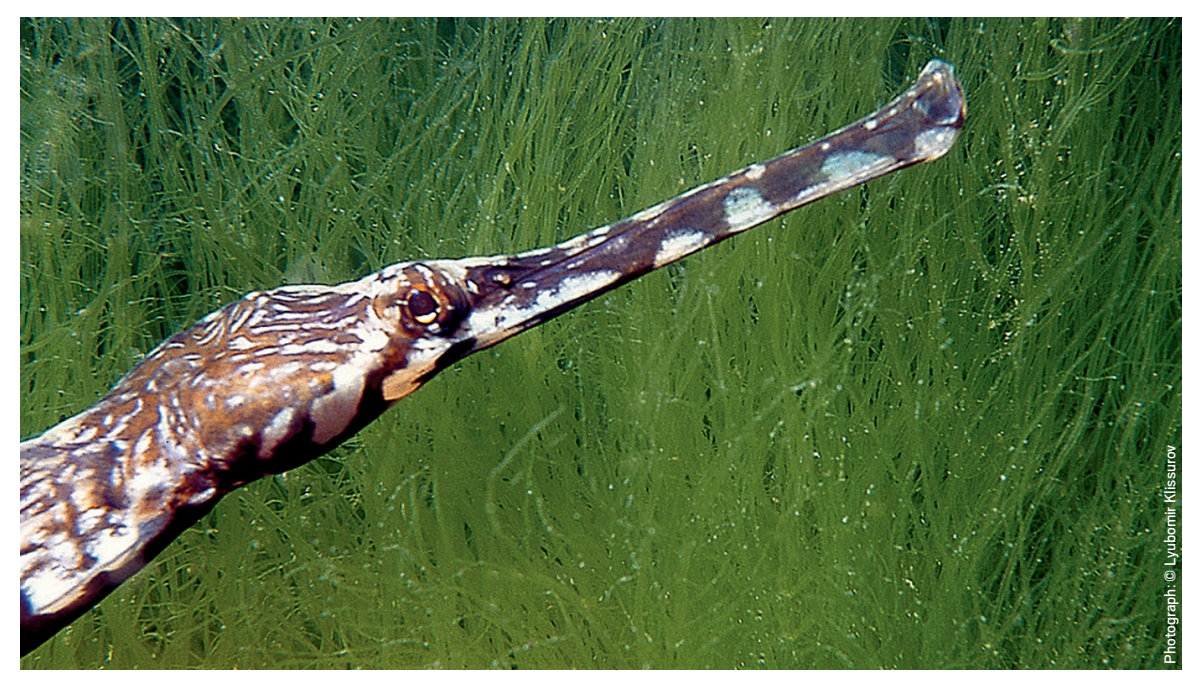


Belone belone euxini Günther, 1866

\section{Common English name: Garfish}

Family Belonidae

A coastal pelagic carnivore fish feeding mainly on anchovy and silverside. Young specimens are most common near the Cystoseira and Zostera beds. The garfish is enlisted in the Black Sea Red Data Book as endangered [86].

\section{Squalus acanthias Linnaeus, 1758}

\section{Common English name: Piked dogfish}

Family Squalidae

The piked dogfish (also commonly known in Bulgaria as spiny shark or simply Black Sea shark) is a predatory species that is abundant at places where it hunts and where the environmental conditions are favorable for both breeding and feeding. It tolerates brackish waters, hence it is often found in enclosed bays, river mouths and firths $[107 ; 109 ; 110]$. It is normally a bottom-dweller, but is also commonly observed in the mid-water column and at the surface water.The species is commercially exploited.

\section{Piked dogfish (Squalus acanthias)}

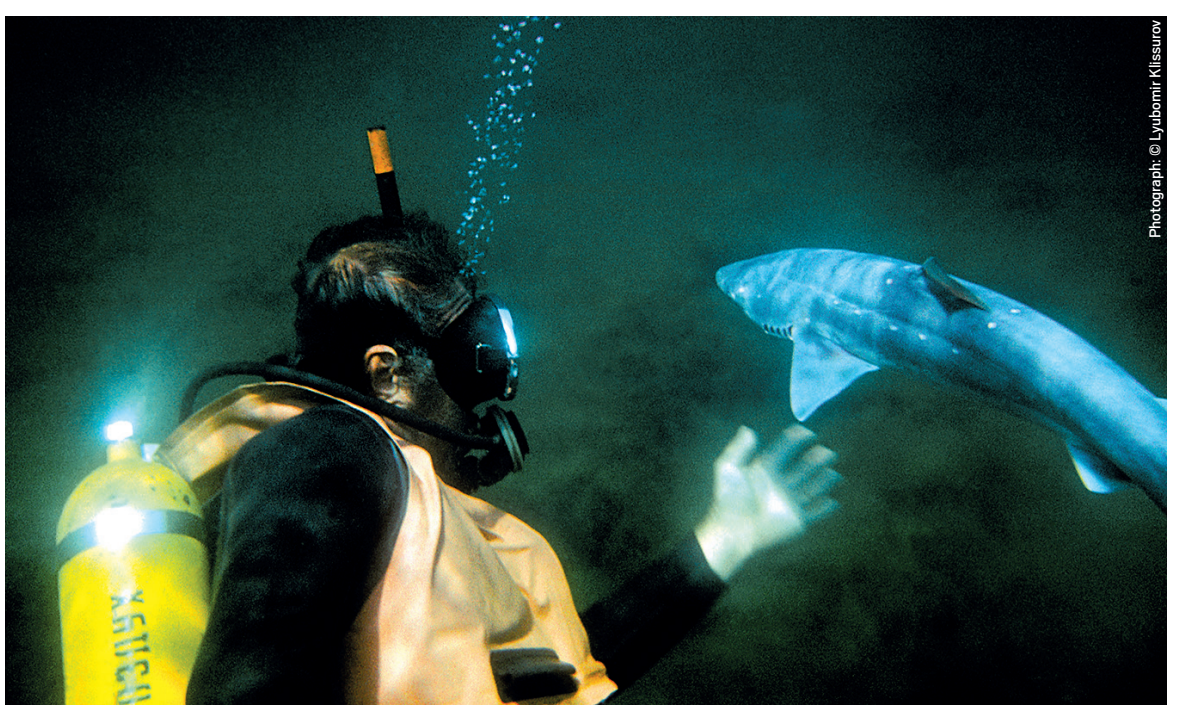

\section{Alosa immaculata Bennett, 1835}

Common English name: Black Sea shad

Family Clupeidae

The Black Sea shad is an anadromous fish. Alosa immaculata lives in the Black Sea and the Sea of Azov, and adults migrate upriver to spawn [107; 109; 110]. The larvae feed on worms and algae, and the adults feed on crustaceans and fish (sprat, anchovy, sand smelt). The species is subject to protection in compliance with the national Biological Diversity Act [111]. It is also enlisted in the Bulgarian Red Data Book as vulnerable [91]

\section{Alosa caspia (Eichwald, 1838)}

\section{Common English name: Caspian shad}

Family Clupeidae

The species inhabits the Black Sea, the Sea of Azov and the Caspian Sea, from where it enters rivers and coastal lakes to spawn. Its main habitats are the open sea and permanent rivers. It is also found in the shallow sea at depths of up to $10 \mathrm{~m}$, including inlets and bays. It feeds on insect larvae, crustaceans, worms, fish eggs and fish $[107 ; 109 ; 110]$. The species is subject to protection in compliance with the national Biological Diversity Act [111]. It is also enlisted in the Bulgarian Red Data Book as vulnerable [91]

\section{Sprattus sprattus (Linnaeus, 1758)}

\section{Common English name: European sprat}

Family Clupeidae

The European sprat (Sprattus sprattus) is one of the most abundant and commercially important pelagic fish species in the Black Sea, and important prey for larger fish. It is distributed over the entire Black Sea, yet is most abundant in the northwestern region and the shelf waters [107; 109; 110]. Throughout its life span it feeds on zooplankton. The basic species in its nutrition ration are the representatives of Copepoda: Calanus helgolauticus, Pseudocalanus elongatis and Acartia clausi. 


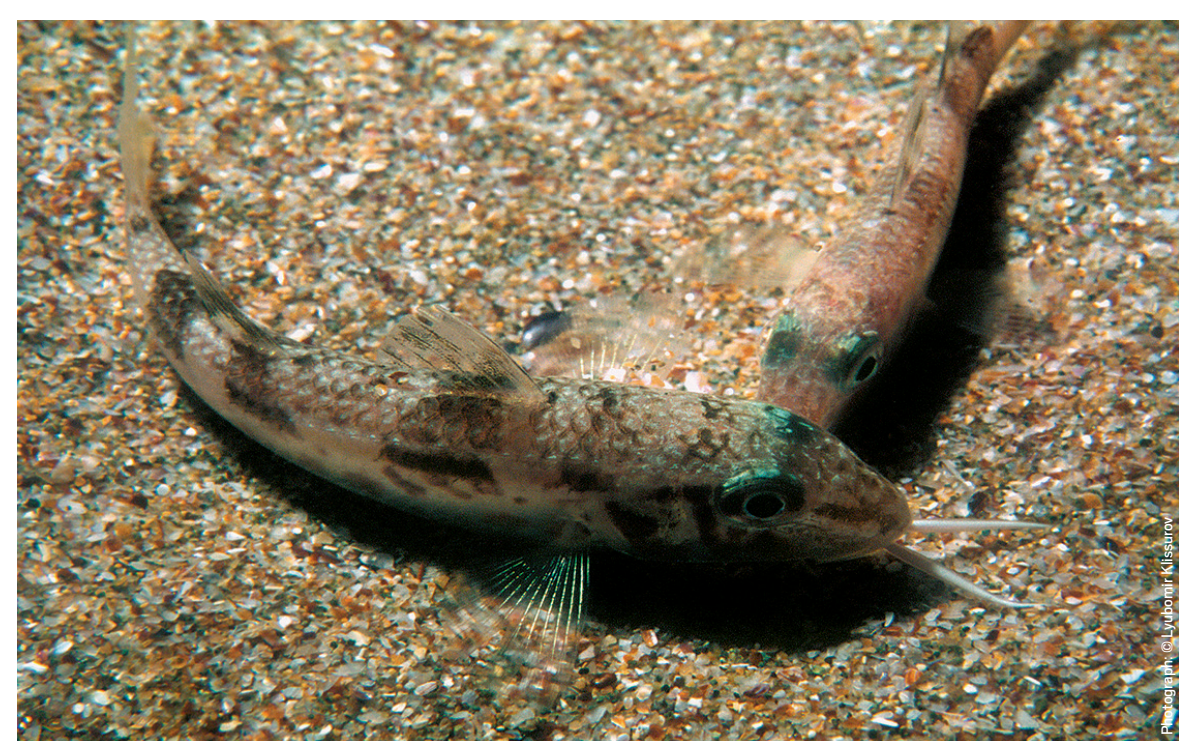

Red mullet (Mullus barbatus)

\section{Engraulis encrasicolus ponticus Alexandrov 192}

\section{Common English name: Black Sea anchovy}

Family Engraulidae

The anchovy is the most abundant pelagic fish of the Black Sea and a major fishing target. It is generally a coastal marine species forming large schools. Spawning peaks are usually in the warmer months which makes it a summer spawner. It predominantly feeds on planktonic organisms [107; 109; 110].

\section{Merlangius merlangus (Linnaeus, 1758)}

\section{Common English name: Whiting}

Family Gadidae

The whiting is a marine benthopelagic species, usually observed in coastal waters on muddy and gravelly bottoms, but also on sand and rock. The whiting is one of the most abundant species of demersal fish in the Black Sea. It feeds on shrimps, crabs mollusks, small fish, and polychaetes. The species is the main predator of the Black Sea sprat [107; 109; 110]

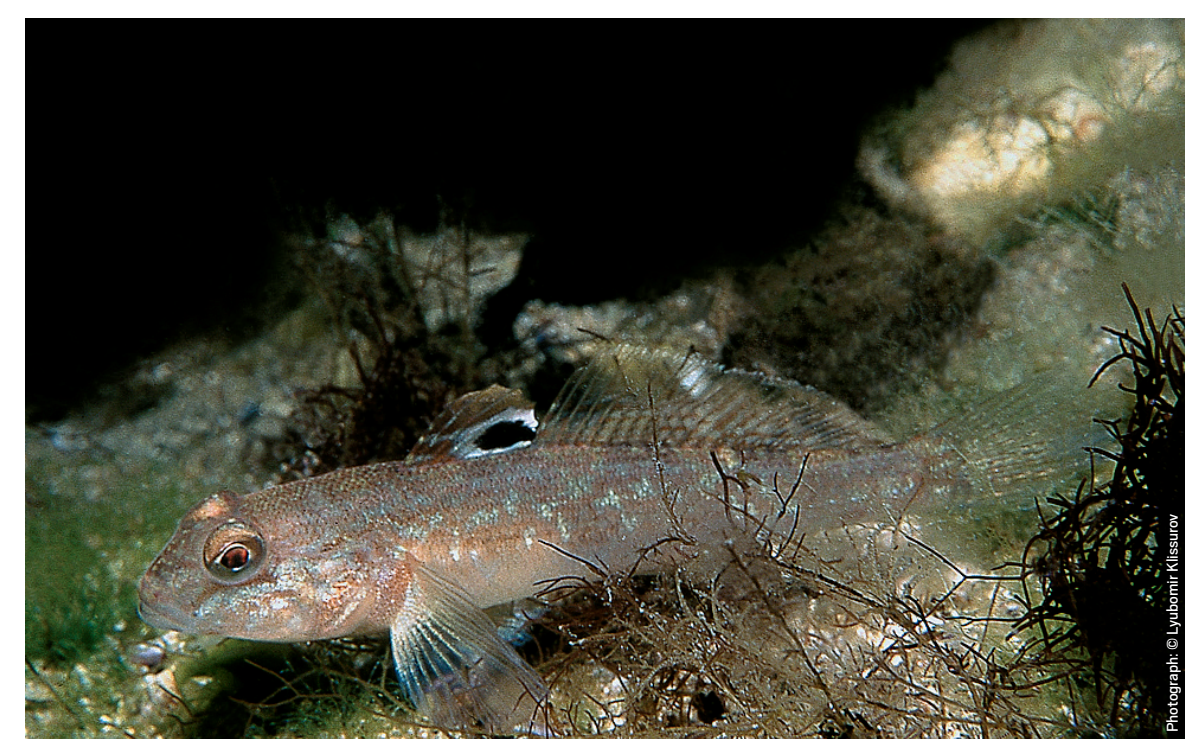

Round goby (Neogobius melanostomus)

Mullus barbatus (Linnaeus, 1758)

Common English name: Red mullet

Family Mullidae

A bottom fish species that usually inhabits shallow sands and muddy bottoms, but may occur at depths between 60 and $80 \mathrm{~m}$. It feeds predominantly on small bottom-living invertebrates (crabs, worms, etc.), but also on zooplankton, fish larvae and vegetal debris [107; 109; 110]. It is a typical gregarious fish. The species is enlisted in the Black Sea Red Data Book as endangered [86].

\section{Neogobius melanostomus (Pallas, 1814)}

\section{Common English name: Round goby}

Family Gobiidae

The round goby is a bottom-dwelling, euryhaline, very adaptable species. It prefers mediolittoral and sublittoral areas with few stones and shells and a sandy bottom. It occurs at depths of up to $20 \mathrm{~m}$ (50-60 $\mathrm{m}$ in the winter). It also inhabits the lower and middle sections of the permanent Black Sea tributaries as well as coastal lakes 
where it successfully survives and breeds. Males guard the eggs until they hatch, a process that usually takes 2-3 weeks. They usually die after the spawning season The species feeds on a wide variety of invertebrates and small fish [107; 109; 110].

\section{Scorpaena porcus Linnaeus, 1758}

Common English name: Scorpionfish

Family Scorpaenidae

The scorpionfish is a benthic species normally found resting among seaweeds and on rocks. It is usually solitary and feeds on small fish such as blennies and gobies, crustaceans and other bottom-dwelling invertebrates [107; 109; 110]. The species is enlisted in the Black Sea Red Data Book [86].

Scorpionfish (Scorpaena porcus)

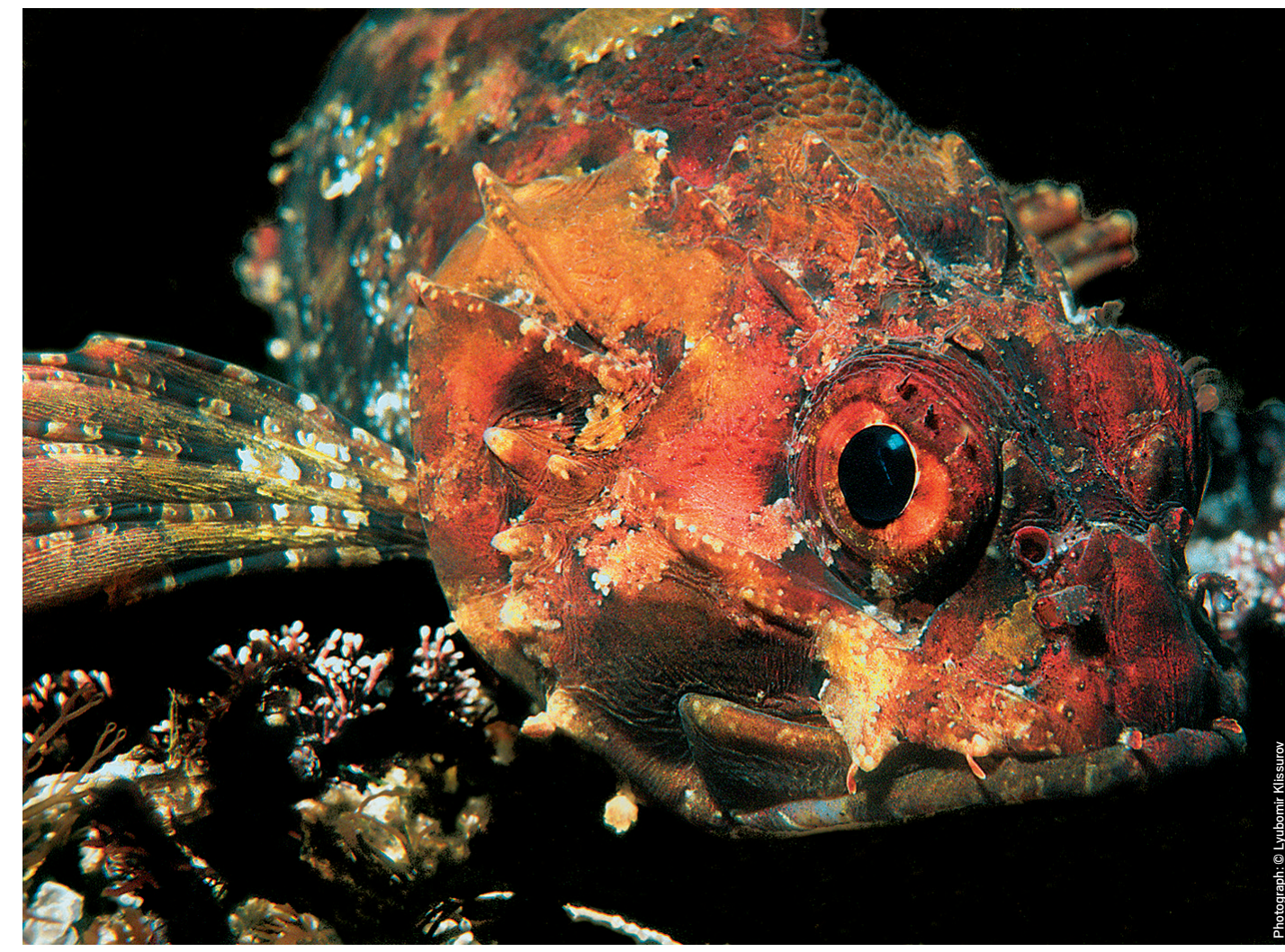

92 PHYSIOGRAPHIC AND OCEANOGRAPHIC CHARACTERISTICS OF THE STUDY AREA

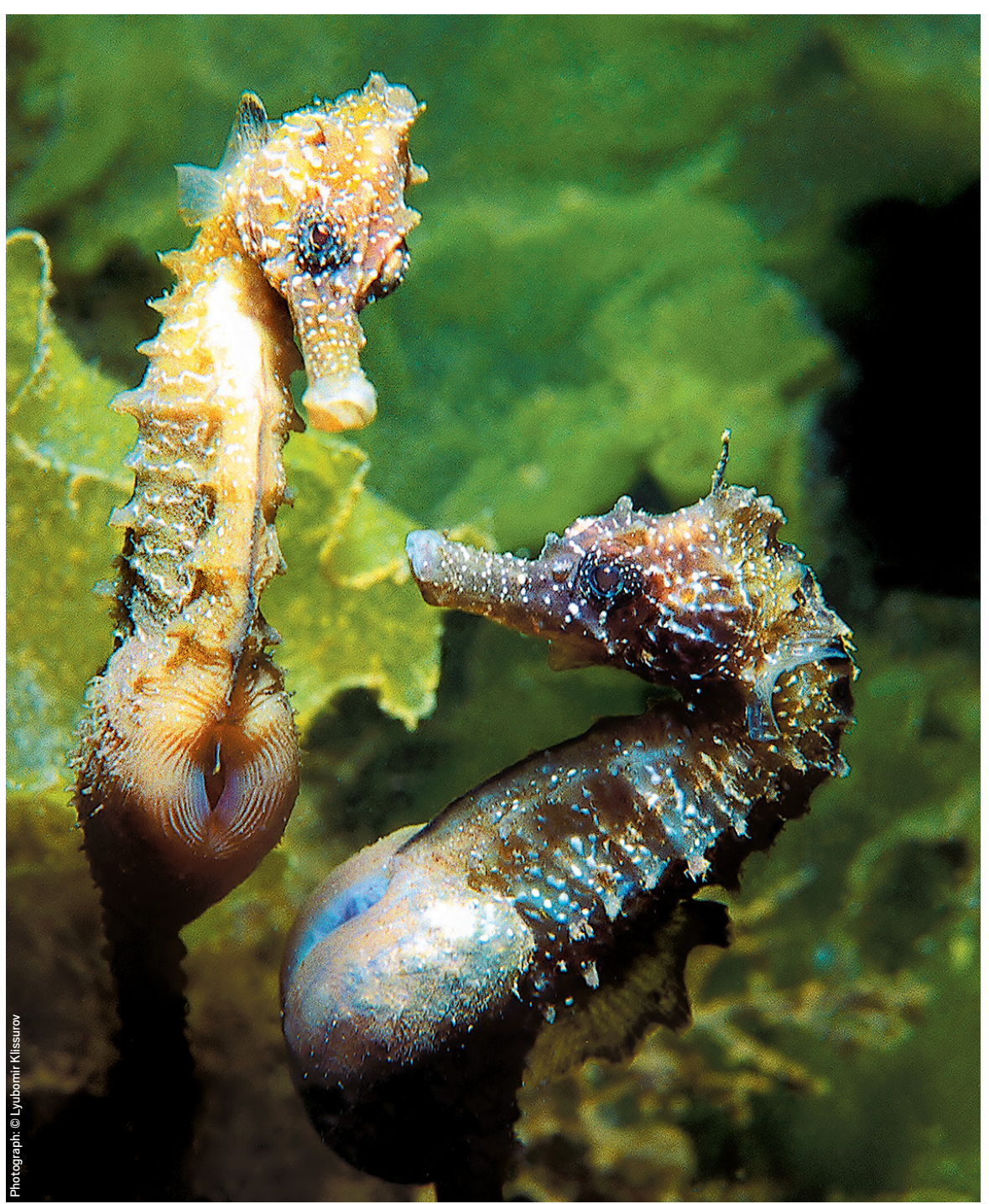

Sea horses (Hippocampus hippocampus)

Hippocampus hippocampus (Linnaeus, 1758)

Common English name: Sea horse

Family Syngnathidae

The sea horse likes shallow coastal waters from 1 to 20 m deep. It is largely present at the subaqueous seagrass beds, or in mixed habitats with sandy bottoms, rocks and algae. The sea horse has a carnivorous diet and feeds on small crustaceans, larvae, fish eggs and other planktonic organisms [107; 109; 110]. The males carry the fertilized eggs in specialized pouches of their bodies. The eggs hatch in these pouches, and the young are expelled through a longitudinal slit in the frontal part of the pouch. The species is enlisted in the Black Sea Red Data Book as endangered [86]. 
Parablennius (Blennius) zvonimiri (Kolombatovic, 1892)

Common English name: Red blenny

Family Blenniidae

Parablennius zvonimiri is a shallow-water species, endemic to the Mediterranean Sea and the Black Sea, where it is abundant. An oviparous species. The female deposits the eggs inside an empty mussel and the male tends the clutch [107; 109; 110].

Aidablennius (Blennius) sphynx (Valenciennes, 1836)

Common English name: Sphinx blenny

Family Blenniidae

The Sphinx blenny (Aidablennius sphynx) is a species of the combtooth blenny, and the only species in genus Aidablennius. Sphinx blennies inhabit shallow, rocky areas in the littoral zone, exposed to sunlight. They feed primarily on benthic algae and invertebrates. The males guard the eggs laid in burrows [107; 109; 110]. The species is enlisted in the Black Sea Red Data Book [86]

Red blenny (Parablennius/Blennius zvonimiri)

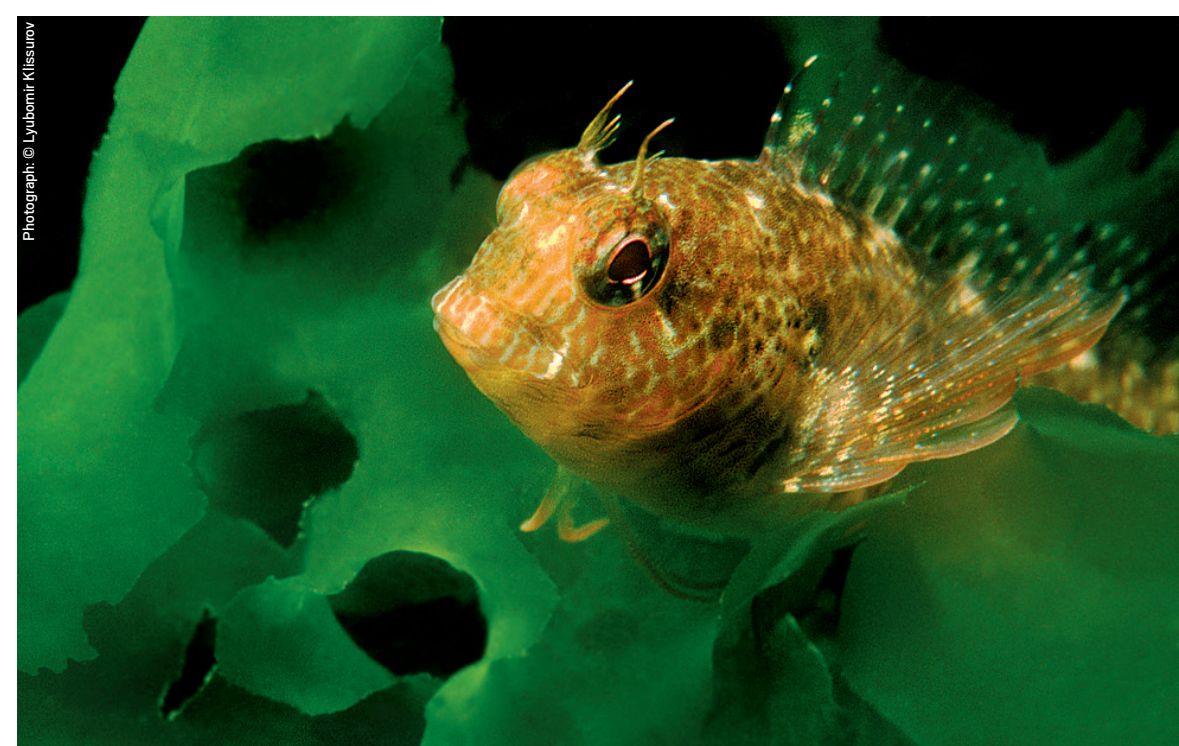

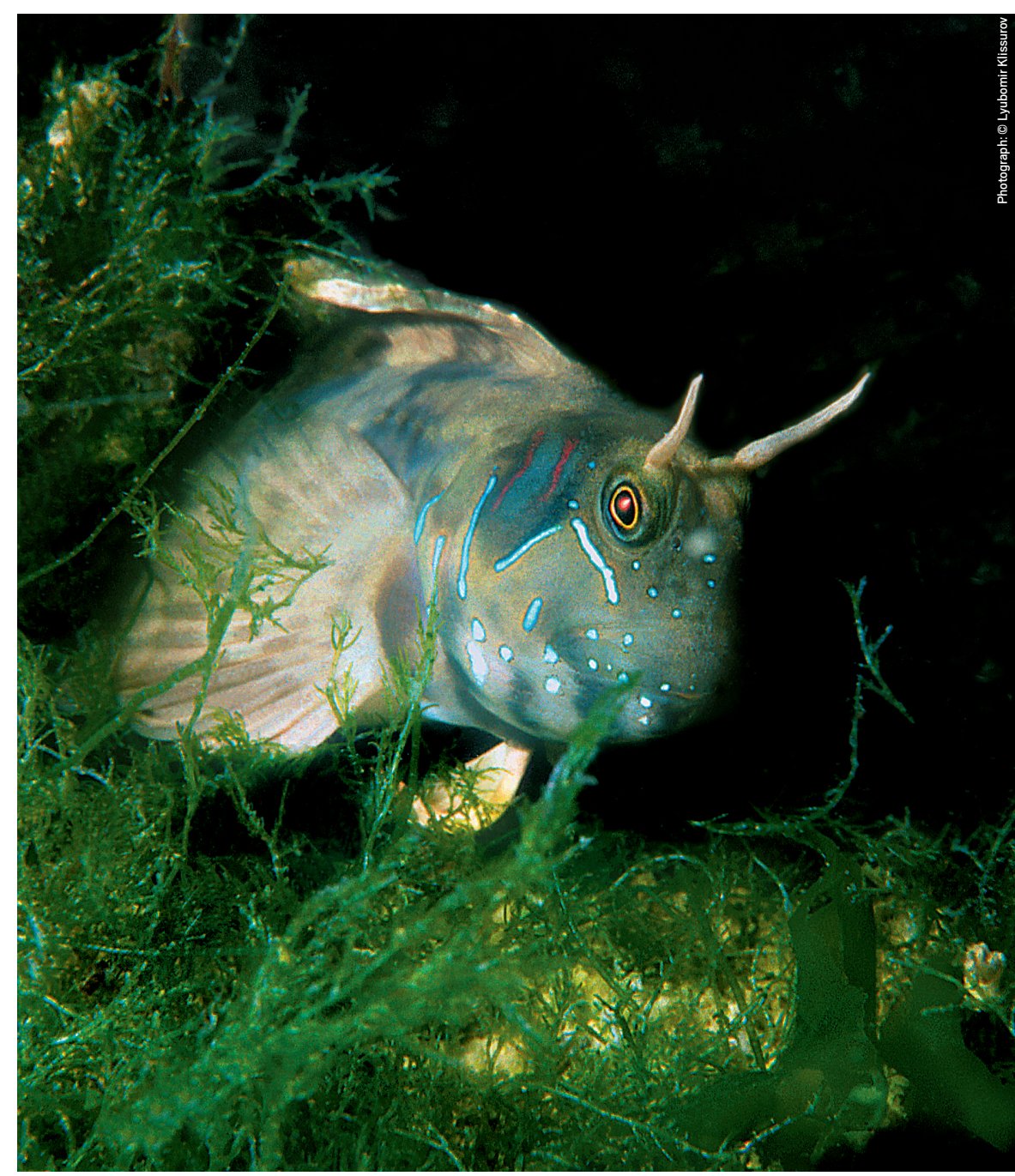

Sphinx blenny (Aidablennius/Blennius sphynx)

Parablennius tentacularis (Brünnich, 1768)

Common English name: Tentacled blenny

Family Blenniidae

Adults occur over sandy bottoms with overgrown boulders. They hide in crevices where the nests are guarded by the males. The species is oviparous [107; 109; 110]. 


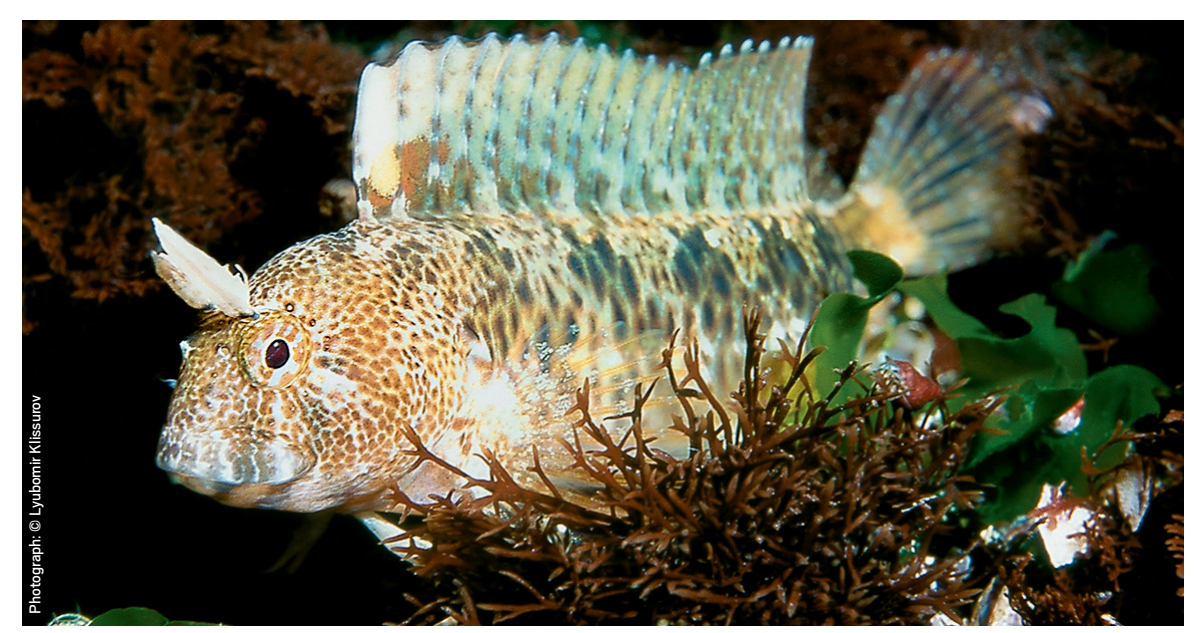

Tentacled blenny (Parablennius tentacularis)

Raja clavata Linnaeus, 1758

Common English name: Thornback ray

Family Rajidae

The thornback ray (Raja clavata) is a benthic species of the family Rajidae. The thornback ray is usually found on accumulative seabed sectors with mud, sand or gravel at depths between 10 and $60 \mathrm{~m}$. Juvenile fish feed on small crustaceans, particularly amphipods and bottom-dwelling shrimps, while adults feed on crabs, shrimps and small fish [107; 109; 110].

\section{Psetta maxima (Pallas, 1814)}

\section{Common English name: Turbot}

Family Scophthalmidae

The turbot is a typical marine demersal species, commonly found on sandy, rocky or mixed bottoms. In the winter, adults are observed at depths of 70-100 m, while in the spring (March - April) they migrate to shallower areas (at depths of $18-30 \mathrm{~m}$ ) in order to mate. After spawning, adults separate and retreat again towards deeper seabed sectors $[107 ; 109 ; 110]$. The species is commercially exploited, despite being enlisted in the Bulgarian Red Data Book as endangered [91].

94 PHYSIOGRAPHIC AND OCEANOGRAPHIC CHARACTERISTICS OF THE STUDY AREA

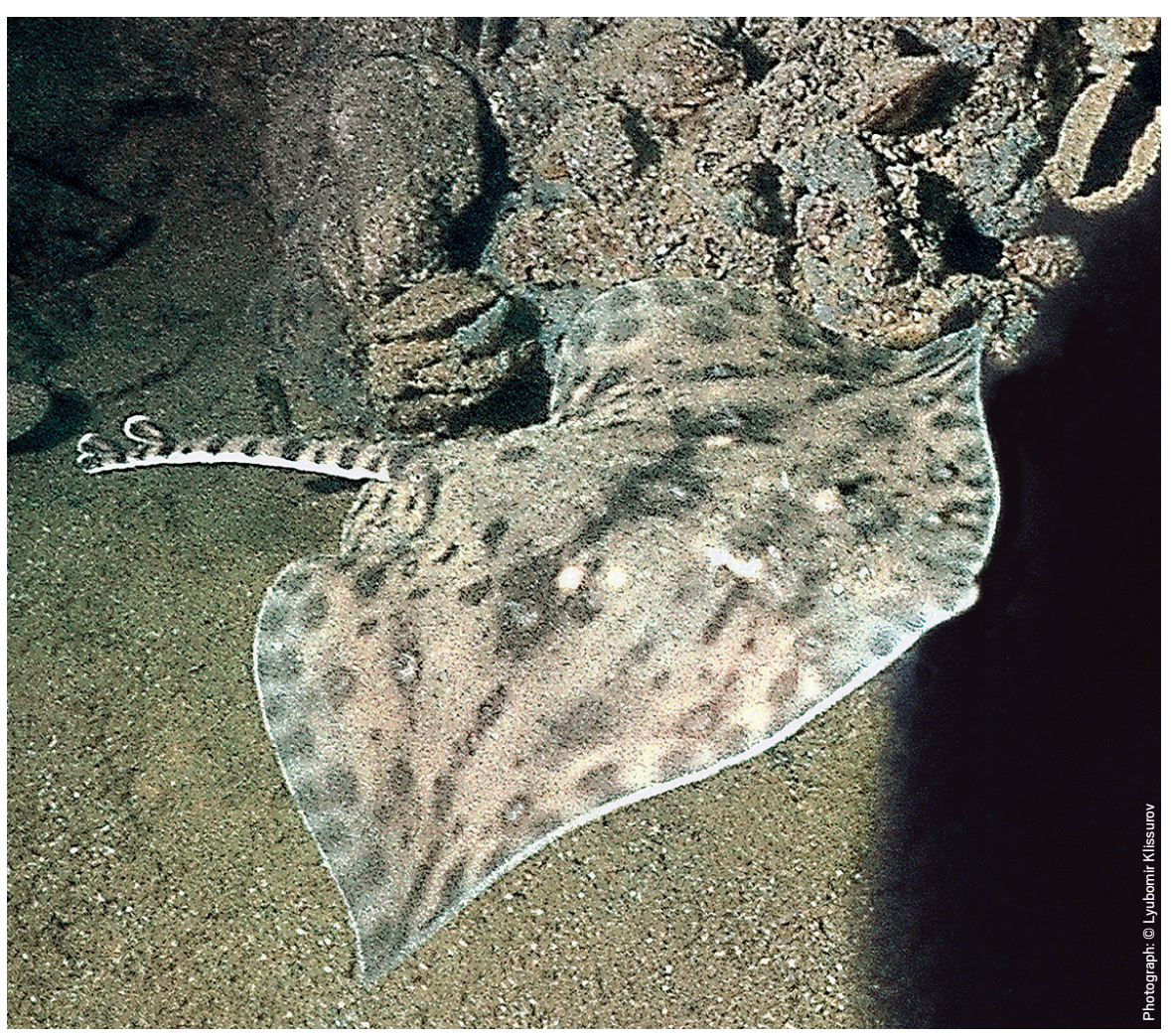

Thornback ray (Raja clavata)

Turbot (Psetta maxima)

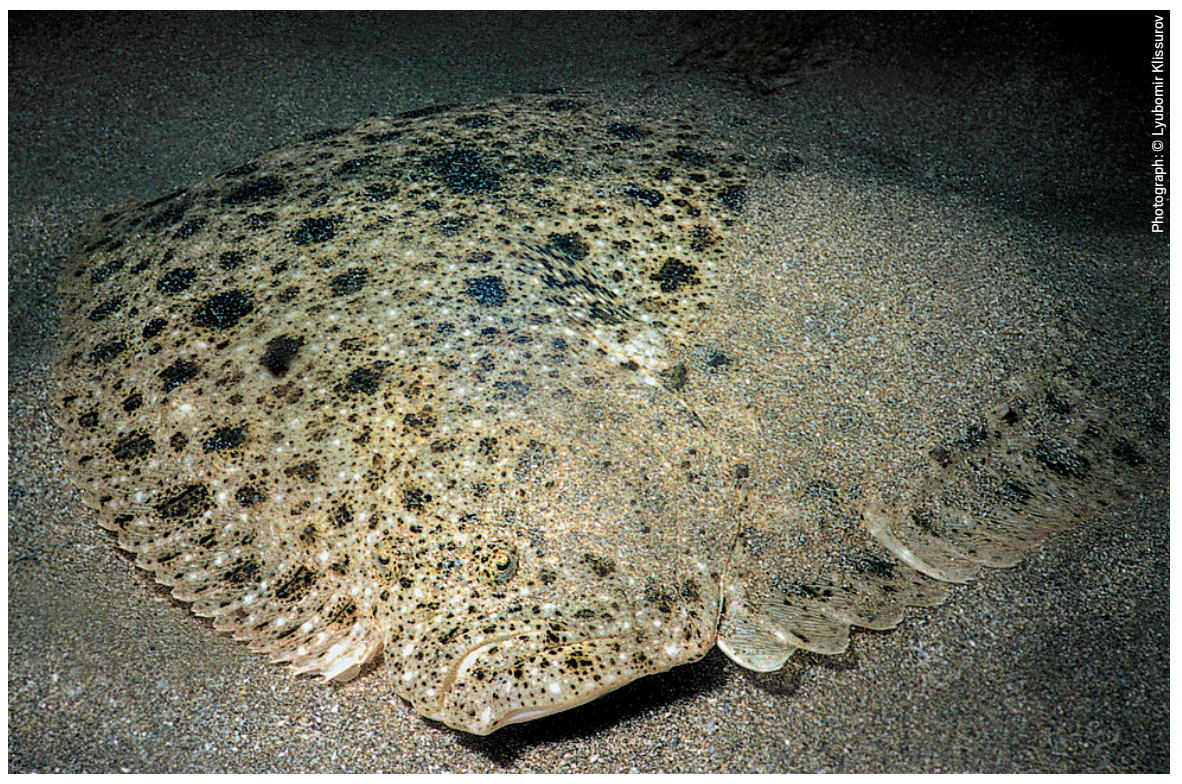


Three cetacean species are found in the Black Sea. Two of them are representatives of the family Delphinidae, namely the common dolphin (Delphinus delphis ponticus Linnaeus, 1758) and the bottlenose dolphin (Tursiops truncatus Montagu, 1821). The third species, the harbor porpoise (Phocoena phocoena Linnaeus, 1758), belongs to the family Phocenidae. All three species are subject to protection in compliance with several international conventions as well as in accordance with the national Biological Diversity Act [111]. In addition, the bottlenose dolphin and the harbor porpoise are both enlisted in the Bulgarian Red Data Book as vulnerable [91].

The three Cetacean species of the Black Sed:

7. Common dolphins (Delphinus delphis ponticus)

2. Bottlenose dolphin (Tursiops truncatus)

3. Harbor porpoises (Phocoena phocoena)
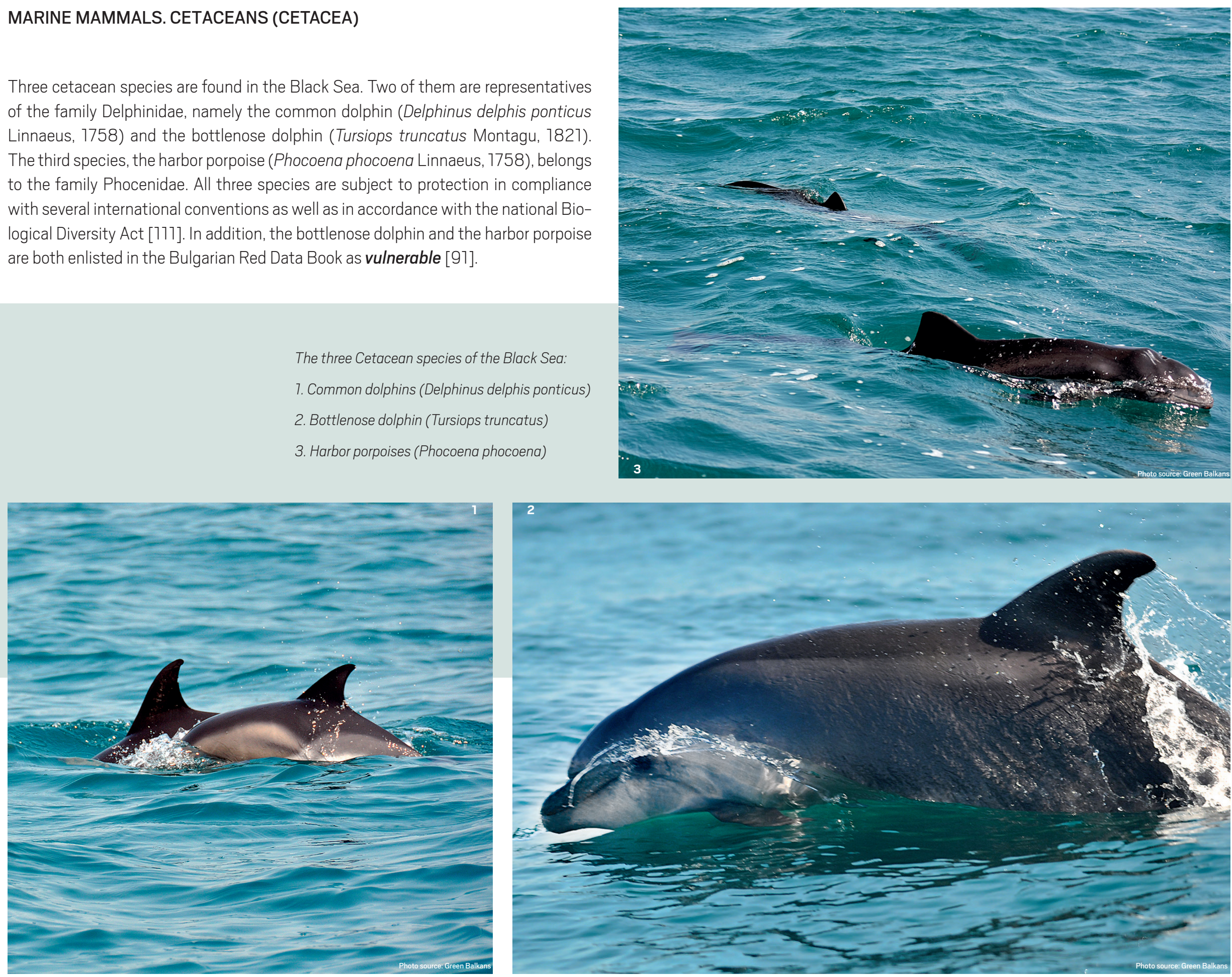


\section{LANDSCAPE DIVERSITY}

\subsection{COASTAL LANDSCAPES}

Bulgaria's Black Sea coast was first differentiated as a separate physiographic unit as early as 1934 [112]. A detailed investigation of its spatio-temporal landscape pattern was carried out by Mishev and Daneva (1979) [2]. Nevertheless, the region remains poorly studied from a landscape perspective [49].

The Black Sea district [49] demonstrates significant differences with the rest of the country when discussing coastal landscape structure and hierarchy (landscape types, genera and kinds). Depending on the marine basin's climate influence, the individual sectors of the Black Sea landscape district have different spatial extents from barely $10 \mathrm{~km}$ inland in Strandzha and the East Balkan Mountains to 40-60 km inland along the Kamchia River Valley, the Varna-Beloslav Lake Complex, the Burgas Lowland, etc.

The coast's morphological features combined with the attenuating influence of the Mediterranean-like climate (from south to north) are the leading factors for the extremely complex landscape pattern of the coast. The cited complexity is additionally augmented by an array of azonal actors, the most prominent of these being the presence of karst topography, local specifics of the moisture regime, contemporary coastal geo- and morphodynamics, etc. [56]. Of substantial scientific interest are the hydromorphic and subhydromorphic landscape complexes developed within the coastal saline, brackish and freshwater wetlands which hold some of the most valuable ecosystems and habitats on the Bulgarian Black Sea coast [113]. Of commensurable nature conservation importance are the relic broad-leaved forest landscapes in the East Balkan Mountains and Strandzha Mountain which belong to the Southeuxinian Floristic Province [82], as well as the coastal dune landscapes [114; 115; 116; 117]. Also, some of the most dynamic geocomplexes in Bulgaria exist along the Bulgarian coast, namely those developed at the landslide sectors or at the natural sand strips.

The environmental issues of the Bulgarian Black Sea coast are substantial. Geo-ecological hotspots include mining sites and Lukoil's oil refinery area at the Burgas Lowland, Rosenets oil tanking terminal near Burgas [e.g., 49; 57; 118, etc.], the Varna-Beloslav Lake Complex west of Varna, etc. [48]. In addition, significant physical damages of the natural landscape pattern and improper levels of anthropogenic pressure are registered near the large coastal resorts and settlements with recreational functions, e.g., The White Lagoon, Albena, Golden Sands, Riviera, Chayka and Varna city (North Bulgarian coast), Sunny Beach, the towns of Nesebar, Pomorie, Sozopol, Primorsko, Tsarevo (South Bulgarian coast), etc. [e.g., 49; 57; 119; 120, etc.]

Some of the most common landscape varieties on the Bulgarian Black Sea coast:

1. Denudation-plateau landscape with steppe vegetation (Dobrudzha coast)

2. Erosive-cliff landscape with hygrophilous vegetation and wild figs (Dobrudzha coast)

3. Lowland-accumulative landscape with longoz forest communities

(the Batova River downstream next to Albena Resort)

4. Landscape with sub-longoze vegetation (Avren Plateau coastal zone)

5. Erosive-denudation landscape with a pseudomaquis community (Avren Plateau coastal zone)

6. Erosive-valley landscape with Turkish oak- and oriental hornbeam-dominated forest (coastal area of the East Balkan Mountains)

7. Accumulative-beach landscape with psammophytic vegetation (Albena-Kranevo sand strip)

8. Accumulative-foredune landscape with psammophytic vegetation (Kamchia-Shkorpilovtsi sand strip)

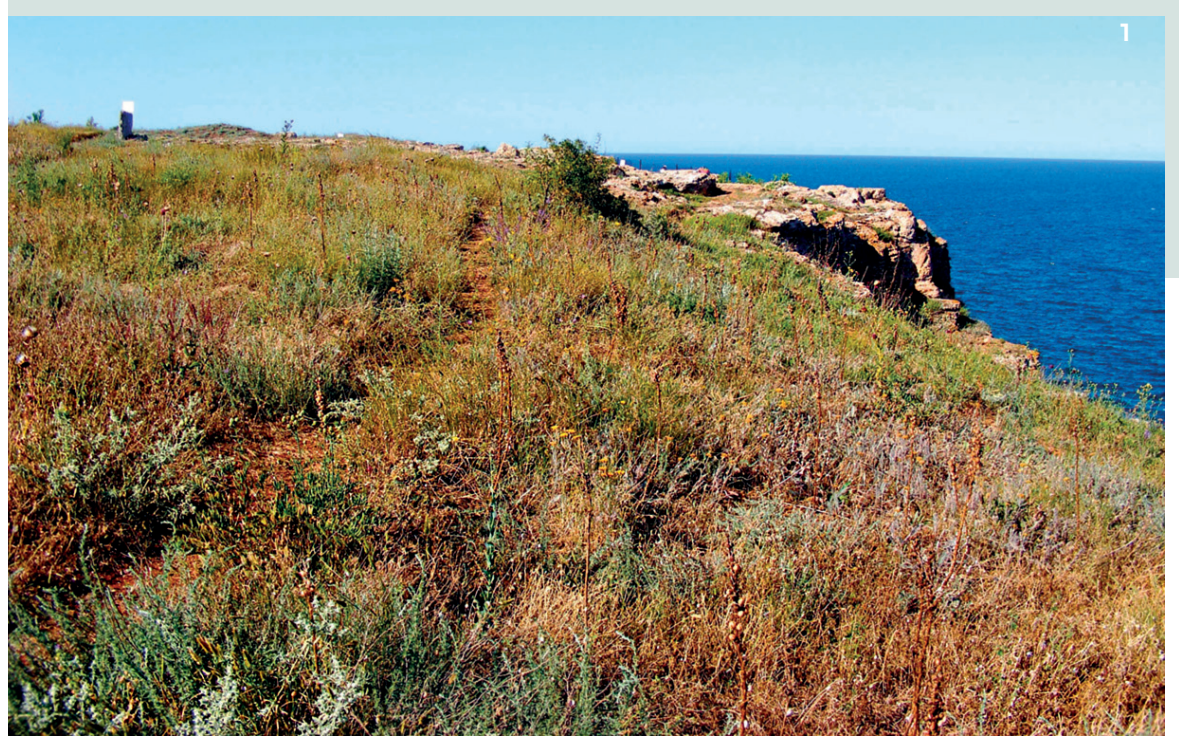

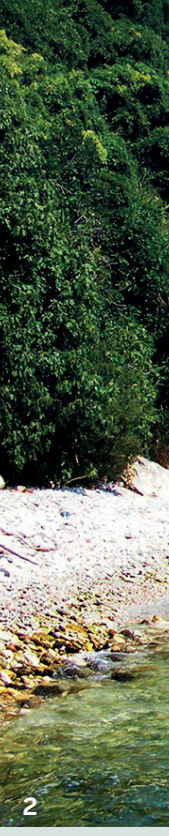

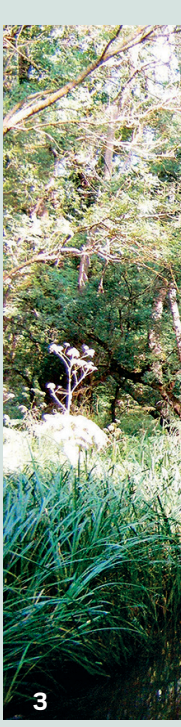

(1)

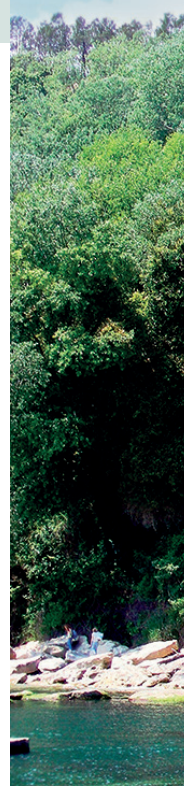




\subsection{SUBMARINE LANDSCAPES (SEASCAPES)}

At basin scale, the Bulgarian Black Sea sector remains the most poorly studied one in terms of landscape properties. This is an inconvenient fact that is in marked contrast to the achievements of the rest of the Black Sea countries in the interdisciplinary field of marine landscape sciences. Complex-based investigations of the seabed environment are a challenge that contemporary Bulgarian oceanography is facing
The initiation (and targeted funding) of the above seascape-scale investigations may assist in numerous practical aspects of critical importance, e.g., assessment of the natural resource potential of the seafloor, elucidation of the seabed habitat pattern, identification of underwater archaeological objects, proper marine spatial planning, fish stock assessment, better marine nature conservation, etc. [56].

What potential lies beneath the sea surface...?

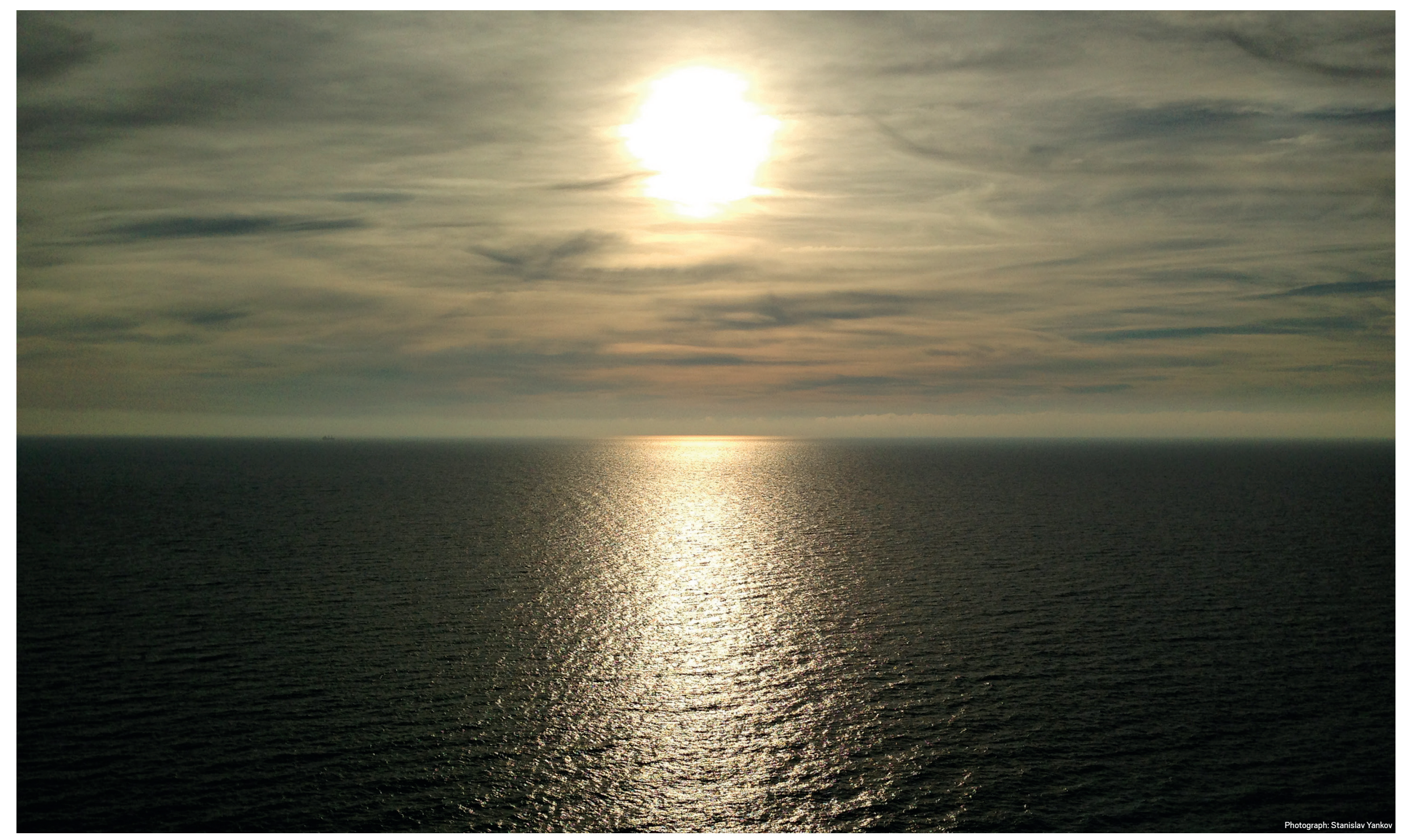


NB: I-III-landscape classes $A-L$-landscape types

A.7-1.7-landscape sub-types

07-22 and Pa-Wb-landscape genera

\section{PLAIN AND FORE-MOUNTAINOUS LANDSCAPES}

\section{A. HILLY SUBTROPICAL HUMID LANDSCAPES}

A.7. SOUTHEUXINIAN FOREST LANDSCAPES

01. Fore-mountainous-hilly erosive-denudation landscapes with forests of Oriental beech (Fagus orientalis), or with mixed oak forests

\section{B. PLAIN AND HILLY SUB-MEDITERRANEAN SEMI-HUMID} LANDSCAPES

B.1. TRANSITIONAL TO SOUTHEUXINIAN FOREST LANDSCAPES (SUB-SOUTHEUXINIAN-STRANDZHAN SUBTYPE)

02. Fore-mountainous-hilly, erosive-denudation landscapes with mixed oak forests (Quercus frainetto, Q. pubescens, Q. cerris, Q. hartwissiana) and pseudomaquis communities

03. Hilly, erosive-denudation landscapes with mixed oak forests (Quercus frainetto, Q. pubescens, Q. cerris), as well as with significant relocation of Mediterranean vegetation and pseudomaquis communities

04. Fore-mountainous-hilly, erosive-denudation landscapes with forests of Oriental beech (Fagus orientalis)

B.2. MEDITERRANEAN FOREST AND PSEUDOMAQUIS LANDSCAPES

05. Fore-mountainous-hilly, terraced landscapes with mixed oak forests (Quercus pubescens, Q. cerris, Q. frainetto) and pseudomaquis communities

06. Fore-mountainous-hilly landscapes with mixed oak forests and Mediterranean vegetation

\section{PLAIN SUB-MEDITERRANEAN SEMI-ARID LANDSCAPES}

C.1. TRANSITIONAL TO WARM-TEMPERATE LANDSCAPES WITH STEPPES AND PSEUDOMAQUIS COMMUNITIES

07. Lowland-accumulative landscapes with oak forests (Quercus frainetto Q. cerris, Q. robur) and steppes

08. Lowland-accumulative, erosive-denudation landscapes with steppes, pseudomaquis communities, and isolated patches of oak forests (Quercus pubescens, Q. frainetto)

\section{PLAIN AND HILLY WARM-TEMPERATE SEMI-HUMID LANDSCAPES}

D.1. TRANSITIONAL TO SUB-MEDITERRANEAN FOREST LANDSCAPES

09. Plain and hilly landscapes with mixed oak forests ( $Q$. frainetto, $Q$. hartwissiana, Q. cerris) with undergrowth of oriental hornbeam (Carpinus orientalis)

D.2. WARM-TEMPERATE FOREST LANDSCAPES

10. Accumulative and erosive-accumulative landscapes with psammophytic vegetation

11. Plateau-karst landscapes with mixed oak forests or common hornbeam (Carpinus betulus) forests and steppes

12. Plateau-hilly landscapes with mixed oak forests and rarely steppes

\section{E. PLAIN AND HILLY SEMI-ARID LANDSCAPES}

\section{E.1. STEPPE LANDSCAPES}

13. Plain-karst landscapes with dry karst valleys and steppe vegetation

14. Plain, accumulative-denudation landscapes with steppe vegetation

\section{E.2. LANDSCAPES WITH FOREST STEPPES AND PSEUDOMAQUIS} COMMUNITIES

15. Plain and accumulative-karst landscapes with forest steppes (Quercus pubescens, Q. frainetto, Q. robur, Carpinus orientalis and Artemisia spp. Stipa spp., Andropogon spp.)

F. HILLY AND FORE-MOUNTAINOUS-HILLY WARM-TEMPERATE HUMID LANDSCAPES

F.1. FOREST AND FOREST STEPPE LANDSCAPES (LUDOGORIE SUBTYPE)

16. Plain, erosive-denudation landscapes with forest steppes

\section{G. PLAIN SEMI-ARID LANDSCAPES}

G.1. STEPPE AND FOREST STEPPE LANDSCAPES (DOBRUDZHA SUBTYPE)

17. Plain, denudation-erosive and accumulative landscapes with forest steppes

18. Plain-hilly, erosive-accumulative and karst landscapes with forest steppes

\section{H. HYDROMORPHIC AND SUBHYDROMORPHIC LANDSCAPES}

19. Lowland- and valley-accumulative landscapes with riparian flooded forests (longoz type) and meadows, or with aquatic or halophytic vegetation

\section{MOUNTAINOUS LANDSCAPES}

\section{MOUNTAINOUS SUB-MEDITERRANEAN LANDSCAPES}

1.7. TRANSITIONAL TO SOUTHEUXINIAN FOREST LANDSCAPES

20. Low-mountainous, erosive-denudation landscapes with mixed oak forests (Quercus frainetto, Q. cerris, Q. pubescens, Q. hartwissiana) and pseudomaquis communities

21. Low-mountainous, erosive-denudation landscapes with mixed broadleaved forests (Carpinus betulus, Fagus orientalis, Quercus frainetto)

22. Low-mountainous, erosive-denudation and karst landscapes with mixed broad-leaved forests (Carpinus betulus, Fagus orientalis, Quercus frainetto) and pseudomaquis communities

\section{ANTHROPOGENIC LANDSCAPES}

\section{J. INSIGNIFICANTLY AND SLIGHTLY ALTERED NATURAL} LANDSCAPES

$\mathrm{Pa}$ - Natural forest landscapes with additional plantations of Pinus sp.

\section{K. LANDSCAPES WITH SIGNIFICANT TO FULL MODIFICATION OF THE} NATURAL VEGETATION

Aa - Agricultural areas (arable land, orchards, vineyards, etc.)

La - Artificial plantations of black locust and/or golden chain (Robinia pseudoacacia, Laburnum anagyroides)

Up - Urban parks

$\mathrm{Br}-$ Bare rocks

\section{LANDSCAPES WITH SIGNIFICANT TO COMPLETE} TRANSFORMATION OF THE NATURAL COMPLEX

$\mathrm{Bu}$ - Built-up areas (settlements, industrial and commercial units, transport and port infrastructure, etc.)

Ds - Dump sites

Qm - Quarries and mines

\section{OTHERS (NON-DIFFERENTIATED):}

Wb - Water bodies (reservoirs, navigable canals, Varna-Beloslav Lake Complex, Burgas Lake Complex, etc.) 
Generalized map scheme of the contemporary landscape complexes on the Bulgarian Black Sea coast (after Velchev et al. 2017 [49], with modifications by the authors based on CORINE Land Cover ver. 2006 [83])

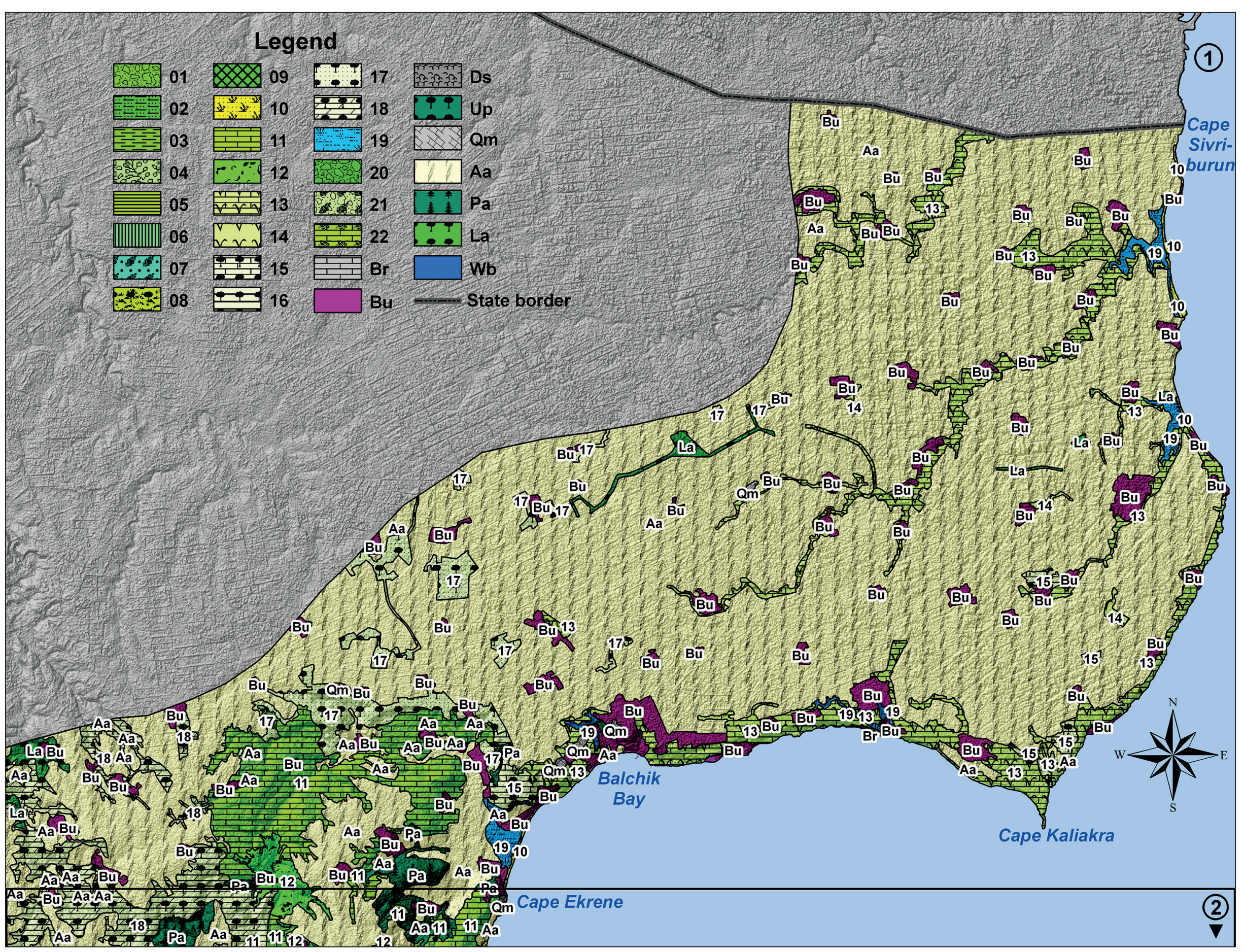

100 PHYSIOGRAPHIC AND OCEANOGRAPHIC CHARACTERISTICS OF THE STUDY AREA 


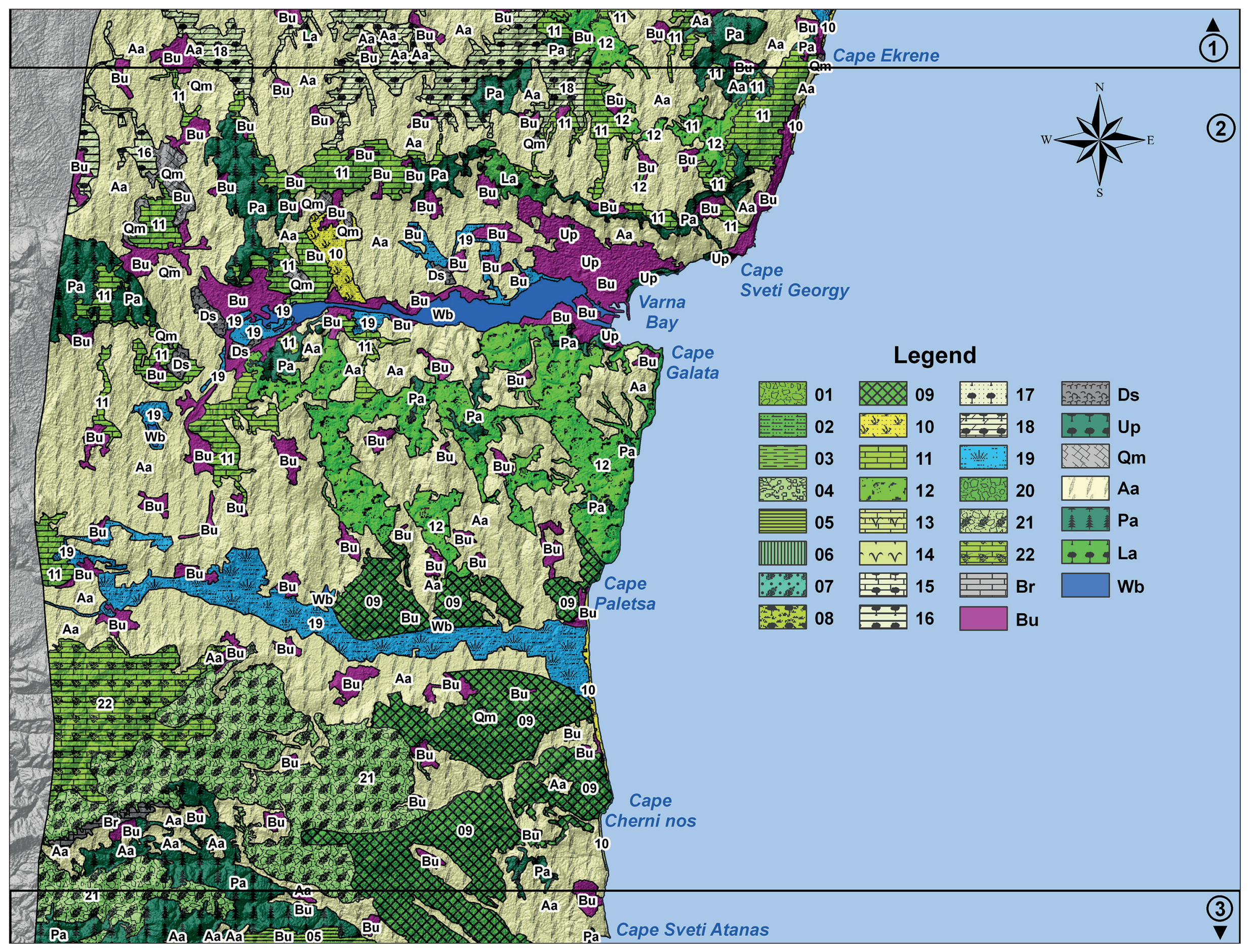




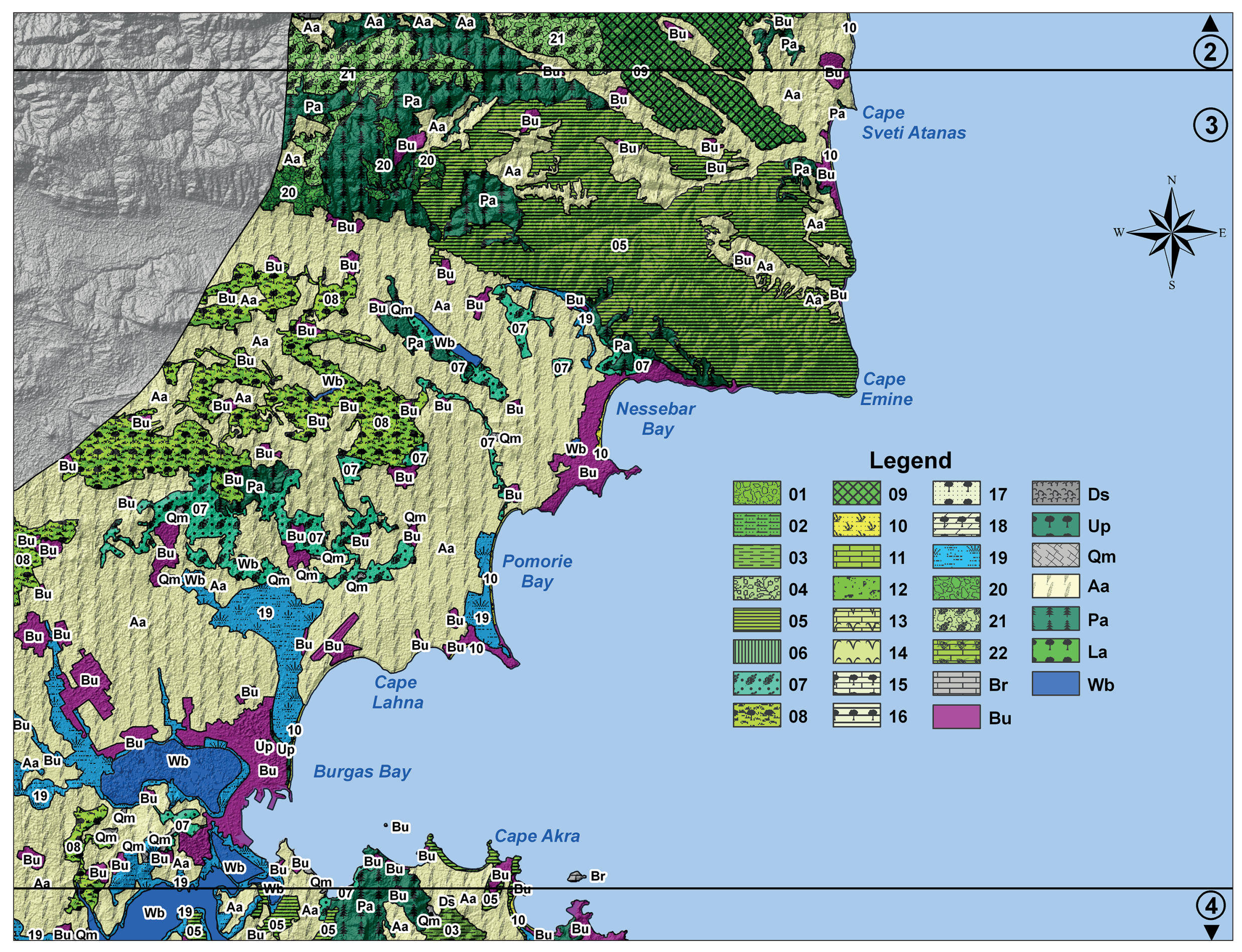

102 PHYSIOGRAPHIC AND OCEANOGRAPHIC CHARACTERISTICS OF THE STUDY AREA 


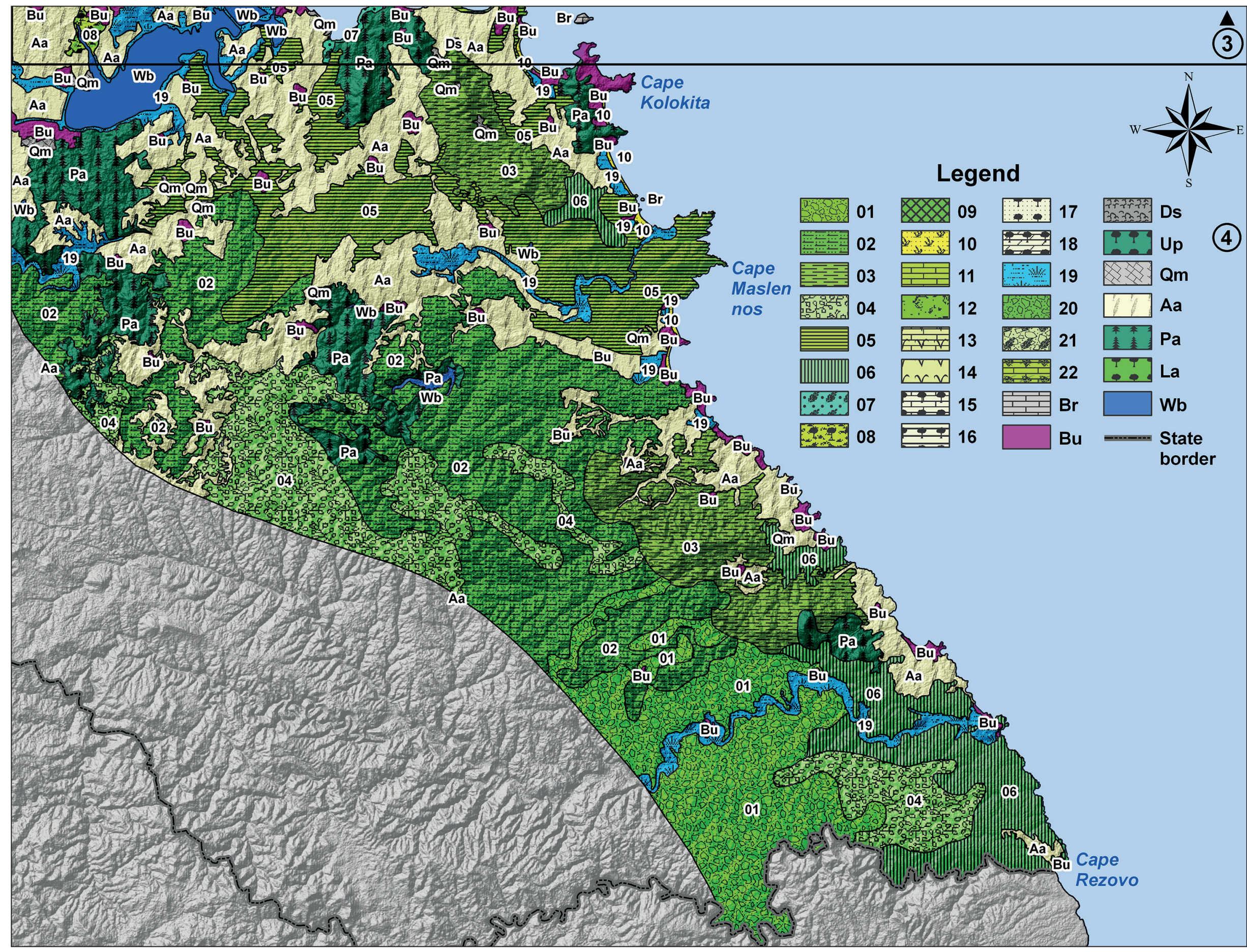




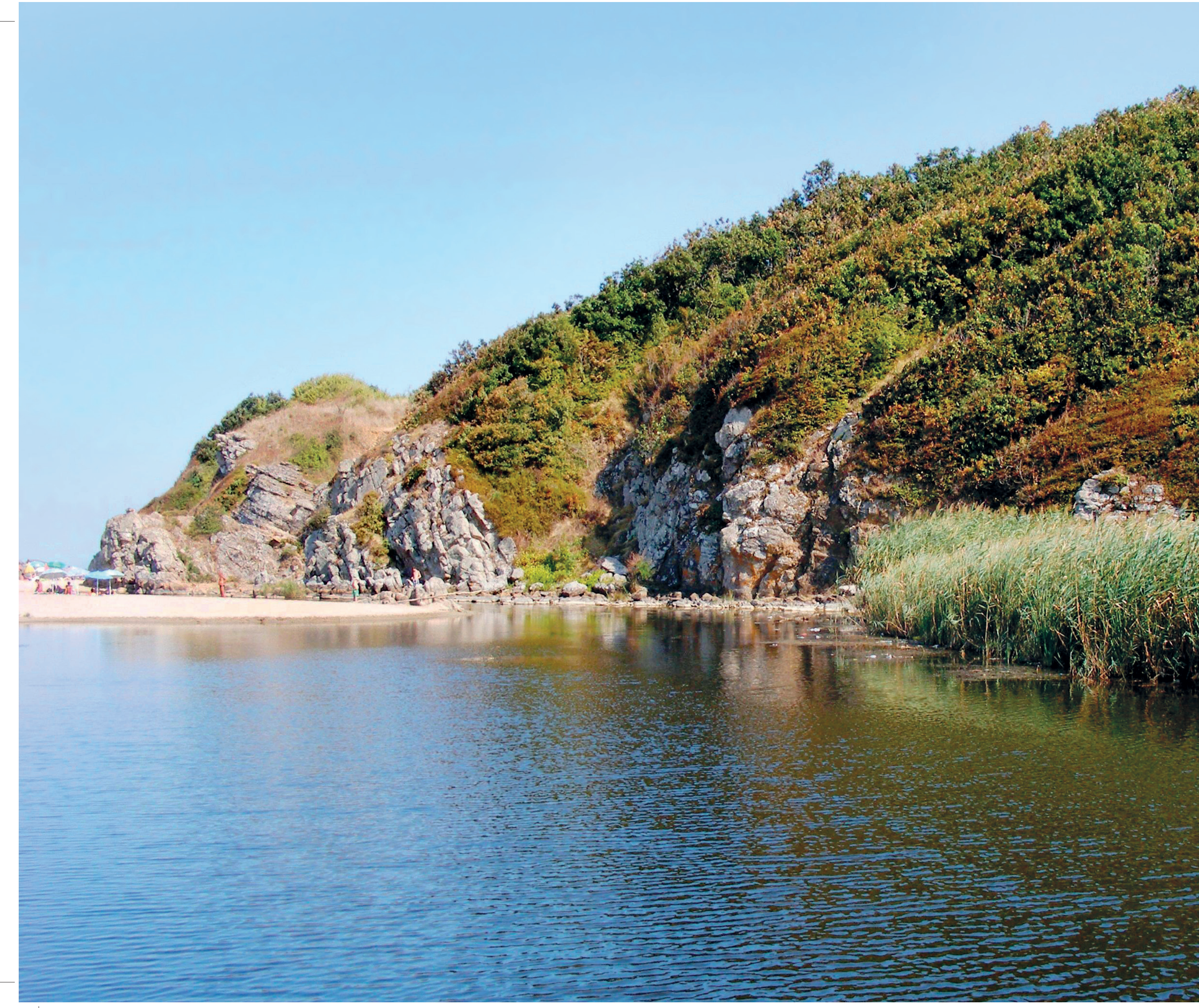


HABITAT PRESERVATION IS AMONG THE FUNDAMENTAL CONCEPTS OF MODERN NATURE CONSERVATION. SUCH AN APPROACH GUARANTEES EFFECTIVE PROTECTION OF THE BIOLOGICAL DIVERSITY IN A GIVEN AREA, AND REPRESENTS THE BACKBONE OF ECOSYSTEM-BASED ENVIRONMENTAL MANAGEMENT [1].

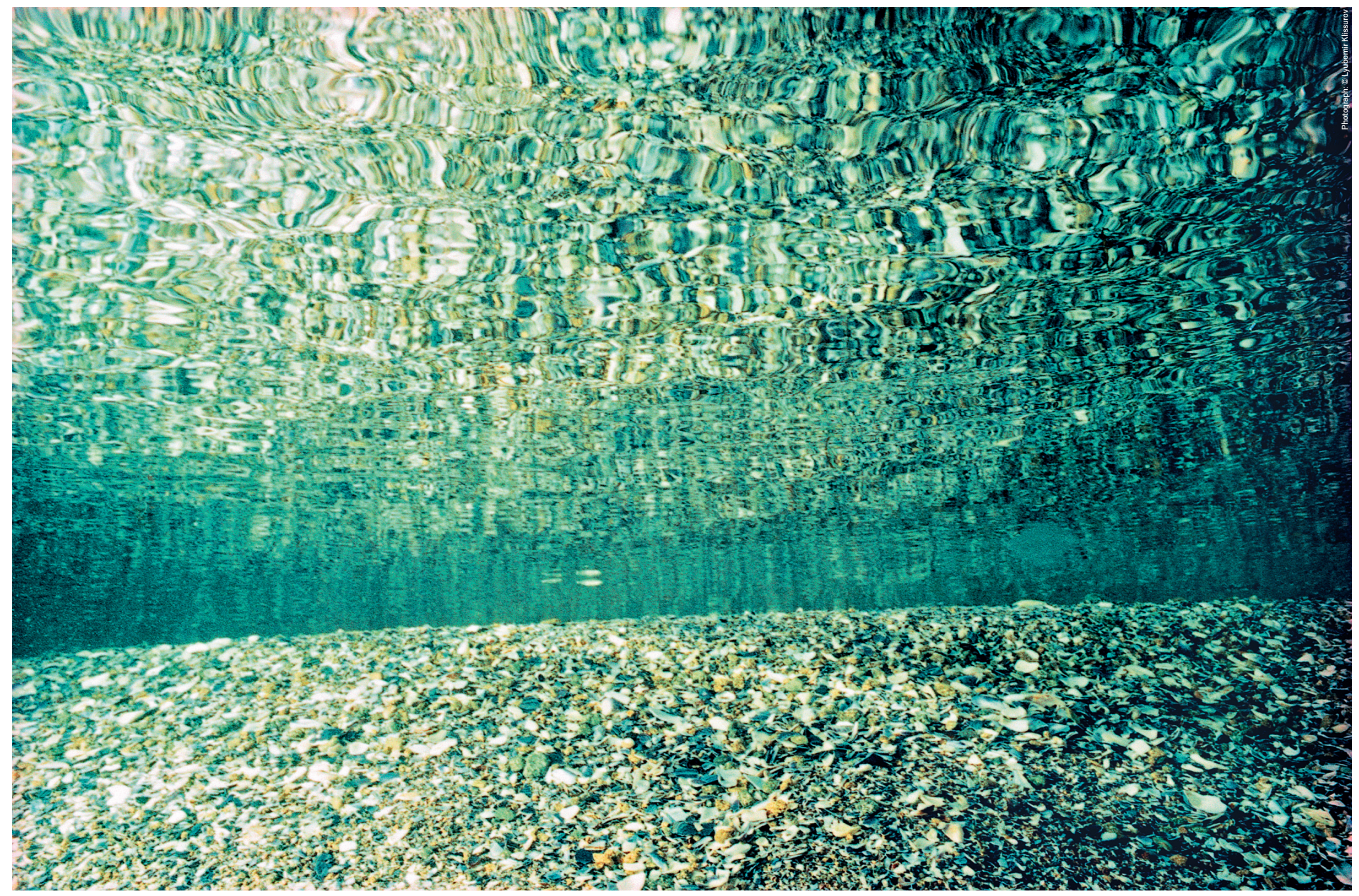




\section{COASTAL HABITATS}

\section{BEACH AND DUNE HABITATS}

Vegetation on the Black Sea gravel beaches [2]. These habitats occur on beaches with erosive-accumulative genesis, predominantly developed at cliff bases, landslide sectors, etc. Such depositional coastal landforms are characterized by a narrow cross-shore profile, which enables wave propagation during storm events, and hence facilitates the further erosion of the cliff base [3]. Most often no vegetation occurs in this habitat type, yet in some places phytocoenoses of annual and perennial plants such as the searocket (Cakiletea maritimae) are observed. The habitat represents a variety of the NATURA 2000 habitat type 1210 (Annual vegetation of drift lines) [4]. It is enlisted in the Bulgarian Red Data Book as endangered [2], and is subject to protection in compliance with the national Biological Diversity Act [5]

Gravel beaches of the Bulgarian coast with examples of the pertinent vegetation

1. Dobrudzha shores near Balchik, North Bulgarian coast

2. Strandzha shores near Sinemorets, South Bulgarian coast

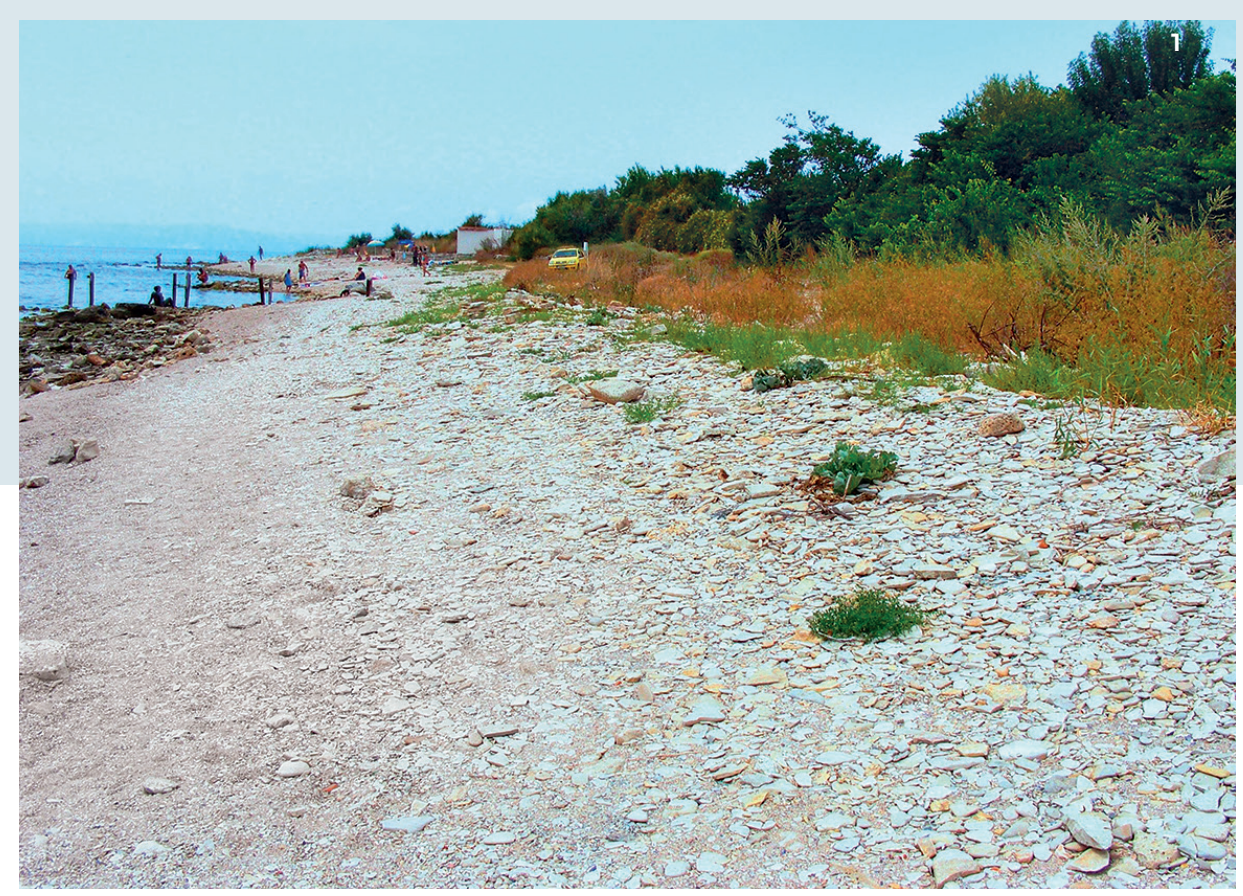

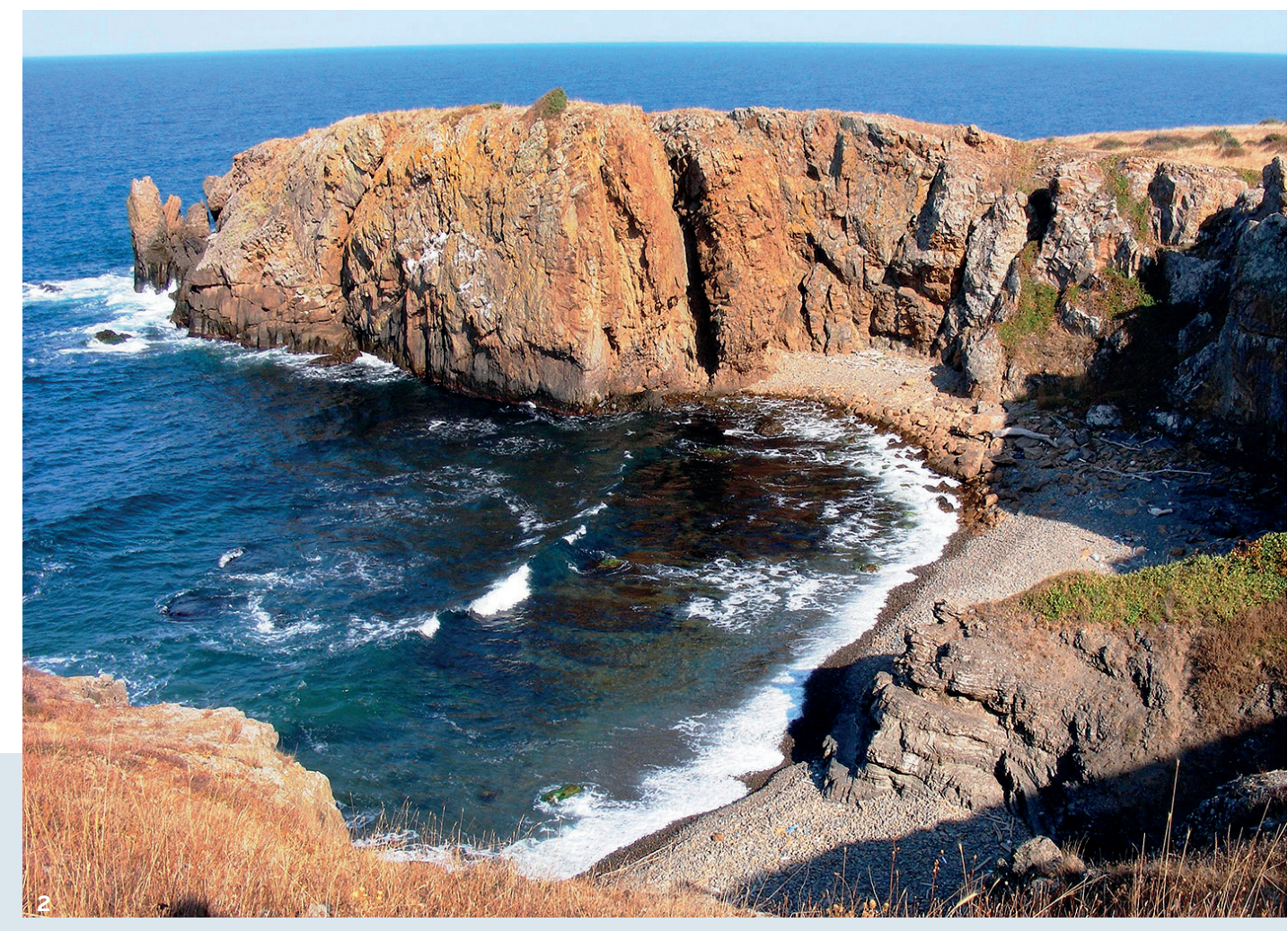

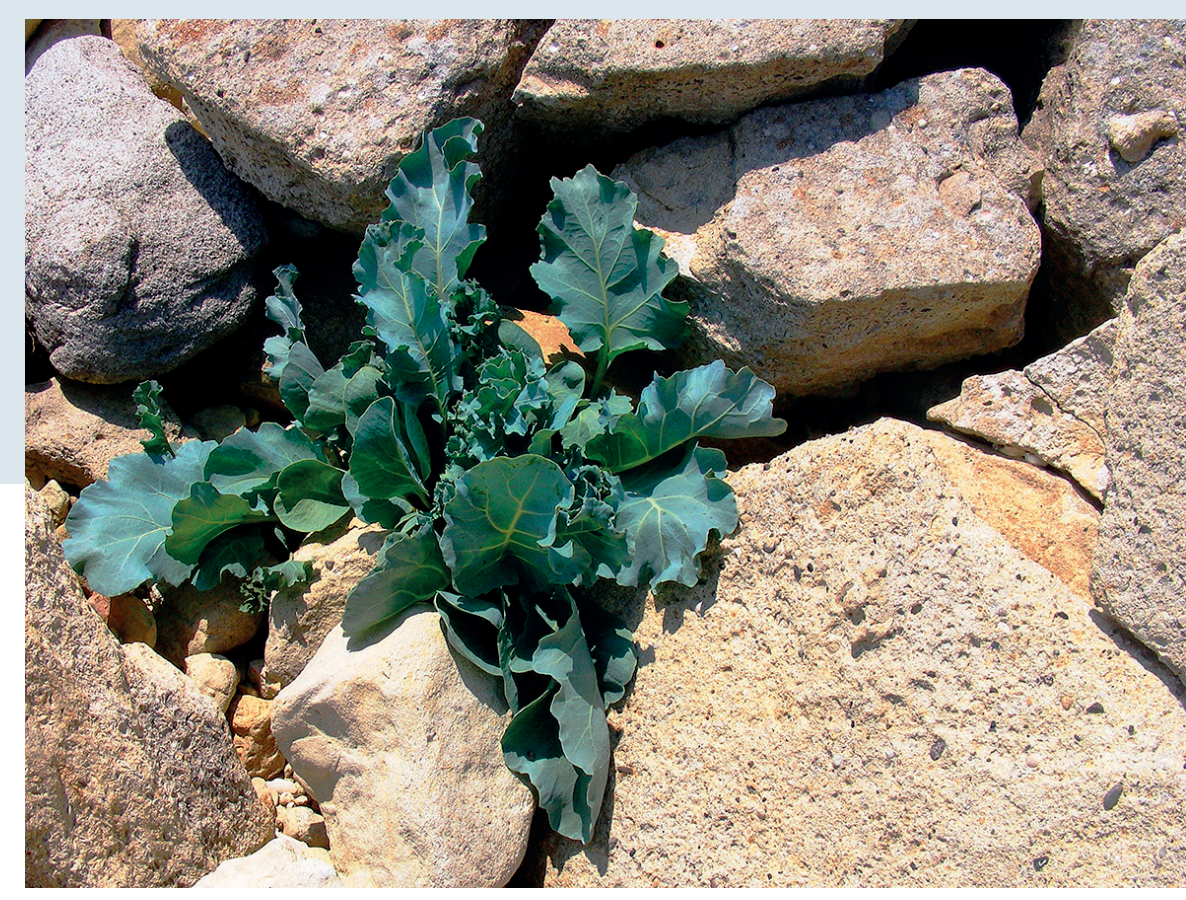


Vegetation on the Black Sea sand beaches [6]. The habitat represents a variety of the NATURA 2000 habitat type 2110 (Embryonic shifting dunes) [4]. The first stage of the beach-dune complex formation can be observed at the coastal sand strips between the surf zone and up to $30 \mathrm{~m}$ inside the beach. Some obligate psammophytic species like Cakile maritima subsp. euxina, Crambe maritima susbp. pontica, Eryngium maritimum, Euphorbia peplis, Lactuca tatarica and Polygonum maritima occur. However, as a result of trampling and removal of plants, these beaches have transformed into mobile sand substrates without any vegetation cover. The habitat type is enlisted in the Bulgarian Red Data Book as endangered [6], and is subject to protection in compliance with the national Biological Diversity Act [5].

Representative vegetation of the Black Sea sand beaches:

1. Crambe maritima subsp. pontica on Varna central beach, North Bulgarian coast

2. Mixed community dominated by Eryngium maritimum, Lactuca tatarica and Leymus racemosus subsp. sabulosus on Albena-Kranevo beach, North Bulgarian coast

3 \& 4. Embryonic dunes at Kamchia Sands locality, Central Bulgarian coast
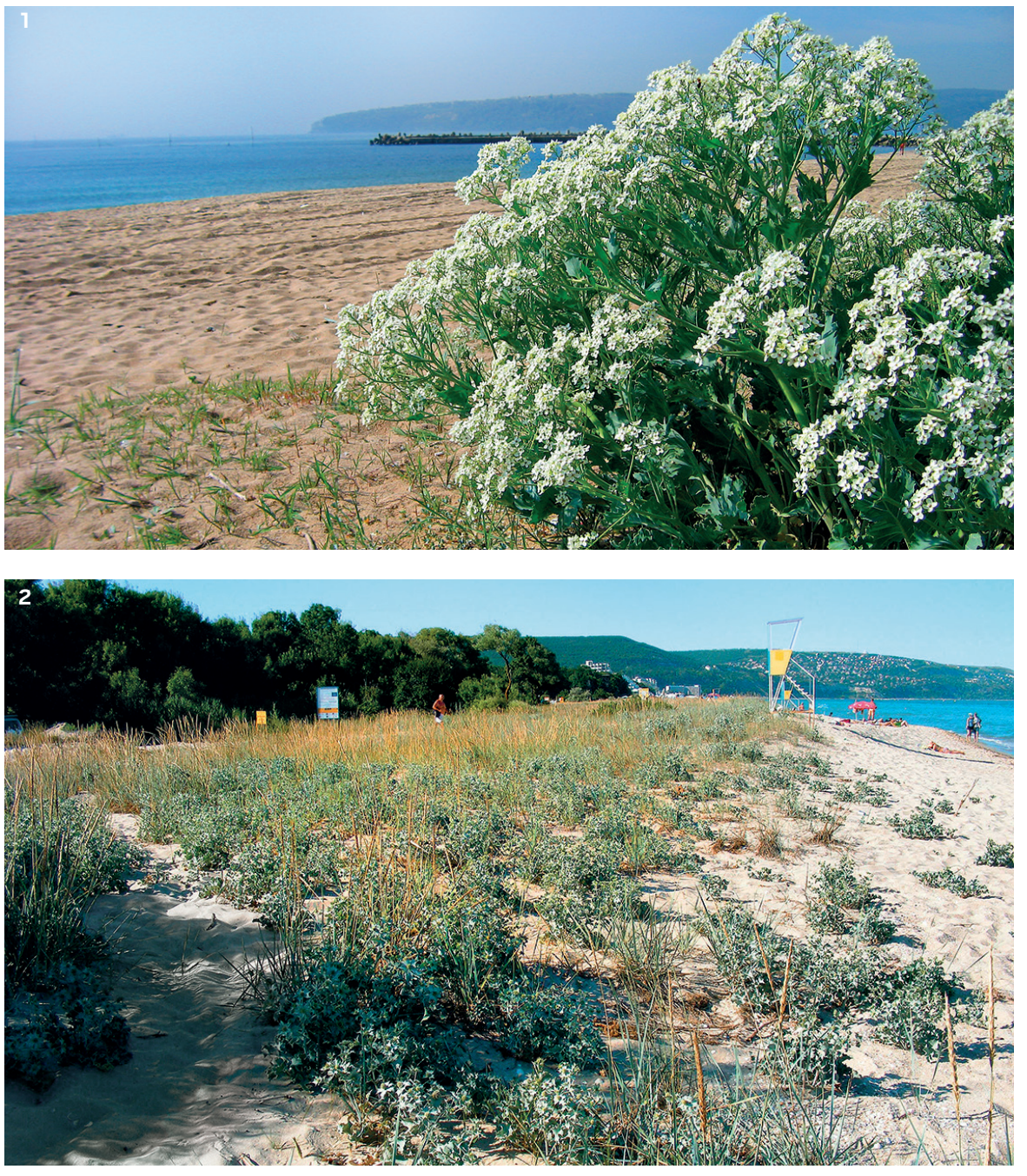
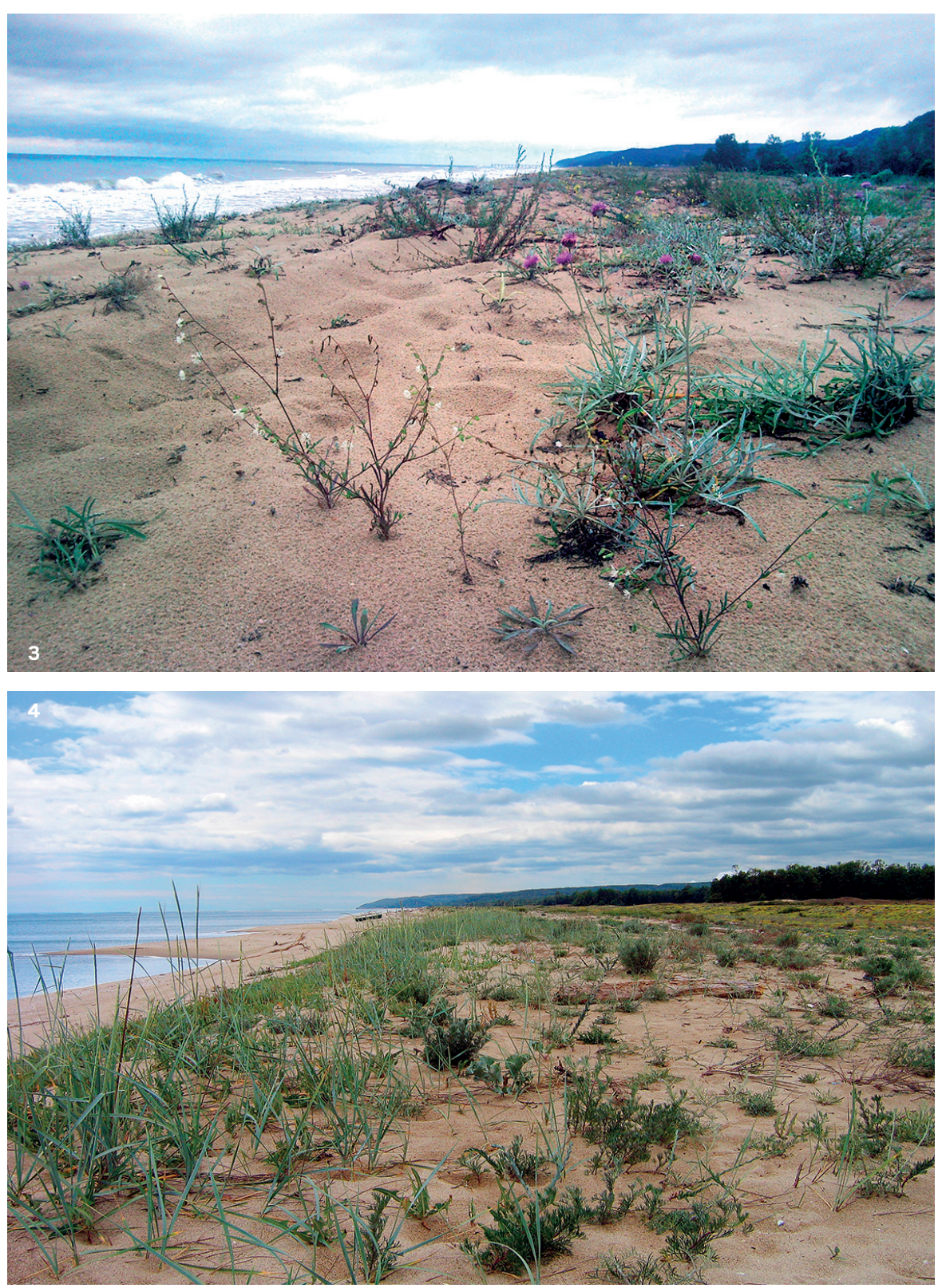

Black Sea embryonic dunes [7]. The habitat represents a variety of the NATURA 2000 habitat type 2110 (Embryonic shifting dunes) [4]. The embryonic dunes develop in the transitional zone between the typical sand beaches and the Pontic mobile (white) dunes or the Pontic fixed (grey) dune complexes. Initial consolidation of sand by the roots and rhizomes of perennial plants is currently taking place. The species include grasses such as Ammophila arenaria, Elymus farctus, Leymus racemosus subsp. sabulosus, but also many other psammophytes such as Centaurea arenaria, Crambe maritima, Eryngium maritimum, Lactuca tatarica, Xanthium italicum, etc. The habitat type is enlisted in the Bulgarian Red Data Book as endangered [7], and is subject to protection in compliance with the national Biological Diversity Act [5]. 
Black Sea mobile (white) dunes [8]. The habitat represents the NATURA 2000 habitat type 2120 (Shifting dunes along the shoreline with Ammophila arenaria, or white dunes) [4]. The mobile (white) dunes form 2-3 m-high dune rows which often run parallel to the sea. These dunes are typical for the sand spits that separate Durankulak, Shabla and Pomorie Lakes from the sea. Their formation is influenced both by the wind and the fluctuations of the water level of the lakes. Similar, but smaller dunes could be found at the estuaries of the rivers that enter the Black Sea (Batova, Veleka, Silistar, and Vaya). These dunes are more stabilized than the embryonic ones and are overgrown by coenoses dominated by grasses such as Ammophila arenaria Festuca vaginata and Leymus racemosus subsp. sabulosus. The habitat type is enlisted in the Bulgarian Red Data Book as endangered [8], and is subject to protection in compliance with the national Biological Diversity Act [5].

White dunes on Albena-Kranevo beach developed in front of the Batova River mouth, North Bulgarian Black Sea coast

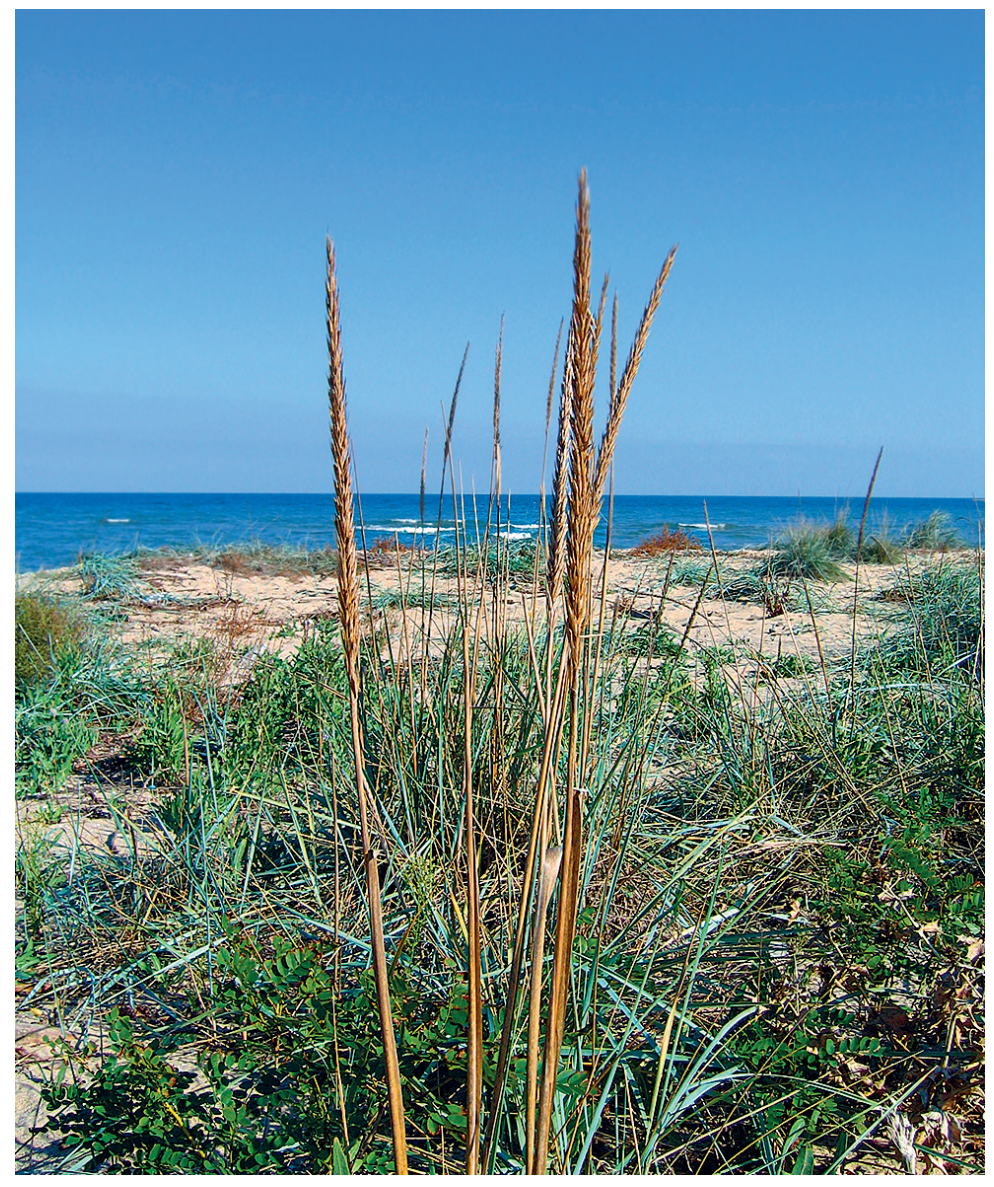

Black Sea fixed (grey) dunes [9]. The habitat represents the NATURA 2000 habitat type 2130 (Fixed coastal dunes with herbaceous vegetation, or grey dunes), identified as a conservation priority at the European level [4]. Fixed coastal dunes are stabilized and colonized by many diverse coenoses, dominated by perennials and with abundant lichens and mosses in some areas. They are spread along the entire Black Sea coast, but mostly to the south of the estuary of the Kamchia River. Northwards, near Durankulak Lake, there is a small, isolated area with grey dunes that differ significantly from the remaining stabilized dunes in Bulgaria. The following species are typical for the grey dunes: Artemisia campestris, Centaurea arenaria, Cionura erecta Jurinea albicaulis subsp. kilaea. Aurinia uechtritziana, Linaria genistifolia subsp. euxina, Silene euxina, Teucrium polium, the Bulgarian endemic Linum tauricum ssp. bulgaricum, etc. The habitat type is enlisted in the Bulgarian Red Data Book as endangered [9], and is subject to protection in compliance with the national Biological Diversity Act [5].
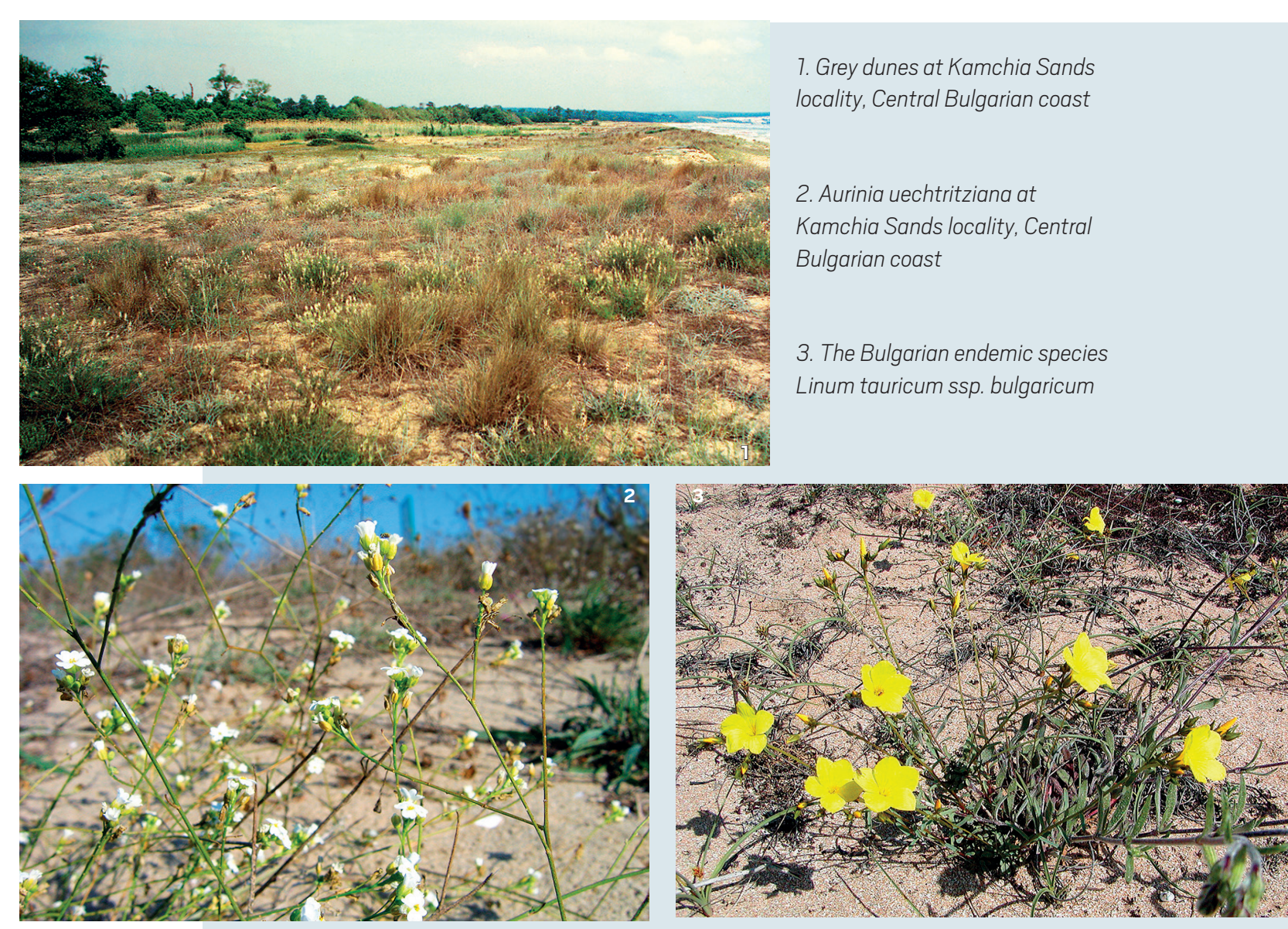
Black Sea wooded dunes [10]. The habitat represents a variety of the NATURA 2000 habitat type 2180 (Wooded dunes of the Atlantic, Continental and Boreal region) [4]. Natural or semi-natural tree and tree-shrub coenoses along the Black Sea coast occur only on the territory of two of the largest dune systems. They are most typical for Cape Kaya in the Ropotamo Nature Reserve covering the eastern, steep slopes of the biggest dune in Bulgaria, which is ca. $50 \mathrm{~m}$ high. Fragments of forest communities also cover the western, less steep slopes of this dune near the Sozopol-Primorsko road. The wood coenoses on the dune have typical xerothermic features, the trees are small and strongly branched. These coenoses are dominated by Carpinus orientalis, Fraxinus ornus, Quercus cerris, Q. frainetto, Q. pubescens, The habitat type is enlisted in the Bulgarian Red Data Book as critically endangered [10], and is subject to protection in compliance with the national Biological Diversity Act [5].

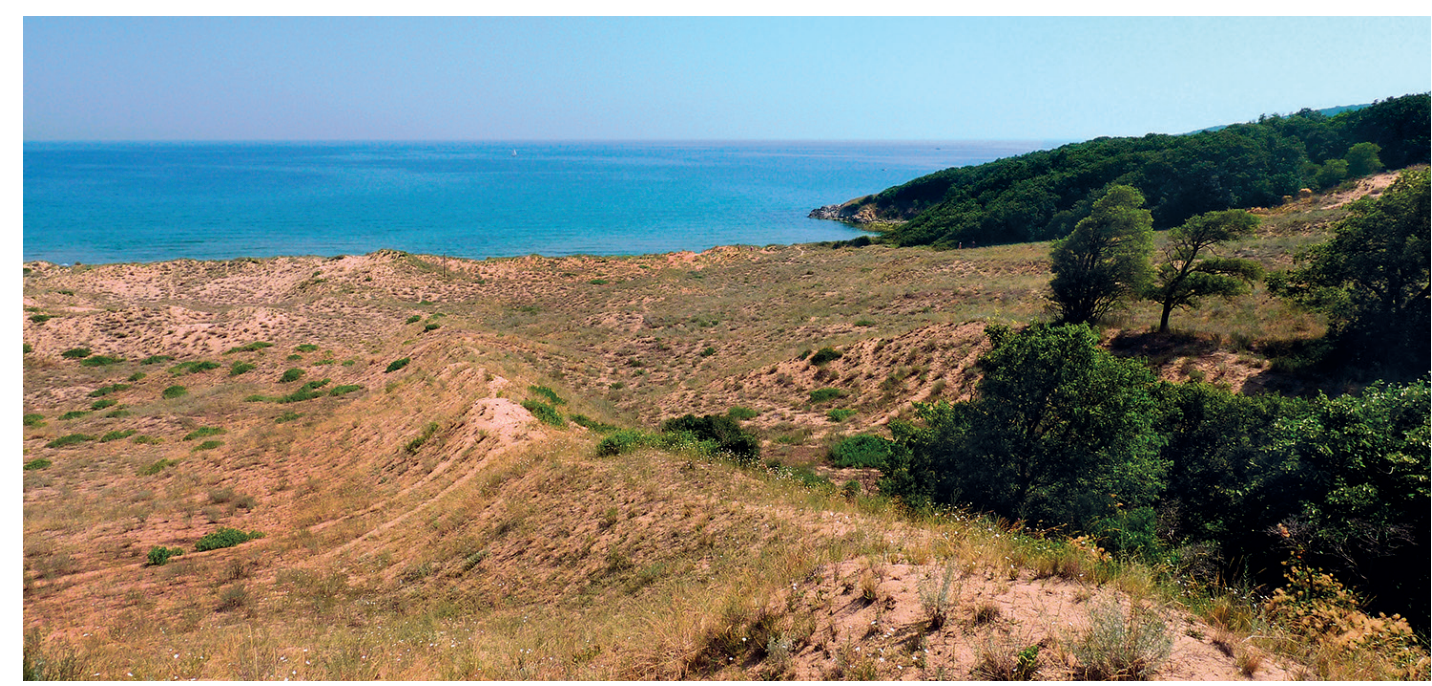

Wooded dunes in Ropotamo Nature Reserve (South Bulgarian coast)

\section{CLIFF HABITATS}

Sea-cliff vegetation [11]. The habitat represents a variety of the NATURA 2000 habitat type 1240 (Vegetated sea cliffs of the Mediterranean coasts with endemic Limonium spp.) [4]. It comprises open, chasmophytic phytocoenoses developing on the cliffs along the entire Black Sea coast. These communities are halophytic and have developed under the influence of the drops of salty water from the sea. The floristic composition depends on the bedrock type. Two basic subtypes of this habitat

110 COASTAL AND MARINE HABITATS. PROTECTED AREAS AND NATURA 2000 SITES exist. The first one includes the 70 m-high limestone cliffs on the North Black Sea coast, especially in the area between the village of Tyulenovo and and Cape Kaliakra Typical for this habitat subtype are Crithmum maritimum, Gypsophila trichotoma and Silene caliacrae. Some Pontic-steppe petrohytes top the cliff ridges: Cephalaria uralensis, Alyssum caliacrae, Artemisia lerchiana, A. pedemontana, Kochia prostrata, and Seseli tortuosum. The second subtype is more typical for the volcanic rocks along the southern coast, mostly southwards of Sozopol and along the Strandzha Mountain coast. Typical species include Atriplex hastata, Convolvulus lineatus, Crithmum maritimum, Limonium gmelinii, Sagina maritima, Silene compacta. Shrub phytocoenoses of the fig (Ficus carica) with Colutea arborescens, Ulmus minor and some others develop in some places, mostly on the southern coast. The habitat type considered is enlisted in the Bulgarian Red Data Book as endangered [11], and is subject to protection in compliance with the national Biological Diversity Act [5].

7. Erosive cliffs with chasmophytic and calcicolous vegetation at Yaylata Archaeological Reserve, North Bulgarian coast

2. Rock samphire (Crithmum maritimum)

3. Silene caliacrae is an endemic species for the Bulgarian Black Sea coast

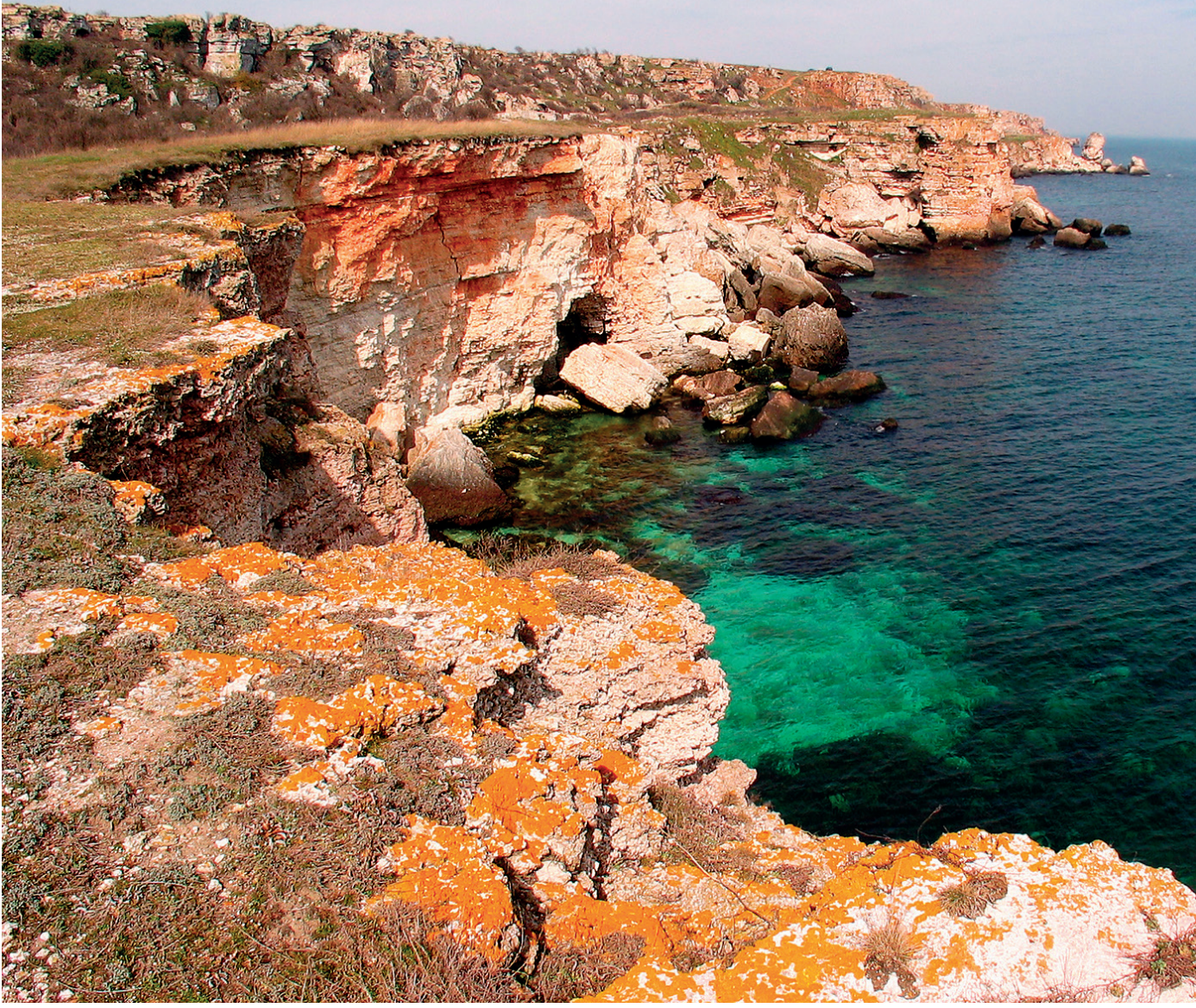




\section{HABITATS OF THE WETLANDS, RIPARIAN FORESTS AND LONGOZES ALONG THE BULGARIAN BLACK SEA COAST}

Estuaries [14]. The habitat represents the NATURA 2000 habitat type 1130 (Estuaries) [4]. It encompasses the lowermost parts of the Black Sea tributaries where they flow into the marine basin (the Batova, Kamchia, Ropotamo, Veleka, Dyavolska, Karaagach, Silistar, Butamyata, etc.), also known as firths. There is a development of marshy vegetation (communities of Phragmites australis, Typha spp., Bolboschoenus maritimus) and of abundant aquatic vegetation in the shallow areas (Potamogeton spp., Myriophyllum spp., Zannichellia palustris, Lemna spp.) The habitat type is enlisted in the Bulgarian Red Data Book as critically endangered [14], and is subject to protection in compliance with the national Biological Diversity Act [5]

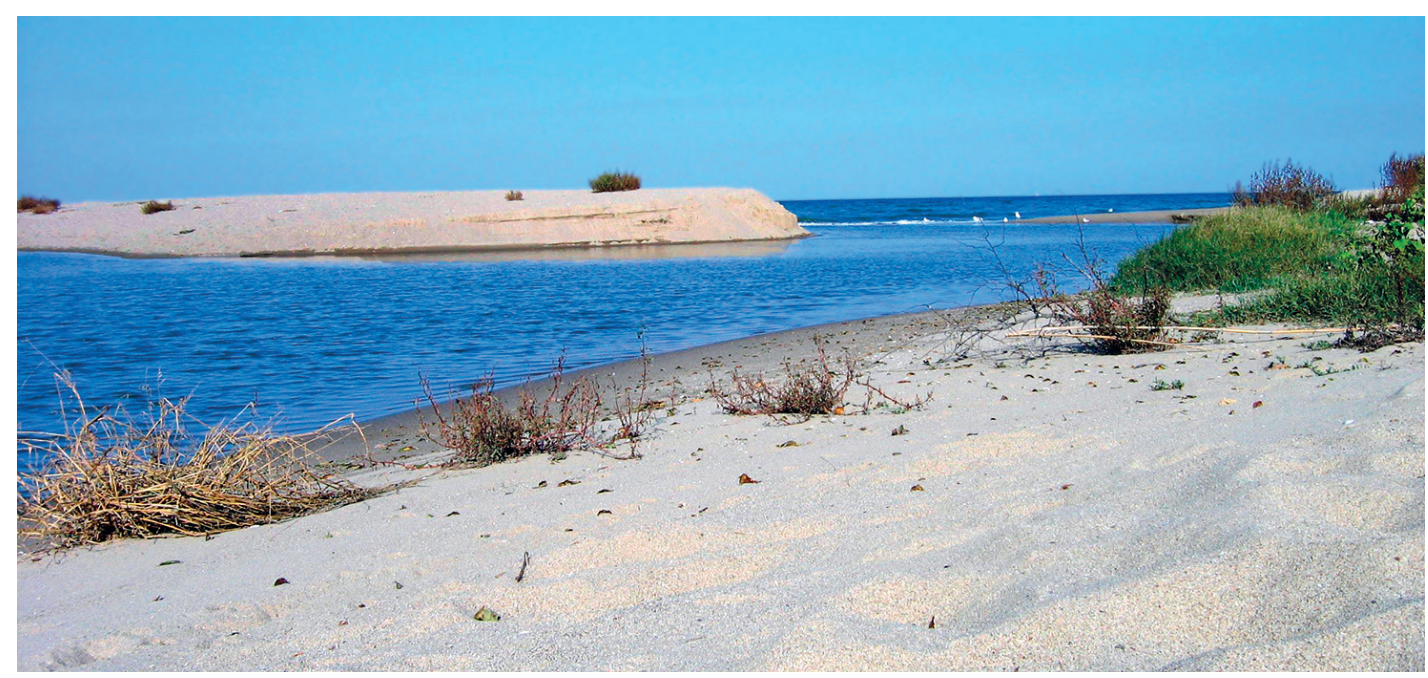

The estuary of the Kamchia River, Central Bulgarian coast

Submerged macrophytic communities in hypersaline water bodies [15]. The habitat represents a variety of the NATURA 2000 habitat type 1150 (Coastal lagoons), identified as a conservation priority at the European level [4]. These are relatively small, coastal, hypersaline water bodies with clayish, muddy bottom and banks. They occur on the North and South Black Sea coast - Shablenska tuzla, Nanevska tuzla and Balchishka tuzla, Atanasovsko Lake, Pomorie Lake. Dominant species include Juncus maritimus, Lemna gibba, Phragmites australis, Ruppia maritima, Scirpus

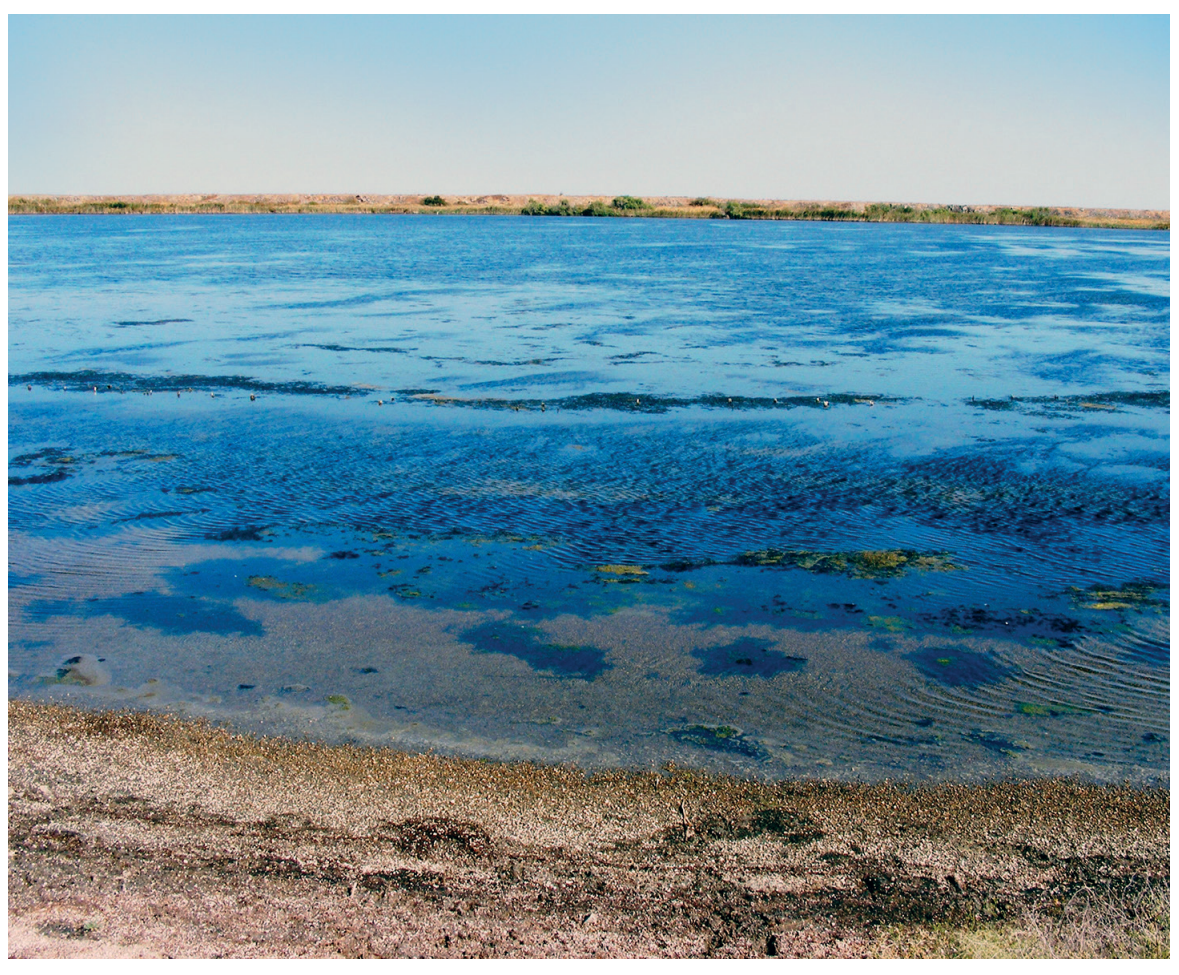

Submerged macrophytic communities in Pomorie Lagoon, South Bulgarian coast

lacustris, S. triqueter, Typha angustifolia, T. latifolia, Zannichellia palustris. The habitat type is enlisted in the Bulgarian Red Data Book as critically endangered [15], and is subject to protection in compliance with the national Biological Diversity Act [5].

Hypersaline coastal lakes and swamps [16]. The habitat represents a variety of the NATURA 2000 habitat type 1150 (Coastal lagoons), identified as a conservation priority at the European level [4]. These lakes are usually small or medium in size, hyper- or mixohaline, holo- or polymictic water bodies with clayish and muddy or sandy bottoms and banks. Atanasovsko Lake and Pomorie Lake are the only large mixo-hyperhaline water bodies that cover relatively large areas. Their depth is small, from 0.5 to $2.5 \mathrm{~m}$. They are separated from the sea by sand spits that get periodically overtopped by the sea waves, mainly in the fall and winter, when their salinity is lower. The rains in spring also decrease their salinity. In the summer and fall the salinity increases since evaporation is more intense than the water influx. The habitat type is enlisted in the Bulgarian Red Data Book as endangered [16], and is subject to protection in compliance with the national Biological Diversity Act [5]. 


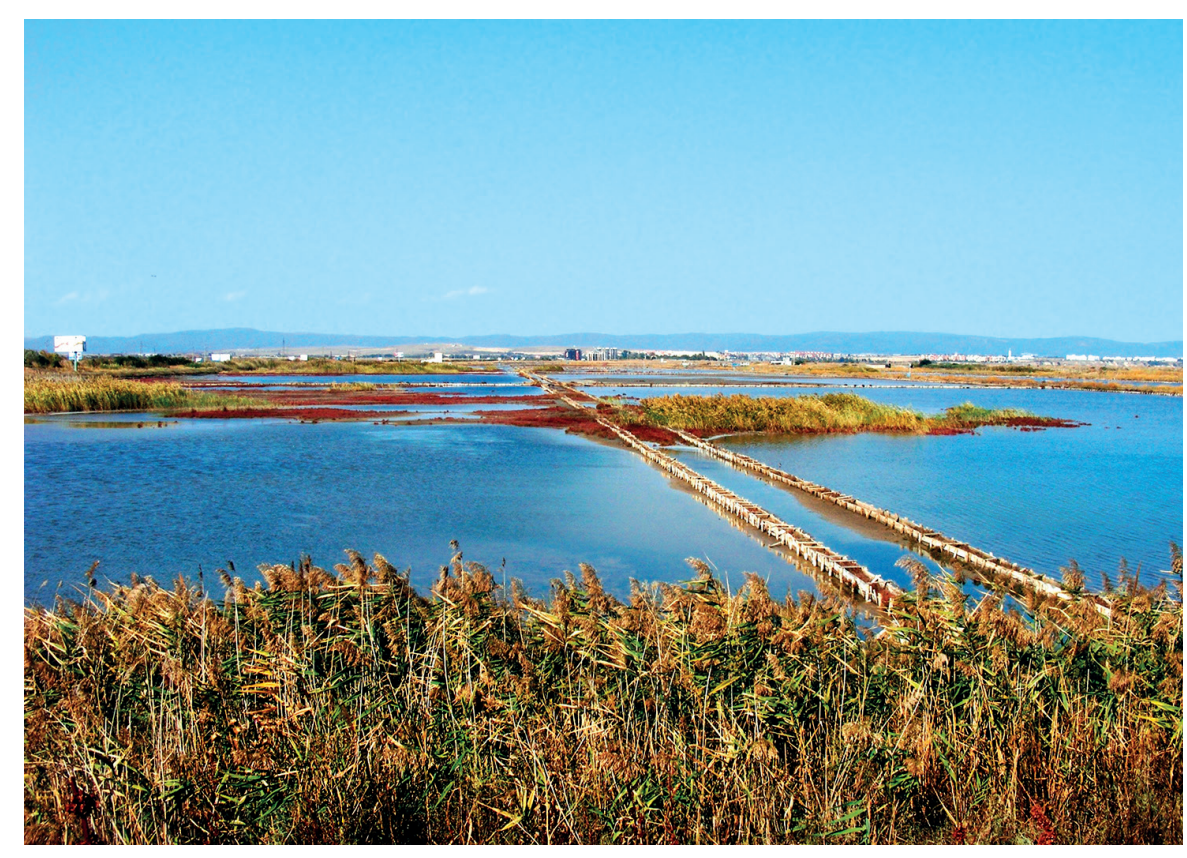

The salt-pans at Pomorie Lagoon

Communities of annual halophytes in coastal salt marshes at the Black Sea [17]. The habitat represents the NATURA 2000 habitat type 1310 (Salicornia spp. and other annuals colonizing mud and sand) [4]. These are communities of mainly annual species of Chenopodiaceae (mostly from the genus Salicornia) or grasses that occupy periodically flooded muddy and sandy places in the periphery of the hyperhaline and more rarely brackish marshes on the Black Sea coast, around hypersaline and brackish lakes - Atanasovsko Lake, Pomorie Lake, Mandra Lake (Poda Protected Area), Varna-Beloslav Lake Complex (Povelyanovo district in the town of Devnya and Yatata Protected Area), Balchishka tuzla Lake, Shablenska tuzla Lagoon and the Ropotamo River estuary. The habitat type is enlisted in the Bulgarian Red Data Book as endangered [17], and is subject to protection in compliance with the national Biological Diversity Act [5].

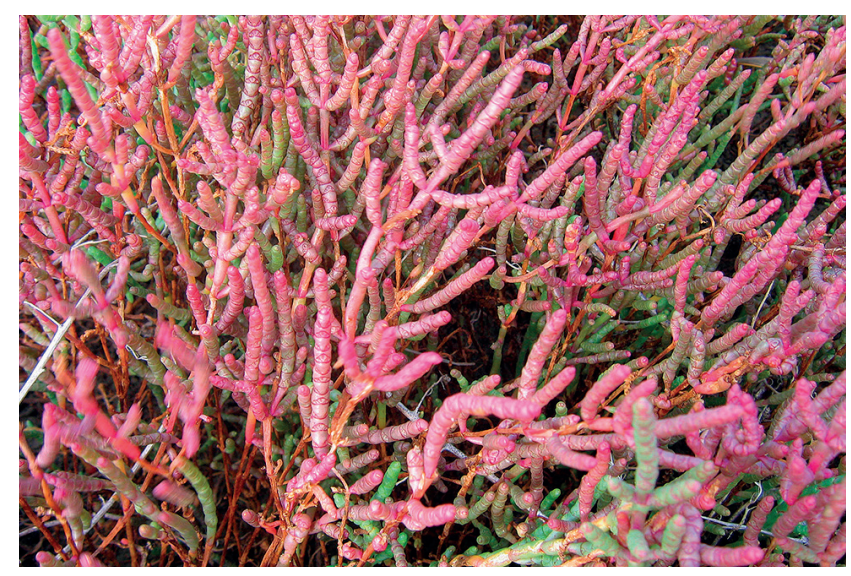

Salicornia europaed
Mediterranean halophytic communities of tall rushes, sedges and grasses [18] The habitat represents the NATURA 2000 habitat type 1410 (Mediterranean salt meadows Juncetalia maritimi) [4]. These communities consist of tall rushes, grasses and sedges in the periphery of hyperhaline or brackish lakes (lagoons or firths) on the Black Sea coast (Varna Lake, Beloslav Lake, Durankulak Lake, Burgas Lake Complex, Chengene skele locality, Kraymorie, Ravadinovo and the mouth of the Ropotamo River). It frequently includes the dominant communities of Elymus elongatus, Juncus littoralis, J. maritimus. The total area of the representative communities of this habitat type does not exceed 5 ha. The water is shallow, not permanent during the vegetation season and often saline to very saline. The habitat type is enlisted in the Bulgarian Red Data Book as critically endangered [18], and is subject to protection in compliance with the national Biological Diversity Act [5].

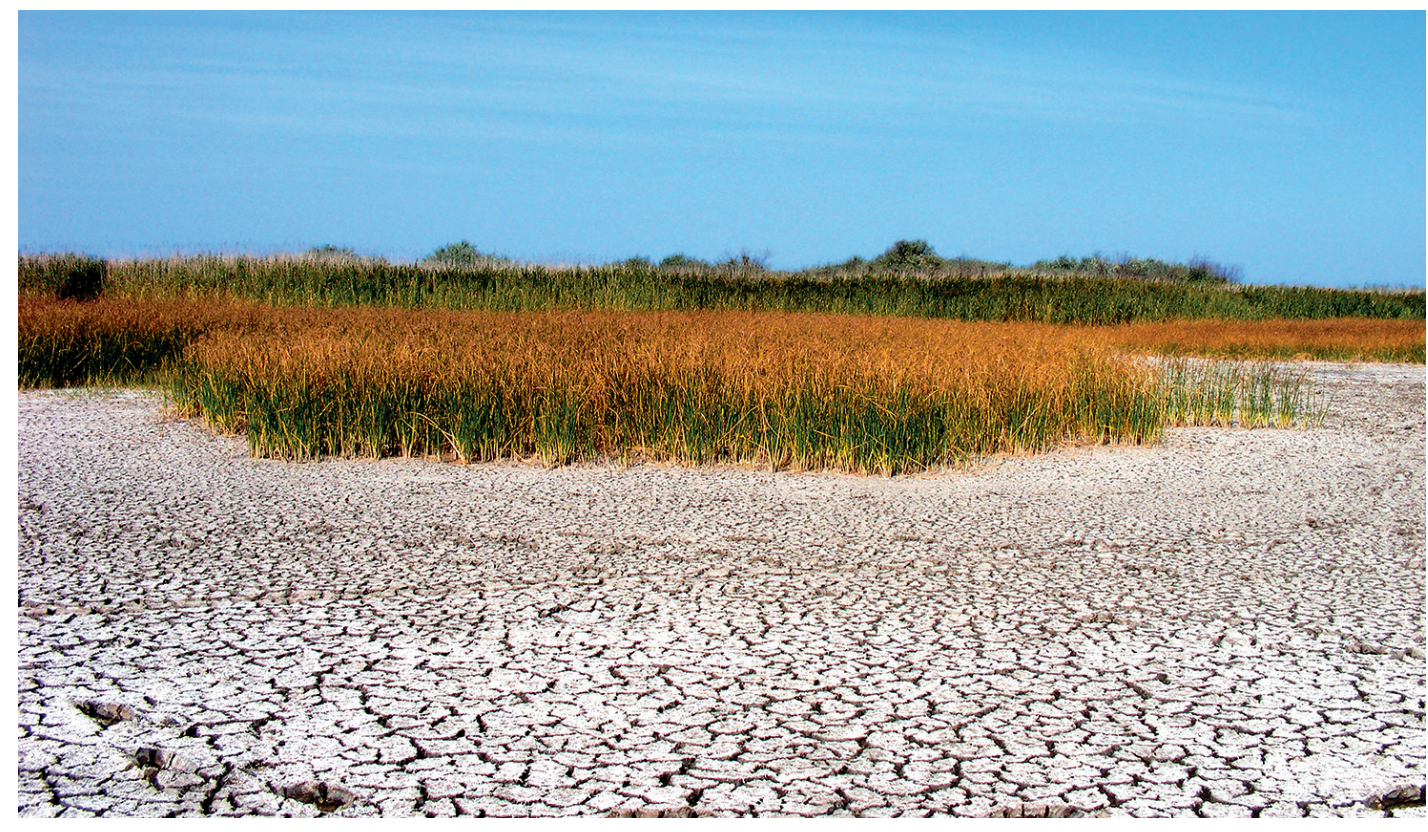

Halophytic communities on the shores of Shablenska tuzla Lagoon

Natural or semi-natural mesotrophic to eutrophic lakes and marshes with macrophytic vegetation [19]. The habitat represents the NATURA 2000 habitat type 3150 (Natural eutrophic lakes with Magnopotamion or Hydrocharition - type of vegetation) [4]. These water bodies represent firths (Durankulak Lake and ShablaEzerets Lake Complex) and brackish lagoons (Arkutino and Alepu swamps) on the Black Sea coast. 
The communities of Nuphar lutea are the rarest that have occurred in recent years at several places along the coast (Shabla-Ezerets Lake Complex, the Veleka River) The habitat type is enlisted in the Bulgarian Red Data Book as endangered [19], and is subject to protection in compliance with the national Biological Diversity Act [5]

Nuphar lutea in Shabla Lake
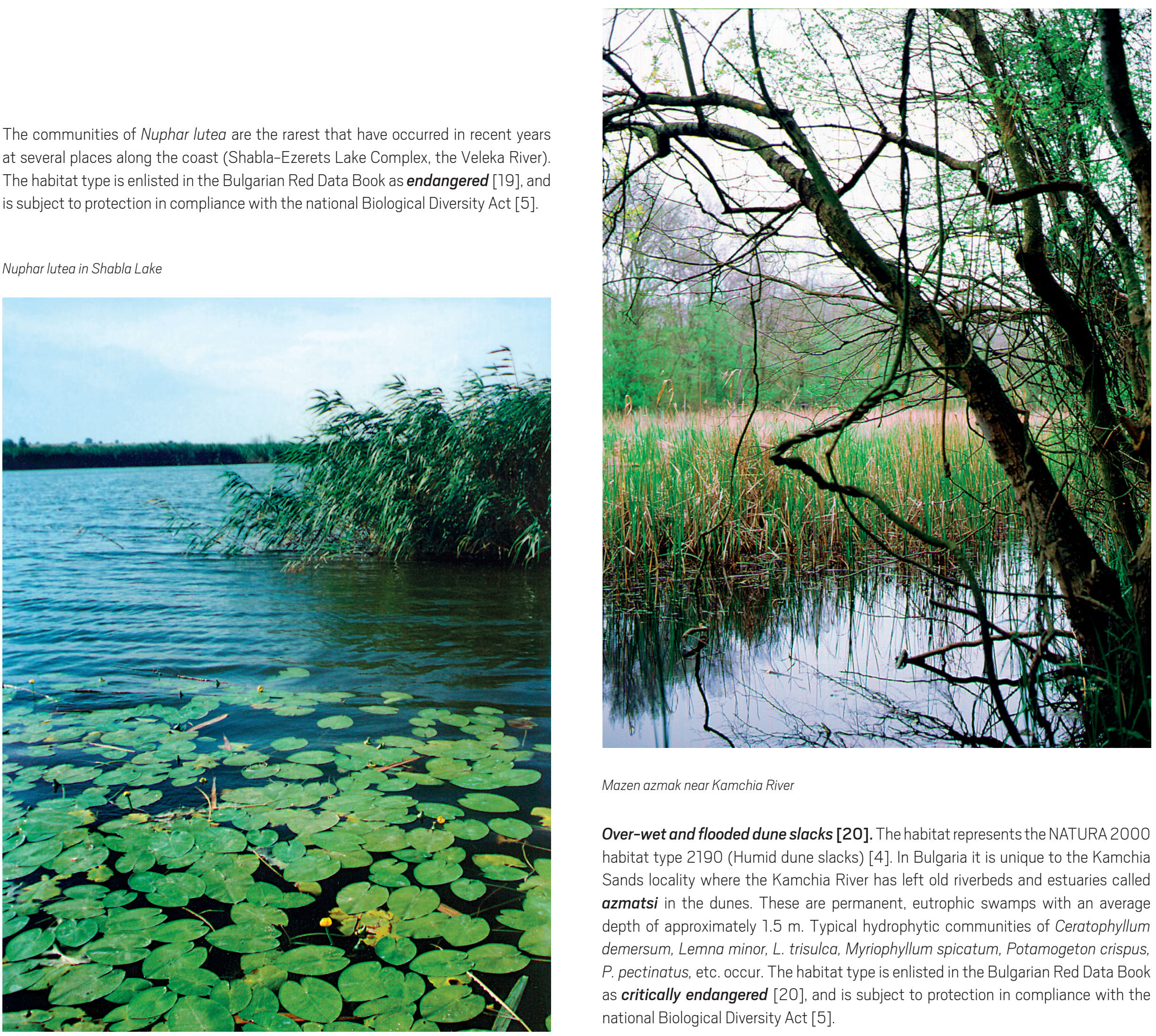

Mazen azmak near Kamchia River

Over-wet and flooded dune slacks [20]. The habitat represents the NATURA 2000 habitat type 2190 (Humid dune slacks) [4]. In Bulgaria it is unique to the Kamchia Sands locality where the Kamchia River has left old riverbeds and estuaries called azmatsi in the dunes. These are permanent, eutrophic swamps with an average depth of approximately $1.5 \mathrm{~m}$. Typical hydrophytic communities of Ceratophyllum demersum, Lemna minor, L. trisulca, Myriophyllum spicatum, Potamogeton crispus, $P$. pectinatus, etc. occur. The habitat type is enlisted in the Bulgarian Red Data Book as critically endangered [20], and is subject to protection in compliance with the national Biological Diversity Act [5] 
7. The longoz forest at the Batova River downstream, established as Baltata Managed Reserve (North Bulgarian coast)

2. The longoz forest at the Kamchia River downstream, established as Kamchia Biosphere Reserve (Central Bulgarian coast)

Riparian and lowland mixed woodlands and longozes [21]. The habitat represents a variety of the NATURA 2000 habitat type 91F0 (Riparian mixed forests of Quercus robur, Ulmus laevis and U. minor, Fraxinus excelsior or Fr. angustifolia, along the great rivers, or Ulmenion minoris) [4]. Longozes are typical for the transitional continental and Mediterranean climate with mild and humid winters. This is the reason why these forests occur mainly in places close to the Black Sea, in the valleys of the Veleka. Ropotamo, Kamchia, Batova, etc., where the sea accounts for a milder climate. The presence of many species with winding stems (lianas) is the reason why these forests are called longoz. The dominant arboreal species are Fraxinus oxycarpa and Ulmus minor. The presence of climbing plants with woody and herbaceous stems is typical for these forests: Calystegia sepium, Clematis vitalba, Hedera helix, Humulus lupulus, Periploca graeca, Smilax excelsa, Tamus communis and Vitis sylvestris. The habitat type is enlisted in the Bulgarian Red Data Book as critically endangered [21], and is subject to protection in compliance with the national Biological Diversity Act [5].
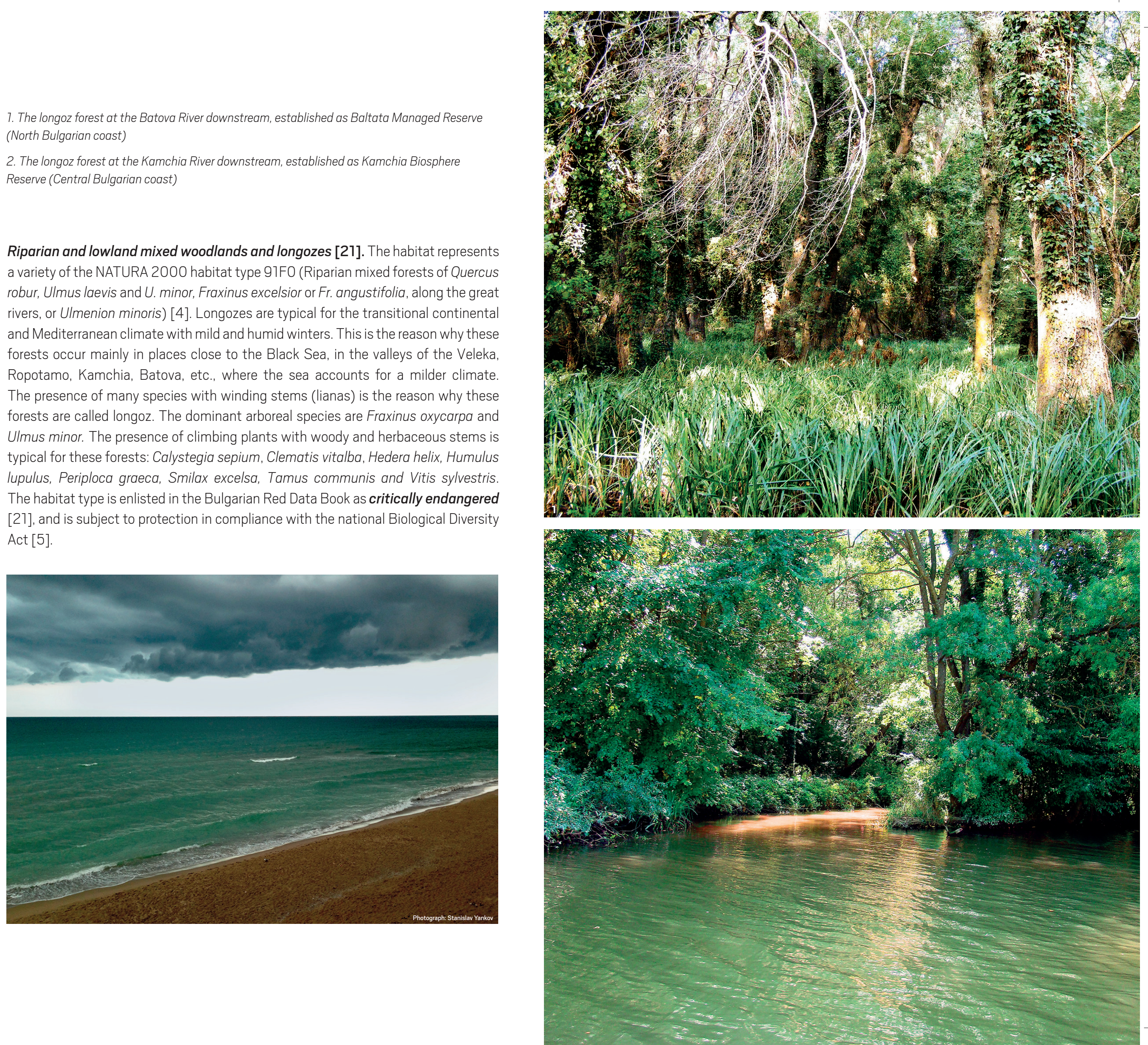


\section{MARINE HABITATS}

\section{HARD-BOTTOM HABITATS}

Mediterranean (blue) mussels and/or barnacle communities on mediolittoral rocks [22]. The habitat represents a variety of the NATURA 2000 habitat type 1170 (Reefs) [4]. It is ubiquitously found in the mediolittoral (pseudolittoral) zone of the Bulgarian Black Sea, at areas with hard (rocky) substrata or submerged structures of anthropogenic origin. Characteristic communities are those dominated by the barnacles Amphibalanus improvisus, A. eburneus, and Chthamalus stellatus (all three are alien species in the Black Sea), the mussels Mytilus galloprovincialis and Mytilaster lineatus. Todorova et al. (2013) [23] distinguish three national biotopes (habitat subtypes) belonging to the above habitat type, namely:
- Upper mediolittoral with Chthamalus stellatus, Melarhaphe neritoides, and Ligia italica;

- Lower mediolittoral with Mytilus galloprovincialis and Mytilaster lineatus;

- Mediolittoral rocks with macro-algae from the genera Corallina spp., Nemalion spp., Scytosiphon spp., etc.

The habitat type is enlisted in the Bulgarian Red Data Book as vulnerable [22], and is subject to protection in compliance with the national Biological Diversity Act [5].

Infralittoral rocks and other hard substrata [24]. The habitat represents a variety of the NATURA 2000 habitat type 1170 (Reefs) [4]. It is distributed at rocky seabed areas, as well as at erosive-landslide and erosive-collapse sectors with underwater accumulations of blocks and boulders, at depths varying between 0.5 and $25 \mathrm{~m}$. The epilithic flora consists of various algal species belonging to phyla Chlorophyta,
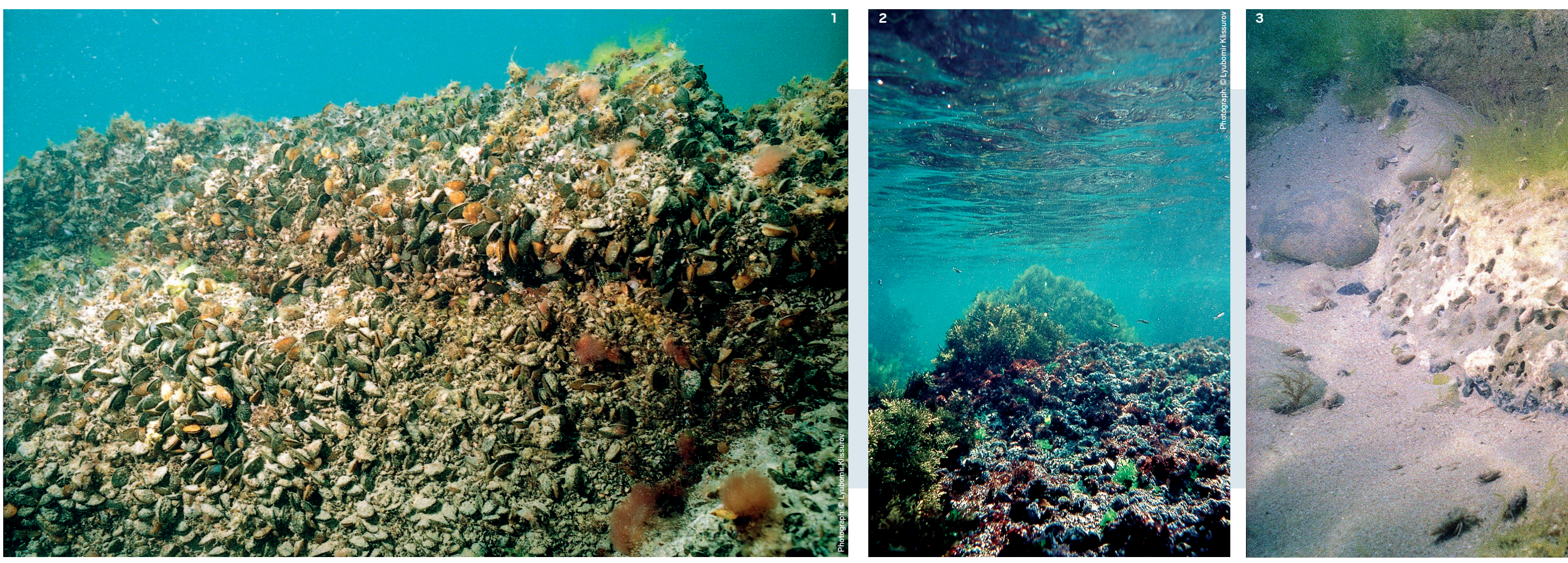


\section{SOFT-BOTTOM HABITATS}

Littoral sands and muddy sands [27]. The habitat represents the NATURA 2000 habitat type 1140 (Mudflats and sand flats not covered by seawater at low tide) [4]. Since the Black Sea is a non-tidal basin, the spatial extent of the mediolittoral (or pseudolittoral) zone overlaps with the surge zone, demarcated by the surf zone from the marine side and by the swash zone from the terrestrial side [23]. Sandy mediolittoral areas are most common for the open types of coast, while the muddy mediolittoral is normally observed at sheltered coastal sites in front of firths, river mouths, and lagoons. Todorova et al. (2013) [23] distinguish one main national biotope (habitat subtype) of marine nature conservation importance belonging to the above habitat type, namely coarse and medium-coarse mediolittoral sands subjected to strong waves with Ophelia bicornis worms and Donacilla cornea clams. Both species are enlisted in the Black Sea Red Data Book as endangered at the regional level and hence requiring basin-scale protection [26]. In addition, the habitat type is enlisted in the Bulgarian Red Data Book as vulnerable [27], and is subject to protection in compliance with the national Biological Diversity Act [5].

Underwater "meadows" of sea grasses [28]. The habitat represents a variety of the NATURA 2000 habitat type 1110 (Sandbanks which are slightly covered by sea water all the time) [4]. Essential habitat engineers are the sea grasses from genera Zostera, Zannichellia, Potamogeton and Ruppia. These macrophytic plants form typical subaqueous "meadows" at depths of 0.5-10 m at protected near-shore sites with unconsolidated substrata (e.g., silty sands, sandy silt, shelly sandy silt, etc.), namely bottoms of river mouths, firths, brackish lagoons, shallow inlets and bays, etc. Both the narrow-leaved eel grass (Zostera marina) and the dwarf eel grass (Z. noltei) are enlisted in the Black Sea Red Data Book [26]. In addition, the habitat type is enlisted in the Bulgarian Red Data Book as endangered [28], and is subject to protection in compliance with the national Biological Diversity Act [5].

Sublittoral sands [29]. The habitat represents a variety of the NATURA 2000 habitat type 1110 (Sandbanks which are slightly covered by sea water all the time) [4]. It is ubiquitously spread along the coastline at depths of 0.5-15 m, reaching as much as $25 \mathrm{~m}$ at the underwater sandbanks. The sandy substrata may vary from fine or very fine gravel and coarse sand to fine and very fine sand. Todorova et al. (2013) [23] distinguish five main national biotopes (habitat subtypes) of marine nature conservation importance belonging to the above habitat type, namely:
- Coarse and medium shallow sand dominated by wedge-shells (Donax trunculus);

- Medium and fine sand dominated by Lentidium mediterraneum clams;

- Clean sand dominated by Arenicola marina worms and Necallianassa sp. burrowing shrimps;

- Sand and silty sand with Chamelea gallina clams;

- Silty sand with Upogebia pusilla mud shrimps (species enlisted in the Black Sea Red Data Book [26]).

The habitat type is enlisted in the Bulgarian Red Data Book as nearly threatened [29], and is subject to protection in compliance with the national Bilogical Diversity Act [5].

Sublittoral mussel beds on sediments [30]. The habitat represents a variety of the NATURA 2000 habitat type 1170 (Reefs) [4]. Principal edificator is the Mediterranean (blue) mussel (Mytilus galloprovincialis) which forms characteristic mussel beds on a broad variety of unconsolidated seabed substrata. These mussel beds represent a constituent part of the natural circum-basin benthic ring of the Mytilidae coenosis which is of critical ecological importance when discussing the self-cleaning abilities of the Black Sea. The habitat type is enlisted in the Bulgarian Red Data Book as vulnerable [30], and is subject to protection in compliance with the national Biological Diversity Act [5]

Some of the soft-bottom habitat varieties in the Bulgarian Black Sea

1 \& 2. Littoral sands and muddy sands

3. Sublittoral sands with hermit crabs

4. An underwater "meadow" of sea grasses

5. A sublittoral mussel bed on sediments 

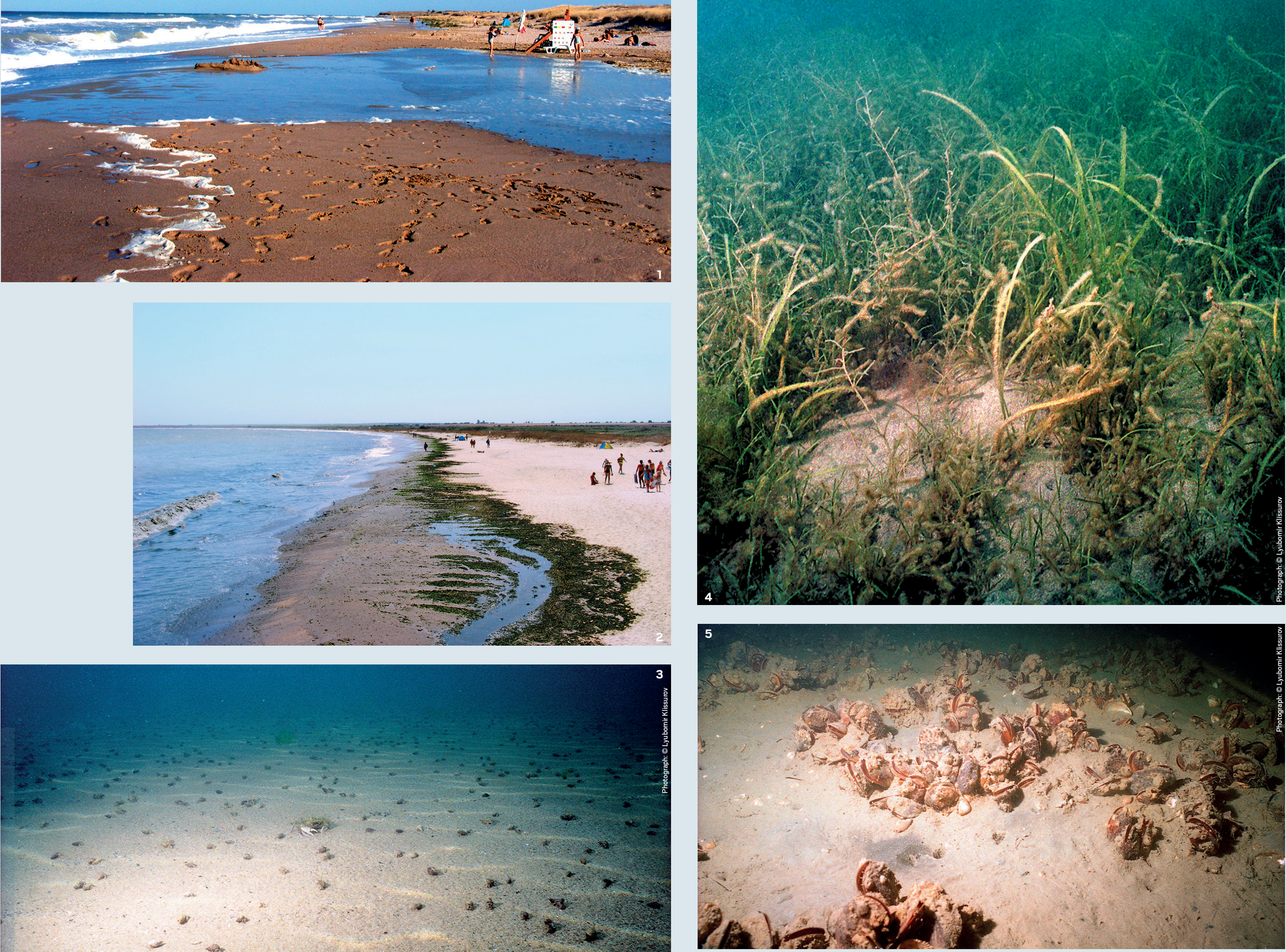

SENSITIVITY MAPPING AND ANALYSIS OF THE BULGARIAN BLACK SEA COASTAL ZONE 


\section{NATIONAL NATURE CONSERVATION AREAS AND NATURA 2000 PROTECTED SITES}

The Black Sea coast is among Bulgaria's physiographic regions with the greatest concentration of nationally designated nature conservation areas (or protected territories as they are termed in the national Protected Territories Act) [37; 32]. Three nature reserves, four managed reserves, two nature parks, numerous protected areas, a lot of natural landmarks, as well as many NATURA 2000 protected sites (declared for the protection of birds, habitats, wild flora and fauna) have been designated here. Nevertheless, far from all nature conservation areas were established solely for the preservation of important biodiversity and natural habitats. Many of them also host rich geodiversity, archaeological, historical, cultural and scientific heritage [33], e.g.:

- Durankulak Lake, Yaylata Protected Area, Kaliakra Reserve and Balchik Botanical Garden on the Dobrudzha coast;

- Zlatni pyasatsi (Golden Sands) Nature Park and Aladzha Monastery Protected Area at the Varna coastal area;

- Pobitite kamani (The Erected Pillars) Protected Area in the vicinity of the Varna-Beloslav Lake Complex;

- Belite skali (The White Cliffs) and Cape Emine natural landmarks at the East Balkan Mountains coastal area;

- Cockatrice Protected Area in Nesebar Bay, its nature conservation properties and importance are discussed in greater detail below:

- Sveti Ivan and Sveti Petar islands Protected Area in front of the coast of Medni rid Ridge;

- Cape Chervenka (Chrisotira) and Cape Agalina natural landmarks, as well as Cape Kolokita Protected Area near Sozopol (Medni rid Ridge coastal area):

- Ropotamo Nature Reserve and Beglik Tash - Ropotamo Protected Area;

- Veleka River Mouth and Silistar Protected Areas in Strandzha Nature Park.

Reserves. Three nature reserves are designated on the Bulgarian Black Sea coast, namely Kaliakra, Kamchia and Ropotamo [35].
Kaliakra Reserve on the Dobrudzha coast is among the very first nature conservation areas in Bulgaria, initially designated as a national park in 1941 for the preservation of Mediterranean monk seals (Monachus monachus) [31]. Nowadays it encompasses the homonymous cape near the village of Balgarevo, together with the representative cliff coastline located northeast of it and the small but picturesque inlet known as Bolata Cove. The purpose of its declaration is to preserve the characteristic Dobrudzha steppe landscapes and ecosystems, numerous rare, relic and endemic plant and faunal species together with their typical habitats, as well as the intriguing coastal and karst landforms. In addition, Kaliakra Reserve is an important area for raptors and migratory birds, as well as one of the two nationally designated nature conservation areas that include marine aquatory. Subject to marine nature conservation are benthic biotopes which represent subtypes of the NATURA 2000 habitats 1110 (Sandbanks which are slightly covered by sea water all the time) and 1170 (Reefs) [34]. Last but not least, Kaliakra Reserve overlaps the homonymous archaeological reserve [35].

Kaliakra Reserve

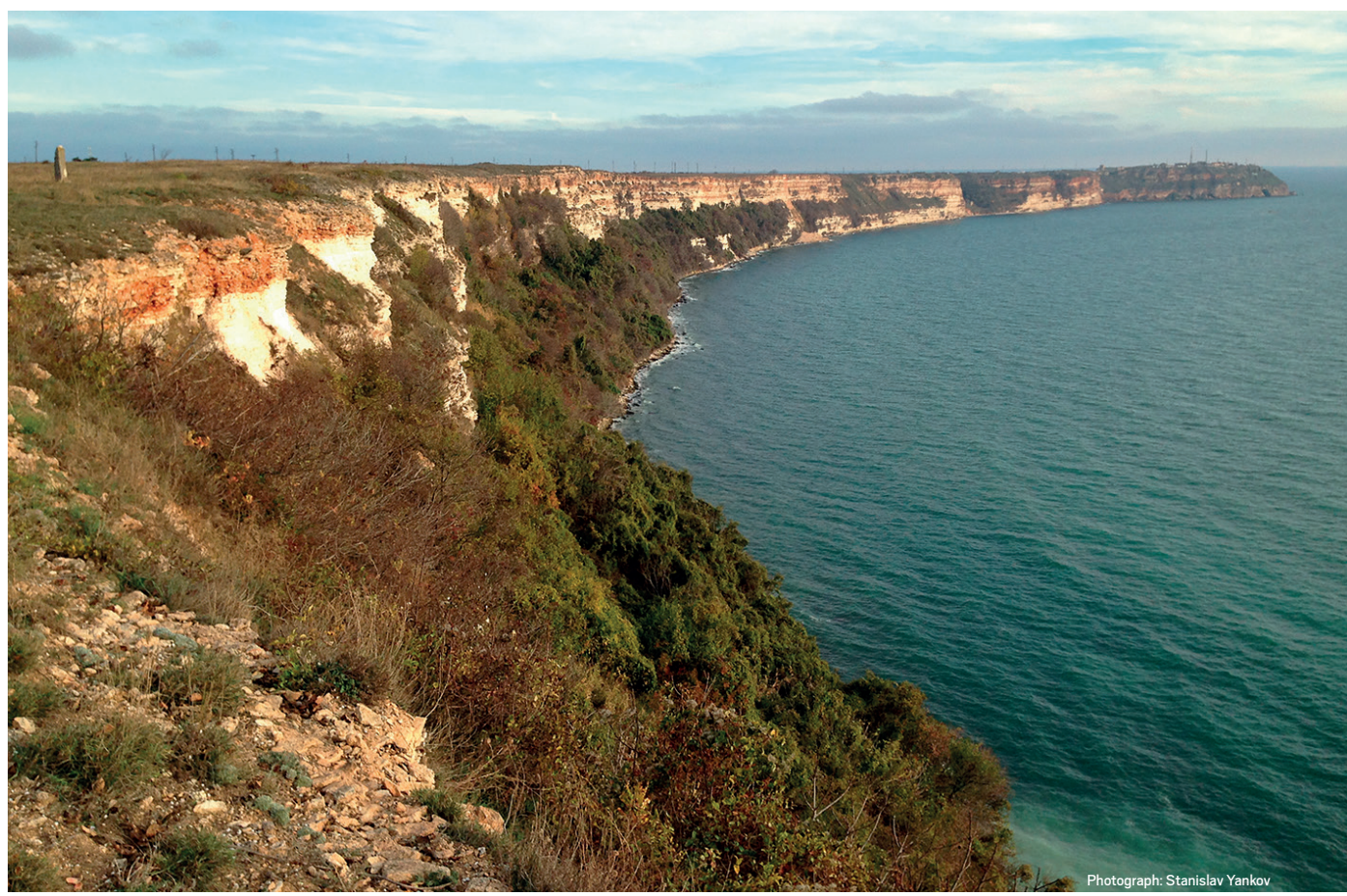




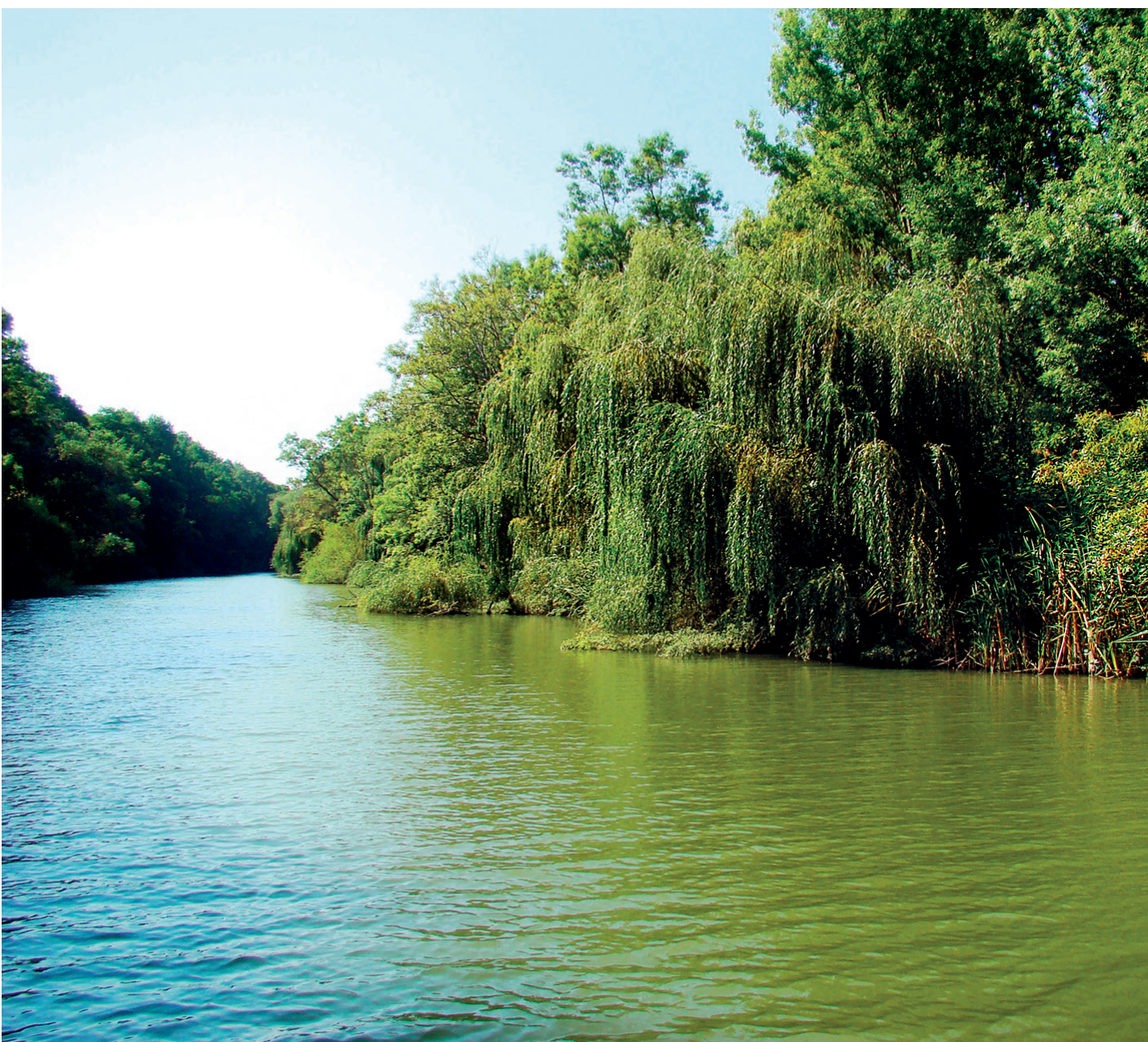

Kamchia Biosphere Reserve

Kamchia Biosphere Reserve is located at the homonymous coastal sector occupying the downstream and the floodplain-firth area of the largest Bulgarian Black Sea tributary, the Kamchia River. The major reason for its designation is the preservation of the endemic floodplain forest landscape, hosting Europe's most representative longoz ecosystems [31]. In addition, Kamchia Reserve is an important area for migratory and wading birds, numerous fresh-water fish species, amphibians, reptiles and some mammals extremely dependent on river habitats, e.g., the otter (Lutra lutra). Formally declared in 1951, the forest's protected status dates back to the period of the Ottoman Empire [36].

Ropotamo Reserve is located north of the town of Primorsko (South Bulgarian coast). It was declared in 1992 after the effacement of the homonymous national

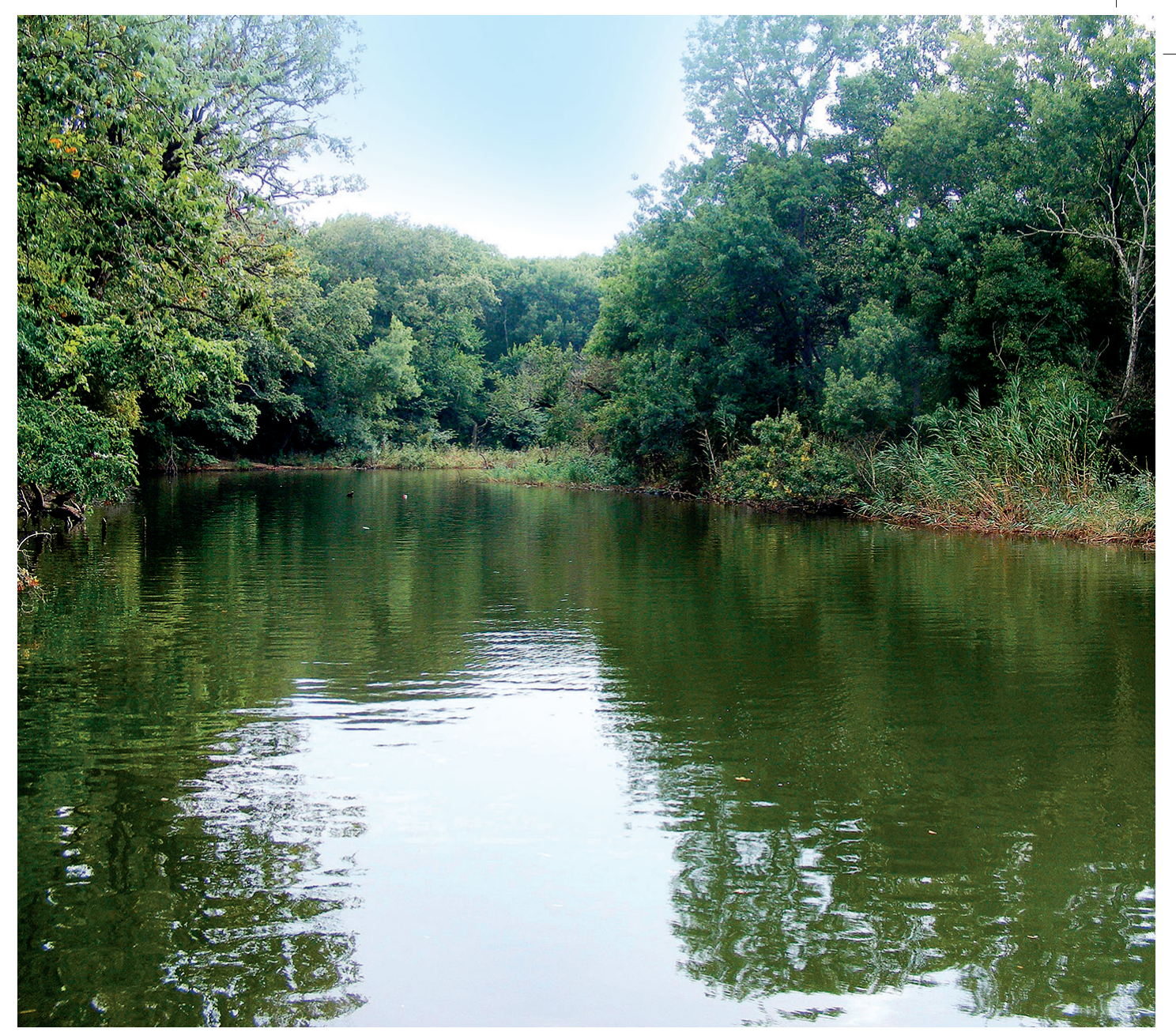

Ropotamo Reserve

park. It includes a large portion of the former nature conservation area, including Arkutino Lagoon, the Ropotamo River downstream, estuary and beach-dune complex the area of Cape Maslen nos and Sveti Toma island [31]. Thanks to the great variety of geomorphic and landscape types included (oak-dominated and longoz-type deciduous forests, a brackish lagoon and a firth, a rocky island, coastal dunes, erosive cliffs, both rocky and accumulative seabed sectors, etc.), the habitat diversity of the reserve is also outstanding, making Ropotamo the most diverse nature reserve on the Bulgarian coast.

Managed reserves. Four managed reserves are designated on the Bulgarian Black Sea coast, namely Baltata, Atanasovsko Lake, Pyasachnata lilia (The Sea Daffodil) and Vodnite lilii (The Water Lilies) 
Baltata Managed Reserve is located north of the Varna coastal area, between the village of Kranevo and Albena Resort. It occupies the river downstream and the floodplain-firth area of the Batova River. The reserve was designated in 1962 following the advice of British researchers Guy Mannford and Eric Hosking in order to preserve Europe's northernmost longoz forest. This nature conservation area has been one of the most conflictive biodiversity hotspots on the Bulgarian coast ever since the construction of the contiguous Albena resort, which even lead to its effacement from the register of protected territories in the period 1974-1978 [31].

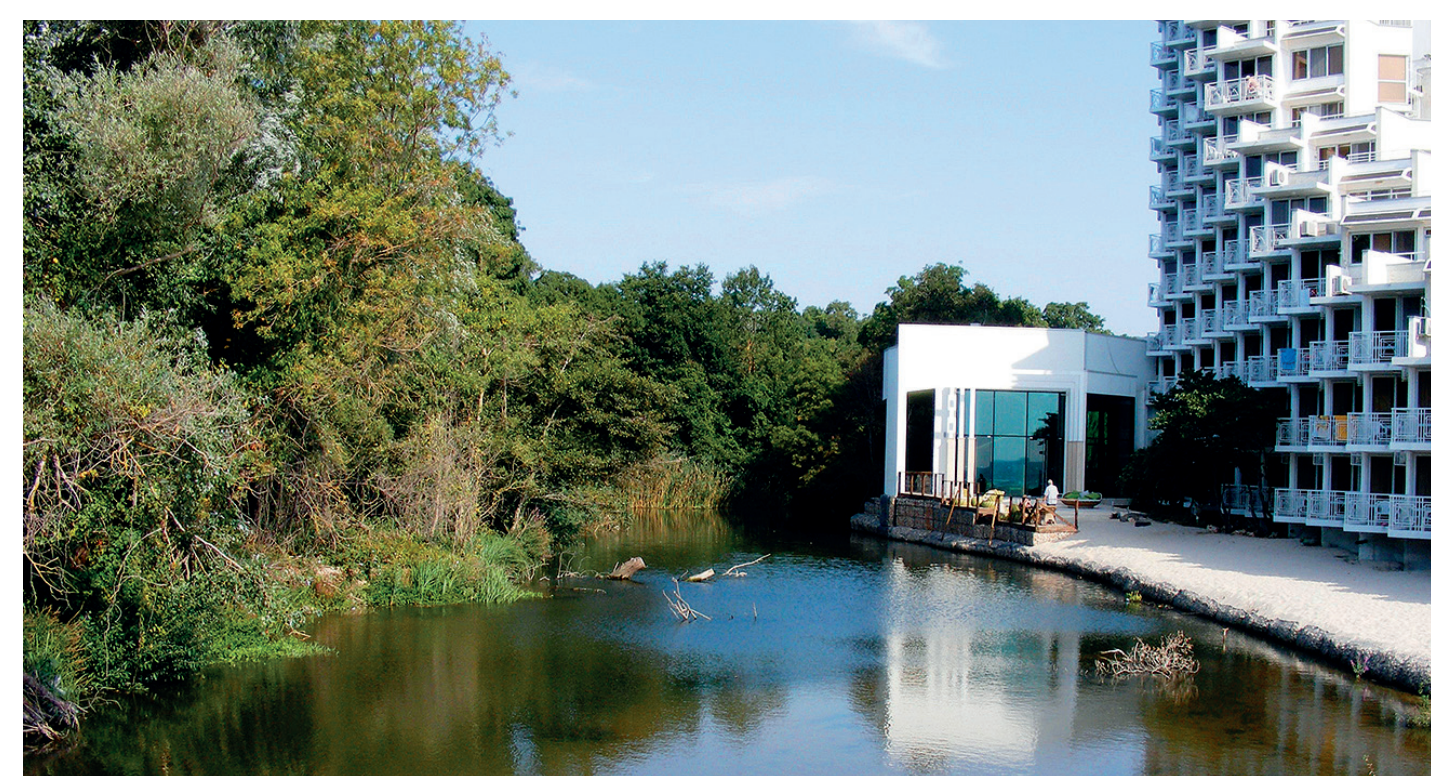

Atanasovsko Lake is located in the Burgas Lowland, north of Burgas. It was established as a protected area in 1974, but was re-categorized into a reserve in 1980 [31]. Despite being a hypersaline basin, in geomorphic sense it is a shallow firth [37]. Most of it was converted into salt works in the period after 1922. The lake is a representative example of the Bulgarian Red Data Book habitat types submerged macrophytic communities in hypersaline water bodies [15], hypersaline coastal lakes and swamps [16], communities of annual halophytes in coastal salt marshes at the Black Sea [17], and Mediterranean halophytic communities of tall rushes, sedges and grasses [18]. In addition, it is among the ornithologically most important sites in Bulgaria [31].

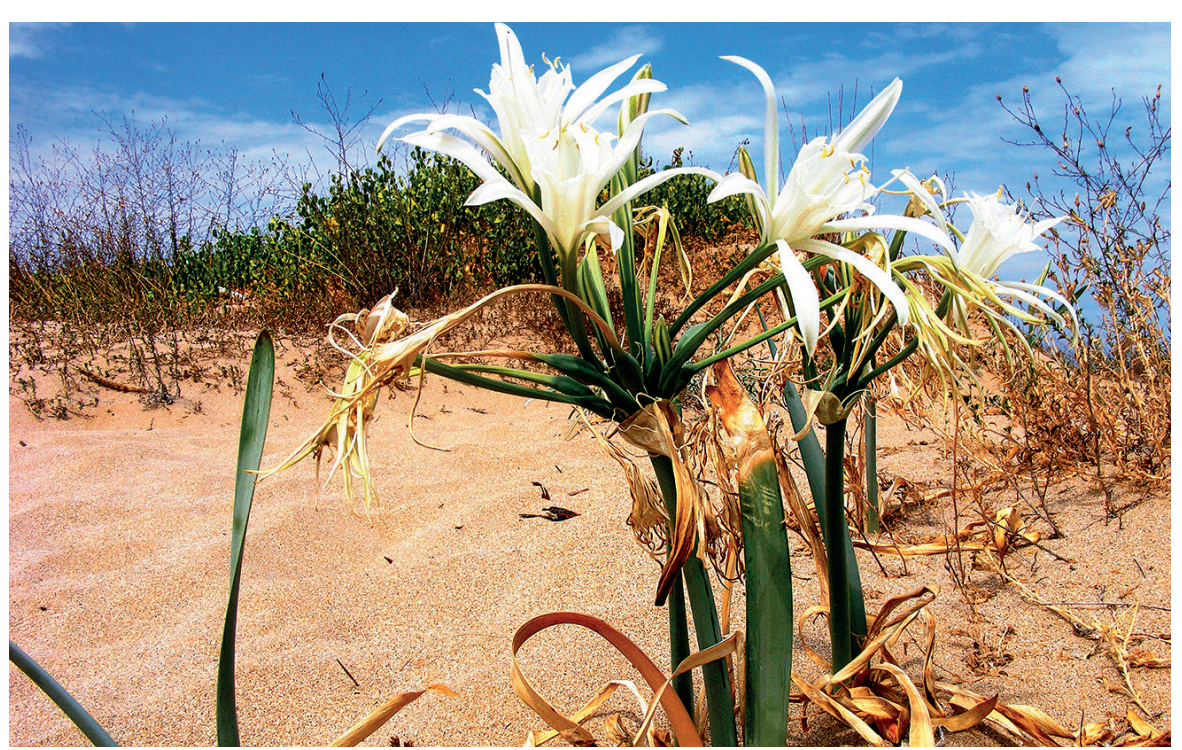

Pyasachnata lilia (The Sea Daffodil) Managed Reserve

Pyasachnata lilia (The Sea Daffodil) Managed Reserve is located in Kavatsite locality south of the town of Sozopol (Medni rid Ridge coastal area). Designated in 1961 in order to preserve one of the most representative dune habitats of the sea daffodil (Pancratum maritimum) in Europe, nowadays it is blacklisted as one of the worst managed nature conservation areas in Bulgaria [37]. The major threat for the managed reserve is the expansion of the resort areas in Sozopol Municipality.

Vodnite lilii (The Water Lilies) Managed Reserve occupies the old river bed of the Ropotamo. It was designated in 1962 in order to preserve the longoz forest and the wetland habitats of the white water lily (Nymphaea alba), yellow water lily (Nuphar lutea), and summer snowflake (Leucojum aestivum) [31].

Nature parks. Two nature parks are designated on the Bulgarian Black Sea coast, namely Zlatni pyasatsi (Golden Sands) and Strandzha.

Zlatni pyasatsi (Golden Sands) Nature Park occupies the northeastern portion of the Franga Plateau. Designated in 1943, nowadays it is located some 17 km north of Varna, between the plateau escarpment and the shore, right above the homonymous seaside resort. The park's landscape pattern consists mainly of deciduous forests 


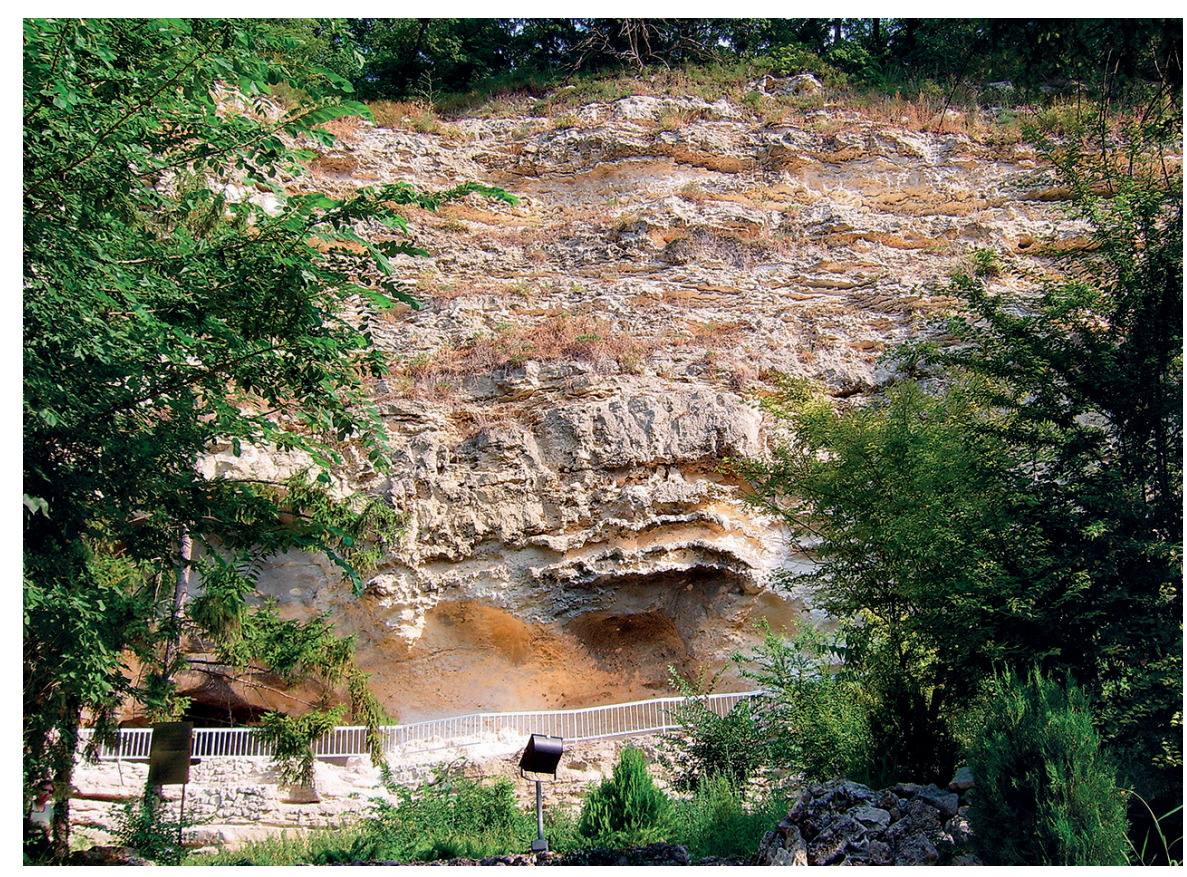

Aladzha Monastery, Zlatni pyasatsi Nature Park

dominated by common hornbeam (Carpinus betulus), Turkish oak (Quecus cerris) and Italian oak (Q. frainetto) [31]. In addition, it preserves examples of the characteristic longoz and sublongoz habitats, sub-Mediterranean shrubs, as well as some protected plants, e.g., violet bird's nest orchid (Limodorum abortivum) - a Tertiary relict species, Caucasian primrose (Primula acaulis ssp. rubra), wood anemone (Anemone nemorosa), Oriental trachystemon (Trachystemon orientalis), etc. The ornithofauna of Zlatni pyasatsi Nature Park includes 80 birds, mostly typical forest species. It is also rich in amphibians, reptiles and mammals [37]. Finally, Zlatni pyasatsi Nature Park preserves rich cultural and historical heritage from a wide range of periods, from the Antiquity to the Late Middle Ages. The most prominent remnant among these is Aladzha Monastery (a medieval cliff complex from the $13^{\text {th }}-14^{\text {th }}$ century), designated as a separate protected area within the nature park [35].

Strandzha Nature Park occupies the southeasternmost part of Bulgaria, contiguous to the border with Turkey, and represents the largest nature conservation area on the Bulgarian coast. Designated in 1995, its purpose is to preserve the examples of Southeuxinian flora and Tertiary relic species in the catchment basins of the Veleka and Rezovska rivers. Similarly to Ropotamo Reserve, Strandzha Nature Park encom- passes a considerable variety of geomorphic and landscape types, which together with the specifics of the regional climate and flora account for an outstandingly rich habitat diversity found nowhere else in Bulgaria. The geological, cultural, historical, and archaeological (Thracian in particular) heritage of the Strandzha Mountain is of paramount importance to researchers. The park includes a great number of additional nature conservation sites, e.g

- The landlocked Silkosia, Tisovitsa, Lopushna, Vitanovo and Sredoka Nature Reserves;

- Several natural landmarks, e.g., Nakovo kladenche near the coastal town of Ahtopol:

- The coastal protected areas of Ustie na reka Veleka (Veleka River Mouth) and Silis$\operatorname{tar}[31]$.

The coastal zone of Strandzha Nature Park

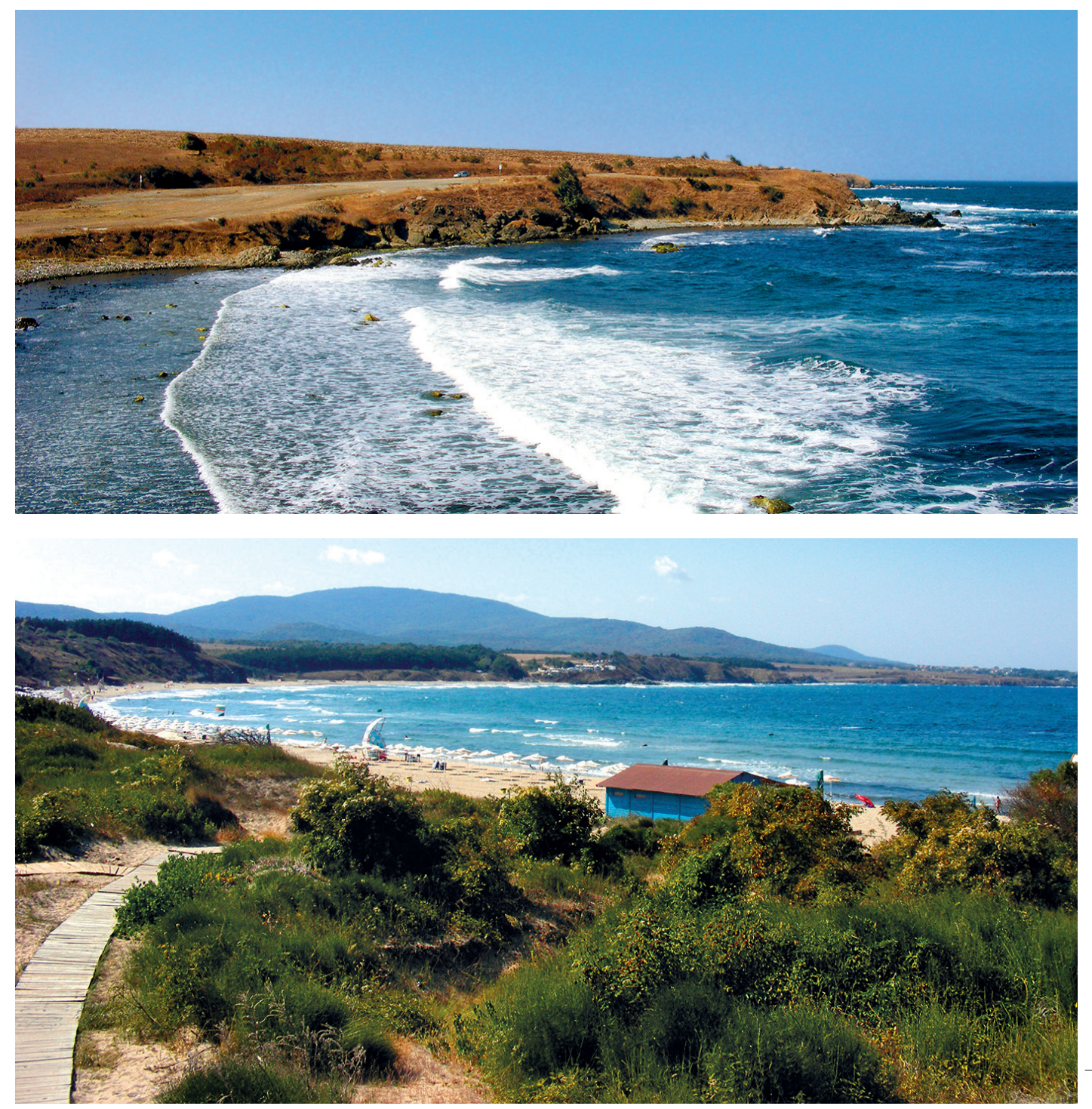


Natural landmarks. The total number of natural landmarks on the Bulgarian coast is impressive. These include the following (from north to south):

- Belite skali (The White Cliffs) - located in the area of Cape Beli nos (north of the town of Byala, Central Bulgarian coast), occupying the space between the northern section of the town's beach and the firth of Belensko dere Ravine. Designated for the preservation of geological and geomorphological heritage [38]
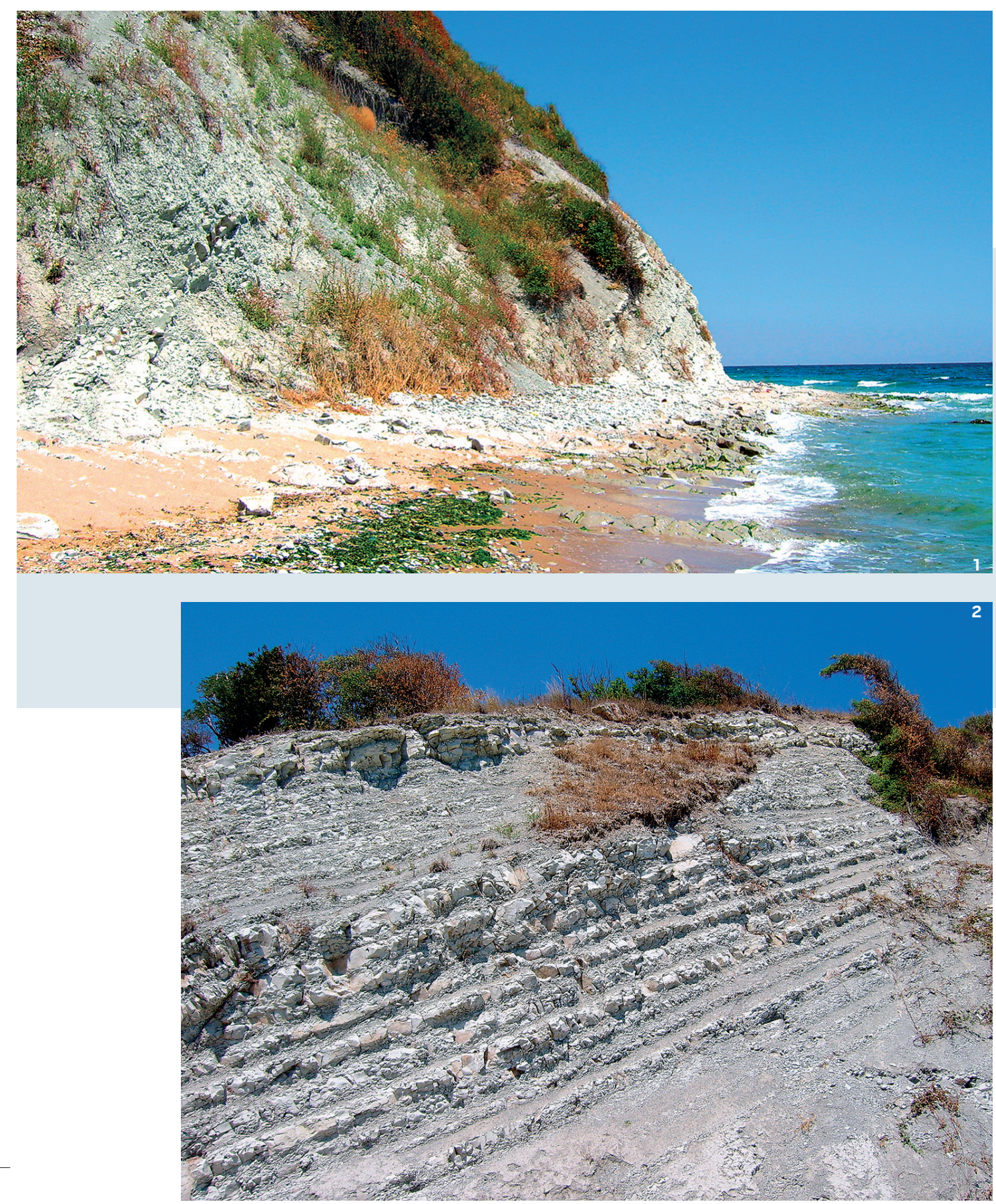

- Cape Emine - represents the easternmost tip of the Balkan Mountains, located $2 \mathrm{~km}$ southeast of the village of Emona (Nesebar Municipality). Designated for the preservation of geological and geomorphological heritage [39];

- Sand dunes at Babata locality-Slanchev bryag (Sunny Beach) - located between Sunny Beach Resort and the town of Nesebar (South Bulgarian coast) Designated for the preservation of a typical dune landscape with psammophytic vegetation [35];

- Cape Chervenka (Chrisotira) - located north of the town of Sozopol, Medni rid Ridge coastal area (South Bulgarian coast). Designated for the preservation of geological and geomorphological heritage [35];

- Sand dunes between Zlatna Ribka and Gradina camp sites - located north of the town of Sozopol. Designated for the preservation of a typical dune landscape with psammophytic vegetation [35]

1 \& 2. Belite skali (The White Cliffs) near the town of Byala 3. Cape Emine

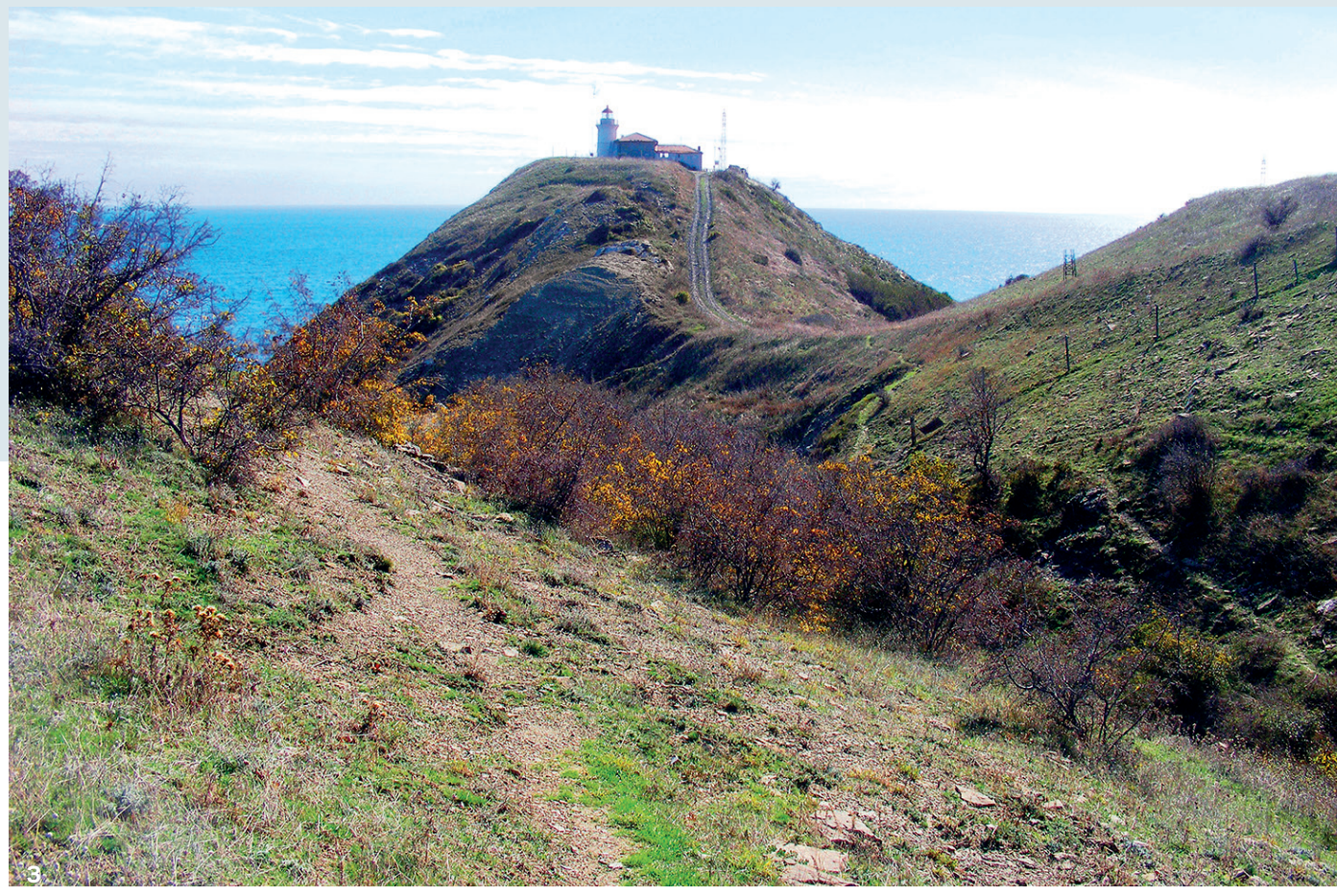


- Sand dunes at Kavatsite locality - located south of the town of Sozopol. Designated for the preservation of a typical dune landscape with psammophytic vegetation [35];

- Cape Agalina - located south of the town of Sozopol. Designated for the preservation of geological and geomorphological heritage [35];

- Alepu - located south of the town of Sozopol. Designated for the preservation of the hygrophilous and hydrophytic vegetation in the brackish lagoon, important habitats of migratory birds as well as the local herpetofauna [35];

- Sand dunes at Perla locality - located north of the town of Primorsko (Strandzha coastal area). Designated for the preservation of the typical dune landscape with psammophytic vegetation [35];

- Sand dunes at the International Youth Center - located south of the town of Primorsko (Strandzha coastal area). Designated for the preservation of the typical dune landscape with psammophytic vegetation [35]

4. Dunes at Babata locality between Sunny Beach resort and the town of Nesebar

5. The area near Cape Agalina

6. Alepu Lagoon

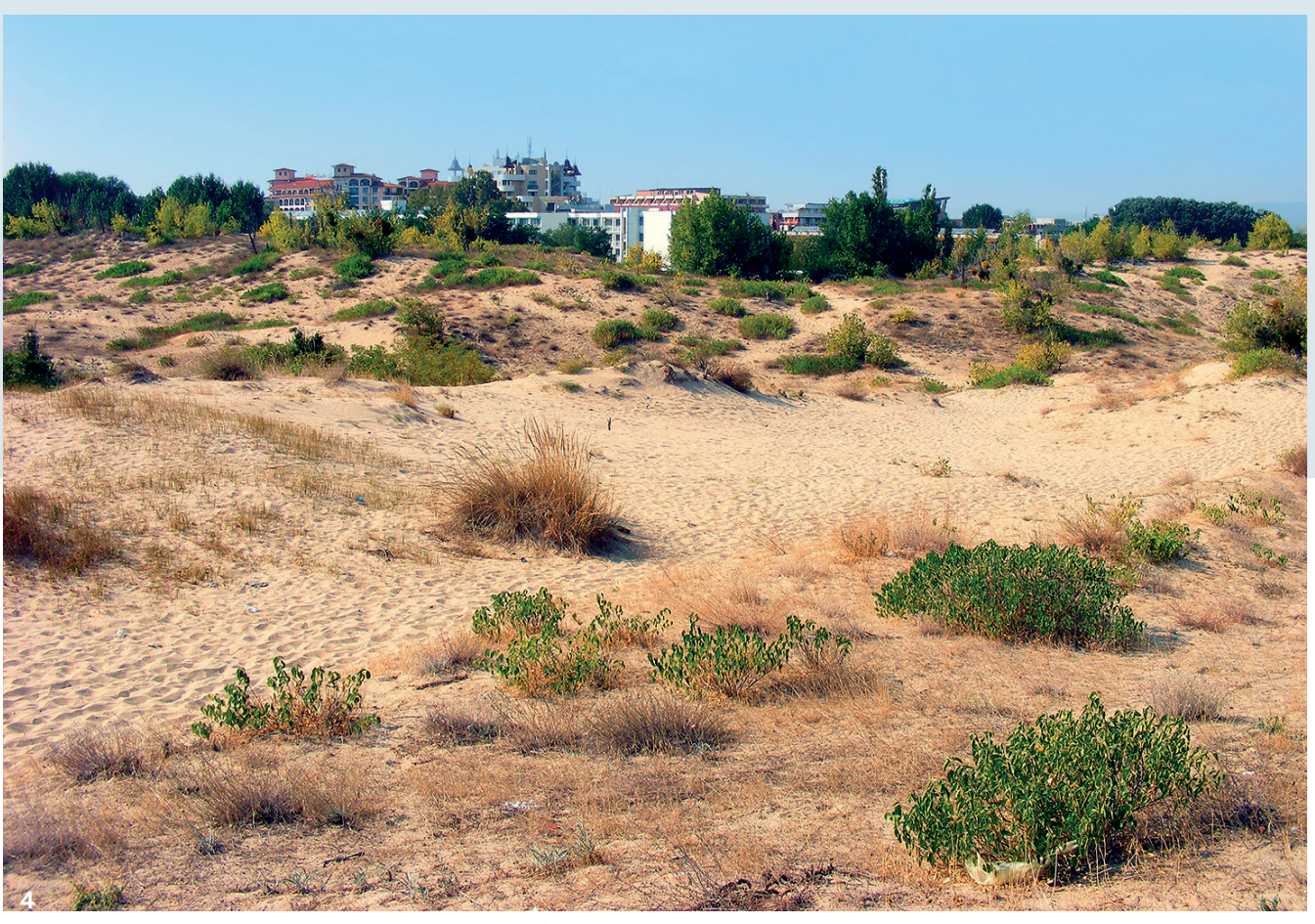

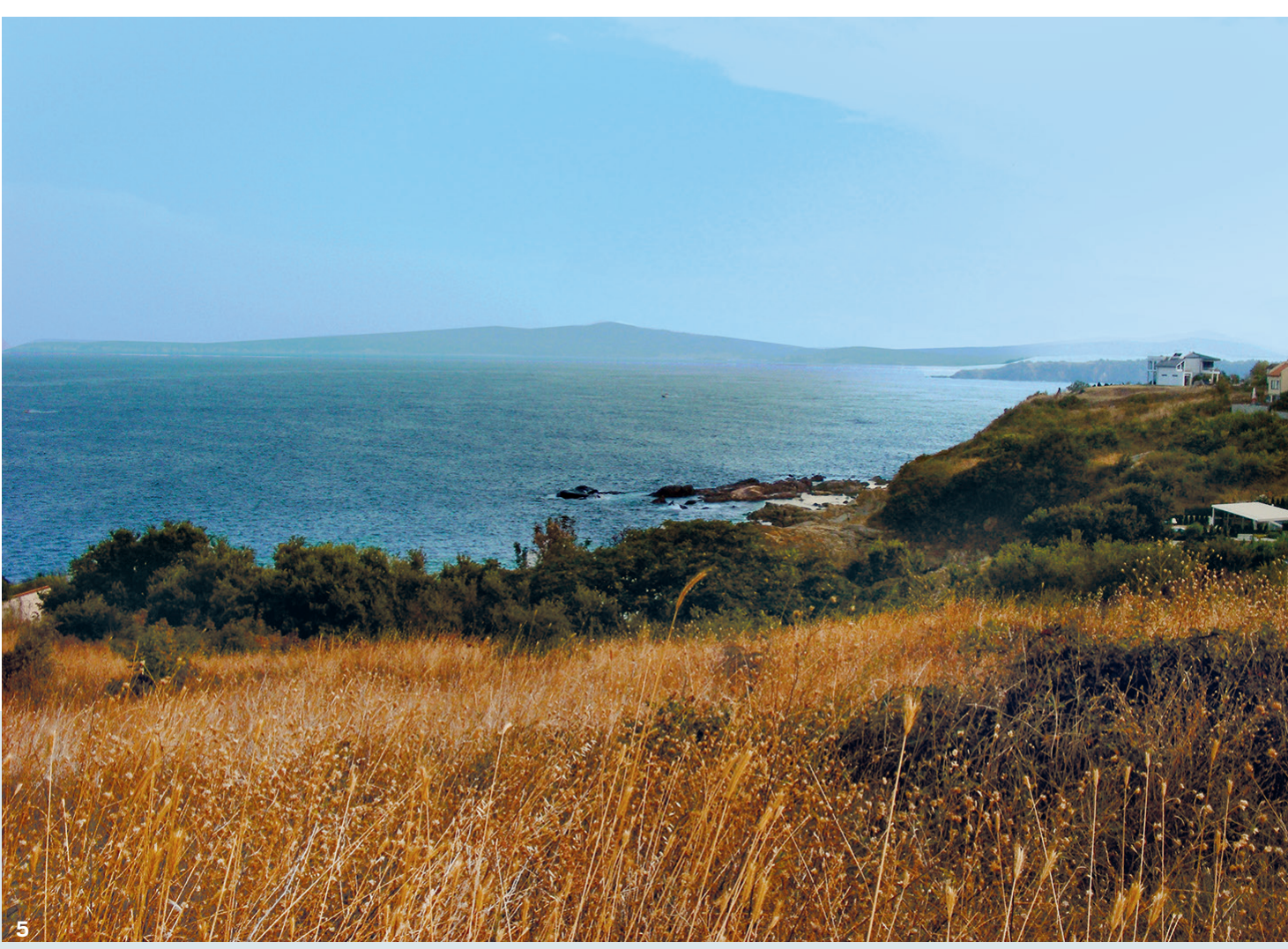

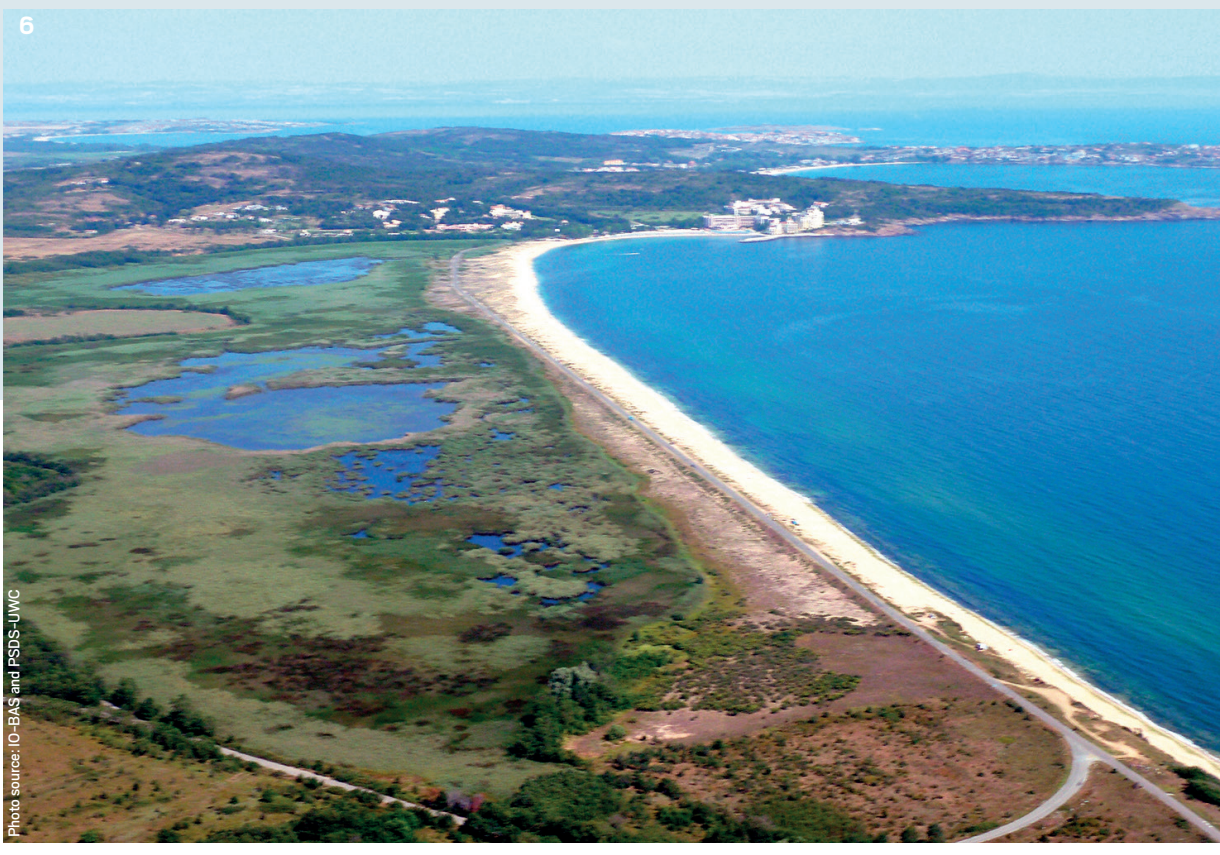

SENSITIVITY MAPPING AND ANALYSIS OF THE BULGARIAN BLACK SEA COASTAL ZONE 
Protected areas. This group includes the highest number of coastal and marine nature conservation sites. These include the following (north to south)

- Durankulak Lake and Shabla Lake - located on the Dobrudzha coast, Shabla Municipality. Designated primarily for the preservation of habitats of migratory birds herpeto- and ichthyofauna, as well as communities of hygrophilous and aquatic vegetation [35];

- Yaylata - located north of Kaliakra Reserve, this protected area shares numerous geomorphic, landscape, habitat and archaeological similarities with it [35];

- Stepite (The Stepppes) - represents the buffer zone of Kaliakra Reserve [35];

- Blatno kokiche (Summer Snowflake) - represents the buffer zone of Baltata Managed Reserve [35];
- Kazashko and Mochurishteto (The Quagmire) - located on the northern shore of Varna Lake, these two are important nesting sites and foraging areas for birds [35];

- Pobitite kamani (The Erected Pillars) - located in the vicinity of the Varna-BeIoslav Lake Complex, west of Varna. The protected area represents a geomorphic complex of 18 groups of pillars (cemented chimneys) scattered in an inland dune landscape with a semi-desert appearance. The genesis of these pillars is subject of ongoing scientific debates. De Boever et al. (2006) [40] suggest that it relates to ancient hydrocarbon seepage.

- Longoza (The Longoz) - represents the buffer zone of Kamchia Biosphere Reserve [35]
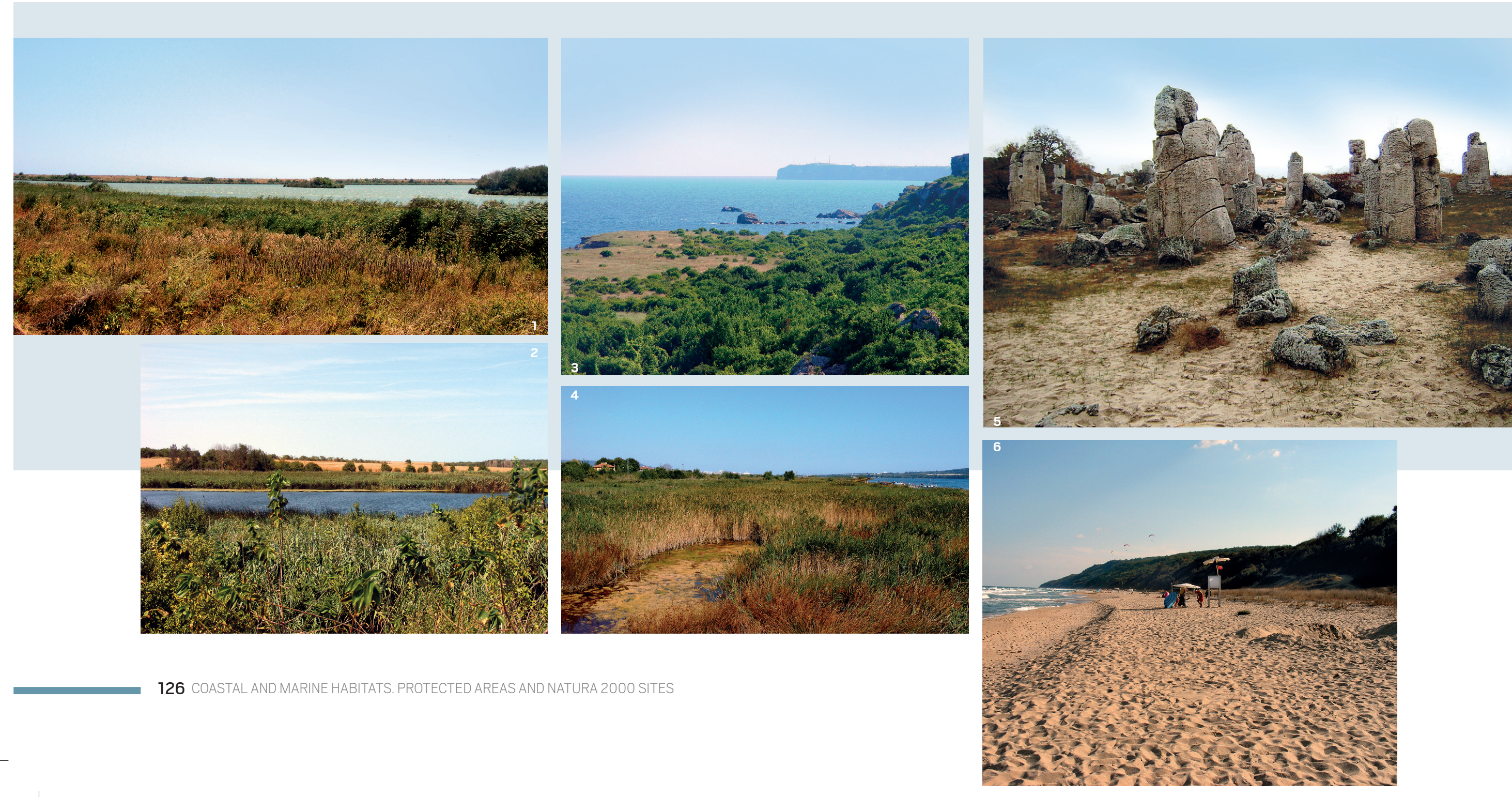


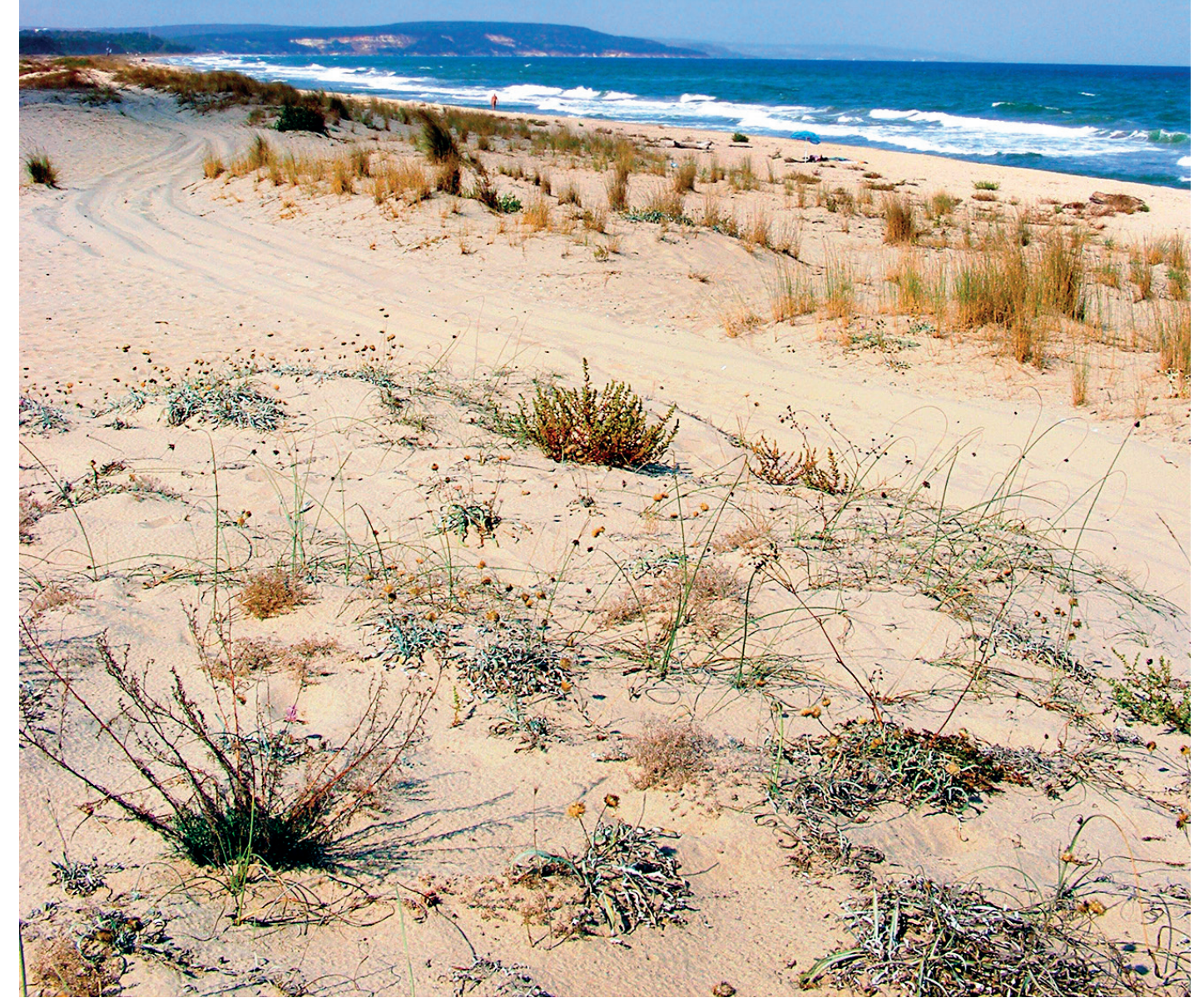

NATURA 2000 protected sites designated in compliance with Council Directive 92/43/EEC (Habitats Directive). As a EU member state, Bulgaria is committed to the creation of a coherent NATURA 2000 ecological network hosting the natural habitat types listed in Annex I and habitats of the species listed in Annex II of Council Directive 92/43/EEC (Habitats Directive) [4]. Also, the country is obliged to enable the habitats and populations of species concerned to be maintained at, or restored to, favorable conservation status [41]. Hence, a total of 28 NATURA 2000 protected sites have been designated on the Bulgarian coast and in the Bulgarian Black Sea [34]. After completion of Extension of the NATURA 2000 ecological network in the Bulgarian Black Sea project [42] the marine spatial extents of six previously existent protected sites (Compleks Kaliakra, Galata, Emine-Irakli, Plazh Gradina-Zlatna Ribka, Ropotamo and Strandzha) were significantly expanded. In addition, three new, entirely marine protected sites were also proposed for designation (Aladzha Bank, Emona and Otmanli). Hence, nowadays 17 protected sites designated in compliance with the Habitats Directive include marine aquatory. The cited previously designated, subsequently extended and newly proposed NATURA 2000 sites comprise the fundament of marine nature conservation in Bulgaria. They preserve national benthic biotopes that represent varieties of habitat types 1140 (Mudflats and sand flats not covered by seawater at low tide), 1110 (Sandbanks which are slightly covered by sea water all the time) and 1170 (Reefs). The purpose of the above 17 NATURA 2000 sites is also to protect the populations of the three cetacean species in the Black Sea, as well as those of the fish species Caspian shad (Alosa caspia) and Black Sea (Pontic) shad (Alosa immaculata).

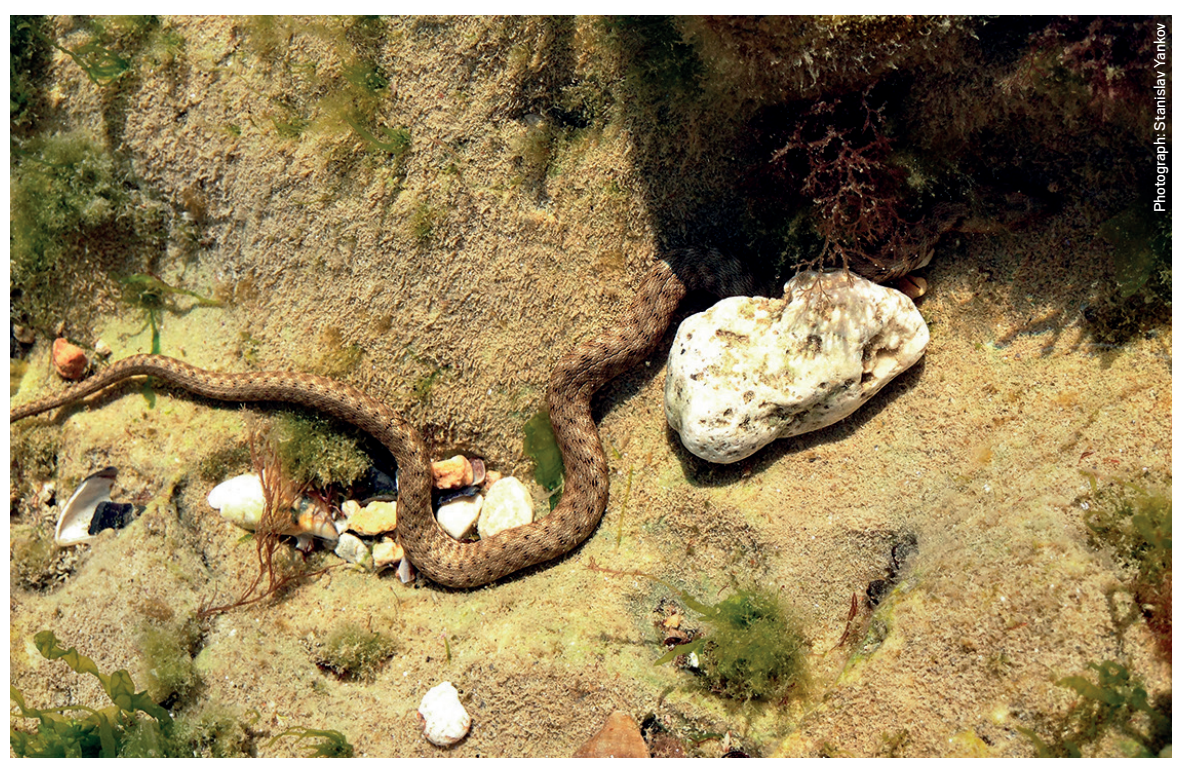


Generalized map scheme of the NATURA 2000 protected sites designated in compliance with Directive 92/43 EEC (Habitats Directive) and the most important nature conservation areas designated on the Bulgarian Black Sea coast in compliance with the Protected Territories Act of Bulgaria (according to data from the Register of the Protected Territories and NATURA 2000 Sites in Bulgaria, 2015 [35])

\section{RESERVES:}

01. Kaliakra

02. Kamchia

03. Ropotamo

\section{MANAGED RESERVES:}

04. Baltata

05. Atanasovsko Lake

06. Pyasachnata lilia (The Sea Daffodil)

07. Vodnite lilii (The Water Lilies)

\section{NATURE PARKS}

08. Zlatni pyasatsi (Golden Sands)

\section{NATURAL MONUMENTS:}

09. Belite skali (The White Cliffs)

10. Cape Emine

11. Sand dunes at Babata locality-Sunny Beach

12. Cape Chervenka (Chrisotira)

13. Sand dunes between Zlatna Ribka and Gradina camp sites

14. Sand dunes at Kavatsite locality

15. Cape Agalina

16. Alepu Swamp

17. Sand dunes at Perla locality

18. Sand dunes at the International Youth Center (town of Primorsko)

\section{PROTECTED AREAS:}

19. Durankulak Lake

20. Shabla Lake
21. Yaylata

22. Stepite (The Steppes)

23. Aromatna matiola (Aromatic Matthiola)

24. Botanicheska gradina - Balchik

(Balchik Botanical Garden)

25. Blatno kokiche (Summer Snowflake)

26. Aladzha Manastir (Aladzha Monastery)

27. Kazashko and Mochurishteto (The Quagmire)

28. Pobitite kamani (The Erected Pillars)

29. Rakitnika

30. Limana (The Firth)

31. Longoza (The Longoz)

32. Smrikite

33. Irakli

34. Cockatrice

35. Ortoto

36. Pomorie Lake

37. Burgaski solnitsi (Burgas Saltworks)

38. Vaya

39. Poda

40. Uzungeren

41. Ustie na reka Izvorska (Izvorska River mouth)

42. Chengene skele

43. Ostrovi Sveti Ivan \& Sveti Petar

(St. Ivan \& St. Petar Islands)

44. Cape Kolokita

45. Beglik Tash-Ropotamo

46. Stomoplo

47. Ustie na reka Veleka (Veleka River mouth)

48. Silistar

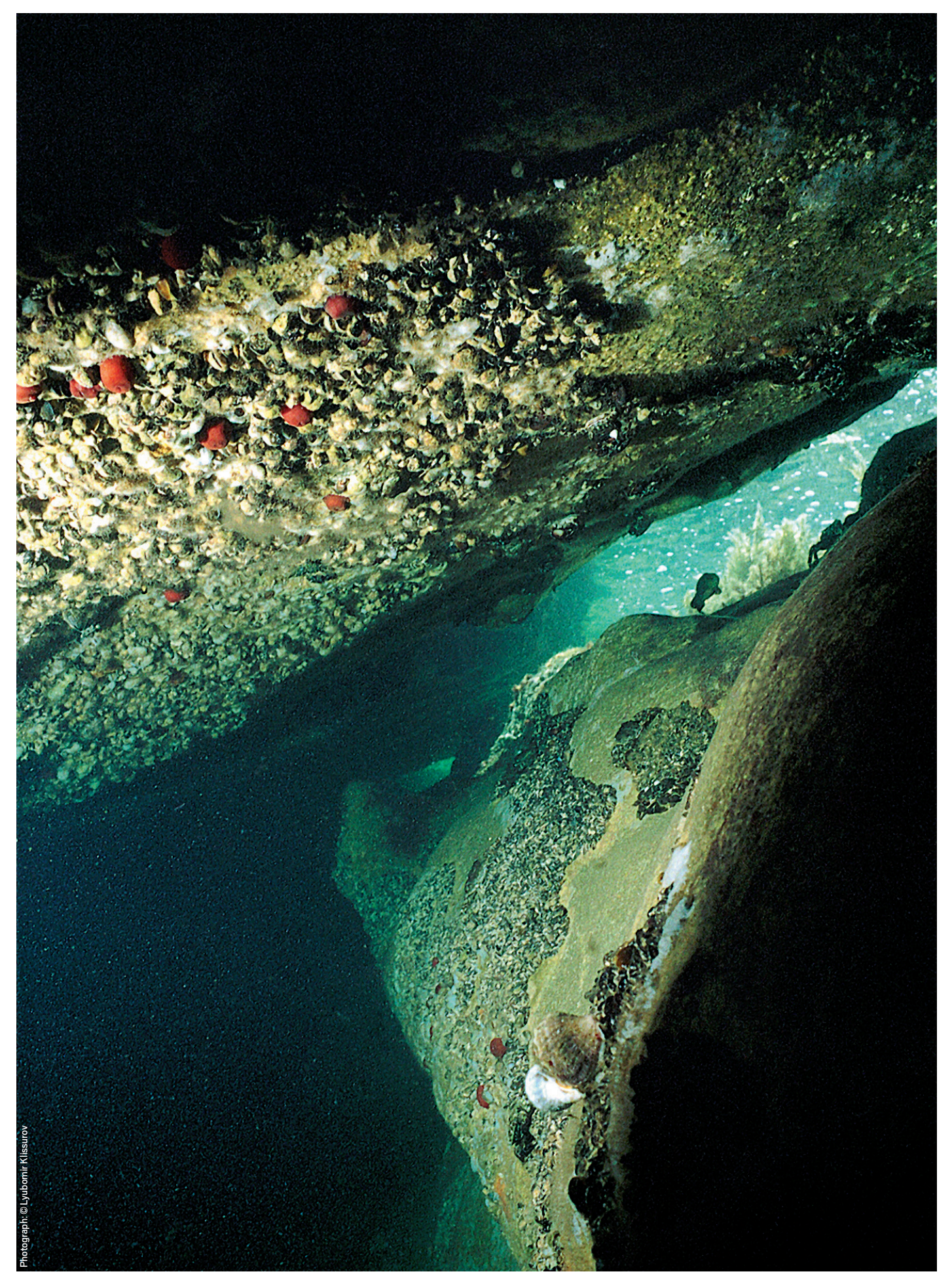

SENSITIVITY MAPPING AND ANALYSIS OF THE BULGARIAN BLACK SEA COASTAL ZONE 


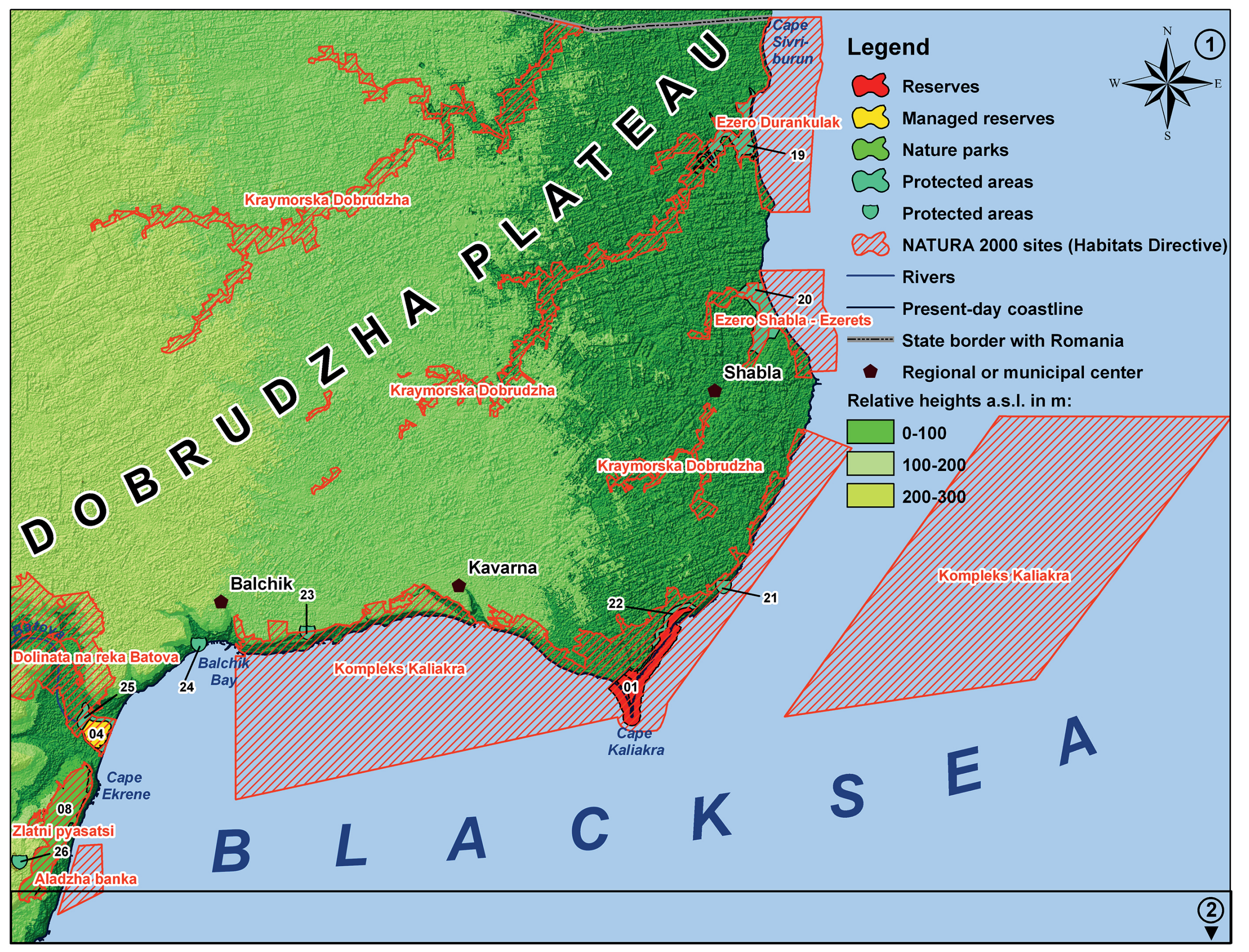

130 COASTAL AND MARINE HABITATS. PROTECTED AREAS AND NATURA 2000 SITES 


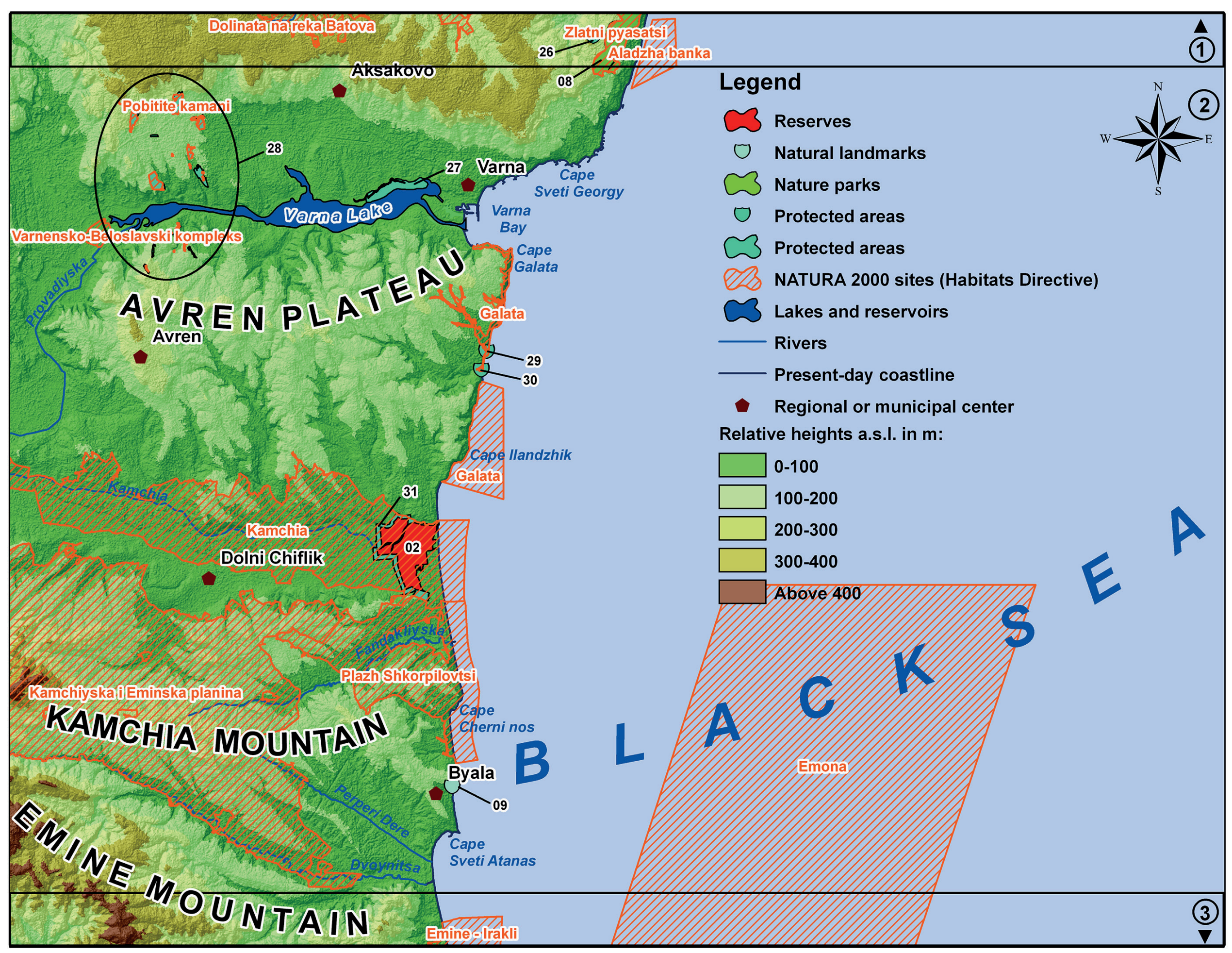




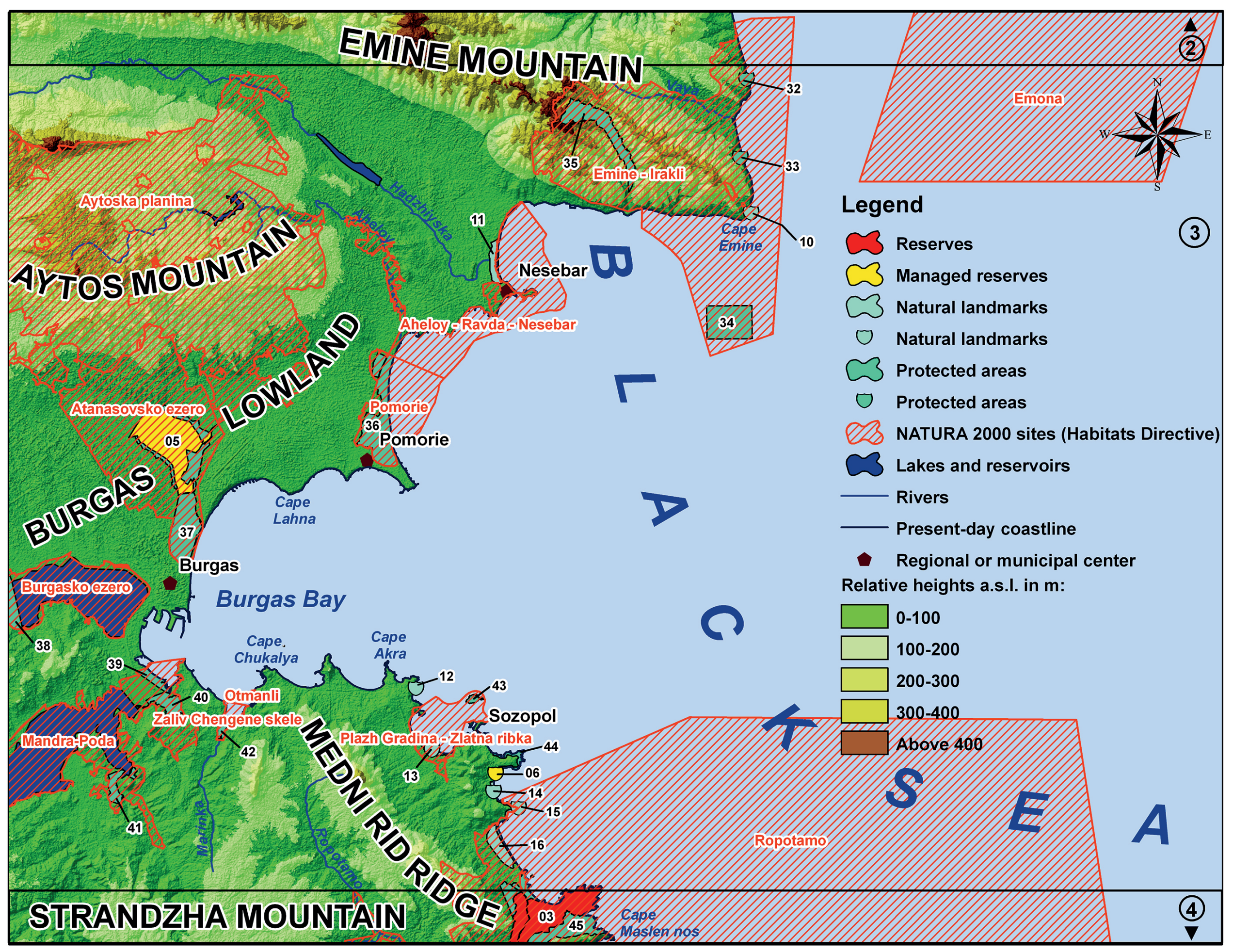

132 COASTAL AND MARINE HABITATS. PROTECTED AREAS AND NATURA 2000 SITES 


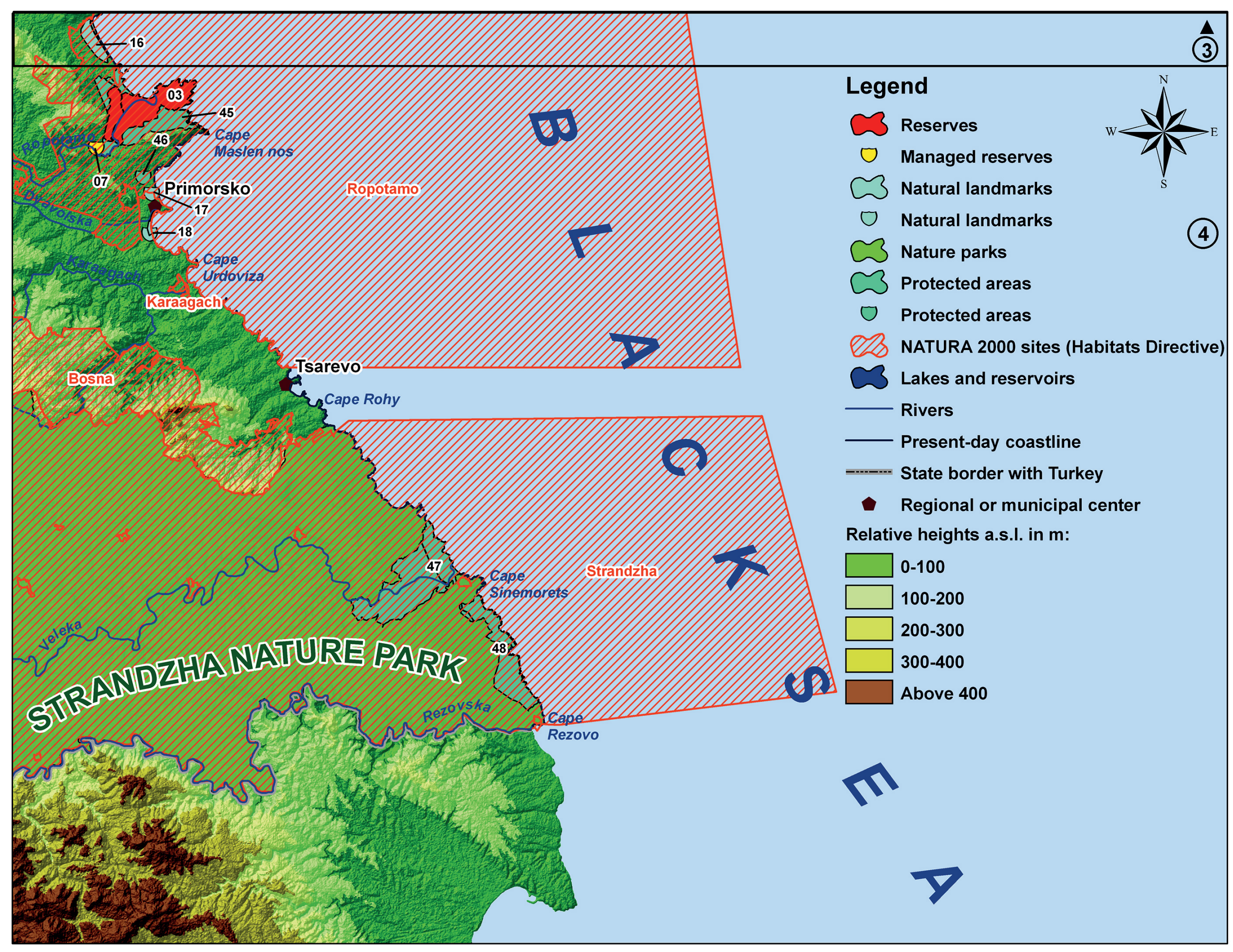




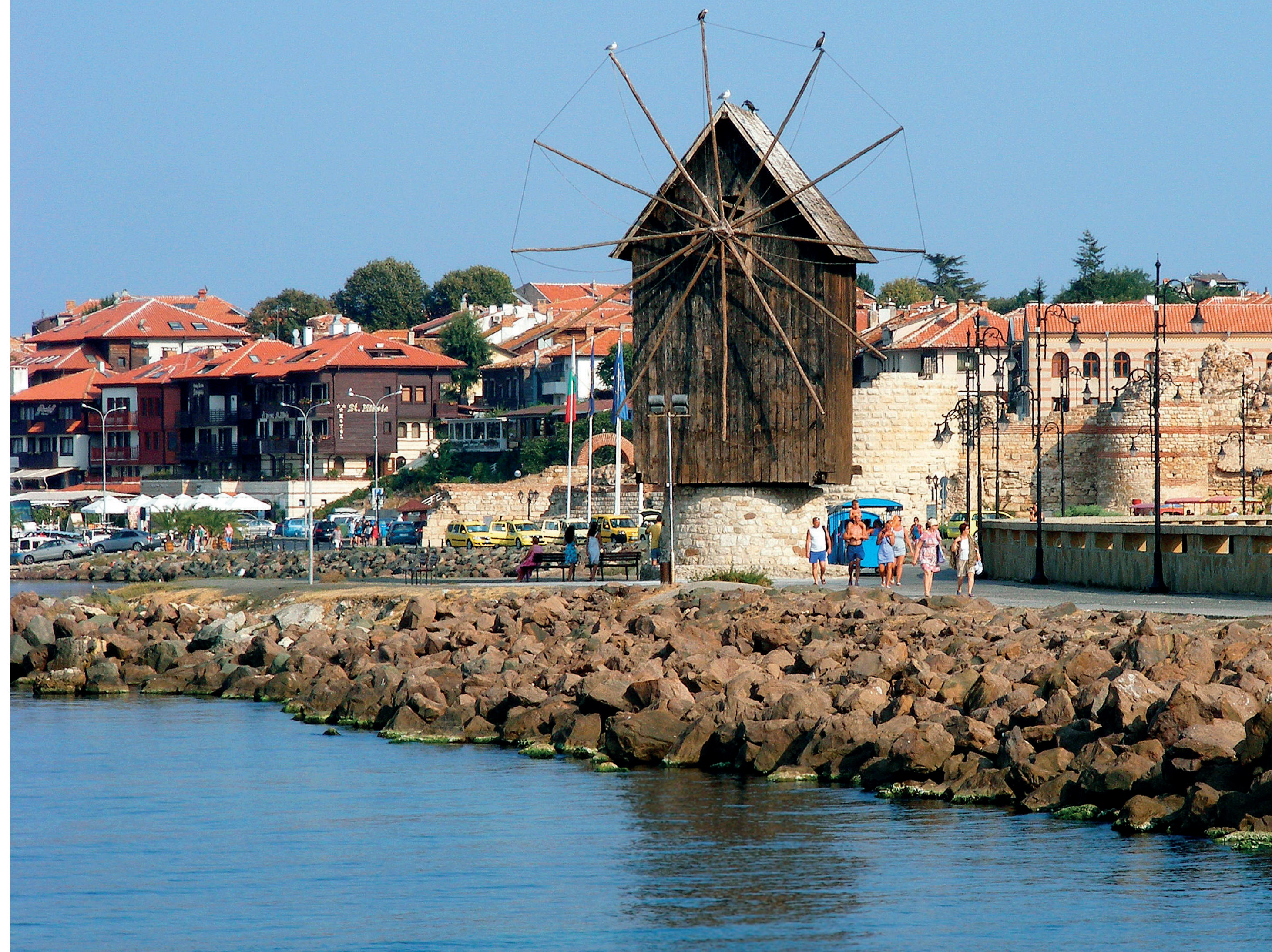




\section{ARCHAEOLOGICAL SITES, HISTORICAL AND CULTURAL HERITAGE OF THE BULGARIAN BLACK SEA COAST}


Ever since ancient times the western coast of the Black Sea has provided a perfect environment for the development of communities of people inhabiting the area. Bulgaria's Black Sea coast and hinterland were an area of permanent cultural and ethnic interactions. The evolution of human communities here cannot be grasped without taking into consideration the freshwater resources essential for any kind of human habitation (be it seasonal or permanent). The earliest evidence of habitation along the Black Sea shore are rudimentary tools made of flint, dated to the Paleolithic. Such tools, alongside specific paleofauna, were identified in coastal caves.

Marine transgressions could also account for the absence of the Early Neolithic in Dobrudzha (6 $6^{\text {th }}$ millennium BC), but the lack of systematic underwater research prevents any convincing arguments on the matter. Most of the Late Neolithic and Eneolithic settlements of Hamangia culture (between 5,200-4,600/4,500 BC) and Gumelniţa culture (between 4,600/4,500-4,000 BC) on the Black Sea coast appeared next to major rivers, especially in proximity to areas in which rivers flew into the Black Sea, where they formed the current coastal lakes.

Hamangia communities settled near major freshwater sources. Their settlments were grouped mainly in areas of large bays (present-day lakes), close to the mouths of the bigger rivers. The largest concentration of habitation, featuring eight archaeological sites, was found in the area of today's Varna-Beloslav Lake Complex, which in the $5^{\text {th }}$ millennium BC was a large marine bay formed at the mouth of the Paleoprovadiyska River valley.

There are numerous antique archaeological and historical sites on the Bulgarian Black Sea coast. In Antiquity, especially after the Ancient Greek colonization, the port systems along the West Pontic coast expanded. During that period the first harbor facilities were built on the western Black Sea coast bringing new architecture to the coastal towns [1]. A series of sunken harbor facilities (Karantinata, Galata, Apollonia Pontica) [1] and ruins of residential quarters of Hellenic poleis were identified on the Bulgarian coast (Bizone, Messambria) [2; 3; 4]. At some locations, such port facilities made use of natural reefs (Shabla, Cherni nos, Sveti Atanas, etc.) [5; 6; 7]

\section{DURANKULAK}

The Durankulak site, located in northeastern Bulgaria, has been investigated for decades by a team lead by H. Todorova. The excavations at Durankulak were conducted in 1974-1997, and as a result 1,204 prehistoric graves were registered and 17 hou- ses were discovered. The settlement at Durankulak was populated between 5,200$4,200 \mathrm{BC}$, the first inhabitants belonging to Hamangia culture. The prehistoric village was made up of several houses which were very well organized, of large dimensions and with several rooms (Picture 7). Around 4,700-4,600 BC the stone architecture had been generalized, becoming a distinctive phenomenon in the final phase of Hamangia culture and highlighting social differences inside the community [8]. Durankulak is one of the few well-preserved settlements of the early farmers providing some valuable archaeological information about their daily lives.

\section{CAPE SHABLA}

The area of Cape Shabla preserves traces of an ancient settlement called Caron Limen (Careas) (Picture 2), which protrudes on the submarine coastal slope to a depth of $4 \mathrm{~m}$ and a length of $400 \mathrm{~m}$. In ancient times, the fortified town and port of Careas occupied the modern Cape Shabla, located some $7 \mathrm{~km}$ east of the present-day town of Shabla, region of Dobrich. It existed at least from the $6^{\text {th }}$ century $\mathrm{BC}$ until the late $6^{\text {th }}$ century - early $7^{\text {th }}$ century AD

The port/town at Cape Shabla is mentioned in several ancient written sources: Pomponius Mela (P. Mela 2, 22), Arrian of Nicomedia (Ar. PPE 35), the Anonymous Periplus of the Pontus Euxinus (Ann. PPE 75), etc. The Late Antique fortress of Careas was built on the ruins of a Late Roman quadriburgium which had been inhabited in the Late Antique period (late $3^{\text {rd }}$ century AD - mid $6^{\text {th }}$ century AD). The fortified town and port, now preserved in ruins, had been built in the middle of the $6^{\text {th }}$ century AD (after AD 543-544), and was later reconstructed by Emperor Justinian I [9].

Pottery discovered there dates back to the $5^{\text {th }}-6^{\text {th }}$ century BC. The earliest amphorae originate from the Chios Island in the Aegean and refer to the second and third quarter of the $6^{\text {th }}$ century BC [5]. Ancient settlement Caron Limen's harbor at Cape Shabla is described in details by M. Lazarov [5], and the first paper on its localization was written by L. Bozhkov [10].

Only the northwestern part of the fortress has been preserved on land, the larger part of it being under the sea due to wave-induced erosion of the shore. The transgression of the Black Sea in the area started in the Early Hellenistic period and continued through the Roman period, Late Antiquity and the Middle Ages. This is the reason why it is impossible to reconstruct the original appearance of the Late Antique fortress of Careas. 
1. Durankulak Lake

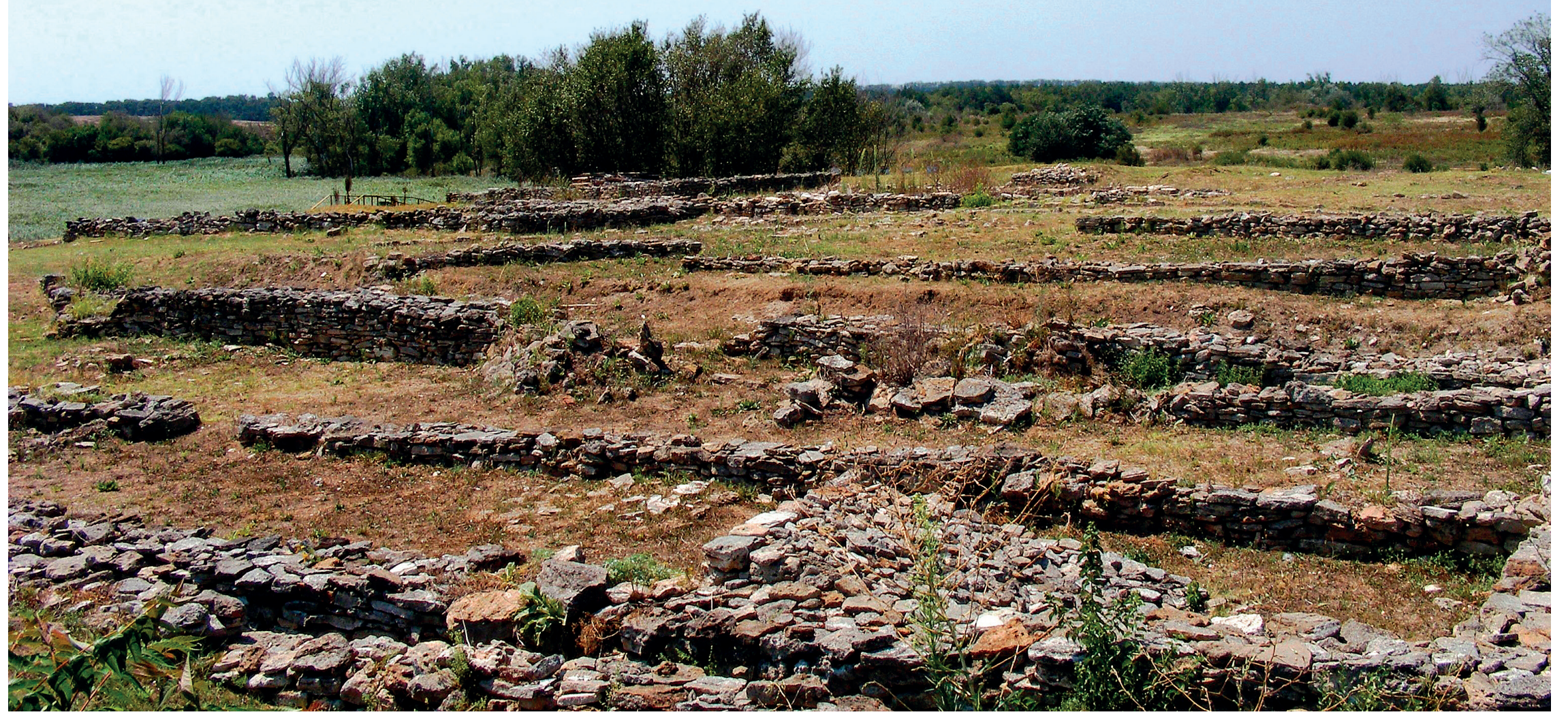

2. Remains of Caron Limen (Careas) ancient settlement

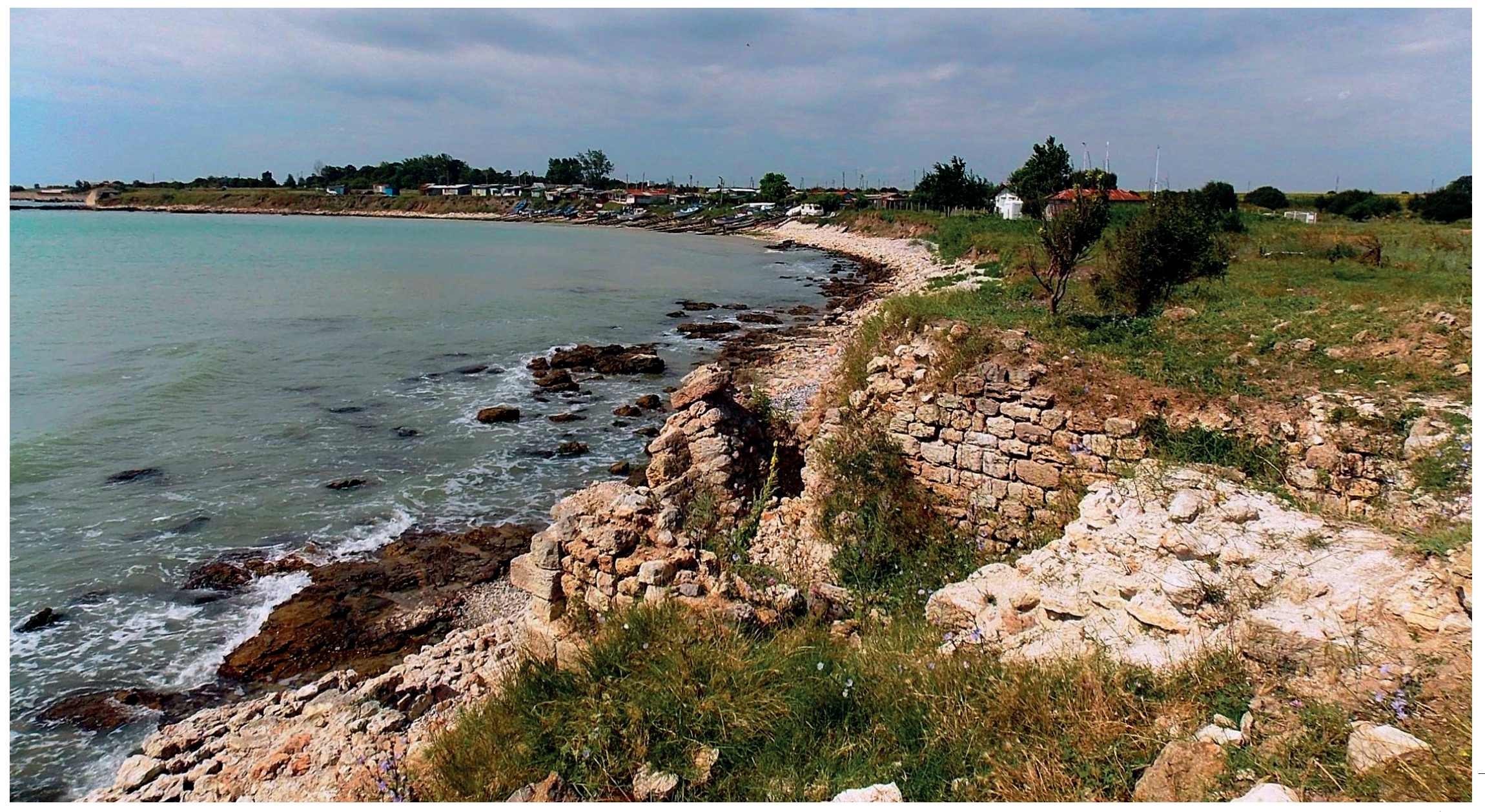




\section{YAYLATA}

The fortified Late Antique settlement at Yaylata area is located $2 \mathrm{~km}$ south of the village of Kamen bryag, region of Dobrich. There are no mentions of it by ancient historians and geographers. The fortress is located on a stunning drifting body of Sarmatian limestones, $2 \mathrm{~km}$ long and $250 \mathrm{~m}$ wide, which was produced by a paleoseismic event. The geomorphic complex of three landslide terraces is quite representative comprising a necropolis, an earlier Thracian cult site and a sanctuary (Picture 3). A small bay exists here and three stone anchors were found east of it, all of them dating from the Late Bronze Age: two single-hole stone anchors [11], and a third one with three holes. Ruins of the Early Byzantine fortress are evidenced by the ceramics dated to the $4^{\text {th }}$ $-6^{\text {th }}$ century AD [12].

\section{RUSALKA}

A small Late Antique fortress is located within the seaside resort of Rusalka (Picture 4). The castle stands some $3 \mathrm{~km}$ away from the village of Sveti Nikola, region of Dobrich. The site was probably destroyed at the end of the $6^{\text {th }}$ or the beginning of the $7^{\text {th }}$ century AD, much like other Late Antique fortresses on the Bulgarian coast [13]

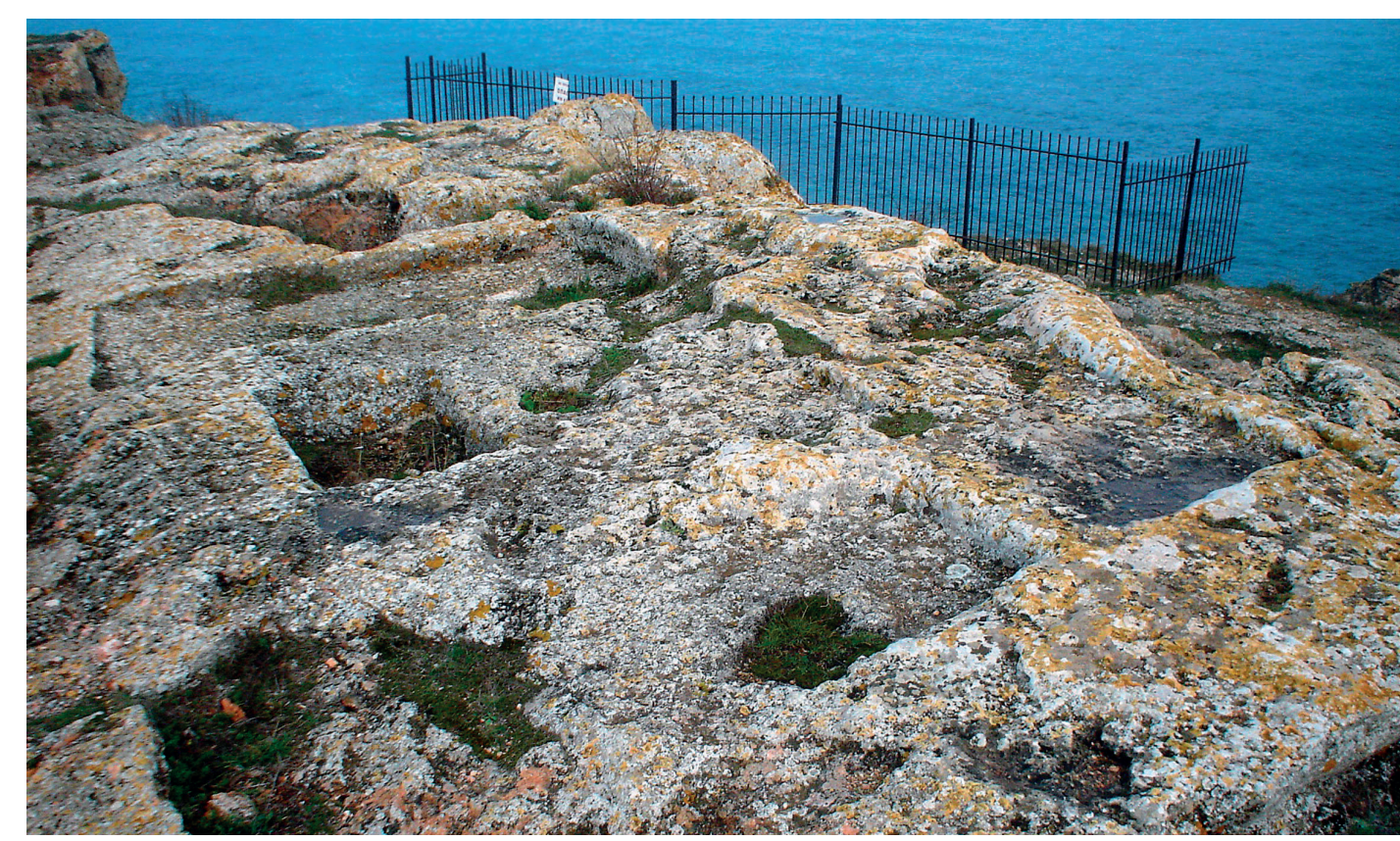

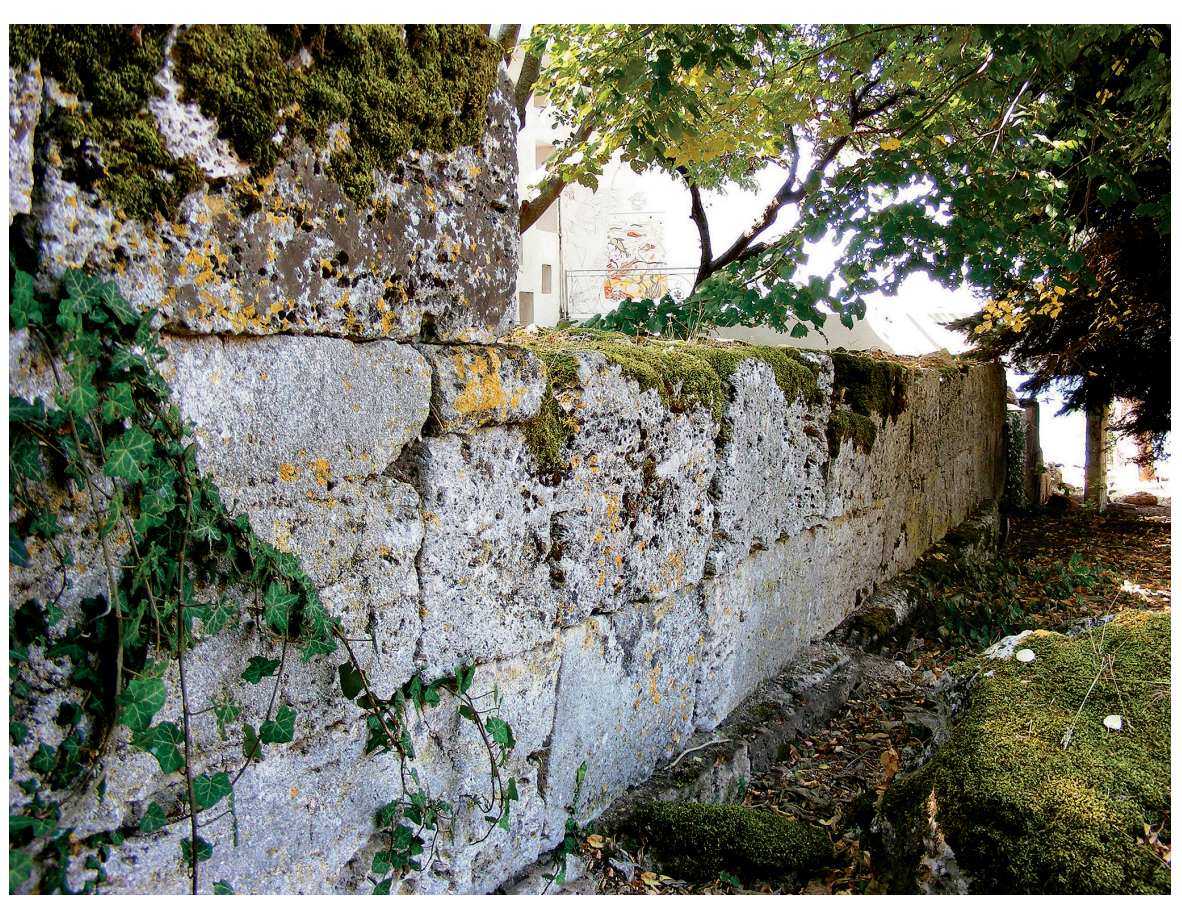

4. Remnants of the Late Antique fortress at Rusalka Resort

\section{KALIAKRA}

Cape Kaliakra and the archaeological reserve there are located $12 \mathrm{~km}$ southeast of the town of Kavarna. This is the largest promontory of the Bulgarian coast, advancing $2 \mathrm{~km}$ into the sea. The vertical cliff which is $70 \mathrm{~m}$ high consists of highly karstified Sarmatian limestones.

The Thracian settlement at Cape Kaliakra was known in Antiquity as Tirizis. The polis is mentioned by Strabo (Str. VII, 6, 1), Ptolemy (3, 10, 3), Pomponius Mela (P. Mela II, 22), and in Tabula Peutingeriana.

The commercial ships which stopped at ancient Tirizis used the deep bay west of Cape Kaliakra for docking, which provided natural protection against the northern and

3. Thracian rock sanctuary 


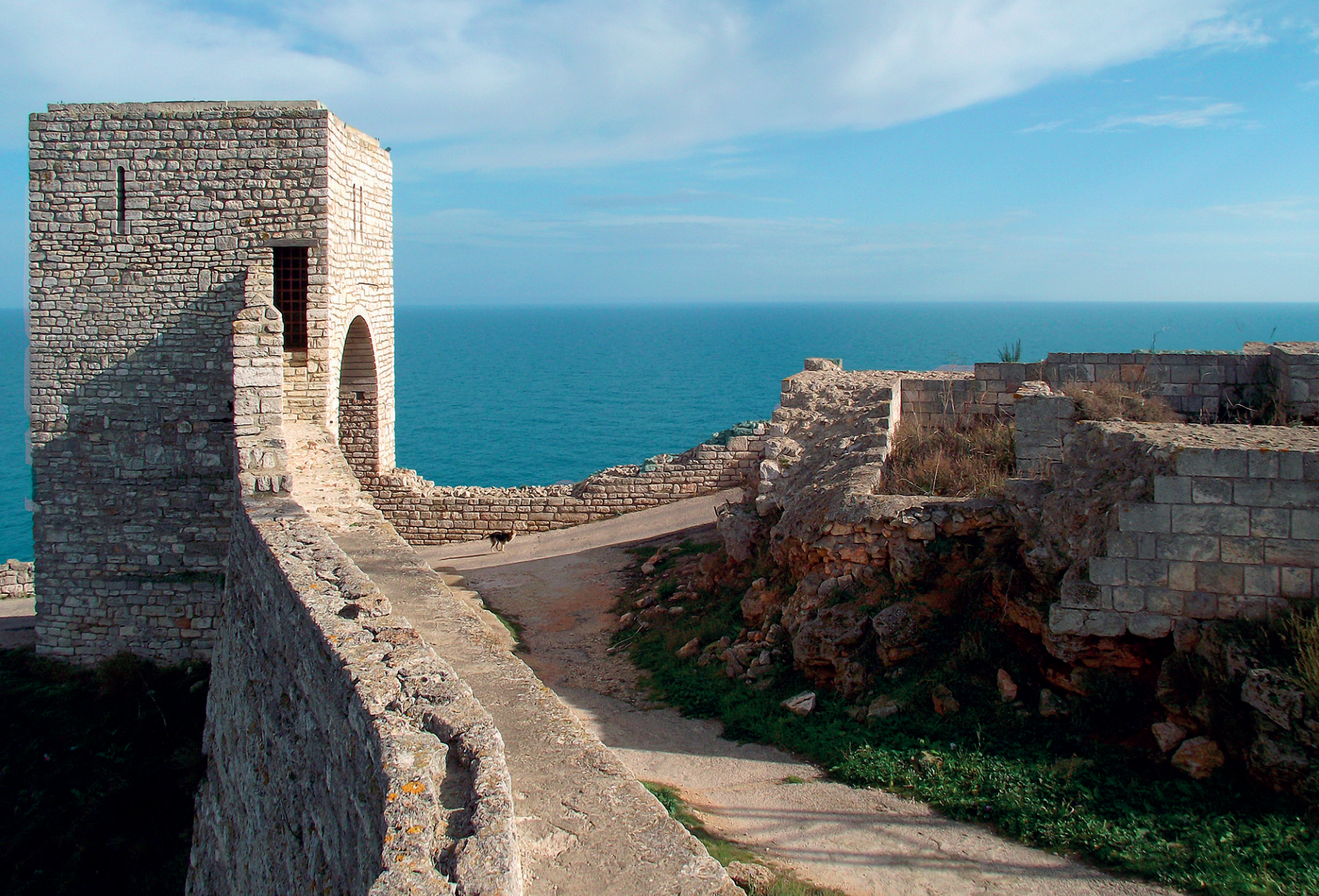

eastern winds. The bay was first used in the Late Bronze Age. Underwater archaeological investigations near Cape Kaliakra have been carried out since 1959 [14]. Three fortification systems with walls, towers, and gates, well preserved and partially reconstructed, are exposed to tourists. They are dated to four different historical periods: Hellenistic, Roman, Late Antique and Medieval [9] (Picture 5).

\section{KAVARNA}

Bizone (modern Kavarna) was founded by Dorian settlers in the $4^{\text {th }}$ century BC (Picture 6). At the end of the $5^{\text {th }}$ century BC, settlers from Messambria moved to Bizone, where they formed one of the last colonies on the Black Sea's western coast. The city developed rapidly and, if we were to judge by the number of anchors found on the seabed, it became one of the most important coastal commercial centers of its time [15]. Pseudo-Scymnos (Ps.-Scymnos 758-760) mentions that the polis was a colony of Megara but according to the Anonymous Periplus of the Pontus Euxinus, it was a colony of barbarians (Ann. PPE 76). Bizone is mentioned in various written sources (Str.VII, 6, 1; Menip. Perg. Peripl. 156; P. Mela II, 22; Plin. E. NH IV, 11, 44, etc.)

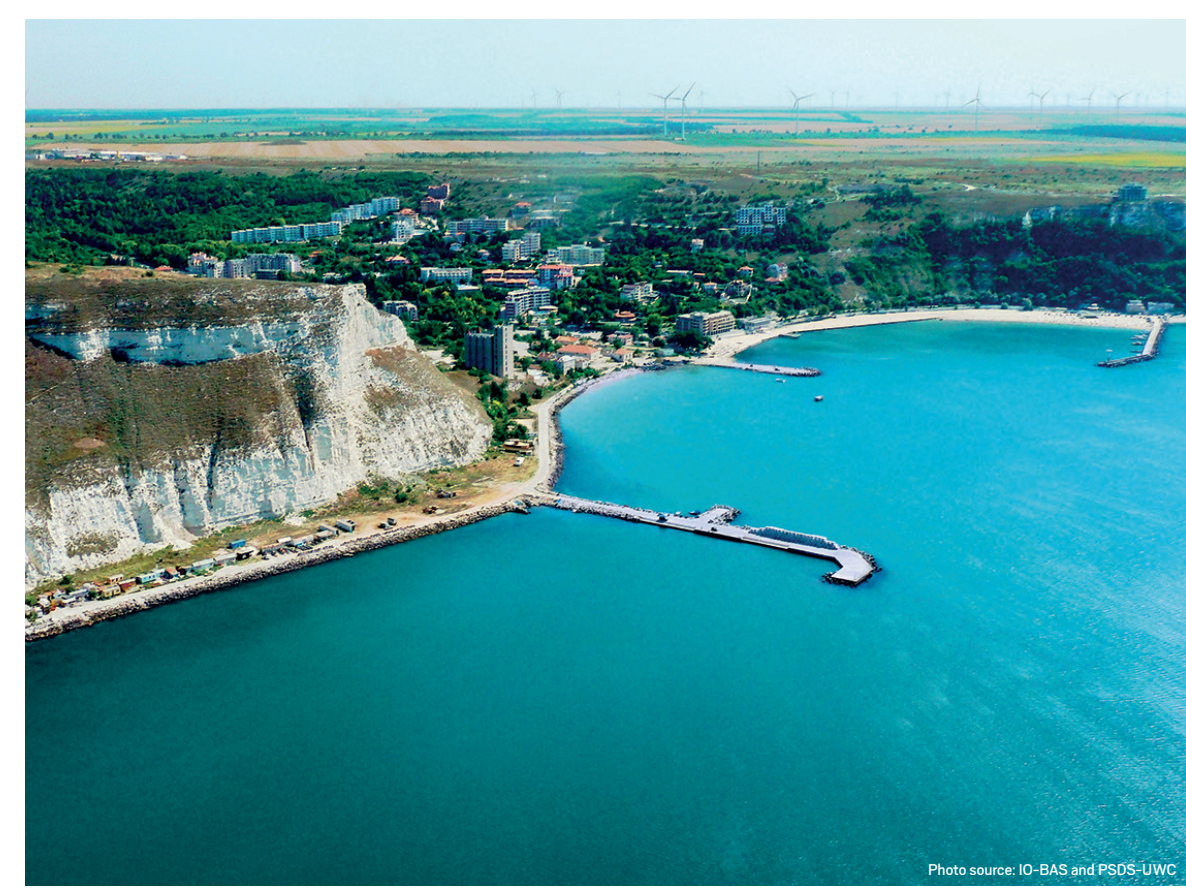




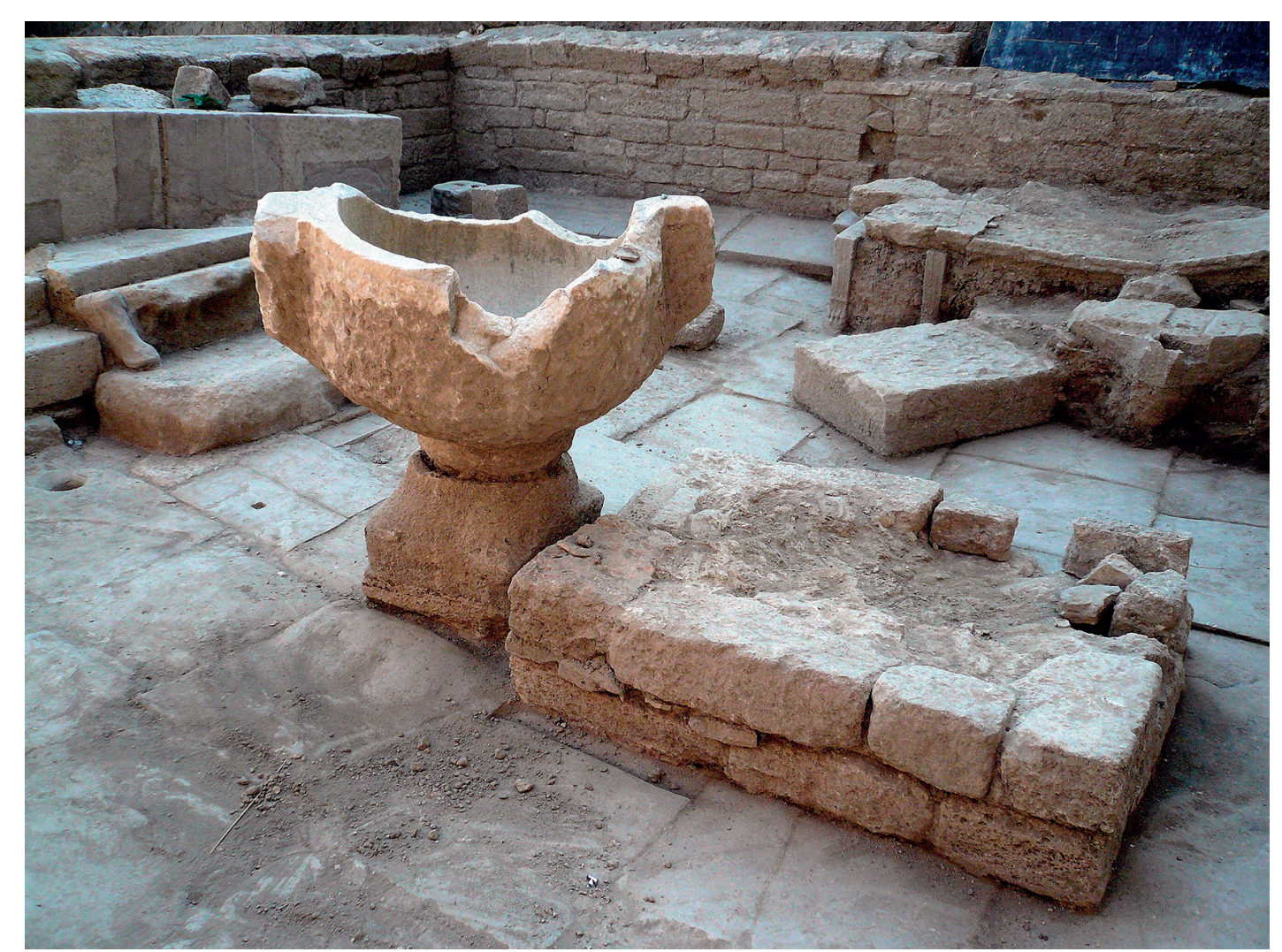

\section{BALCHIK}

The name Dionysopolis occurs in a number of short messages: Pseudo-Scymnos (Ps.-Scymnos 751-757), the Anonymous Periplus of the Pontus Euxinus (Ann. PPE 78-79), Plinius the Elder (Plin. E. NH 4, 11, 44), Strabo (Str. VII, 6, 1). According to ancient literary sources on the topography of the polis, the modern town of Balchik coincides with the ancient Dionysopolis. All ancient written sources mention that previously the polis had been called Krunoi (Kpouvol). Archaeological excavations date the most ancient evidence to no earlier than the $4^{\text {th }}$ century BC [16]. In the spring of 2006 a team of archaeologists discovered a temple dedicated to the Hellenistic goddess Cybele [17] (Picture 7)

Throughout the Varna Bay area at least four ancient ports existed and functioned as early as the Antiquity: Kastritsi at the homonymous medieval castle located in the present-day Euxinograde Residence; Odessos; Karantinata at the locality of the same name; and at Cape Galata. Two of them, namely Karantinata and Galata, had harbor structures.

\section{KASTRITSI}

Varna Bay's northernmost harbor was the castle of Kastritsi. The harbor basin is located to the west of Cape Sveti Yani, a couple of meters from the southern wall. The earliest pottery found there is Early Byzantine, dated to the end of the $4^{\text {th }}$ century AD. The harbor seized to exist in the early $15^{\text {th }}$ century (Picture 8).

\section{Temple of Cybele, Balchik}

V 8. Restored part of Kastritsi Medieval site

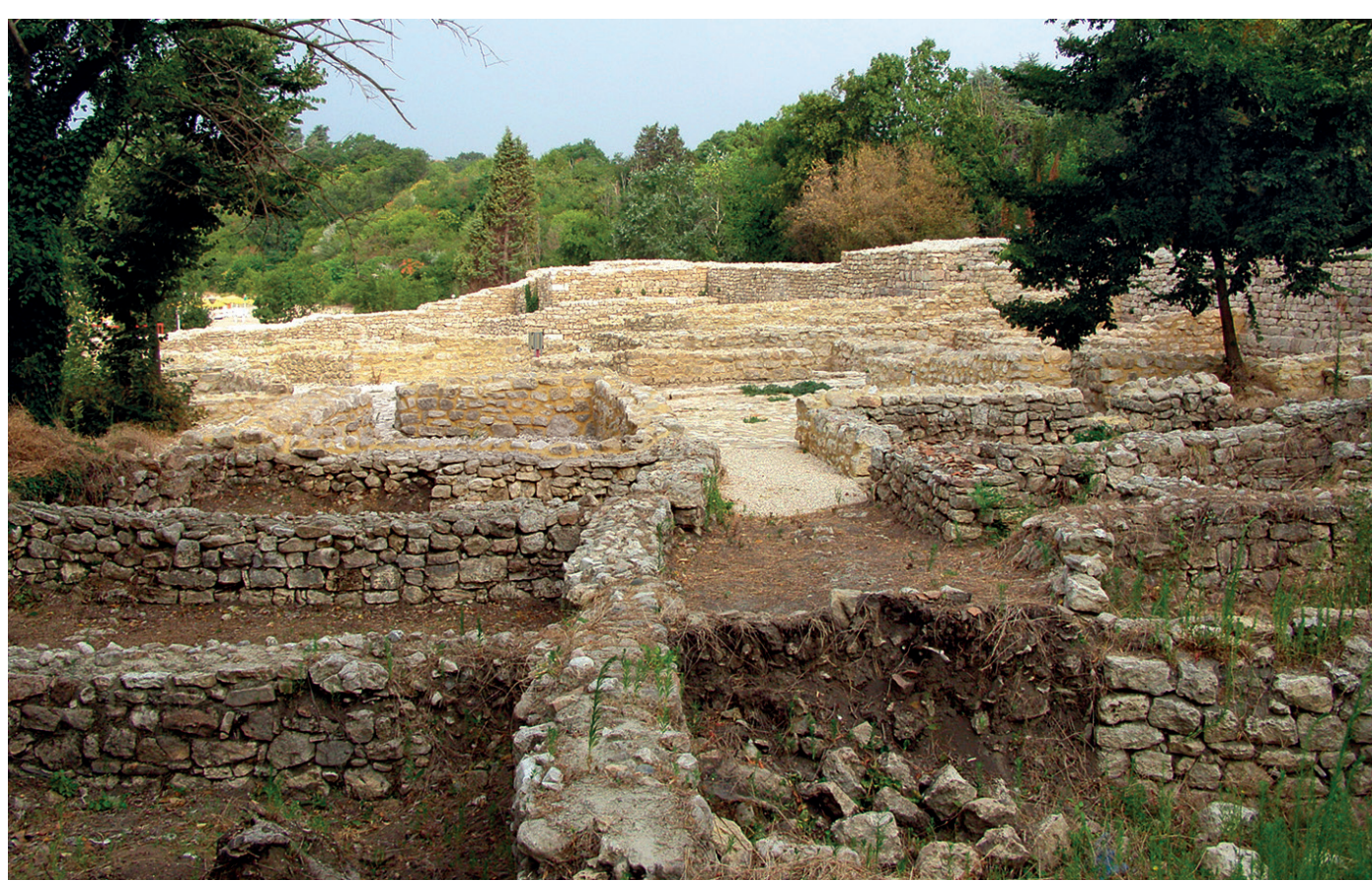




\section{ODESSOS}

According to Pseudo-Scymnos (Ps.-Scymnos 748-750) Odessos was founded by Milesian settlers during the reign of the Midian king Astiagus (second quarter of the $6^{\text {th }}$ century BC) as confirmed by the Anonymous Periplus of the Pontus Euxinus (Ann. PPE 79-80). Therefore, according to the ancient authors, Odessos was established during the second half of the $6^{\text {th }}$ century BC. At the same time cultural activities began in the bay area west of Cape Varna.

Speaking of Odessos and its harbor, we have to take into consideration the works of $G$. Toncheva [18] and M. Lazarov [19;20]. The earliest pottery was dated by M. Lazarov [19] to the middle of the $6^{\text {th }}$ century BC. Archaic artifacts dated to the same period were also found by G. Toncheva [21], and they confirmed the evidence coming from the written sources.

Details about the exact location of the ancient port of Odessos are unavailable. It could be assumed though that at the commencement of the construction of Varna Port in the late $19^{\text {th }}$ century it occupied the same spot as the port of Odessos established back in the $6^{\text {th }}$ Century BC. Excavation observation suggests Odessos port was located near the present-day Varna Central Railway Station. It was confirmed by G. Toncheva [18], too. The ancient coastline could be traced to the old port warehouses - large stone buildings constructed during the Ottoman period.

Varna boasts a number of archaeological and historical monuments: larger sections of the Hellenistic $\left(4^{\text {th }}-3^{\text {rd }}\right.$ century BC), Roman $\left(7^{\text {st }}-3^{\text {rd }}\right.$ century AD) and Late Antique $\left(4^{\text {th }}-6^{\text {th }}\right.$ century $\left.A D\right)$ walls of Odessos, Europe's fourth largest Roman baths (thermae), the remains of several Early Christian basilicas plus the mosaic floors in some of them, a Late Antique/Early Medieval earth rampart, part of the fortification system of Odessos, the ruins of one of the Medieval churches Sveti Georgi, or St George ( $13^{\text {th }}$ century), plenty of museums, e.g., the Archaeological Museum, the Ethnographic Museum, the Museum of Bulgarian National Revival, the Maritime Museum, the Museum of Natural History as well as buildings dating to the late $19^{\text {th }}$ century and the first half of the $20^{\text {th }}$ century, e.g. The Dormition of the Mother of God Orthodox Cathedral, the Sea Baths (Picture 9), and many more.

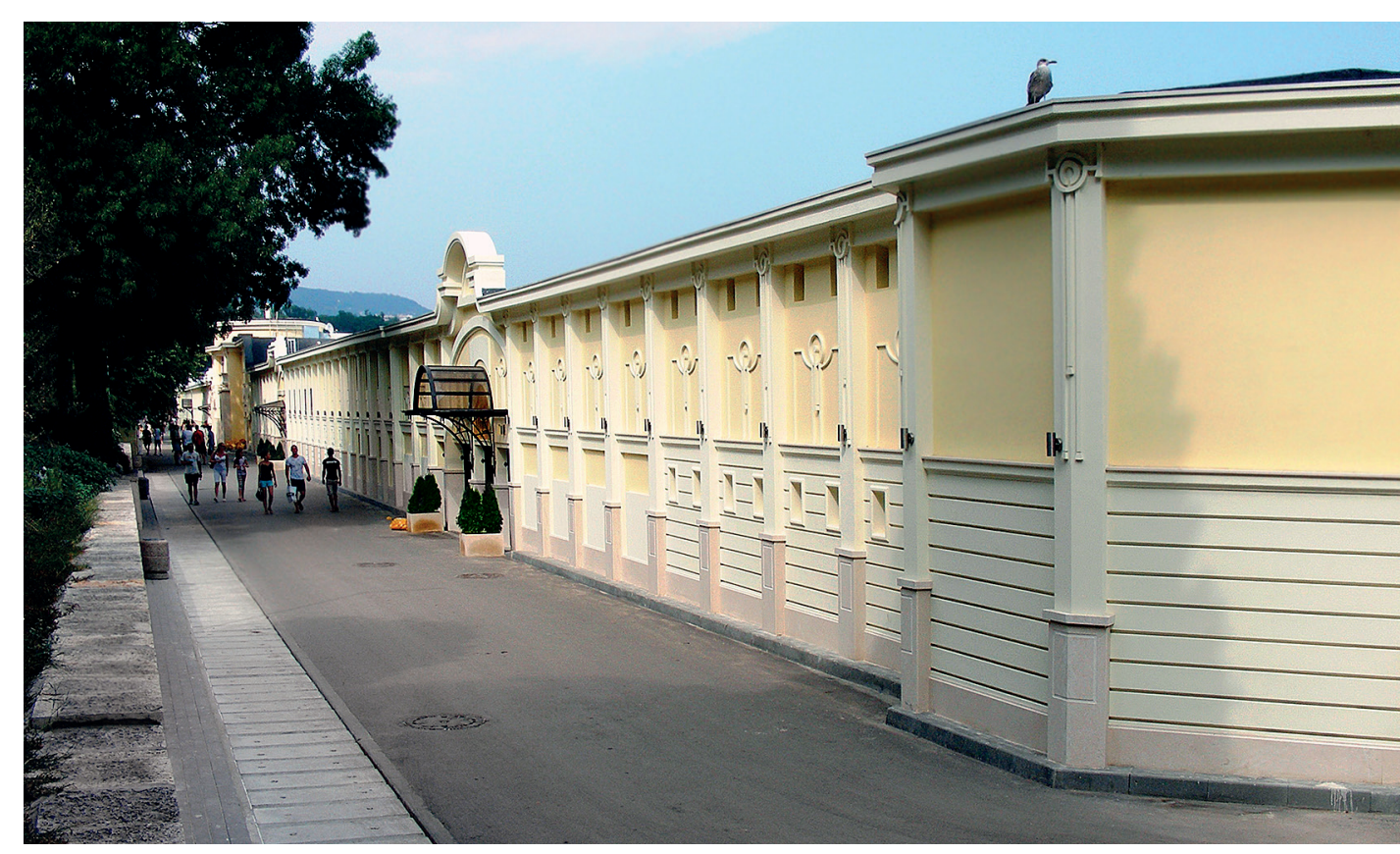

\section{KARANTINATA}

Underwater archaeological investigations in the early 1960s confirmed the existence of a submerged antique harbor construction. A perpendicular $250 \mathrm{~m}$-long coastal jetty was constructed from medium-sized broken stones without the use of mortar, which were paneled with bigger oval stones [18]. The highest parts of the construction are at a depth of $2.5 \mathrm{~m}$ below the present level and $4.5 \mathrm{~m}$ from the bottom The function of the wall was to protect its western territory from the waves and the eastern and northeastern winds.

West of the pier and east of the old iron bridge in the Karantinata locality lies the aquatory of the ancient port. In the 1960s, during underwater archaeological excavations, numerous fragments of amphorae, bowls, anchors were found, and they keep emerging from the sea.

During our underwater observations we never saw the cross section of the underwate jetty that G. Toncheva had suggested [18]. Moreover, it is quite probable that it is not an artificial structure but a natural reef now lying below the current sea level some 2-3 m deep. 
Apart from the numerous and varied ceramic material, three iron anchors were also found and excavated at the Karantinata locality. Two of them are grapnels and the third one is T-shaped. Chronologically, the T-shaped anchor is earlier, as that type of iron anchors had been used by sailors during the $6^{\text {th }}-8^{\text {th }}$ century AD while grapnels appeared much later and came into use during the late Middle Ages.

\section{GALATA}

The other underwater quay is located in the area of the lighthouse at Cape Galata. The first archaeological evidence there (anchors and amphorae) were found in 1962. In the same year an underwater wall was discovered close to the modern jetty of the Varna-Galata ferryboat line near Romantika Restaurant. Regular diving investigations along the southern coast of Varna Bay were carried out until the end of the 1960s.

10. Collapsed remnants at Cape Galata

$\nabla$ 11. Late Antique/Early Medieval rampart near Shkorpilovtsi, region of Varna

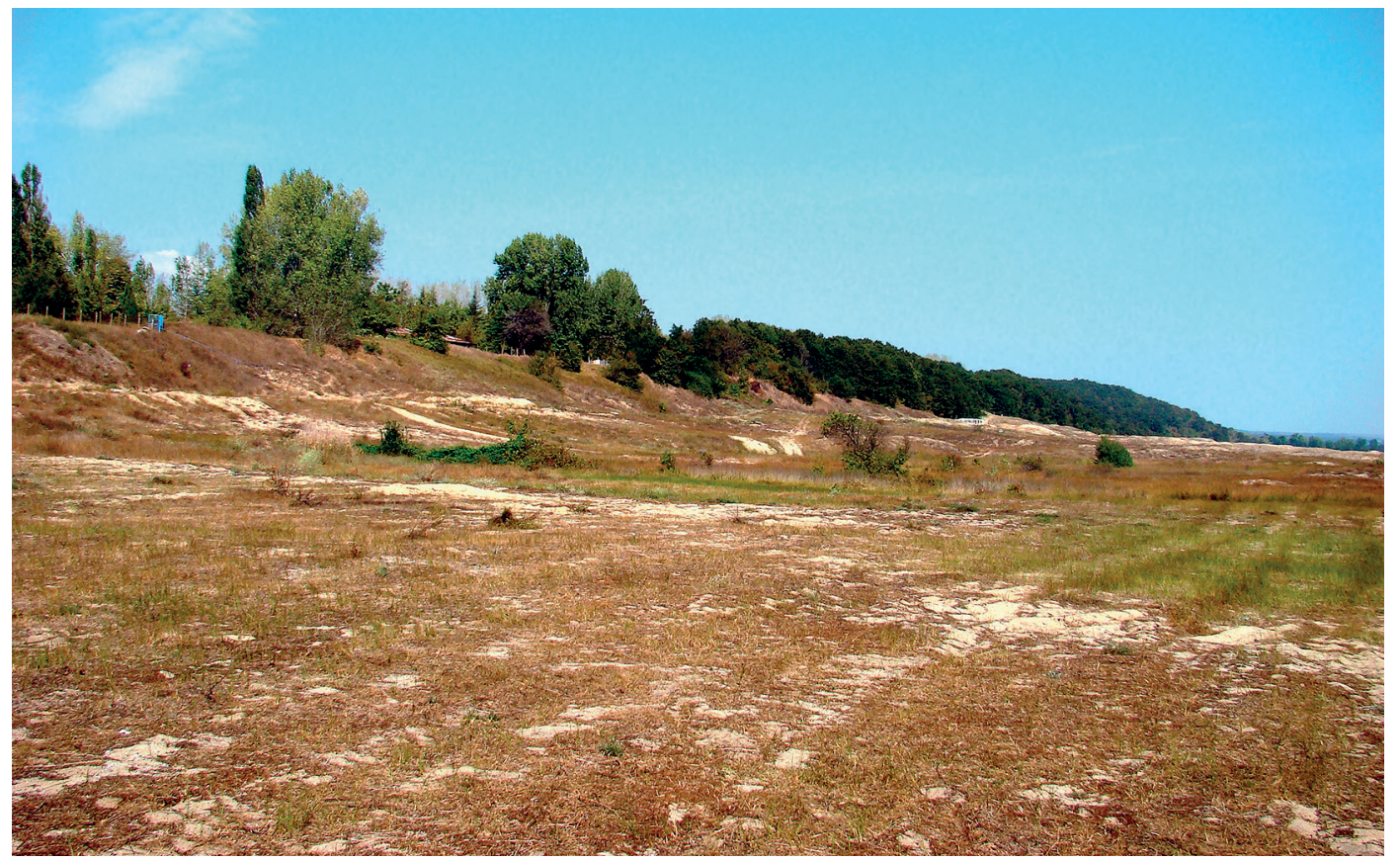

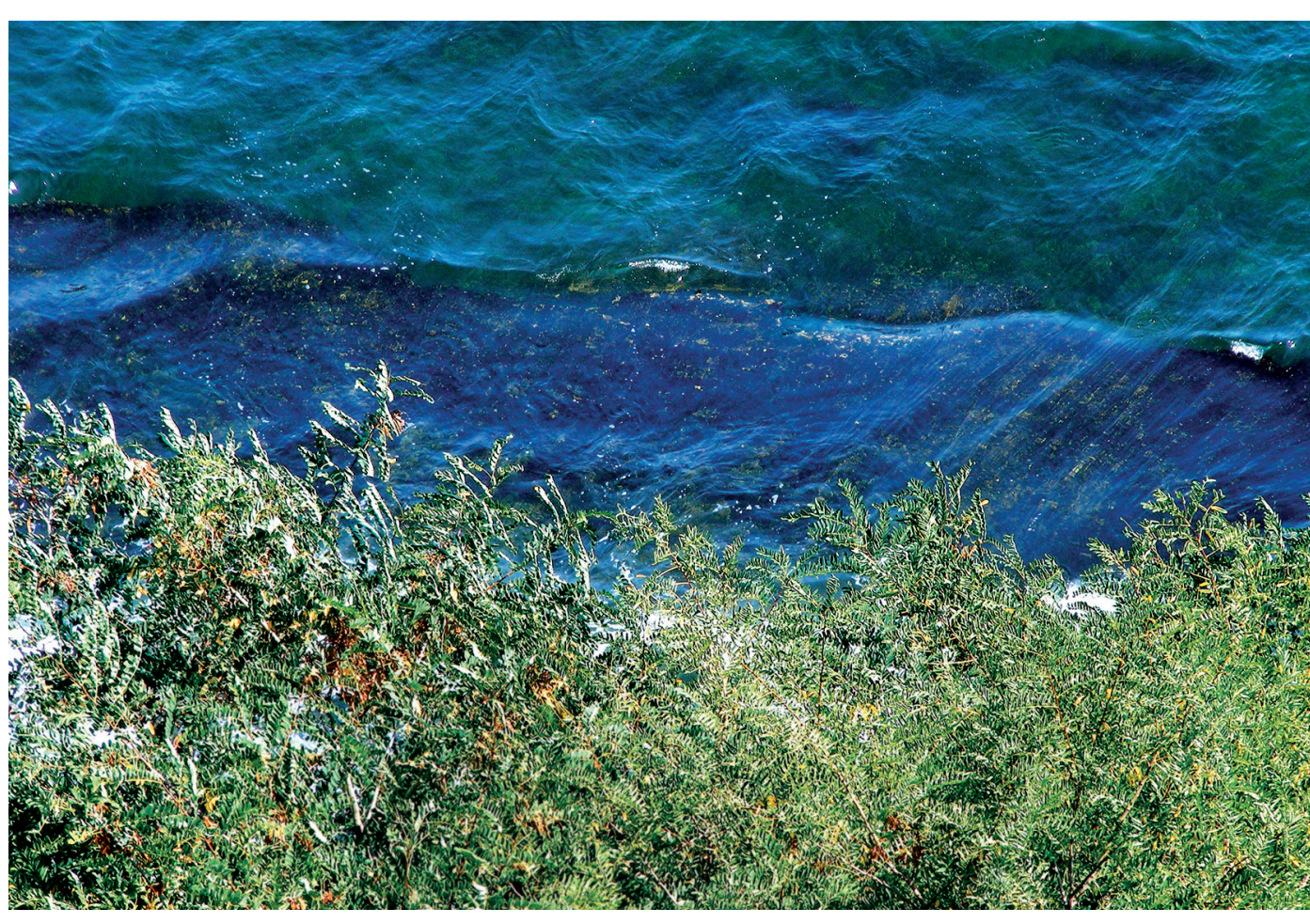

\section{SHKORPILOVTSI}

An earth rampart similar to the one in the Asparuhovo quarter of Varna is located in the vicinity of the village of Shkorpilovtsi. Its location was inspected with relation to the remaining coastal ramparts at Kranevo, the mouth of the Kamchia River and the rampart between Byala and Obzor, forming an accomplished common defensive system (Figure 17).

\section{SVETI ATANAS}

The ancient name of the fortress at Cape Sveti Atanas remains unknown, but in Medieval times it was known as Viza. Several excavation campaigns were carried out in the last decades and nowadays, following a reconstruction, a number of archaeological objects are exhibited, e.g., an Early Christian basilica, its baptisteries, a finely preserved winery, a bath and other buildings dated from the $5^{\text {th }}-6^{\text {th }}$ century $\operatorname{AD}[22]$. 


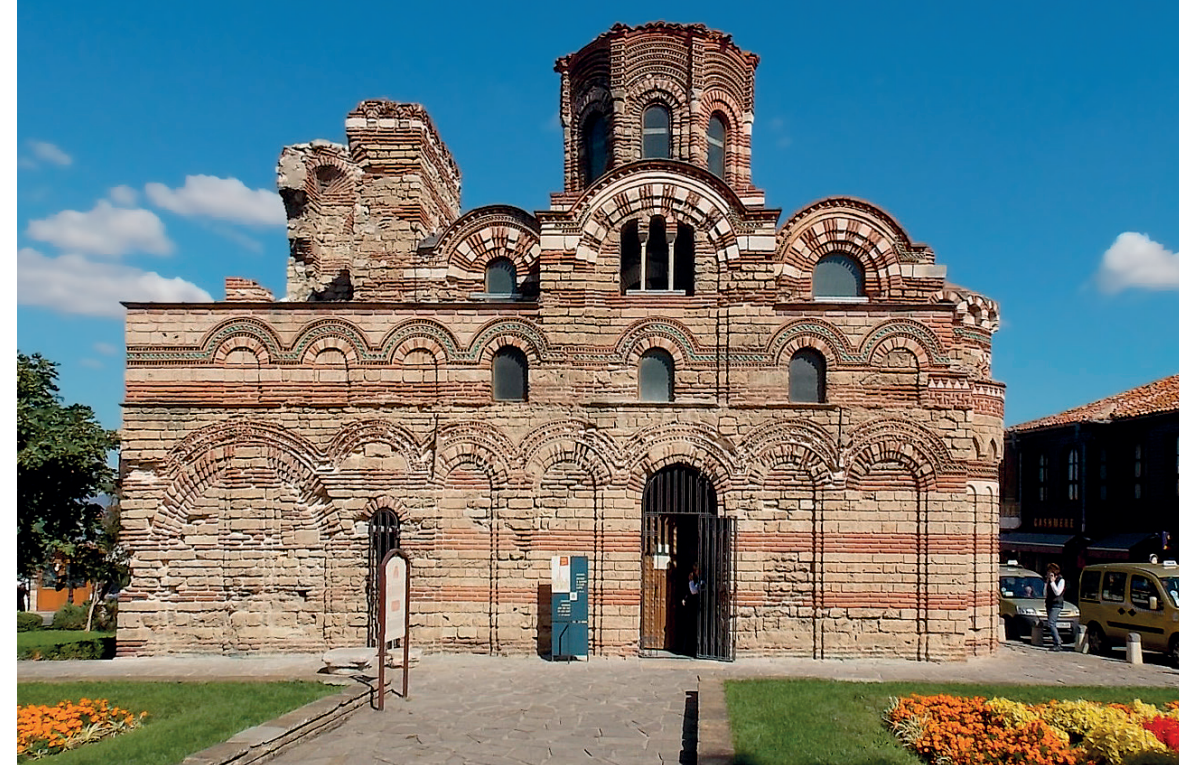

12. Christ Pantokrator Medieval church $\left(13^{\text {th }}-14^{\text {th }}\right.$ century $)$

\section{NESEBAR}

Given Strabo's information for Messambria we could conclude that the apoikia there was established at an area that had been previously inhabited by the Thracians. Herodotus (Hdt. IV, 93) mentions Messambria in his story of the Scythian campaign of Darius I (521-486 BC) in 519-513/512 BC. Herodotus mentions (Hdt. VI, 33) that the settlers were of Byzantine and Chalcedonian origin. Messambria is mentioned by Scylax (Peripl. 67), Pliny the Elder (Plin. E. NH 4, 45), Pomponius Mela (P. Mela II, 22), etc.

The contemporary archaeological research focused on Messambria started more than one hundred years ago [3; 4]. The first fortification wall there dates back to the Early Iron Age. The polis' ancient fortress was built at the end of the $6^{\text {th }}$ - early $5^{\text {th }}$ century $B C$. The main gate of the Late Antique $\left(5^{\text {th }}-6^{\text {th }}\right.$ century AD) and Medieval $\left(17^{\text {th }}-14^{\text {th }}\right.$ century AD) fortress is very well preserved.

Nesebar has been a national architectural and archaeological reserve since 1956 In 1983 the city was included in the UNESCO World Heritage List. The town's ancient ruins and buildings of various historical periods can be observed everywhere.
Modern-day Nesebar boasts the ruins of many Orthodox churches from the Early Christian period until the $17^{\text {th }}$ century AD. These include St Sofia, the Old Metropolitan Church ( $5^{\text {th }}-6^{\text {th }}$ century AD), St John the Baptist Church ( $10^{\text {th }}-17^{\text {th }}$ century), the Church of Holy Archangels Michael and Gabriel ( $13^{\text {th }}$ century), the Church of Christ Pantokrator (13 ${ }^{\text {th }}-14^{\text {th }}$ century) (Picture 12), St John Aliturgetos Church (14 ${ }^{\text {th }}$ century). St Stephan Church (first built in the $11^{\text {th }}-13^{\text {th }}$ century, and expanded in the $16^{\text {th }}$ $18^{\text {th }}$ century), Sveti Spas Church (1609), Bulgarian National Revival period wooden houses (19 ${ }^{\text {th }}$ century), etc.

\section{POMORIE}

No written data on how and when the town was established exist today. Its ancient name is Anchialo and the first author who mentions it is Strabo (Str. VII, 6, 1). Later Anchialo is mentioned by Ovidius (Tr. 1, 10, 35) and the Anonymous Periplus of the Pontus Euxinus (Ann. PPE 85-86). According to Strabo (Str. VII, 6, 1), the settlement was an apoikia of Apollonia Pontica (modern-day Sozopol). Anchialo's port had a very good infrastructure: coins minted in that period show the entrance to the harbor.

A small section of the Medieval wall is preserved near the modern-day harbor. A few traditional $19^{\text {th }}$ century wooden houses are preserved in Pomorie (Picture 13). The Salt Museum, the only one of its kind on the Balkan Peninsula, is a major tourist site.

13. A typical wooden house in Pomorie ( $19^{\text {th }}$ century)

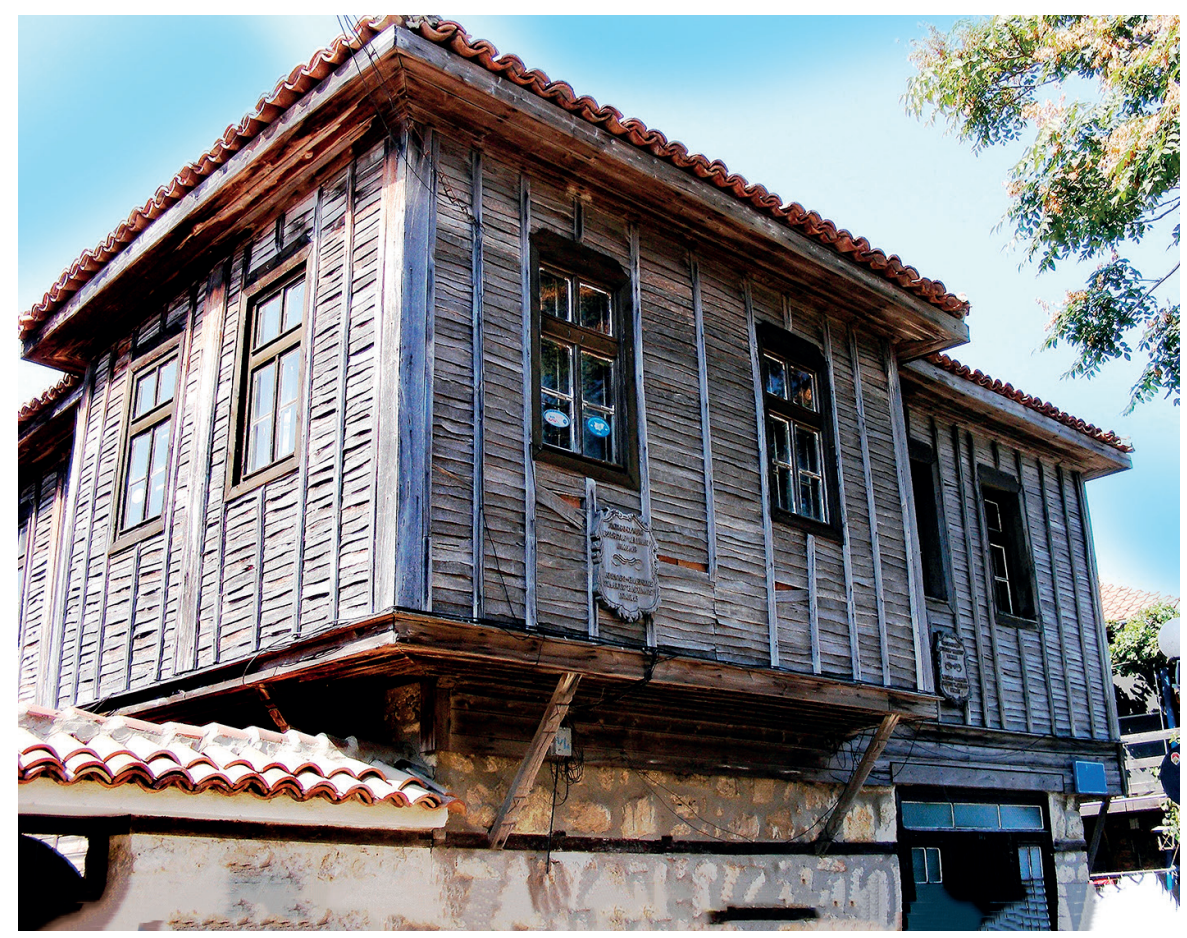


AKRA

The Late Antique fortress is located at Cape Akra (also known as Cape Akin) at the northernmost part of a small peninsula called Sveti Nikola, or St Nicholas some $3 \mathrm{~km}$ south of the village of Chernomorets, region of Burgas (Picture 14). The cape occupies an important strategic position in the southern part of the large Burgas Bay. Over the centuries it had been heavily eroded by the sea and a large part of it has submerged. The fortified town covers an area of about 1.5 ha, but in the past it was obviously much larger, perhaps double in size [23]. It is located on a rough sloping rocky terrace, the highest part of which is occupied by the ruins of a military base decommissioned in the $20^{\text {th }}$ century. Unfortunately, the construction of the modern structures destroyed the most interesting part of the ancient site.

The earliest historical and archaeological reference to the fortress was made by brothers Karel Skorpil and Hermengild Skorpil in 1901. No archaeological research at Cape Akra was performed before 2012 due to the severe restrictions of the above military base [24].

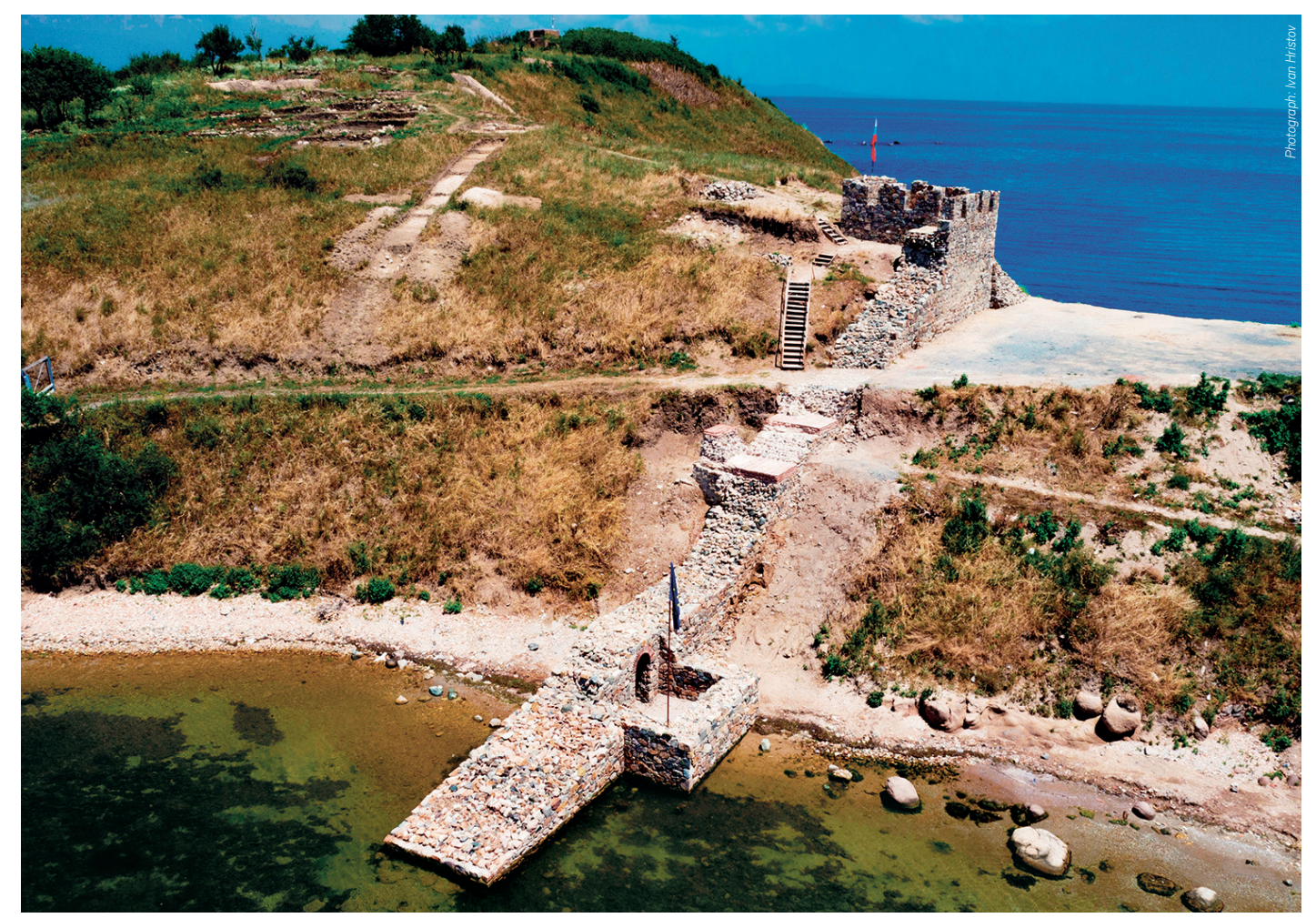

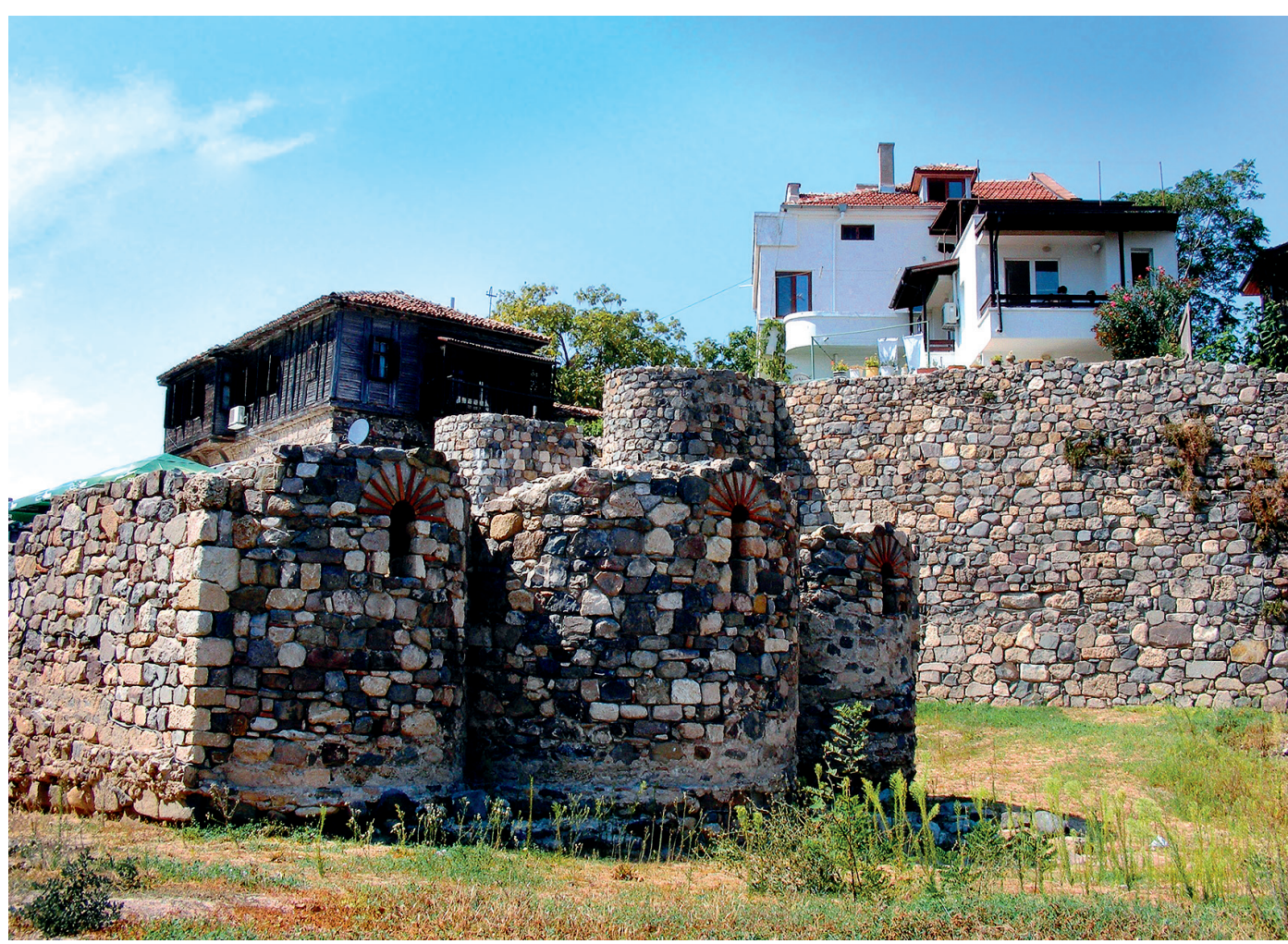

15. Medieval remnants in the Old Town of Sozopol

\section{SOZOPOL}

The ancient city state of Sozopol was established at the end of the $8^{\text {th }}$ century BC by colonists from Miletus (Ps.-Scymnos 728-737; Ann. PPE 84-87). Its ancient name was Apollonia Pontica, after the Greek god Apollo.

Archaeological surveys in Sozopol started in the late $19^{\text {th }}$ century. According to the artifacts of human activity, life in the area started during the Late Eneolithic and Early Bronze Age. Nowadays, the fortifications from the Late Antique and the Medieval Period are well preserved and date from the $6^{\text {th }}$ to the $14^{\text {th }}$ century AD [9]. Many structures from different historical periods have been excavated and restored (Picture 15). Recently, a reliquary with relics of St John the Baptist was discovered during the excavations of the Medieval monastery St John the Baptist on Sveti Ivan Island [25]. In Sozopol, the Old Town area boasts many traditional wooden houses from the $19^{\text {th }}$ century, similar to those in Pomorie.

4 14. Fortification system of the Akra Antique fortress 


\section{URDOVIZA}

The area of the Urdoviza Peninsula and the adjacent aquatory are of great interest to a wide range of experts due to the large variety of artifacts.

The Late Antique fortress of Urdoviza is located on the little peninsula of the same name within the modern town of Kiten. Its name is of Thracian origin and the earliest archaeological findings date back to the Late Bronze Age. A larger Thracian settlement and most probably a port appeared in the $5^{\text {th }}$ century BC. The name of the site is also mentioned in medieval maritime portolans and charts. Several partial reconstructions of the wall were carried out during the $6^{\text {th }}$ century $A D$, as well as a few centuries later in the Medieval period between the $9^{\text {th }}-14^{\text {th }}$ century [26] (Picture 16)

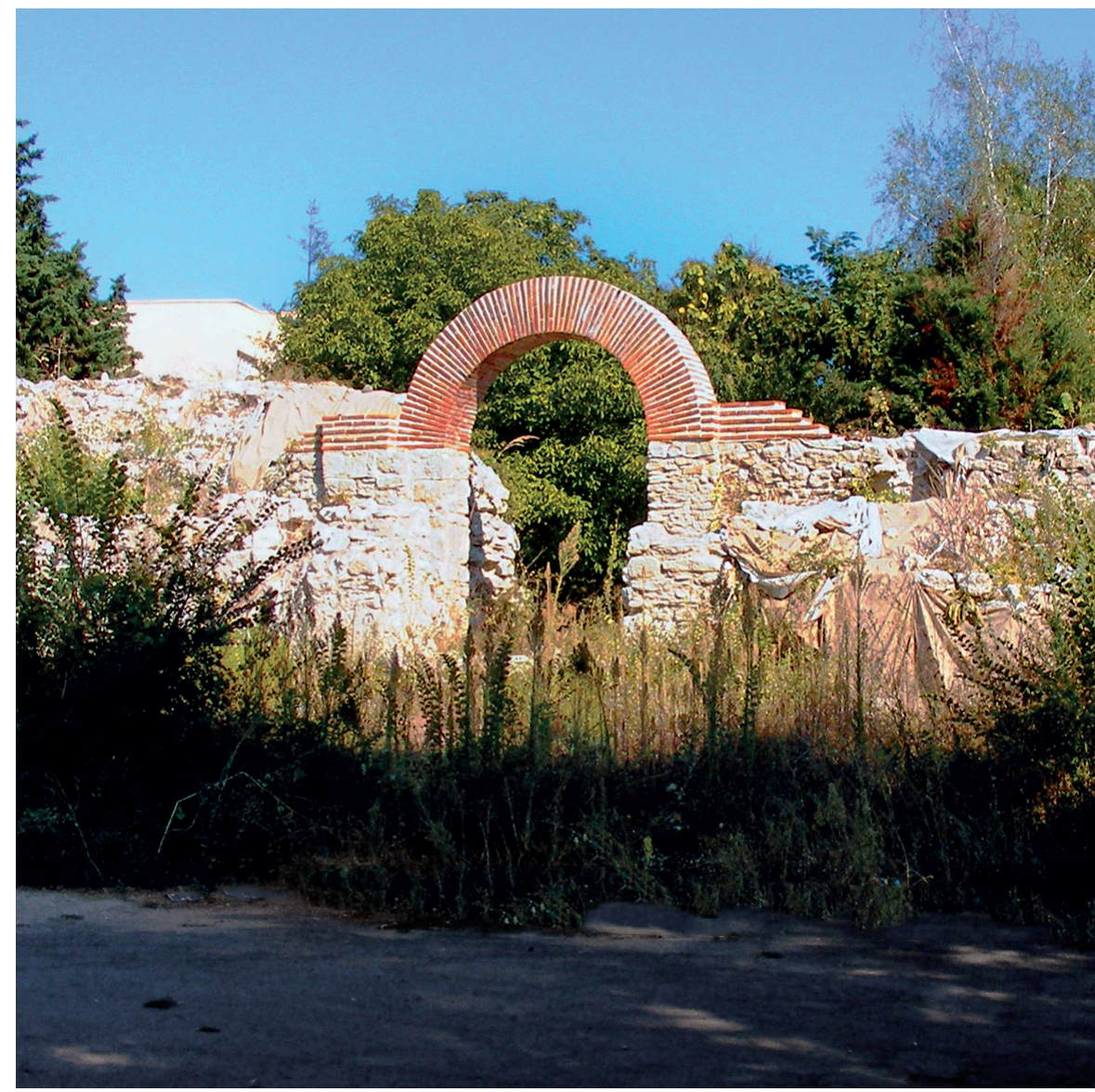

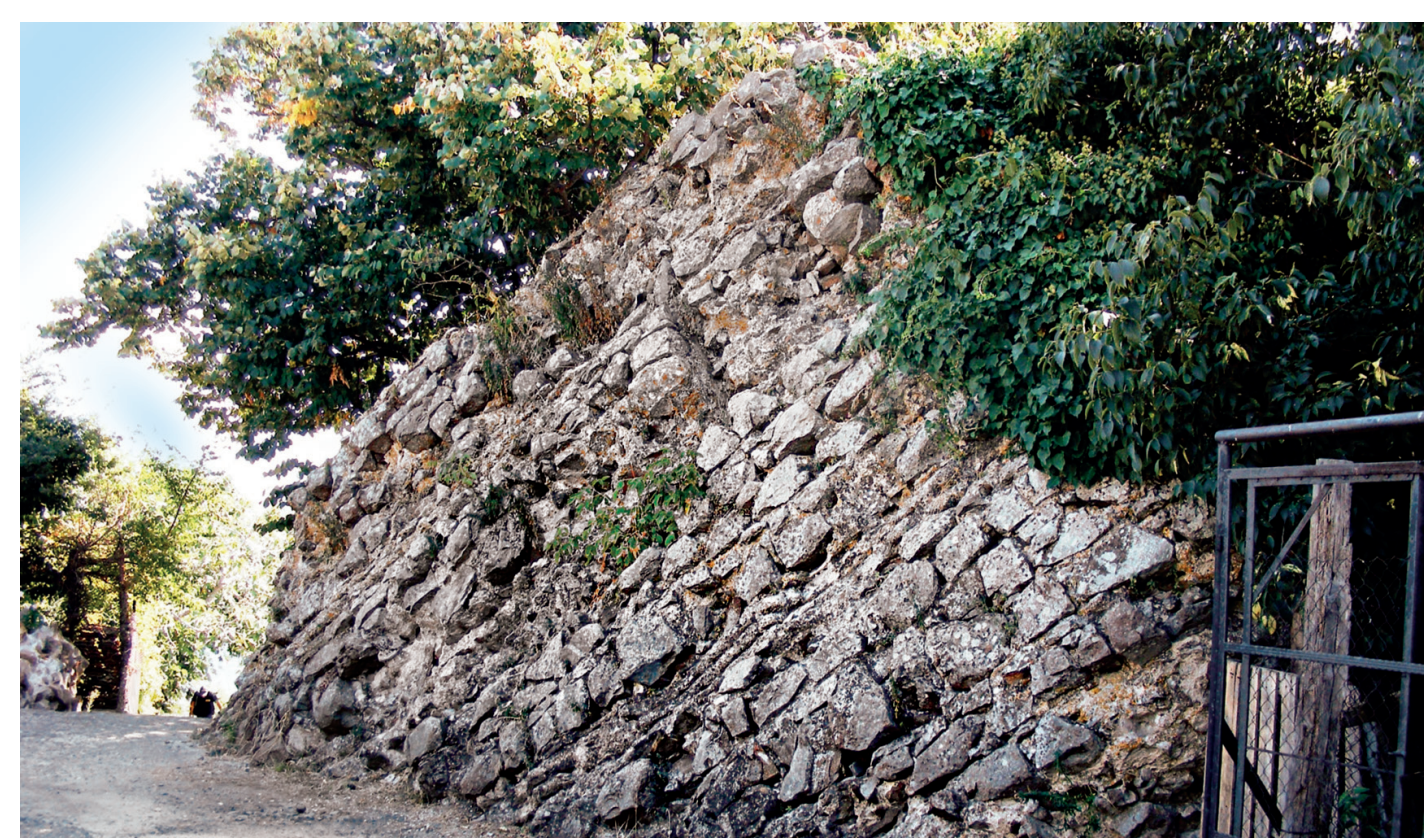

17. Ruins of the Medieval fortification of Ahtopol

\section{AHTOPOL}

Modern-day Ahtopol's ancient name was Agathopolis. Arrian (Arr. PPE 36) mentions the apoikia between Chersonessos and Cape Ineada. The same information is repeated in the Anonymous Periplus of the Pontus Euxinus (Ann. PPE 87). The settlement is located inside the modern town of Ahtopol [27]. Exactly when it was established remains a mystery but it is generally assumed that the apoikia has existed since the $5^{\text {th }}$ century BC.

Nowadays, large sections of the Late Antique and Medieval fortification system are preserved $\left(5^{\text {th }}-15^{\text {th }}\right.$ century $\left.A D\right)$, and these can be observed in the town's harbor area [9] (Picture 77).

16. Fortification of the fortress at Cape Urdoviza, Kiten, region of Burgas 


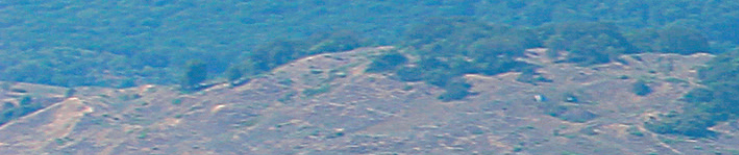

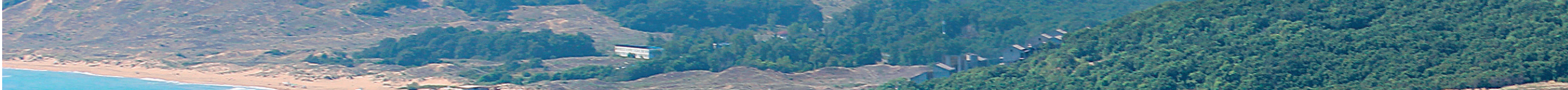

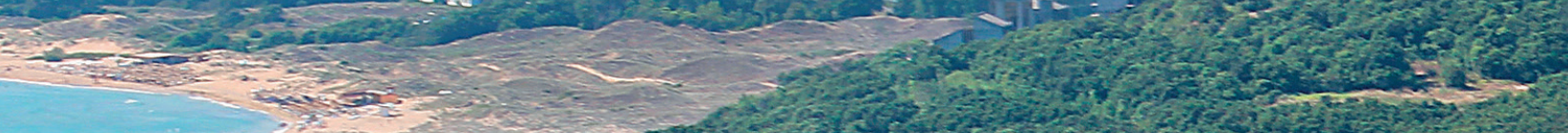

are.

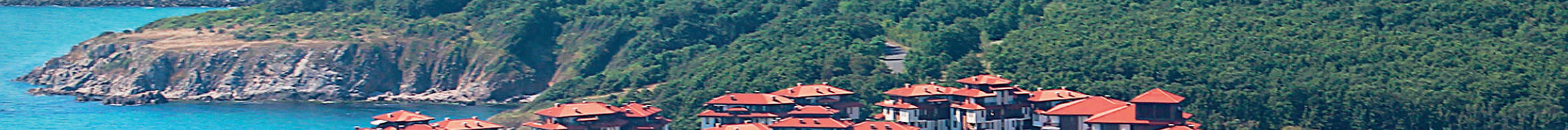

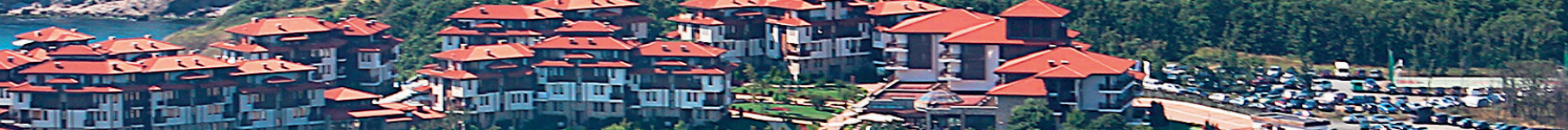
Min

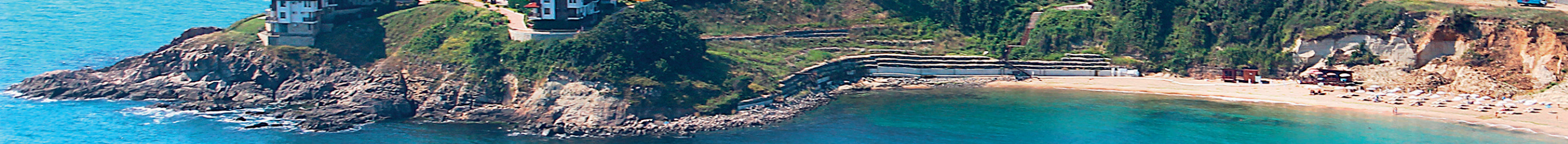

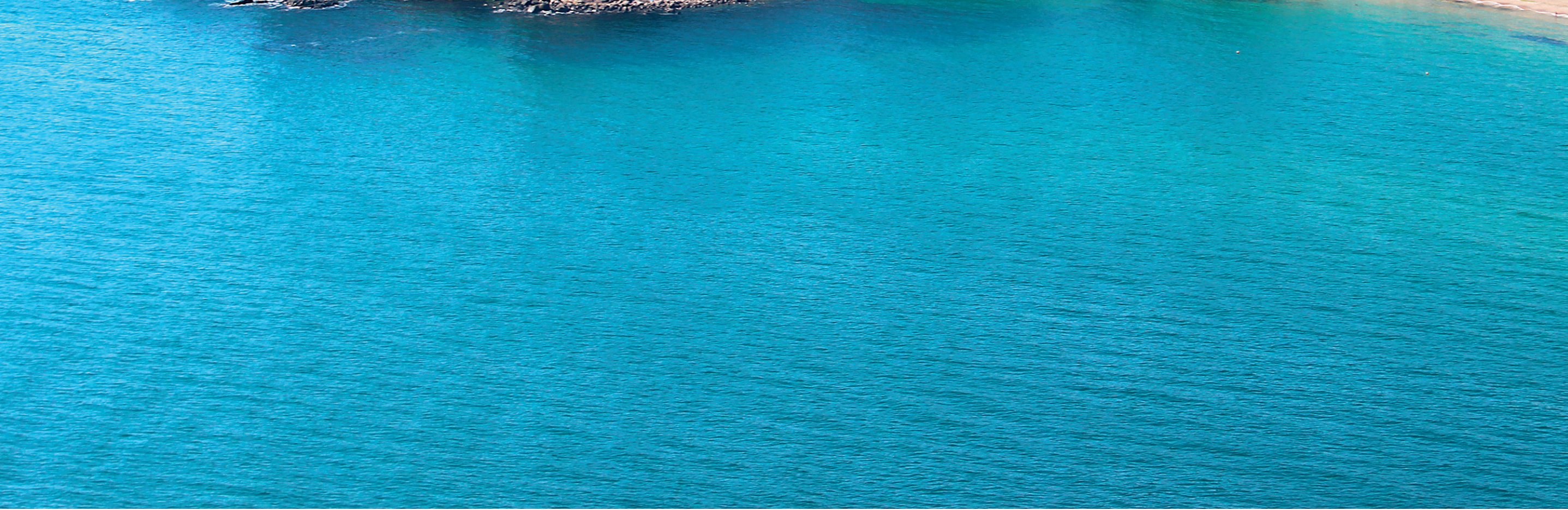




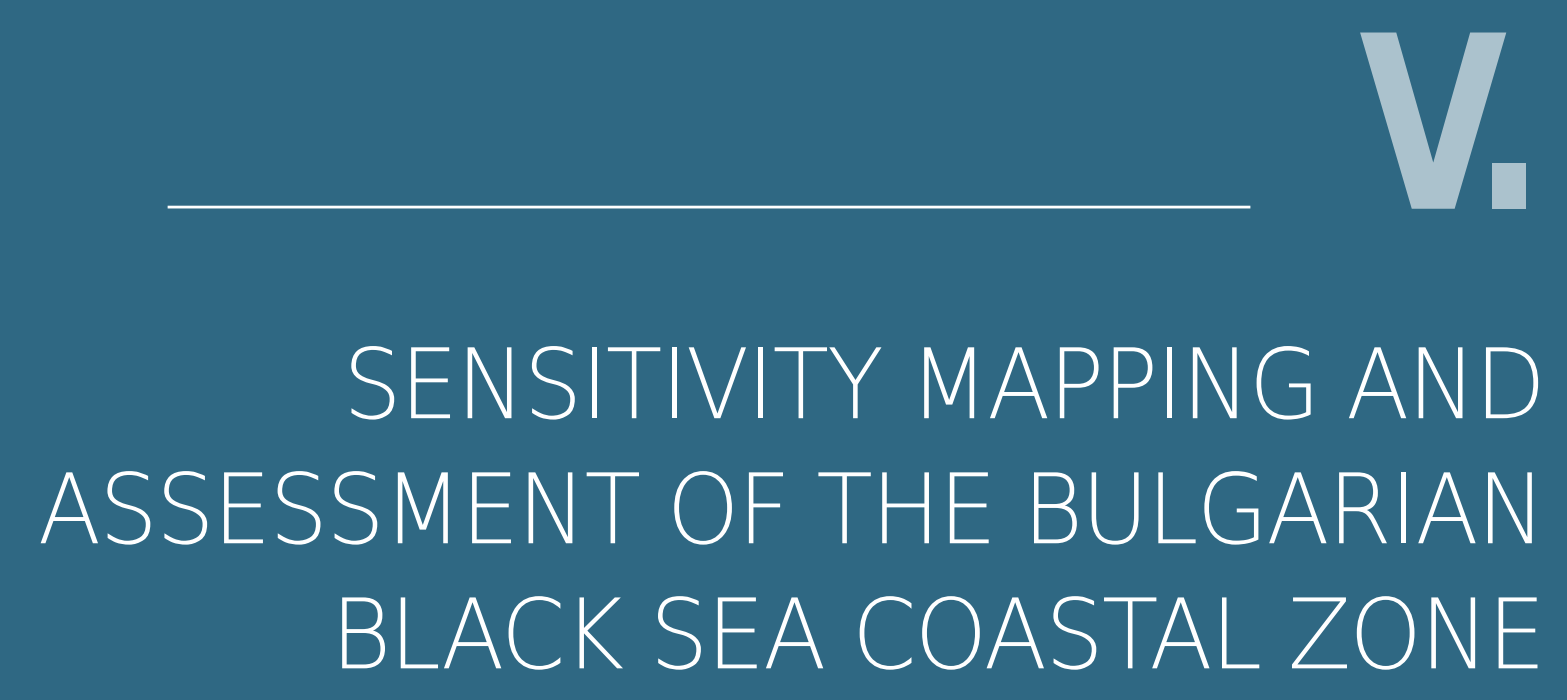




\section{INTRODUCTION}

The mapping of the sensitivity of the environment to oil spill is an essential step in oil pollution preparedness, response and cooperation efforts, and maps are a crucial tool to assist responders during an incident [1]. Environmental sensitivity analysis and mapping projects have been carried out in many countries, along thousands of kilometers of shoreline around the world, primarily as part of national efforts to establish a knowledge-based response system to oil spills that may affect the coastline. Many approaches have been used and described, including GIS applications and remote sensing techniques $[1 ; 2]$

The sensitivity maps presented in this chapter were prepared by Prof. Fridtjof Nansen Institute of Oceanology - BAS in 2015 for TOTAL E\&P Bulgaria B.V. and its partners as part of the safety and environmental preparedness for the exploration activities in the Black Sea deep offshore Block 1-21 Han Asparuh

The process of sensitivity mapping of the Bulgarian Black Sea coast involved severa interconnected steps and tasks. The first task included a detailed desk study, data collection and review of existing data. As a result a gap analysis was done, and the need for additional checking through field campaigns was considered. The second task was to produce an Environmental Sensitivity Index Map. The process was organized in 4 main phases:

\section{PHASE 1}

Coastal Classification: it was done according to the methodology described by IPIECA (2012) [1]. Using orthophoto images from 2010 and 2011 with resolution of $0.4 \mathrm{~m}$ [3], aerial photographs from 2013 (IO-BAS and PSDS WCU) and a field survey from 2015 , the coastline was segmented into the following coastal types corresponding to the 10 levels of the Environmental Sensitivity Index (ESI) of IPIECA (2012) [1]:

- Index 1:

1A Exposed rocky shore:

1B Exposed, solid man-made structures;

1C Exposed rocky cliffs with boulder talus base;

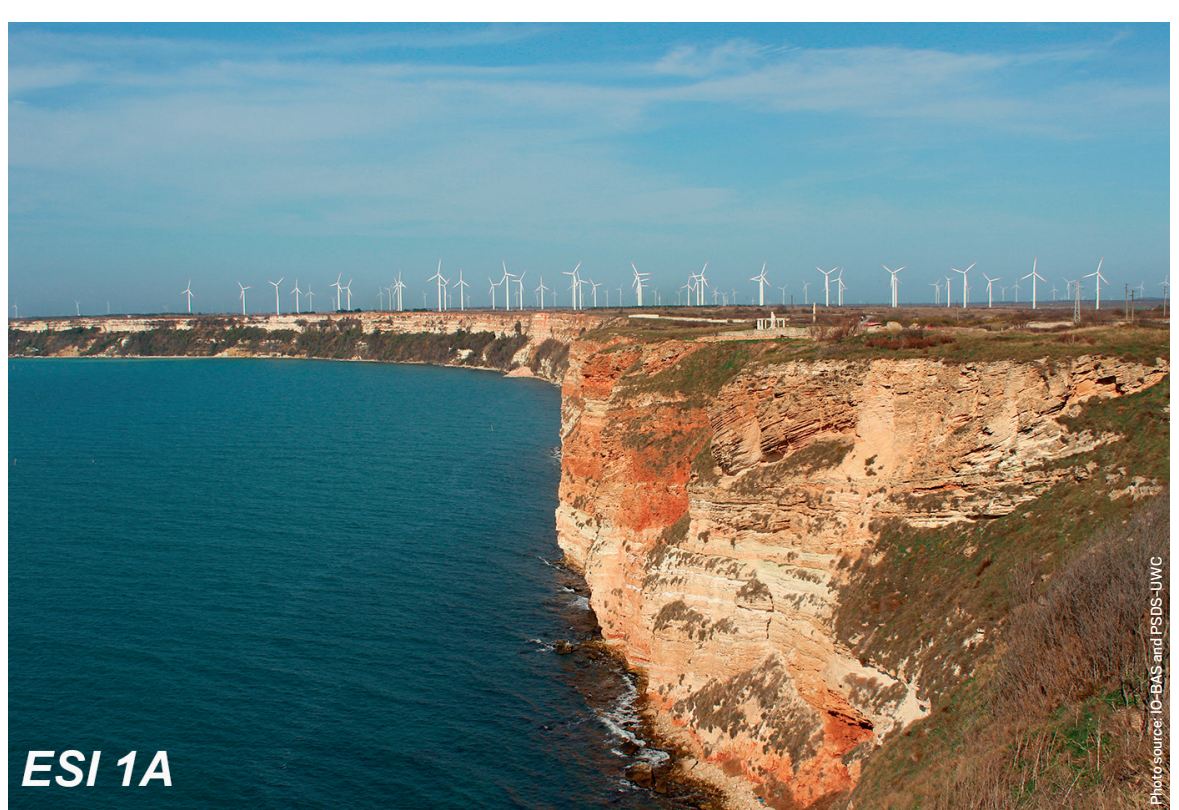

- Index 2:

2A Exposed platforms/slopes;

2B Exposed scarps and steep slopes in clay;

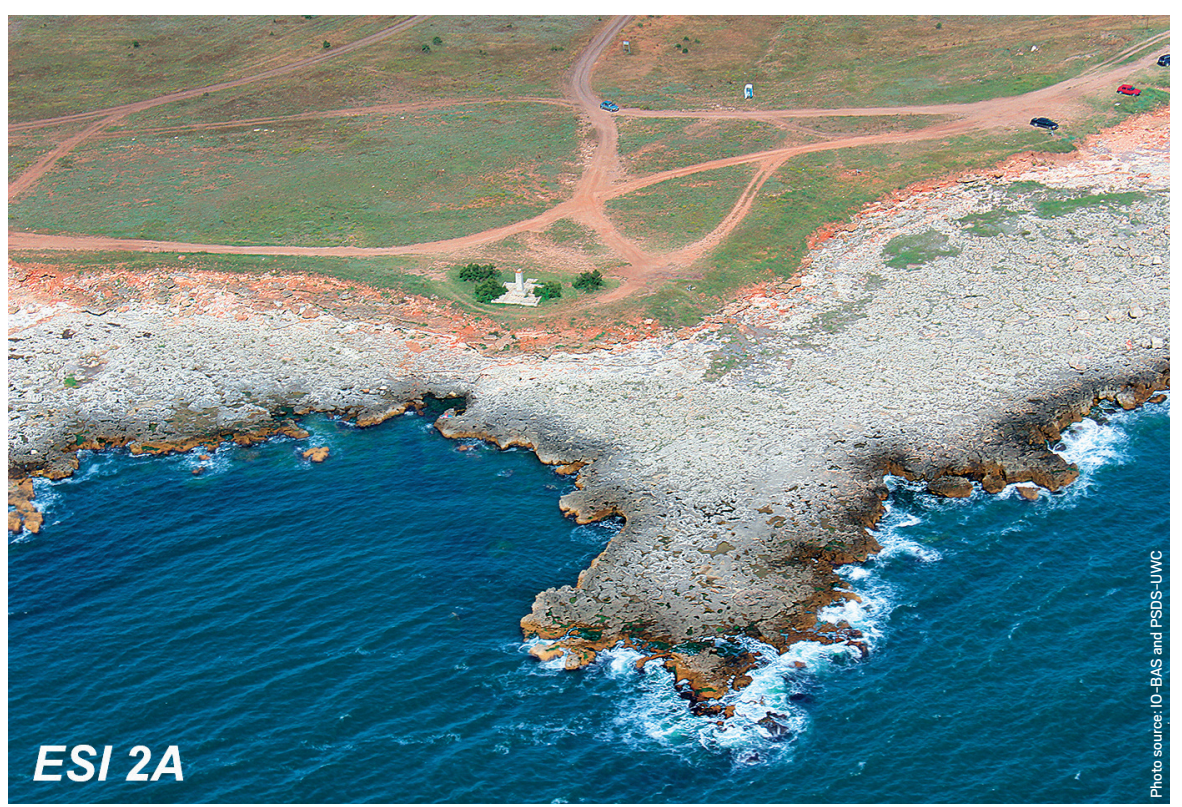


- Index 3:

3A Fine-grained sand beaches;

3B Scarps and steep slopes in sand;

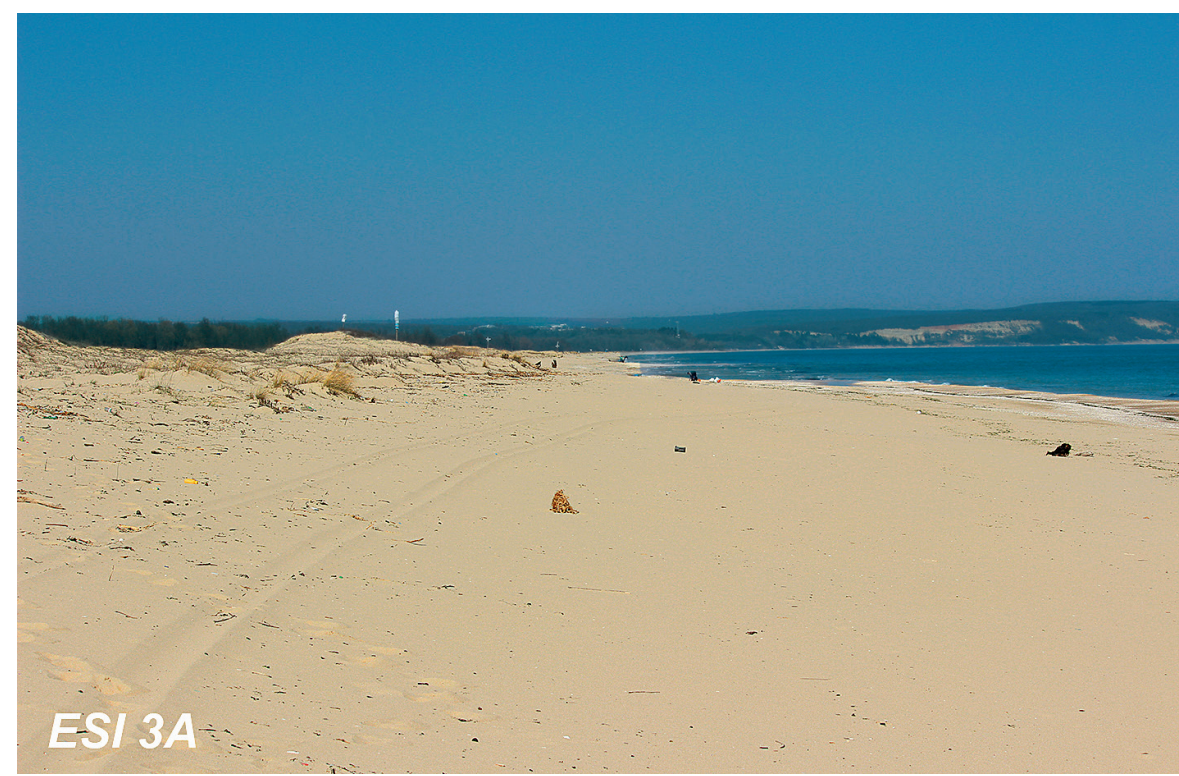

- Index 4:

Coarse-grained sand beaches;

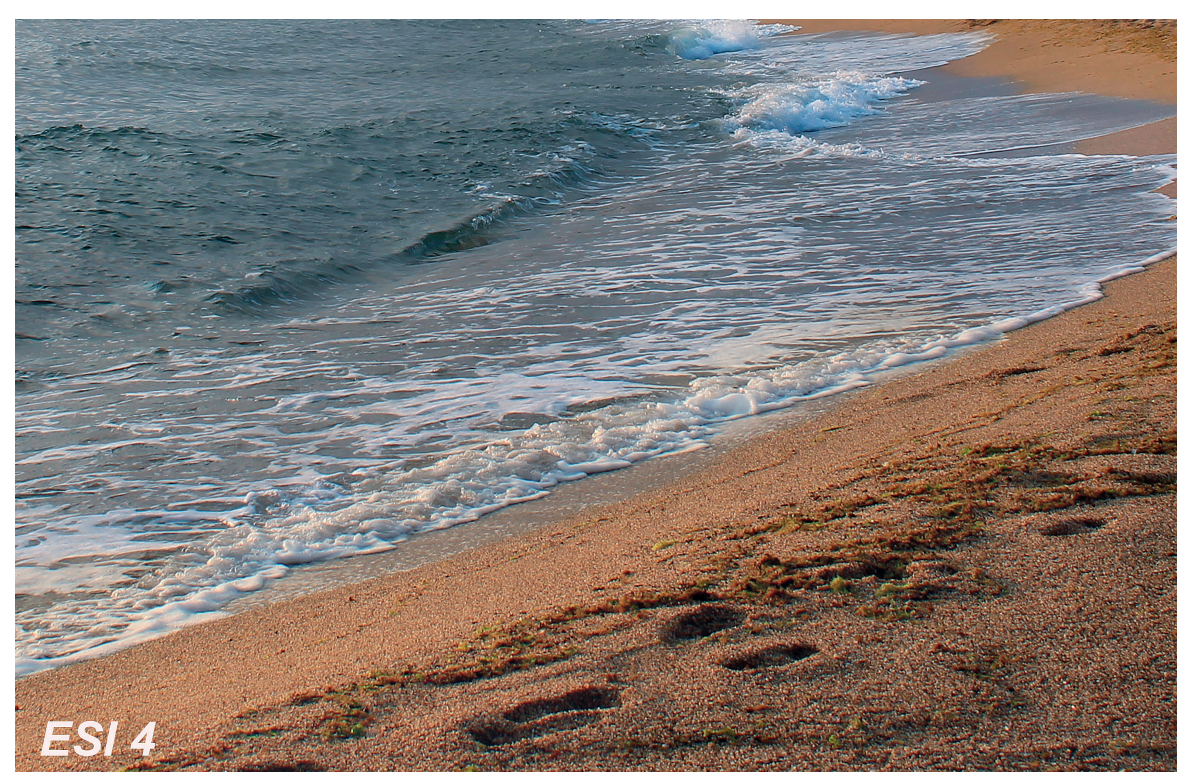

- Index 5:

Mixed sand and gravel beaches;

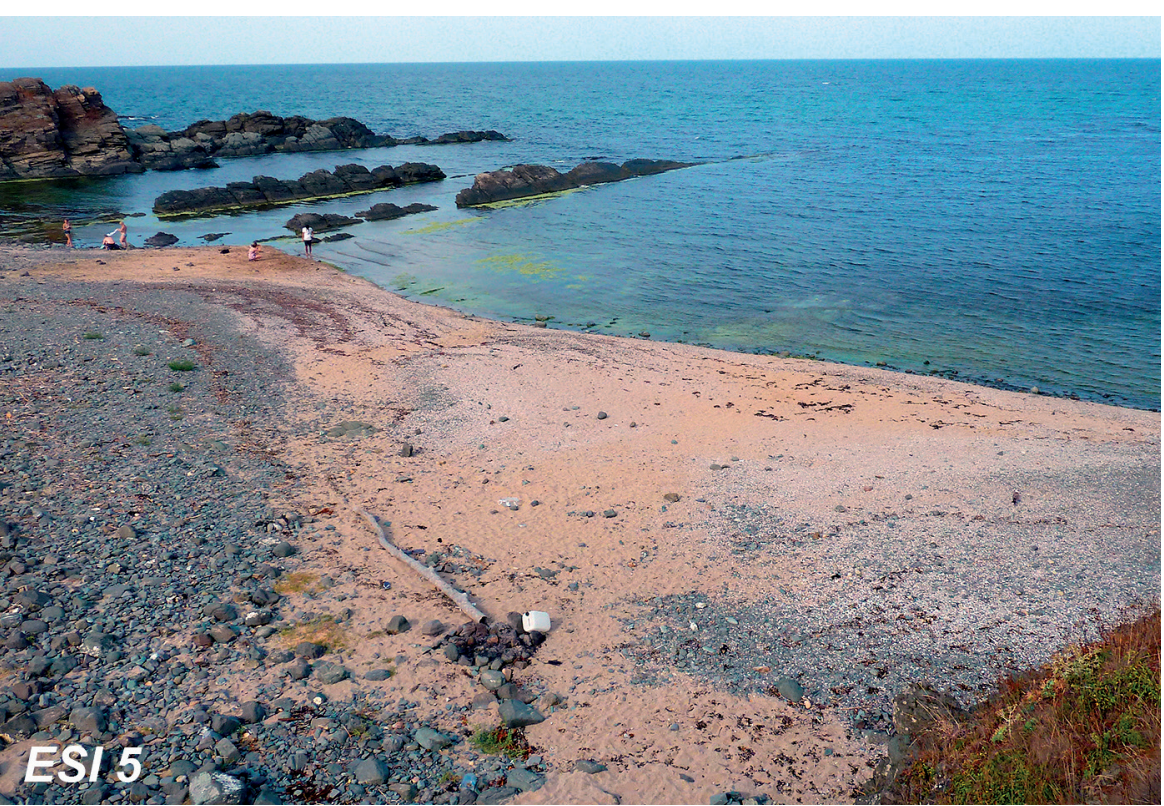

- Index 6:

6A Gravel beaches (granules and pebbles);

6B Riprap structures and gravel beaches (cobbles and boulders);

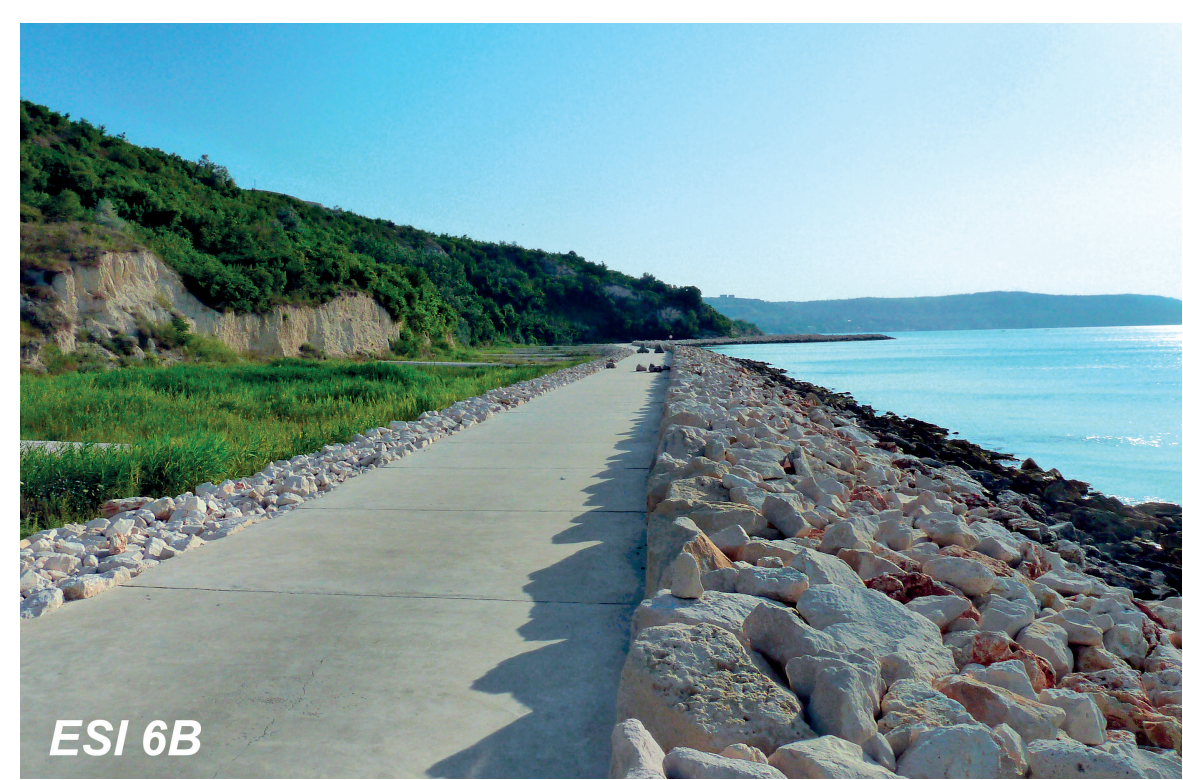

SENSITIVITY MAPPING AND ANALYSIS OF THE BULGARIAN BLACK SEA COASTAL ZONE 
- Index 7:

Exposed tidal flats (not present on the Bulgarian coast);

- Index 8:

8A Sheltered scarps and sheltered rocky shores;

8B Sheltered, solid man-made structures;

8C Sheltered riprap

8D Sheltered rocky rubble shores;

$8 \mathrm{E}$ Peat shorelines (not present on the Bulgarian coast);

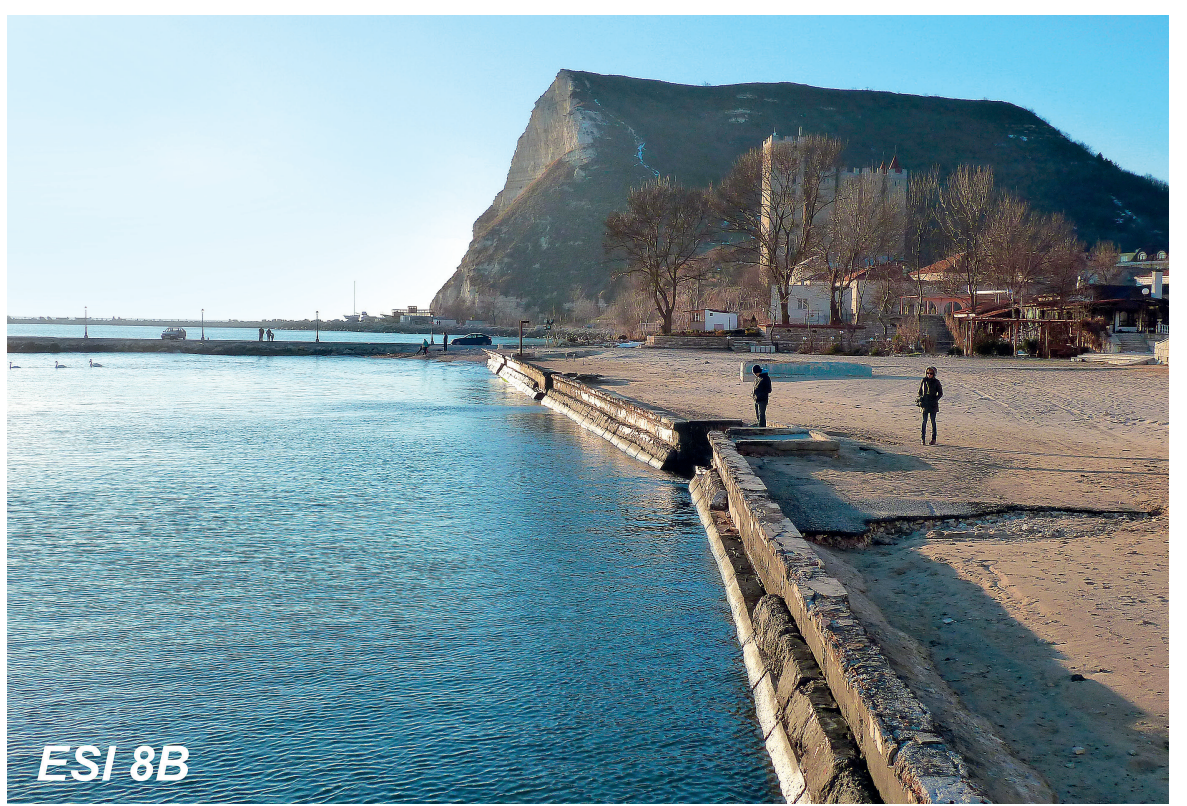

- Index 9:

9A Sheltered tidal flats (not present on the Bulgarian coast);

9B Vegetated low banks;

9C Hypersaline tidal flats (not present on the Bulgarian coast);
- Index 10:

10A Salt and brackish water marshes;

10B Freshwater marshes (not present on the Bulgarian coast)

10C Swamps:

100 Mangroves (not present on the Bulgarian coast);

10E Inundated low-lying tundra (not present on the Bulgarian coast).

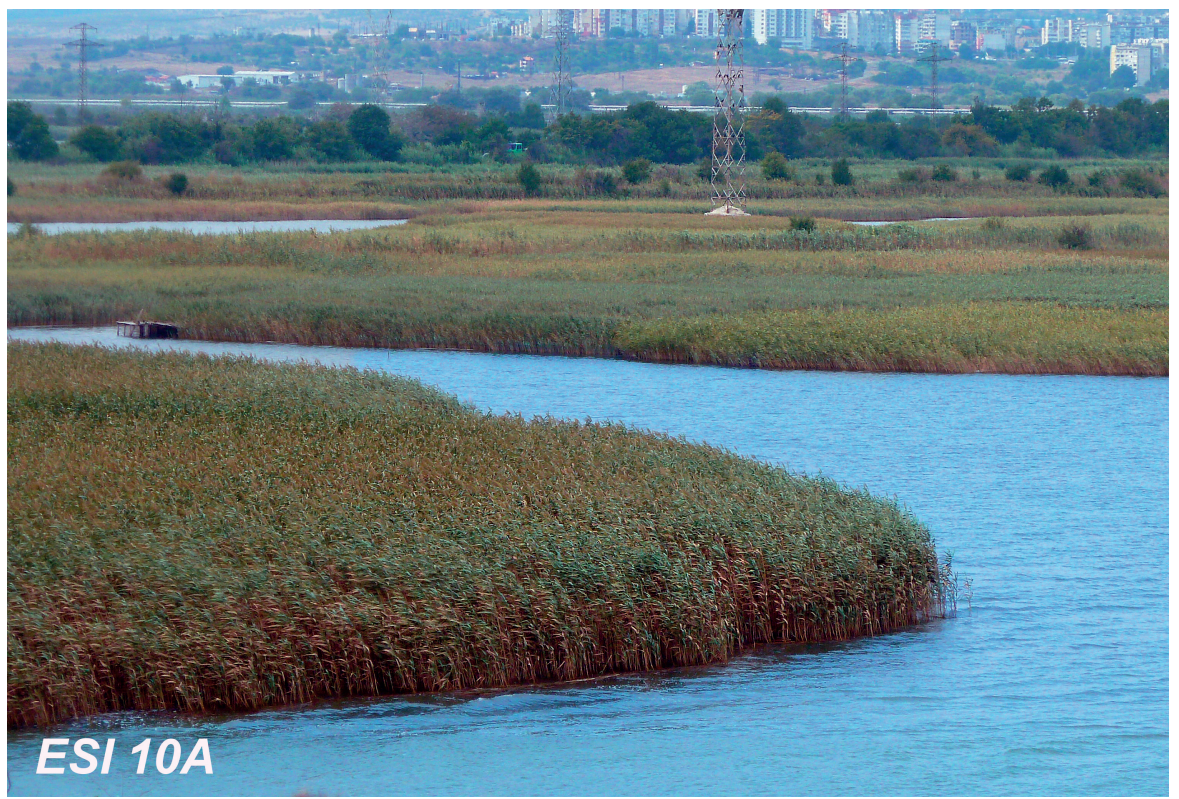

\section{PHASE 2}

Biological Sensitivities. It included:

- Intertidal and shallow subtidal reefs;

- Fish: e.g., habitats and spawning areas;

- Seagrass;

- Marine mammals: e.g., endemic Black Sea dolphin and porpoise species;

- Seabirds and waders: e.g., migratory species; 
- Protected areas: national reserves, Ramsar and NATURA 2000 sites;

- Low-lying areas such as coastal inlets and lagoons set back from the shoreline;

- Threatened and endangered species / habitats.

\section{PHASE 3}

Human-Use Sensitivities. It included:

- Marinas and ports;

- Intakes and outfalls and their purposes;

- Oil terminals

- Offshore platforms and pipelines;

- Commercial shipping routes;

- Coastal aquaculture and artisanal fishing areas;

- Fishing boat landing sites:

- Beach amenity use and tourism activities;

- Archaeological and historical sites.

\section{PHASE 4}

Logistical and Operational Oil Spill Response Features:

- Location of oil spill response equipment (operators)

- both onshore and offshore;

- Dispersant use / non-use areas (usually depth and distance to shore);

- Coastal road access;

- Beach access;

- Boat launching sites;

- Airports.

\section{ORTHOPHOTO IMAGE INTERPRETATION}

The precise detection and measurement of the coastline position and length have been improved by the availability of larger spatial databases and analysis technologies including: Light Detection and Ranging (LIDAR), Differential Global Positioning System (DGPS), High Resolution (HR) or Very High Resolution (VHR) satellite images and aerial images/orthophotos, and GIS [3; 4; 5; 6; 7]

Orthophoto images covering the Bulgarian Black Sea coast

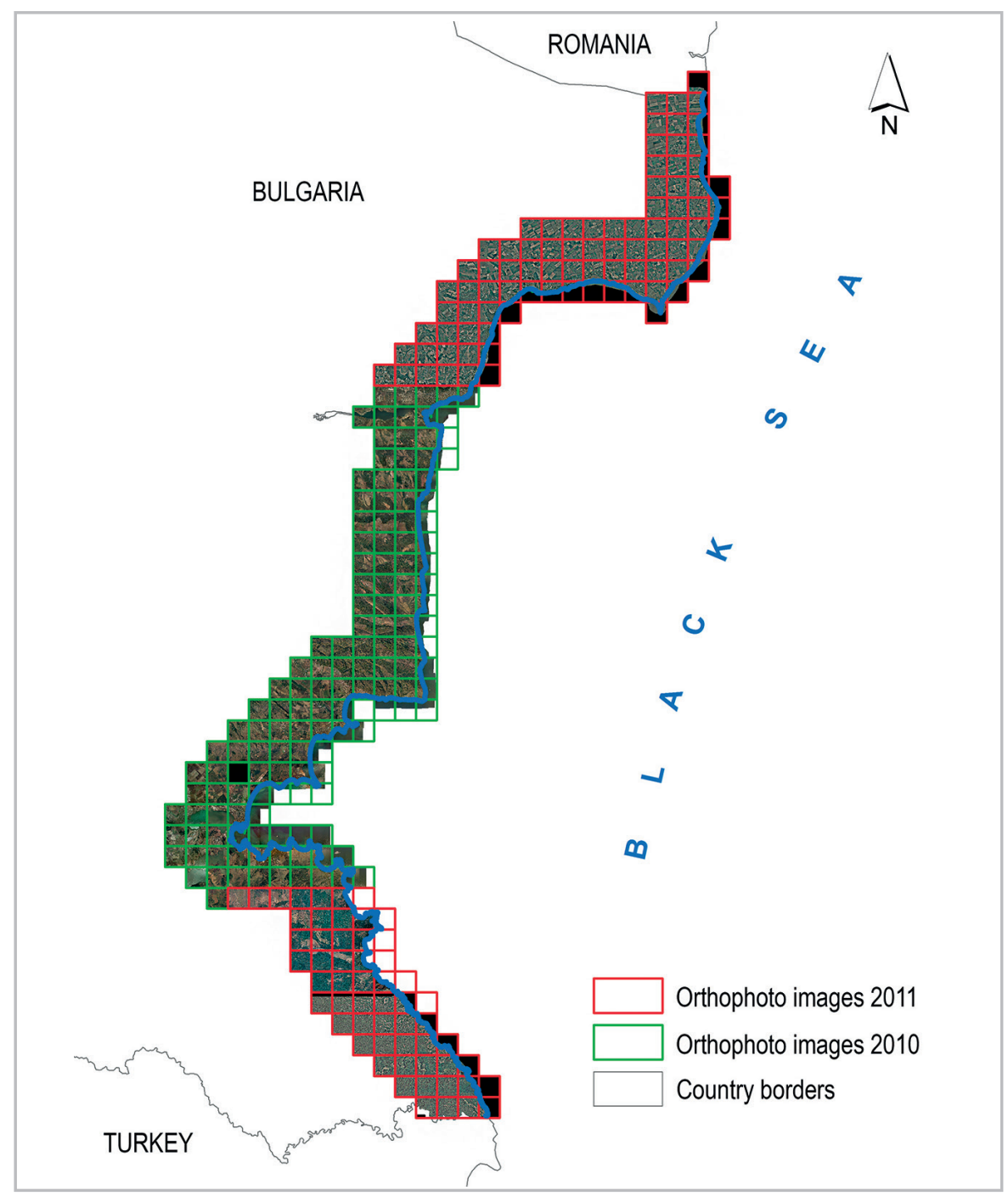


To digitalize the Bulgarian coastline, modern color orthophoto images were used They were provided by the Ministry of Agriculture and Food of the Republic of Bulgaria under a scientific research project titled Joint GIS-Based Coastal Classification of the Bulgarian-Romanian Black Sea Shoreline for Risk Assessment. The images were taken in 2010 and 2011 with a spatial resolution of $0.4 \mathrm{~m}$. A total of 107 images were used along the entire coast. Fifty six were taken in 2010 and 51 in 2011, and each image has a size of $4 / 4 \mathrm{~km}$

The orthophoto images are registered in a Projected Coordinate System: WGS_1984_ UTM_ZONE_35N as the data were preliminarily orthorectified. In High Resolution (HR: 30 to $5 \mathrm{~m}$ ) and Very High Resolution (VHR: 4 to $1 \mathrm{~m}$ or less) imagery, the details of sand beaches, dunes, cliff foot/top, shoreline position, human structures, etc., are clearly visible and this allows precise mapping [3]. The mapping of natural landforms/ human structures and analysis was performed using Arclnfo 10.2.

For a more accurate identification, and mapping of the coast, a large number of aerial digital photographs were used. The photos were taken on July 10-11, 2013 at an angle of approximately $45^{\circ}$, and an elevated position of $200 \mathrm{~m}$ above the sea [8]. A Cessna aircraft was used with 3 coastal researchers on board: Dr. Margarita Stancheva and Dr. Hristo Stanchev from IO-BAS, and Prof. Robert Young from WCU, USA [9]. During the 2-day photo survey of the entire Bulgarian Black Sea coast (from the border with Romania to the north to the border with Turkey to the south), more than 2,000 digital photos of the coast were taken.

\section{The aircraft and the researchers who took the aerial photos}
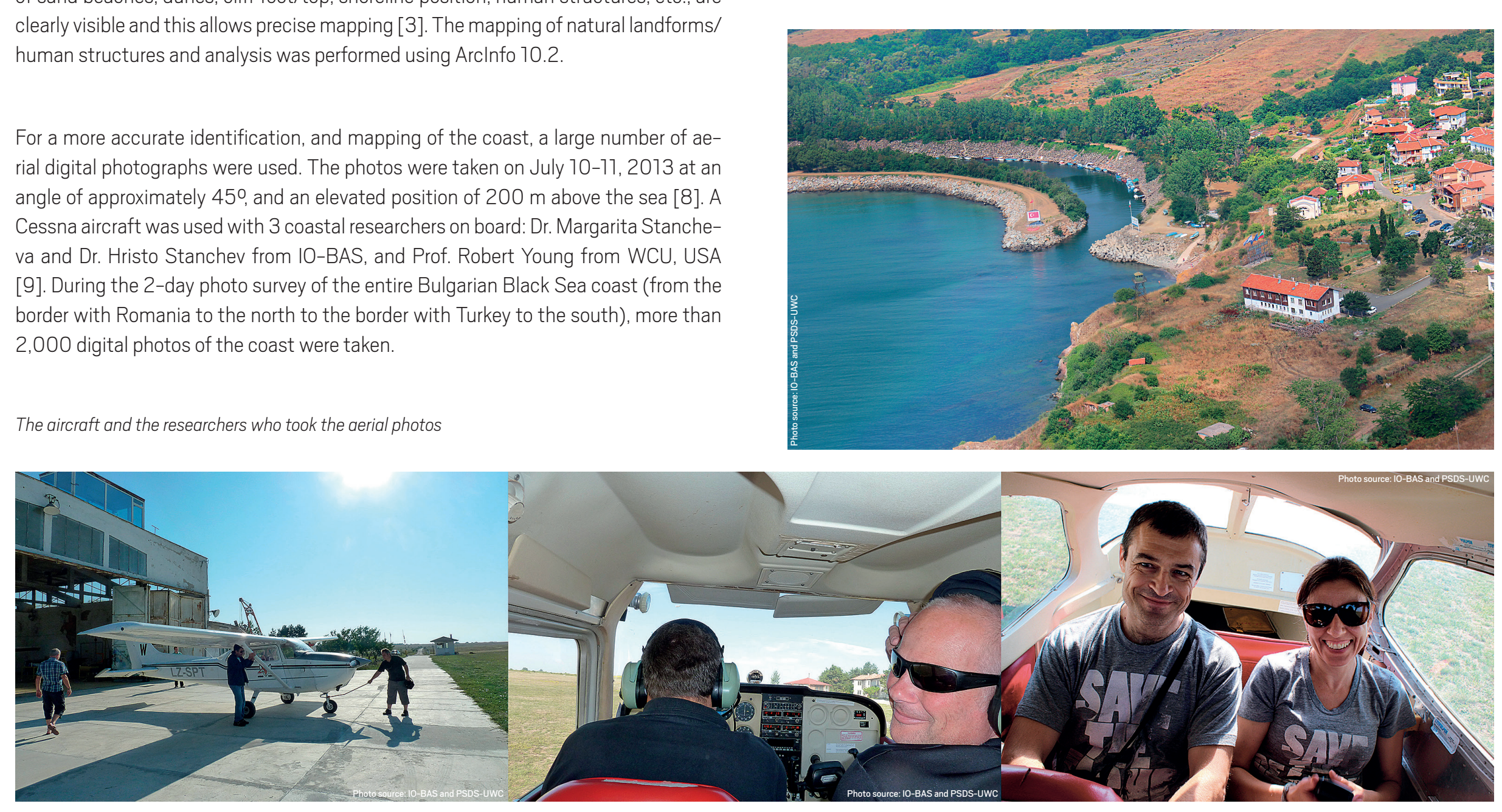

152 SENSITIVITY MAPPING AND ASSESSMENT OF THE BULGARIAN BLACK SEA COASTAL ZONE

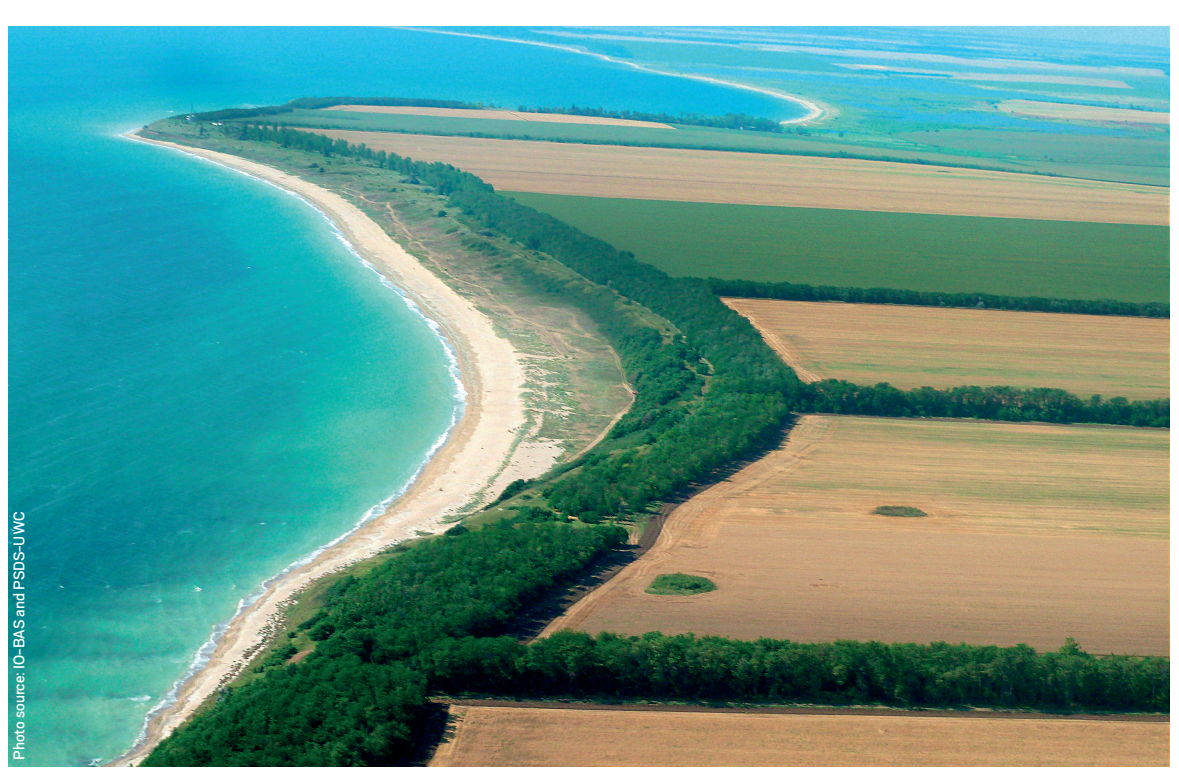

The northernmost (above) and southernmost (below) portions of the Bulgarian coast 
In addition, in the summer of 2015 , field visits on coastal segments unclearly visible on orthophoto images were made. During these visits, numerous ground photographs were taken.

Table 1. Identified coastal geomorphic types

\begin{tabular}{|c|c|}
\hline Coastal geomorphic types & Number of segments \\
\hline Artificial beach & 4 \\
\hline Beach & 441 \\
\hline Boat quay wall & 5 \\
\hline Boulder & 1 \\
\hline Rocky cliff & 267 \\
\hline Cobbles and boulders & 6 \\
\hline Fishing boat site & 2 \\
\hline Groin (permeable) & 5 \\
\hline Groin & 231 \\
\hline Jetties/Marinas & 42 \\
\hline Lake-sea canal & 4 \\
\hline Loess cliff & 6 \\
\hline Low-lying area & 3 \\
\hline Marina & 12 \\
\hline Marshes, canal & 3 \\
\hline Oil tanker terminal & 5 \\
\hline Platform & 27 \\
\hline Port & 19 \\
\hline Port mole & 26 \\
\hline Quay wall & 23 \\
\hline Riprap & 145 \\
\hline Scarp & 1 \\
\hline Sea wall & 42 \\
\hline Spur & 17 \\
\hline Total & 1,337 \\
\hline
\end{tabular}

In result of the digitalization of the orthophoto images, a total of 1,337 individual segments along the Bulgarian coast were identified and mapped (Table 1 and Table 2)

Table 2. Identified types of coastal segment according to ESI

\begin{tabular}{|c|c|}
\hline Type of coastal segment according to ESI & $\begin{array}{c}\text { Number of coastal } \\
\text { segments (ESI) }\end{array}$ \\
\hline 1A Exposed rocky shore & 152 \\
\hline 1B Exposed, solid man-made structures & 99 \\
\hline 1C Exposed rocky cliffs with boulder talus base & 113 \\
\hline 2A Exposed wave-cut platform in bedrock & 28 \\
\hline 2B Exposed scarps and steep slopes in clay & 2 \\
\hline 3A Fine- to medium-grained sand beaches & 282 \\
\hline 3B Scarps and steep slopes in sand & 1 \\
\hline 4 Coarse grained sand beaches & 37 \\
\hline 5 Mixed sand and gravel beaches & 96 \\
\hline 6A Gravel beaches (granules and pebbles ) & 11 \\
\hline $\begin{array}{l}\text { 6B Riprap structures and gravel beaches } \\
\text { (cobbles and boulders) }\end{array}$ & 329 \\
\hline $8 \mathrm{~A}$ Sheltered scarps and sheltered rocky shores & 7 \\
\hline $\begin{array}{l}\text { 8B Sheltered, solid man-made structures } \\
\text { (permeable) }\end{array}$ & 1 \\
\hline 8B Sheltered, solid man-made structures & 111 \\
\hline 8C Sheltered riprap & 56 \\
\hline 8D Sheltered rocky rubble shores & 2 \\
\hline 9B Vegetated low banks & 3 \\
\hline 10A Salt and brackish water marshes & 7 \\
\hline Total & 1,337 \\
\hline
\end{tabular}




\section{Bulgarian coastal sensitivity map}

\section{Environmental Sensitivity Index}

ESI 1 - Exposed rocky shores

ESI 2 - Exposed platforms/slopes

ESI 3 - Fine-grained sand beaches

ESI 4 - Coarse-grained sand beaches

ESI 5 - Mixed sand and gravel beaches

ESI 6 - Gravel beaches \& riprap structures

ESI 7 - Exposed tidal flats (not present on the Bulgarian coast)

ESI 8 - Sheltered rocky shores

ESI 9 - Vegetated low banks

ESI 10 - Swamps \& marshes

\section{Biological resources}

(4) Birds

Fish

(6) Dolphin

(iii) Seagrass

C3 National Reserve

02 Ramsar site

C NATURA 2000 site - Birds Directive

O NATURA 2000 site - Habitats Directive
Human use resources

* Historical site

(AQ) Aquaculture

Artisanal fishing area

Boat launching site

(4.) Marina

(¿) Port

(d) Intakes

Outfalls

(ख) Airport

- Fish boat landing site

* Gas platform

Cities

Hotels

Sea resort

(A) Camping site

- Desalination plant

Main road

Pipelines

Recreational beach

$\therefore$ Dispersant non-use area
Hydrographic data
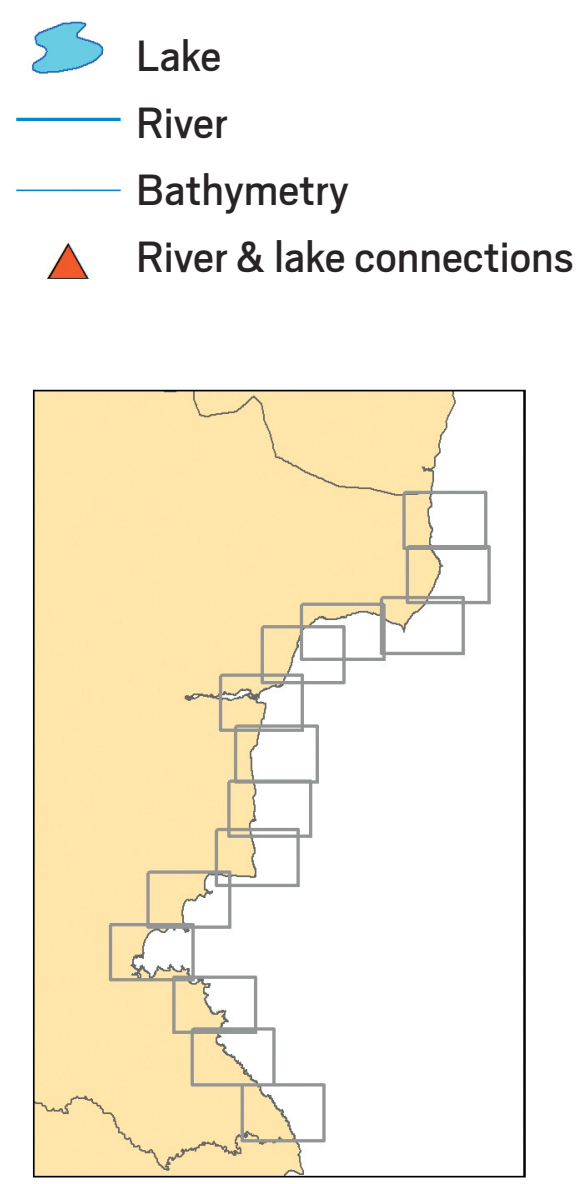

Projection: UTM 35 N (WGS 84) 
Coastal sensitivity maps of Bulgaria at 7:700,000 scale

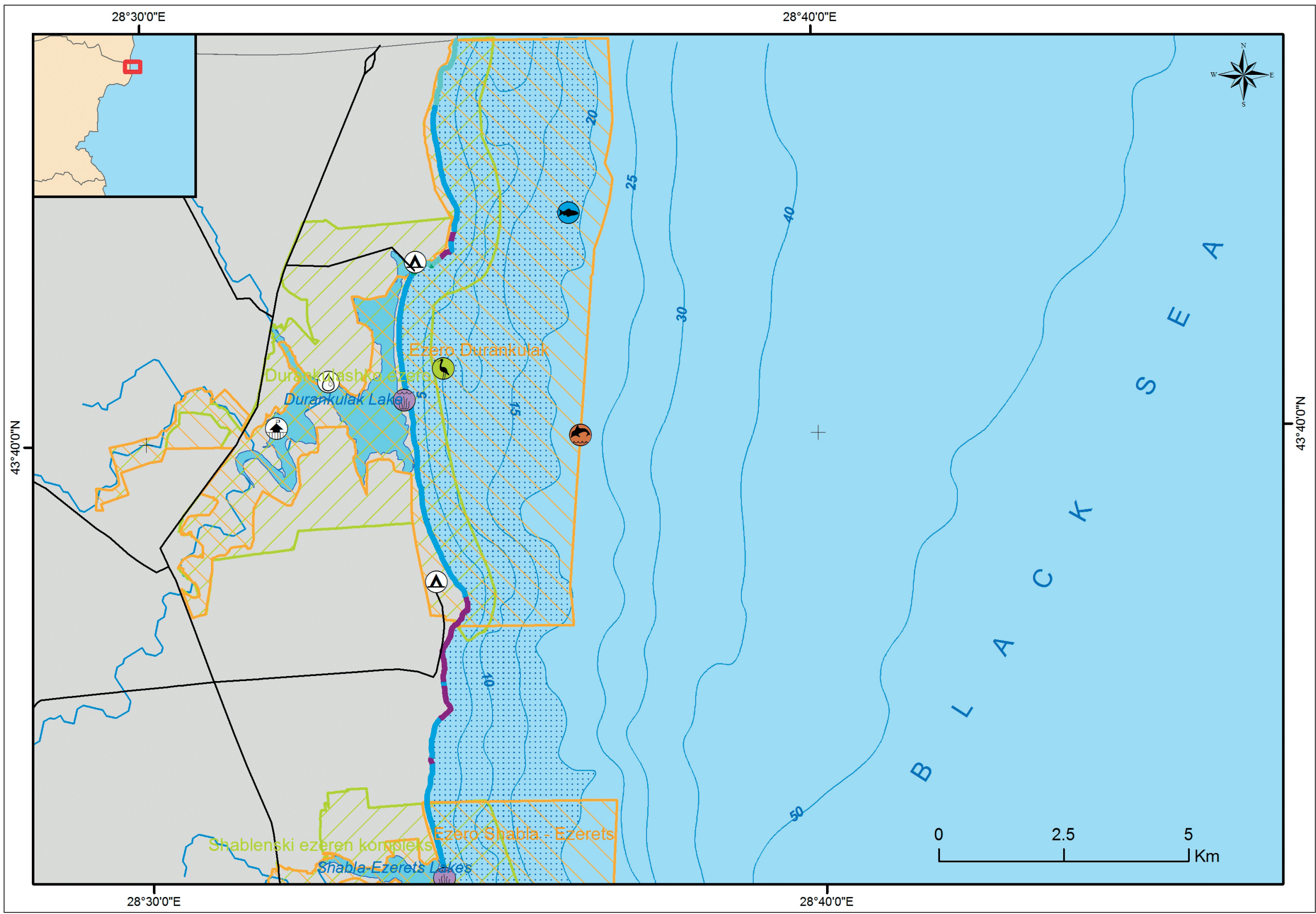




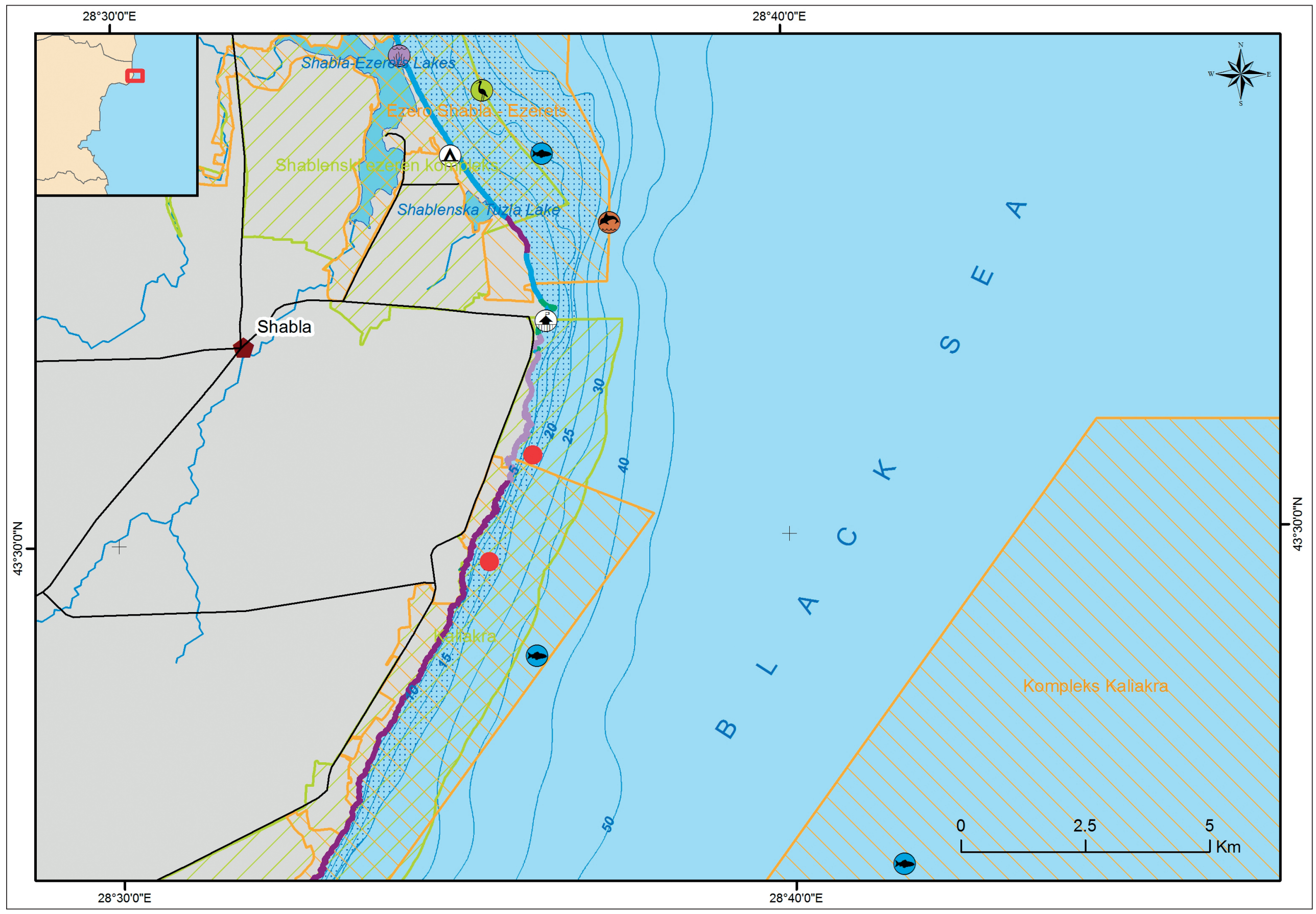

156 SENSITIVITY MAPPING AND ASSESSMENT OF THE BULGARIAN BLACK SEA COASTAL ZONE 


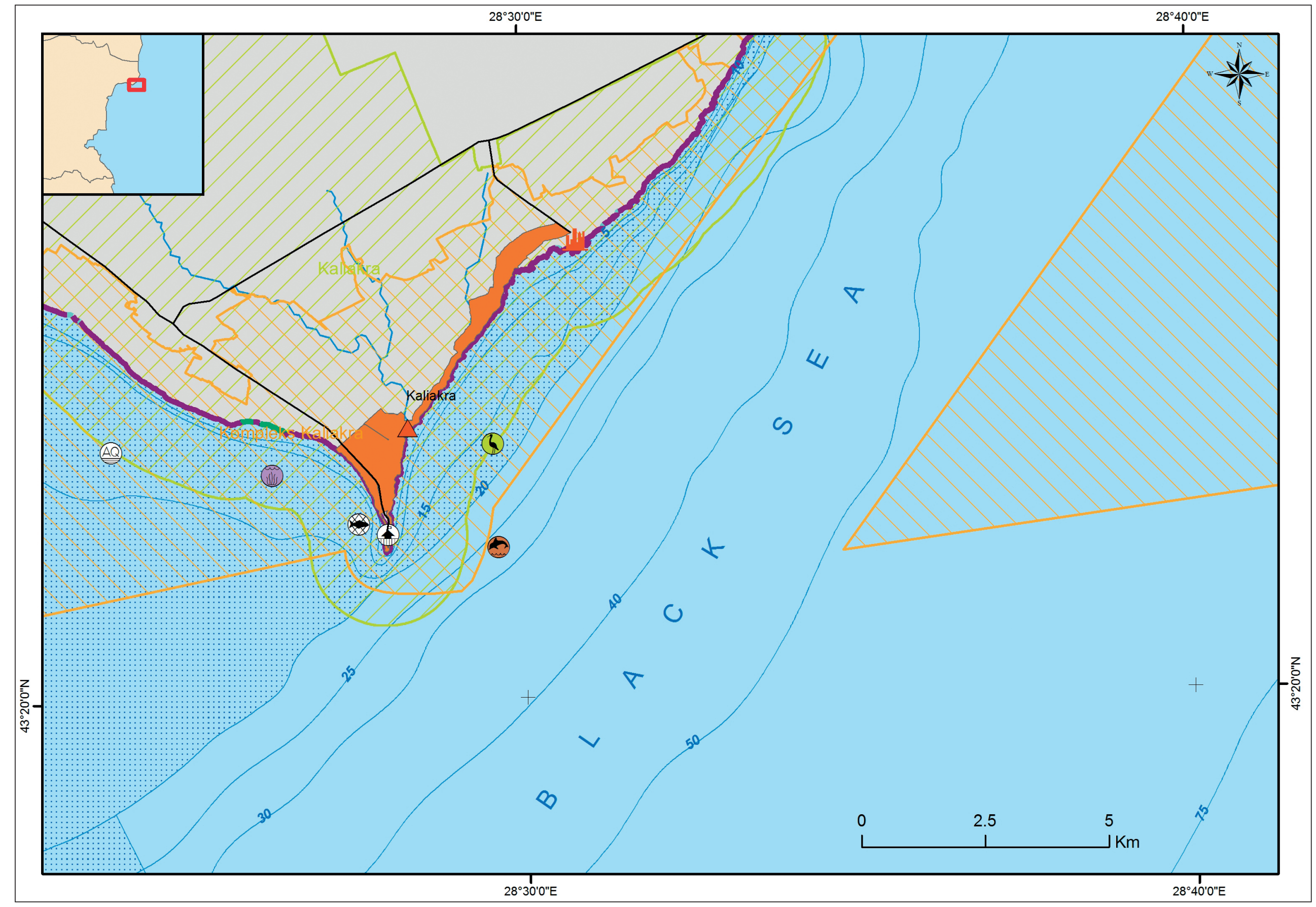




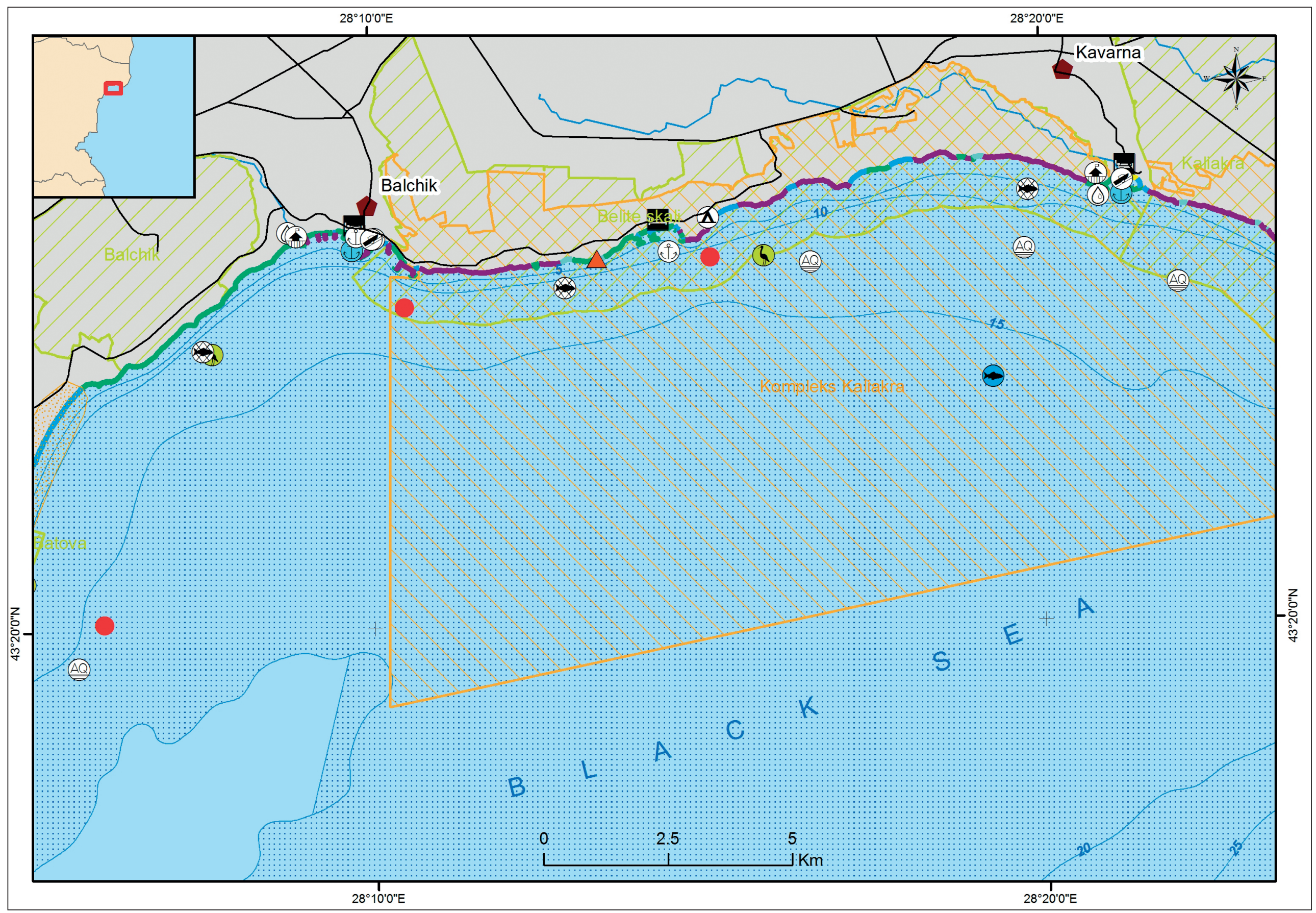

158 SENSITIVITY MAPPING AND ASSESSMENT OF THE BULGARIAN BLACK SEA COASTAL ZONE 


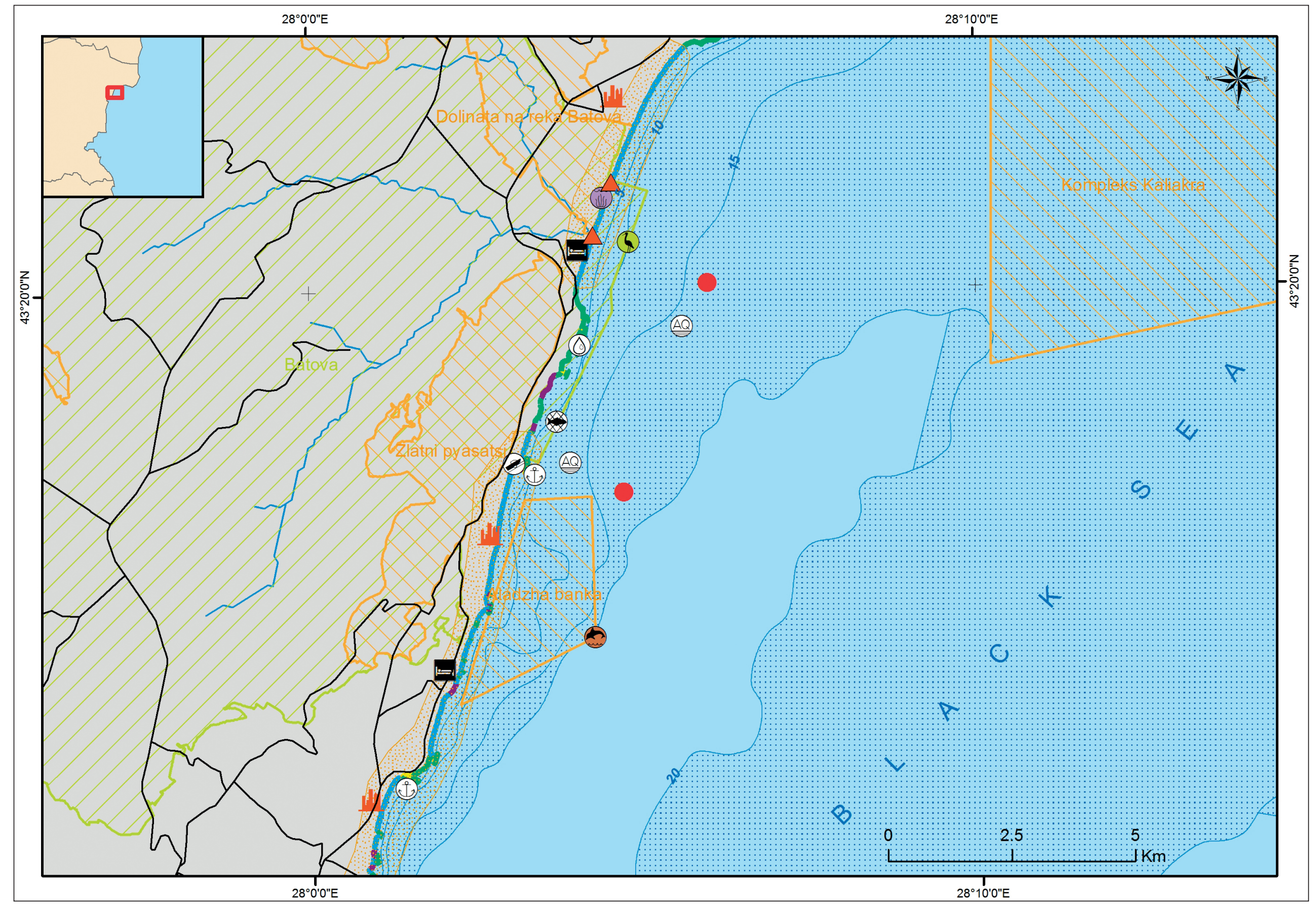




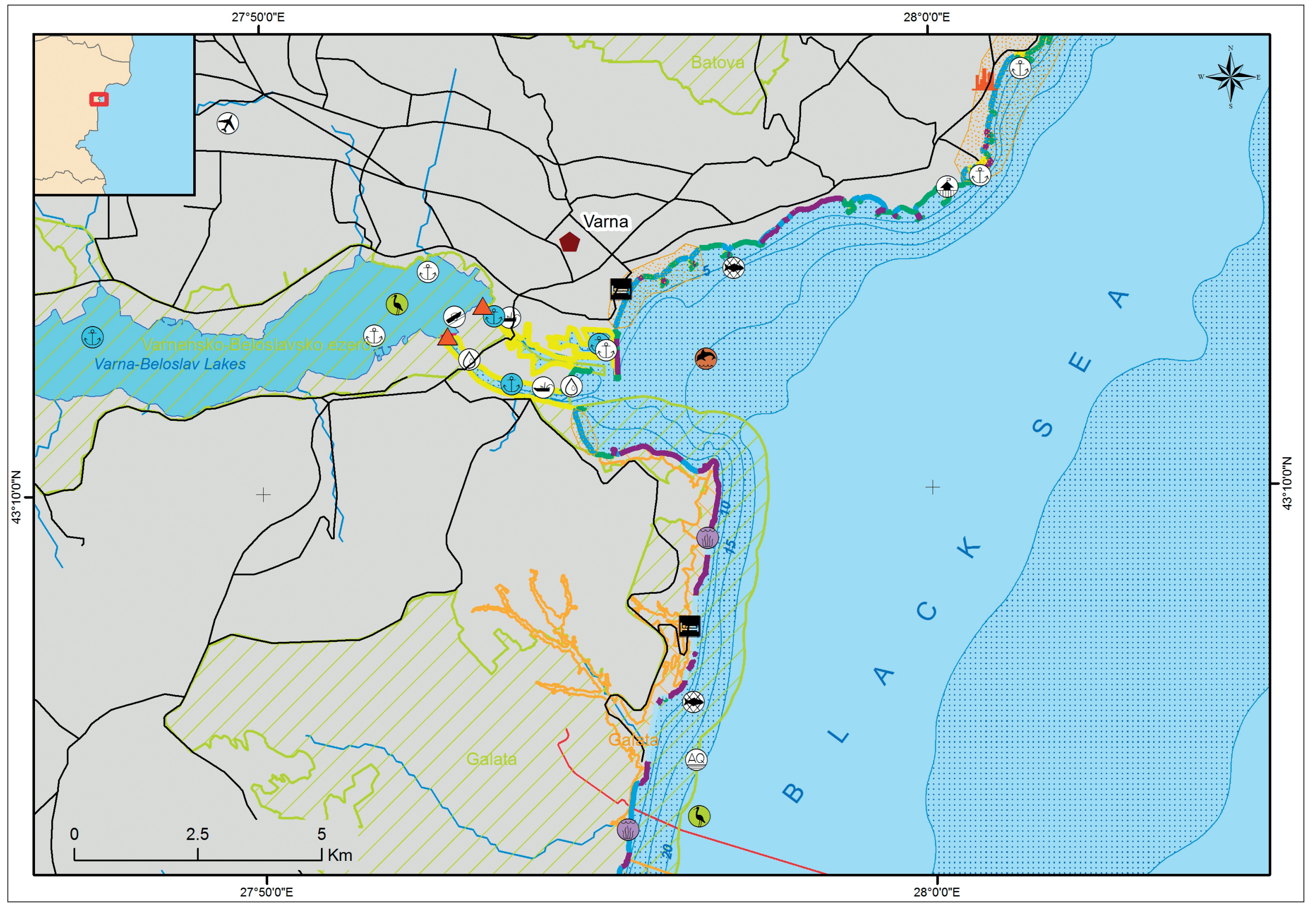

160 SENSITIVITY MAPPING AND ASSESSMENT OF THE BULGARIAN BLACK SEA COASTAL ZONE 


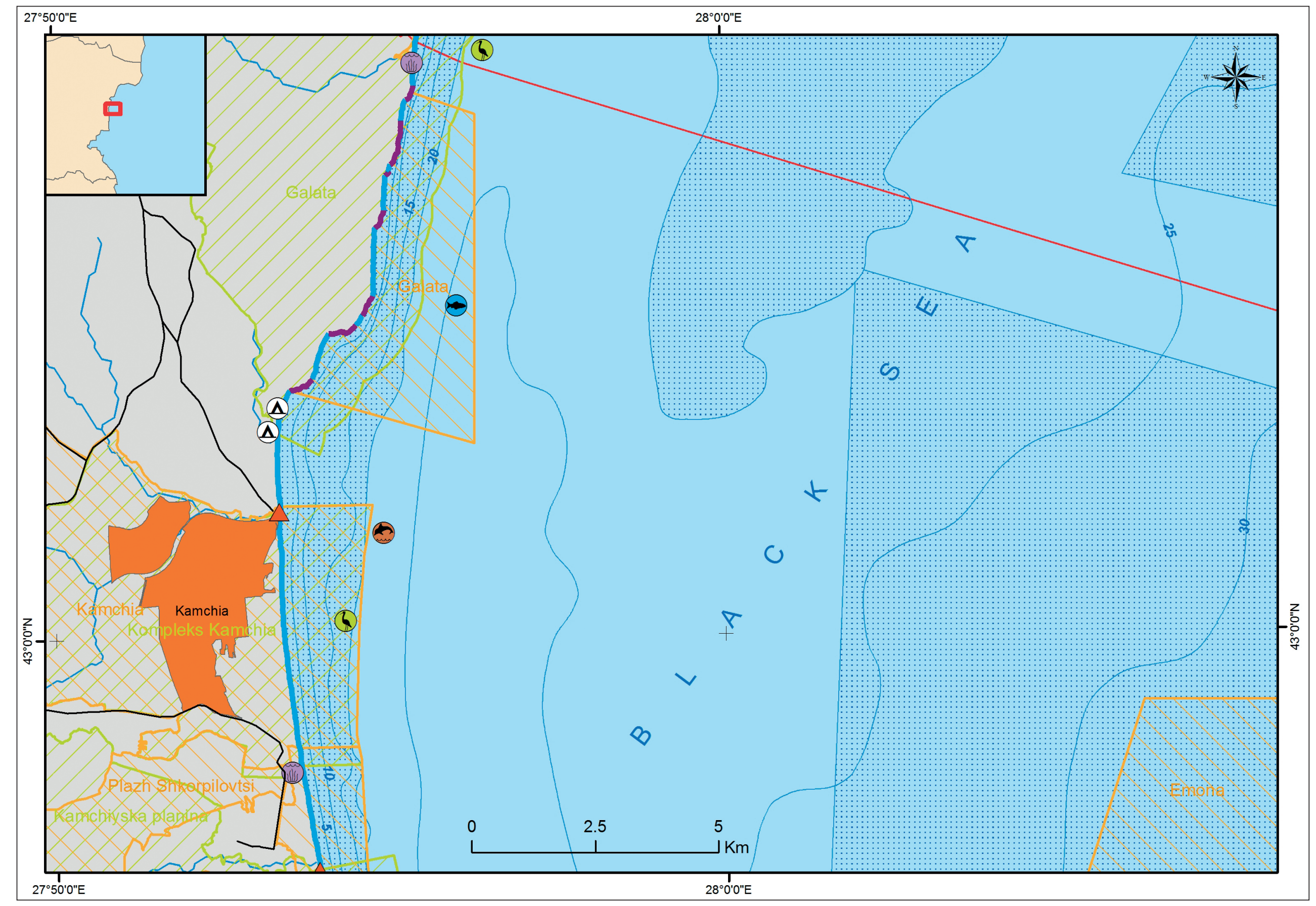




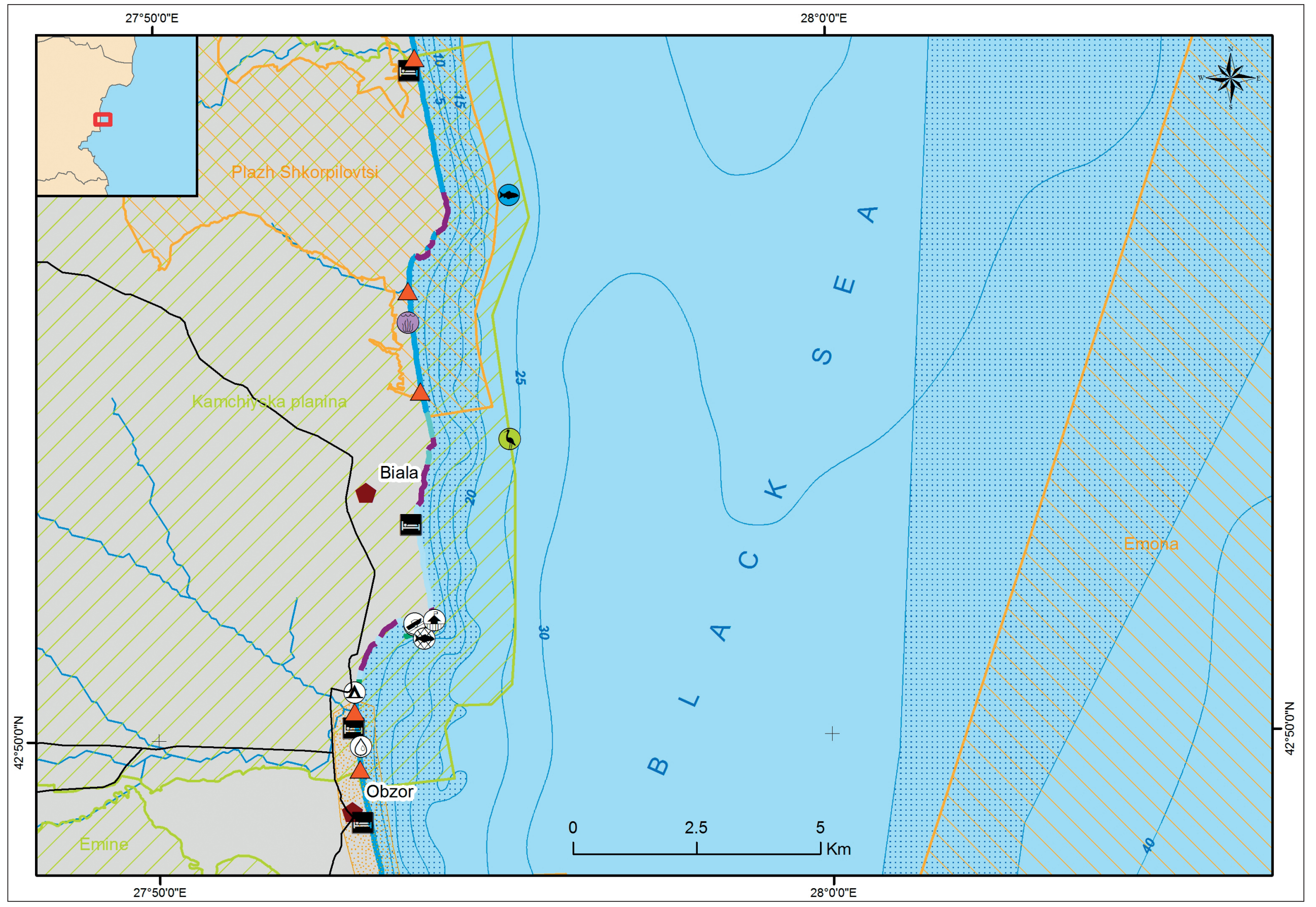

162 SENSITIVITY MAPPING AND ASSESSMENT OF THE BULGARIAN BLACK SEA COASTAL ZONE 


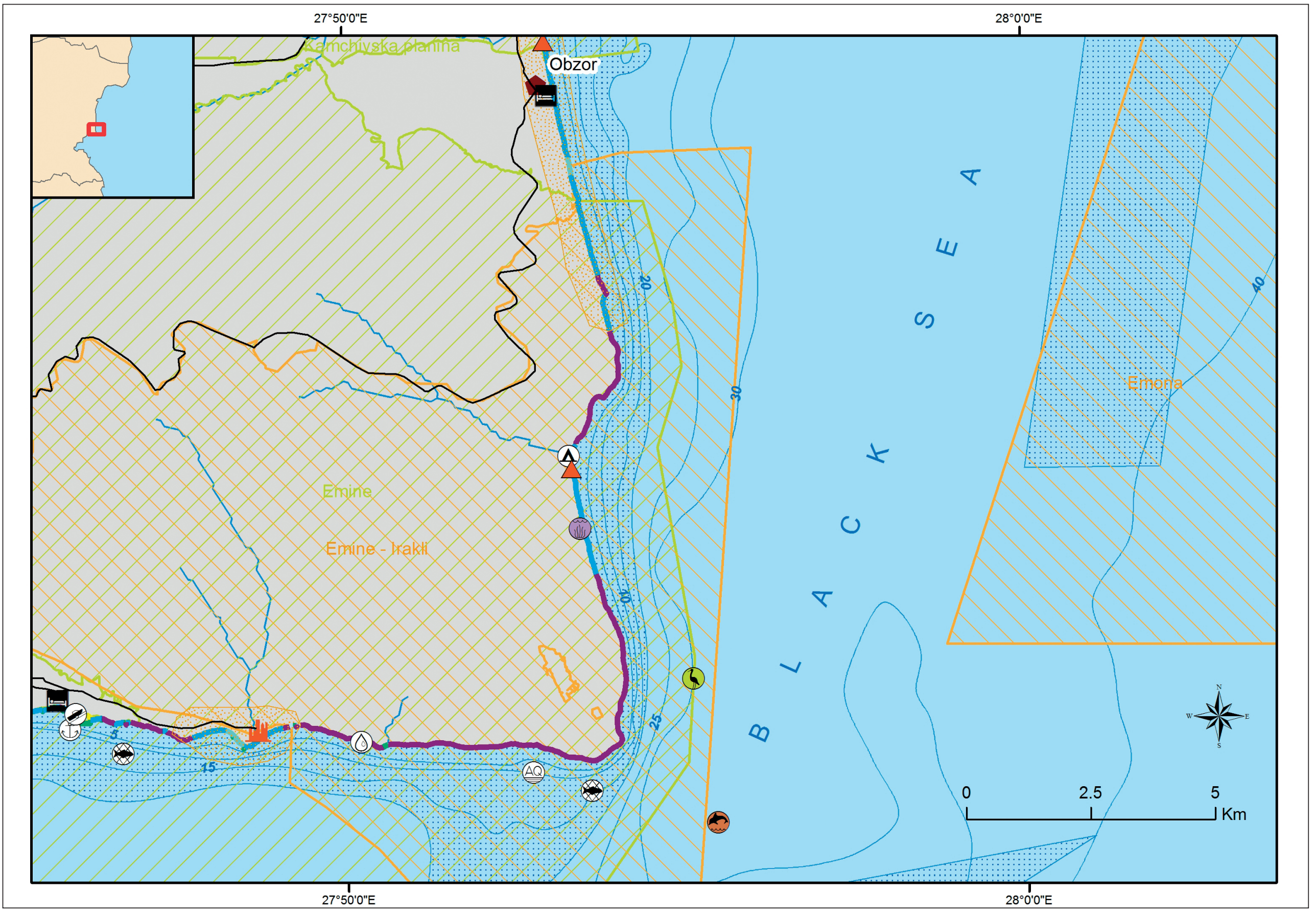




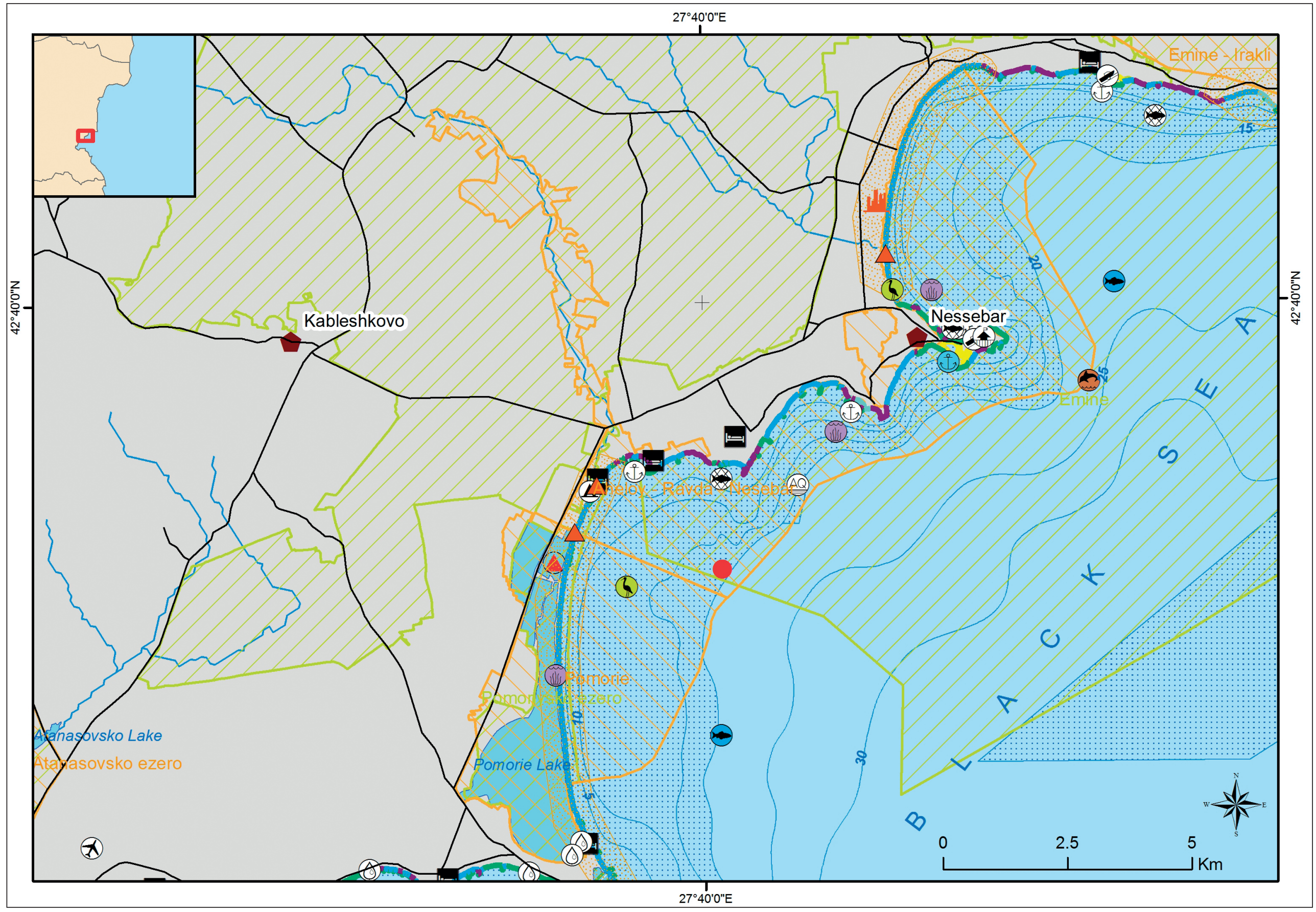

164 SENSITIVITY MAPPING AND ASSESSMENT OF THE BULGARIAN BLACK SEA COASTAL ZONE 


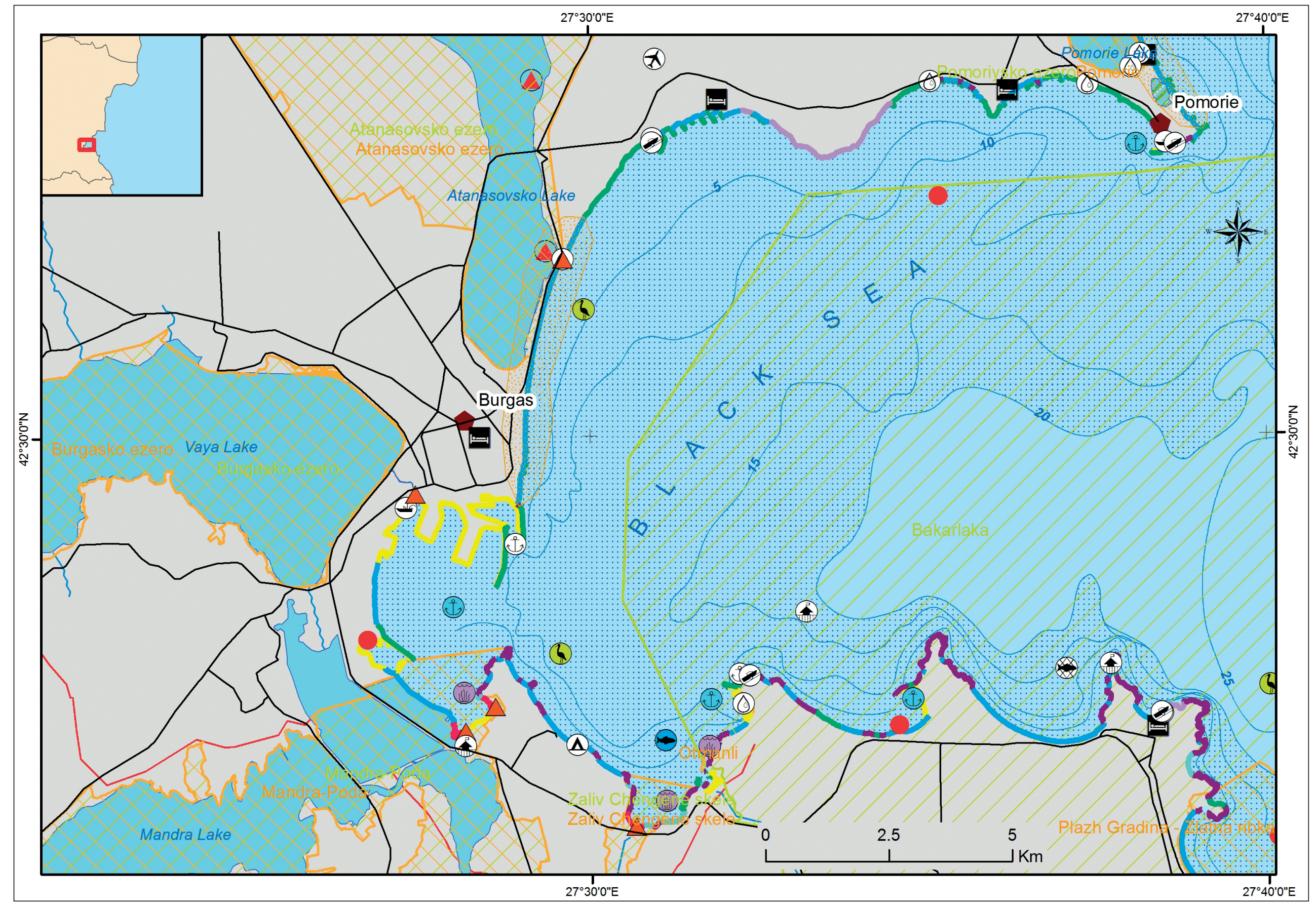




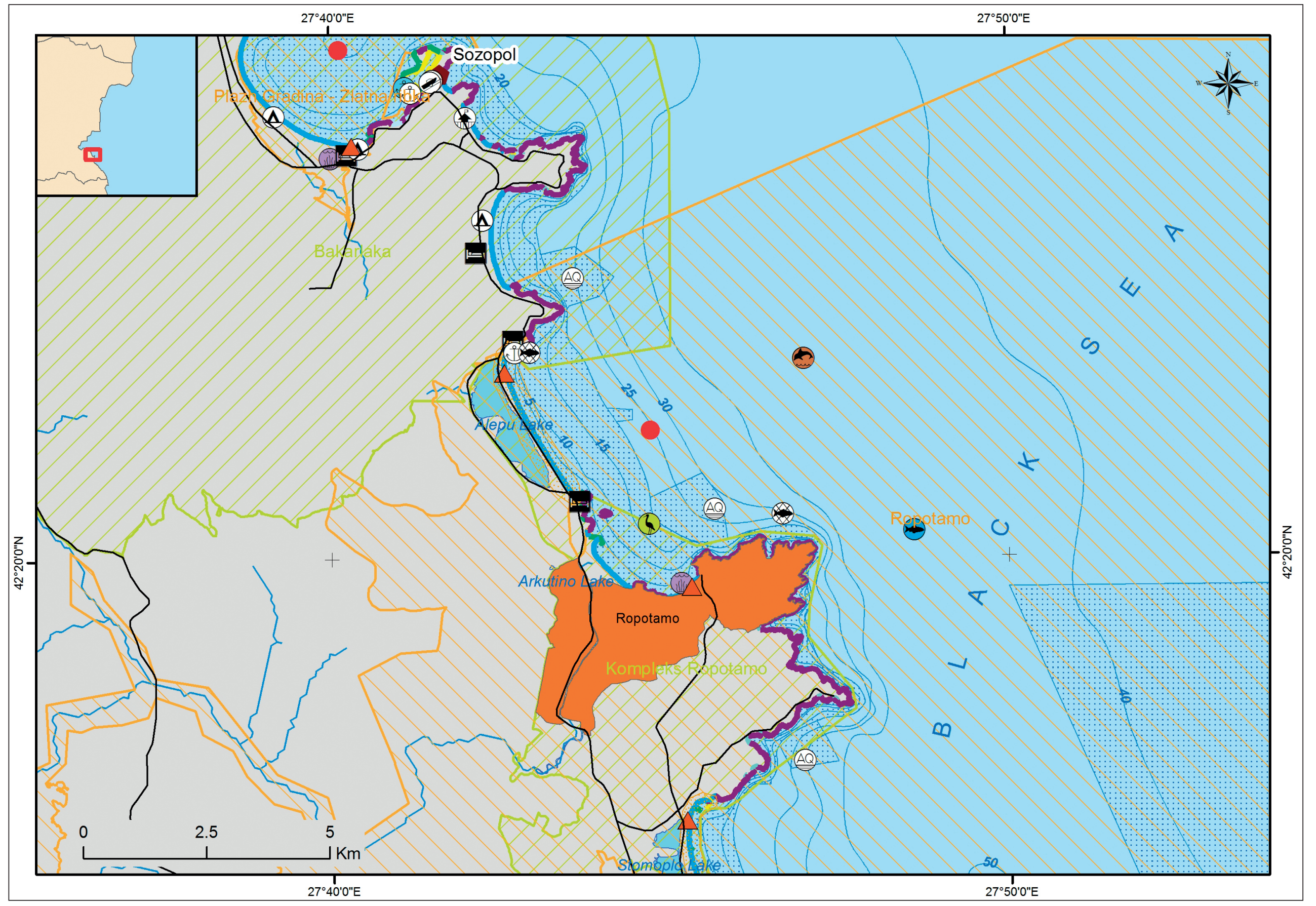

166 SENSITIVITY MAPPING AND ASSESSMENT OF THE BULGARIAN BLACK SEA COASTAL ZONE 


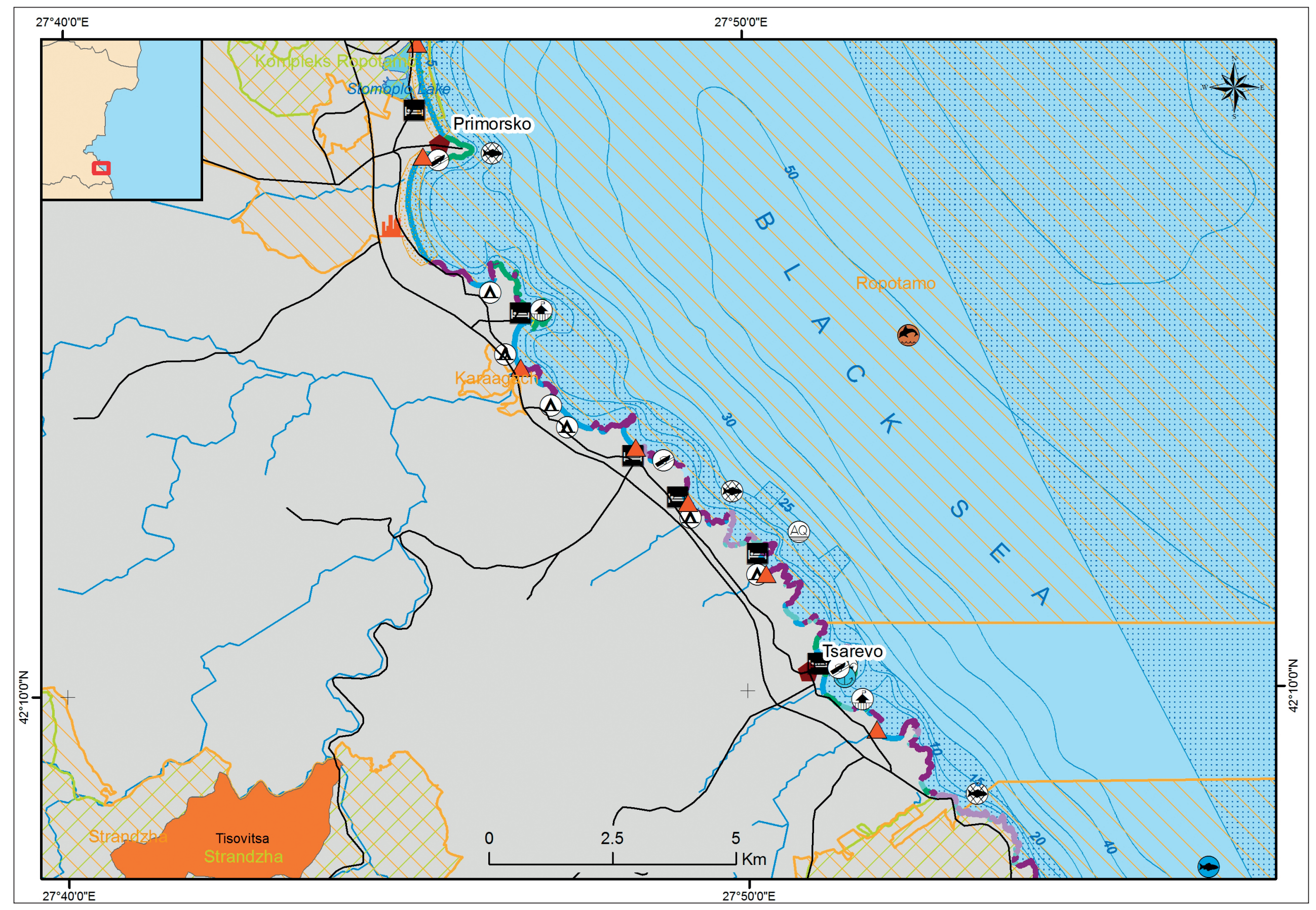




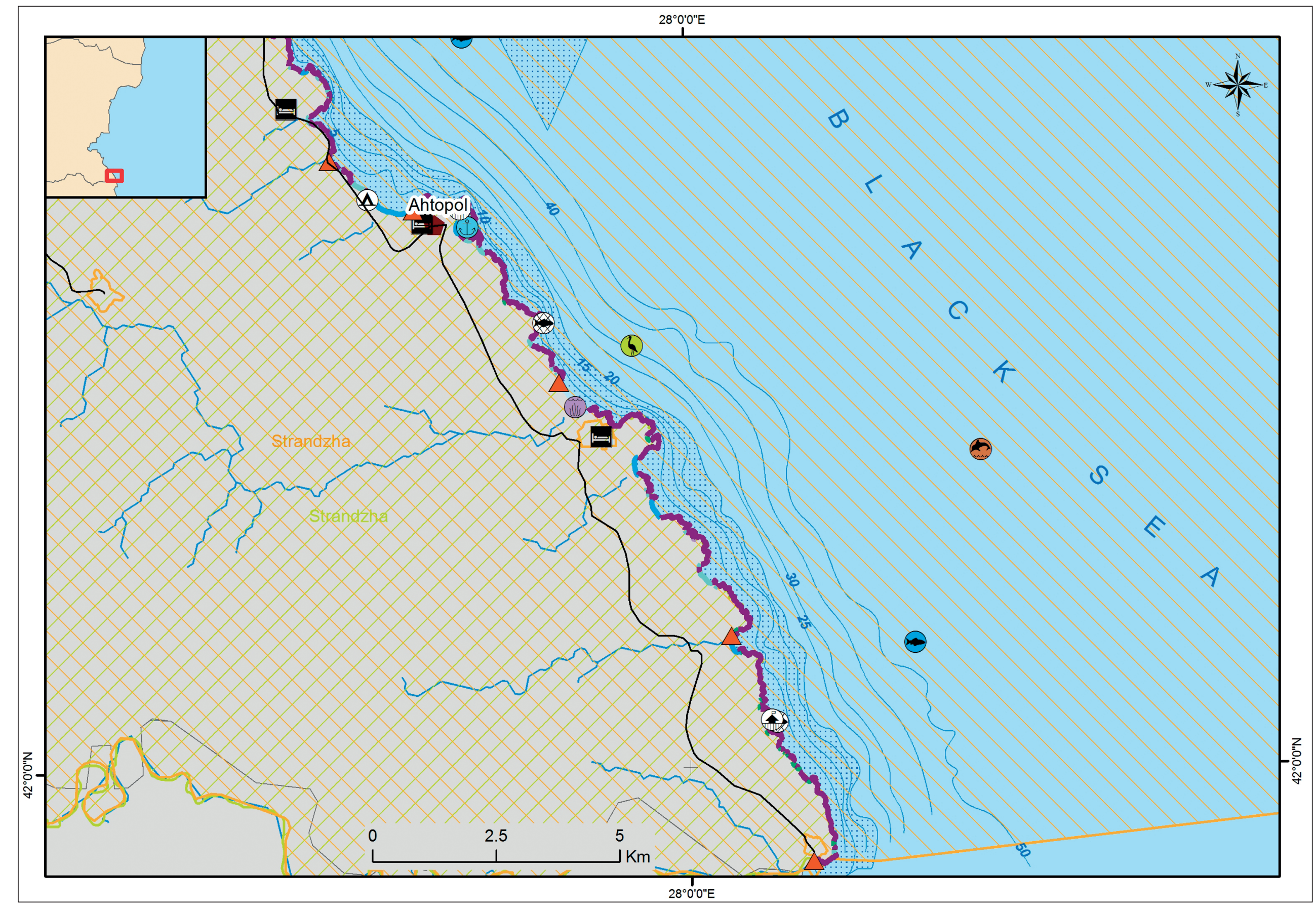

168 SENSITIVITY MAPPING AND ASSESSMENT OF THE BULGARIAN BLACK SEA COASTAL ZONE 
As there is no single method of prioritizing sensitive sites and resources, the data on coastline type, biological and social features was analyzed using a map-based approach to simplify and rank the sensitivity information. The authors followed the 3-step approach recommended by IPIECA (2011):

Step 1: Ranking of the sensitivity of the types of shore

The ESI already ranks the environmental sensitivity of the shoreline into 10 levels. These can be simplified into 3 to 5 classes, keeping only the most sensitive types of shore for the strategic map.

Step 2: Ranking of the sensitive ecosystems and natural resources

Ecosystems were ranked depending on their recovery time after a spill, with those having longer recovery times being more sensitive. In addition, other existing classification systems were used to rank them (e.g., IUCN Red List). The sensitivity ranking takes into account the level of statutory protection (e.g., low to medium sensitivity for local protection status, medium for national status and high for international status)

Step 3: Ranking of the socio-economic features

Socio-economic and human-use features were ranked according to appropriate metrics such as the economic value of an activity, the number of employees, the duration of interruption for various degrees of pollution, the number of users/visitors, etc.

The strategic sensitivity map could be finally produced with the three types of sensitivities ranked and integrated as described above. The strategic maps will highlight the most sensitive sites and, preferably, will maintain a minimum amount of information to be as clear as possible.

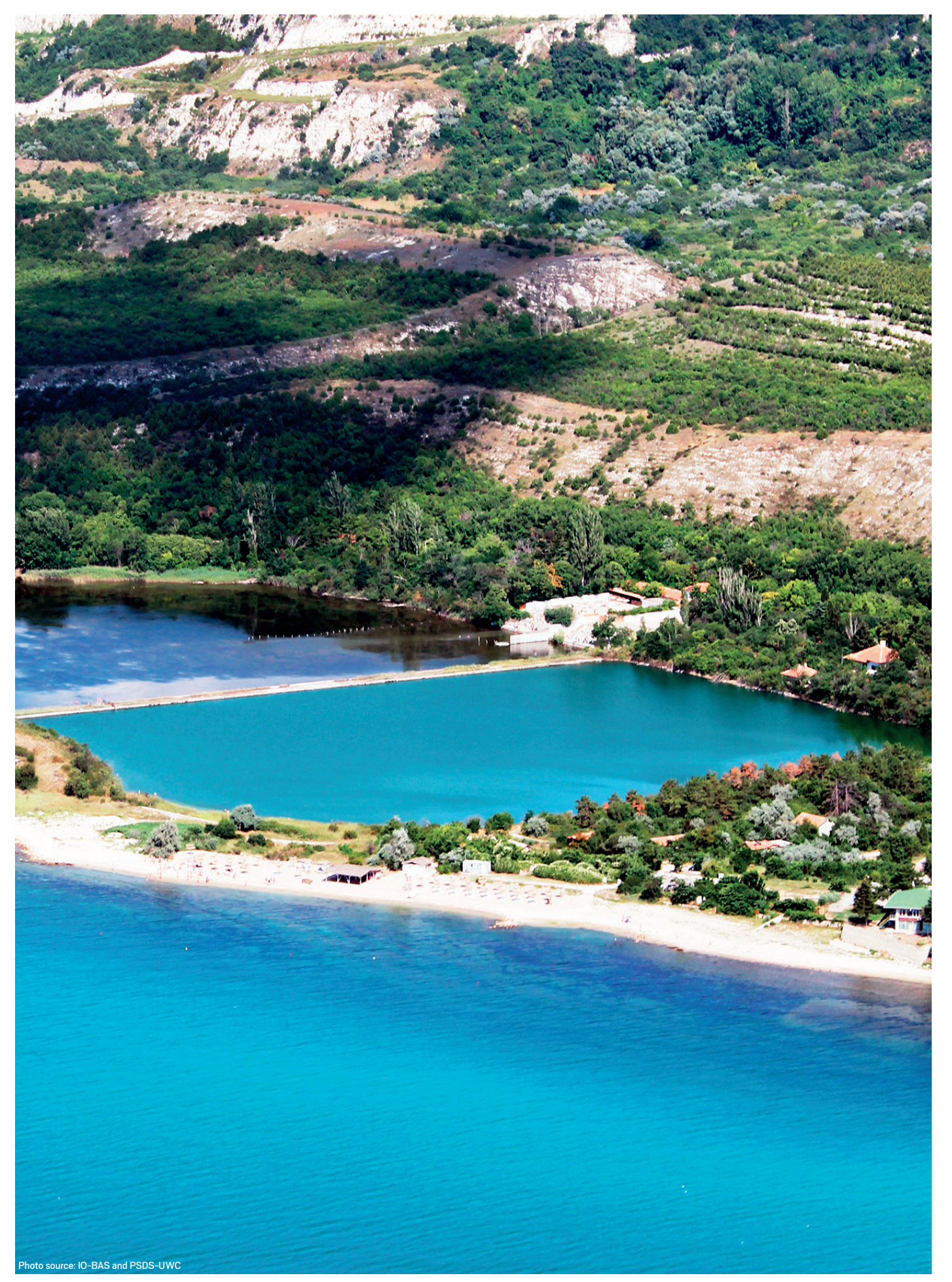




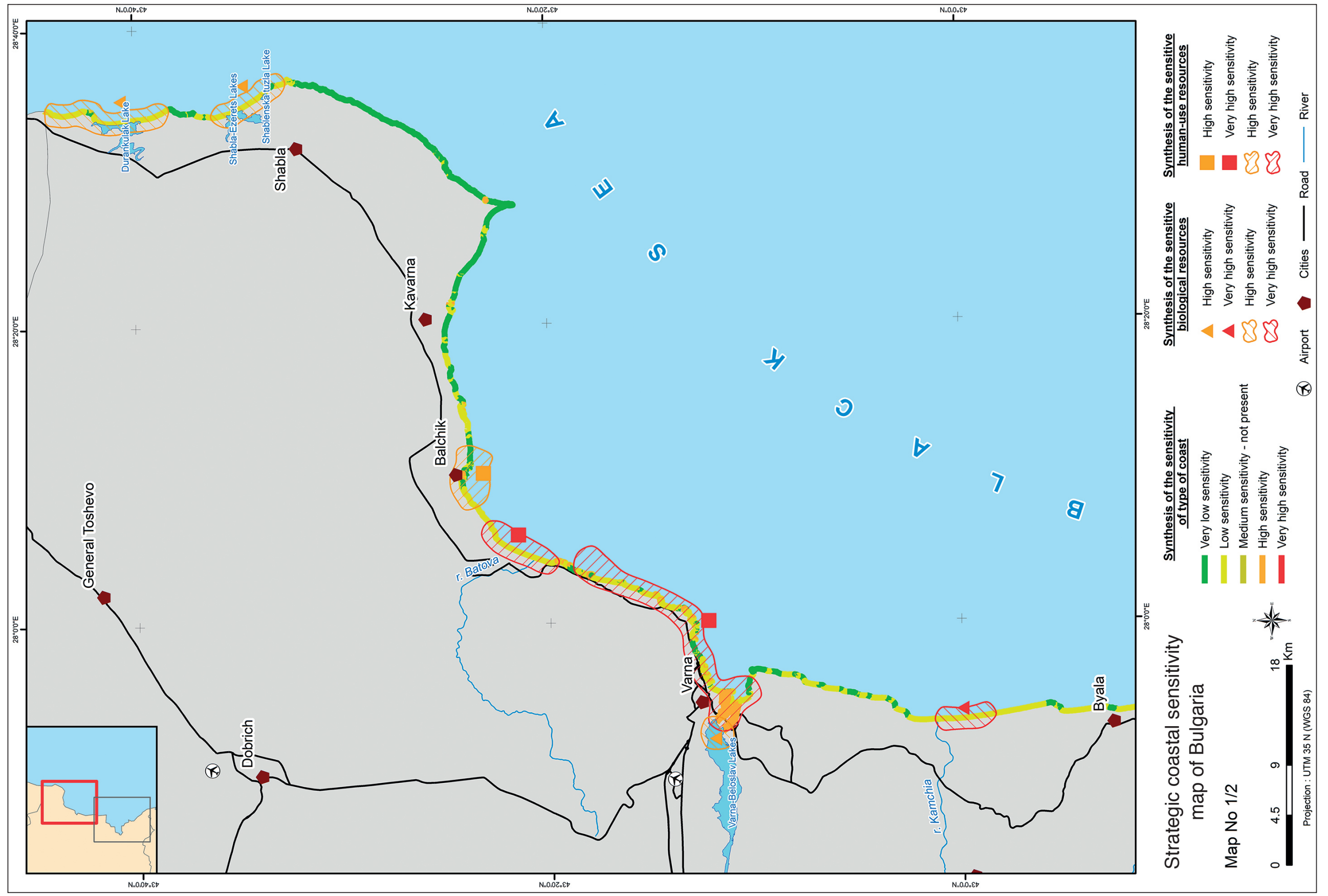




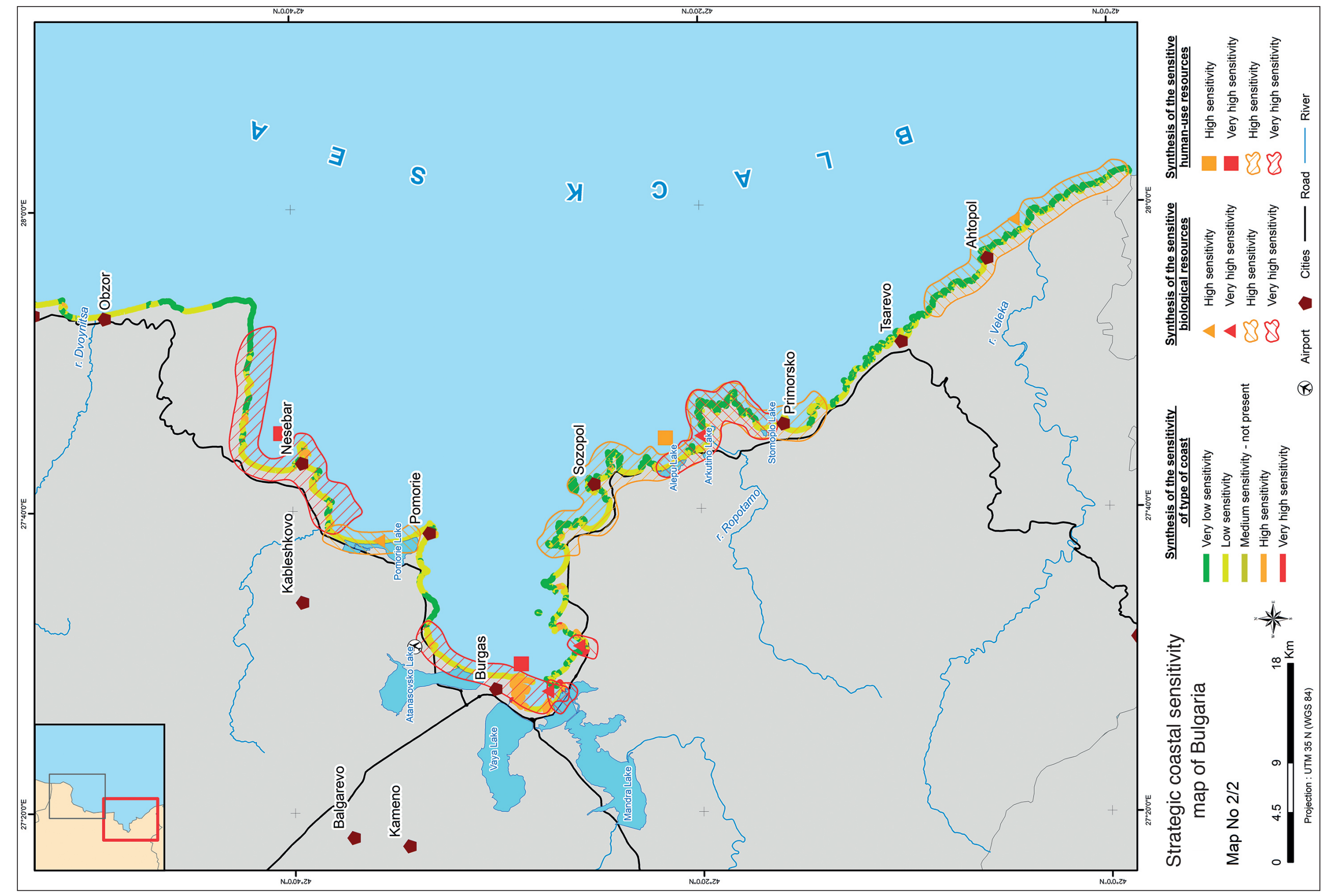




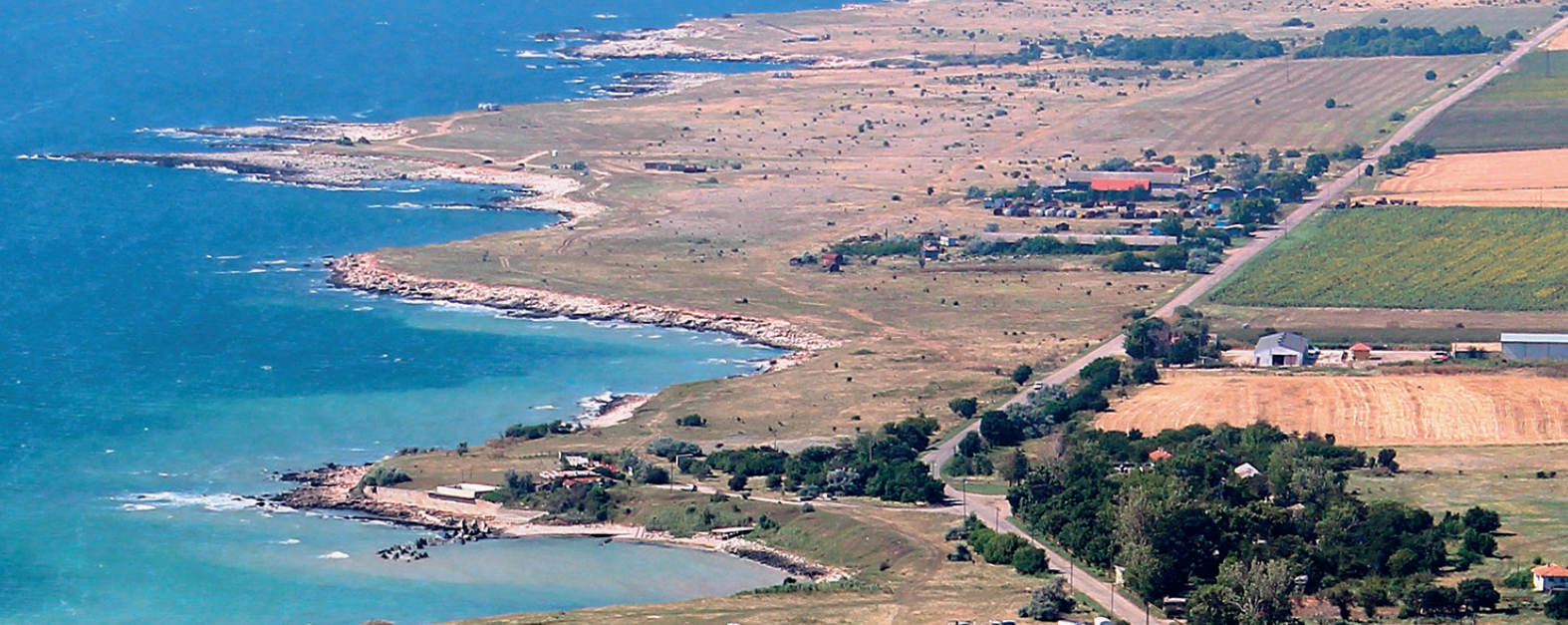

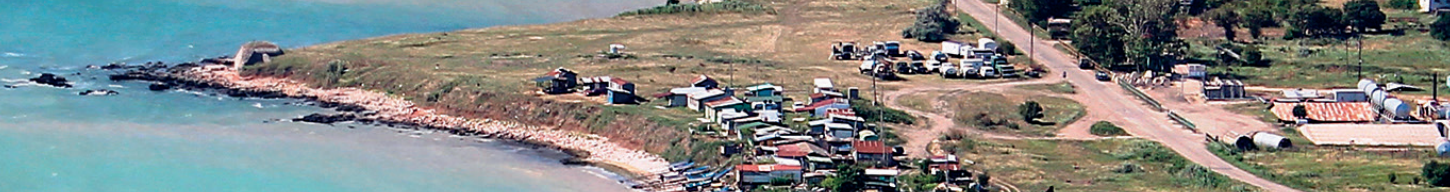
tons

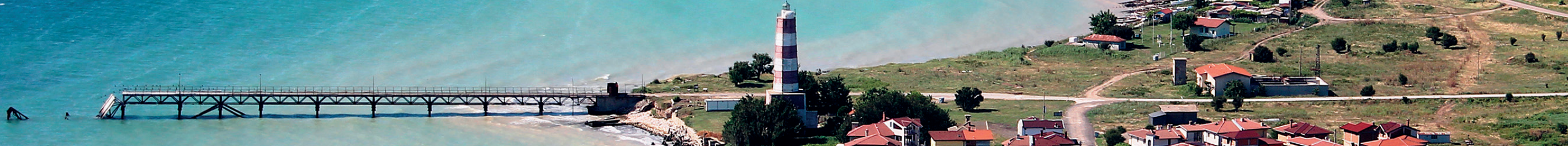

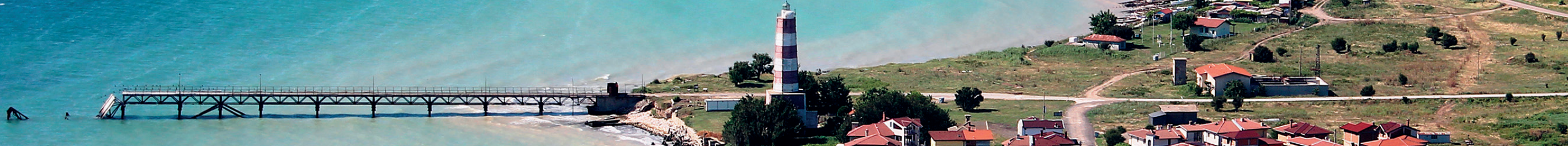
(4)

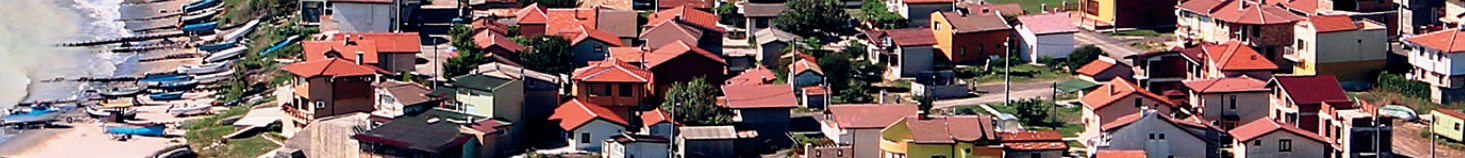

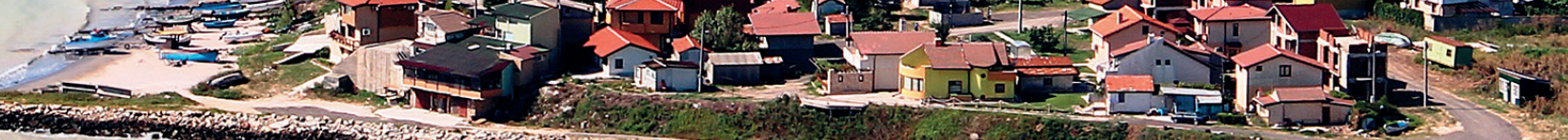

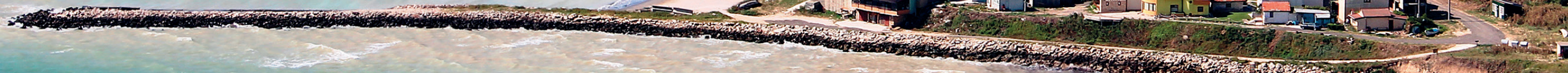

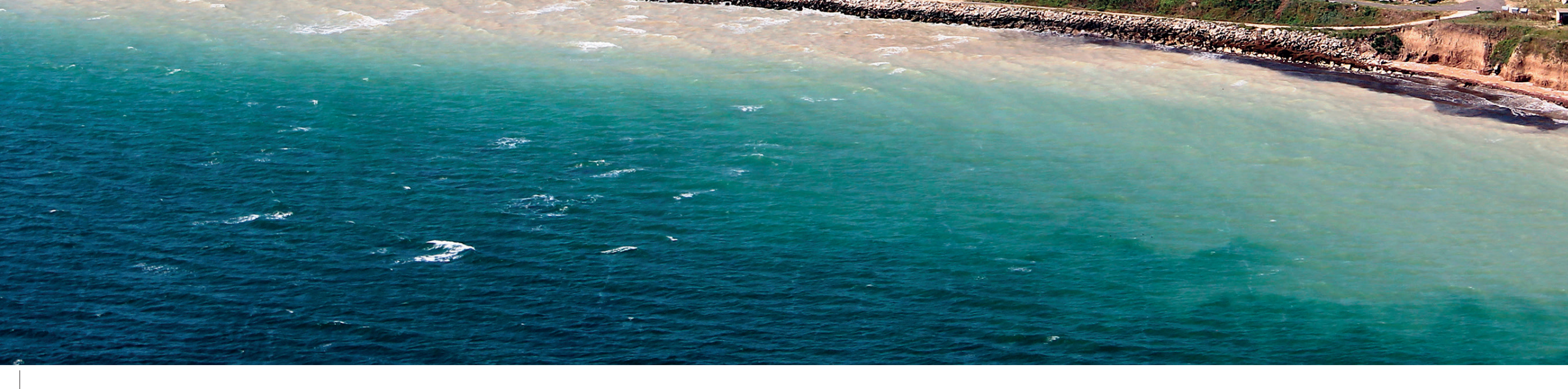




\section{DESCRIPTION BY REGIONS OF THE BULGARIAN BLACK SEA COASTAL ZONE}




\section{INTRODUCTION}

The process of complex-based regionalization is an essential stage of every research that considers a given part of the geosphere as a landscape system $[1 ; 2 ; 3 ; 4 ; 5$ and references therein].

According to the most recent physiographic and landscape regionalization schemes of Bulgaria, the study area coincides with the so-called Black Sea coastal physiographic/landscape district, which is one of this country's most heterogeneous regional units [2; 3]. The leading factors for its landscape-based regional differentiation are the climate influence of the marine basin and the paleogeographic evolution of its shores [2; 6; 7], which largely control the formation and spatial distribution of the remaining landscape components [6; 8]. The above is particularly valid for the "youngest" elements of the physiographic complex, namely the zonal soil types and vegetation cover [3]. The climate is also the principal factor for the existence of particular land use practices and processes of landscape anthropogenization [e.g., 9; 10; $11 ; 12 ; 13$, etc.], as well as the main reason for certain features in the present-day landscape dynamics of the Bulgarian coast [14]

Bulgaria's physiographic/landscape districts are divided by the authors into regions [e.g., 2; 3] or subdistricts [e.g., 4], which represent smaller regional units. The authors of the present coastal sensitivity analysis share the idea that based on complex physiographic (or landscape) criteria the Bulgarian coast can be divided into three regions, namely:

- northern coastal region (Cape Sivriburun - Cape Paletsa), encompassing the coastal areas of the Dobrudzha Plateau, the Batova River Valley, the Franga Plateau, the valley of the Varna and Beloslav lakes, and the Avren Plateau;

- central coastal region (Cape Paletsa - town of Sveti Vlas), encompassing the coastal areas of the Lower Kamchia River Valley, the Kamchia and the Emine Mountains (the East Balkan Mountains):

- southern coastal region (town of Sveti Vlas - the Rezovska River mouth), encompassing the coastal areas of the Lower Hadzhiyska River Valley, the Burgas Lowland and the Burgas Lake Complex with the contiguous wetlands, the Medni rid Ridge and the Strandzha Mountain.
The above three regions can be further subdivided into 11 coastal sectors, representing the smallest regional physiographic (or landscape) units defined for the purpose of the present coastal sensitivity analysis. Due to a lack of sufficient data on benthic biota, habitats or submarine landscapes, the boundaries of the contiguous shallow seabed areas were drawn on the basis of geologic and geomorphic criteria [14]. The cited 11 coastal sectors are as follows:

\section{Northern coastal region}

- Durankulak-Shabla coastal sector (Cape Sivriburun - Cape Shabla)

- Shabla-Balchik coastal sector (Cape Shabla - Fish-Fish locality)

- Batova River Valley coastal sector (Fish-Fish locality - Cape Ekrene)

- Varna coastal sector (Cape Ekrene - Karantinata locality)

- Avren Plateau coastal sector (Karantinata locality - Cape Paletsa)

\section{Central coastal region}

- Lower Kamchia River Valley coastal sector (Cape Paletsa - Cape Cherni nos)

- East Balkan Mountains coastal sector (Cape Cherni nos - town of Sveti Vlas)

\section{Southern coastal region}

- Lower Hadzhiyska River Valley coastal sector (town of Sveti Vlas - Nesebar Peninsula)

- Burgas Lowland coastal sector (Nesebar Peninsula - Cape Chukalya)

- Medni rid Ridge coastal sector (Cape Chukalya - Ropotamo River)

- Strandzha Mountain coastal sector (Ropotamo River - Rezovska River)

Map scheme of the suggested regionalization of the Bulgarian Black Sea coastal area and the contiguous seabed sector 


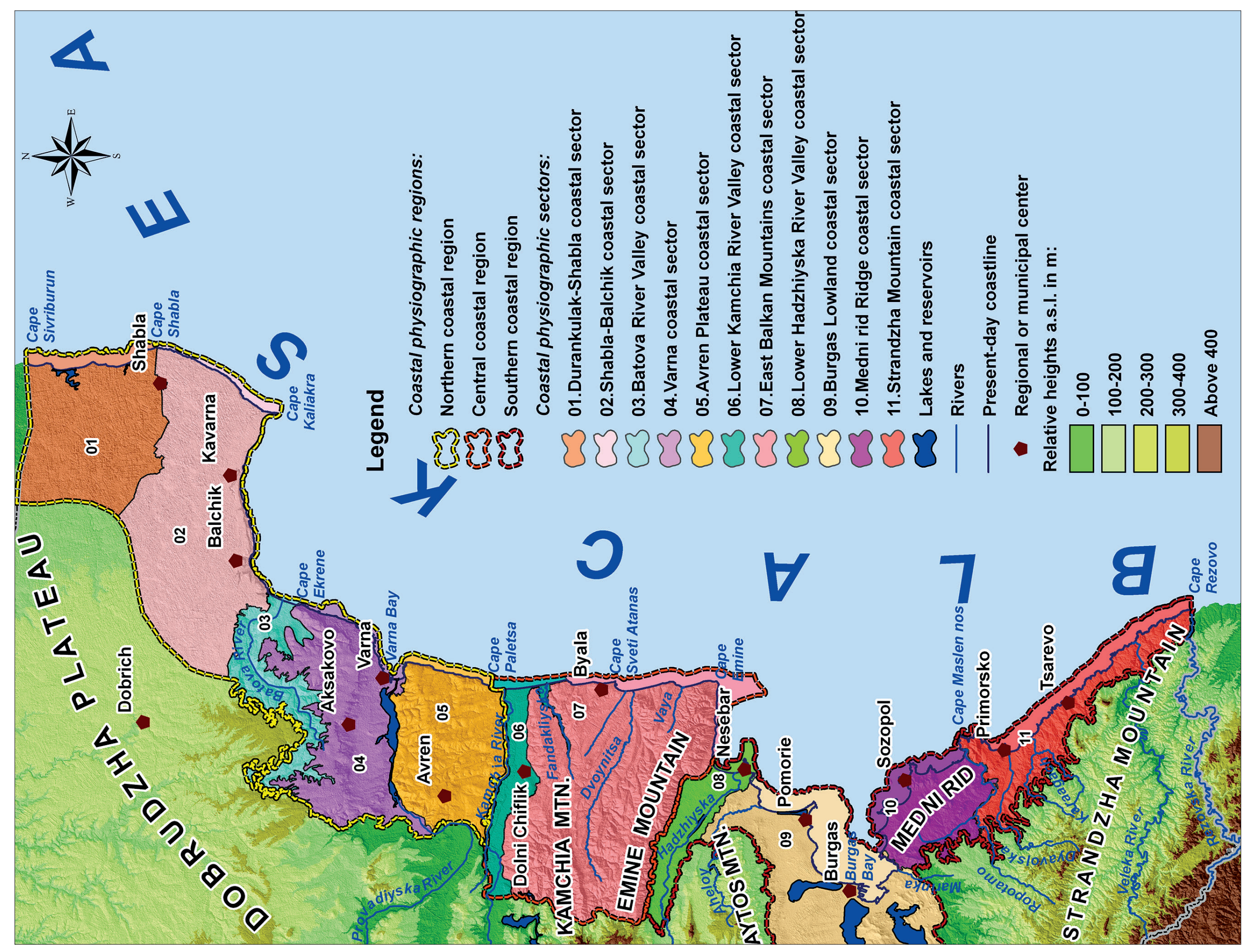




\section{NORTHERN COASTAL REGION}

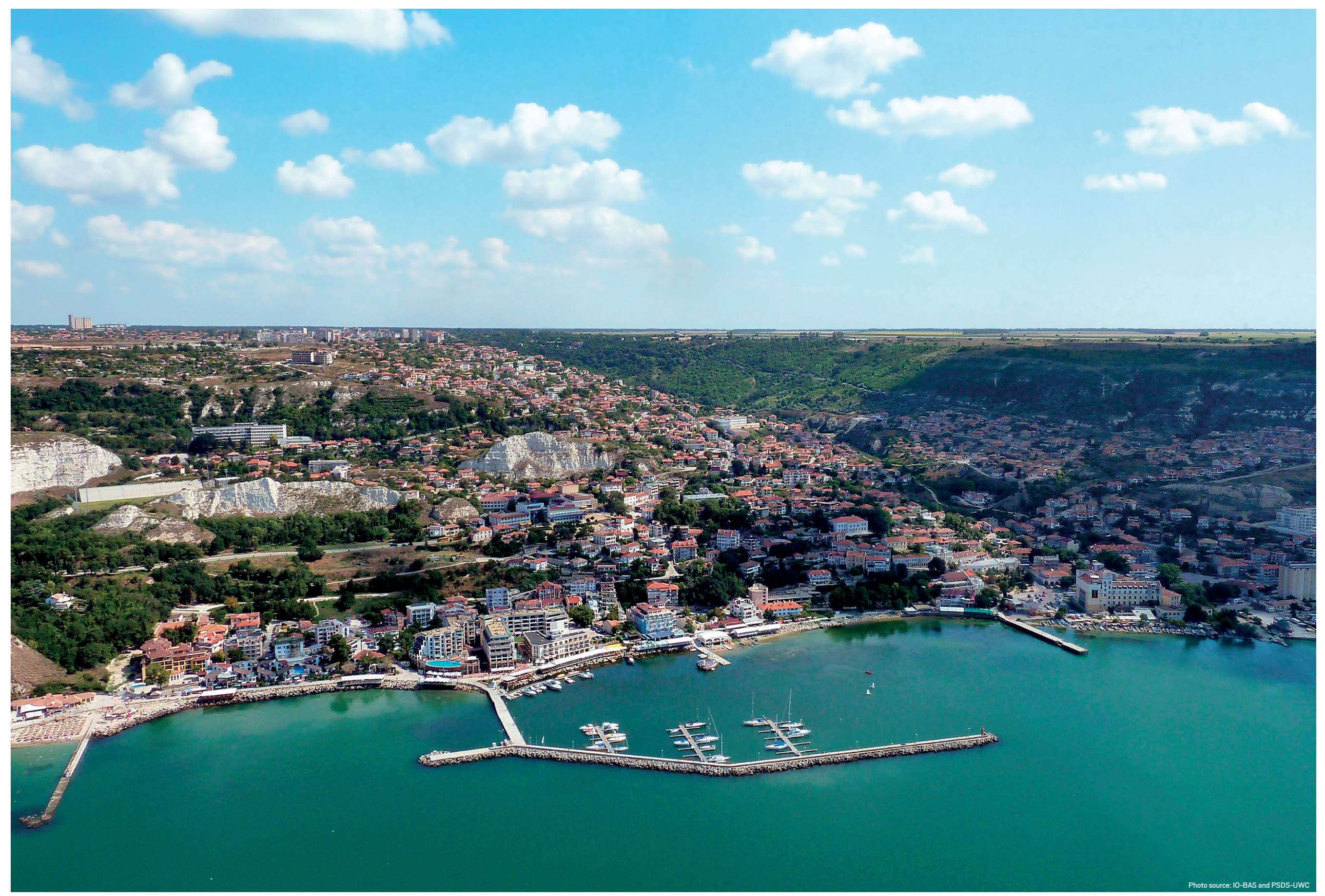

176 DESCRIPTION BY REGIONS OF THE BULGARIAN BLACK SEA COASTAL ZONE 


\section{GENERAL DESCRIPTION}

The northern coastal region encompasses the area between the state border with Romania to the north and the Lower Kamchia River Valley to the south, thereby including the coastal areas of the Dobrudzha Plateau, the Batova River Valley, the Franga Plateau, the valley of the Varna and Beloslav lakes, and the Avren Plateau. Within the extent of the coastal zone, the above region is confined between Cape Sivriburun (Dobrudzha Plateau) and Cape Paletsa (Avren Plateau).

The northern coastal region occupies the easternmost part of the Moesian (Danubian) Platform. The platform's morphostructures are also traced on the contiguous submarine coastal slope and the continental shelf. Its geology is dominated by Miocene sedimentary rocks, e.g., limestones, sandy limestones, sandstones, marls, clays, etc., veiled by a loess cover in Dobrudzha and in limited parts of the Franga and Avren plateaus [15; 16; 17]. The lithology of the adjacent seabed sector is represented by Holocene sands of various grain size and silts along with the above-mentioned varieties of solid sedimentary rocks [18].

The loess cliff near Krapets, Dobrudzha Plateau (Durankulak-Shabla coastal sector)
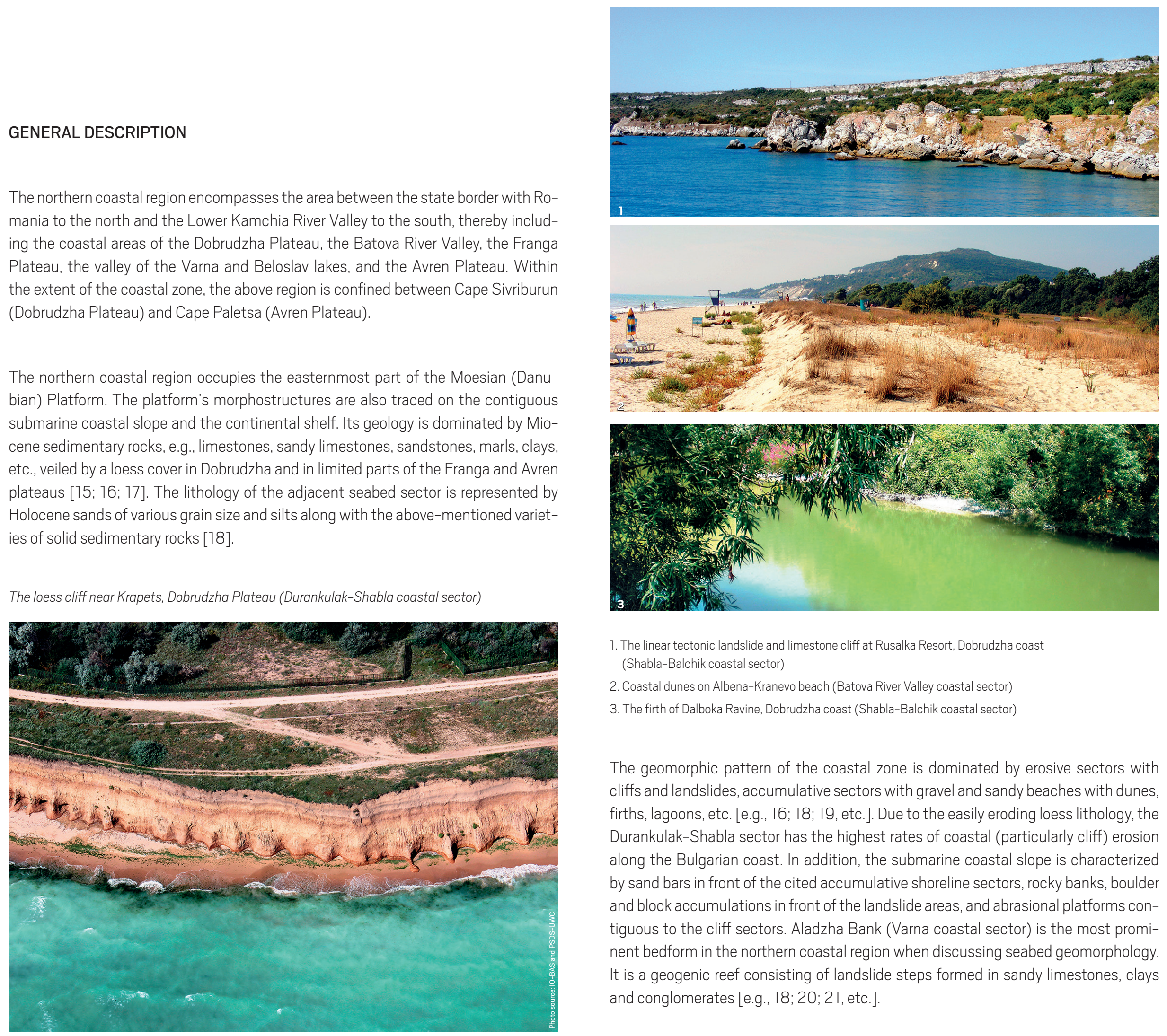

1. The linear tectonic landslide and limestone cliff at Rusalka Resort, Dobrudzha coast (Shabla-Balchik coastal sector)

2. Coastal dunes on Albena-Kranevo beach (Batova River Valley coastal sector)

3. The firth of Dalboka Ravine, Dobrudzha coast (Shabla-Balchik coastal sector)

The geomorphic pattern of the coastal zone is dominated by erosive sectors with cliffs and landslides, accumulative sectors with gravel and sandy beaches with dunes, firths, lagoons, etc. [e.g., 16; 18; 19, etc.]. Due to the easily eroding loess lithology, the Durankulak-Shabla sector has the highest rates of coastal (particularly cliff) erosion along the Bulgarian coast. In addition, the submarine coastal slope is characterized by sand bars in front of the cited accumulative shoreline sectors, rocky banks, boulder and block accumulations in front of the landslide areas, and abrasional platforms contiguous to the cliff sectors. Aladzha Bank (Varna coastal sector) is the most prominent bedform in the northern coastal region when discussing seabed geomorphology. It is a geogenic reef consisting of landslide steps formed in sandy limestones, clays and conglomerates [e.g., 18; 20; 21, etc.]. 
According to the Köppen-Geiger classification scheme, the climate on the Bulgarian coast and the study area respectively is categorized as humid subtropical [22]. The specifics of the regional climate are dictated by the strong temperate-continental influence to the north in Dobrudzha, which gradually attenuates southwards along with an improvement of the pluvial regime [23]. The available quantitative data on climate properties demonstrate that the mean annual temperature varies between $11.8^{\circ} \mathrm{C}$ in the north (Shabla, Kaliakra and Balchik stations, Dobrudzha coastal area) and $12.1^{\circ} \mathrm{C}$ in the south (Varna Station). The mean annual precipitation varies from $412 \mathrm{~mm} / \mathrm{y}$ in the north (Kaliakra Station, Dobrudzha coastal area) to 603 mm/y in the south (Priseltsi Station, Avren Plateau coastal area) [7; 24]

The main hydrological objects in the northern coastal region include Kartaliysko (Orlovo) Swamp, Durankulak Lake, the Shabla-Ezerets Lake Complex and Shablenska tuzla Lagoon (Durankulak-Shabla coastal sector); Nanevska tuzla Lake, the firths of the Bolata dere Ravine, Dalboka Ravine and Balchishka tuzla Lake (Shabla-Balchik coastal sector); the Batova and Kranevska River mouths (Batova River Valley coastal sector); the Varna-Beloslav Lake Complex, representing the navigable estuary of the Provadiyska River (Varna coastal sector), the firth of Pasha dere Ravine (Avren Plateau coastal sector), etc. In addition, the cliff coast west of Cape Kaliakra along the southern portion of the Dobrudzha Plateau's sea-facing slopes, as well as the coastline of the Franga Plateau (Varna coastal sector) are characterized by significant ground water discharge causing a frequent landslide activity [e.g., 16; 20; 25, etc.]

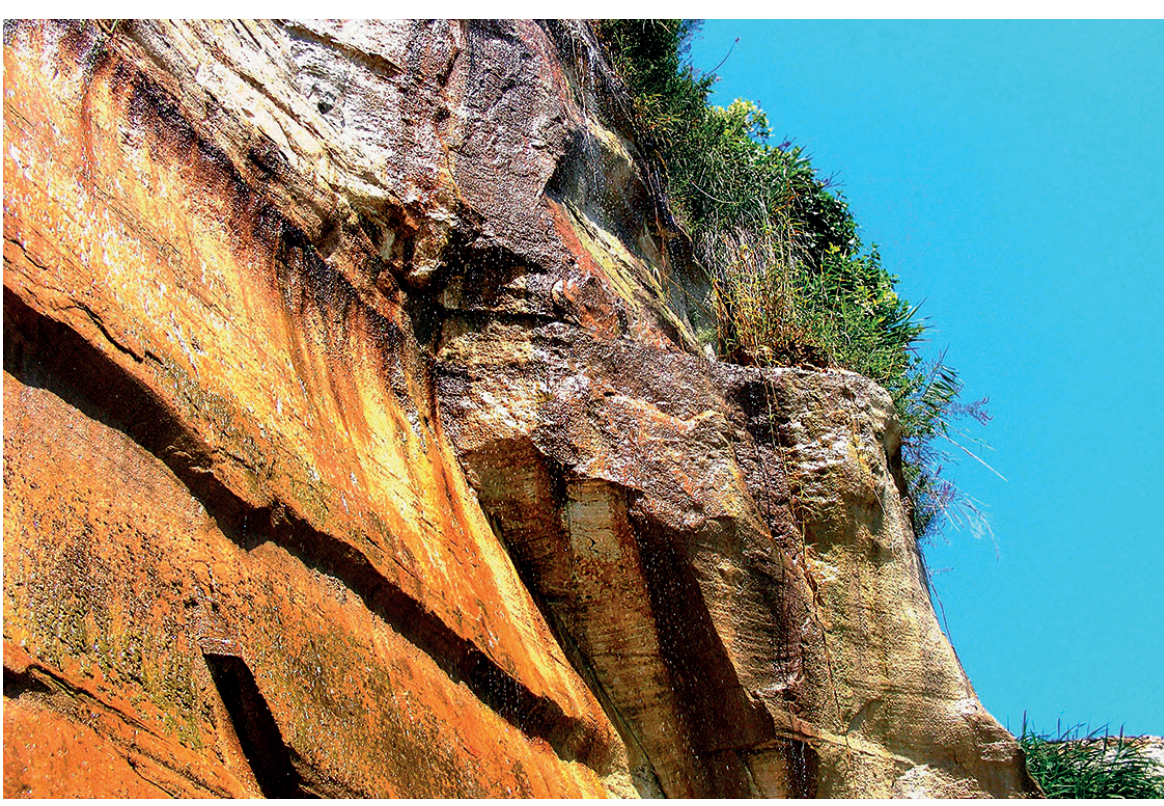

The soil diversity of the northern coastal region is largely determined by its lithologic and climate specifics [e.g., 4; 6; 7; 17, etc.]. Kastanic chernozems, whose genesis is related to the loess cover are widely spread in the Dobrudzha Plateau and on the southern slopes of the Franga Plateau (along the Varna-Beloslav Lake Complex). Luvisols are the second most spread soil variety, occupying large portions of the inland Dobrudzha, the Franga and Avren plateaus. Other pedologic types present include fluvisols (e.g., along the river downstreams of the Kranevska and the Batova), solonchaks (at Shablenska tuzla Lagoon, the peripheries of Nanevska tuzla and Balchiska tuzla landslide lakes, the shores of the Varna-Beloslav Lake Complex, etc.), phaeozems (e.g., north of Pasha dere Ravine, Avren Plateau coastal area), colluviosols (ubiquitously present in all coastal sectors at cliff bases and landslide areas), arenosols (at natural sand strips and dunes, as well as the highest denudation surfaces of the Avren Plateau), gleysols (at firth peripheries and river mouths), rendzinas (at areas with exposed carbonate-rich lithology), nitisols or terra rossa (Cape Kaliakra area, Dobrudzha coast), etc. [17; 26; 27, etc.].

The northern coastal region's vegetation cover has been significantly changed due to millennia of human presence and the associated exploitation of the soils and forests [28]. At many locations, communities of secondary origin have replaced the contemporary vegetation. Steppe communities occupy limited areas at the coastal part of South Dobrudzha. The preserved non-urbanized portions of the plateaus' sea-facing slopes are covered predominantly with oak- and hornbeam-dominated woods. The most characteristic feature of the northern coastal region's vegetation cover is the longoz forest formed in the Batova River downstream, as well as the sub-longoz communities within the landslide sectors with ground water discharge [10; 14; 29]. Hygrophytic and aquatic vegetation occupies the coastal firths, lagoons and landslide lakes. Psammophytes are spread on the large sand strips with dunes developed in front of firths and lagoons, e.g., the Durankulak beach, Krapets beach and Shabla beach (Durankulak-Shabla coastal sector), Albena-Kranevo beach (Batova River Valley coastal sector), Asparuhovo beach (Varna coastal sector), Pasha dere beach (Avren Plateau coastal sector), etc. In addition, the largest psammophytic communities in Bulgaria are spread on the inland dunes at the Pobitite Kamani Protected Area (Varna and Avren Plateau coastal sectors) [30].

Ground water discharge within the cliff base, Zelenka locality west of Cape Kaliakra, Dobrudzha coast (Shabla-Balchik sector) 

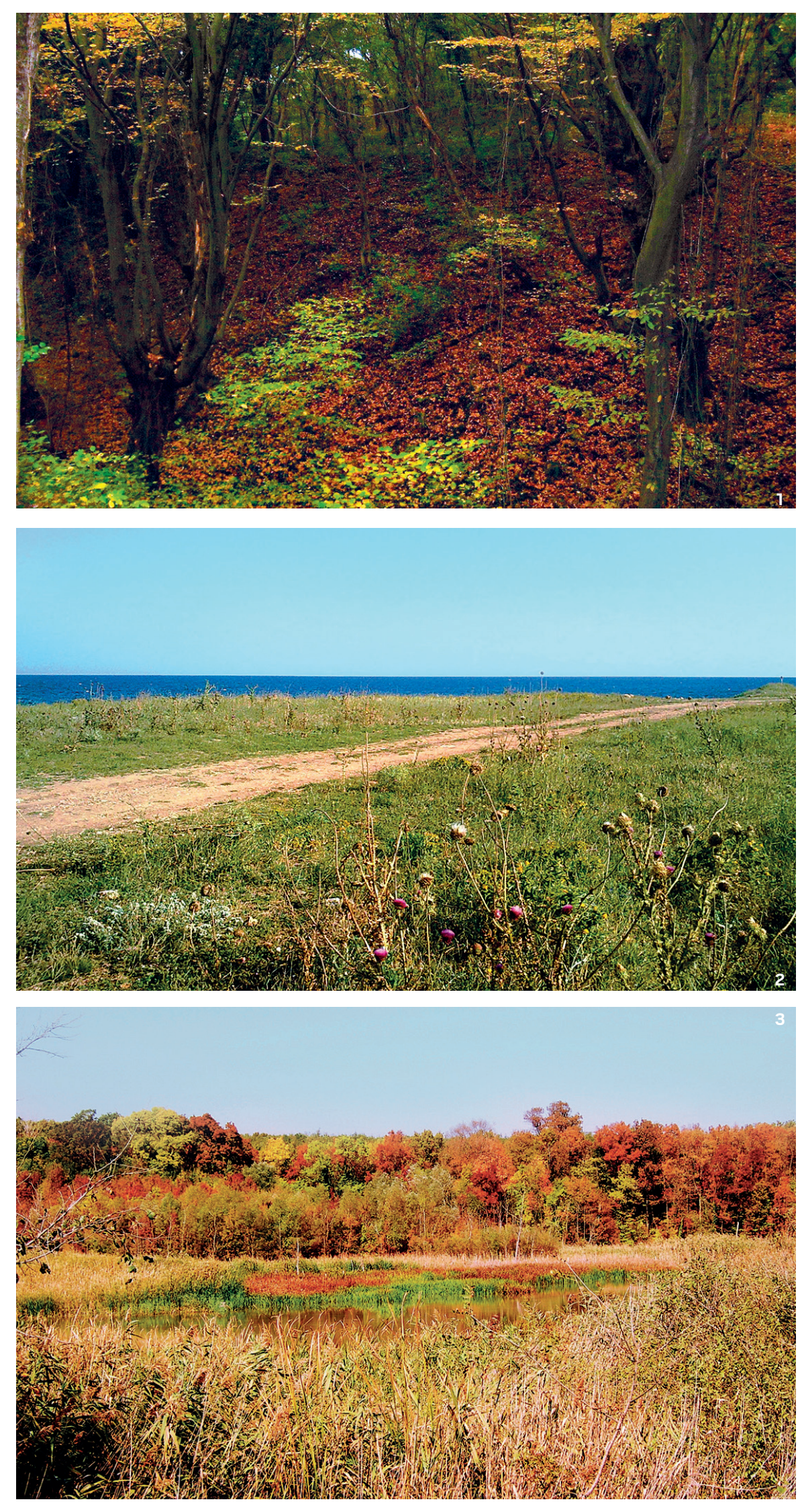

The anthropogenic landscapes (e.g., agricultural, artificially planted and built-up areas, coastal protection infrastructure, port facilities, etc.) prevail in the spatial pattern of the northern coastal region. The Shabla-Balchik and the Varna coastal sectors are among the areas with the highest levels of technogenic load on the Bulgarian shore [37; 32; 33]. Significant geo-ecological problems exist in the Varna-Beloslav Lake Complex due to the drastic alterations of the natural lacustrine environment following the digging of the navigable canals and the subsequent influx of marine waters [34]. By contrast, the Batova River Valley and the Avren Plateau coastal areas have experienced comparatively lower levels of man-induced transformations. However, although well preserved in general, the natural landscapes at the Batova River Valley coastal sector have been significantly transformed around the village of Kranevo and especially in the area of Albena Resort, despite the fact that the cited resort is among the best managed ones in Bulgaria. Hence, the sector is seen as one of the Bulgarian coast's hotspots when discussing nature conservation [3; 14]. Due to the specifics of the spatial development over the Socialist Period, the natural landscape pattern of the Avren Plateau coastal sector is generally well preserved. New construction has taken place in the southeastern periphery of the sector close to the Kamchia River mouth (central coastal region). The natural landscape diversity is represented predominantly by plain-karst and accumulative-karst complexes with dry valleys, vegetated by steppe and forest steppe communities (Dobrudzha coastal area), plateau-karst complexes with mixed oak or common hornbeam forests (Franga Plateau), as well as plain and hilly or plateau-hilly complexes with mixed oak forests (Avren Plateau). Characteristic azonal complexes include accumulative-beach and erosive-accumulative landscapes with psammophytic vegetation (sand strips and dunes); erosive-cliff landscapes with xerophytic vegetation and erosive-landslide landscapes with sub-longoz communities; lowland- and valley-accumulative landscapes with longoz forests, meadows, aquatic or halophytic vegetation (in the peripheries of firths, lagoons and landslide lakes), etc. [35].

1. A field elm- and Oriental hornbeam-dominated forest at the Franga Plateau (Varna coastal sector) 2. Steppe vegetation near Cape Shabla, Dobrudzha coast (Shabla-Balchik coastal sector) 3. Hygrophytic vegetation lining the firth of Pasha dere Ravine (Avren Plateau coastal sector) 

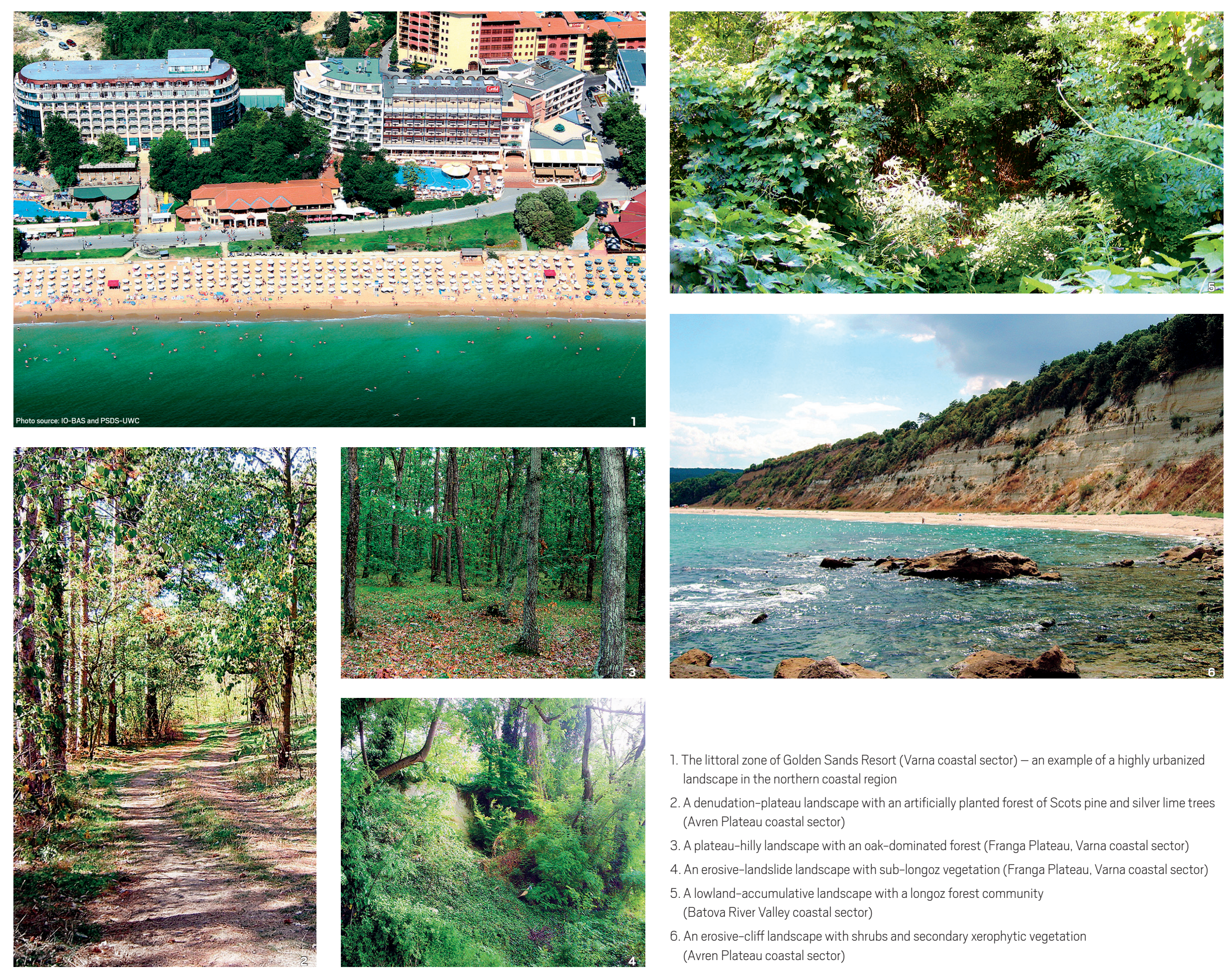

1. The littoral zone of Golden Sands Resort (Varna coastal sector) - an example of a highly urbanized landscape in the northern coastal region

2. A denudation-plateau landscape with an artificially planted forest of Scots pine and silver lime trees (Avren Plateau coastal sector)

3. A plateau-hilly landscape with an oak-dominated forest (Franga Plateau, Varna coastal sector)

4. An erosive-landslide landscape with sub-longoz vegetation (Franga Plateau, Varna coastal sector)

5. A lowland-accumulative landscape with a longoz forest community (Batova River Valley coastal sector)

6. An erosive-cliff landscape with shrubs and secondary xerophytic vegetation (Avren Plateau coastal sector) 


\section{MARINE FAUNA}

The mediolittoral and sublittoral areas with sand and silt are populated by various native clam and mussel communities, e.g., ones dominated by corneous wedgeclams (Donacilla cornea), the clams Chamelea gallina, wedge shells (Donax trunculus), Mediterranean clams Lentidium mediterraneum, white furrow shells (Abra alba), Mediterranean (blue) mussels (Mytilus galloprovincialis), bean mussels (Modiolula phaseolina), etc. [36]. The alien bivalves unequal arc (Anadara inaequivalvis) and softshell clam (Mya arenaria) are also frequently registered [37]. The shallow hardand soft-bottom habitats serve as nurseries and spawning grounds for many species: a variety of wrasses, gobbies, blennies, pipefish, etc. A large number of fish species have been described for the area, e.g., thornback ray (Raja clavata), common stingray (Dasyatis pastinaca), European eel (Anguilla anguilla), garfish (Belone belone), whiting (Merlangius merlangius), southern ninespine stickleback (Pungitius platygaster), three-spined stickleback (Gasterosteus aculeatus), short-snouted seahorse (Hippocampus hippocampus), flathead mullet (Mugil cephalus), sand-smelt (Atherina pontica), red mullet (Mullus barbatus), bluefish (Pomatomus saltatrix), golden grey mullet (Liza aurata), blackhand sole (Pegusa nasuta), flounder (Platichthys flesus), scorpionfish (Scorpaena porcus), the exceptionally rare star-gazer (Uranoscopus scaber), greater weever (Trachinus draco), etc. The main commercially exploited fish species are sprat (Sprattus sprattus), Black Sea horse mackerel (Trachurus mediterraneus ponticus), anchovy (Engraulis encrasicolus), bonito (Sarda sarda), shad (Alosa immaculata), picked dogfish (Squalus acanthias), and numerous goby species

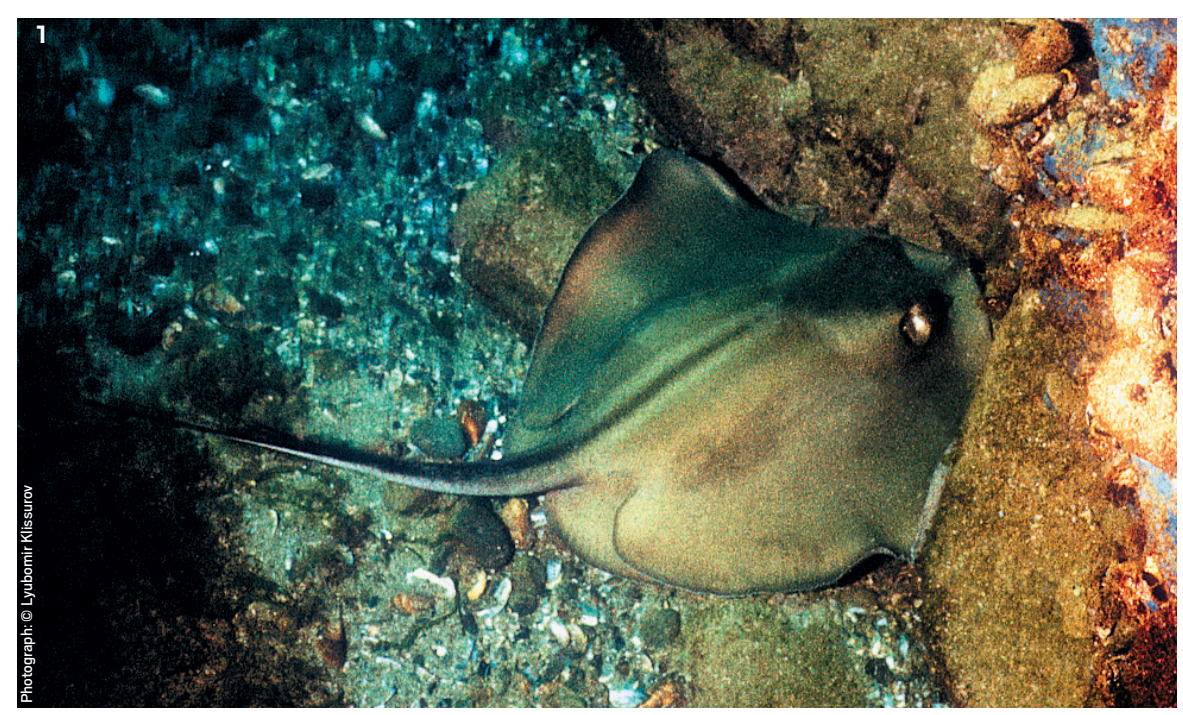

(Gobiidae). Turbot (Psetta maxima) is a very important demersal fish for the commercial fishery as well. The cetaceans harbor porpoise (Phocoena phocoena), common dolphin (Delphinus delphis) and bottlenose dolphin (Tursiops truncatus) are also frequently registered, with Cape Shabla, Cape Kaliakra, Cape Ekrene, Cape Galata and Cape llandzhik being among the best sites for their observation [38].
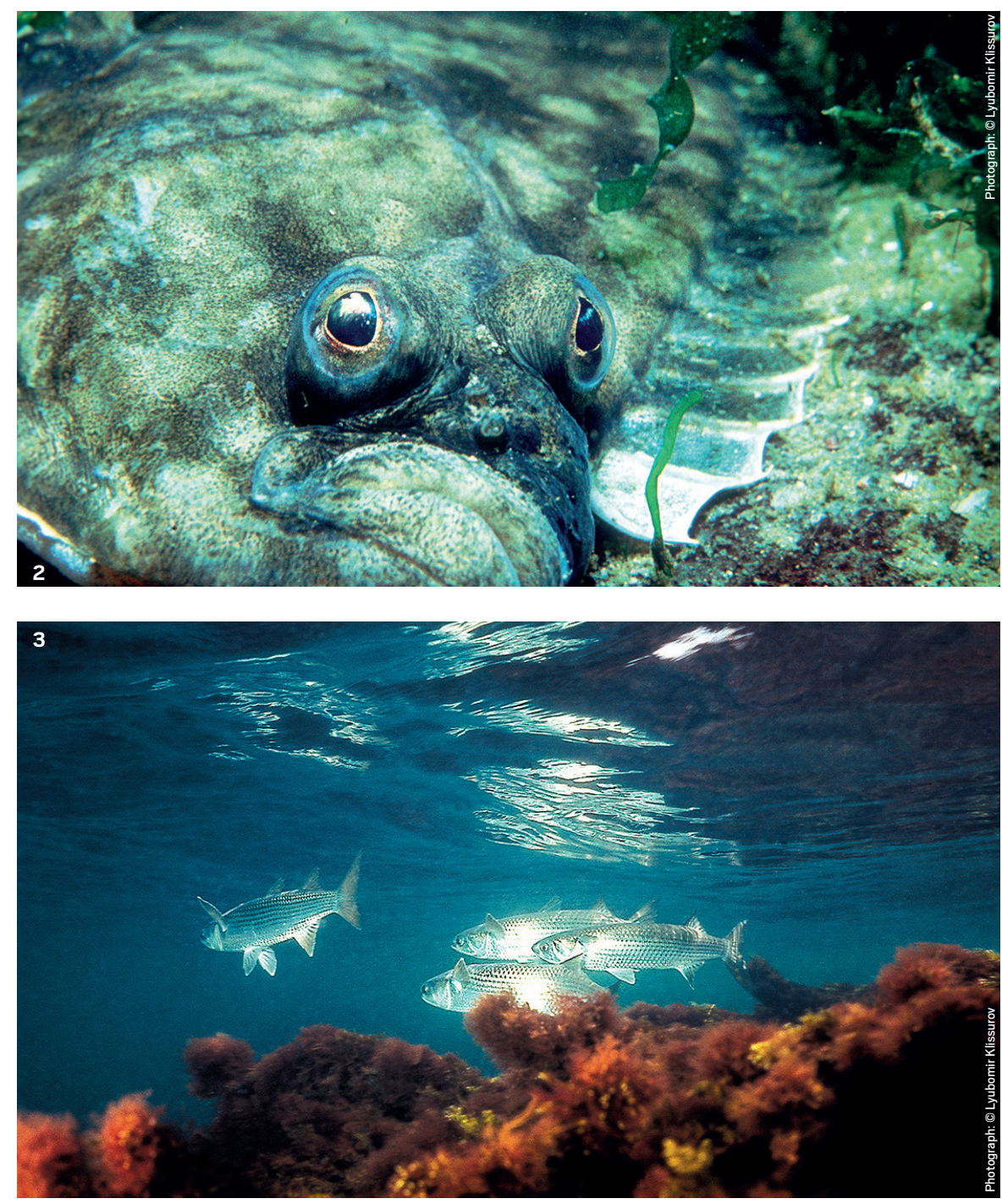

1. Common stingray (Dasyatis pastinaca)

2. Flounder (Platichthys flesus)

3. Golden grey mullet (Liza aurata) 


\section{BULGARIAN RED DATA BOOK COASTAL AND MARINE HABITATS}

The northern coastal region is rich in habitats of nature conservation importance Hence, a considerable part of it is included in the NATURA 2000 ecological network [38; 69]. Beach and dune habitats with psammophytes and cliff habitats with chasmophytic, calcicolous or xerophytic shrub vegetation are widely spread. Important wetlands are formed in the coastal lakes' peripheries and river mouths, e.g., the ones at Durankulak Lake, the Shabla-Ezerets Lake Complex, Shablenska tuzla Lagoon, Nanevska tuzla Lake, Balchiska tuzla Lake, the Batova River mouth, the Varna-BeIoslav Lake Complex, the firth of the Pasha dere Ravine, etc. These are also important bird areas as they are located on the Via Pontica migratory route [29].

The squacco heron (Ardeola ralloides), a species enlisted in the Bulgarian Red Data Book as endangered, is a common visitor of the Dobrudzha wetlands

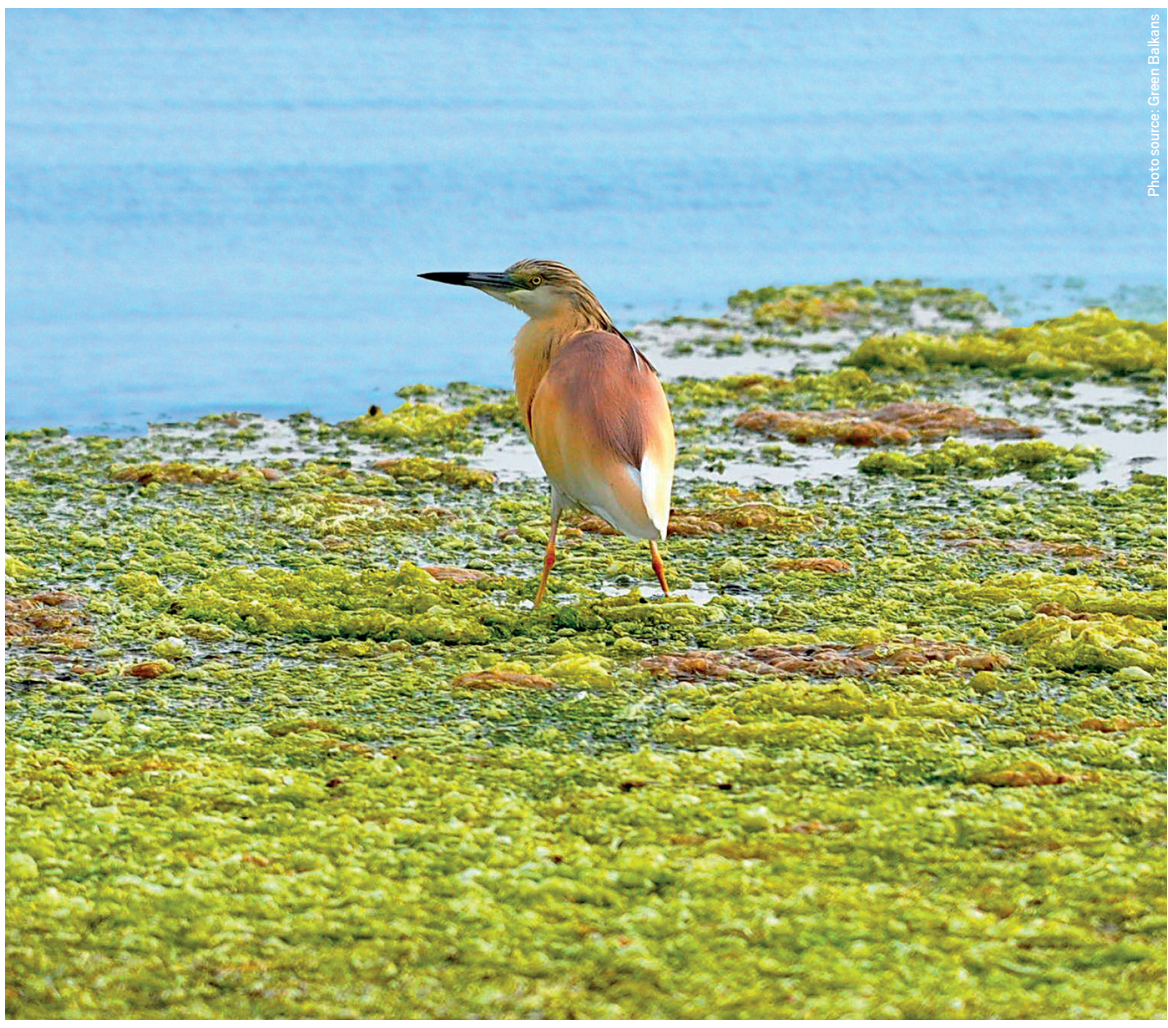

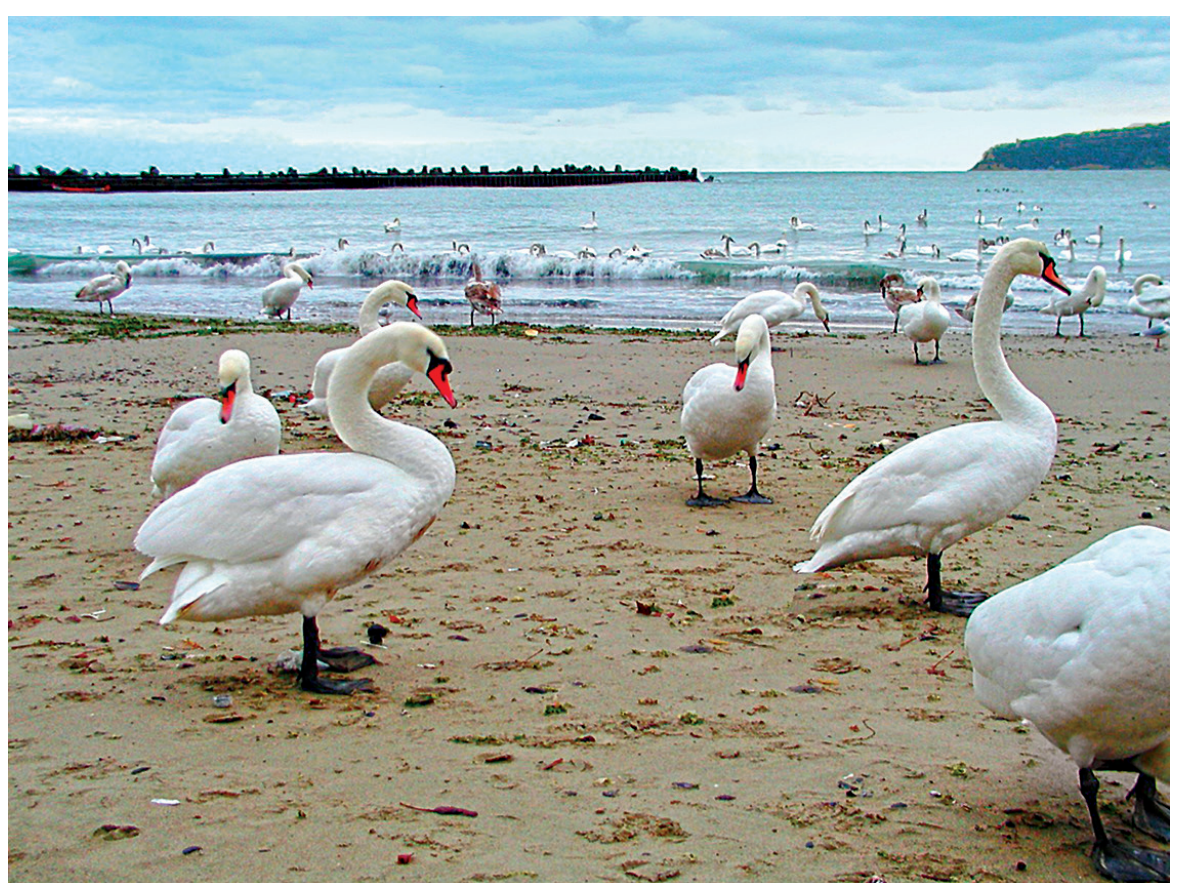

Mute swans (Cygnus olor) on Varna beach, a species enlisted in the Bulgarian Red Data Book as vulnerable

Common pochards (Aythya ferina) in the Beloslav Lake, a species enlisted in the Bulgarian Red Data Book as vulnerable

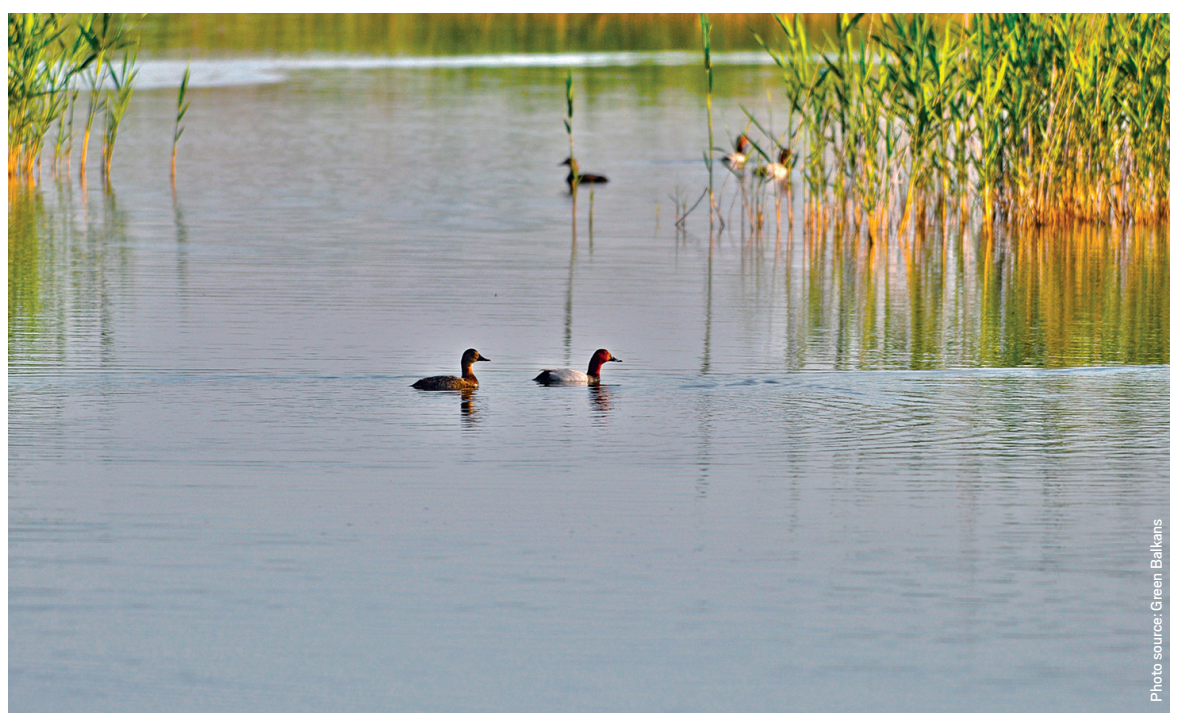



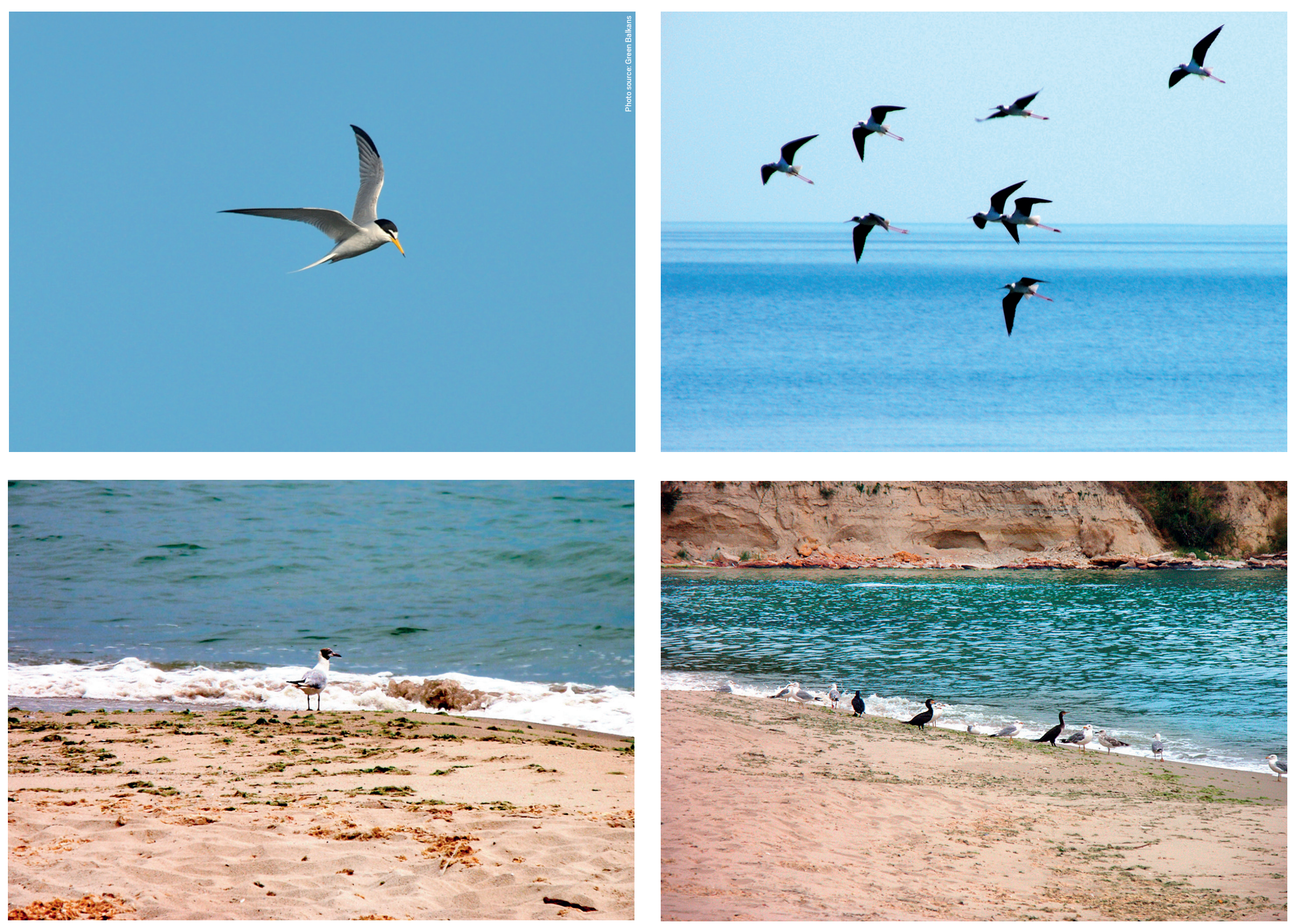
The Dobrudzha coastal steppes within dry gullies, ravines cliff and landslide areas and particularly around the capes of Shabla and Kaliakra match up with the habitat type Western-Pontic petrophytic steppes, categorized as endangered in the Bulgarian Red Data Book [39].

Examples of the marvelous coastal flora of Dobrudzha:

1. Peonies; 2. Lilacs
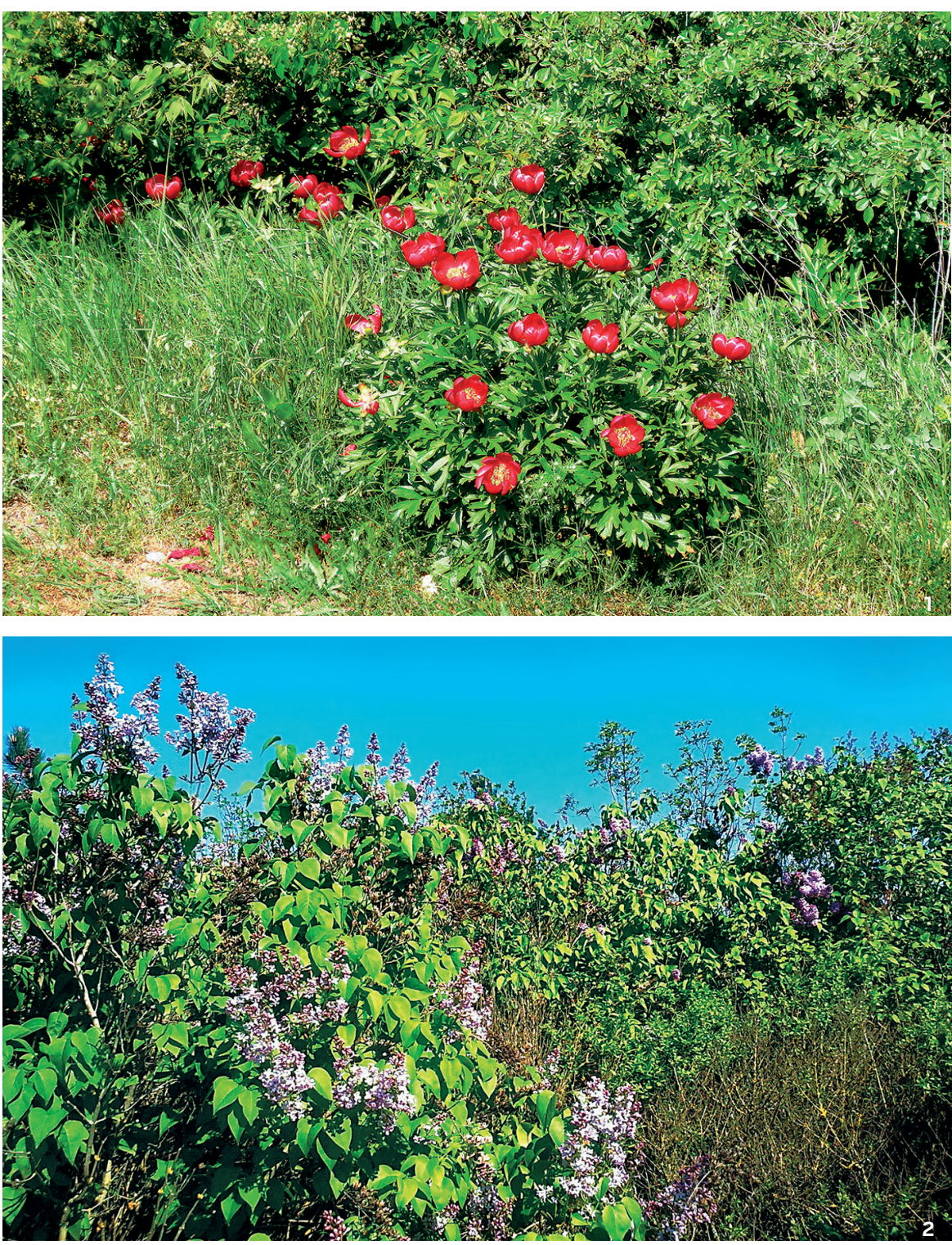

The erosive cliffs (ubiquitously present in all five coastal sectors) with petrophytic vegetation correspond to the habitat type sea-cliff vegetation, categorized as endangered [40]

The presence of Balkan pseudomaquis communities in the investigated coastal region is not indicated on the distribution maps published in the Bulgarian Red Data Book. However, field surveys carried out in 2007 and 2008 confirmed their presence in the coastal zone south of Pasha dere [14]. According to the Bulgarian Red Data Book, their status is nearly threatened [41].

Balkan pseudomaquis community, Rodni Balkani beach (Avren Plateau coastal sector)

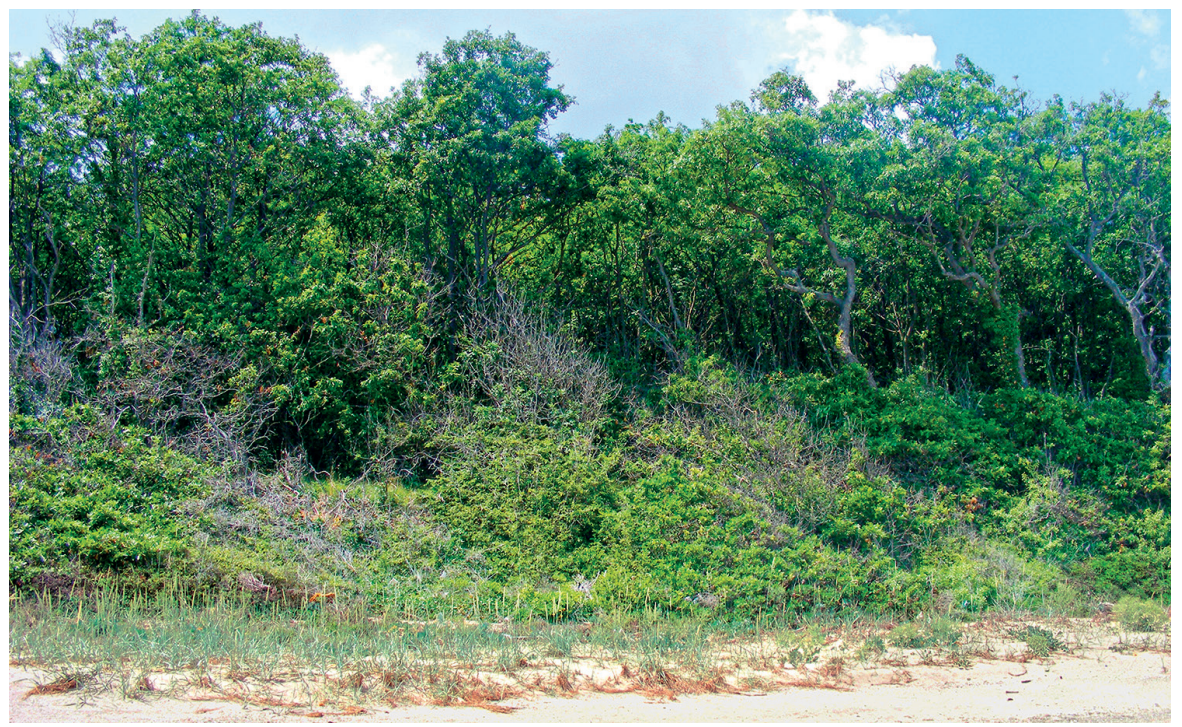

The beaches and dunes with psammophytic communities correspond to the habitat types vegetation on the Black Sea gravel beaches [42], vegetation on the Black Sea sand beaches [43], Black Sea embryonic dunes [44], Black Sea mobile (white) dunes [45], Black Sea fixed (grey) dunes [46], all five categorized as endangered. Black Sea wooded dunes (critically endangered) [47] are present in the Batova River Valley coastal sector. The habitat type over-wet and flooded dune slacks (e.g., Shabla and Krapets beaches, Durankulak-Shabla coastal sector), categorized as critically endangered, is also present [48]. The Pobitite kamani Protected Area (Varna and Avren Plateau coastal sectors) corresponds to the habitat type inland dunes with standing stones [49], categorized as endangered 

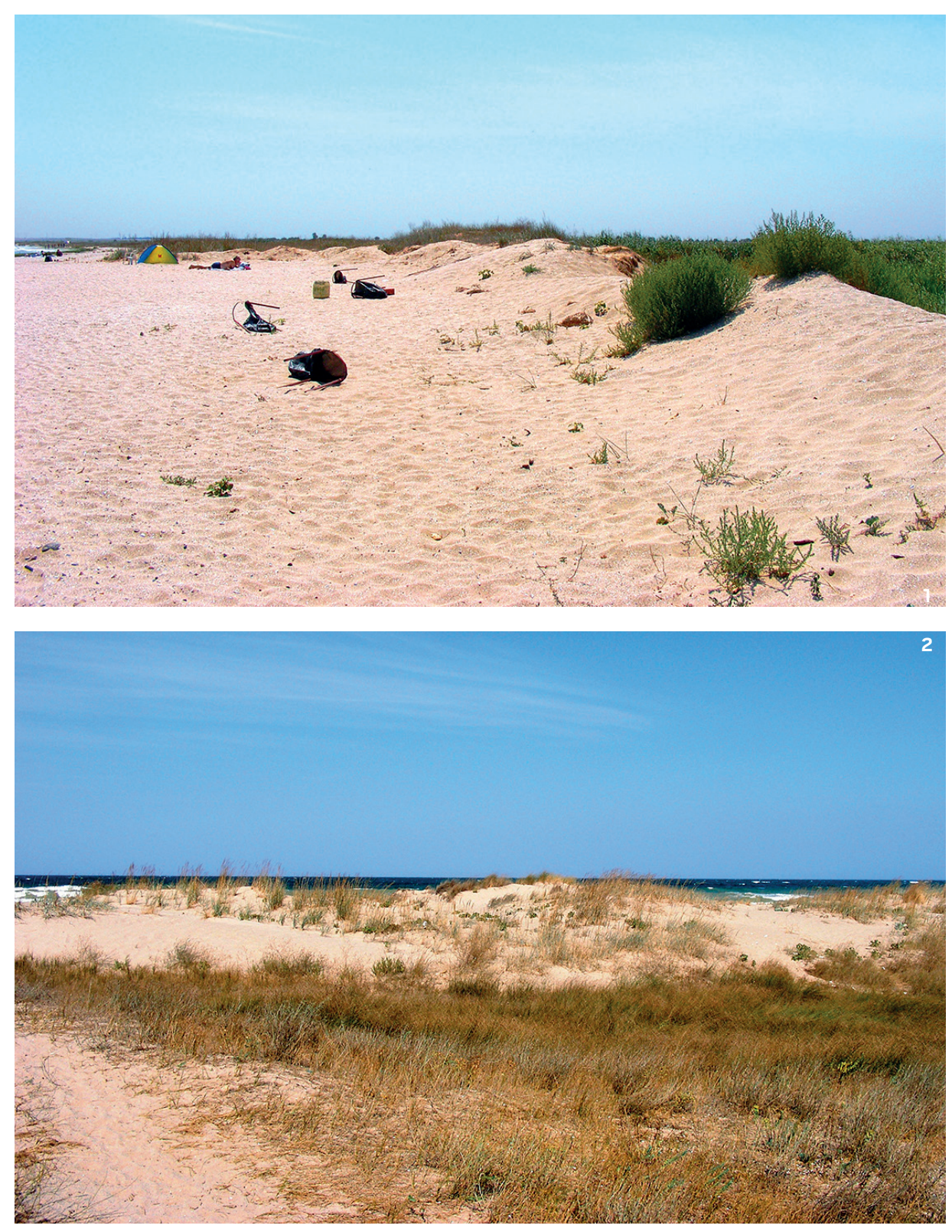

1. Embryonic dunes at Durankulak beach

2. White dunes at Shabla beach

3. Grey dunes at Shabla beach

4. Wooded dunes at Albena-Kranevo beach

5. Inland dunes with standing stones at Pobitite kamani Protected Area
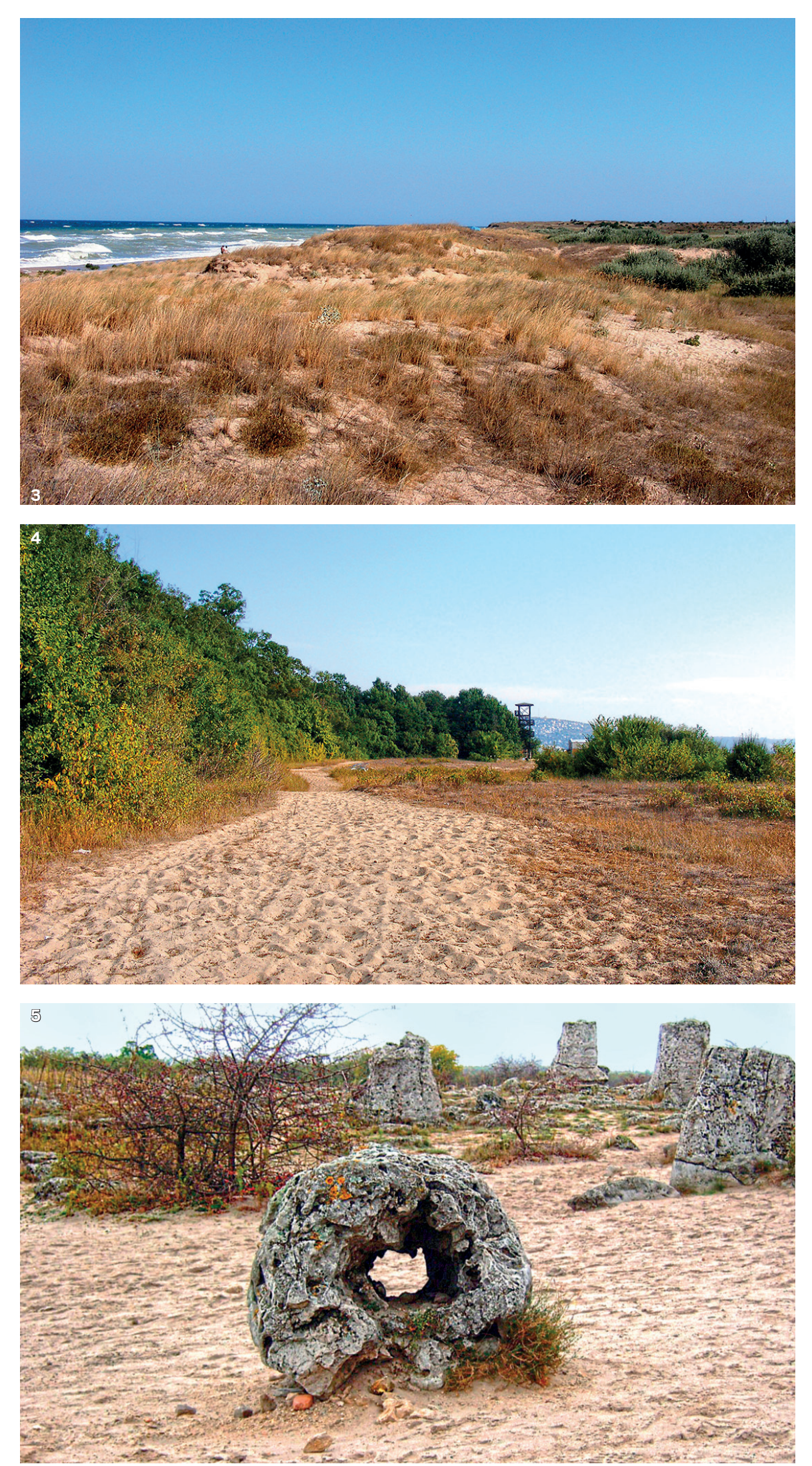
The Shablenska tuzla Lagoon (Durankulak-Shabla coastal sector), Nanevska tuzla and Balchishka tuzla lakes (Shabla-Balchik coastal sector) match up with the Bulgarian Red Data Book habitat types submerged macrophytic communities in hypersaline water bodies (critically endangered) [50], hypersaline coastal lakes and swamps (endangered) [51], communities of annual halophytes in coastal salt marshes at the Black Sea (endangered) [52], and Mediterranean halophytic communities of tall rushes, sedges and grasses (critically endangered) [53]. The latter two habitat types also occur at the Varna-Beloslav Lake Complex (Varna coastal sector).

All the firths in the study area (e.g., Orlovo blato Swamp, Durankulak Lake, ShablaEzerets Lake Complex, Varna-Beloslav Lake Complex, the Batova and Kranevska river mouths, the firths of Bolata dere, Dalboka Ravine, Pasha dere, etc.) correspond to the habitat type natural or semi-natural mesotrophic to eutrophic lakes and marshes with macrophytic vegetation, categorized as endangered [54].

The longoz forests in the Batova and the Kranevska river downstreams (Batova River Valley coastal sector), as well as the firth of Pasha dere (Avren Plateau coastal sector), their water bodies and river mouths correspond to the habitat types riparian and lowland mixed woodlands and longozes [55], and estuaries (both critically endangered) [56]

Sea caves formed in the limestone cliff between Cape Shabla and Cape Kaliakra

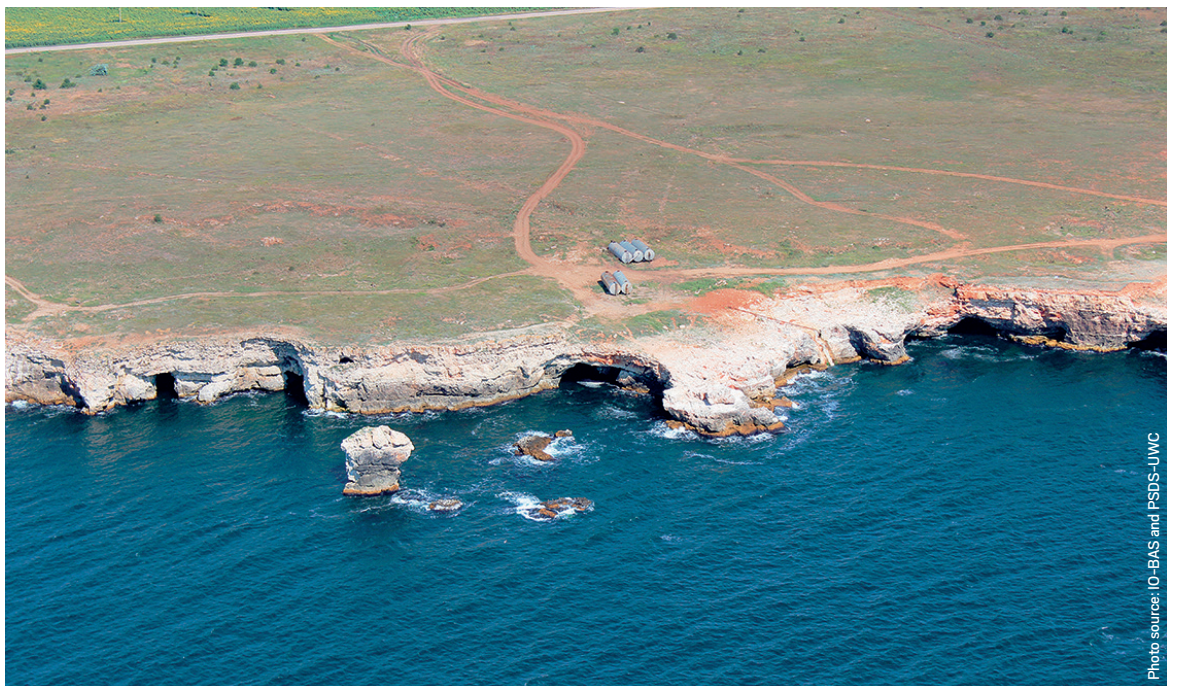

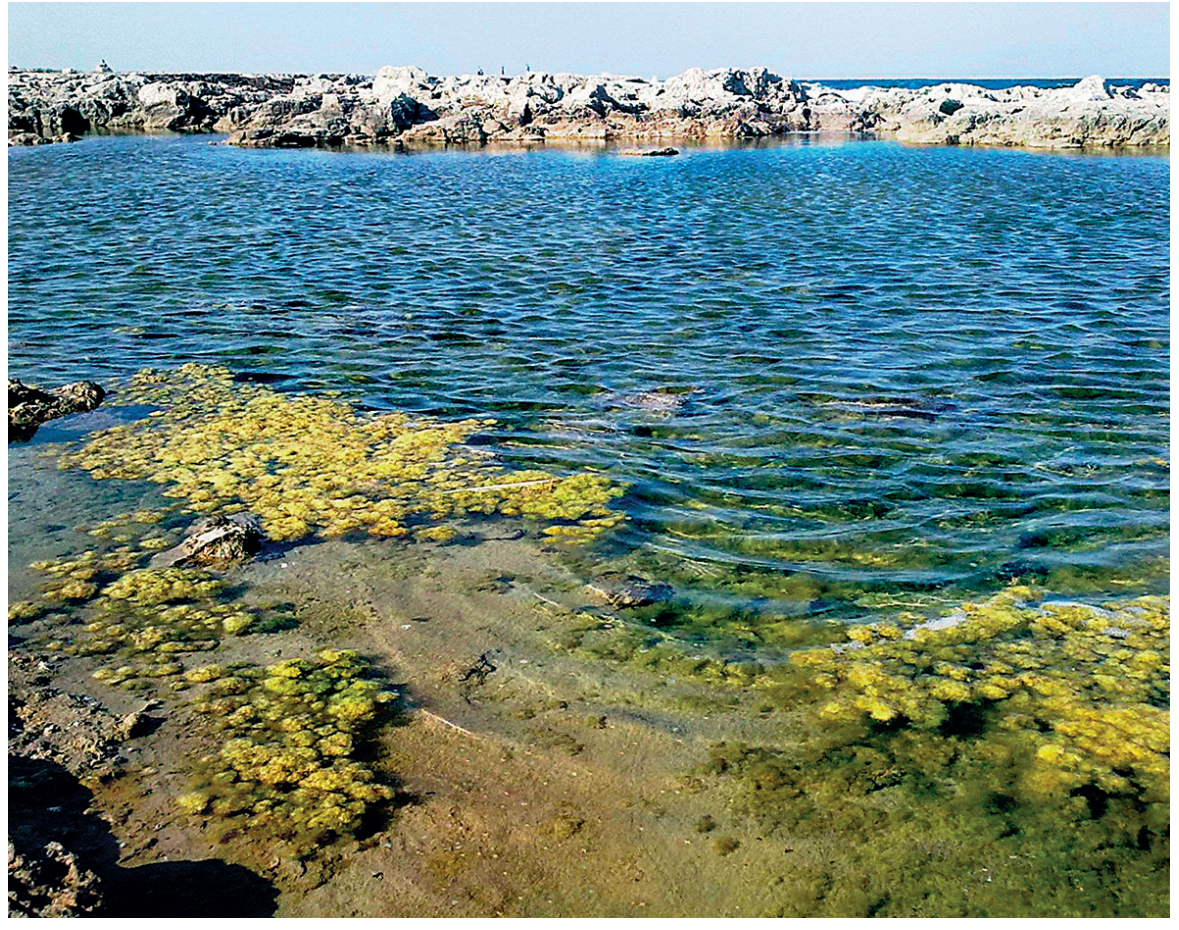

Lithotelms formed in the coastal karstified terraces of the Shabla-Balchik sector represent a mediolittoral habitat with rather extreme ecological conditions

The spatial distribution of important marine hard-bottom habitats, i.e., the Bulgarian Red Data Book types Mediterranean mussels and/or barnacle communities on mediolittoral rocks (vulnerable) [57], infralittoral rocks and other hard substrata (vulnerable) [58], Cystoseira spp. on exposed to waves infralittoral bedrock and boulders (endangered) [59], and sea caves (endangered, present only in Shabla-Balchik coastal sector between Cape Shabla and Cape Kaliakra) [60] is closely related to the cliff and landslide areas and the ongoing geo- and morphodynamic processes in the coastal zone [21; 36; 38]

Marine soft-bottom habitats, e.g., the Bulgarian Red Data Book types littoral sands and muddy sands (vulnerable) [61], sublittoral sands (nearly threatened) [62] and underwater "meadows" of sea grasses (endangered) [63] are predominantly found on the submarine coastal slope in front of the above-mentioned firths and lagoons. Sublittoral mussel beds on sediments (vulnerable) [64] are registered in the deeper soft-bottom areas with sandy silt and silt. 

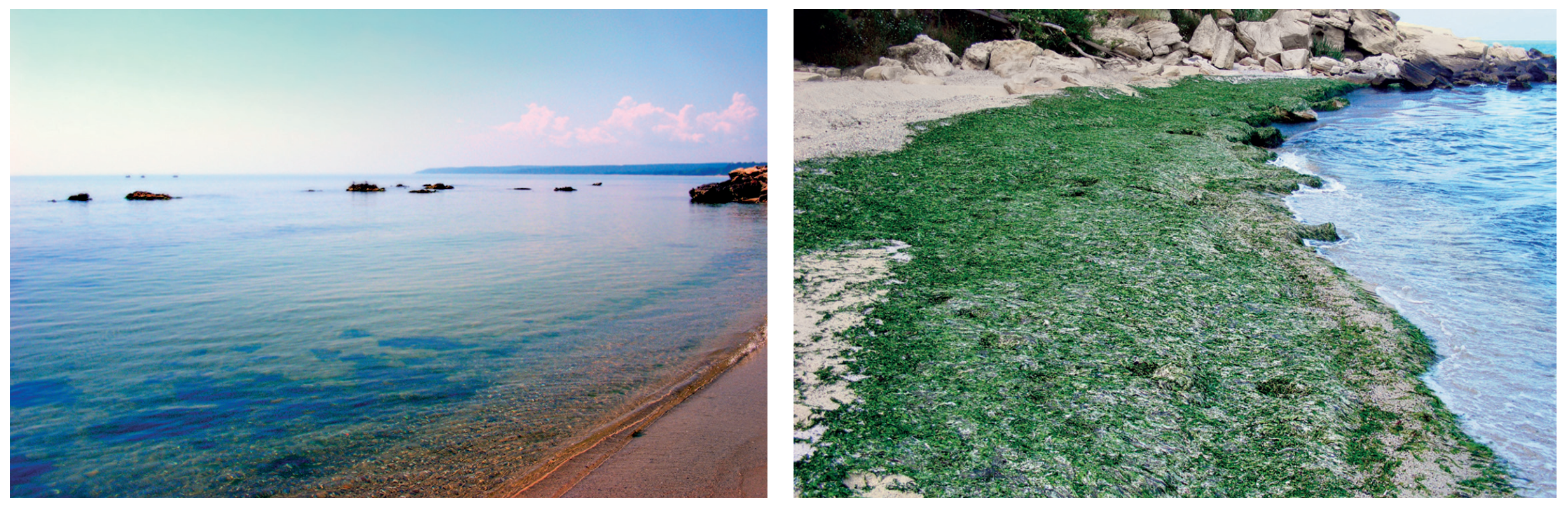

Littoral sands (left) and muddy sands (right) in the coastal zone of the Avren Plateau sector

\section{MAIN THREATS, PRESSURES AND ACTIVITIES WITH IMPACT ON HABITATS}

\section{LOW:}

- Human-induced trampling of communities and habitats

- Professional passive fishing and netting

- Tourism and associated noise pollution

- Forestry clearance

- Inundation due to natural processes

- Fertilization

\section{MODERATE:}

- Unauthorized camping

- Grazing

- Tree felling

- Disposal of household / recreational facility waste

- Disposal of industrial waste
- Urbanization and resort construction

- Construction and use of tourist harbors or recreational piers

- Landfill, land reclamation and drying out

- Artificial planting of non-native arboreal species

- Shipping lanes

- Exploitation of quarries

- Wind energy production

- Seismic acquisition

- Disposal of inert materials

- Pollution of the terrestrial, riverine and lacustrine environment

- Pressure by invasive non-native species

- Professional active fishing

- Coastal erosion
HIGH:

- Military exercises

- Habitat fragmentation

- Extraction of sand, gravel and other inert materials

- Bottom trawling and extraction of clams

- Hunting and poaching

- Fires

- Technogenic load of the coastal zone

- Hydrocarbon spills

- Pollution of the marine waters and transport of polluted water quantities by currents

- Exploitation of freshwater resources and associated alterations in water balance

- Modifying structures of inland water courses [38] 

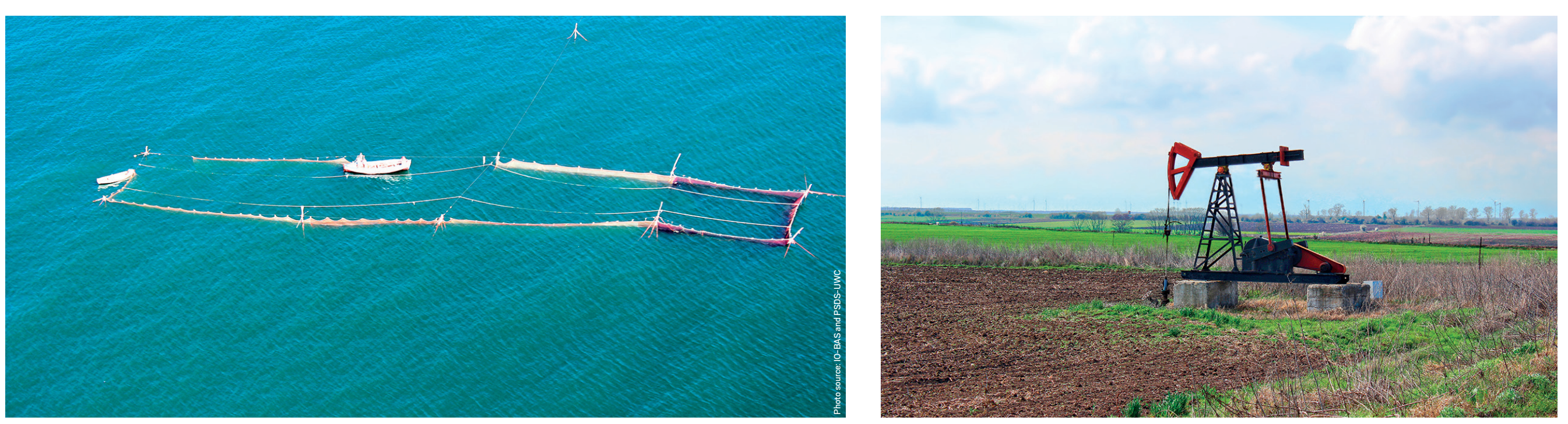

Passive fishing using stationary pound nets or dalyani (Varna coastal sector)

Small-scale oil extraction near Cape Shabla (Durankulak-Shabla coastal sector)

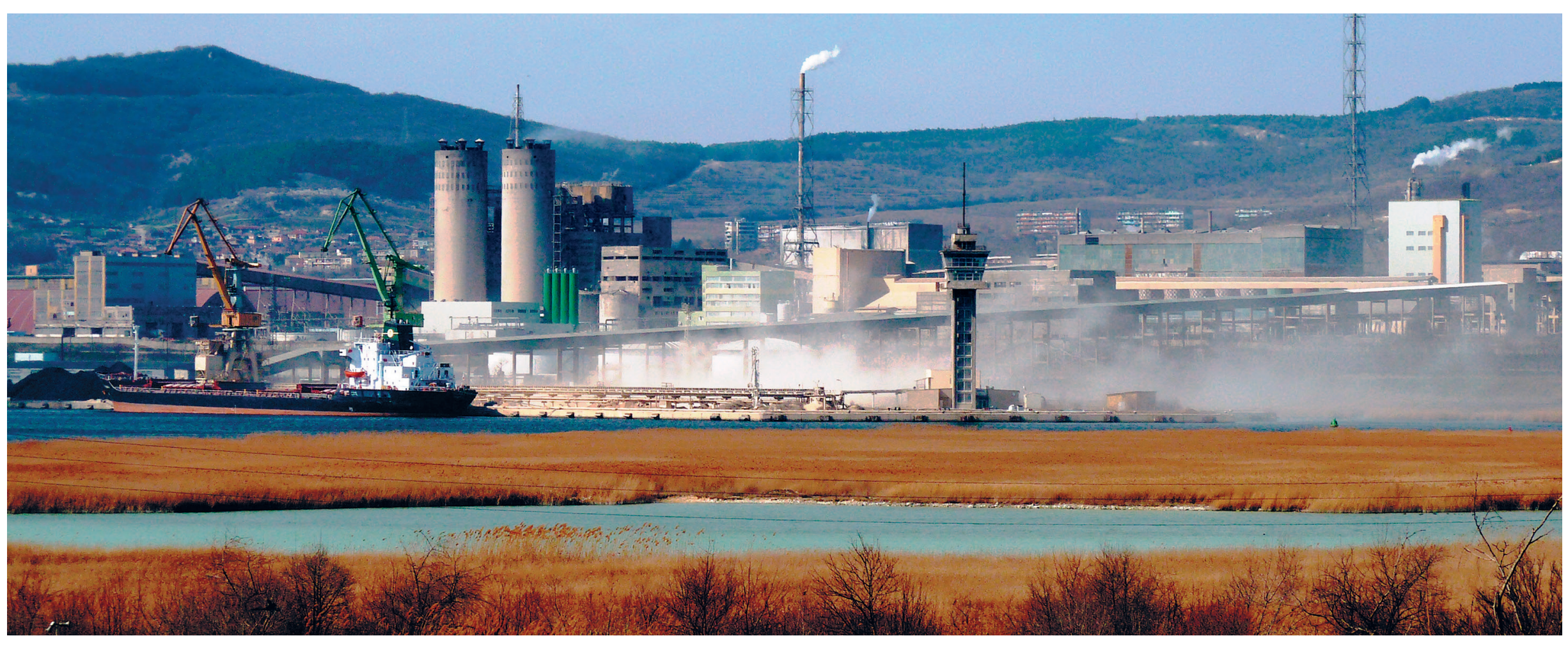

Port Varna-West remains among the main sources of pollution in the Varna-Beloslav Lake Complex 


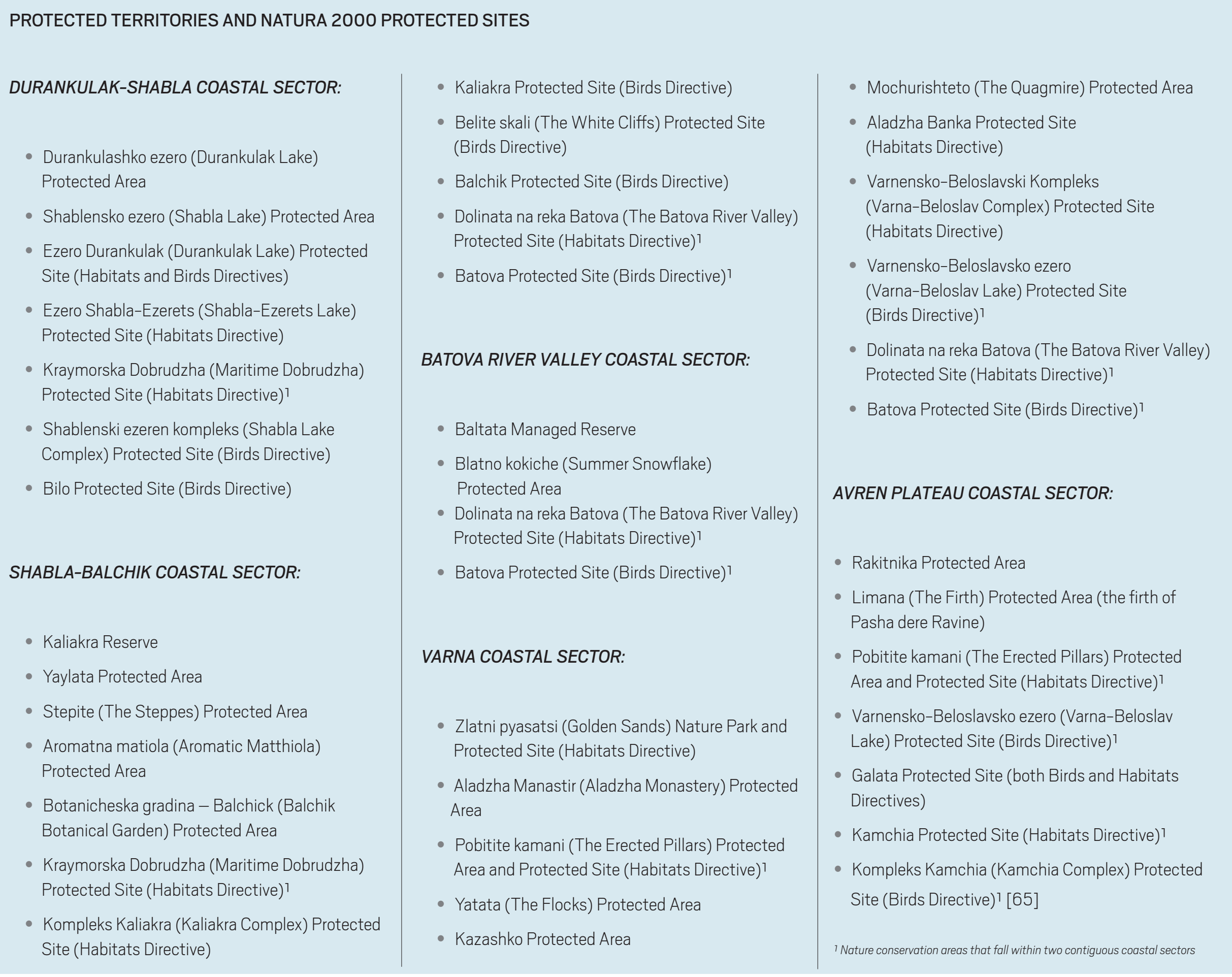




\section{CENTRAL COASTAL REGION}

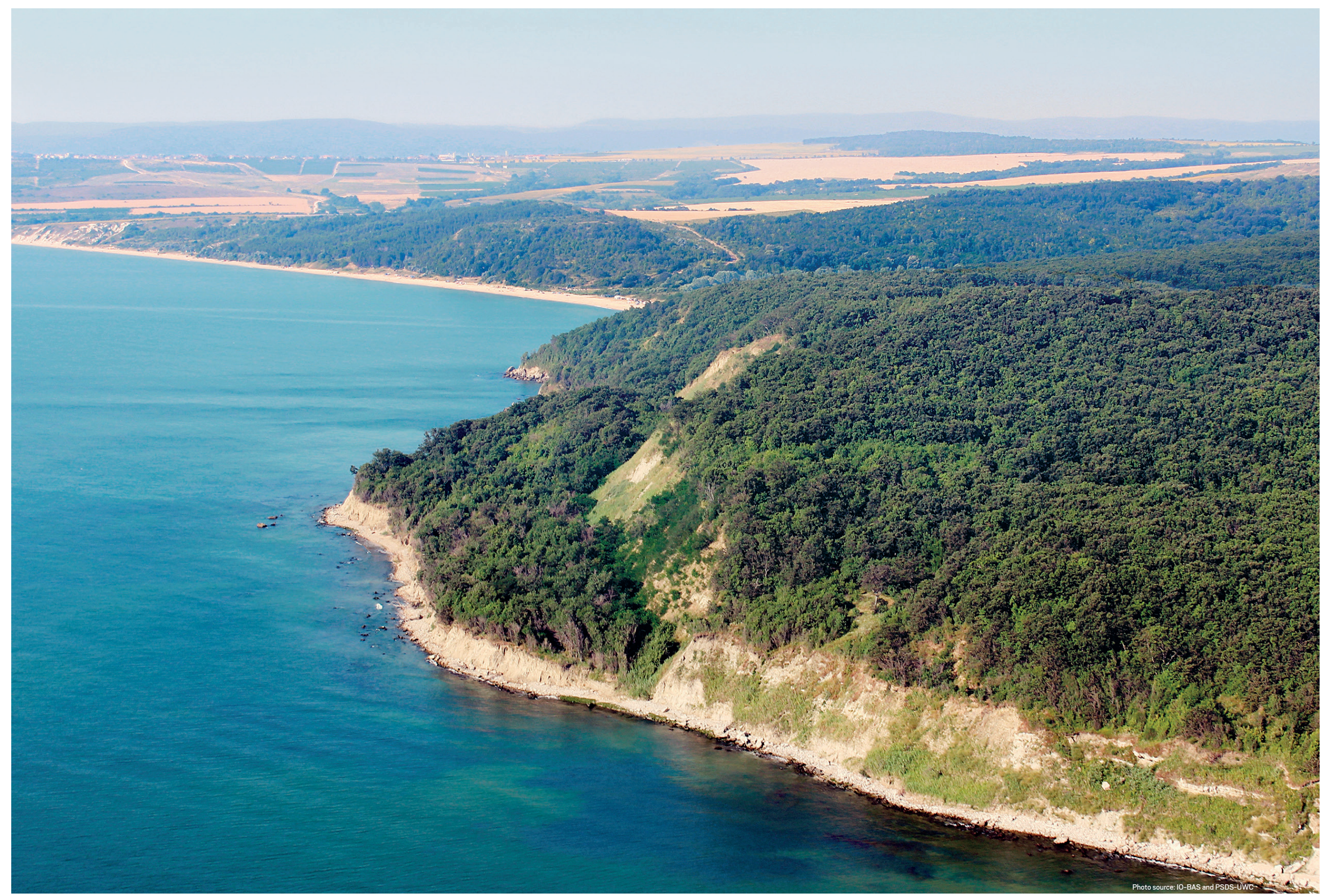




\section{GENERAL DESCRIPTION}

The central coastal region encompasses the area between the Lower Kamchia River Valley in the north and the Sveti Vlas Resort to the south. Within the coastal zone it is delimited by Cape Paletsa (Avren Plateau coastal sector) and the area of the above-mentioned resort located in the southern foothills of the Emine Mountain (East Balkan Mountains). The central coastal region is a transitional zone between the northern and the southern Bulgarian Black Sea coastal parts, demonstrating distinct landscape features in many aspects that cannot be assigned to either of the above-mentioned larger physiographic units.

The central coastal region's main morhpostructures are the Kamchia Depression and the easternmost part of the Balkan young-folded Alpine zone that includes the coastal peripheries of the Kamchia Mountain (part of the Fore-Balkan) and the Emine Mountain (part of the Main Balkan Mountains Chain). These morphotectonic units are clearly traced eastward and southeastward on the contiguous seabed sector [e.g. 16; 20; 66, 67, etc.]. The Kamchia Depression's geology is composed of Valanginian-Upper Cretaceous layers veiled by Neozoic sediments [15; 16]. The Quaternary deposits are presented by unconsolidated material with alluvial genesis, e.g., pebbles, sands, clays, etc. The littoral of the Kamchia Depression is dominated by contemporary sand accumulations of an origin associated with the erosion of Chokrakian sandstones transported by the coastal currents and the river runoff of the Kamchia and Fandakliyska [20]. The coast of the East Balkan Mountains is predominantly composed of Upper Cretaceous and Paleogene sedimentary layers, e.g., flysch deposits, sandstones, marls, conglomerates, limestones, etc. [15].

The investigated coastal region's main accumulative landforms are the Kamchia-Shkorpilovtsi spit (a $12 \mathrm{~km}$-long beach-dune geomorphic system, the largest on the Bulgarian coast; its genesis is related to the solid runoff of the Kamchia and Fandakliyska rivers), Kara dere beach (formed in front of the Kara dere and Belensko dere ravines), Byala beach, Obzor beach (formed in front of the Perperi dere and the Dvoynitsa River mouths), and Irakli beach (mainly related to the solid runoff of the Vaya River), etc. [e.g., 6; 16; 18; 20; 68, etc.]. Cliffs occupy the relatively steep coastlines of the Kamchia Mountain and the Emine Mountain. Remarkable cliff sectors have developed at the capes of Cherni nos, Beli nos, Sveti Atanas, and Emine [16; 18; 20]. The cited coastal areas of the East Balkan Mountains are characterized by a well-preserved relic geomorphic complex of marine terraces and denudation surfaces. Small tectonically predisposed landslides are also present at Cape Cherni nos, north of Cape Beli nos, north of Cape Emine, etc. [16;20].
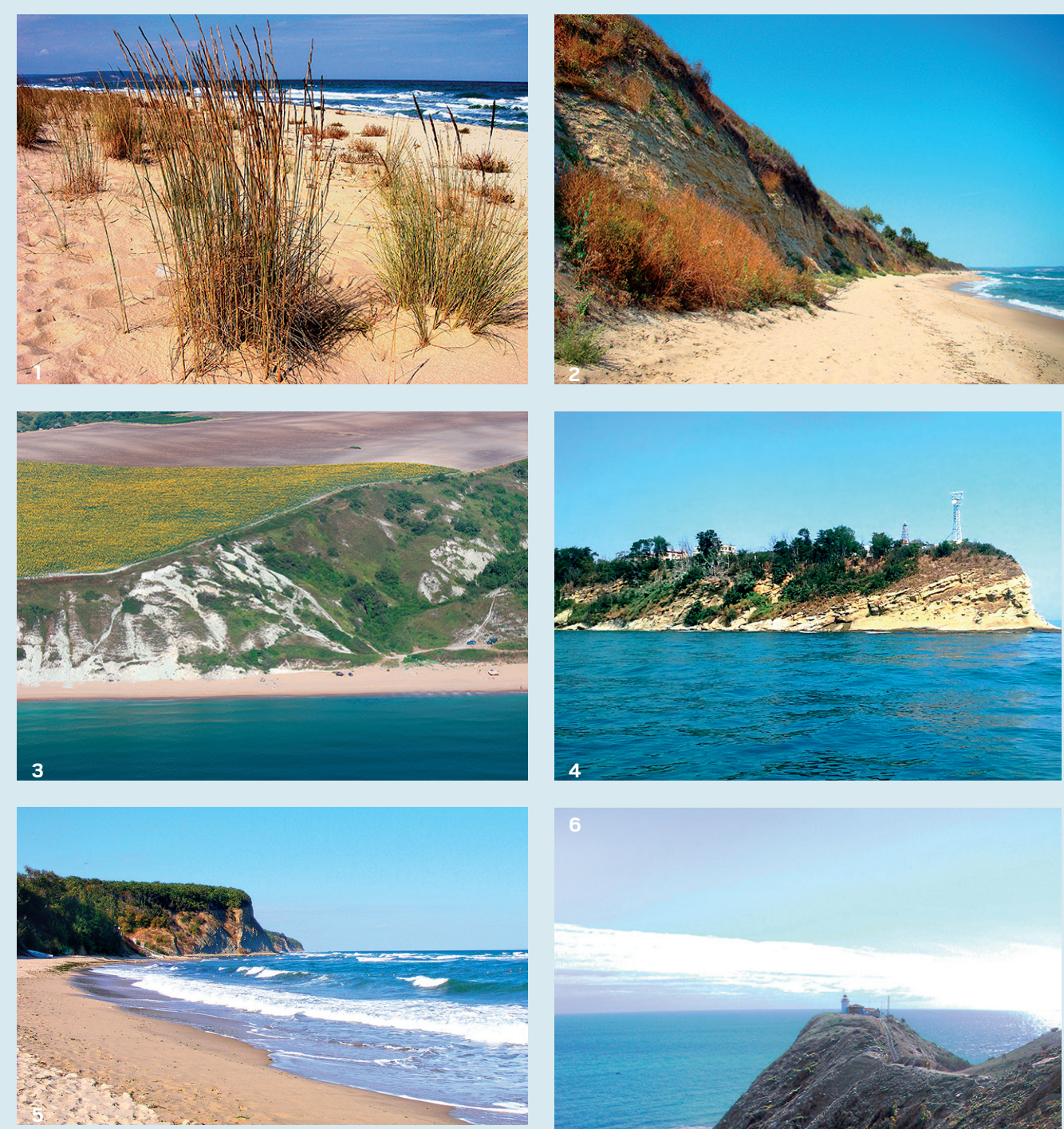

Remarkable accumulative and erosive sectors in the central coastal region:

1. Kamchia-Shkorpilovtsi beach

2. The cliffs at Cape Cherni nos

3. Kara dere beach with The White Cliffs Natural Landmark

(left section of the photograph) near Cape Beli nos

4. Cape Sveti Atanas

5. Irakli beach

6. Cape Emine

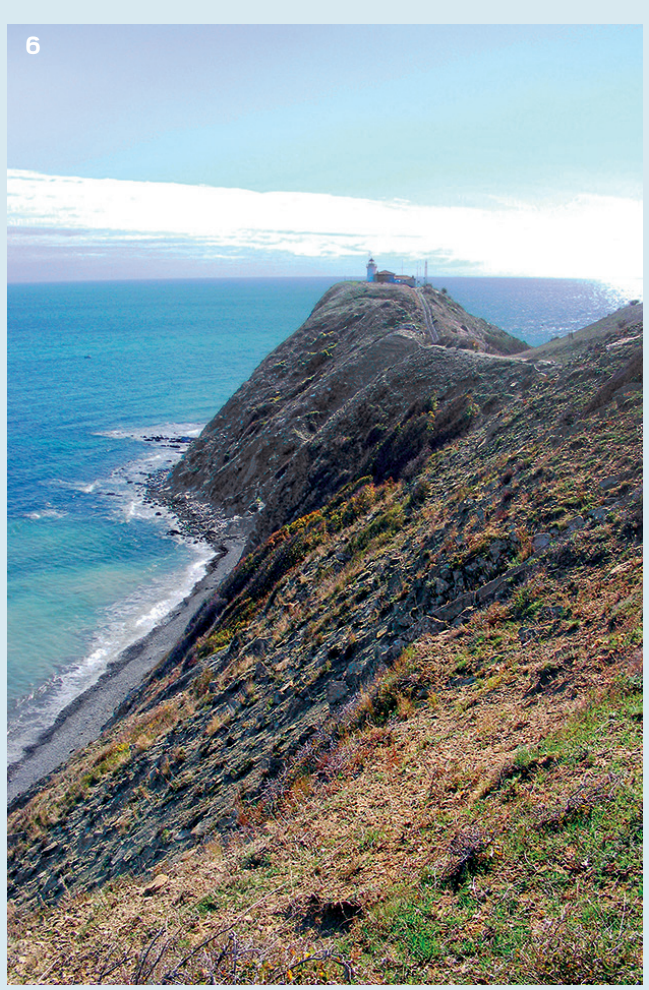


Typical firths are the mouths of the Kamchia, the Fandakliyska (Lower Kamchia River Valley coastal sector), the Kara dere, the Belensko dere, the Perperi dere, the Dvoynitsa and the Vaya (East Balkan Mountains coastal sector) [6; 16; 20].

The submarine coastal slope is a mosaic of depositional, structural and abrasional bedforms, e.g., underwater sand bars, structural steps, abrasional platforms, geogenic reefs, block and boulder accumulations, etc. A rocky bank, several kilometers long runs parallel to the Kamchia-Shkorpilovtsi beach [16; 18; 20]

The climate properties of the central coastal region are governed by the continental-Mediterranean influence, which increases gradually southward, together with an increase of the annual precipitation and improvement of the moisture regime. This is particularly valid for the Emine Mountain coastal area south and west of the homonymous cape $[4 ; 6 ; 7 ; 23]$. The available quantitative data on climate properties demonstrate that the mean annual temperature at Obzor Station (East Balkan Mountains coastal sector) is $12.4^{\circ} \mathrm{C}$, while the mean annual precipitation is $593 \mathrm{~mm} / \mathrm{y}$ [7]

The main hydrological objects are the above-mentioned rivers and ravine-like creeks (dereta in Bulgarian), along with their mouths (typical firths). There are no salt-wate lagoons formed in this part of the Bulgarian coast [16; 18; 20; 34]

Hydrological objects in the central coastal region:

7. Kamchia River downstream; 2. Fandakliyska River mouth: 3. Vaya River mouth

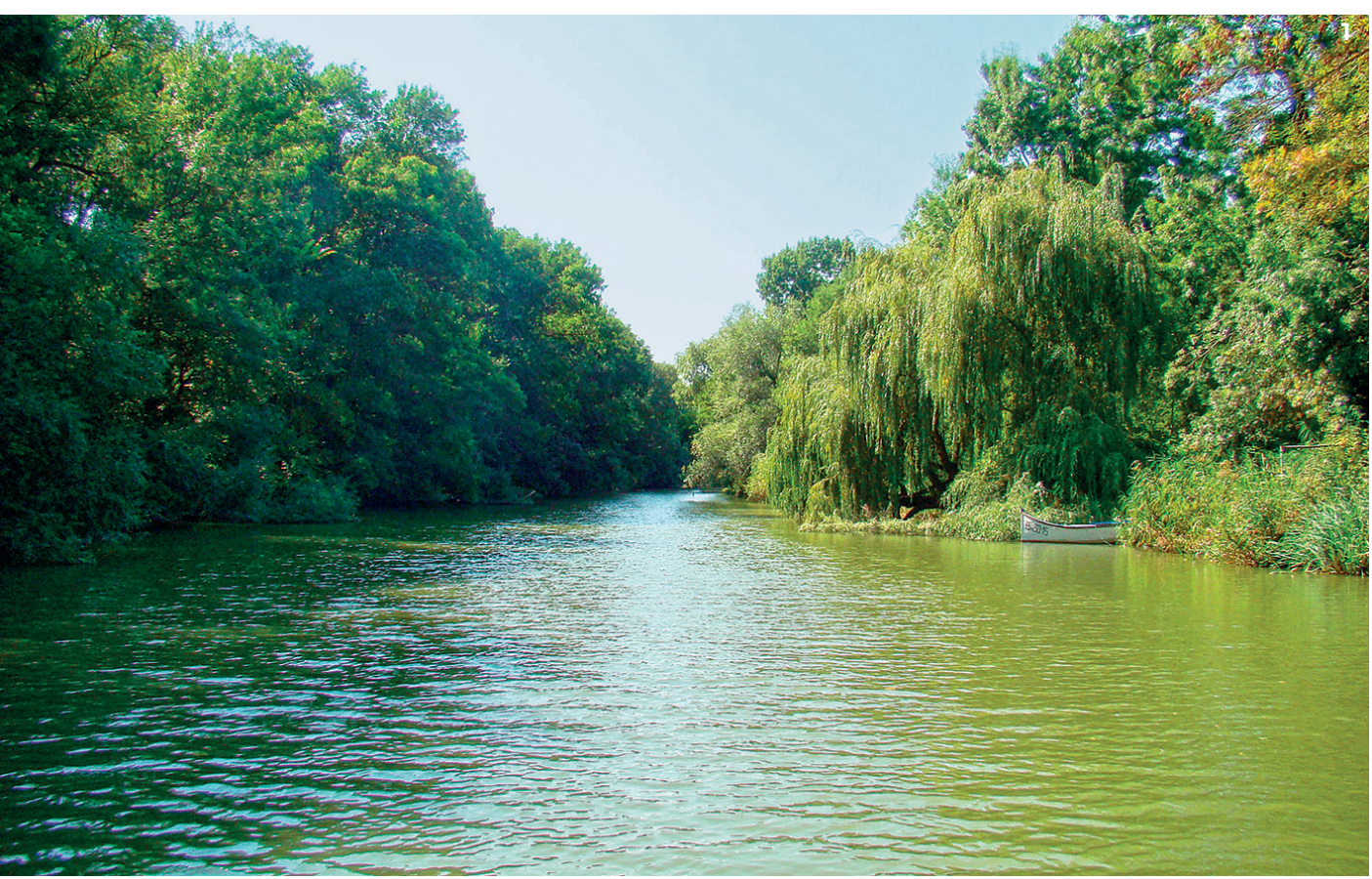

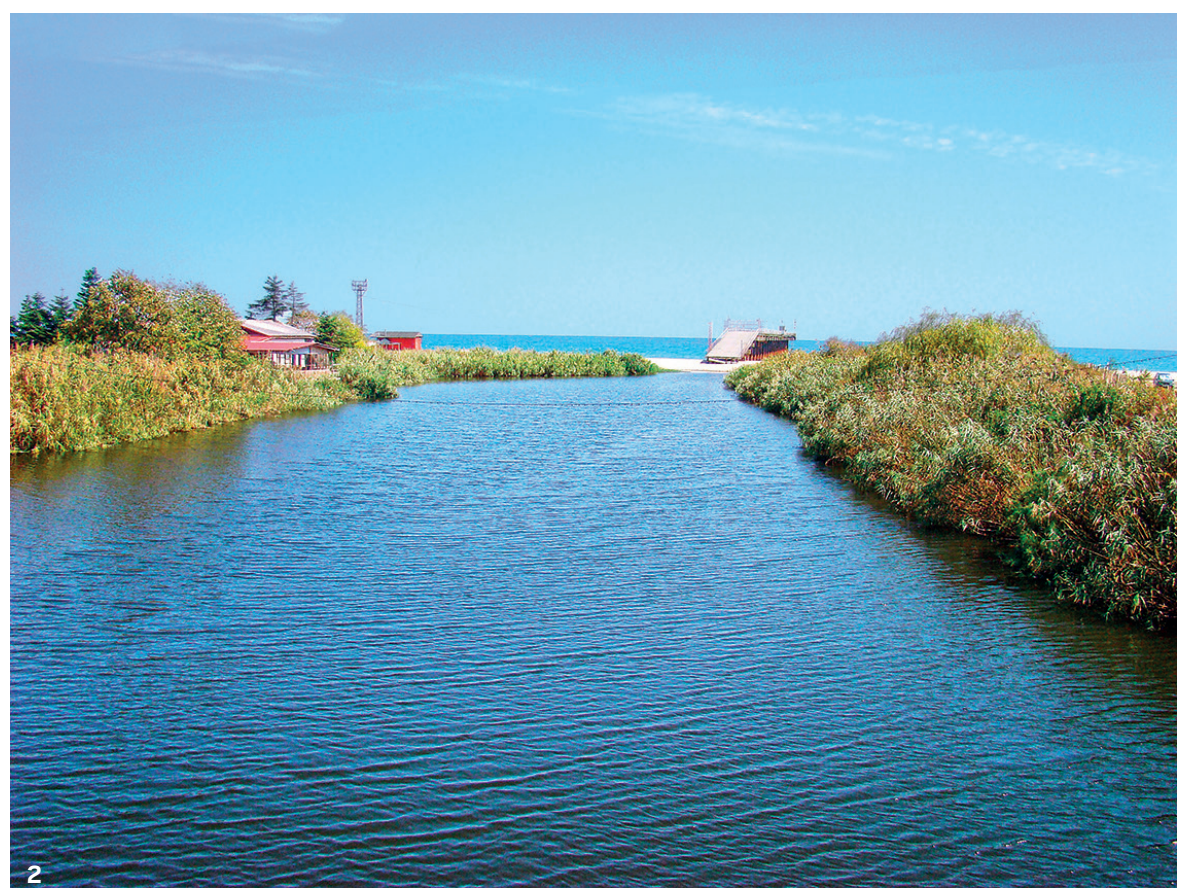

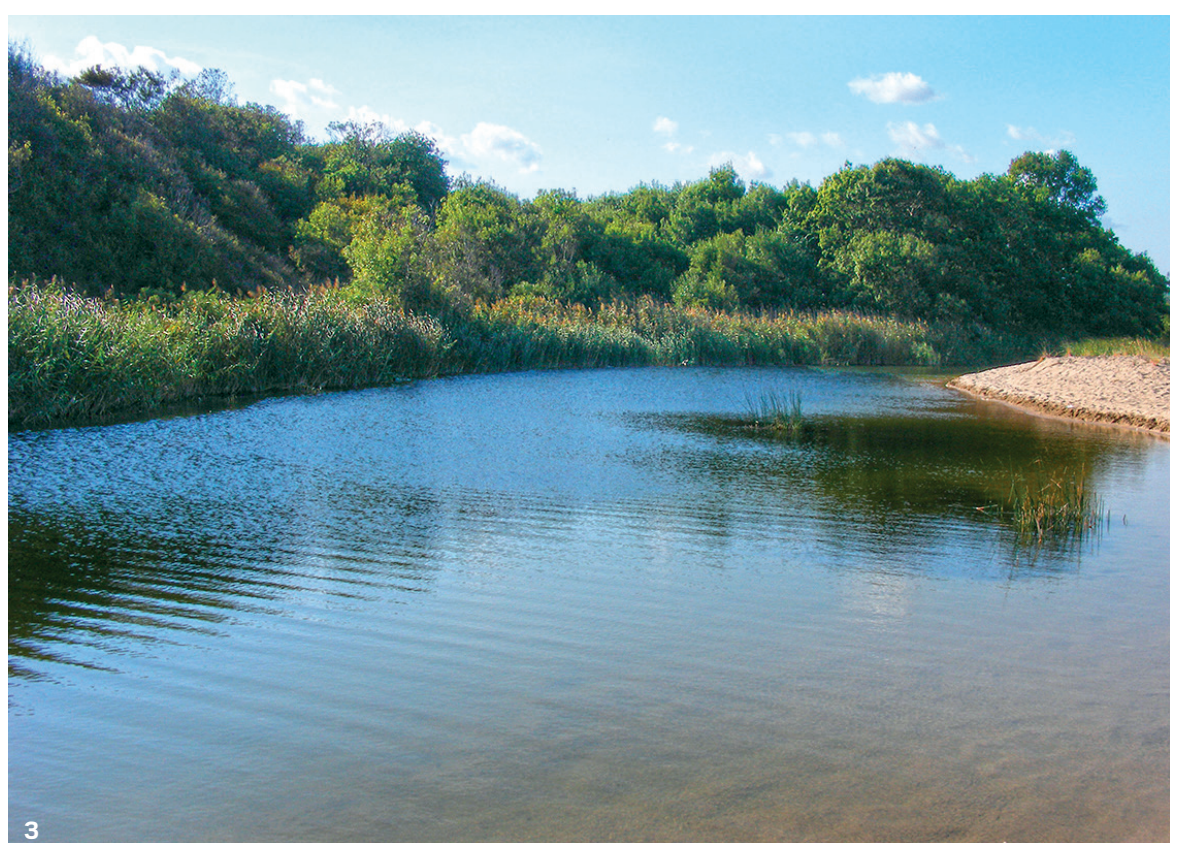

The soil diversity is presented mainly by luvisols (the forested areas excluding the Kamchia longoz), rendzinas (the areas with exposed carbonate-rich lithology), chromic cambisols (the southern slopes of the Emine Mountain near the village of Emona), gleysols (the firths of the Kamchia, the Fandakliyska, the Perperi dere, the Dvoynitsa, the Vaya, etc.), fluvisols (especially along the Kamchia, the Fandakliyska and the Dvoynitsa downstreams), arenosols (sand strips and dunes), colluviosols (bases of erosive cliffs), etc. [26; 27]. 
The vegetation cover is rather diverse thanks to the interactions of climate, moisture conditions and topography [14; 29; 30]. Longoz forests, aquatic communities and meadows are formed in the downstreams and around the mouths of the Kamchia, the Fandakliyska, the Dvoynitsa and the Vaya. Mixed oak forests are observed in the coastal areas of the Kamchia and the Emine Mountains, the latter also preserving forest communities of the relic Southeuxinian type [30]. Formations of the mock privet (Phyllirea latifolia) and steppe communities with a prevalence of scented grass (Chrysopogon gryllus) and bluestem (Dichantium ischaemum) are present around Cape Emine and west of it. Psammophytic communities are distributed on the sandy beaches and dunes, while chasmophytic vegetation grows on the coastal cliffs [30].

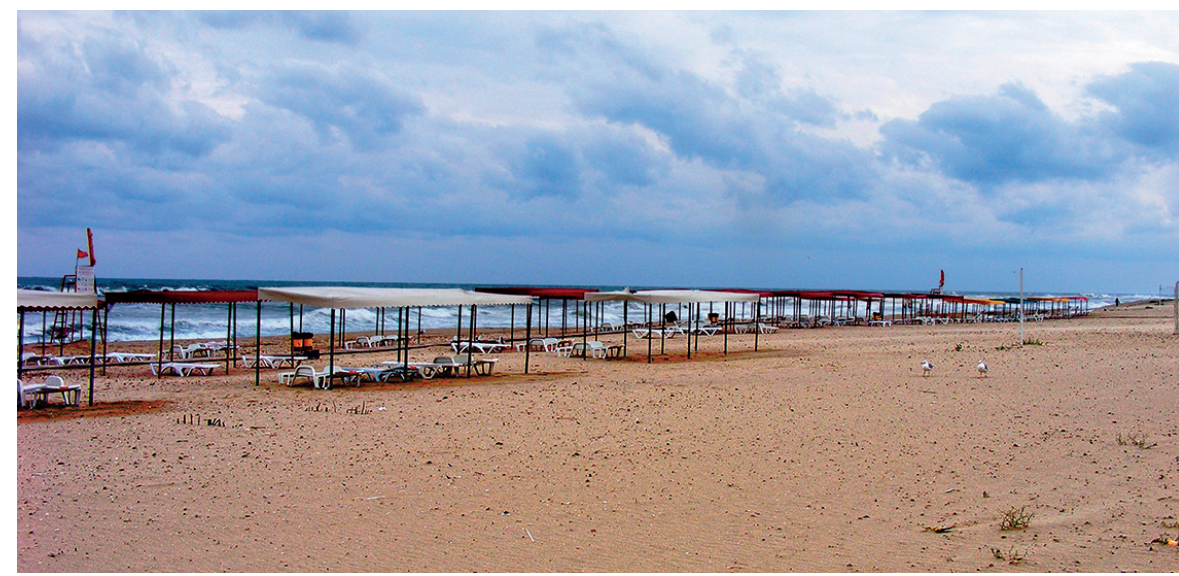

The urbanized northern part of Kamchia-Shkorpilovtsi beach (Lower Kamchia River Valley coastal sector)

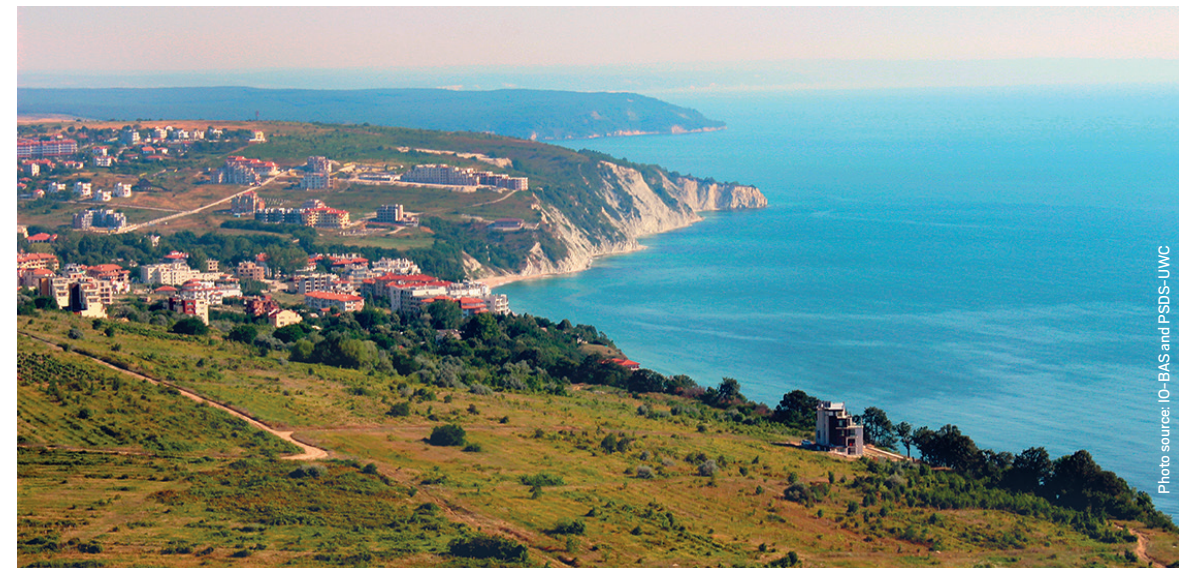

The rural landscape in the vicinity of Byala (East Balkan Mountains coastal sector) is undergoing significant transformation due to real estate development
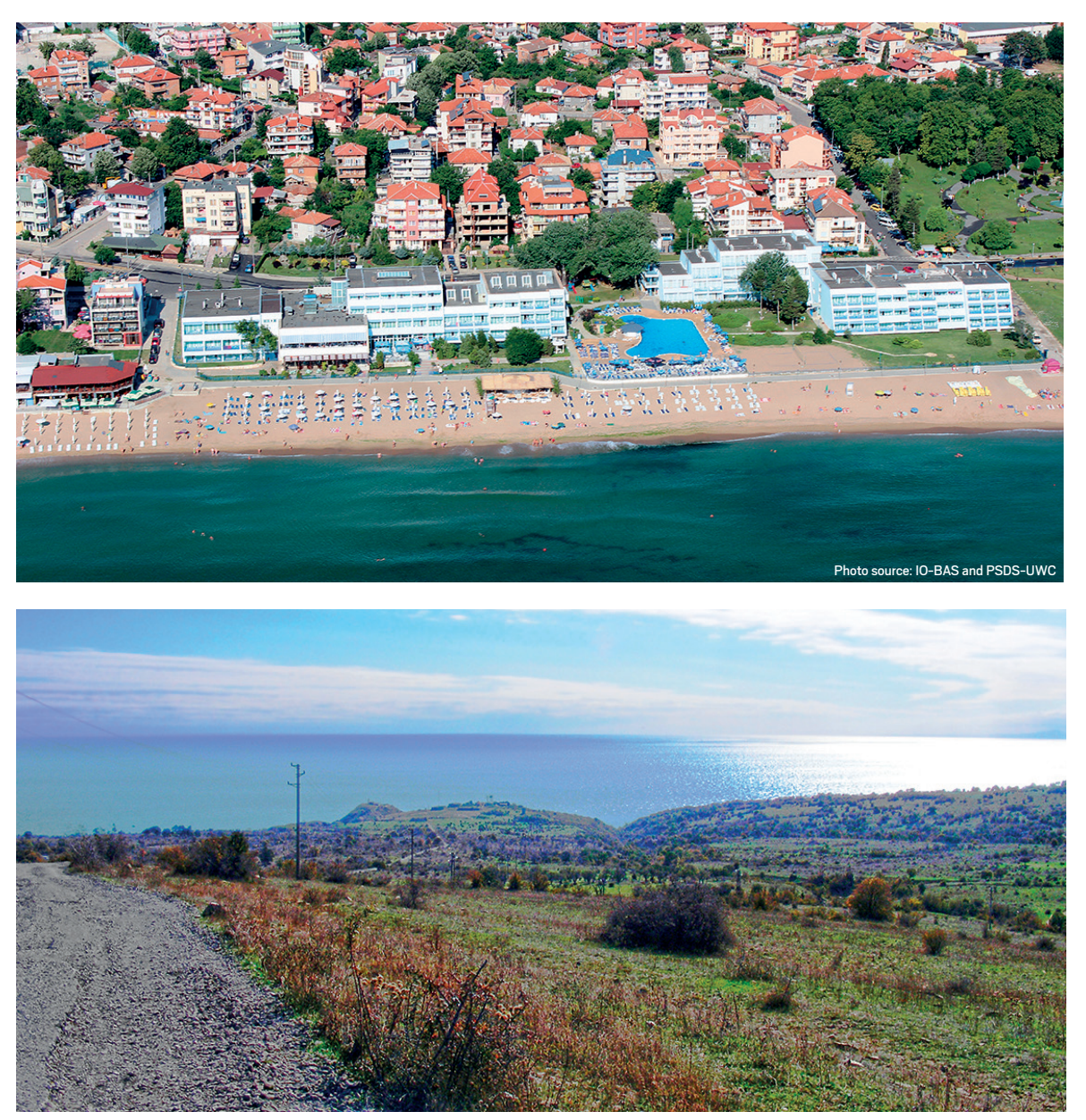

The coastal landscape at Obzor (above) and Emona (below) (East Balkan Mountains coastal sector)

The natural landscape pattern is greatly transformed within the recreational and rural areas near Shkorpilovtsi, Samotino, Byala, Obzor, Emona and Sveti Vlas, along the Kamchia and the Fandakliyska downstreams, etc. A larger concentration of recreational areas and camp sites with a fishermen's village occurs on the northern bank of the Kamchia River downstream, the rear southern part of Shkorpilovtsi beach, near Obzor, at the Kladeri locality north of the Irakli Protected Area, as well as along the southern foothills of the Emine Mountain between Cape Kozluka and Sveti Vlas. Yet, conservationally important natural complexes (e.g., ones with oak, longoz and Southeuxinian forests, psammophytic and chasmophytic plant communities, etc.) are preserved at the Kamchia Biosphere Reserve and the hard-to-access coastal sites of the East Balkan Mountains [14]. 


\section{MARINE FAUNA}

The shallow sublittoral areas with coarse sand are inhabited by communities of the wedgeclam (Donacilla cornea), the clam Chamelea gallina, while the ones with fine and medium sand are populated by wedge shells (Donax trunculus), the Mediterranean clam Lentidium mediterraneum, etc. The seabed areas with clean sands are also inhabited by the sandworm Arenicola marina and Callianasa shrimps (Necalianassa truncata) [37]. The ones with muddy sand and sandy silt at depths greater than $8 \mathrm{~m}$ are populated by the flat-browed shrimp Upogebia pusilla, major staple food for many demersal fish species [36]. The rocky banks of flysch, limestone, solid clay and marl near Cape Beli nos and Cape Emine are important physical habitats for the boring petricola (Petricola lithophaga), the common piddock (Pholas dactylus) and the white piddock (Barnea candida). The following fish species are common: shad (Alosa immaculata, A. maeotica), sand-smelt (Atherina pontica), garfish (Belone belone), the critically endangered beluga (Huso huso), knout goby (Mesogobius batrachocephalus), long-snouted seahorse (Hippocampus guttulatus), various wrasses, gobbies blennies, etc. All three cetaceans - the harbor porpoise (Phocoena phocoena), the common dolphin (Delphinus delphis) and the bottlenose dolphin (Tursiops truncatus) are frequently registered, and the coastal zone of the East Balkan Mountains is one of the top spots for their observation [38].

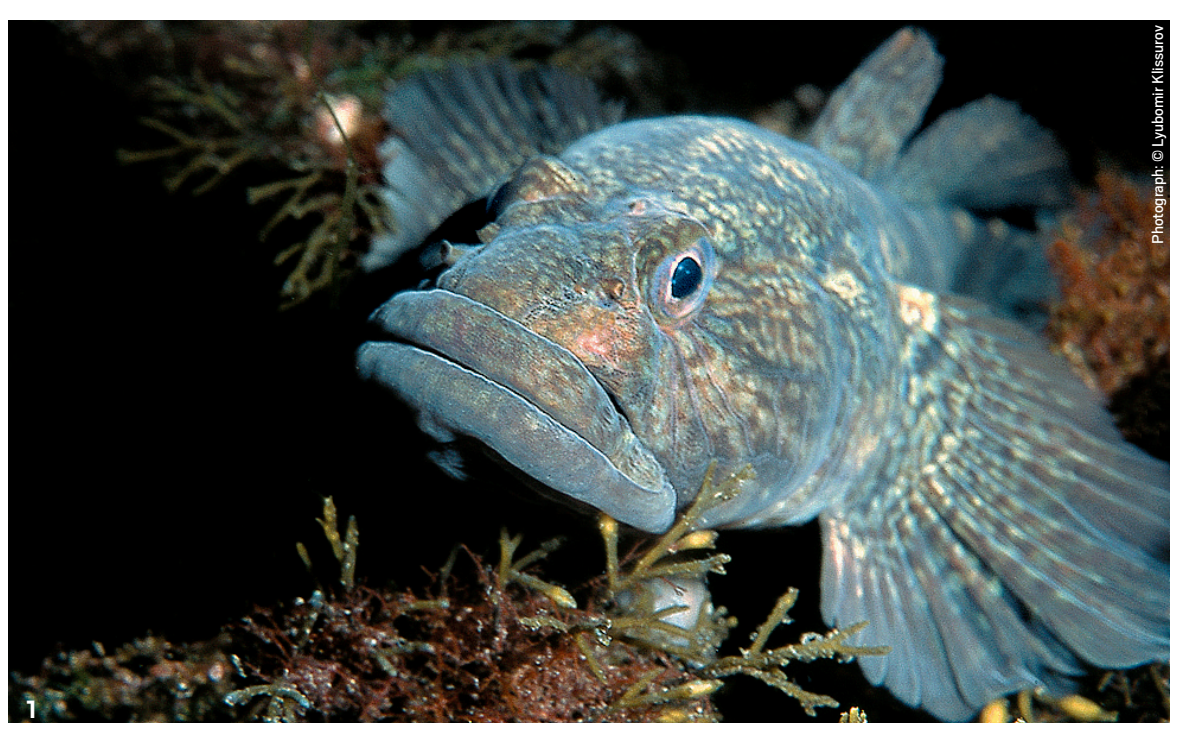

Typical marine species of the central coastal region

7. Knout goby (Mesogobius batrachocephalus)

2. East Atlantic peacock wrasse (Symphodus tinca)

3. Wedge shell (Donax trunculus)

4. Bottlenose dolphin (Tursiops truncatus)
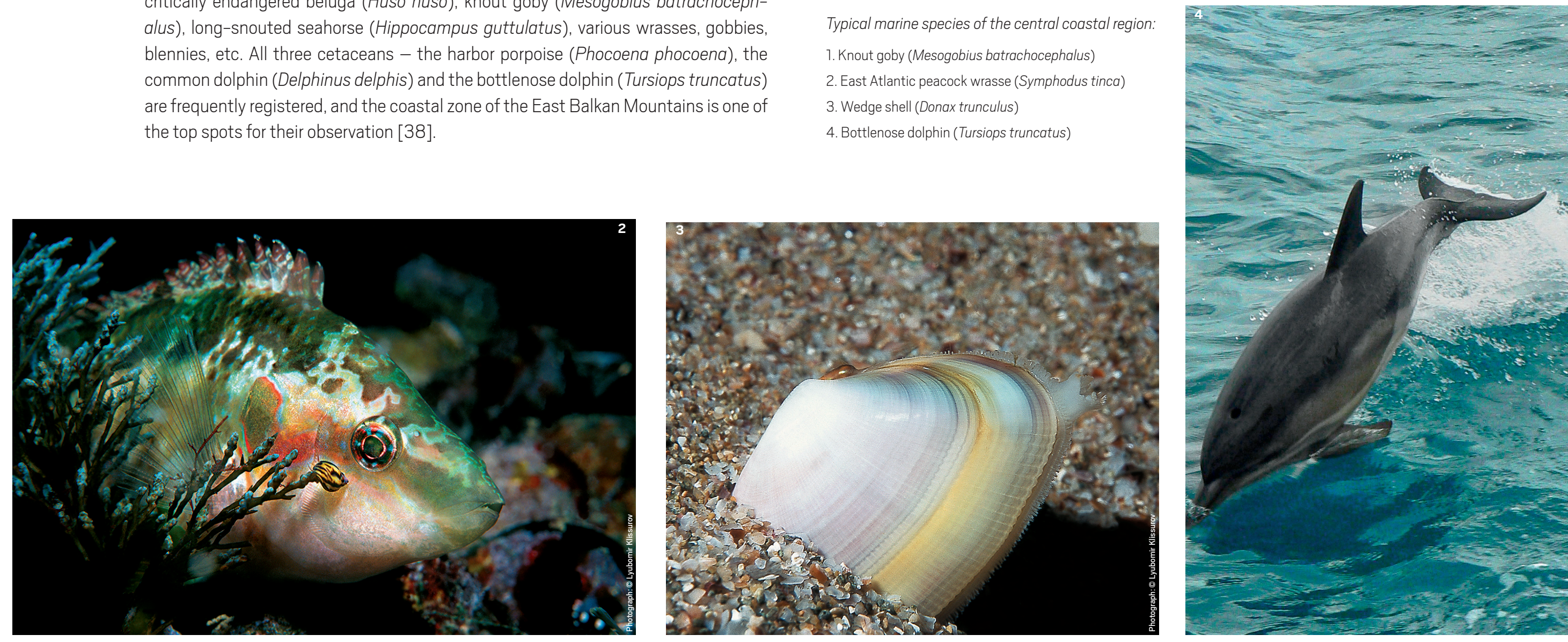


\section{BULGARIAN RED DATA BOOK COASTAL AND MARINE HABITATS}

The central coastal region and its contiguous shallow seabed sector are of crucial nature conservation importance, so currently considerable shares of them are nationally designated protected territories and/or are included in the NATURA 2000 European ecological network as protected sites [38; 65]. Important NATURA 2000 protected sites include Kamchia, Plazh Shkorpilovtsi (Shkorpilovtsi Beach), Emine-Irakli (its spatial extent includes the Cockatrice sand bank) and Emona, designated in compliance with the Habitats Directive [29; 38; 69]. The presence of relic Southeuxinian forest communities of Oriental durmast oak (Quercus polycarpa) and Oriental beech (Fagus orientalis) in the Emine Mountain makes the East Balkan Mountains one of Bulgaria's most important nature conservation areas [e.g., 14; 29; 30, etc.]. Representative beach and dune habitats with psammophytic vegetation and cliff habitats with chasmophytic vegetation and scrubs are widely spread. Important wetland habitats are formed in the river mouths and firths of the Kamchia, the Fandakliyska, the Kara dere, the Belensko dere, the Perperi dere, the Dvoynitsa and the Vaya. These are also important bird areas as they are located on the Via Pontica migratory route [29;38].

Black-tailed godwit (Limosa limosa) in the Kamchia River downstream

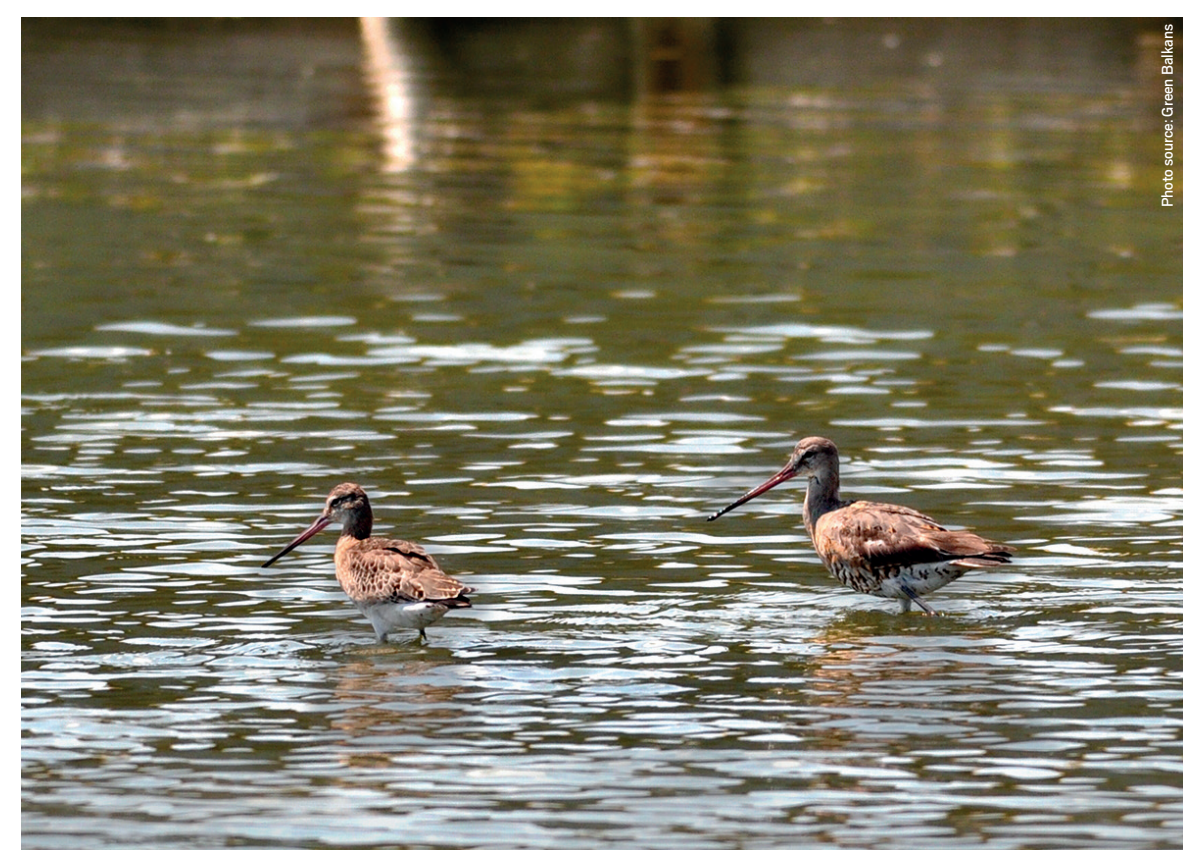

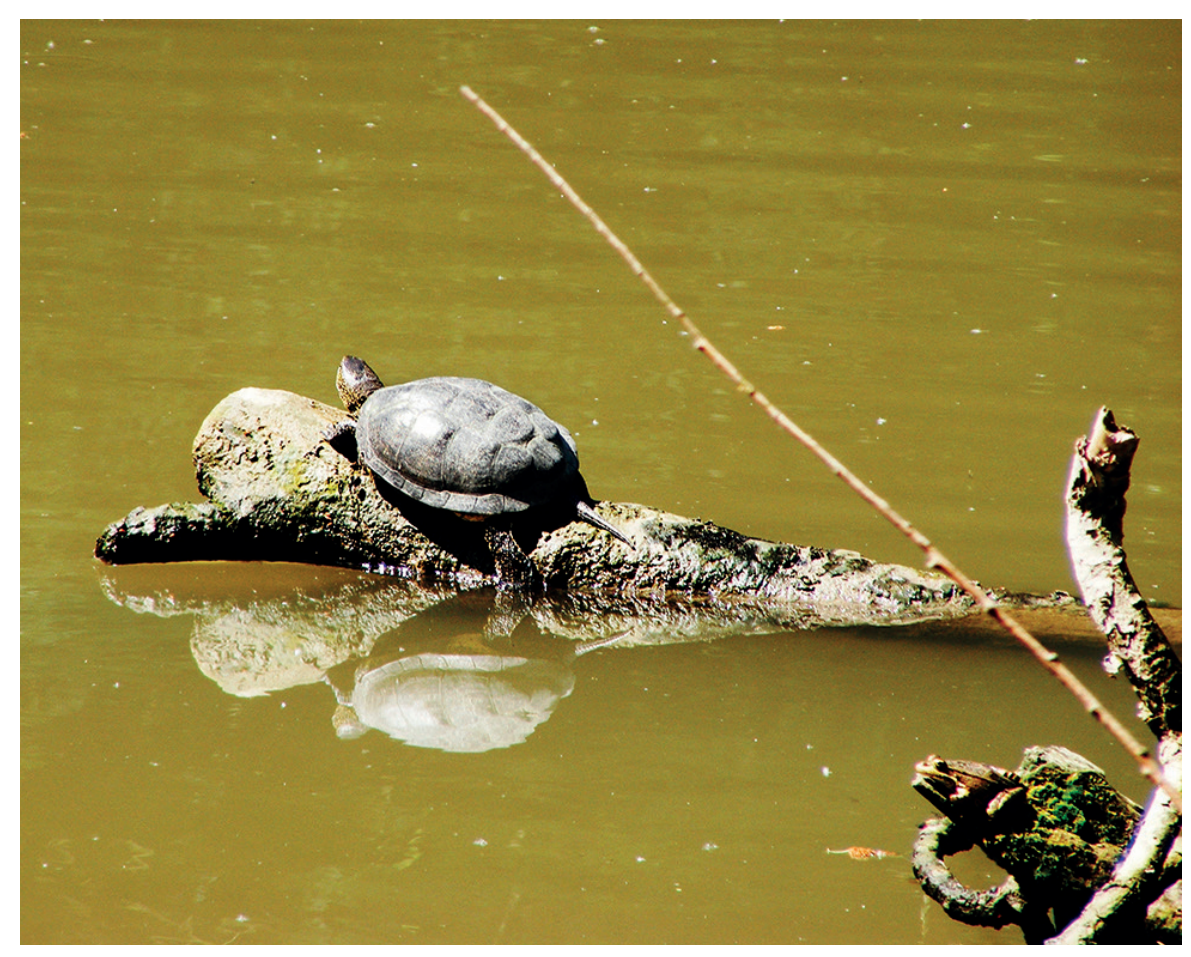

Typical representatives of the central coastal region's herpetofauna

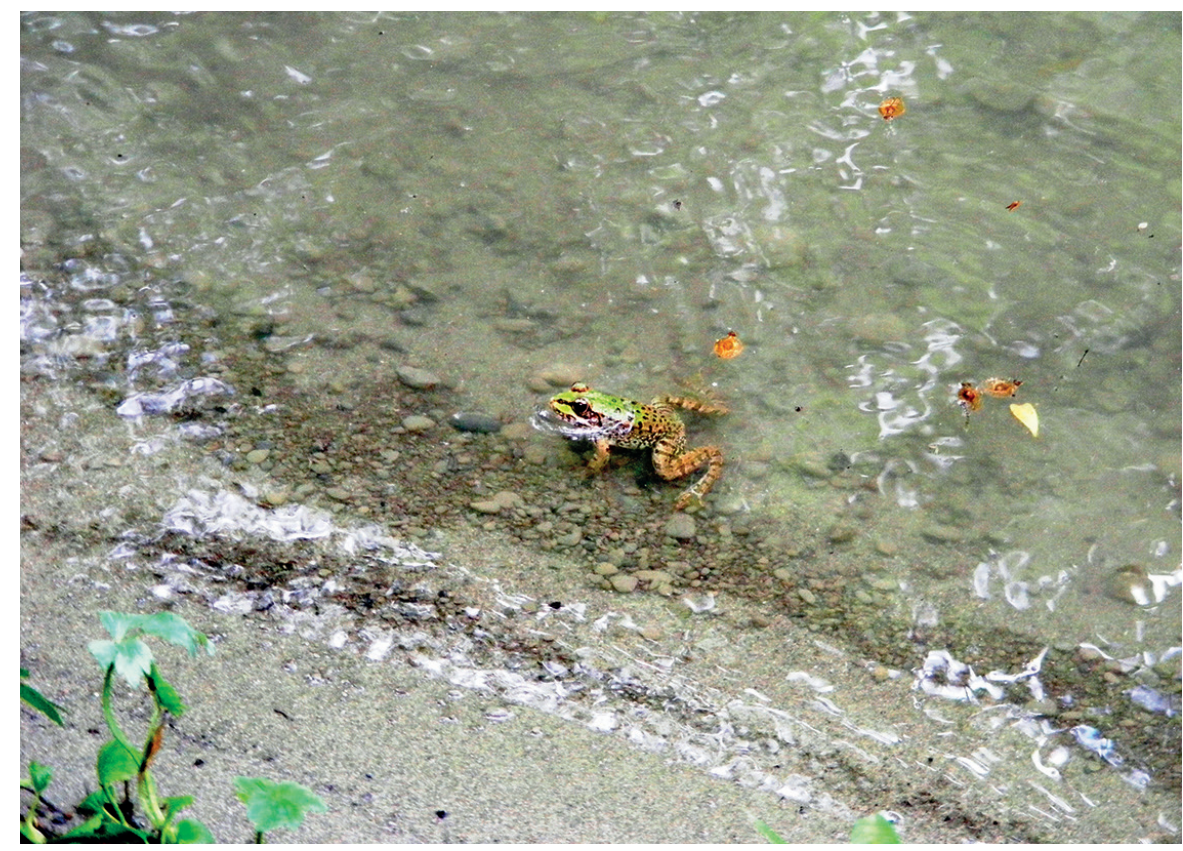


The beaches and dunes with psammophytic communities in the central coastal region correspond to the habitat types vegetation on the Black Sea gravel beaches [42], vegetation on the Black Sea sand beaches [43], Black Sea embryonic dunes [44] and Black Sea mobile (white) dunes [45], all of them categorized as endangered. The habitat types Black Sea fixed (grey) dunes (endangered) [46], Black Sea wooded dunes [47] and over-wet and flooded dune slacks (both categorized as critically endangered) [48] are present on the Kamchia-Shkorpilovtsi beach.

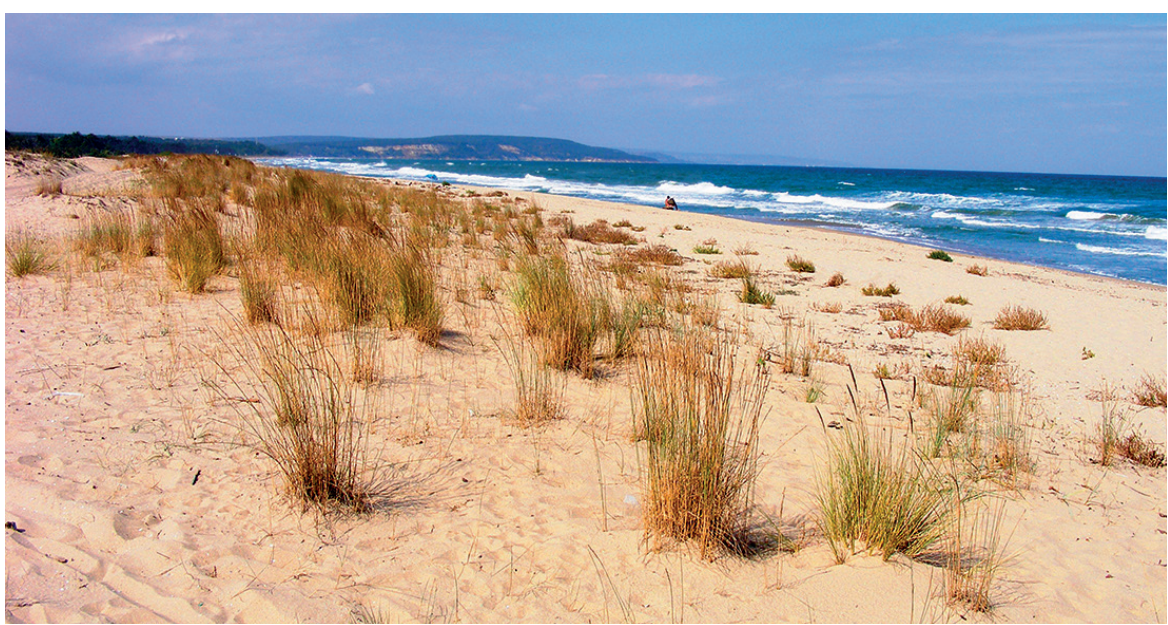

White dunes at Kamchia Sands locality (Lower Kamchia River Valley coastal sector)

Grey dunes on Kamchia-Shkorpilovtsi beach (Lower Kamchia River Valley coastal sector)

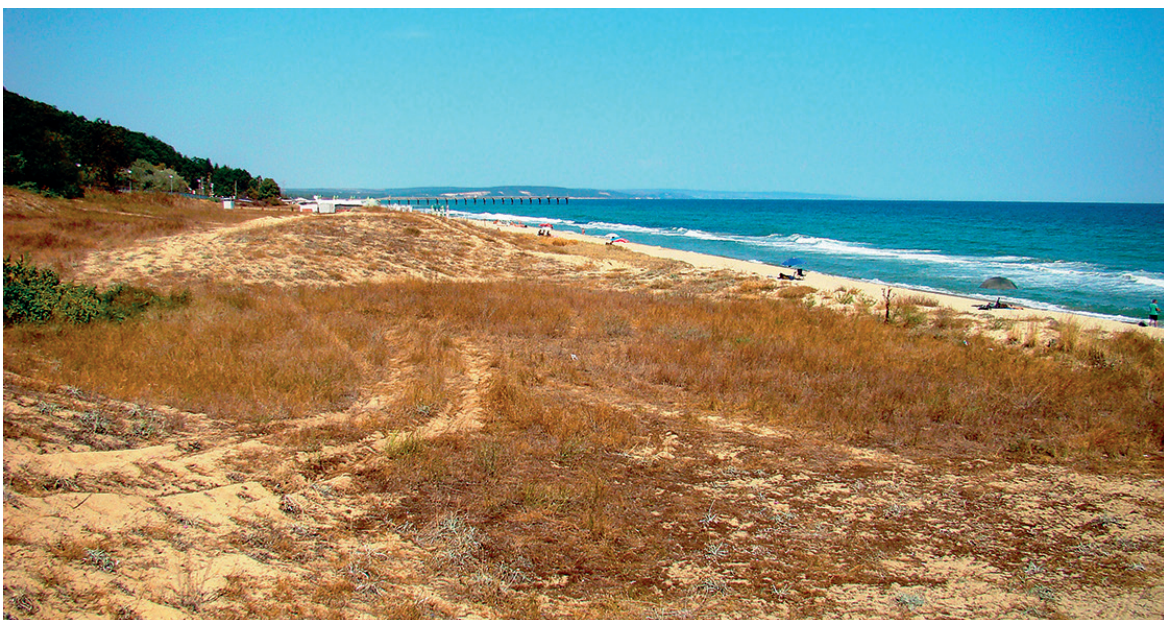

The cliff areas around Cape Cherni nos, Cape Beli nos, Cape Sveti Atanas, Cape Emine, etc., correlate with the habitat type sea-cliff vegetation, categorized as endangered [40]

The areas with steppe communities around and west of Cape Emine correspond to the habitat type sub-Mediterranean petrophytic steppes, categorized as vulnerable [73]

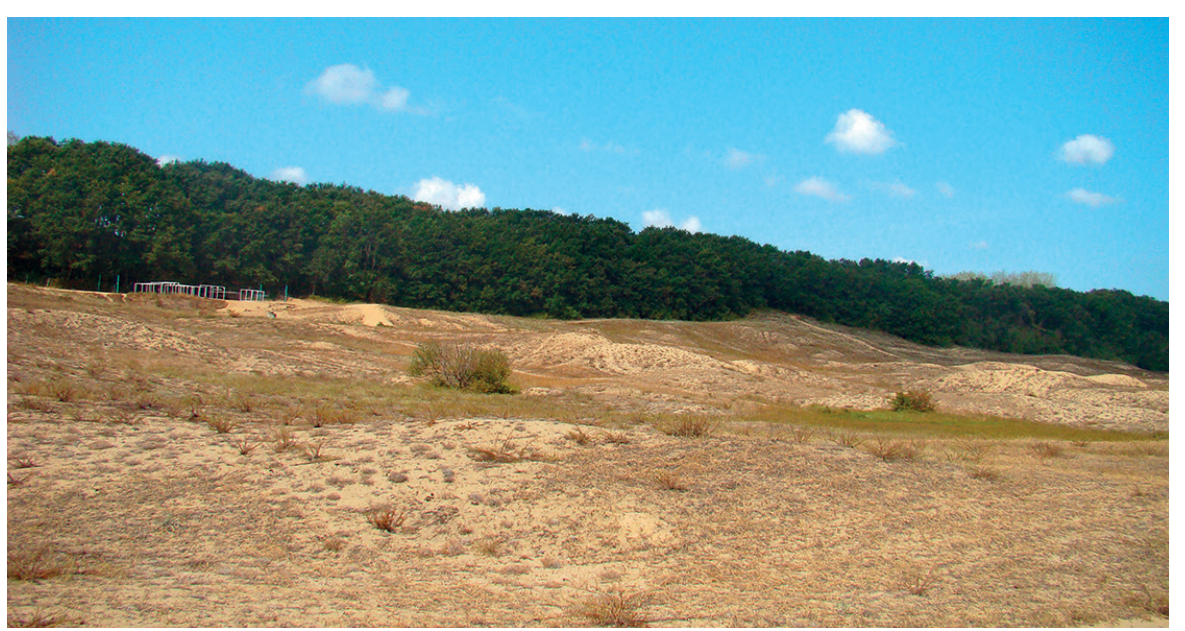

Wooded dunes near the research station of the Institute of Oceanology - Bulgarian Academy of Sciences (Lower Kamchia River Valley coastal sector)

Balkan pseudomaquis in the rear part of the Obzor-South beach (East Balkan Mountains coastal sector)

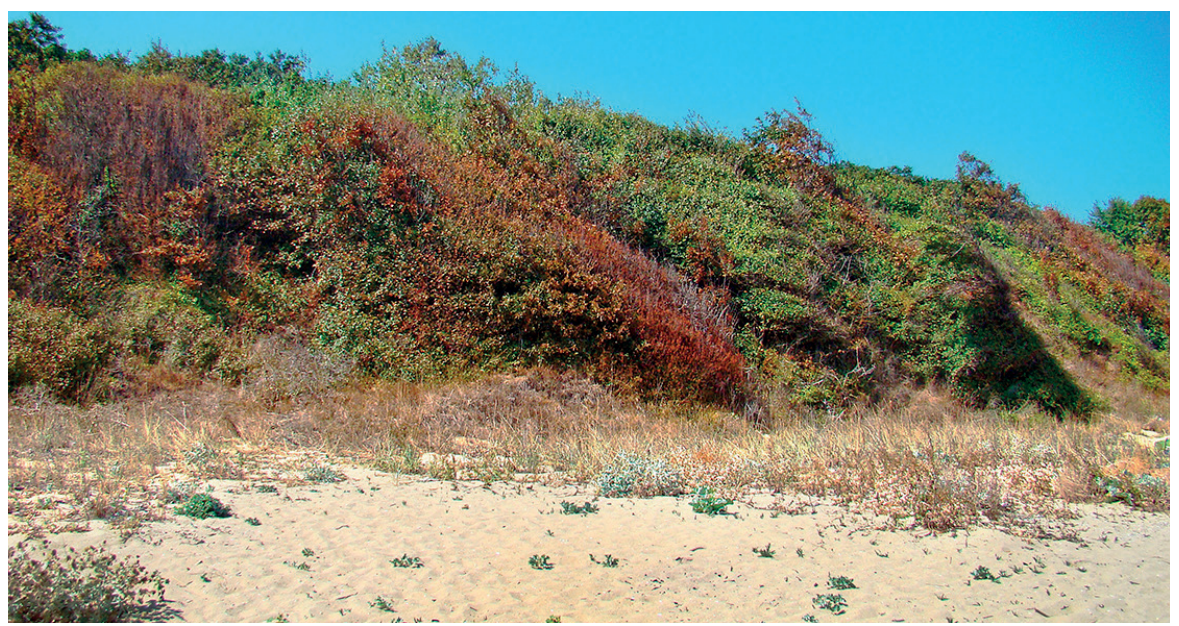


The sites with xerophytic shrubs with Mediterranean elements in the East Balkan Mountains coastal area match up with habitat type Balkan pseudomaquis, categorized as nearly threatened [41].

The longoz forest communities of the Kamchia, the Fandakliyska and to a lesser extent of the Kara dere, the Belensko dere, the Perperi dere, the Dvoynitsa and the Vaya downstreams, their water bodies and river mouths correspond to the habitat types riparian and lowland mixed woodlands and longozes (critically endangered) [55], natural or semi-natural mesotrophic to eutrophic lakes and marshes with macrophytic vegetation (endangered) [54] and estuaries (critically endangered) [56].

The spatial distribution of important marine hard-bottom habitats, i.e., the Bulgarian Red Data Book types Mediterranean mussels and/or barnacle communities on mediolittoral rocks (vulnerable) [57], infralittoral rocks and other hard substrata (vulnerable) [58], and Cystoseira spp. on exposed to waves infralittoral bedrock and boulders (endangered) [59], is closely related to the cliff and landslide areas and the ongoing geo- and morphodynamic processes in the coastal zone [36; 38].

These underwater structural-morphologic steps near Cape Emine (East Balkan Mountains coastal sector) match up with the Bulgarian Red Data Book habitat type infralittoral rocks and other hard substrata, categorized as vulnerable

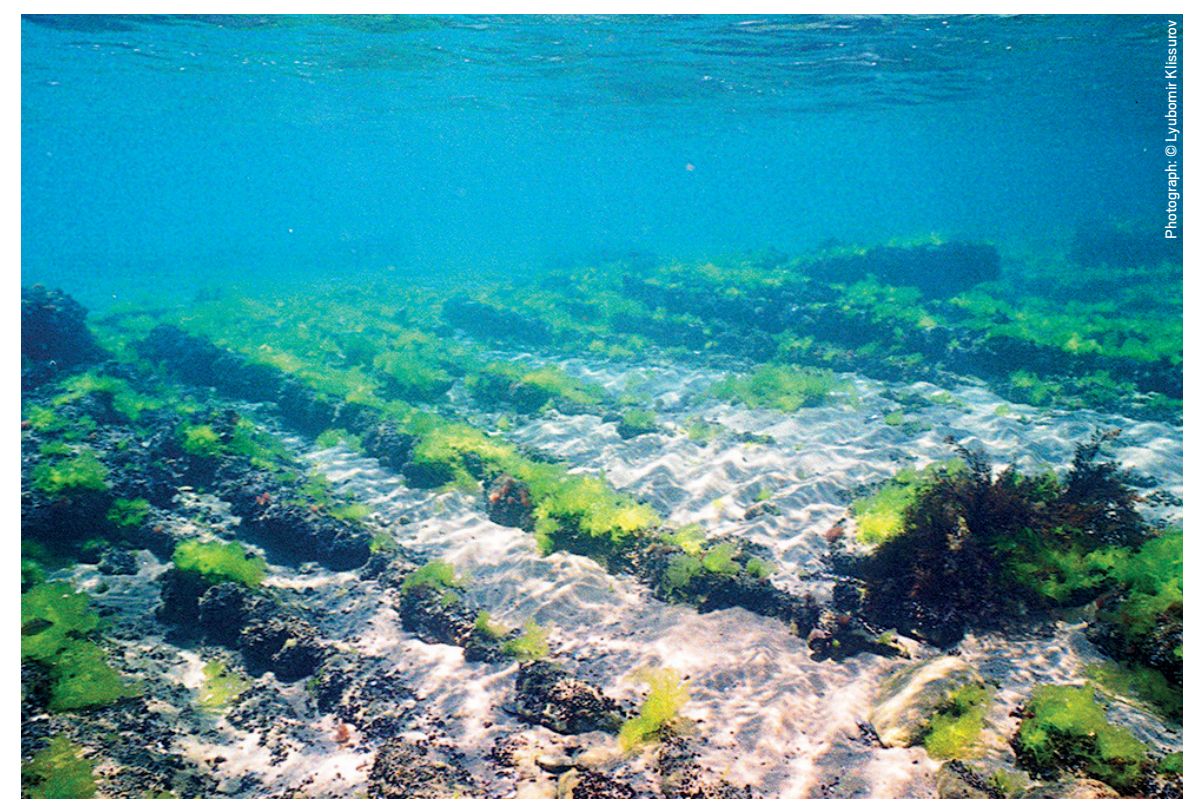

Marine soft-bottom habitats, e.g., the Bulgarian Red Data Book types littoral sands and muddy sands (vulnerable) [61], sublittoral sands (nearly threatened) [62] and underwater "meadows" of sea grasses (endangered) [63] are predominantly found on the submarine coastal slope in front of the above-mentioned firths. Sublittoral mussel beds on sediments (vulnerable) [64] are registered in the deeper soft-bottom areas with sandy silt and silt.

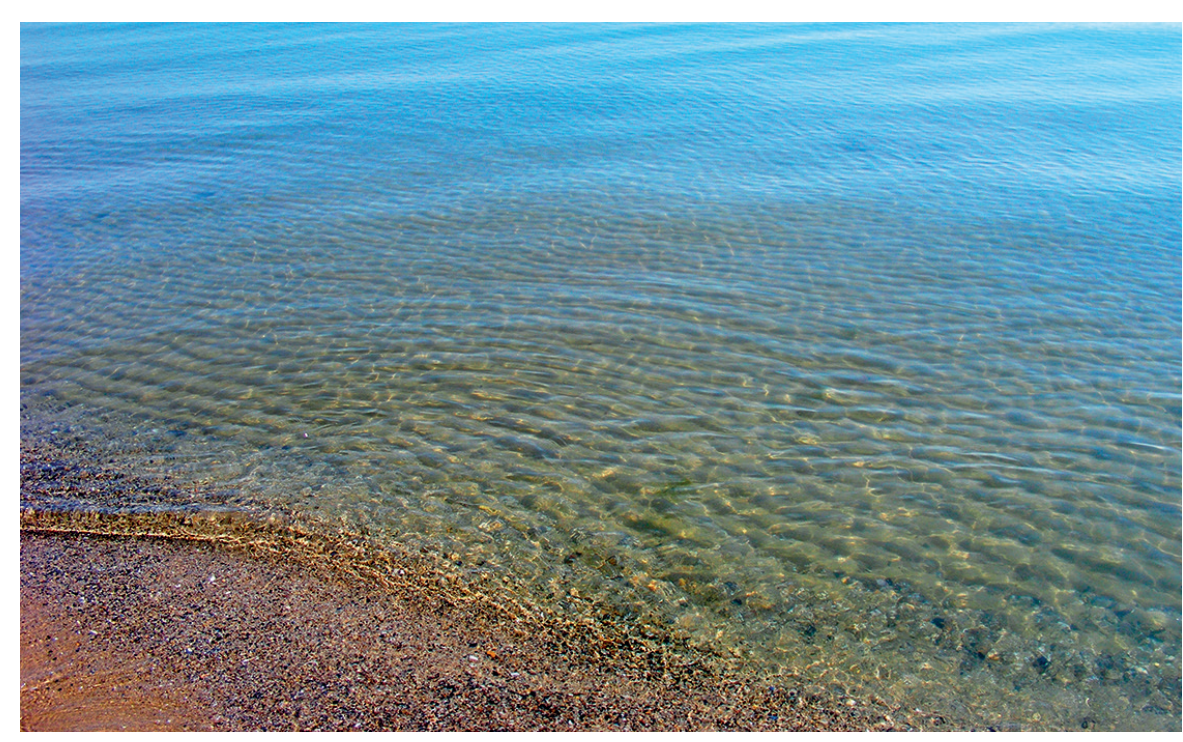

Littoral sands (above) and muddy sands (below) (Lower Kamchia River Valley coastal sector)

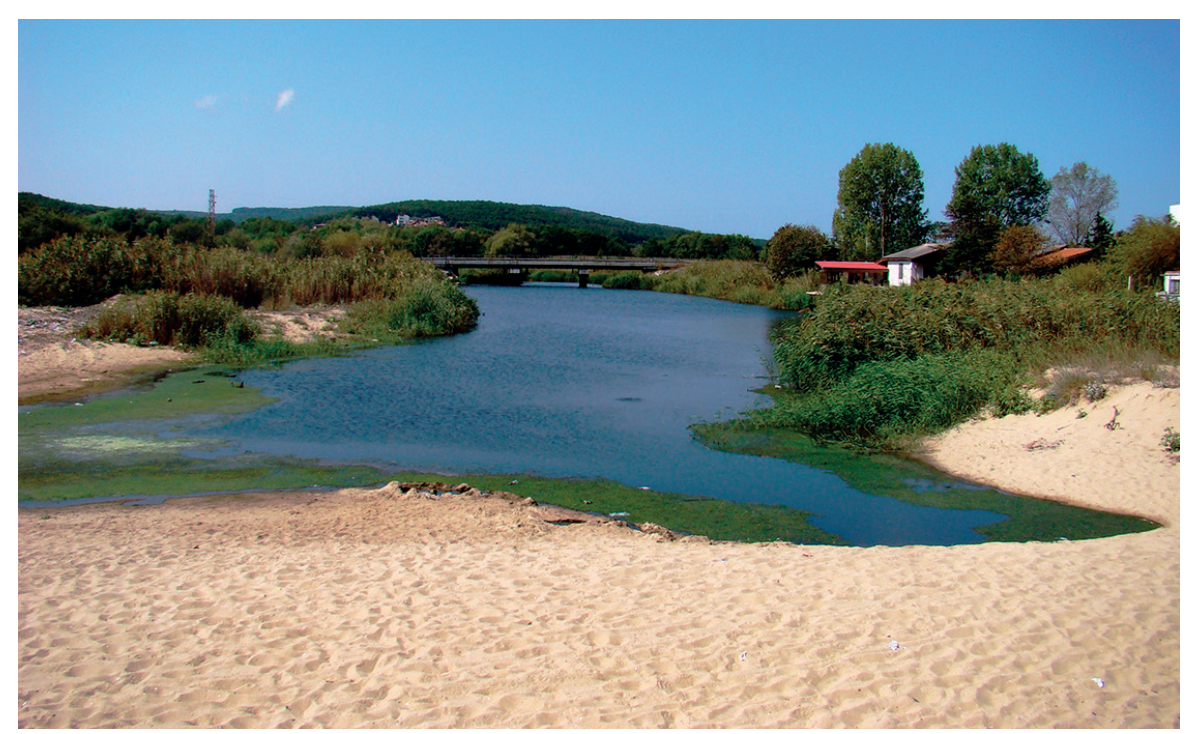




\section{MAIN THREATS, PRESSURES AND ACTIVITIES WITH IMPACT ON HABITATS}

\section{LOW:}

- Human-induced trampling of communities and habitats

- Tourism and associated noise pollution

- Unauthorized camping

- Grazing

- Forestry clearance

- Professional passive fishing and netting

- Marine and freshwater aquaculture

- Fertilization

- Shipping lanes

\section{MODERATE:}

- Sand and gravel extraction

- Professional active fishing

- Disposal of household / recreational facility waste

- Landfill, land reclamation and drying out

- Dykes, embankments, creation of artificial beaches

- Construction of new resorts, sport and leisure structures

- Taking / removal of terrestrial plants

- Pollution of surface waters by storm overflows

\section{- Seismic acquisition}

HIGH:

- Hydrocarbon spills

- Hunting and poaching

- Continuous urbanization

- Changes in the freshwater balance

- Removal of beach materials and dunes

- Pollution of river and marine waters

- Bottom trawling and extraction of clams

- Tree felling

- Fires [38]

\section{PROTECTED TERRITORIES AND NATURA 2000 PROTECTED SITES}

\section{LOWER KAMCHIA RIVER VALLEY COASTAL} SECTOR:

- Kamchia Biosphere Reserve

- Longoza Protected Area

- Kamchia Protected Site (Habitats Directive) ${ }^{1}$

- Kompleks Kamchia (Kamchia Complex) Protected Site (Birds Directive) ${ }^{\top}$

- Plazh Shkorpilovtsi (Shkorpilovtsi Beach) Protected Site (Habitats Directive) ${ }^{\top}$

- Kamchiyska planina (Kamchia Mountain) Protected Site (Birds Directive)

\section{EAST BALKAN MOUNTAINS COASTAL SECTOR:}

- Belite skali (The White Cliffs) Natural Landmark

- Cape Emine Natural Landmark

- Smrikite Protected Area

- Irakli Protected Area

- Cockatrice Protected Area

- Plazh Shkorpilovtsi (Shkorpilovtsi Beach) Protected Site (Habitats Directive)

- Kamchiyska i Eminska planina (Kamchia and Emine Mountains) Protected Site (Habitats Directive)
- Emine-Irakli Protected Site (Habitats Directive)

- Emona (Habitats Directive)

- Kamchiyska planina (Kamchia Mountain) Protected Site (Birds Directive)

- Emine Protected Site (Birds Directive) [65]

Nature conservation areas that fall within two or more contiguous coastal sectors 


\section{SOUTHERN COASTAL REGION}

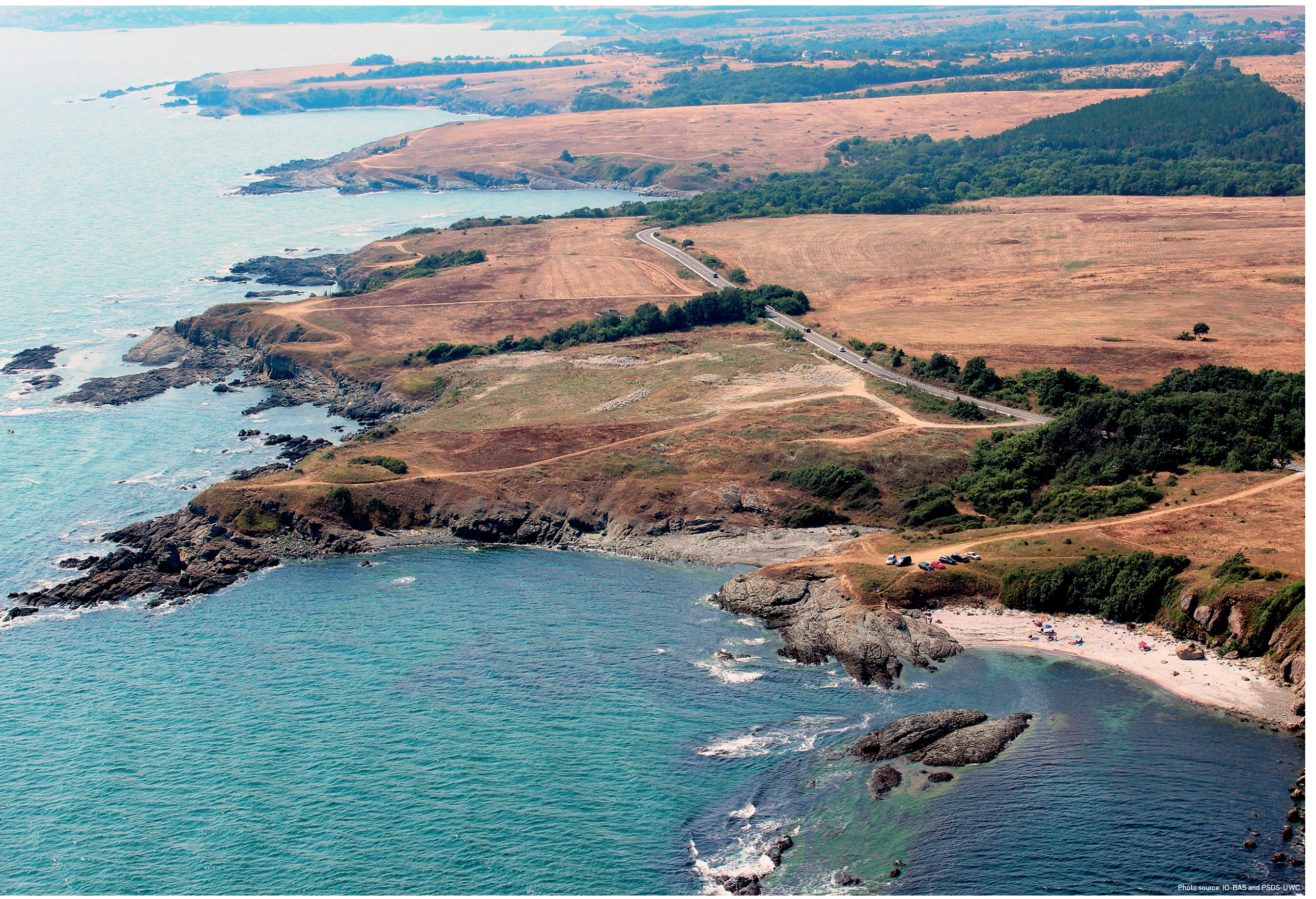


A patchwork of rich historical and cultural heritage, pristine nature and marvelous beaches, but also an array of environmental issues in result of inadequate spatial development. These are the phrases that best describe Bulgaria's southern coastal region. It extends as far north as the East Balkan Mountains and the Bulgarian-Turkish border to the south. Within the coastal zone itself, the southern coastal region takes in the area between the resort of Sveti Vlas to the north and the mouth of the Rezovska to the south. It comprises the following geomorphologic units: the lower part of the Hadzhiyska Depression, the Burgas Lowland, the Medni rid Ridge and the Strandzha Mountain [e.g., 4; 6; 7; 16; 70, etc.]
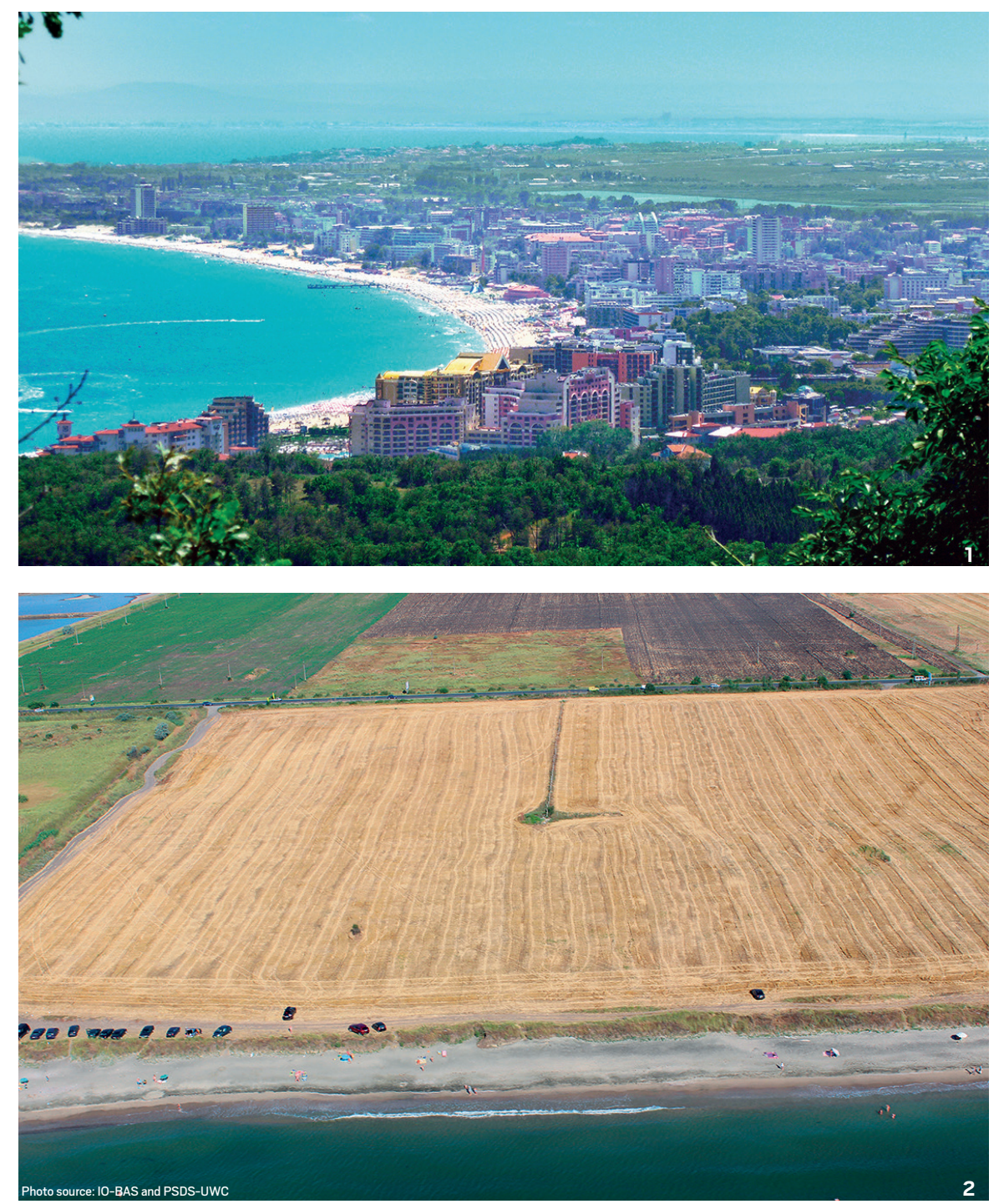

200 DESCRIPTION BY REGIONS OF THE BULGARIAN BLACK SEA COASTAL ZONE
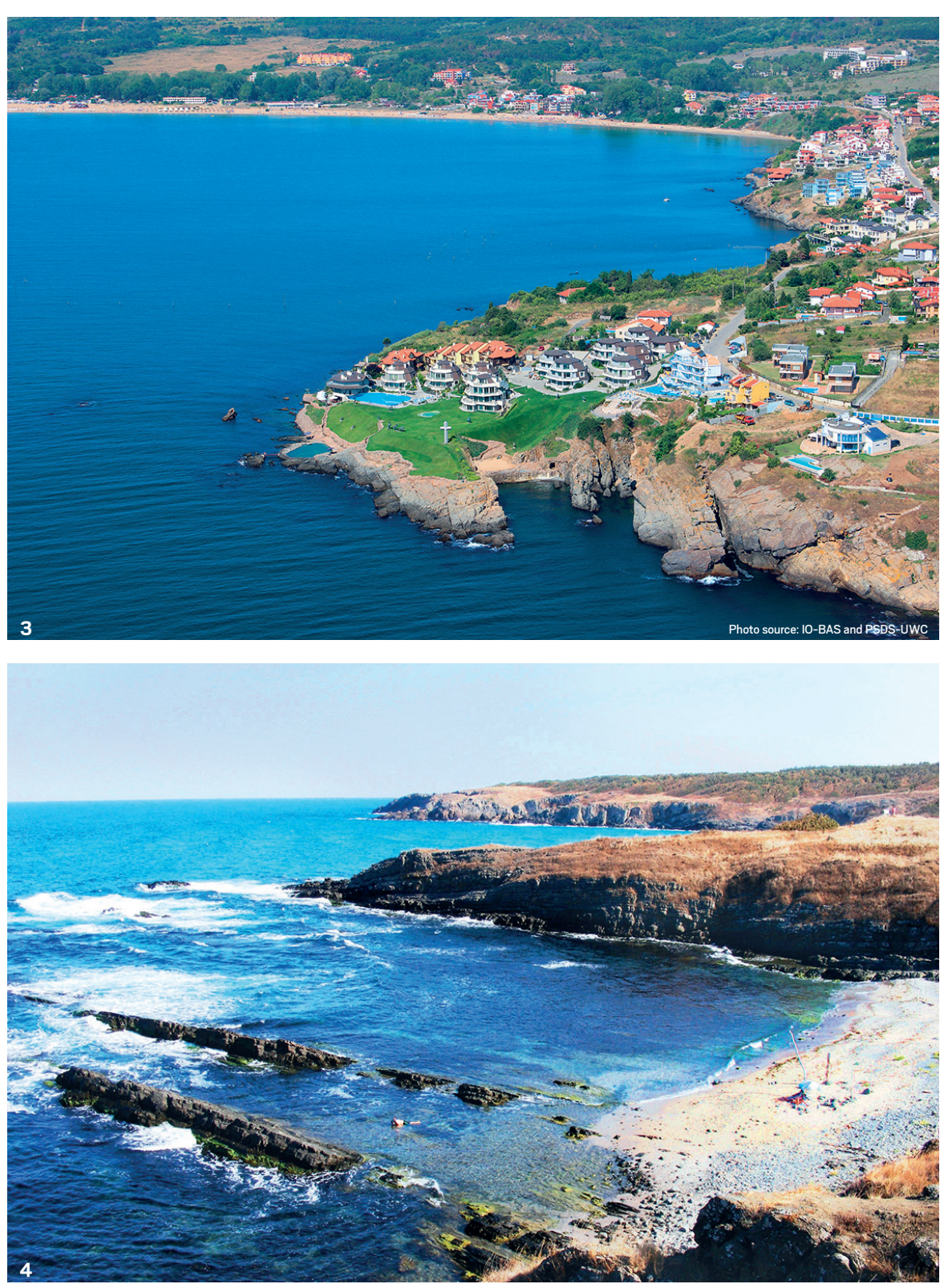

1. The Hadzhiyska Depression and Sunny Beach Resort

2. The Burgas Lowland

3. The Medni rid coast

4. The Strandzha coast 
The region's main morphostructures include the Burgas Synclinorium with the embedded Burgas graben-syncline and the much smaller Hadzhiyska River Depression, formed to the south of the Balkan young-folded Alpine zone (the East Balkan Mountains) [e.g., 6; 16; 70, etc.]. The geologic fundament of the cited depression is filled up with Quaternary deposits and unconsolidated fluvial varieties, e.g., pebbles, sands, silts, clays, etc. The geological structure of the Burgas Synclinorium is composed of predominantly Upper Cretaceous extrusive rocks, e.g., andesites, trachiandesites, trachites, volcanoclastic tuffs, etc., while the Burgas graben-syncline is dominated by Upper Eocene coal-rich formations and younger Pliocene, Pleistocene and Holocene sediments [e.g., 4; 7; 15; 70, etc.]. The Burgas Lowland coast consists of Paleogene and Neogene layers veiled by Quaternary alluvium [e.g., 6; 15; 16, etc.]. Further south, the shores of Medni rid and Strandzha are composed of an Upper Cretaceous volcanogenic-sedimentary geological complex formed by extrusive igneous rocks, e.g., andesites, andesite tuffs, basalts, etc., with interbeds of marine sediments. The coastal geology is occasionally diversified by plutonic rocks, e.g., monzonites, monzodiorites, syenites, monzosyenites, etc. [e.g., 15; 16; 70, etc.].

The coastal geomorphology of the littoral zone comprises a diversity of sand strips, cliffs, capes, islands, lagoons, firths, river mouths, bays and inlets, along with relic denudation surfaces and marine terraces [e.g., 6; 16; 70, etc.]. Larger beach-dune systems include the ones formed at the resort of Sunny Beach (Babata locality), Nesebar, Pomorie spit, Burgas, Kraymorie district of Burgas, the beach of the Gradina and Zlatna Ribka camping sites (between the towns of Chernomorets and Sozopol), Harmanite and Kavatsite localities south of Sozopol, the beaches in the areas of Alepu and Arkutino lagoons, the Ropotamo River mouth, Perla locality north of Primorsko, the International Youth Center south of Primorsko, the spit at the Veleka River mouth (the village of Sinemorets), the sand strip at the Silistar River mouth and many more [e.g., 6; 16; 18; 20; 68, etc.].
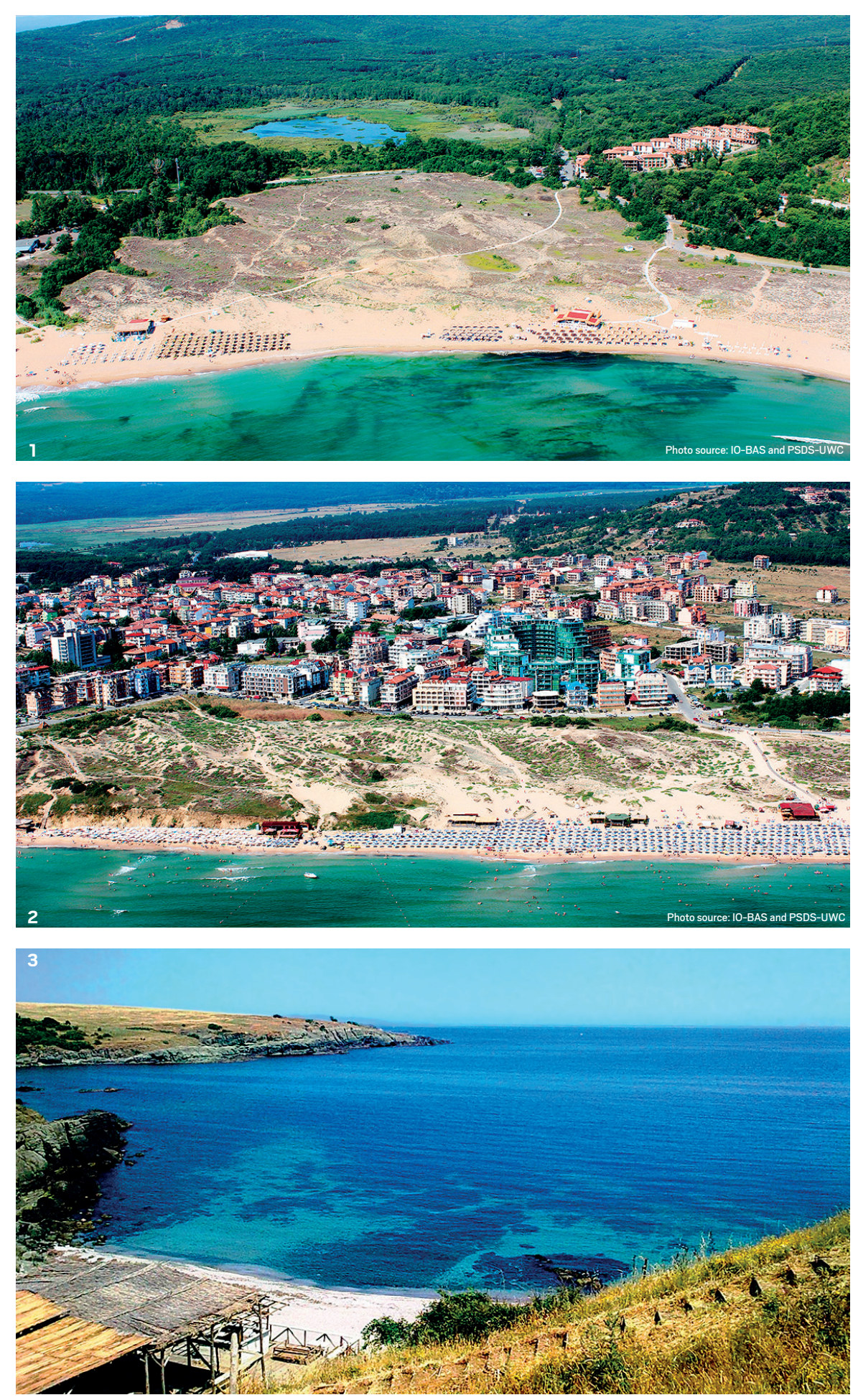

1. Dunes at Arkutino beach (Medni rid Ridge coastal sector)

2. Dunes at Primorsko - North beach (Strandzha Mountain coastal sector) 3. Varvara beach (Strandzha Mountain coastal sector) 

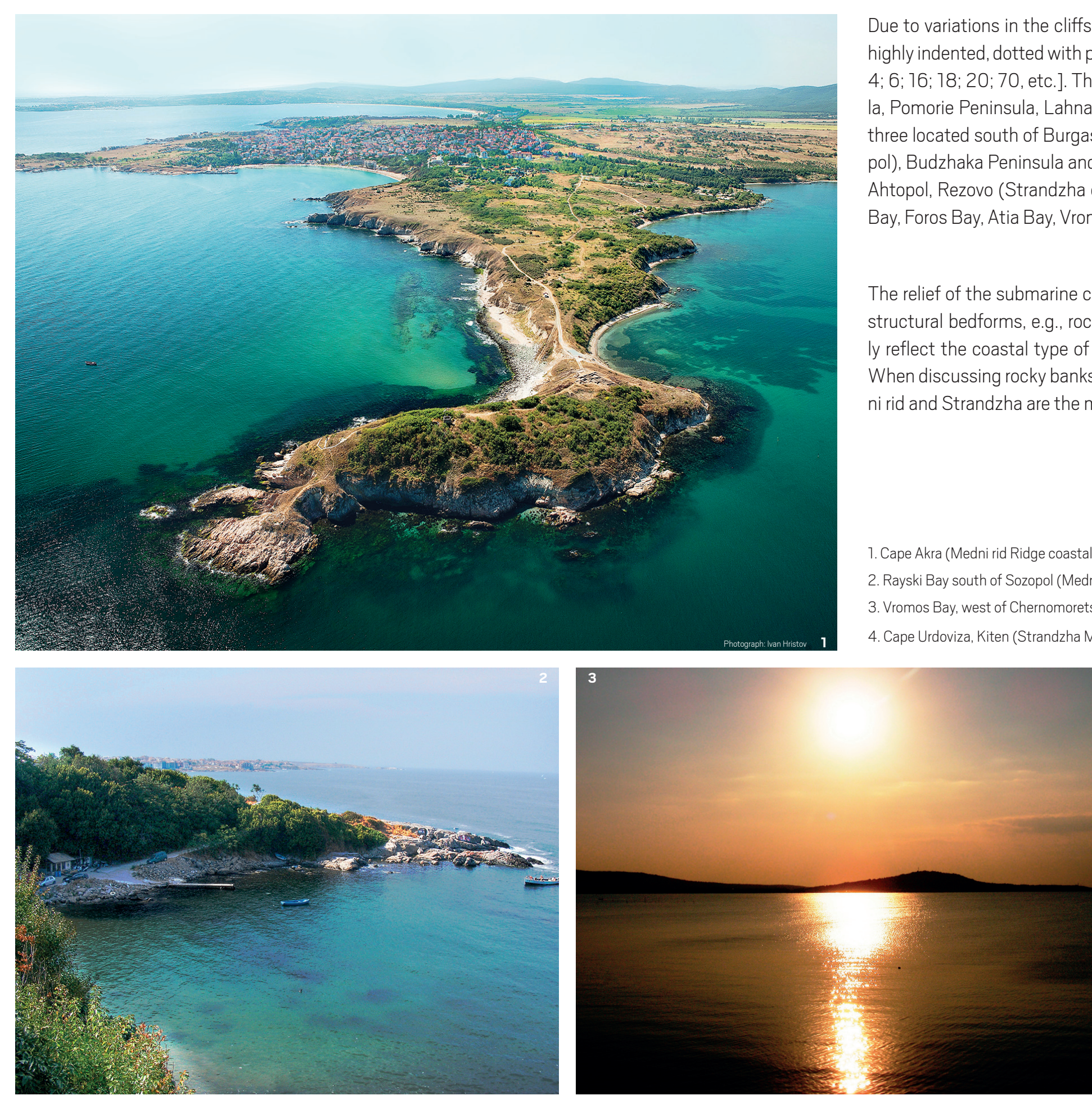

2. Rayski Bay south of Sozopol (Medni rid Ridge coastal sector)

3. Vromos Bay, west of Chernomorets (Medni rid Ridge coastal sector)

4. Cape Urdoviza, Kiten (Strandzha Mountain coastal sector)

Due to variations in the cliffs' resistance to erosion, the coastline south of Burgas is highly indented, dotted with peninsulas, capes, rocky islets, small inlets and bays [e.g., 4; 6; 16; 18; 20; 70, etc.]. The larger capes and peninsulas are the Nesebar Peninsula, Pomorie Peninsula, Lahna (Sarafovo district of Burgas), Foros, Chukalya, Atia (all three located south of Burgas), Akra (near Chernomorets), Chrisotira (north of Sozopol), Budzhaka Peninsula and Agalina (south of Sozopol), Maslen nos, Limnos, Rohy, Ahtopol, Rezovo (Strandzha coastal area), etc. Larger bays are Nesebar Bay, Burgas Bay, Foros Bay, Atia Bay, Vromos Bay, Sozopol Bay, Kavatsite Bay, Stomoplo Bay, etc.

The relief of the submarine coastal slope is a mixture of depositional, abrasional and structural bedforms, e.g., rocky banks, structural steps, sand bars, etc. These largely reflect the coastal type of the adjacent shoreline sections [e.g., 16; 18; 20, etc.]. When discussing rocky banks, the submarine coastal slope near Pomorie, along Medni rid and Strandzha are the most common examples.

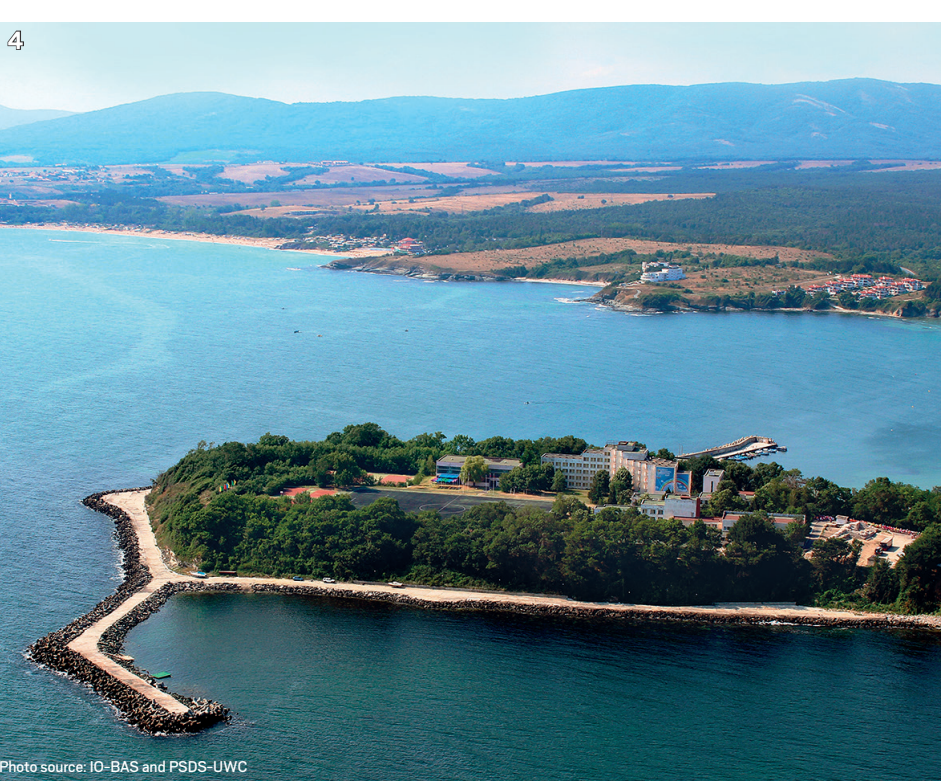


Five islands are located in the southern coastal region, namely Sveta Anastasia (Burgas Bay), Sveti Kirik (Sozopol Bay, now part of the port of Sozopol), Sveti Ivan and Sveti Petar (in front of Sozopol Bay), and Sveti Toma (northeast of Arkutino beach) [e.g., 4; 7; 70, etc.]

The region's climate is humid subtropical [22] with a strong continental-Mediterranean influence [23], especially along the coast of Medni rid and Strandzha. The mean temperatures are positive throughout the year, with precipitation quantities increasing southward, alongside a prevailing late fall-winter maximum [e.g., 4; 6; 7, etc.]. The available quantitative data on climate properties demonstrate that the mean annual temperature varies between $12.7^{\circ} \mathrm{C}$ in the north (Nesebar and Burgas stations, Burgas Lowland coastal sector) and 13.1-13.3 ${ }^{\circ} \mathrm{C}$ in the south (Sozopol Station at Medn rid Ridge coastal sector and Tsarevo Station at Strandzha Mountain coastal sector respectively). The mean annual precipitation varies from $449 \mathrm{~mm} / \mathrm{y}$ in the north (Nesebar Station) to $655 \mathrm{~mm} / \mathrm{y}$ (Tsarevo Station). The Strandzha Mountain coastal sector is the warmest part of the Bulgarian coast, where snowfalls are uncommon and occur once in $4-5$ years $[7 ; 24]$

Lagoons and firths are a common feature of the coastal geomorphology, and important hydrological objects, too. Major firths include the mouths of the Hadzhiyska, the Aheloy, the Ropotamo, the Dyavolska, the Karaagach, the Veleka, the Silistar and the Rezovska, Atanasovsko and Burgas lakes, Poda locality, Mandra Lake (converted into a reservoir), Uzungeren, etc. Lagoons include Pomorie Lake, Alepu, Arkutino, and Stomoplo. The southern coastal region hosts the most important wetlands and bird areas along the Bulgarian coast, the Burgas Wetland Complex being the most prominent of all [29; 34]
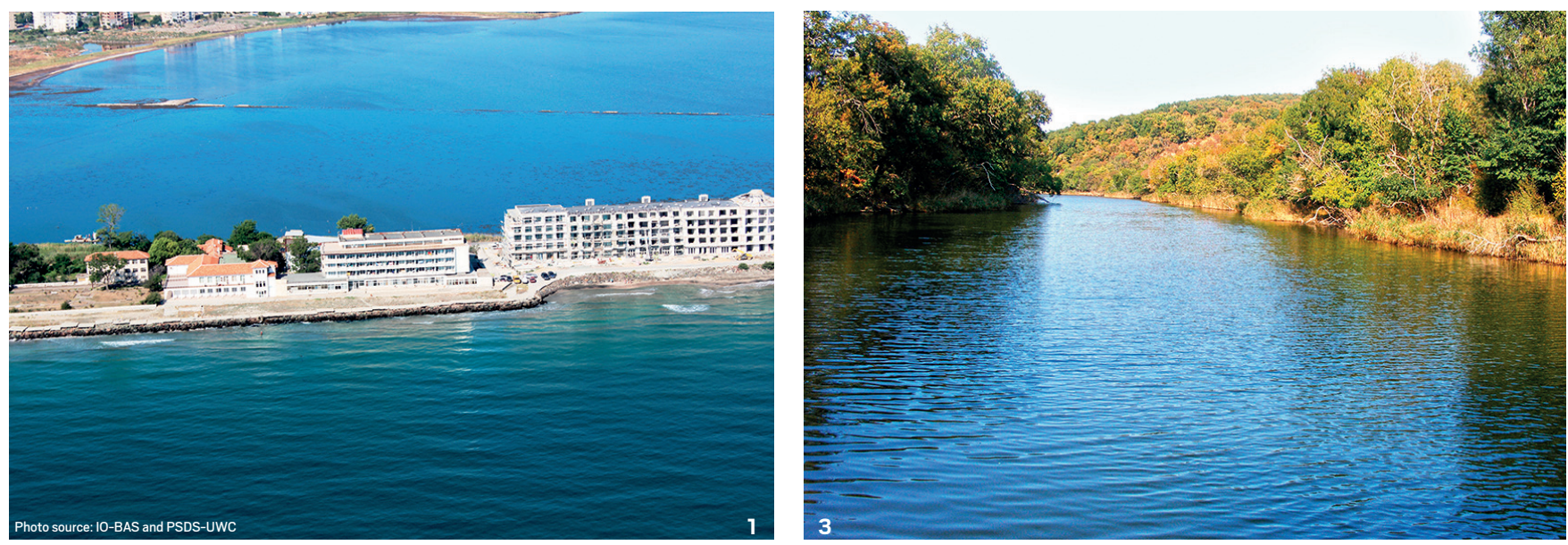

1. Pomorie Lagoon next to the homonymous resort town (Burgas Lowland coastal sector)

2. Mandra Lake near Burgas

3. The Ropotamo River downstream north of Primorsko (Medni rid Ridge coastal sector)

4. The Rezovska River mouth marking the state border with Turkey (Strandzha Mountain coastal sector)
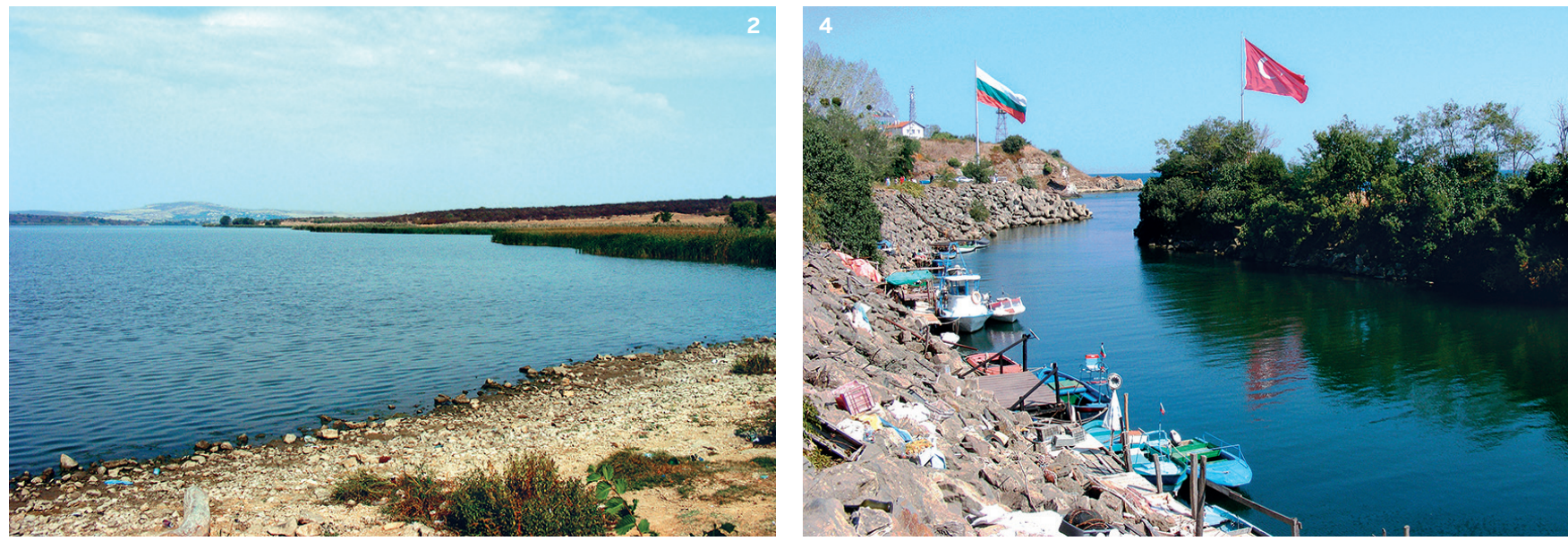
The soil cover is represented by vertisols (the Burgas Lowland). cambisols (in the area of Primorsko and Kiten), luvisols (the forest areas of the Medni rid and the Strandzha), fluvisols (the river downstreams of the Hadzhiyska, Aheloy, Ropotamo, Dyavolska, Karaagach, Veleka, Silistar, Rezovska, etc.), gleysols (the peripheries of the fresh-water and brackish lakes, e.g., Burgas, Mandra, Uzungeren, Alepu, Arkutino, Stomoplo, etc.), solonchaks (the peripheries of the hypersaline Atanasovsko and Pomorie lakes), colluviosols (the cliff bases), arenosols (the sand strips and dunes), etc. Alisols (zhaltozemi in Bulgarian, literally yellow soils) are among the most characteristic features of the Strandzha Mountain [26; 27]

The present-day vegetation has been largely replaced by agrophytocoenoses in the Burgas Lowland, along the river valleys, around the Burgas Lakes, and around coastal towns and villages. However, the Medni rid and the Strandzha Mountain in particular host well-preserved oak forests with many Mediterranean elements, as well as Southeuxinian forest communities (one of the main reasons for the mountain's designation as a nature park and a NATURA 2000 protected site) [e.g., 29; 38; 65, etc.] Representative flood-plain longoz forests are formed along the river downstreams of the Ropotamo, the Dyavolska, the Karaagach, the Veleka, the Silistar, the Rezovska, etc. Aquatic freshwater or halophytic communities occupy the above-mentioned coastal lakes and firths. Valuable chasmophytic communities are common for the coastal cliffs. Psammophytic vegetation is spread on the sand strips and dunes [3; $4 ; 13 ; 29 ; 30$, etc.].

A longoz forest at Arkutino Lagoon (Medni rid Ridge coastal sector)

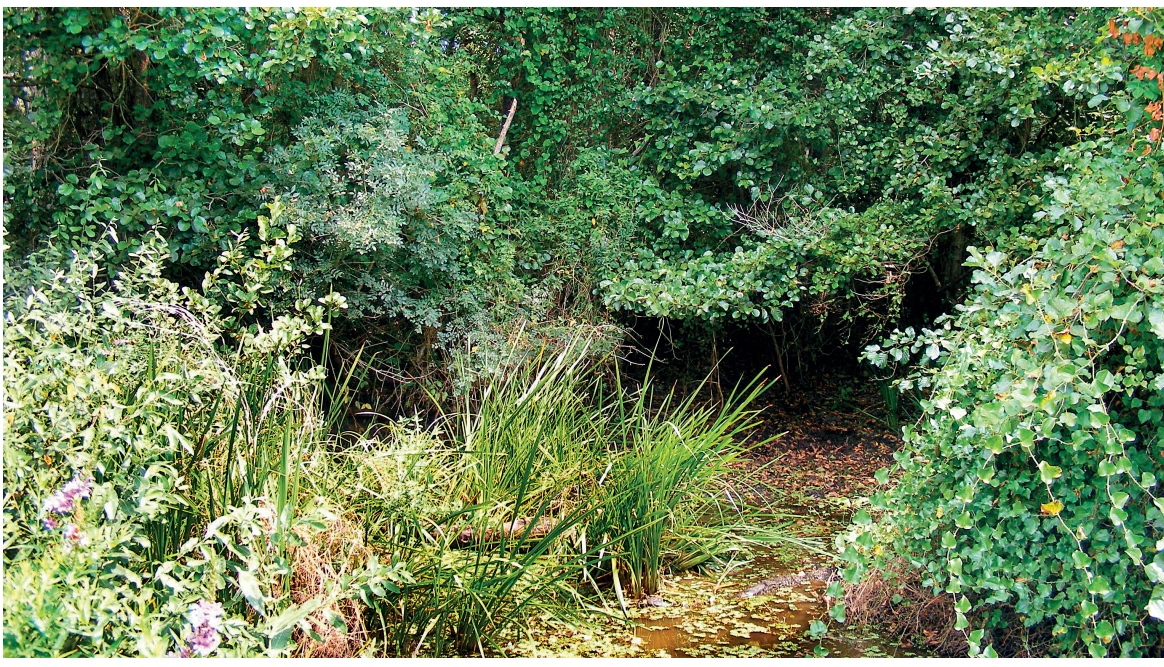

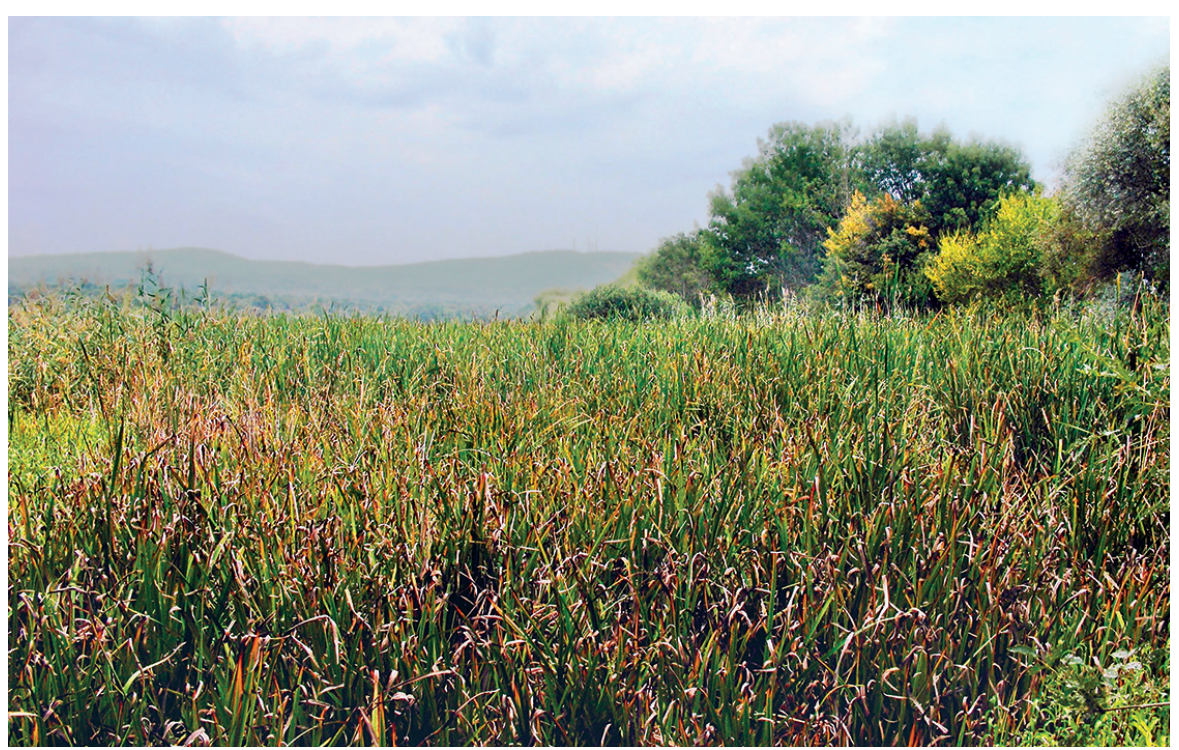

Reed beds in the periphery of Stomoplo Lagoon (north of Primorsko), a protected area

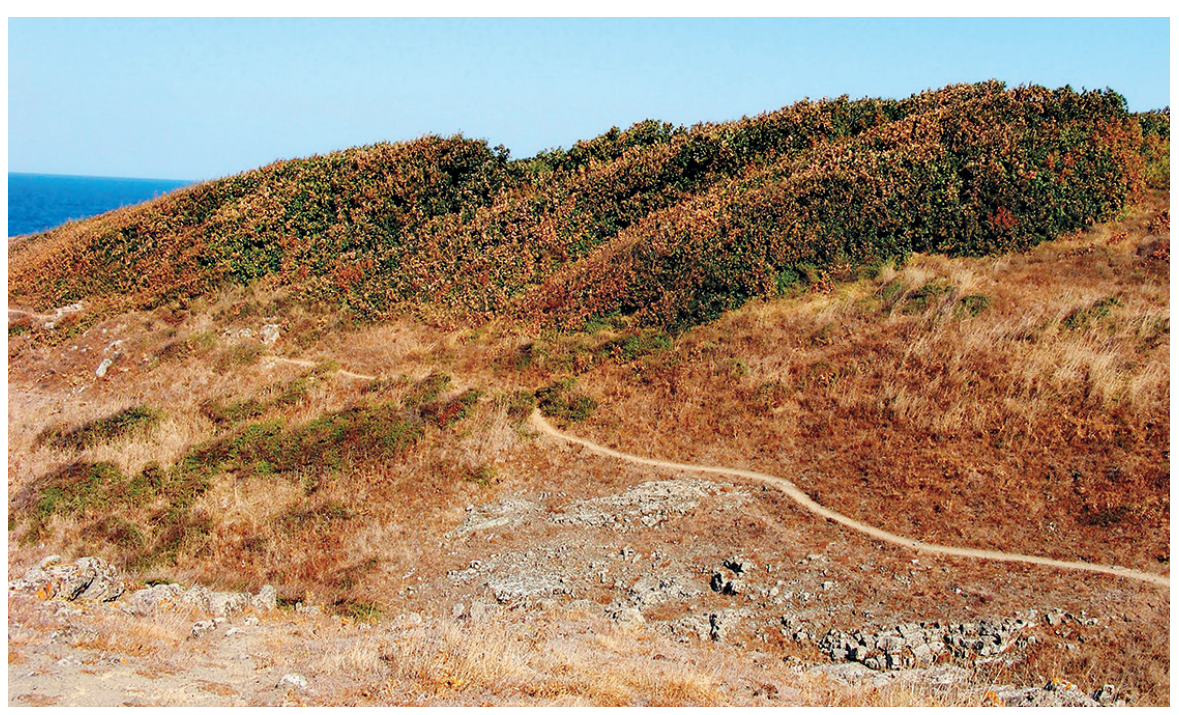

A pseudomaquis community on the Strandzha coast, a protected habitat type

Three features of the benthic flora are worth mentioning. First, the vast occurrence of the epilithic Cystoseira spp. beds [59] thanks to the wide distribution of appropriate hard substrata, e.g., rocky banks and geogenic reefs, structural steps, abrasional platforms, accumulations of blocks and boulders, etc. [e.g., 16; 18; 20, etc.]. Second, the rare communities of the sciophilic red algae Phyllophora crispa [58] normally found at the Kiten Reef (Strandzha Mountain coastal sector) at depths greater than $20 \mathrm{~m}$. Finally, the river mouths and their adjacent sublittoral areas provide an excellent environment for the existence of seagrass beds [e.g., 36; 63; 71, etc.]. 
The coastal landscapes have undergone millennia of human-induced changes, as the South Bulgarian shore belongs to the earliest inhabited areas in Europe [e.g., 3; 13 18, etc.]. Medni rid's landscapes have experienced significant transformations since ancient times [e.g., 4; 13; 18, etc.]. The first alterations of the ridge's geologic and geomorphic fundament are associated with copper mining by the ancient Thracians. The same is valid for the usage of the oak forests for timber and charcoal production [13; 18]. Significant transformations of the coastal landscape pattern took place over the Socialist Period, especially in the Burgas Lowland and around the region's administrative center of Burgas [9]. The pollution hazard is primarily related to the Lukoil refinery near Burgas, its serving port and oil terminal next to Cape Chukalya, as well as the numerous coastal resorts. A mass expansion of the resorts dictated by private interests occurred in the late $20^{\text {th }}$ and the first decade of the $21^{\text {st }}$ century. The natural dune landscapes between Sunny Beach and Nesebar (Lower Hadzhiyska River Valley coastal sector) were almost completely wiped out [68]. The dunes that remain in place are squeezed in between the highly urbanized areas. The same is also valid for the area of Sveti Vlas and the natural oak-dominated forests there, as well as for the sub-Mediterranean petrophytic steppes west of Sunny Beach, Nesebar, Pomorie and Sozopol. The shoreline between Elenite Resort and Burgas is one of the areas with the strongest technogenic load [e.g., 31; 32; 33, etc.], which has some serious implications on the coastal and marine environment [36]. An unprecedented urbanization process has taken place in the coastal areas near Chernomorets and Sozopol, exerting strong anthropogenic pressure. Although the coastal landscapes of the Strandzha Mountain are the best preserved ones among all 11 coastal sectors, severe tourism-related impacts are also quite common. The resort expansion in the coastal areas near Primorsko, Kiten, Tsarevo and Lozenets has lead to the effacement and subsequent building up of numerous camping sites along the Strandzha coast, particularly in the Tsarevo Municipality. Recent plans to expand the recreational area near Ahtopol are nothing short of alarming. In result, today the region faces many unsolved issues that call for optimization of urban development, spatial planning, marine and land use, as well as the adoption of an effective integrated coastal management strategy that extends beyond the mere ecosystem-based management [e.g., 9; 4; $11 ; 12 ; 13$, etc.].

1. The shore in Kraymorie district of Burgas

2. The coast of Kiten

(Strandzha Mountain coastal sector)

3. Dunes in the urban environment:

one of the anthropogenic "phenomena" of Sunny Beach - Nesebar recreational zone (Lower Hadzhiyska River Valley coastal sector)

4. Coastal armoring in Nesebar (Lower Hadzhiyska River Valley coastal sector)
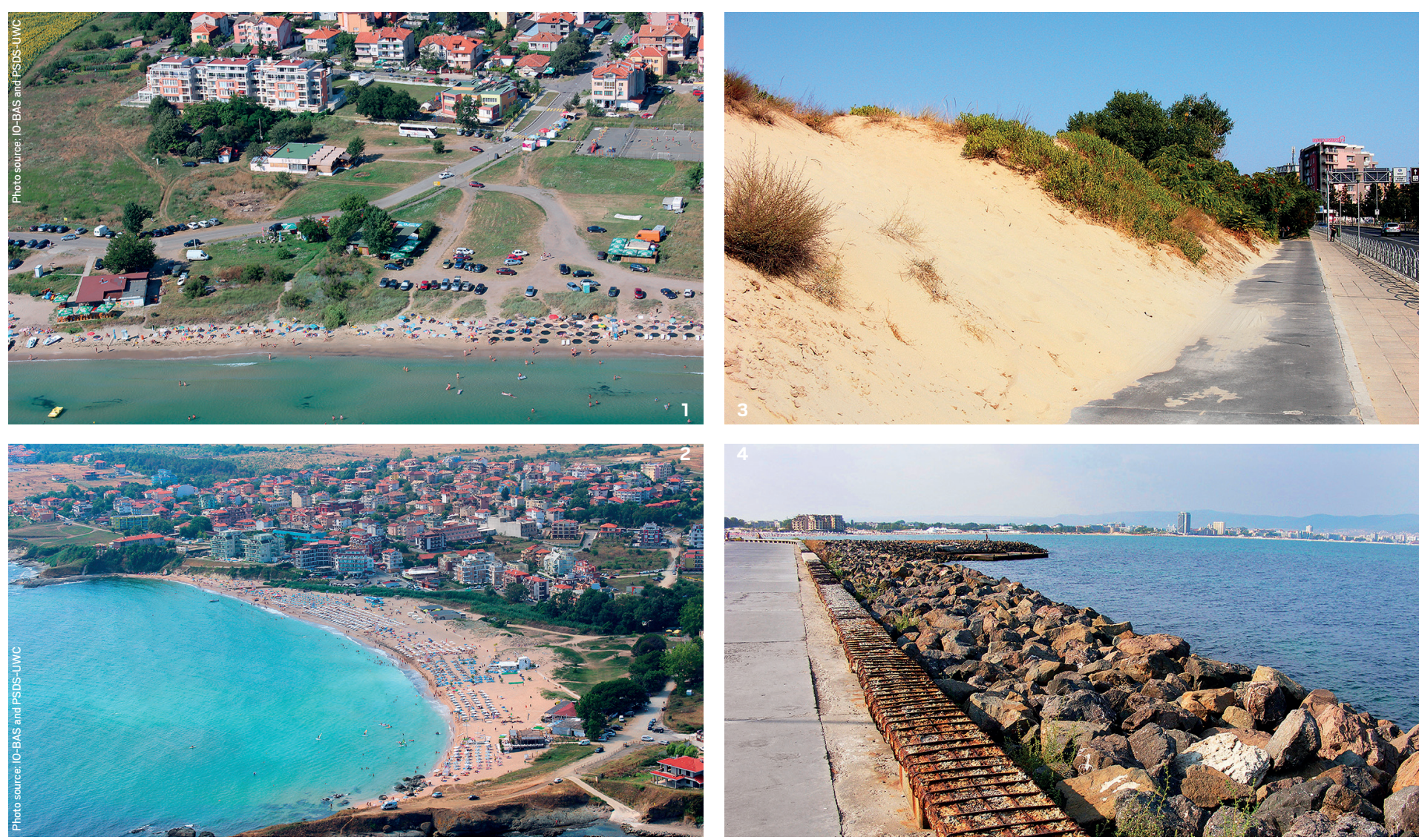

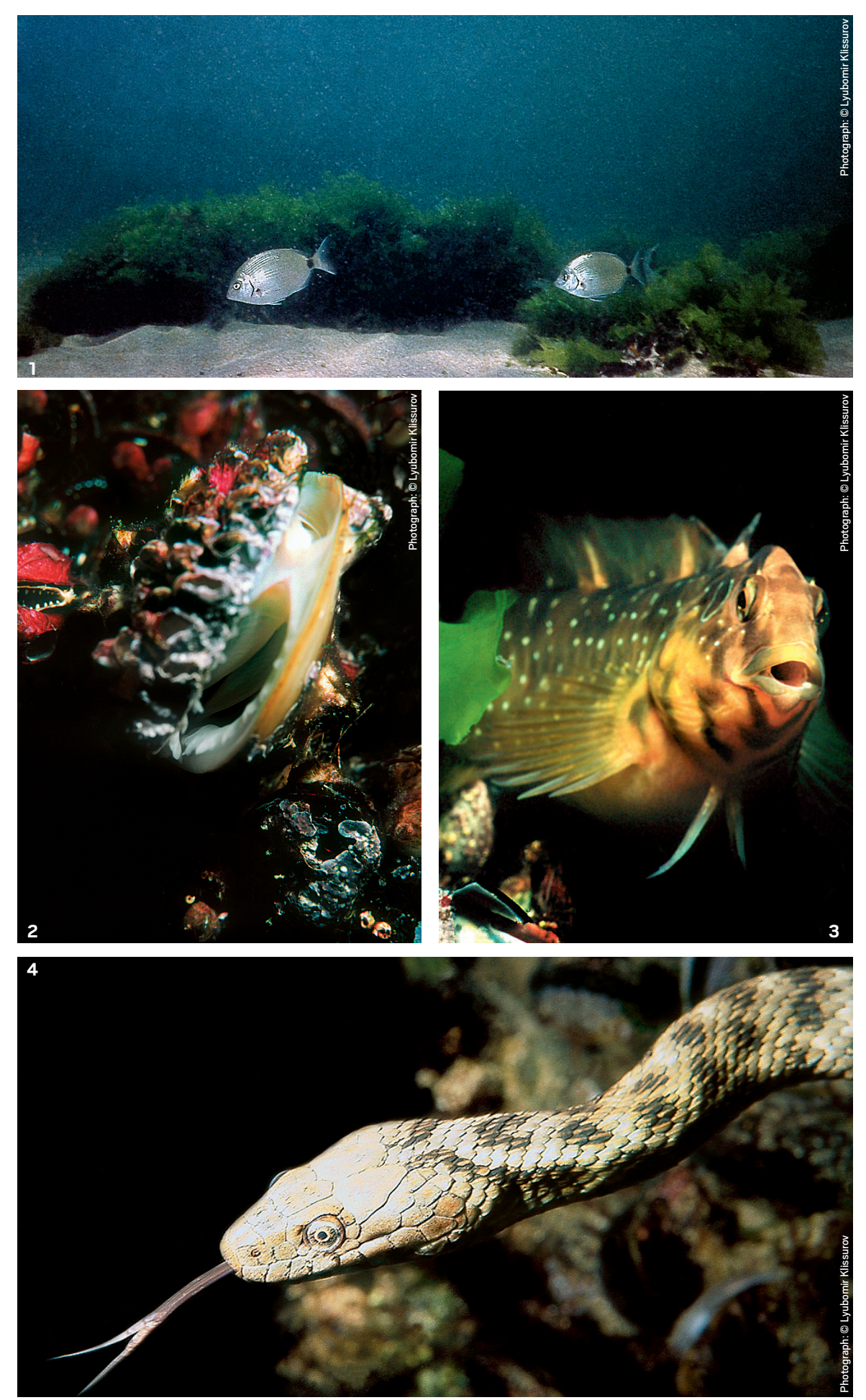

\section{MARINE FAUNA}

The coarse sand in the mediolittoral zone is inhabited by dense populations of the small wedgeclam Donacilla cornea, a species threatened by the impact of tourism on beaches, water pollution and the construction of coast-protection structures that disrupt the natural water circulation [37]. Occasional reports indicate that the Strandzha Mountain coast might still be sporadically visited by monk seals (Monachus monachus), a worldwide threatened species. Of preservation importance are the sand banks with seagrass beds inhabited by invertebrates and fish, e.g., seahorse (Hippocampus guttulatus), sand sole (Pegusa lascaris), Montagu's blenny (Coryphoblennius galerita), knout goby (Mesogobius batrachocephalus), southern ninespine stickleback (Pungitius platigaster), sargassum pipefish (Syngnathus typhle), sand smelt (Atherina pontica), three-spined stickleback (Gasterosteus aculeatus), the reptiles dice snake (Natrix tesselata) and grass snake (Natrix natrix). European anchovy (Engraulis encrasicolus), Mediterranean horse mackerel (Trachurus mediterraneus), European sprat (Sprattus sprattus), Atlantic bonito (Sarda sarda) and bluefish (Pomatomus saltatrix) are the major pelagics of fishing value. As for mammals, the harbor porpoise (Phocoena phocoena), the common dolphin, (Delphinus delphis) and the bottlenose dolphin (Tursiops truncatus) are very important species for preservation. Cape Maslen nos and the Strandzha Mountain coast south of Sinemorets are among the best places to observe cetaceans [29; 38]. Important inhabitants in the communities formed by the epilithic brown algae from genus Cystoseira are hydrozoans, bryozoans, the snail pheasant shell (Tricolia pulus), the decapods Xantho poressa, marbled rock crab (Pachygrapsus marmoratus), hairy (bristly) crab (Pilumnus hirtellus), the sea horse Hippocampus guttulatus, a variety of wrasses (Symphodus ocellatus), gobbies (Neogobius melanostomus, $N$. gymnotrachelus), blennies (Aidablennius sphynx, Coryphoblennius galerita, Salaria pavo), etc. [37]. When discussing protected fish species (as enlisted in Annex II of the Habitats Directive) [69], two species of shad (Alosa immaculata and A. caspia) are present [71]. Other important habitats are the sediments inhabited by thallasinid crustaceans, clean sands with Calianassa burrowing shrimps (Necallianassa truncata), and sandy silts with Mediterranean (flat-browed) mud shrimps (Upogebia pusilla), the latter being a rare species [37; 72].

1. White seabream (Diplodus sargus): a rare species in the Bulgarian Black Sea

2. European flat (edible) oyster (Ostrea edulis): a species considered to be extinct in the Bulgarian Black Sea 3. Peacock blenny (Salaria pavo) 4. Dice snake (Natrix tesselata) 


\section{BULGARIAN RED DATA BOOK COASTAL AND MARINE HABITATS}

The southern coastal region stands out for its rich bio- and habitat diversity. The beach and dune habitats with psammophytic vegetation and the cliff habitats with chasmophytic vegetation and xerophytic shrubs have a wide overall distribution, and this is particularly valid for the beaches of the Strandzha coast, the cliff areas of the Medni rid, Cape Maslen nos, the Sinemorets-Rezovo cliff sector, etc. Important wetland habitats are formed in the river mouths of the Marinka, the Ropotamo, the Dyavolska, the Karaagach, the Veleka, the Rezovska, and Pomorie, Atanasovsko, Mandra, Burgas, Alepu, and Stomoplo lakes, etc. These are also important bird areas as they are located on the Via Pontica migratory route [29; 38].

The beaches and dunes with psammophytes correspond to the habitat types vegetation on the Black Sea gravel beaches [42], vegetation on the Black Sea sand beaches [43], Black Sea embryonic dunes [44], Black Sea mobile (white) dunes [45], and Black Sea fixed (grey) dunes [46], all of them categorized as endangered. Black Sea wooded dunes (critically endangered) [47] are found in the Ropotamo Reserve (Medni rid Ridge coastal sector). Over-wet and flooded dune slacks (critically endangered) are present in the Babata locality between Sunny Beach and Nesebar, south of the above town (Lower Hadzhiyska River Valley coastal sector), at Gradina - Zlatna Ribka beach, Kavatsite locality and Arkutino beach (Medni rid Ridge coastal sector), at some of the dune sites of the Strandzha Mountain coastal sector, etc. [48].

The areas with petrophytic steppe communities around Sunny Beach, Pomorie and Sozopol correspond to the habitat type sub-Mediterranean petrophytic steppes, categorized as vulnerable [73].

The cliff areas with chasmophytic vegetation and xerophytic shrubs, e.g., along the coastline of the East Balkan Mountains near Sveti Vlas, around the capes, peninsulas and islands, etc. match up with the habitat type sea-cliff vegetation, categorized as endangered [40] and Balkan pseudomaquis (nearly threatened) respectively [41].

The Hadzhiyska, the Ropotamo, the Veleka, the Butamyata, the Silistar, the Rezovska, etc. river downstreams correspond to the habitat type riparian and lowland mixed woodlands and longozes (critically endangered) [55].
The firths formed in the river mouths, as well as Alepu, Arkutino and Stomoplo brackish lagoons correspond to the habitat type natural or semi-natural mesotrophic to eutrophic lakes and marshes with macrophytic vegetation (endangered) [54] and estuaries (critically endangered, however, the cited lagoons do not match up with this habitat type) [56].

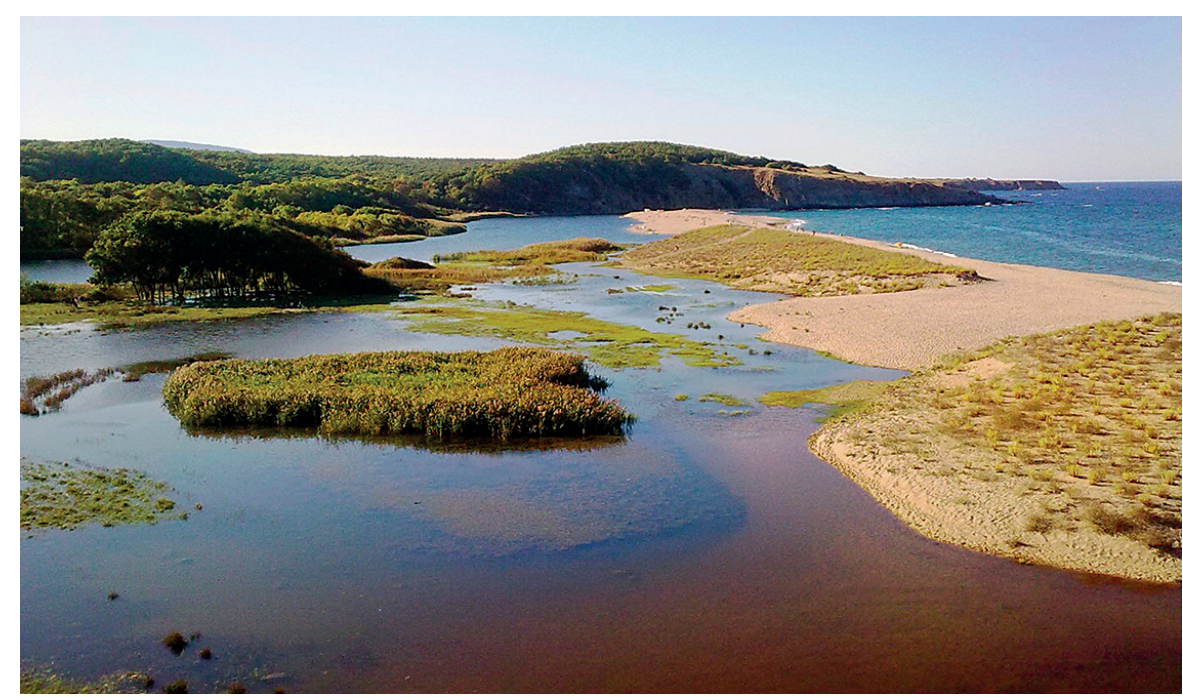

Veleka River Mouth near Sinemorets, Strandzha Nature Park

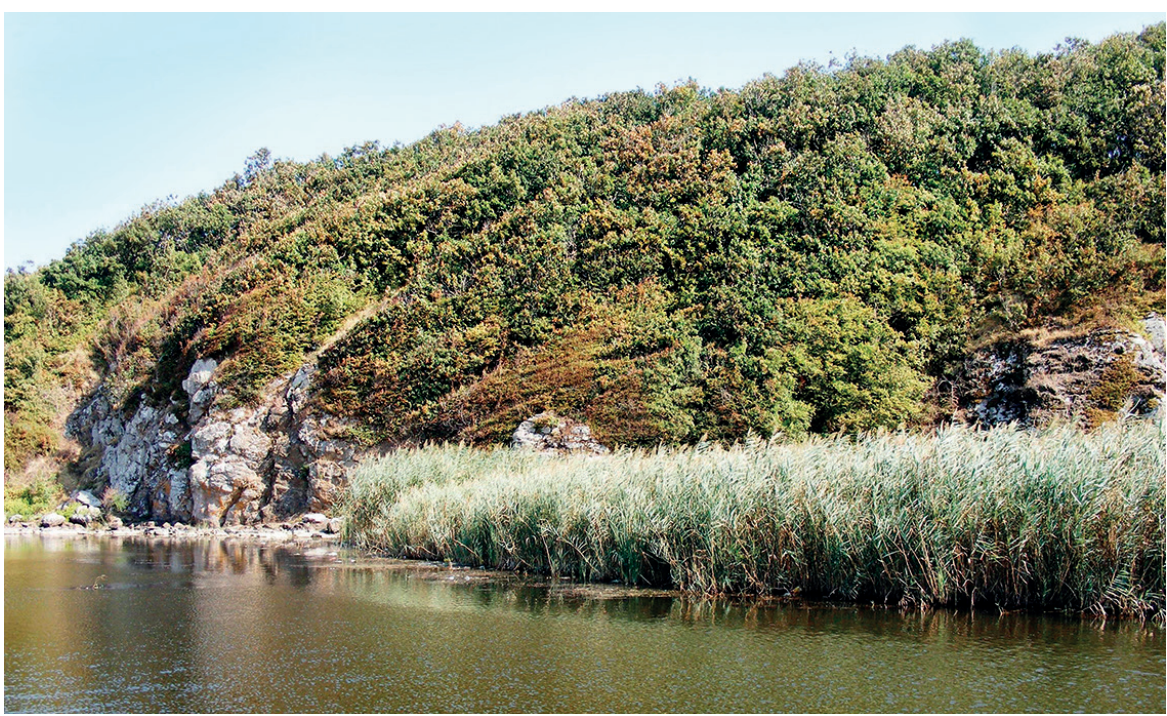

Butamyata River mouth south of Sinemorets, Strandzha Nature Park 
Pomorie and Atanasovsko lakes (Burgas Lowland coastal sector) correspond to the habitat types submerged macrophytic communities in hypersaline water bodies (critically endangered) [50], hypersaline coastal lakes and swamps (endangered) [51], communities of annual halophytes in coastal salt marshes at the Black Sea (endangered) [52], and Mediterranean halophytic communities of tall rushes, sedges and grasses (critically endangered) [53]

The spatial distribution of important hard-bottom habitats, e.g., the Bulgarian Red Data Book types Mediterranean mussels and/or barnacle communities on mediolittoral rocks (vulnerable) [57], infralittoral rocks and other hard substrata (vulnerable) [58], and Cystoseira spp. on exposed to waves infralittoral bedrock and boulders (endangered) [59], and sea caves (endangered) [60] is closely related to the cliff areas [36; 38]. In addition, the seabed sector of the southern coastal region hosts Bulgaria's largest geogenic reef, namely the Kiten Reef that lies roughly from Cape Maslen nos to the town of Tsarevo [36; 71]. Several NATURA 2000 protected sites have been designated in compliance with the Habitats Directive [69]. Among these, of particular marine nature conservation interest are the Ropotamo and the Strandzha NATURA 2000 sites as they boast the largest protected marine sectors $[38 ; 65 ; 71]$.

The curious geological phenomenon nicknamed Krokodila (The Crocodile), located south of Cape Maslen nos, is a rocky reef subject to protection (Strandzha Mountain coastal sector)

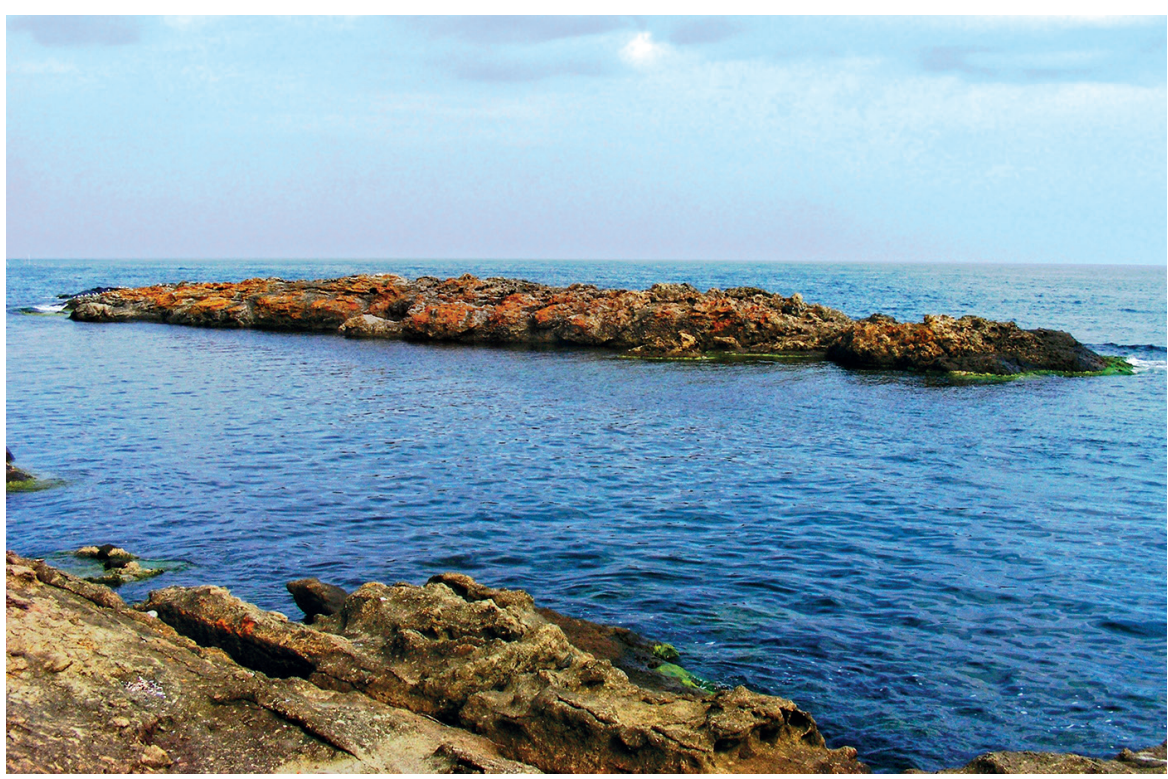

Marine soft-bottom habitats, e.g., the Bulgarian Red Data Book types littoral sands and muddy sands (vulnerable) [61], sublittoral sands (nearly threatened) [62] and underwater "meadows" of sea grasses (endangered) [63] are found on the submarine coastal slope in front of the above-mentioned river mouths, lagoons and firths, and the wave-protected inlets and bays. Sublittoral mussel beds on sediments (vulnerable) are ubiquitously registered at deeper soft-bottom areas with sandy silt and silt [64]

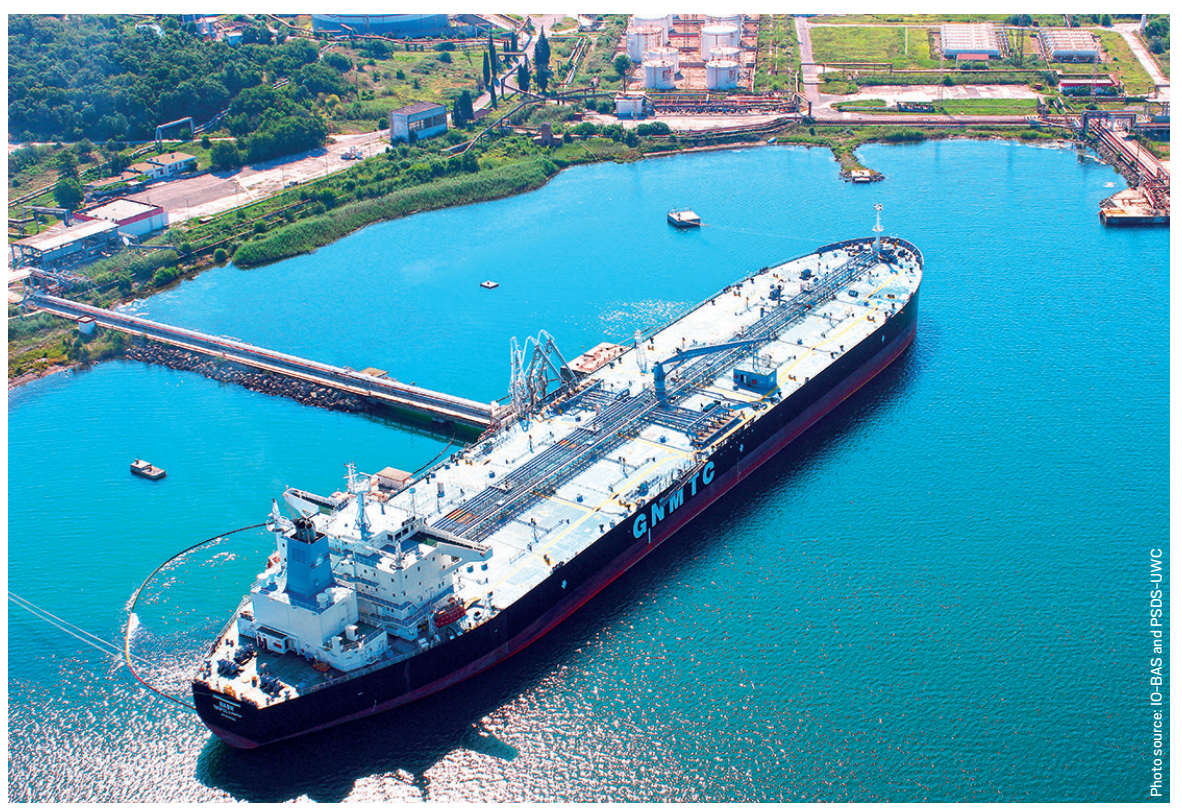

Rosenets oil terminal (Medni rid Ridge coastal sector)

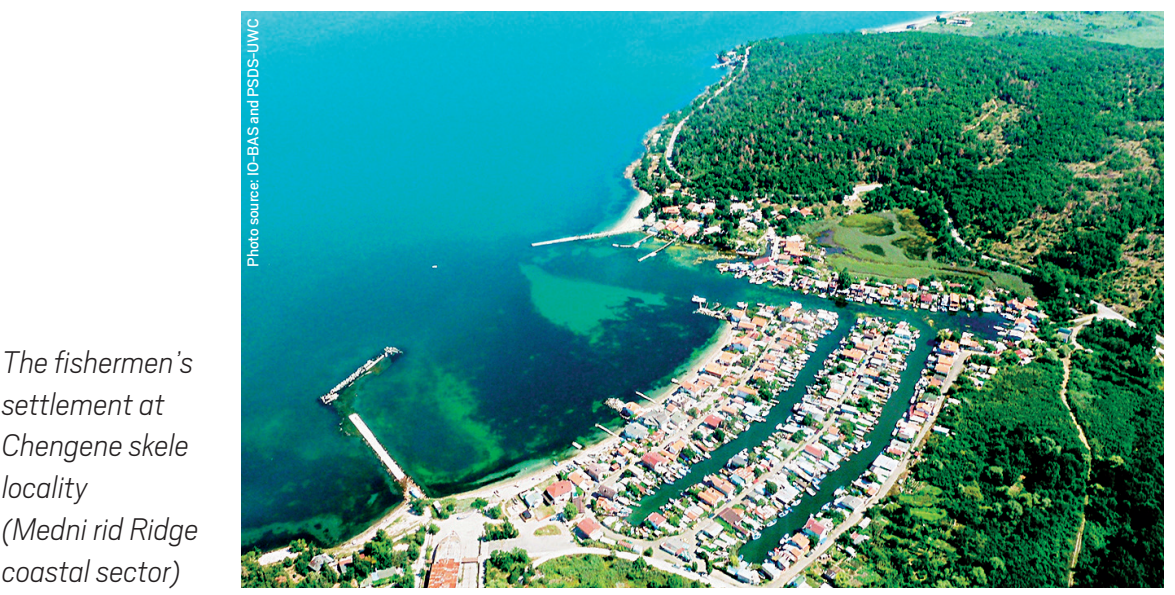




\section{MAIN THREATS, PRESSURES AND ACTIVITIES WITH IMPACT ON HABITATS}

LOW:

- Human-induced trampling of communities and habitats

- Tourism and associated noise pollution

- Unauthorized camping

- Grazing

- Forestry clearance

- Professional passive fishing and netting

- Marine and freshwater aquaculture

- Fertilization

- Forest planting on open ground

- Irrigation

- Shipping lanes

- Disposal of inert materials
- Use of biocides and chemicals

- Reclamation of land from sea, estuary or marsh

\section{MODERATE:}

- Sand and gravel extraction, removal of dunes and sand

- Artificial planting on open ground of non-native trees

- Marine and river pollution

- Disposal of household / recreational facility waste

- Disposal of industrial waste

- Modifying structures of inland water courses

- Eutrophication

- Professional active fishing
- Seismic acquisition

- Mining

- Fires

\section{HIGH:}

- Bottom trawling and extraction of clams

- Habitat fragmentation

- Hydrocarbon spills

- Military exercises

- Hunting and poaching

- Urbanization and resort construction

- Exploitation of freshwater resources and associated alterations of the water balance

- Technogenic load of the coastal zone [38]
The highest dune on the Balkan Peninsula in Ropotamo Reserve, Medni rid Ridge coastal sector

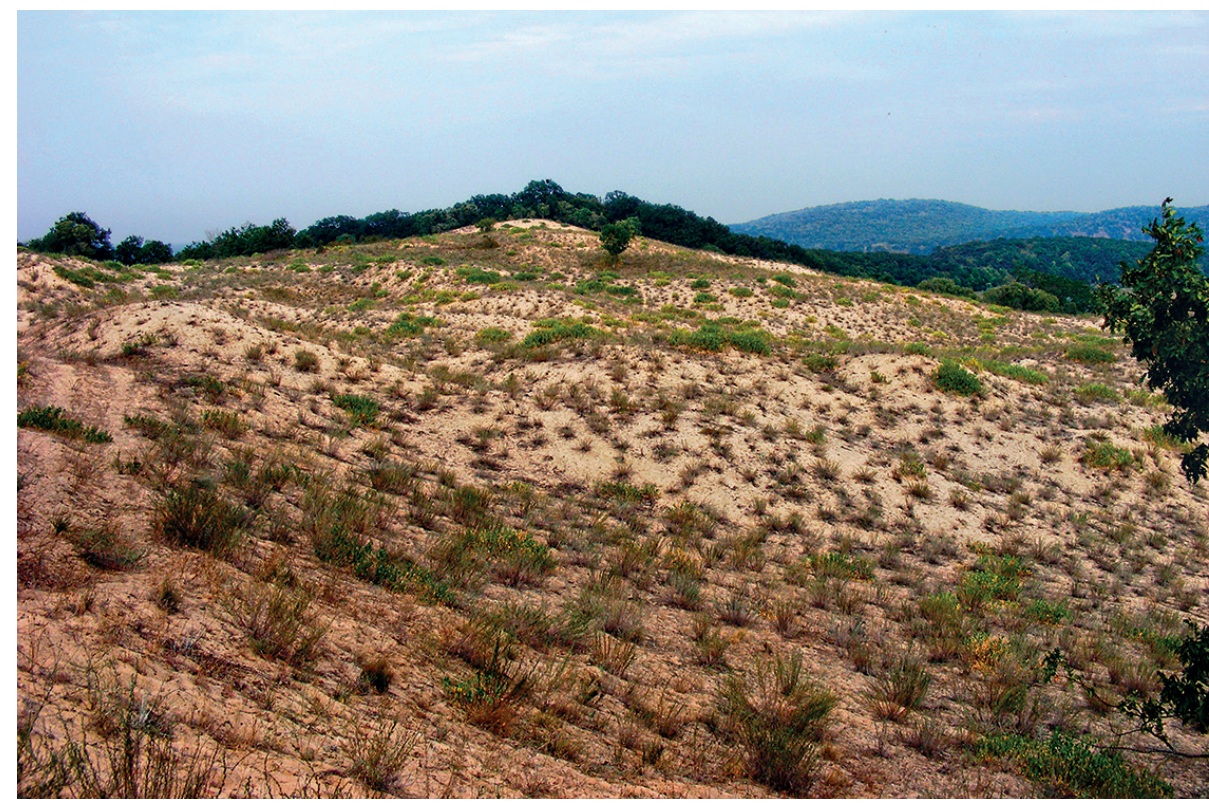

The cliffs of Sveta Paraskeva Bay inside Beglik Tash-Ropotamo Protected Area, Strandzha Mountain coastal sector

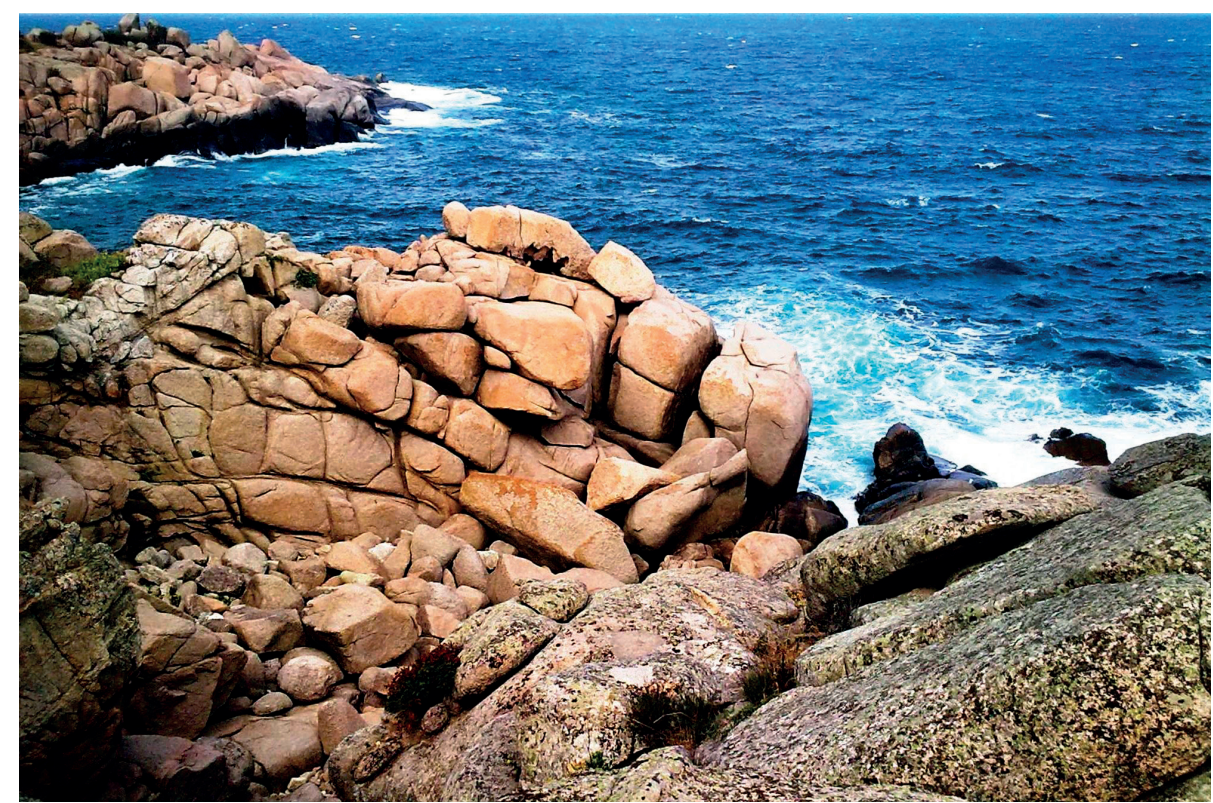




\section{PROTECTED TERRITORIES AND NATURA 2000 PROTECTED SITES}

\section{LOWER HADZHIYSKA RIVER VALLEY COASTAL} SECTOR:

- Pyasachni dyuni v mestnost Babata Slanchev bryag (Sand Dunes at Babata Locality Sunny Beach) Natural Landmark

- Ortoto Protected Area

- Emine Protected Site (Birds Directive)

- Aheloy - Ravda - Nesebar Protected Site (Habitats Directive) ${ }^{1}$

\section{BURGAS LOWLAND COASTAL SECTOR}

- Atanasovsko ezero (Atanasovsko Lake) Managed Reserve

- Paysachni dyuni - 5 broya (Five Sand Dunes) Natural Landmark

- Pomoriysko ezero (Pomorie Lake) Protected Area

- Burgaski solnitsi (Burgas Saltworks) Protected Area

- Vaya Protected Area

- Poda Protected Area

- Uzungeren Protected Area

- Chengene skele Protected Area

- Ustie na reka Izvorska (Izvorska River Mouth) Protected Area

- Aheloy - Ravda - Nesebar Protected Site (Habitats Directive) ${ }^{1}$

- Pomorie Protected Site (Habitats Directive)

- Pomoriysko ezero (Pomorie Lake) Protected Site (Birds Directive)

- Atanasovsko Ezero (Atanasovsko Lake) Protected Site (Birds and Habitats Directives)
- Burgasko ezero (Burgas Lake) Protected site (Birds and Habitats Directives)

- Mandra - Poda Protected Site (Birds and Habitats Directives)

- Zaliv Chengene skele (Chengene skele Bay) Protected Site (Birds and Habitats Directives)

- Otmanli Protected Site (Habitats Directive)

- Emine Protected Site (Birds Directive) ${ }^{1}$

- Bakarlaka Protected Site (Birds Directive)

\section{MEDNI RID RIDGE COASTAL SECTOR:}

- Ropotamo Reserve ${ }^{7}$

- Vodnite lilii (The Water Lilies) Managed Reserve

- Pyasachnata lilia (The Sea Daffodil) Managed Reserve

- Cape Chervenka (Chrisotira) Natural Landmark

- Pyasachni dyuni mezhdu camping Zlatna Ribka i camping Gradina (Sand Dunes Between Zlatna Ribka and Gradina Camping Sites) Natural Landmark

- Pyasachni dyuni - Kavatsite (Sand Dunes Kavatsite locality) Natural Landmark

- Cape Agalina Natural Landmark

- Blatoto Alepu (Alepu Swamp) Natural Landmark

- Ostrovi Sveti Ivan i Sv. Petar (Sveti Ivan and Sveti Petar Islands) Protected Area

- Kolokita Protected Area

- Beglik Tash - Ropotamo Protected Area

- Plazh Gradina - Zlatna Ribka (Gradina - Zlatna Ribka Beach) Protected Site (Habitats Directive)

- Ropotamo Protected Site (Habitats Directive) ${ }^{1}$
- Bakarlaka Protected Site (Birds Directive) ${ }^{1}$

- Kompleks Ropotamo (Ropotamo Complex) Protected Site (Birds Directive)

\section{STRANDZHA MOUNTAIN COASTAL SECTOR}

- Ropotamo Reserve 1

- Skalnite obrazuvania, fiordite i tyulenovata peshtera (The Rock Formations, The Fjords and The Seal's Cave) Natural Monument

- Pyasachni dyuni - mestnost Perla (Sand Dunes in Perla locality) Natural Monument

- Pyasachni dyuni - Mladezhkia centar (Sand Dunes at the International Youth Center) Natural Monument

- Strandzha Nature Park

- Beglik Tash - Ropotamo Protected Area

- Stomoplo Protected Area

- Ustie na reka Veleka (Veleka River Mouth) Protected Area

- Silistar Protected Area

- Ropotamo Protected Site (Habitats Directive) ${ }^{1}$

- Kompleks Ropotamo (Ropotamo Complex) Protected Site (Birds Directive) ${ }^{1}$

- Strandzha Protected Site (Birds and Habitats Directives) [65]

1 Nature conservation areas that fall within two or more contiguous coastal sectors 
The present publication was sponsored by TOTAL E\&P Bulgaria B.V. and its partners in Block 1-21 Han Asparuh - OMV Offshore Bulgaria GmbH and Repsol Bulgaria B.V., under the project for Preparation of Sensitivity Maps Focusing on the Bulgarian Black Sea Coastal Zone and the Contiguous Shallow Marine Sector in connection with their exploration operations The book was suggested by Tatiana Gusachenko, Total E\&P Bulgaria's Health, Safety and Environment (HSE) Manager, and is a result of the excellent collaboration between the Institute of Oceanology with the Bulgarian Academy of Sciences (IO-BAS) and all members of Total E\&P Bulgaria's HSE team. A photo-taking field campaign was carried out in the summer of 2016 funded specifically for the purposes of the present book. Project leaders and principal editors of the present publication are Dr. lliyan Kotsev and Dr. Hristo Stanchev from IO-BAS.

For the purposes of a detailed coastal classification very high resolution orthophoto and satellite images were used. They were provided by the Ministry of Agriculture and Food under Contract No DNTS 02/11 from 29.09.2010 in the framework of a Joint Research Project between Bulgaria and Romania (2010-2012), funded by the National Science Fund with the Bulgarian Ministry of Education and Science.

All oblique aerial photographs were provided by Prof. Robert Young (PSDS), Dr. Hristo Stanchev and Dr. Margarita Stancheva (IO-BAS). The Program for the Study of Developed Shorelines (PSDS) [1] was collaborated with IO-BAS for the first comprehen- sive photo survey of the Bulgarian Black Sea coast. The images were taken on July 10 and 11, 2013. The flight progressed from the Romanian border in the north to the Turkish border in the south with close to continuous coverage. The project was funded jointly by PSDS and IO-BAS with support from the Bulgarian Fulbright Commission.

All professional underwater photographs published herein were provided by Lyubomir Klissurov ${ }^{\oplus}$. All pro-
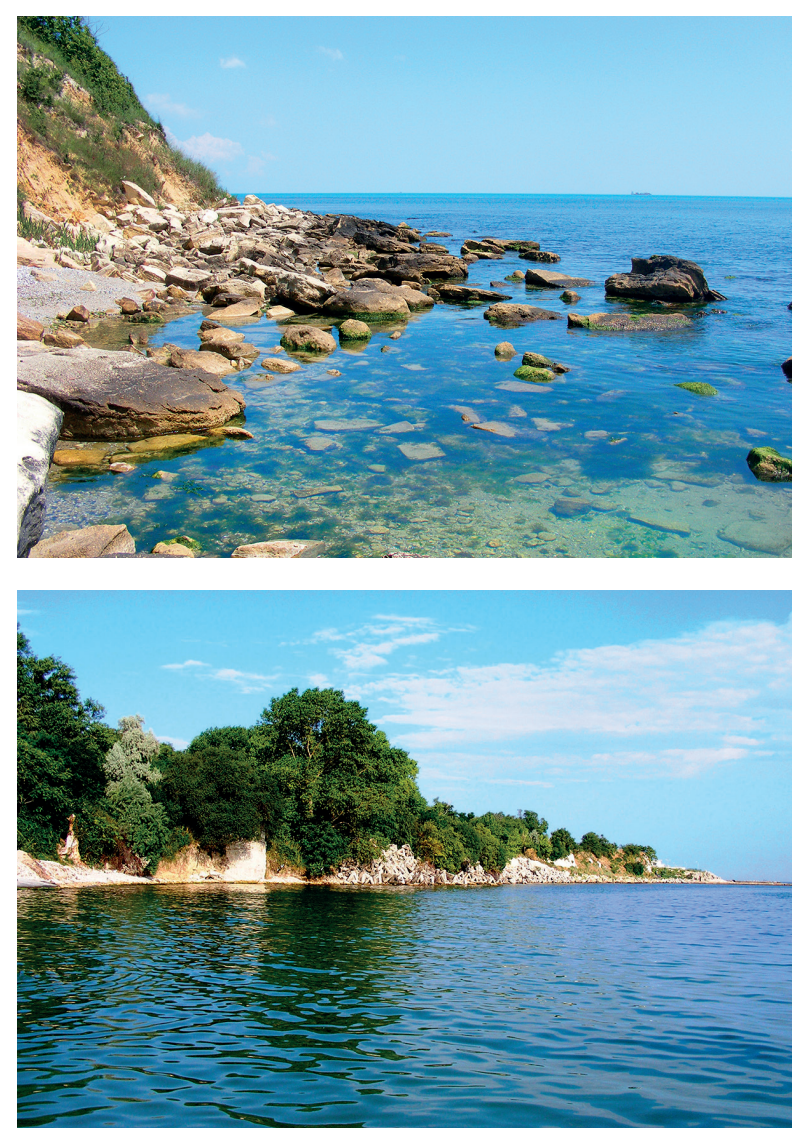

fessional photographs of bird species and cetaceans were provided by Green Balkans, NGO.

Most of the field photographs were provided by $\mathrm{Dr}$ lliyan Kotsev, Dr. Margarita Stancheva and Dr. Hristo Stanchev (IO-BAS). Most of the photographs of plant and animal species were provided by Professor Mariyana Filipova-Marinova, Dsc (Varna Museum of Natura History) and Dr. Danail Pavlov (Prof. Dr. Paraskev Stoyanov Medical University of Varna).
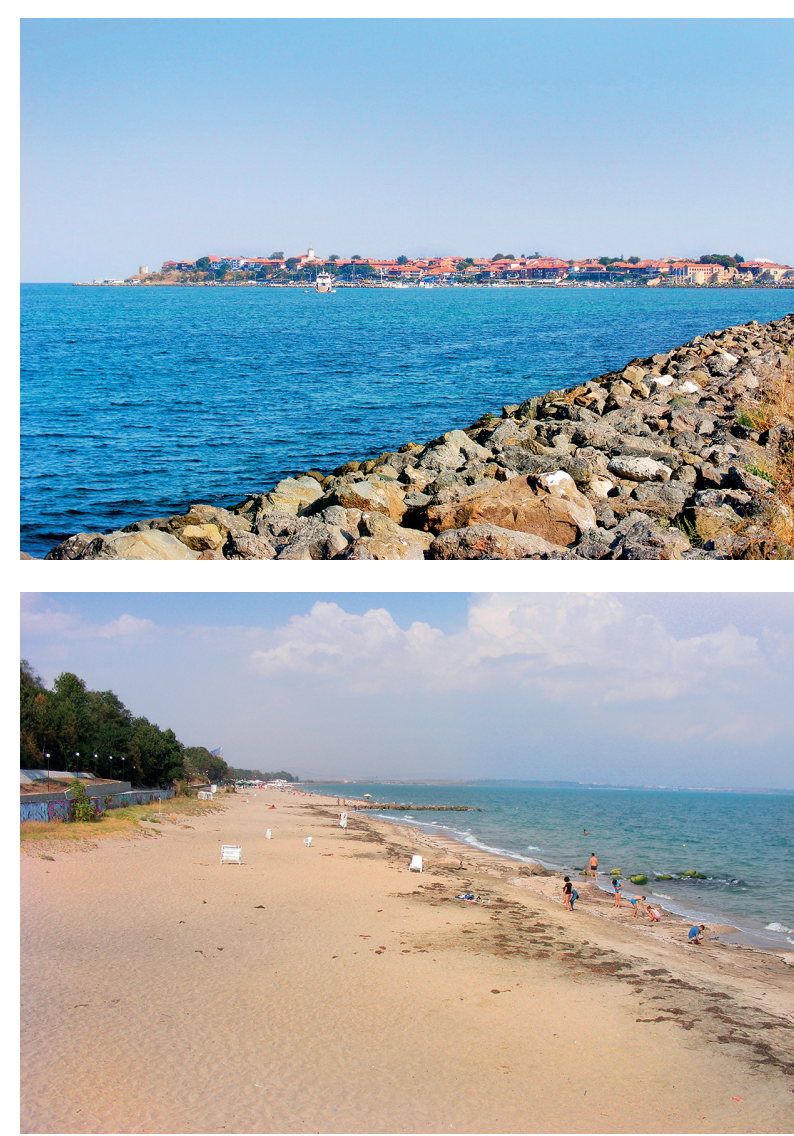


\section{REFERENCES}

\section{FOREWORD AND OBJECTIVES}

[1]. Penin, R. (2007). Physical geography of Bulgaria, 279 pp. Publ. house BULVEST 2000, Sofia (in Bulgarian)

[2]. Stanchev, Hr., Young, R., Stancheva, M. (2013). Integrating GIS and high-resolution orthophoto images for the development of a geomorphic shoreline classification and risk assessment - a case study
of cliff/bluff erosion along the Bulgarian coast. Journal of Coastal Conservation, 17: 719-728

[3]. Stancheva, M. (2013). Chapter 19 - Bulgaria. In Pranzini, E., Williams, A

[4]. Golemansky, V., Peev, D., Chipev, N. Beron, P., Biserkov, V. (Eds.) Red Data Book of the Republic of Bulgaria, Vol. III (Natural Habitats). 422 pp. BAS \& MoEW, Sofia

[5]. Georgiev, G. (2004). Black Sea biogeographic region. In National and otture parks and reserves Libris, Sofia (in Bulgarian)

[6]. Peel, M. C.. Finlayson, B. L.. McMahon, T. A. (2007). Updated map of the Köppen-Geiger climate classification. Hydrology and Earth System Sciences, 11: 1633-1644

[7]. Velev, S. (2002). Climatic regions. In Kopralev, I. (Ed.) Geography of Bulgaria, 155-157. Forkom Publishers. Sofia (in Bulgarian)

[8]. Lazarov, M. (Ed.) (2009). Ancient navigation along the Western Black Sed
Bulgarian)

[9]. Peev, P. (2014). Paleogeography of the harbor basins in the ancient marine history and archaeology along the Western Black Sea. PhD of Sciences, varna (in Bulurion)

[10]. Popkonstantinov, K., Drazheva, Ts., Kostova, R. (2015). Monastery of St. John Forerrunner on the Island of Sveti Ivan in light of recent
archaeological investigations (2008-2013) Proceedings of the archaeological investigations (2008-2013). Proceedings of National Museum in Burgas, Vol. 5 , Burgas (in Bulgarian)

[1]]. Stancheva, M., Stanchev, Hr., Peev, Pr., Anfuso, G., Williams, A. T. (2016). Coastal protected areas and historical sites in North Bulgaria - challenges, mismanagement and future perspectives.
Ocean \& Coastal Management, 130: 340-354

[12]. Stanchev, Hr., Palazov, A., Stancheva, M. (2009). 30 GIS model for flood risk assessment of Varna Bay due to extreme sea level CS2009 (Proeedings of CS'2009, Poh lal)

[13]. Stancheva, M. (2010). Human-Induced Impacts along the Coastal
Zone of Bulgaria. A Pressure Boom Versus Environment Comptes rendus de /'Academie bulgare des Sciences, 63(1): 137-146
[14]. Stancheva, M., Ratas U., Orviku K., Palazov A., Rivis R., Kont A., Peychev V., Tônisson H., Stanchev H. (2011). Sand dune destruction

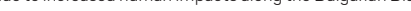
Estonian Batic Sea coasts. Jum mal b Coastak Research, Spec

[15]. Velchev, A., Todorov, N., Penin, R., Konteva, M. (2011). Landscape geography of B

[16]. Nam, K. (2002). Opportunities to realize the idea of sustainable development in the Strandzha Mountain region. In Proceedings of Science, Environment and Sustainable Development scientific (in Bulgarian)

[177]. Richard, C., Benzzoni.,Fr., Dutrieux, E...Chaineau, Cl.-H. (2017). Marine sensitivity mapping of the southern coast of Yemen (from Balha

\section{CHAPTERI}

GEOLOGICAL SETTINGS OF THE BULGARIAN BLACK SEA COAST AND SHELF

CHAPTER II

PHYSIOGRAPHIC AND OCEANOGRAPHIC CHARACTERISTICS OF THE STUDY AREA

[1]. Peychev, V.. Dimitrov, D. (2012). Oceanology, 490 pp. Publ. house Ongal, Varra (in Bulgarian)

[2]. Mishev, K., Daneva, M. (1979). The Bulgarian Black Sea Coast. Academic $P$ (ulgarian)
Bus

[3]. Popov, VI., Mishev, K. (1974). Geomorphology of the Bulgarian Blac Sea coast and shelf, $253 \mathrm{pp}$. Academic Press of the Bulgarien Acador of Sciences, Sofia (in Bulgarian)

[4]. Cheshitev, G. Kunchev, I. Vulkov, V., Marinova, R., Shilyafova, Zh., Ruseva, M... liev, K. (1989). Geological map of the Republic of Bulgaria at scale 1:500,000. Published by Committee of Geology. Departof Geophysical Prospecting and Geological Mapping, So Bulgaria (in Bulgarian and English)

[5]. Keremedchiev, St., Trifonova, E., Valchev, N., Andreeva, N., Eftimova, P. Demireva, D. (2007). PLANCOAST - spatial planning of Varna coastal area between Cape Ekrene and Cape Paletsa. Final project report. Scientific fund of Prof. Fridtjof Nansen Institute of Oceano ogy, Varna - Bulgarian Academy of Sciences (in Bulgarian

[6]. Dimitrov, L.., Keremedchiev, St., Doncheva, V. (2013). Benthal. In Todorova, V... Moncheva, Sn. (Eds.) Initial assessment of the state of the

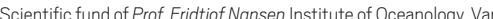
na - Bulgarian Academy of Sciences 34-45 (avalable at http: www.bsbd.org/UserFiles/File//nitial\%20Assessment_new.pdf, in Bulgarian, last accessed on September 30, 2016)
[7]. Kozhuharov, E., Dimitrov, L., Hristova, R., Doncheva, V. (2010). Geologic map of the Bulgarian Black Sea sector - explanatory notes. Scientific fund of Prof. Fridtijof Nansen Institute of Oceanology, Varna - Bulgarian Academy of Sciences, 65 pp. (in Bulgarian)

[8]. Prodanov, B. (2017). Seabed mapping of the Bulgarian continenta shelf in front of the Avren Platecu coastal area for habitat classification . Ph. D thesis. 763 pp (in Bulgarian)

[9]. Peychev, V. (2004). Black Sea level fluctuations during the Quaternary and the contemporary epoch. In Morphodynamic and Lithodynamic Processes in the Coastal Zone, 180-199. Publ house Slavena, Varna (in Bulgarian)

[10]. Filipova-Marinova, M. (2007). Archaeological and paleontological vidence of climate dynamics, sea-level change, and coastline migration in the Bulgarian sector of the Circum-Pontic Region. In Yanko-Hombach, V., Gilber, A. S., Panin, N.., Dolukhanov, P. .M. (Eds) The Black Sea Flood Question. Changes in Coastline, Climate and

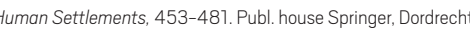

[1]]. Filipova-Marinova, M., Pavlov, D., Coolen, M. Giosan, L. (2013). First high-resolution marinopalynological stratigraphy of Late QuaternaQuaternary International, 293: 1700-183

[12]. Konikov, E., Likhodedova, O., Pedan. G. (2007). Paleogeographic econstructions of sea-level change and coastline migration on the northwestern Black Sea shelf over the past 18 kyr. Quaternary International, 167-168: 49-60

[13]. Christova, R. (2015). The Bulgarian Black Sea shelf and coast during the Quaternary - geologic evolution and climate changes, $127 \mathrm{pp}$ Bulgarian)

[14]. Baltakov, G. (2000). Basic features of the paleogeographic adaptation at the sculpture morphogenesis of the contemporary geomorphic complex in Bulgaria. Annual journal of Sofia University St. Kil-
ment Ohridski, Book No2 (Geography), 93: $123-135$ (in Bulgarian)

[15]. Baltakov, G. (2003). Pleistocene and Holocene evolution of the martime coasts and the littoral zone of the eastern Bakkan Peninsula (Geography). 96: 69-87 (in Bulgarian)

[16]. Baltakov, G., Kenderova, R. (2003a). Development of the World Ocean and some of the enclosed marine basins during the QuaOcean and some of the enclosed marine basins during the Qua-
ternary. In Quatemary Paleogeography, 201-220. Publ. house Maleo-63, Varna (in Bulgarian)

[17]. Baltakov, G., Kenderova, R. (2003b). The Balkan Peninsula and the Bulgarian lands during the Quaternary. In Quaternary Poleogeogrophy, 264-281. Publ. house Maleo-63, Varna (in Bulgarian)
[18]. Balabanov, I. P. (2007). Holocene sea-level changes of the Black Sea. In Yanko-Hombach, V., Gilbert, A. S., Panin, N., Dolukhano P.M. (Eds.) The Black Sea Flood Question: Changes in Coastline, limate and Human Settlements, 711-730. Publ. house Springe.

[19. Popov, VI., Antsyferov, S., Belberov, Z., Massel, S., (Eds.) (1990). Dynamical Processes in Coastal Regions, 190 pp. Academic Press of the Bulgarian Academy of Sciences, Sofia

[20]. Vaptsarov, I. (1997). Denudation surfaces. In Yordanova, M., Donchev, D. (Eds.) Geography of Bulgaria, 86-92. Professor Man Drinov Academic Press, Sofia (in Bulgarian)

[21]. Marinski, Y., Bruchev, I... Kochev, K., Milev, G., Frangov, G.. Aleksiev, G (1998). Protection and Long-Term Stabilization of the Slopes oftte Sofia (in Bulgarian)

[22]. Keremedchiev, St., Stancheva, M. (2006). Assessment of the geo-morphodynamical activity of the Bulgarian Black Sea coast. comptes Rendus de l'Academie Bulgare des Sciences, 59(2):

[23]. Trifonova, E. Valchev, N. Andreeva, N. Eftimova, P. (2012). Critica storm thresholds for morphological changes in the

[24]. Stancheva, M. (2013). Chapter 19 - Bulgaria. In Pranzini, E., Wiliams, A. T. (Eds.) Coastal Erosion and Protection in Europe, 3

Stanchev Hr. Young R Stancheva M (2013) Integrating GIS high-resolution orthophoto images for the development of a geomorphic shoreline classification and risk assessment - a case study of cliff/bluff erosion along the Bulgarian coast. Journal of Coastal

26]. Keremedchiev, St. (2004). Geomorphic analysis of the Avren Plateau coastal zone. Problems of Geography, 3-4: 126-134 (in Bulgarian)

[27]. Blagoeva, E. (1980). Investigations of the landscape's lithologic fundament. In Velchev, A., Blagoeva, E., Petrov, P... Kundev, Tr. (Eds)

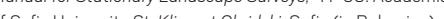

[28]. Keremedchiev, St. (2002). Morphological characteristics of the terGeography, 1-2: $127-133$ (in Bulgarian)

[29]. Keremedchiev, St. (2001). Morphohydrographic analysis of the Bulgarian Black Sea coastal zone. Proceedings of the Institute of

[30]. Dimitrov, P., Solakov, D., Peychev, V., Dimitrov, D. (2003). The source provinces of the Black
ology - BAS, 4: 29-3 
[31]. Keremedchiev, St. (2005). Morphostructural and geodynamic prerequisites for the up-to-date morphological development of the Bigan

[32]. Keremedchiev, St., Cherneva, Zh. (2003). A geomorphologic analySis of 4

[33]. Keremedchiev, St. (2005). Morphological analysis of the up-to-date relief of the Bulgarian Black Sea coast. Comptes Rendus de l'Ac

[34]. Kanev, D. (1989). Geomorphology of Bulgaria, 322 pp. Academic Press of Sofia University St. Kliment Ohridski, Sofia (in Bulgarian)

[35]. Stancheva, M. (2009). Indicative GIS-based segmentation of the Bulgarian Black Sea coastline for risk assessment. Comptes Ren-

[36]. Stancheva, M., Stanchev, Hr., Palazov, A., Young, R. (2015). Coastal dune changes under natural/human hazards. In Özhan, E. (Ed.) Proceedings of the Twelfth International Conference on the Medterranean Coastal Environment MEDCOAST'75, October $6^{\text {th }}-10$ 2015, Varna, Bulgaria, 1: 385-395

[37]. Trifonova, E.. Valchev, N. Andreeva, N.. Eftimova, P., Kotsev, I. (2011) Measurements and analysis of storm induced short-term mophologlcas Special Issue 64 (Proceed higs of th Research, Special Issue 64 (Proceedings of the
Coastal Symposium, Szczecin, Poland): $149-154$

[38]. Peychev, V., Dimitrov, D., Peycheva, M. (2014). Geodynamical processes along the Bulgarian Black Sea coast. Bulletin of the Union of

[39]. Ministry of Environment and Water (2013). Project Information system for protected sites of the Bulgarian Natura 2000 network
(available at http://www.natura2000.moew.government.bg, in Bulgarian, last accessed on November 30, 2016)

[40]. Stancheva, M., Rangel-Buitrago, N., Anfuso, G.., Palazovv, A., Stanchev, H. and Correa, I. (2011). Expanding level of coastal armouring Special Issue 64 (Proceedings of the $77^{\text {th }}$ International Caastal Symposium, Szczecin, Poland):1815-1819

[47]. Maev, E. G.. Kozlov, V. B., Krustev, T. I., Limonov, A. F., Mislivets, V. 1.. Parlichev, D. G.. Chistyakov, A. A. (1980). Structural-geomorphic characteristics of the continental terrace. In Geologic-GeophysAcademic Press of the Bularive Academy of Sciences Sofitin

[42]. Krustev, T. (1992). Structural-geomorphic development of the continental terrace within the Bulgarian Black Sea sector. DSc dis-

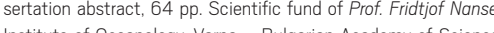
(in Bugarian)

[43]. Dimitrov, P., Dimitrov, D., Peychev, V., Tsaneva, M. (2015). Physiographic, geologic and lithologic characteristics of the Bulgarian
Black Sea sector Geology and Mineral Resources of the World Dlack Sea sector, Geology and Min 40 (2): $170-176$ (in Russian)
Ocean

[44]. Inatov, E. I. (2008). Coastal and bottom topography. In Kostiano,

[45]. Parlichev, D., Petrov, P. (1974). An attempt for geomorphic regionalization of the Bulgarlian Black Sea shelf. Problems of Geography Bulgaria, 4: 69-80 (in Bulgarian)
[46]. Popov, V. (1975). Taxonomic units for landscapes (the Black Sea landscape being taken as an example). Geographic Proble

[47]. Velev, S. (1997). Climate. In Yordanova, M., Donchev, D. (Eds.) Geography of Bulgaria, 108-150. Professor Marin Drinov Academic Press, Sofia (in Bulgarian)

[48]. Penin, R. (2007). Physical geography of Bulgaria, 279 pp. Publ house BULVEST 2000, Sofia (in Bulgarian)

[49]. Velchev, A., Todorov, N., Penin, R., Konteva, M. (2011). Landscape geography of Bulgaria, 235 pp. Publ. house BULVEST 2000, Sofia geography of B $B$ gy
(in Bulgarian)

[50]. Velev, S. (2002). Climatic regions. In Kopralev, I. (Ed.) Geography of Bulgaria, 155-157. Forkom Publishers, Sofia (in Bulgarian)

[51]. Velev, St. (1990). Climate regionalization of Bulgaria. In Climate of Bulgaric 87-88 Academic Press of the Bulgarian Academy of SciBulgaria, 87-88. Academic
ences, Sofia (in Bulgarian)

[52]. Harding, A. E., Palutikoff, J., Holt, T. (2009). The climate system In J. C. Woodward (Ed.) The Physical Geography of the Mediterranean, 69-88. Oxford University Press, Oxford

[53]. Kotteck, M., Grieser, J., Beck, Ch., Rudolf, Br., Rubel, Fr. (2006) World Map of the Köppen-Geiger climate classification updated
Meteorologische Zeitschrift, 15(3): 259-263

[54]. Peel, M. C., Finlayson, B. L., McMahon, T. A. (2007). Updated map of the Köppen-Geiger climate classification. Hydrology and Earth System Sciences, 11: 1633-1644

[55]. Rubel, Fr., Kottek, M. (2010). Observed and projected climate shifts

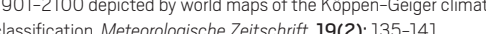

[56]. Kotsev, I. (2014). Structure, dynamics and regionalization of the landscape complexes between Cape Kaliakra and Cape Emine
Bulgarian Black Sea coastal zone (docotoral thesis), 297 pp. Pub house Aquaprint, Varna (in Bulgarian)

[57]. Nam, K. (2003). Physical geography of Bulgaria, 283 pp. Publ. house Geosfera, Sofia (in Bulgarian)

[58]. Ivanov, K., Marinov, IV., Panayotov, T., Petkov, Al. (1967). Hydrology of Bulgaria, 374 pp. Publ. house Nauka \& Izkustvo, Sofia (in Bulgarian

[59]. Ivanova, E. .I., Nedkov, R. D., Ivanova, I. B., Radeva, K. L. (2012). Mor(2)

60]. Rozhdestvenskiy, A. V. (1986). Hydrochemistry of the Bulgarian sector of the Black Sea, $189 \mathrm{pp}$. Academic Press of the Bulgarian Academy of Sciences, Sofia (in Bulgarian)

[6]]. Truhchev, D.., Peneva, E., Peychev, V., Slabakova, V.. Tomova, Z. (Eds) Initial assessment of the state of the marine enviroment in compliance with Aticle 8 of the RPEMW. Scientific fund of Prof Fridtiof Nansen Institute of Oceanology - BAS, 47-67 (available at http://www.bsbd.org/UserFiles/File/lnitial\%20Assessment_new. pdf, in Bulgarian, last accessed on September 30, 2016)

[62]. Shtereva, G., Hristova, O., Dzhurova, B. (2013). Chemical characteristics. In Todorova, V. Moncheva, Sn. (Eds.) Initial assessment
of the state of the marine environment in compliance with Aticd 8 of the RPEMW. Scientific fund of Prof. Fridtiof Nansen Institute of Oceanology - BAS, 68-75 (available at http://www.bsbd.org/ Userfiles/Alie/nitial\%20Assessment_new.pdf, in Bulgarian, las accessed on September 30, 2016)
[63]. Dineva, S. 2013. Black Sea water environment along the Bulgarian coast. Bulg. J. Agric. SCi., Supplement 1: 6-11

[64]. Moncheva, S., Stefanova, K., Shtereva, G. Slabakova, N. Mavrodeva, R., Krastev, A., Hristova, O., Dzhurova, B., Slabakova, V. (2010) On the recent features of chemical and biological regimes in the AME Project, April 2010, Athens, Greec

[65]. Krastev, A., Shtereva, G., Hristova, O., Dzhurova, B. (2005). Pecullarities of Indicative Chemical Parameters Distribution of Bulgarian Sea Coostal Pegion BU-2003 period. In Moncheva, S. (Ed.) Black Indicators. CESUM-BS collected papers, 79-86

[66]. Krastev. A. Shtereva, G.. Hristova, O. Dzhurova, B. (2006). Nutrients in the Western Black Sea Area - Spatial and Vertical Distribution. Proceedings of $7^{\text {th }}$ Black Sea Conference Black Sea Ecosystem

[67]. Kostianoy, A., Kosarev, A. (Eds.) (2008). The Black Sea Environment, 457 pp. Vol. $5 / Q$, Springer-Verlag Berlin Heidelberg

[68]. Golubev, U.N. Tuzhilkin, V.S. (1990). Some Aspects of climatic variations of Black Sea hydrophysical fields, 72 pp. Sevastopol. MHI AS USSR (in Russian)

[69]. Baltov, A.S., Bulgakov, N.P., vvanov, V.A., Kosarev, A.N. Tuzhilkin, VS (1984). Variations of Black Sea hydrophysical fields, 240 pp. Pub house Gidrometeoizdat, Leningrad

[70]. Zatsepin, A., Ginzburg, A., Kostianoy, A., Kremenetskiy, V., Kri-

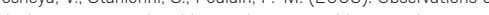
Black Sea mesoscale eddies and associated horizontal mixing. $J$

[7]]. Korotaev, G.K., Saenko, O.A., Koblinsky, C.J. (2001). Satellite altimetry obse

[72]. Oguz, T, Besiktepe, S. (1999). Observations on the Rim Current Gtructure, CIW formation and transport in the western Black S a (10) $1733-1753$

[73]. Oguz, T., Aubrey, D.G., Latun, V.S., Demirov, E., Koveshnikov, L., Diaconu, V., Sur, H.I., Besiktepe, S., Duman, M., Limeburner, R., Eremeev, V. (1994). Mesoscale circulation and thermohaline structure
of the Black Sea observed during HydroBlack '97. Deep-Sea Res. Part I. 41(4):603-628

[74]. Stanev, E.. Truhchev, D., Rusenov, V. (1988). Water circulation and numerical modeling of Black Sea currents, 222 pp. Academic Press

[75]. Krastev, A., Shtereva, G.. Hristova, O., Dhurova, B. (2007). Vertical hydrochemical structure of the Bulgarian Black Sea part. Rapp. Comm. int. Mer. Medtr., Vol. 38:9-13, April 2007, Istanbul, Turkey.

[76]. Shtereva, G.. Krastev, A... Hristova, O., Dzhurova, B. (2008). Nutrients in Western Black Sea Area during the SESAME Cruises (October 2007 - April 2008). First Scientific SESAME Workshop, November 2008, Palma de Mallorca, Spain

[77]. Ninov, N. (1997). Soils. In Yordanova, M. Donchev, D. (Eds.) Geograhy of Bulgaria, 225-259. Professor Marin Drinov Academic Press,

[78]. World Reference Base for Soil Resources. A framework for international classification, correlation and communication (2006). Sec-
ond edition, World Soil Resources Reports No. 103, FAO, Rome
[79]. State of the soils (2017). In National Report on the State of Environment in Bulgaria (avalable at http://eea.government.bg/b/ soer/2011/and-use/sastoyanie-na-

[80]. Koleva-Rekalova, E. (1998). Formational conditions of the Sarmatran sedimentary rocks from the Balchik area, North-eastern Bugaria. Review of
Bulgarian)

[87]. Velchev, V. (2002). Types of vegetation. In Kopralev, I. (Ed.) Geogriophy of Bulgaria, 324-336. Forkom Publishers, Sofia (in Bulgarian)

[82]. Bondev, I. (1991). Vegetation of Bulgaria: 7:600,000 map with explanatory text, 180 pp. Academic
Kliment Ohridski, Sofia (in Bulgarian)

[83]. CORINE Land Cover 2006 in Bulgaria (2008). Final report, 46 pp.

84]. Petrova. V. Draganov, St. (1978). Flora. In Black Sea (almanac), 95 107. Publ. house Georgy Bakalov, Varna (in Bulgarian)

[85]. Golemansky, V., Peev, D., Chipev, N. Beron, P., Biserkov, V. (Eds.) Red Data Book of the Republic of Bulgaria, Vol. III (Natural Habitats). 422 pp. BAS \& MoEW, Sofia

[86]. Black Sea Red Data Book (1999). Available at http://www.grid unep.ch/bsein/redbook/index.htm (last accessed on Novembe 19. 2016)

[87]. Todorova, V. Keremedchiev, St., Karamfilov, V., Berov, D., Dimitrov, L Kotsev, I. Dencheva, Kr. (2013). Dominant benthic habitat types. I Initial assessment of the state of the maine environment, in accordance with Article 8 of the RPEMW. Scientific fund of Prof. Fridt) of Nansen Institute of Oceanology, Varna - Bulgarian Academy of File/lnitialo/20Assessmentnew df in Bulgarian last accessed on September 30, 2016)

[88]. Dencheva, Kr. (2013). Macrophytobenthos. In Assessment report concerning the ecological status of the marine waters in compliance with the Water Framework Directive, 231-289. Scientific fund of of Sciences (in Bulgarian)

[89]. Todorova, V., Panayotova, M. (2015a). Cystoseira spp. on exposed to waves infralittoral bedrock and boulders. In Golemansky, V. Peev D.., Chipev, N., Beron, P., Biserkov, V. (Eds.) Red Data Book of the
Republic of Bulgaria, Vol. III (Natural Habitats), 56-58. BAS \& Republic of Bulgaria, Vol. III (Natural Habitats), 56-58. BAS

[90]. Todorova, V. (2015). Underwater "meadows" of sea grasses. In Golemansky, V., Peev, D., Chipev, N., Beron, P., Biserkov, V. (Eds.) ReData Book of the Republic of Bulgaria, Vol. III (Natural Habitats),

[91]. Golemanski, V., Peev, D., Chipev, N., Beron, P., Biserkov, V. (Eds) (2015). Red Data Book of the Republic of Bulgaria, Vol. II (Animals)

[92]. Josifov, M. (1988). Über den zoogeographischen charakter der südeuropaischen Insektenfauna unter besonderer Berücksichtigung der Heteropteren. Berichte des noturwissenscha
inischen Vereins, Innsbruck, 75: $177-184$ (in German)

[93]. Todorova, V., Panayotova, M. (2015b). Sublittoral mussel beds on sediments. In Golemansky, V., Peev, D.. Chipev, N.., Beron, P.., B-
serkov. V. (Eds.) Red Data Book of the Republic of Bulgaria, Vol.

[94]. Micu, D. Micu, S. (2006). Recent records growth and proposed IUCN status of Donacilla cornea (Poli, 1795) from the Romania
Black Sea Cercetari Marine $117-132$ 
[95]. Serge, G. (2012). Chamelea gallina (Linnaeus, 1758). World Regiscessed on December 7, 2016

[96]. ICES (2004). Alien Species Alert: Rapana venosa (veined whelk) In Mann, R. Occhipinti, A. Hard
Research Report No 264.14 pp.

197]. Gofas, S. Marshall, B. (2016). Tritia reticulato (Lineevs 1758) (Available at http://www.marinespecies.org. last accessed on De(Avalable at http
cember 7. 2016)

[98]. Nicolaidou A., Nott J., 1999. The role of the marine gastropod Cerithium vulgatum in the biogeochemical cycling of metals. Chapter NATO ASI Series $137-146$.

99]. Valkanov, A. Marinov, T. (1978). Invertebrates. In Black Sea (almonac), 108-123. Publ. house Georgy Bakalov, Varna (in Bulgarian)

[100]. Abed-Navandi, D., Dworschak, P.C. (1997). First record of the thalassinid Callianassa truncata Giard \& Bonnier, 1890 in the .

101]. Benvenuto Ch., Sartoni G., Francesca Gh. (2003). Foraging behavior of the hermit crab Clibanarius ertthropus in a Mediterranean
shore. Journal of the Marine Biological Association of the United Kingdom, 83(3): 457-467

[102]. Ates, A. Katagan, T., Kocatas, A. (2007). Gastropod Shell Species Coast of the Aegean Sea Turkish journal of zoology 31: 13-18

(103]. Skewes, M. (2008). Bristly crab - Pilumnus hirtellus. Marine Life Information Network. Marine Biological Association of the United Kingdom (avallable at http://Www.marlin.ac.uk, last accessed on

[104]. Yankova, M., Raykov, V., Ivanova, P., Mgeladze, M., Diasamidze, R., Radu, Gh., Nicolaev, S., Agapov, St., Grinchenko, M., Ozturk, B., Oral, M.. Bat, L., Shlyakhov, VI., Boltachev, Al., Karpova, E. (2011). Black Sea Fish Species List. Black Sea Commission Publication (available at www.blacksea-commission.org/_publications.asp. last accessed on December 7, 2016)

[105]. Yankova, M., Pavlov, D., Ivanova, P., Karpova, E., Boltachev, A., Öztürk, B., Bat L., Oral, M., Mgeladze, M. (2014). Marine fishes in the Black Sea: recent conservation status. Mediterranean Marine Setence, 366-379

[106]. Stoikov, S.T. (1978). The food of the horse mackerel (Trachurus mediterraneus ponticus, Aleev) during the 1978 fishing seaso

[107]. Stoyanov, S., Georgiev, Z., Ivanov, L., Hristov, D., Kolarov, P., Aleeva, K... Karapetkova, M. (1963). Fish in the Black Sea, 98 pp. Varna State Publishers, Sofia, Bulgaria (in Bulgarian)

[108]. Yankova, M., Raykov, V., Bogomilova, P. (2008). Diet composition

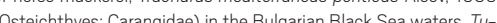
kish Journal of Fisheries and Aquatic Sciences, 8: 321 - 327

[109]. Georgiev, Zh. Aleksandrova-Kolemanova, K. (1978). Fish species. in Black Sea (almanac), 124-150. Publ. house Georgy Bakalov. Varna (in Bulgarian)

[110]. Karapetkova, M. Zhivkov. M. (2010). Fish species in Bulgaria, 215 pp. Publ. house Gea-Libris, Sofia (in Bulgarian)

[117]. National Biodiversity Act of the Republic of Bulgaria (2016) (availble in Bugarian at http.//www.lex.bg, last accessed on November 19,2016)
[112]. Batakliev, I. (1934). Landscape division of Bulgaria. Annual journal

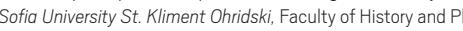

[113]. Georgiev, G. (2004). Black Sea biogeographic region. In Nationa and nature parks and reserves in Bulgaria, 217-271. Publ house

[114]. Tzonev, R. (2015a). Black Sea embryonic dunes. In Golemansky, V. Peev, D., Chipev, N., Beron, P., Biserkov, V. (Eds.) Red Data Book of the Republic of Bulgaria, Vol. II

[115]. Tzonev, R. (2015b). Black Sea mobile (white) dunes. In Golemansky, V.. Peev, D., Chipev, N., Beron, P., Biserkov, V. (Eds.) Red Data
Book of the Republic of Bulgaria, Vol. III (Natural Habitats), 67-68 BAS \& MoEW, Sofia

[116]. Tronev, R. (2015c). Black Sea fixed (grey) dunes. In Golemansky, V.. Peev, D., Chipev, N. Beron, P., Biserkov, V. (Eds.) Red Data Book
of the Republic of Bulgaria, Vol III (Natural Habitats), 69-71. BAS $\&$ MoEW, Sofia

[117]. Tzonev, R., Gussev, Ch. (2015). Black Sea wooded dunes. In Golemansky, V., Peev, D., Chipev, N., Beron, P., Biserkov, V. (Eds.) Red Data Book of the Republic of Bulgaria, Vol. III (Natural Habitats)

[118]. Velchev, A.. Todorov, N., Penin, R. (1992). Anthropogenic transformations and disturbance of the landscapes in the Burgas Lowland,
their differentiation and classification. In Proceedings of Ecology' 92 International Symposium, September 24-26, 1992, Burgas, Bugaria (in Bulgarian)

[119]. Nam, K. (2002). Rationalization of the land use between Cape Atia and the mouth of Rezovska River. In Proceedings of the Internaand the mouth of Rezovska River. In Proceedings of the Interna-
tional Scientific Conference in Memoriam of Prof. Dimitar Yaranov. Varna, 2002 (in Bulgarian)

[120]. Nam, K. (2002). Opportunities to realize the idea of sustainable development in the Strandzha region. In Proceedings of Science, EnVironment and Sustainable Development scientific conference wir
international participation, Veliko Tarnovo, 2002 (in Bulgarian)

\section{CHAPTER III.}

\section{COASTAL AND MARINE HABITATS. PROTECTED AREAS AND} NATURA 2000 SITES

[1]. Roussakova, V. (2015). Natural habitats as a part of the biological di-

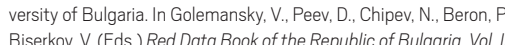
(Natural Habitats). 23-29 BAS \& MoEW. Sofia

[2]. Tzonev, R., Gussev, Ch. (2015a). Vegetation on the Black Sea gravel beachess. In Golemansky, V. Peev, D., Chipev, N., Beron, P., Biserkov. V. (Eds.) Red Data Book of the Republic of Bulgaria, Vol. III (Natura Habitats), 75-76. BAS \& MoEW, Sofia

[3]. Huggett, R. J. (2007). Coastal landscapes. In Fundamentals in Geomorphology, (2nd edition), 376-347. Routledge Taylor \& Francis

[4]. Council Directive 92/43/EEC of 21 May 1992 on the conservation of natural habitats and of wild fauna and flora (Habitats Directive) $19,2016)$

[5]. National Biodiversity Act of the Republic of Bulgaria (2016). Available 2016
[6]. Tzonev, R. (2015a). Vegetation on the Black Sea sand beaches. In Golemansky, V., Peev, D., Chipev, N., Beron, P.., Biserkov, V. (Eds.) Red 64-65. BAS \& MoEW. Sofia

[7]. Tzonev, R. (2015b). Black Sea embryonic dunes. In Golemansky, V Peev, D., Chipev, N. Beron, P.. Biserkov, V. (Eds.) Red Data Book of MoEW, Sofia

[8]. Tzonev, R. (2015c). Black Sea mobile (white) dunes. In Golemansky, ...Peev, D., Chipev, N., Beron, .... Biserkovv, V. (Eds.) Red Data Book \& MoEW Sofia

[9]. Tzonev, R. (2015d). Black Sea fixed (grey) dunes. In Golemansky, V. Peev, D., Chipev, N., Beron, P., Biserkov, V. (Eds.) Red Data Book of the Republic of Bulgaria, Vol. IIII (Natural Habitats), 69-71. BAS \&

[10]. Tronev, R., Gussev, Ch. (2015b). Black Sea wooded dunes. In Golemansky, V., Peev, D., Chipev, N., Beron, P.. Biserkov, V. (Eds.) Red Data Book of the Republic of
72-73. BAS \& MoEW, Sofia

[11]. Tzonev, R., Gussev, Ch. (2015c). Sea-cliff vegetation. In Golemansky V... Peev, D., Chipev, N., Beron, P., Biserkov, V. (Eds.) Red Data Book MoEW, Sofia

12]. Peev, D., Petrova, A., Apostolova, I. Assyov, B. (Eds.) (2012). Important plant areas in Bulgaria, 471 pp. Publ. house PENSOFT, Sofia

[13]. Petrov, B., Pandurski, I. (2015). Sea caves. In Golemansky, V., Peev, D.." Chipev, N... Beron, MoEW, Sofia T2. Traykov, I., Ivanov, Pl. (2015). Estuaries. In Golemansky, V., Peev, D.., Chipev, N.., Beron, P., Biserkov, V. (Eds.) Red Data Book of the Republic of Bulgaria, Vol. III (Natural Habitats), 104-106. BAS

[15]. Valchev, VI., Vassilev, V., Georgiev, V. (2015). Submerged macrophytic communities in hypersaline water bodies. In Golemansky, V. the Republic of Bulgaria, Vol. III (Natutural Habitatats). 52-54. BAS \& MoEW, Sofia

[16]. Kozhuharov, D., Uzunov, Y., Vassilev, V. (2015). Hypersaline coastal

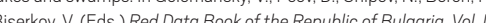
(Natural Habitats), 90-92. BAS \& MoEW. Sofia

[17]. Tzonev, R.. Gussev, Ch. (2015d). Communities of annual halophytes In coastal salt marshes at the Black Sea. In Golemansky, V., Peev,

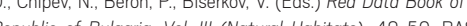
Republic of Bulgaria, Vol. III (Natural Habitats), 49-50. BAS

[18]. Gussev, Ch. (2015). Mediterranean halophytic communities of tall rushes, sedges and grasses. In Golemansky, V., Peev, D., Chipev, N.
Beron, P., Biserkov, V. (Eds.) Red Data Book of the Republic of BuBeron, P., Bssentor, V. (Eds.) Red Data Book of the Republic of Bu, P.

[19]. Tzonev, R., Valchev, VI., Georgiev, V. (2015). Natural or semi-natural mesotrophic to eutrophic lakes and marshes with macrophytic veg-
etation In Golemansky V Peev D Chipev N Beron P Biserkov V. (Eds.) Red Data Book of the Republic of Bulgaria. Vol. III (Natura Habitats), 84-87. BAS \& MoEW, Sofia
[20]. Tzonev, R. (2015e). Over-wet and flooded dune slacks. In Golemansky, V., Peev, D., Chipev, N., Beron, P., Biserkov, V. (Eds.) Red Dato

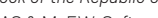

[27]. Dimitrov, M. Tzonev, R. (2015). Riparian and lowland mixed woodlands and longozes. In Golemansky, V., Peev, D., Chipev, N. Beron, P. (Natural Habitats), 281-284. BAS \& MoEW, Sofia
(ats

[22]. Todorova, V. (2015a). Black mussels and/or barnacle communities

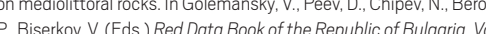
III (Natural Habitats), 44-45. BAS \& MoEW, Sofia

233]. Todorova, V., Keremedchiev, St., Karamfilov, V., Berov, D., Dimitrov, L.. Kotsev, I., Dencheva, Kr. (2013). Dominant benthic habitat types. In mitital assessment of the state of the marine environment, in accorSancewith Ariclo 8 of the Re Nansen, Institute of Oceanology Varna - Bulgarian Academy of
Sciences. 76-164 (available at http://www.bsbd.org/Userfilies/ File//nitial\%20Assessment newpdf in Bulgarian. last accessed on September 30, 2016)

[24]. Todorova, V., Panayotova, M. (2015a). Infralittoral rocks and other hard substrates. In Golemansky, V.. Peev, D., Chipev, N., Beron, P... (Natural Habitats). 54-56. BAS \& MoEW. Sofia

[25]. Todorova, V.. Panayotova, M. (2015b). Cystoseira spp. on exposed to waves infralittoral bedrock and boulders. In Golemansky, V.. Peev, Republic of Bulgaria, Vol. III (Natural Habitats), 56-58. BAS \& MoEW, Sofia

[26]. Black Sea Red Data Book (1999). Available at http://www.grid. unep.ch/bsein/redbook/index.htm (last accessed on November 9, 2016)

[27]. Todorova, V. (2015b). Littoral sands and muddy sands. In Golemansky, V., Peev, D., Chipev, N., Beron, P., Biserkov, V. (Eds.) Red Data

288. Todorova, V. (2015c). Underwater "meadows" of sea grasses. In Go-

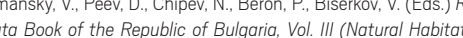
51-52. BAS \& MoEW, Sofia

[29]. Todorova, V., Panayotova, M. (2015c). Sublittoral sands. In GoleMansky, V... Peev, D., Chipev, N... Beron, P... Biserkov, V. (Eds.) Red 60-62. BAS \& MoEW, Sofia

30]. Todorova, V. Panayotova, M. (2015d). Sublittoral mussel beds on sediments. In Golemansky, V., Peev, D., Chipev, N., Beron, P.., Bi(Notural Habitots) 62-63 BAS \& MOEW. Sofia

[31]. Georgiev, G. (2004). Black Sea biogeographic region. In National and nature porks and reserves in Bulgoria, 217-277. Publ. house Gea-

[32]. Protected Territories Act of the Republic of Bulgaria (2016). Avail-

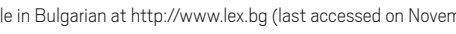

[33]. Stancheva, M. Stanchev, Hr., Peev, Pr., Anfuso, G., Williams, A. T. 2016). Coastal protected areas and historical sites in North Bulgaria - challenges, mismanagement and future perspectives.
Ocean \& Coastal Manogement. 130: 340-354 
[34]. Project Information system for protected sites of the Bulgarion NATURA 2000 network (2013) (avallable at hitp.l Mww.natura2000.moew.gove
vember 20, 2016)

[35]. Register of the protected territories and NATURA 2000 sites Bulgaria, Executive Environment Agency, 2014 (available at http:// eea.government.bg/zpo/en/index.jsp, last accessed on Novemb 20,2016

[36]. Dimitrov, B. (1992). The influence of the Kamchia River inundations on the longoz ecosystems. Annual journal of Sofia University St. K K-

Mishev, K. Daneva, M. (1979). The Bulgarian Black Sea Coast. Academic Prever the Bugarian Academy of Sciences Sofia (in Bulgarian)

[38]. Sinyovski, D. (2009a). Belite Skali (The White Cliffs) geological phenomenon. In Geological Phenomena in Bulgaria, online informa-

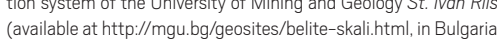

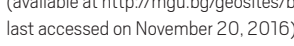

[39]. Sinyovski, D. (2009b). Cape Emine geological phenomenon. In Geological Phenomena in Bulgaria, online information system of the
University of Mining and Geology St Ivan Rilski (available a thttp: mgu.bg/geosites/nos-emine html, in Bulgarian, last accessed on mgu.bg/geosites/nos-
November 20, 2016)

[40]. De Boever, E., Swennen, R., Dimitrov, L. (2006). Lower Eocene carbonate chimneys (Varna, NE Bulgaria): formation mechanisms Geology 185:159-173

[47]. Kotsev, I., Keremedchiev, St., Todorova, V., Trifonova, E., Dimitrov, L. Andreeva, N., Eftimova, P. (2012). Mapping of the sub-littoral substrates as a basis for the identification of NATURA 2000 habita types 1710 and 170 in the Bulgarian Black Sea. Proceedings of the GIS Technologies for conservation of Natural and Cultural Heritoge Sites, May 21-23, 2012, Sofia, Bulgaria, 31-38 (available at http" proc.scgis.scgisbg.org/, last accessed on November 20, 2016)

[42]. Todorova, V. et al. (2012). Report on implementation of grant Contract No. 7976/04.04.2017, between EMEPA and the Institute Oceanology - BAS with reference to Project Extensilon of the NAT-
URA 2000 ecological network in the Bulgarian Black Seg mari area to overcome the moderate insufficiencies regrding marie area to overcome the moderate insutficiencies regarding marin
habitats 1110 (Sandbanks which are slightly covered by sea water all the time) and 1770 (Reefs) and species 4125 (Alosa immaculata), 1349 (Tursiops truncatus) and 1351 (Phocoena phocoena) and partial filing of scientific reserve for habitat 1180 (Submarin structures made by leaking gases) and species 1349 (Tursiops
truncatus) in accordance with the conclusions from the Marine Black Sea Seminar Brindisi June 75th, 2010 . Scientific fund of 10-BAS (in Bulgarian)

CHAPTER IV. ARCHAEOLOGICAL SITES, HISTORICAL AND CULTURAL HERITAGE OF THE BULGARIAN BLACK SEA COAST

[1]. Dimitrov, B., Orachev, A., Porozhanov, K. (1982). The harbors of Appolonia and Messambria. In Thracian monuments 3. The Megaliths in Thrace, $438-458$ (in Bulgarian)

[2]. Ognenova-Marinova, L. (1975). Underwater explorations in Nesseba Vekove 3: 43-48 (in Bulgarian)

[3]. Ognenova-Marinova, L. (1980). Le systeme de defense hellenique de Mesambria du cote nord a la lumiere des recherches sous-marines.
In Nessebre II, 96-109 (in French)
[4]. Preshlenov, H. 2008. Morphodynamics of the coastal zone of the Nesebar Peninsula (Bulgaria): archaeological and geologica benchmarks. Proceedings of the Intemnational Conference Bulgaria, 305-307. Publ. house Sv. Ivan Rilski, Sofia

[5]. Lazarov, M. (1988). The mystic Carian port. Far'88: 33-42 (in Bulgarian)

[6]. Peev, P. (2008). Underwater sites in the area of Cape Shabla (Northeast Bulgaria). Proceeedings of the International Conference Bulgaria, 303-304. Publ. house Sv. Ivan Rilski, Sofia

[7]. Peev, P. (2014). Palceogeography of the harbour basins in the ancient marine history and archaeology along the Western Black Sea. PhD

[8]. Todorova, H. (1984). Dobrudzha during the Prehistoric times. History of Dobrudzha, Vol. 1: 23-71 (in Bulgarian)

[9]. Minchev, A. (2014). Bulgaria. In 40 medieval city-ports in North Aegean and the Black sea. A cultural guide. Thessaloniki

[10]. Bozhkov, L. (1925). Where is the localization of the ancient port Car-
ia? Journal of Bulgarion engineering-architectural union, XXV (8) $118-123$ (in Bulgarian)

[1]. Porozhanov, K. (1989). Dating of the stone anchors with holes from Bulgarian Black Sea coast. Achievements and problems. Archaeol-

[12]. Velkov, V. (1984). Dobrudzha during the Late Antiquity. History of Dobrudzha, Vol. 1: 156-173 (in Bulgarian)

[13]. Kitov, G. (1971). Early Byzantine fortress within the seaside resort

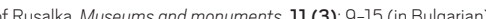

[14]. Lazarov, M. (Ed.) (2009). Ancient navigation along the western Black Sea. Bibliotheca Pontica. Publ. house Slavena, Varna (in Bulgarian)

[15]. Salkin, A. (Ed.). (2007). Bizone. In Ancient Greek colonies in the Black 675. Archaeopress, Ox-

[16]. Lazarov, M. (1975). The Sunken fleet. Varna (in Bulgarian)

[17]. Lazarenko, I., Mircheva, E., Encheva, R., Sharankov, N. (2010). The Temple of the Pontic mother of gods at Dionysopolis. Ancient sacral

[18]. Toncheva, G. (1964). The sunken ports. Varna (in Bulgarian)

[19]. Lazarov, M. (2000). Bulgarian Black Sea during the Archaic period.
Proceedings of the National Museum in Burgas, Vol. 3 (Studia in Proceedings of the National Museum in Burgas, Vol. 3 (Studia in memoric

[20]. Lazarov, M. (Ed.) (2003). Odessos - Varna. Slavena, Varna (in Bulgarian)

[21]. Toncheva, G. (1967). Archaic findings from Odessos. Proceedings of Archaeological Institute, XXX: 157-180 (in Bulgarian)

[22]. Yotov, V.. Minchev, A. (2013). The Late Antique fortress at Cape Sveti Atanas. Sofia (in Bulgarian)

[23]. Hristov, I. (Ed.) (2013a). Akra. In Exploring the Early Byzantine fortress on St. Nikola Peninsula near the town of Chernomorets, Vol.
1. Publ house Unicart, Sofia 1. Publ. house Unicart, Sofia

[24]. Hristov, I. (Ed). (2013b). Akra between Anhialo and Sozopol. Publ house Unicart, Sofia
[25]. Popkonstantinov, K., Drazheva, Ts., Kostova, R. (2015). Monastery of St. John Forerunner on the island of Sveti Ivan in light of the recent archaeological investigations (2008-2013). Proceedings of the

[26]. Daskalov, M.. Panayotova, K. (2008). Exploration of the fortress discoveries and excavations in 2007: 458-462 (in Bulgarian)
d

[27]. Dimitrov, B. (1987). Agatopol. In Bulgarian cities and fortress of Danube and Black Sec 412-427 Varna (in Bulgarian)

\section{CHAPTER V.} SENSITIVITY MAPPING AND ASSESSMENT OF THE BULGARIAN BLACK SEA COASTAL ZONE

[1]. IPIECA, (2012). Sensitivity mapping for oil spill response, OGP Report Number 477. Available at http://www.ipieca.org/resources/goodpractice/sensitivity-mapping-for-oil-spill-response (last accessed

[2]. Adler, E., Inbar, M. (2007). Shoreline sensitivity to oil spills, the Mediterranean coast of Israel: assess

[3]. Stanchev, H., Young, R., Stancheva, M. (2013). Integrating GIS and high resolution orthophoto images for the development of a geomorphic shoreline classification and risk assessment-a case
study of cliff/bluff erosion along the Bulgarian coast Journal of Coastal Conservation, 17(4): 719-728

[4]. Boak, E. H.. Turner, I. L. (2005). Shoreline definition and detection: a review. Journal of coastal research.

[5. Puissant, A., Lefevere, S., Weber, J. (2008). Coastline extraction in VHR imagery using mathematical morphology with spatial and spectral knowledge. In SPRS Congress Belijing 2008, 1305-1310

[6]. Goodchild, M., F. (2009). Geographic information systems and science: today and tomorrow. Annals of GIS, 15(1): 3-9

[7]. Gens, R. (2010). Remote sensing of coastlines: detection, extraction and monitoring. Intermational Journal of Remote Sensing, 31(7):

8]. htpps://psds.shutterfly.com/bulgaria (last accessed on December 8, 2016)

[9]. Coastal processes and sustainable development of the Bulgarian

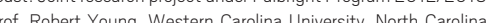
Prof. Robert Young,
USA

CHAPTER VI.

REGIONALIZATION OF THE BULGARIAN BLACK SEA COASTAL AREA AND THE CONTIGUOUS SHALLOW SEABED SEC-

[1]. Petrov, P. (1990). Landscape science, 265 pp. University Press of Sofia University St. Kliment Ohridski, Sofia (in Bulgarian)

[2]. Velchev, A., Todorov, N. Penin, R. (2003). Regional differentiation of thelandscape complexes in Bulgaria. In Proceedings of the 30 " Jubilee Symposium of Shumen University St. Konstantin Preslavsky. Preslavsky", Shumen (in Bulgarian)

[3]. Velchev, A., Todorov, N. Penin, R.. Konteva, M. (2017). Landscape gegrraphy of Bulgaria, 235 pp. Publ. house BULVEST 2000, Sofia (in Bulgarian)
44. Nam, K. (2003). Physical geography of Bulgaria, 283 pp. Publ. house Geosfera, Sofia (in Bulgarian)

[5]. Nam. K. (2013). Landscape ecology, 298 pp. Publ. house Simolini-94 SD, Sofia (in Bulgarian)

[6]. Mishev, K., Daneva, M. (1979). The Bulgarian Black Sea Coast. Academic Press
Bulgarian)

[7]. Penin, R. (2007). Physical geography of Bulgaria, 279 pp. Publ. house BULVEST 2000, Sofia (in Bulgarian)

[8]. Popov, V. (1975). Taxonomic units for landscapes (the Black Sea landscape being taken as an example)
Environment, $189-199$ (in Bulgarian)

[9]. Velchev, A., Todorov, N., Penin, R. (1992). Anthropogenic transformations and disturbance of the landscape complexes in the Burgas Ecology' 92 International Symposium, September $24^{t+}-26^{-1}, 1992$. Burgas, Bulgaria (in Bulgarian)

[10]. Todorov, N. Velchev, A. (1999). Evolution of the landscapes near Sts. Konstantine and Helena Resort. Annual journal of Sofia University 89: 211-227 ( Bulgarian)

[11]. Nam, K. (2002). Rationalization of the land use between Cape Atia and the mouth of Rezovska River. In Proceedings of the International Scientific Conference
Varna, 2002 (in Bulgarian)

[12]. Nam, K. (2002). Opportunities to realize the idea of sustainable development in the Strandzha Mountain region. In Proceeding conference with international participation, Veliko Tarnovo, 2002 (in Bulgarian)

[13]. Nam, K. (2005). Specifics of the landscape-ecological properties and anthropogenic presence at the eastern spurs of Bosna Ridg St Ktiment Mountain, Bulgaria). Annual jounnal of Sofia Universty garian)

14]. Kotsev, I. (2014). Structure, dynamics and regionalization of the landscape complexes between Cape Kaliakra and Cape Emine
Bulgarian Black Sea coastal zone (doctoral thesis) 297 pp. Publ Bulgarian Black Sea coastal zone (doctoral thesis), 297 pp. Publ. house Aquaprint, Varna (in Bulgarian)

[15]. Cheshitev, G.. Kunchev, I., Vulkov, V.. Marinova, R., Shilyafova, Zh. Ruseva, M., lliev, K. (1989). Geological map of the Republic of Department of Geophysical Prospecting and Geological Mapping Sofia, Bulgaria (in Bulgarian and English)

[16]. Popov, VI., Mishev, K. (1974). Geomorphology of the Bulgarian Black Sea coast and shelf, $253 \mathrm{pp}$. Academic Press of the Bulgaria

[17]. Koleva-Rekalova, E. (1998). Formational conditions of the Sarmatian sedimentary rocks from the Balchik area, North-eastern Bugaria. Review of the Bulgarian Geological Society, 59(1): 69-74 (in Bulgarian)

[18]. Peychev, V.. Peev. P. (2006). Holocene Evolution of the Bulgarion Black Sea Coast since the Early Holocene, 123 pp. Publ. house Slavena, Varna (in Bulgarian)

[19]. Trifonova, E., Stancheva, M. (2005). Features of dynamics and development of the beaches from Cape Kaliakra to Momchillov dol
Gully. Proceedings of Institute of Oceanology - BAS, 5: 229-238 (in Bulgarian) 
[20]. Peychev, V., Dimitrov, D. (2012). Oceanology, 490 pp. Publ. house Ongal, Varna (in Bulgarian)

[21]. Keremedchiev, St., Peychev, V. (2003). Geomorphodynamic analysis Final project ropert Scientific fund of the Instituma Dere Ravine. Prof. Fridtiof Nansen, Varna - Bulgarian Academy of Sciences (in Bulgarian)

[22]. Peel, M. C., Finlayson, B. L., McMahon, T. A. (2007). Updated map of the Köppen-Geiger climate classiffation. Hydrology and Ea

[23]. Velev, St. (1990). Climate regionalization of Bulgaria. In Climate Sciences, Sofia (in Bulgarian)

[24]. Agrometeorological Atlas of Republic of Bulgaria (1960). Academic Press of the Bulgarian Academy of Sciences, Sofia (in Bulgarian)

[25]. Rozhdestvenskiy, A. V. (1986). Hydrochemistry of the Bulgarian sector of the Black Sea, $189 \mathrm{pp}$. Academic Press of the Bulgarian Academy of Sciences, Sofia (in Bulgarian)

[26]. Ninov, N. (1997). Soils. In Geography of Bulgaria, 225-259. Professor Marin Drinov Academic Press, Sofia (in Bulgarian)

[27]. State of the soils (2017). In National Report on the State of Environment in Bulgaria (available at http:///eea.government.bg/bg/
soer/2017/ soer/2011/land-use/sastoyanie-na-pochvite, in Bulgarian, last
accessed on November 25, 2016)

[28]. Tonkov, S., Beug, H.J., Bozilova, E., Filipova-Marinova, M., Jungner, H. (2017). Palaeoecological studies at the Kaliakra area, northeastern Bulgarian Black Sea coast: 6000 years of natural and anthropogenic change. Vegetation history and archaeobotany, 20
(1): $29-40$

[29]. Georgiev, G. (2004). Black Sea biogeographic region. In National and nature parks and reserves in Bulgaria, 217-271. Publ. house Gea-Libris, Sofia (in Bulgarian)

[30]. Bondev, I. (1997). Vegetation of Bulgaria: 7:600,000 map with explanatory text, $180 \mathrm{pp}$. University Press of Sofia University St.

[31]. Stanchev, Hr., Young, R., Stancheva, M. (2013). Integrating GIS and high-resolution orthophoto images for the development of a geomorphic shoreline classification and risk assessment - a case study of cliff/bluff erosion along the Bulgarian coast. Journal of Coastal

[32]. Stancheva, M.. Rangel-Buitrago, N.. Anfuso, G.. Palazov, A.., Stanchev, H., Correa, I. (2017). Expanding level of coastal armouring: case studies from different countries. Journal of Coastal Research, Special Issue 64: (Proceedings of the 17th Internation Coastal Symposium, Szczecin, Poland):1815-1879

[33]. Stancheva, M. (2009). Indicative GIS-based segmentation of the Bulgarian Black Sea coastline for risk assessment. Comptes Ren-
dus de I'Academie Bulgare des Sciences, 62(10): $1311-1318$

[34]. Ivanov, K., Marinov, IV., Panayotov, T., Petkov, Al. (1961). Hydrology of Bulgaria, 314 pp. Publ. house Nauka \& I Zkustrvo, Sofia (in Bulgarian)

[35]. Velchev, A., Todorov, N., Asenov. A., Berouchashvili, N. (1992). Map of the landscape complexes in Bulgaria at scale $1: 500,000$. (Geography), 84: 85-105 (in Bulgarian)
[36]. Todorova, V. Keremedchiev, St., Karamfilov, V., Berov, D., Dimitrov, L. Kotsev, I. Dencheva, Kr. (2013). Dominant benthic habitat types In Inititia assessment of the state of the marine environment, in ac-

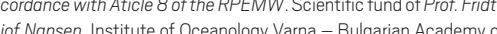
Sciences, 76-164 (available at http://www.bsbd.org/Userfilies/ File/Initial\%20Assessment_new.pdf, in Bulgarian, last accesse on September 30, 2016)

[37]. Begun, T., Muresan, M. Zaharia, T., Dencheva, K., Sezgin, M., Bat, L. Velikova, V. (2012). Conservation and Protection of the Black Sea Biodiversity. Review of the existing and planned protected areas in
the Black Sea (Bulgaria Romania and Turkey) with a special focus on possible deficiencies regarding law enforement and implementation of management plans. EC DG Env. MISIS Project Deliverables (available at www.misisproject.eu, last accessed on October 15 . 2016)

[38]. Project Information system for protected sites of the Bulgarion NAT-

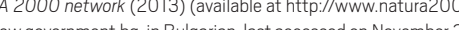
2016)

[39]. Tzonev, R.., Roussakova, V., Dimitrov, M. (2015). Western-Pontic petrophytic steppes. In Golemansky, V.. Peev, D.. Chipev, N., Beron. P... Biserkov, V. (Eds.) Red Data Book of the Republic of Bulgaria, Vo

[40]. Tzonev, R., Gussev, Ch. (2015a). Sea-cliff vegetation. In Golemansky, V., Peev, D., Chipev, N.. Beron, P., Biserkov, V. (Eds.) Red Data Book of the Republic of Bulgaria, Vol. III (Natural Habitats), $77-78$ BAS \& MoEW, Sofia

[41]. Gussev, Ch., Dimitrov, D., Tzonev, R. (2015). Balkan pseudomaquis In Golemansky, V., Peev, D., Chipev, N., Beron, P., Biserkov, V. (Eds) tats), 258-260. BAS \& MoEW. Sofia

[42]. Tzonev, R. Gussev, Ch. (2015b). Vegetation on the Black Sea grave beaches. In Golemansky, V. Peev, D., Chipev, N. Beron, P., Biserkov.
V (Eds) Red Data Book of the Republic of Bulgaria Vol II (Natured (Eds.) Red Data Book of the Republic or Buigaria, Vol. III (Natud Habitats), 75-76. BAS \& MoEW, Sofia

[43]. Tzonev, R. (2015a). Vegetation on the Black Sea sand beaches. In Golemansky, V., Peev, D., Chipev, N. Beron, P., Biserkov, V. (Eds, Red Data Book of the Republic of
tats), 64-65. BAS \& MoEW, Sofia

[44]. Tzonev, R. (2015b). Black Sea embryonic dunes. In Golemansky, V. Peev, D., Chipev, N. Beron, P., Biserkov, V. (Eds.) Red Data Book Habitats), 65-66. BAS \&

[45]. Tzonev, R. (2015c). Black Sea mobile (white) dunes. In Golemansky V.. Peev, D., Chipev, N., Beron, P., Biserkov, V. (Eds.) Red Data Book of the Republic of Bulgaria, Vol. III (Natural Habitats), 67-68. BAS

[46]. Tzonev, R. (2015d). Black Sea fixed (grey) dunes. In Golemansky. V. Peev, D., Chipev, N. Beron, P., Biserkov, V. (Eds.) Red Data Book
of the Republic of Bulgaria, Vol. III (Natural Habitats), 69-71. BAS \& thoEW, Sofia

[47]. Tzonev, R., Gussev, Ch. (2015c). Black Sea wooded dunes. In Golemansky, V., Peev, D., Chipev, N. Beron, P., Biserkov, V. (Eds.) Red Data Book of the Republic of Bulgaria, Vol. III (Natural Habitats).

[48]. Tzonev, R. (2015)). Over-wet and flooded dune slacks. In Golemansky, V., Peev, D., Chipev, N., Beron, P., Biserkov, V. (Eds.) Red Data
Book of the Republic of Bulgaria. Vol III (Natural Habitats). 73-75 BAS \& MoEW, Sofia
[49]. Petrova, A. (2015). Inland dunes with standing stones. In Golemansky, V., Peev, D., Chipev, N., Beron, P., Biserkov, V. (Eds.) Red Dato

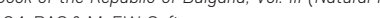

[50]. Valchev, VI., Vassilev, V., Georgiev, V. (2015). Submerged macrophytic communities in hypersaline water bodies. In Golemansky, V.
Peev D. Chipev, N. Beron, P. Biserkov, V (Eds) Red Data Book of the Republic of Bulgaria, Vol. III (Natural Habitats), 52-54. BAS \& MoEW, Sofia

[51]. Kozhuharov, D., Uzunov, Y.. Vassilev, V. (2015). Hypersaline coastal Biserkoy $Y$ (Eds) Red Data Book of the Repulic of Bulgeria Vol (Natural Habitats), 90-92. BAS \& MoEW, Sofia

[52]. Tzonev, R., Gussev, Ch. (2015d). Communities of annual halophytes in coastal salt marshes at the Black Sea. In Golemansky, V., Peev, Republic of Bulgaria, Vol. III (Natural Habitats), 49-50. BAS \& Roew, Sofia

[53]. Gussev, Ch. (2015). Mediterranean halophytic communities of tall rushes, sedges and grasses. In Golemansky, V.. Peev, D., Chipev, N. Beron, P..Biserkov, V. (Eds.) Red Data Book of the Republic of Bu-
garia, Vol. III (Natural Habitats), 47-48. BAS \& MoEW, Sofia

[54]. Tzonev, R., Valchev, VI., Georgiev, V. (2015). Natural or semi-natura mesotrophic to eutrophic lakes and marshes with macrophytic vegV. (Eds.) Red Data Book of the Republic of Bulgaria, Vol. III (Natura Habitats), 84-87. BAS \& MoEW, Sofia

[55]. Dimitrov, M., Tzonev, R. (2015). Riparian and lowland mixed woodlands and longozes. In Golemansky, V., Peev, D.., Chipev, N.., Beron, P. (Natural Habitats), 281-284. BAS \& MoEW, Sofia

[56]. Traykov, I., Ivanov, PI. (2015), Estuaries. In Golemansky, V. Peev, D., Chipev, N.. Beron, P.. Biserkov, V. (Eds.) Red Data Book of the
Republic of Bulgaria, Vol. III (Natural Habitats), 104-106. BAS \& MoEW. Sofia

[57]. Todorova, V. (2015a). Black mussels and/or barnacle communities on mediolittoral rocks. In Golemansky, V. Peev, D., Chipev, N. Beron. P., Biserkov, V. (Eds.) Red Data Book of the Republic of Bulgaria, Vol. III (Natural Habitats), 44-45. BAS \& MoEW. Sofia

[58]. Todorova, V., Panayotova, M. (2015a). Infralittoral rocks and other hard substrates. In Golemansky, V., Peev, D., Chipev, N., Beron, P. (Natural Habitats), 54-56. BAS \& MoEW, Sofia

[59]. Todorova, V., Panayotova, M. (2015b). Cystoseira spp. on exposed to waves infralittoral bedrock and boulders. In Golemanskyy. V. Peev, D... Chipev, N., Beron, P., Biserkov, V. (Eds.) Red Data Book of the
Republic of Bulgaria, Vol. III (Natural Habitats). 56-58. BAS \& Republic of B

[60]. Petrov, B., Pandurski, I. (2015). Sea caves. In Golemansky, V., Peev, D., Chipev, N., Beron, P., Biserkov, V. (Eds.) Red Data Book of the Republic of Bulgaria, Vol. III (Natural Habitats), 59-60. BAS \&
MoEW, Sofia

[61]. Todorova, V. (2015b). Littoral sands and muddy sands. In Golemansky, V., Peev, D., Chipev, N. Beron, P., Biserkov, V. (Eds.) Red Data Book o the Repubilic of Bulgaria, Vol. III Natural Habitats), 46-47.
BAS \& MoEW, Sofia

[62]. Todorova, V., Panayotova, M. (2015c). Sublittoral sands. In Golemansky, V., Peev, D., Chipev, N.., Beron, P., Biserkov, V. (Eds.) Red Data Book of the Repubilic of Bulgaria, Vol. III (Natural Habitats). Data-62. BAS \& MoEW, Sofia
[63]. Todorova, V. (2015c). Underwater "meadows" of sea grasses. In Golemansky, V., Peev, D., Chipev, N.. Beron, P., Biserkov, V. (Eds.) Red

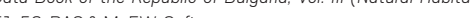

64]. Todorova, V., Panayotova, M. (2015d). Sublittoral mussel beds on serkov, V. (Eds.) Red Datata Book of the Republic of Bulgaria, Vol. III (Natural Habitats), 62-63. BAS \& MoEW, Sofia

[65]. Register of the protected territories and NATURA 2000 sites in

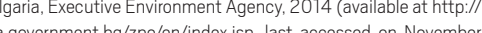
20, 2016)

[66]. Maev, E. G., Kozlov, V. B., Krustev, T. I., Limonov, A. F., Mislivets, VI. 1.. Parlichev, D. G.. Chistyakov, A. A. (1980). Structural-geomorphic characteristics of the continental terrace. In Geologic-GeophisiAcal Investigations of the Bulgantan Black Sea Sector, 145-155. Russian)

[67]. Krustev, T. (1992). Structural-geomorphic development of the continental terrace within the Bulgarian Black Sea sector. DSc dissertation abstract, 64 pp. Scientific fund of Prof. Fridtjof Nansen

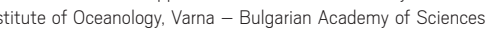
(in Bulgarian)

[68]. Stancheva, M., Stanchev, Hr., Palazov, A., Young, R. (2015). Coastal dune changes under natural/human hazards. In Özhan, E. (Ed.) Proceedings of the Twelfth International Conference on the Mediterronean Coastal Environment MEDCOAST'15, October $6^{\text {th }}-10^{\text {th } 2015,}$ Varna, Bulgaria, 1: 385-395

[69]. Council Directive 92/43/EEC of 27 May 1992 on the conservation eur-lex.europa.eu, last accessed on November 19, 2016)

[70]. Kanev, D. (1989). Geomorphology of Bulgaria, 322 pp. University ress of Sofia University St. Kliment Ohridski, Sofia (in Bulgarian)

[71]. Todorova, V. et al. (2012). Report on implementation of grant ConOceanology - BAS with reference to Project. Extension of the NATURA 2000 ecological network in the Bulgarian Black Sea marine area to overcome the moderate insufficiencies regarding marine habitats 1110 (Sandbanks which are slightly covered by sea water all the time) and 1170 (Reefs) and species 4125 (Alosa immaculata), 1349 (Tursiops truncatus) and 1351 (Phocoena phocoena) and partial filling of scientific reserve for habitat 1180 (Submarine tructures made by leaking gases) and species 7349 (Tursiops Black Sea Seminar. Brindisi, June 75th, 2010. Scientific fund of IO-BAS (in Bulgarian)

[72]. Black Sea Red Data Book (1999). Available at http://www.grid. unep.ch//ssein/reabook/index.htm (last accessed on November

73]. Tzonev, R.. Dimitrov, M., Gussev, Ch. (2015). Sub-Mediterranean petrophytic steppes. In Golemansky, V., Peev, D., Chipev, N.., Beron, P..Biserkov, V. (Eds.) Red Data Book of the Republic of Bulgaria, Vol

\section{ACKNOWLEDGEMENTS}

[1]. https://psds.shutterfly.com/bulgaria (last accessed on December 8 , 


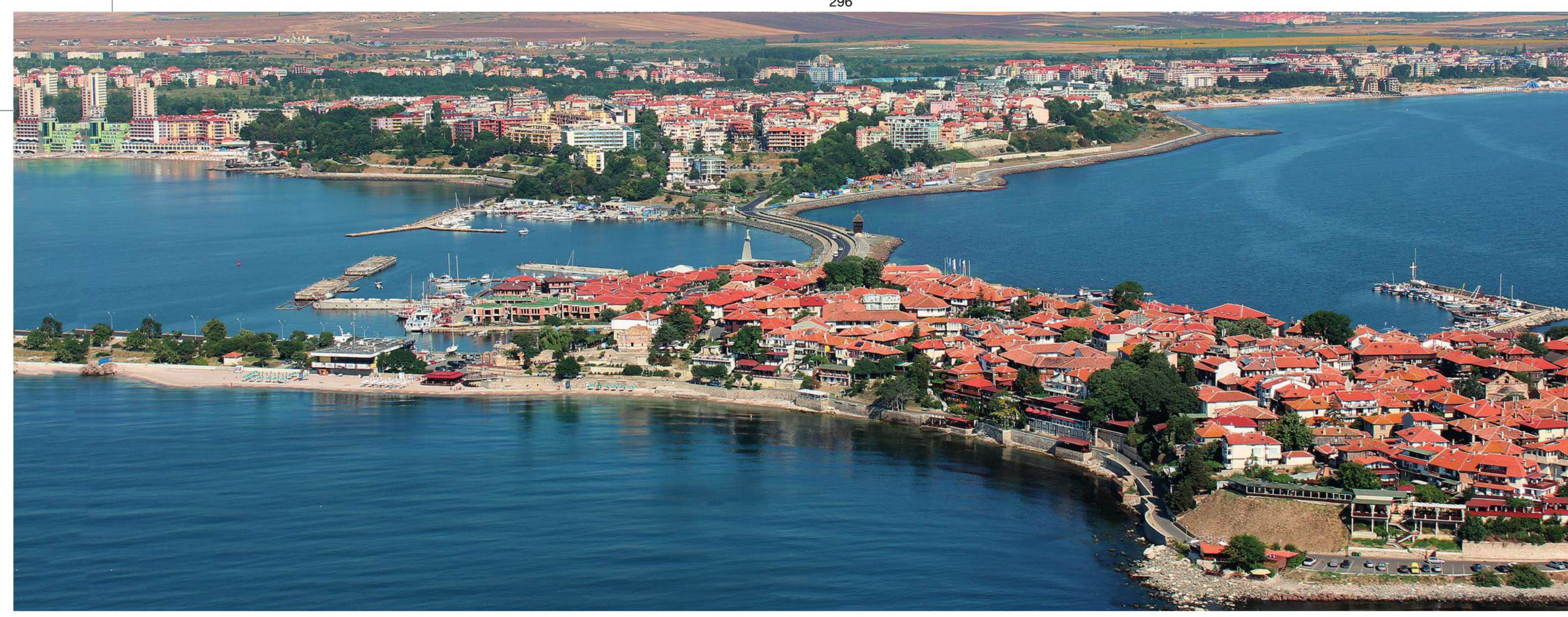

\section{SENSITIVITY MAPPING AND ANALYSIS of the Bulgarian Black Sea Coastal Zone}

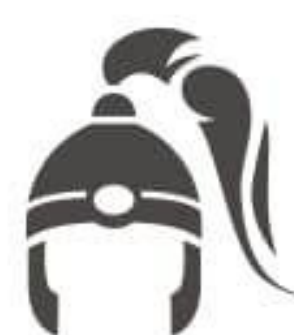

HAN ASPARUH

EXPLORATION

The first step in preserving the nature of our Black Sea coastal area is to gain good knowledge of its richness and biodiversity. Sensitivity mapping is a tool to achieve identification of the most sensitive locations where priorities and protective measures could be applied, and to help manage the ecological balance of the Bulgarian shoreline.

As a leading energy company conducting its business in a responsible manner with a particular focus on Health, Safety \& Environment TOTAL E\&P Bulgaria B.V. has developed this Sensitivity Mapping and Analysis of the Bulgarian Black Sea Coastal Zone together with the Institute of Oceanology of the Bulgarian Academy of Sciences. The book provides extensive data on the present status of the area and is aimed to be of use to both scientists and non-specialist readers as well as public decision makers.

TOTAL E\&P Bulgaria B.V. is a subsidiary of the Paris-based global energy group TOTAL S.A. In partnership with Repsol Bulgaria B.V and OMV Offshore Bulgaria GmbH, TOTAL E\&P Bulgaria holds a permit for prospecting and exploration of oil and gas in Block 1-21 Han Asparuh. The area of the Block covers 14,220 sq km, located in the western deep-water zone of Bulgaria's Black Sea. The drilling of the first deep off-shore exploration well Polshkov-7 was successfully completed up to the highest technical and operational standards in September 2016. Through its exploration program TOTAL and its partners have been working on studying and exploring the oil and gas potential of the area while collaborating with different stakeholders including the Bulgarian Government, the non-governmental organizations, the business and academic communities

Financed and Directed by

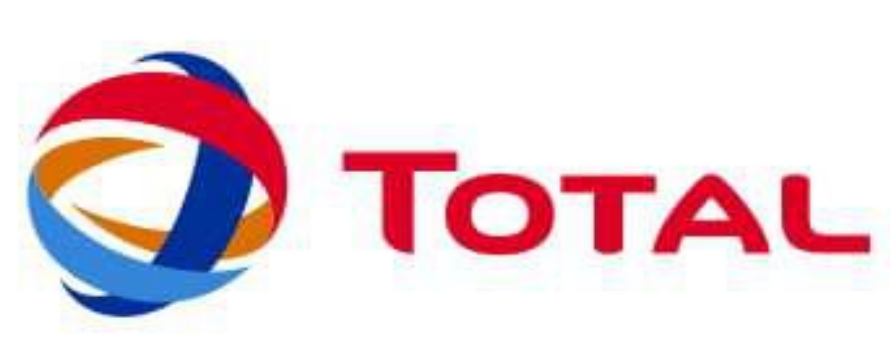

Realized by

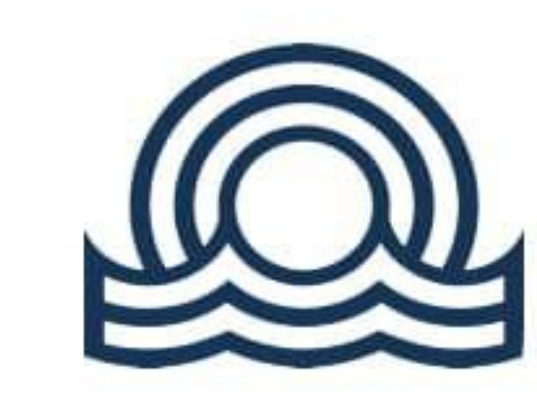

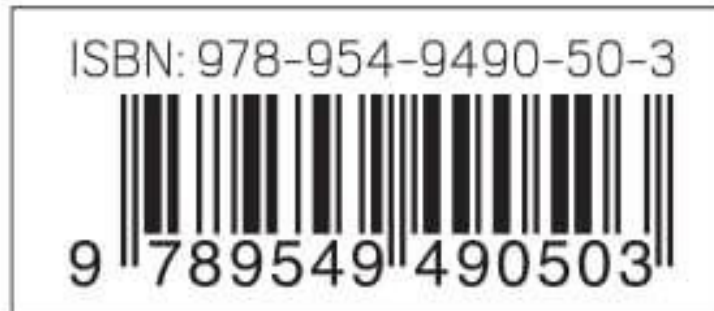

